
UNIVERSIDADE DE SÃO PAULO
INSTITUTO DE PSICOLOGIA

Natália Cristina Ribeiro Alves

A construção sociopolítica dos Transtornos Mentais e do Comportamento Relacionados ao Trabalho

São Paulo

2015 
Natália Cristina Ribeiro Alves

\section{A construção sociopolítica dos Transtornos Mentais e do Comportamento Relacionados ao Trabalho (versão original)}

Tese apresentada ao Instituto de Psicologia da Universidade de São Paulo como parte dos requisitos para obtenção do grau de Doutora em Psicologia.

Área de Concentração: Psicologia Social e do Trabalho

Orientadora: Prof. Dra. Leny Sato

São Paulo

2015 
Alves, Natália Cristina Ribeiro.

A construção sociopolítica dos transtornos mentais e do comportamento relacionados ao trabalho / Natália Cristina Ribeiro Alves; orientadora Leny Sato. -- São Paulo, 2015.

$493 \mathrm{f}$.

Tese (Doutorado - Programa de Pós-Graduação em Psicologia. Área de Concentração: Psicologia Social e do Trabalho) - Instituto de Psicologia da Universidade de São Paulo.

1. Psicologia do trabalho 2. Saúde mental e trabalho 3. Saúde ocupacional 4. Psicologia social I. Título. 


\title{
A construção sociopolítica dos Transtornos Mentais e do \\ Comportamento Relacionados ao Trabalho
}

\author{
Natália Cristina Ribeiro Alves
}

São Paulo, 30 de junho de 2015

Banca Examinadora:

Prof. Dra. Leny Sato - USP

Profa. Dra. Maria Elizabeth Antunes Lima - UFMG

Prof. Dra. Vera Lúcia Navarro - USP Ribeirão Preto

Prof. Dr. Francisco Antônio de Castro Lacaz - UNIFESP

Profa. Dra. Renata Paparelli - PUC SP 
Ao meu pai, Orvile Alves Moreira

(in memorian) 


\section{AGRADECIMENTOS}

A realização deste trabalho só foi possível graças à colaboração direta ou indireta de muitas pessoas. Manifesto minha gratidão a todas elas, e de forma particular:

À minha família: Orvile (in memorian), Raciolina, Luciana e Tânia, e os queridos "agregados" Carlos e Leandro, sempre presentes, mesmo em minhas ausências.

À minha orientadora, professora Leny Sato, pela acolhida, pela delicadeza em momentos pessoais conturbados que vivi durante o doutoramento e, sobretudo, por generosamente seguir comigo no caminho que escolhi trilhar.

Aos professores que participaram do exame de qualificação, Dra. Maria Elizabeth Antunes Lima e Dr. Francisco Antônio de Castro Lacaz, pelas preciosas sugestões que redefiniram a concepção deste trabalho.

Aos professores integrantes da banca de defesa, Dra. Maria Elizabeth Antunes Lima, Dr. Francisco Antônio de Castro Lacaz, Dra. Vera Lúcia Navarro e Dra. Renata Paparelli, por sua disponibilidade para a leitura e contribuição com o trabalho.

Aos profissionais entrevistados, que comigo compartilharam com generosidade suas vivências e experiências, e com os quais aprendi muito além do que está expresso na tese.

A Serlane Alves por me ajudar a "desbravar" a floresta de material consultado: sem seu apoio, não teria sido possível.

A Lina Moreira, Tânia Alves, Serlane Alves, Leonardo Valério e Carlos Guedes pelo grande apoio nas transcrições das entrevistas.

A Jayane Maia pela inestimável ajuda no tratamento dos dados das entrevistas e por me introduzir nos "mistérios" do ATLAS.ti.

A Raciolina Cândida Ribeiro Moreira pela revisão

A Tânia Ribeiro Alves pela carinhosa leitura.

Aos colegas do Grupo de Orientandos pelas sugestões de leitura e diálogo e pelas muitas risadas compartilhadas, em especial a Júlia Dorigo ("irmã gêmea" mais nova) e à ("mãe") Maristela Pereira.

A Fábio de Oliveira e Augusto de Souza Campos por compartilharem materiais essenciais à elaboração da tese e a Manuel Deudesdit Junior, Maristela Pereira e Carlos Carrusca por compartilharem comigo suas teses "recém-saídas do forno" e que muito dialogam com este trabalho. 
A Marcos Pereira Feitosa pela atenção na elaboração do Abstract.

Aos professores que me iniciaram no árduo e prazeroso caminho da pesquisa, José Newton Garcia de Araújo e Maria Elizabeth Antunes Lima; ao antropólogo Eduardo Viana Vargas, meu orientador no mestrado, cujas provocações contribuíram para a busca de um olhar "desnaturalizado" para o campo da saúde; ao sociólogo Renarde Freire Nobre por despertar meu interesse pelo raciocínio "genealógico" e manter a inquietação da investigação presente no hiato temporal entre o mestrado e o doutorado; e ao professor Francisco Antônio de Castro Lacaz, com quem pude redescobrir o campo de debates da Saúde do Trabalhador.

Ao Departamento de Psicologia Social e do Trabalho do Instituto de Psicologia da Universidade de São Paulo, em especial a Nalva Gil e Rosângela Segaki.

Aos colegas do Centro Universitário Una, em especial Carolina Marra, Átila Simões, Rebeca Duarte e Ricardo Paiva, pela compreensão das ausências e pelo irrestrito apoio.

A Augusto Galery, eterno cúmplice.

Aos amigos André Feitosa, Augusto Galery, Karla Cipreste, Luiz Fernando Braga, Mariana Vilas Bôas e Thiago Saltarelli por não me deixarem desistir de buscar o doutorado.

Aos amigos Ana Paula Vargas, Fabíola Machado, Flávia Abreu, Júlia Dorigo, Luiz Fernando Braga, Maria Flávia Bastos, Mariana Vilas Bôas, Renata Ramos e Vinícius Amaral pelo incentivo constante para continuar e pelo encorajamento na difícil reta final.

À amiga Raquel Mendonça Macedo por estar lá.

À amiga e colega Cecília Coelho, cuja retaguarda e amizade tornaram possível passar por um dos mais difíceis períodos de minha vida.

A Sílvia Barbosa, fiel escudeira, por cuidar tão bem de mim e dos miaus e tolerar quatro anos de papéis e livros pela casa.

E um agradecimento mais que especial ao meu pai, Orvile Alves Moreira, exemplo de vida, amigo e companheiro que, enquanto esteve conosco, nesta e em outras empreitadas, sempre me dizia: "não desista! ". Pai, esta tese é para você. 
O grande paradoxo da experiência da doença é que ela é tanto a mais individual quanto a mais social das coisas.

(Marc Augé, 1984) 
ALVES, N. C. R. A construção sociopolítica dos Transtornos Mentais e do Comportamento Relacionados ao Trabalho. Tese de Doutorado. Instituto de Psicologia, Universidade de São Paulo, São Paulo, 2015.

\section{RESUMO}

Os Transtornos Mentais e do Comportamento Relacionados ao Trabalho (TMC), reconhecidos no Brasil por meio do Decreto $n^{\circ} 3.048$ de 1999, representam atualmente a terceira causa de concessão de benefícios previdenciários acidentários por doença. Esta pesquisa buscou investigar como, historicamente, começam a se reconhecer como categoria os TMC e compreender como essa categoria diagnóstica passou a fazer parte das políticas públicas e legislação referentes à relação saúde/trabalho, bem como discutir como implica e é implicada no aparecimento de uma estrutura conceitual voltada a seu tratamento. Partiu-se das perspectivas da Saúde do Trabalhador, da Psicologia do Trabalho e da Saúde Mental e Trabalho, e do conceito de determinação social do processo saúde-doença. O trabalho de campo contou com pesquisa bibliográfica e documental, além de entrevistas individuais, realizadas com profissionais ligados à área sindical, à academia (pesquisa) e à rede de saúde (SUS). Buscou-se analisar o campo científico - na acepção de Bourdieu ligado a essas doenças, com seus vários grupos socioprofissionais, acordos e divergências teóricos, relações de reciprocidade e de subordinação que mantêm entre si e sua articulação com forças presentes em outros espaços sociais. A análise propôs um recorte histórico do campo de relações entre trabalho-saúde, em especial trabalho e saúde mental, para compreender, no que tange aos TMC, os processos de transformação e as lutas travadas entre os diversos grupos de interesse envolvidos que, por sua vez, têm decisiva contribuição na determinação de critérios para estabelecer o que será considerado saúde e doença, em quais situações e para quais sujeitos. Constataram-se condições que possibilitaram a emergência dos TMC como categoria legalmente reconhecida, destacando-se rupturas políticas, epistemológicas e éticas introduzidas no campo das relações saúde/trabalho pelas abordagens da Saúde do Trabalhador, da Psicologia do Trabalho e da Saúde Mental e Trabalho; o processo de redemocratização do país e mobilização pela Reforma Sanitária, que levou à proposição na nova Constituição de um sistema universal de saúde, o SUS, pautado pelas premissas da Saúde do Trabalhador; o contexto socioeconômico de precarização do trabalho e novas formas de gestão, intensificando o processo de adoecimento psíquico; estudos e pesquisas empreendidos pela academia e movimento sindical. Conclui-se que a discussão sobre os TMC mobiliza, historicamente, diferentes grupos, ações político-técnicas e representações sobre saúde e doença, diagnóstico, tratamento e etiologia, que evocam quadros clínicos e sintomatológicos descritos e vivenciados de forma diferenciada, por isso sendo defendido neste trabalho se tratarem os TMC, a partir de seu reconhecimento legal, uma "nova" doença.

Palavras-chave: Psicologia do Trabalho. Saúde Mental e Trabalho. Saúde do Trabalhador. Psicologia Social. 
Disorders. Doctoral dissertation. Psychology Institute, University of São Paulo, São Paulo, 2015.

\begin{abstract}
Work-Related Behavior and Mental Disorders (WRBMD), acknowledged in Brazil with Decree \#3048 in the year 1999, currently represent the third cause for granting benefits concerning incidents of illness. This research reports on a historical investigation beginning to acknowledge WRBMD as a category and its diagnosis now takes part of public politics and laws concerning work and health issues, as well as its implications in the arising conceptual structure concerning its treatment. The starting point stems from perspectives in workers' health, Labor Psychology and Mental Health and Work, and the concept of social determination of the health-illness process. The fieldwork counted on bibliographical and documental research, in addition to individual interviews performed with professionals connected with the workers' unions area, academic research and the public health system from Brazil, SUS (Sistema Único de Saúde: Unified Health System). An analysis in the scientific field was sought within Bourdieu's line of thought connecting these illnesses to their various socioprofessional groups, theoretical agreements and divergences, and relations of reciprocity and subordination keeping their articulation with forces found in other social spaces. A proposal stems from this analysis for a historical cut on the field of relations between work and health, especially work and mental health, so as to understand, in what regards WRBMD, the transformation processes and struggles found among various groups of interest involved, which contributes decisively with the determination of criteria to establish what will be considered health and illness, in what situations, and for what subjects. The results point to conditions bringing about the emergence of WRBMD as a legally acknowledged category, such as: political, epistemological and ethical ruptures introduced in the field of health/work relations according to the approaches of Workers' Health and Labor Psychology; the process of re-democratization of the country and the mobilization towards a Sanitary Reform, leading to the proposition of a new Constitution and a unified health system (SUS), based on the assumptions from Workers' Health; the socioeconomic context of precarious labor and new forms of management, intensifying the process of psychical ailment; and studies and researches academically employed and workers' union movements. As a conclusion, the discussion on WRBMD mobilizes, historically, different groups, political-technical actions and representations on health and illness, diagnosis, treatment and etiology, evoking clinical and symptom conditions described and suffered differently. WRBMD is thus indicated as a "new" illness in this research.
\end{abstract}

Keywords: Labor Psychology. Mental Health and Work. Occupational Health. Social Psychology. 


\section{LISTA DE ILUSTRAÇÕES}

Figura 1 - Diagrama dos principais temas das entrevistas e suas inter-relações.

Figura 2 - Fatores que promoveriam os Transtornos Mentais e do Comportamento Relacionados ao Trabalho, na percepção dos entrevistados.

Figura 3 - Agravos relacionados ao trabalho notificados no SINAN (2007-2014) *

Gráfico 1 - Número de benefícios acidentários concedidos a segurados com transtornos mentais e do comportamento de 2006 a 2010

Gráfico 2 - Número de benefícios concedidos por incapacidade temporária (acidentários e previdenciários) aos segurados com transtornos mentais e comportamentais de 2006 a 2010.

Gráfico 3 - Auxílios-Doença - Previdenciários concedidos (B-31)*: Principais Grupos de Causas (CID-10, 2010)

Gráfico 4 - Aposentadoria por invalidez - Previdenciários concedidos*: Principais causas (CID10, 2010)

Gráfico 5 - Percentuais das Principais Profissões, por CBO, com Doenças Relacionadas ao Trabalho notificadas: Transtornos Mentais e do Comportamento Relacionados ao Trabalho (Brasil, 2007 a 2013)

Gráfico 6 - A atenção básica no campo da saúde e trabalho e os TMCs......

Gráfico 7 - Atores relevantes na discussão dos TMCs.

Gráfico 8 - Características do campo da Saúde do Trabalhador em relação aos TMCs. 462

Gráfico 9 - Exigências para caracterização dos TMCs

Gráfico 10 - Concepções sobre Trabalho .463

Gráfico 11 - Papel do CEREST .463

Gráfico 12 - Conflitos no campo da Saúde do Trabalhador

Gráfico 13 - Desafios no campo da Saúde do Trabalhador, sobretudo quanto aos TMCs .....

Gráfico 14 - Fatores que influenciam no adoecimento, sobretudo quanto aos TMCs.....

Gráfico 15 - Dificuldades existentes no campo da Saúde do Trabalhador, sobretudo quanto aos TMCs

Gráfico 16 - Fontes de encaminhamento dos TMCs

Gráfico 17 - Motivação do interesse do entrevistado pelo campo da Saúde do Trabalhador 468

Gráfico 18 - Opiniões dos entrevistados quanto às Listas " $B$ " $\mathrm{e}$ " $\mathrm{C}$ ". .469

Gráfico 19 - Opiniões dos entrevistados sobre o Manual do Ministério da Saúde. 469

Gráfico 20 - Opiniões dos entrevistados sobre o NTEP. .470

Gráfico 21 - Perfil de profissões com maior incidência de TMCs.

Gráfico 22 - Opiniões dos entrevistados sobre a perícia médica 
Gráfico 24 - Opiniões dos entrevistados sobre o papel da Psicologia na Saúde do Trabalhador ....472

Gráfico 25 - Opiniões dos entrevistados sobre "simulação"” de doenças, sobretudo dos TMCs ....472

Gráfico 26 - Reflexões sobre terminologias usadas no campo da Saúde do Trabalhador, sobretudo sobre os TMCs .............................................................................4 473

Gráfico 27 - Quando/por que começa a visibilidade da Saúde Mental e Trabalho/dos TMCs ........474

Gráfico 28 - Pontos positivos / avanços do campo da Saúde do Trabalhador.

Quadro 1 - Ocorrências de morbidade/mortalidade em categorias de problemas relacionados ao trabalho

Quadro 2 - Atuação do psicólogo em Saúde do Trabalhador

Quadro 3 - Os transtornos mentais e do comportamento relacionados ao trabalho e os agentes etiológicos ou fatores de risco de natureza ocupacional..........................................259

Quadro 4 - Informações sobre as entrevistas e entrevistados ...............................................440

Quadro 5- Processo de inclusão das doenças na Lista B.........................................................475

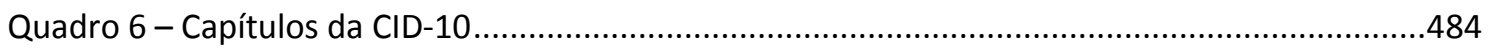

Quadro 7 - Transtornos Mentais e do Comportamento Relacionados ao Trabalho, quadros nosológicos e agentes etiológicos.....................................................................485

Quadro 8 - Benefícios Acidentários Relacionados ao Trabalho ................................................488

Quadro 9 - Normas Regulamentadoras de Segurança e Saúde no Trabalho.................................490 


\section{LISTA DE TABELAS}

Tabela 1 - Acidentes do trabalho registrados por espécie / Brasil - 1971 a 1995

Tabela 2 - Acidentes do trabalho por capítulo da CID (1999-2012)

Tabela 3 - Acidentes do trabalho por capítulo da CID: percentuais por motivo/situação (19992012)

Tabela 4 - Benefícios acidentários por incapacidade concedidos, por CID (2008-2012)

Tabela 5 - Benefícios acidentários por incapacidade concedidos por CID e percentual de cada grupo (2008-2012).

Tabela 6 - Auxílios-Doença Acidentários concedidos por CID e percentual de cada grupo (20082012)

Tabela 7 - Aposentadorias Acidentárias concedidas por CID e percentual de cada grupo (20082012)

Tabela 8 - Acidentes do Trabalho (Doença do Trabalho com CAT) por CID (F/Z) e percentual de cada grupo (1999-2012) .

Tabela 9 - Acidentes do Trabalho (Típico, com CAT) por CID (F/Z) e percentual de cada grupo (1999-2012)

Tabela 10 - Distribuição das notificações de agravos à saúde relacionados ao trabalho, por agravo, segundo o ano de notificação (Brasil, 2007-2013) 


\title{
LISTA DE ABREVIATURAS E SIGLAS
}

\author{
AA - $\quad$ Aposentadoria Acidentária \\ $A B C, A B C$ Paulista, Região do Grande $A B C$ ou $A B C D$ - área industrial da Região Metropolitana de São \\ Paulo, composta pelas cidades de Santo André, São Bernardo do Campo, São \\ Caetano do Sul, Diadema, Mauá, Ribeirão Pires e Rio Grande da Serra

\begin{tabular}{|c|c|}
\hline $\mathrm{ABHM}-$ & Archivos Brasileiros de Hygiene Mental \\
\hline ABNT - & Associação Brasileira de Normas Técnicas \\
\hline ABPA - & Associação Brasileira de Prevenção de Acidentes \\
\hline ABRASCO - & Associação Brasileira de Saúde Coletiva \\
\hline ADA - & Auxílio-Doença Acidentário \\
\hline ADI - & Ação Direta de Inconstitucionalidade \\
\hline AEAT Infologo - & Base de Dados Históricos de Acidentes do Trabalho da Previdência Social \\
\hline AEPS Infologo - & Base de Dados Históricos da Previdência Social \\
\hline $\mathrm{Al}-$ & Adicional de Insalubridade \\
\hline Al-5- & Ato Institucional no 5 \\
\hline ANAMT - & Associação Nacional de Medicina do Trabalho \\
\hline ANPEPP - & Associação Nacional de Pesquisa e Pós-Graduação em Psicologia \\
\hline ARENA - & Aliança Renovadora Nacional (partido político) \\
\hline B31 - & Auxílio-doença Previdenciário \\
\hline B91 - & Auxílio-doença Acidentário \\
\hline BEAT - & Boletim Estatístico de Acidente do Trabalho \\
\hline CAPS - & Centro de Atenção Psicossocial \\
\hline CAT - & Comunicação de Acidente de Trabalho \\
\hline $\mathrm{CBO}-$ & Classificação Brasileira de Ocupações \\
\hline CEBES - & Centro Brasileiro de Estudos sobre Saúde \\
\hline CEREST - & Centro de Referência em Saúde do Trabalhador \\
\hline CERSAT - & Centro de Referência em Saúde do Trabalhador \\
\hline CESAT - & Centro de Saúde do Trabalhador \\
\hline CESTEH - & Centro de Estudos da Saúde do Trabalhador e Ecologia Humana (Fiocruz) \\
\hline CFE - & Conselho Federal de Educação \\
\hline CFP - & Conselho Federal de Psicologia \\
\hline CGT - & Central Geral dos Trabalhadores \\
\hline CID-10 - & $\begin{array}{l}\text { Classificação Estatística Internacional de Doenças e Problemas Relacionados à } \\
\text { Saúde }\end{array}$ \\
\hline CIESP - & Centro das Indústrias do Estado de São Paulo \\
\hline CIPA - & Comissão Interna de Prevenção de Acidentes \\
\hline $\mathrm{CLT}-$ & Consolidação das Leis do Trabalho \\
\hline CNAE - & Classificação Nacional de Atividades Econômicas \\
\hline CNS - & Conferência Nacional de Saúde \\
\hline CNST - & Conferência Nacional de Saúde do Trabalhador \\
\hline CONCLAT - & $\begin{array}{l}\text { Coordenação Nacional da Classe Trabalhadora (posteriormente, Central Geral } \\
\text { dos Trabalhadores-CGT) }\end{array}$ \\
\hline CONPAT - & Congresso Nacional de Prevenção de Acidentes do Trabalho \\
\hline CPDOC/FGV- & Centro de Pesquisa e Documentação de História Contemporânea do Brasil - FGV \\
\hline CREPOP - & Centro de Referência Técnica em Psicologia e Políticas Públicas do CFP \\
\hline
\end{tabular}




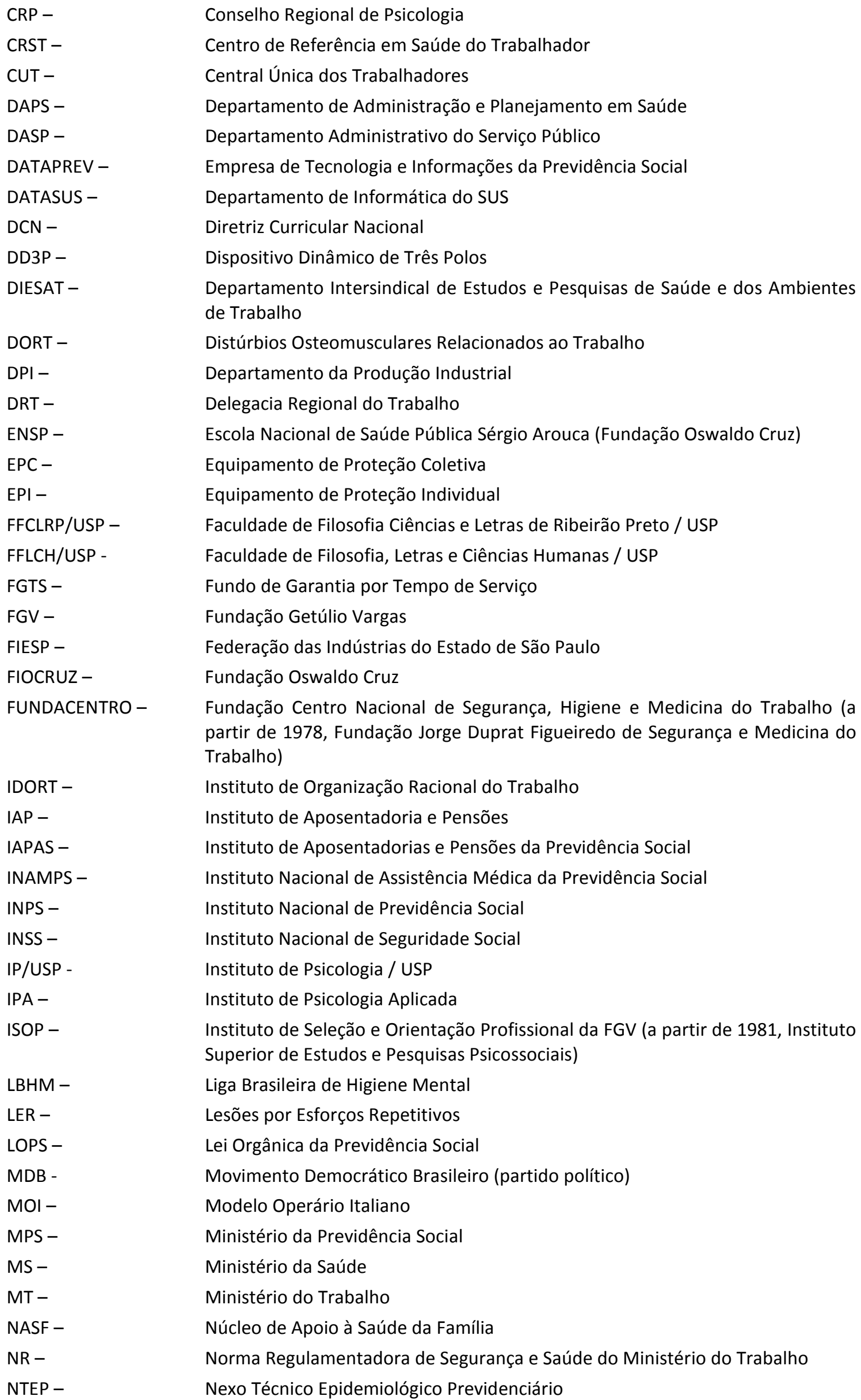




\begin{tabular}{|c|c|}
\hline OIT - & Organização Internacional do Trabalho \\
\hline OPAS - & Organização Pan-Americana de Saúde \\
\hline PAIR - & Perda Auditiva Induzida por Ruído \\
\hline PCB - & Partido Comunista Brasileiro \\
\hline PCMSO - & Programa de Controle Médico de Saúde Ocupacional \\
\hline $\mathrm{PIO}-$ & Psicologia Industrial e Organizacional \\
\hline PLR - & Participação nos Lucros e Resultados \\
\hline PMK - & Psicodiagnóstico Miocinético \\
\hline PNSST - & Política Nacional de Segurança e Saúde no Trabalho \\
\hline PNSTT - & Política Nacional de Segurança e Saúde do Trabalhador e da Trabalhadora \\
\hline POT - & Psicologia Organizacional e do Trabalho \\
\hline PPP - & Perfil Profissiográfico Previdenciário \\
\hline PPRA - & Programa de Prevenção de Riscos Ambientais \\
\hline PSM\&T - & Projeto Saúde Mental e Trabalho \\
\hline PST - & Programa de Saúde do Trabalhador \\
\hline PT - & Partido dos Trabalhadores \\
\hline PUC- & Pontifícia Universidade Católica \\
\hline QVT - & Qualidade de Vida no Trabalho \\
\hline RENAST - & Rede Nacional de Atenção Integral à Saúde do Trabalhador \\
\hline $\mathrm{RH}-$ & Recursos Humanos \\
\hline SAS/MS - & Secretaria de Atenção à Saúde do Ministério da Saúde \\
\hline SBPOT - & Sociedade Brasileira de Psicologia Organizacional e do Trabalho \\
\hline SEMSAT - & Semana de Saúde do Trabalhador \\
\hline SENAC - & Serviço Nacional de Aprendizagem Comercial \\
\hline SENAI - & Serviço Nacional de Aprendizagem Industrial \\
\hline SESC - & Serviço Social do Comércio \\
\hline SESI - & Serviço Social da Indústria \\
\hline SESMT - & Serviço Especializado em Engenharia de Segurança e Medicina do Trabalho \\
\hline SEST/UFMG - & $\begin{array}{l}\text { Serviço Especializado em Saúde do Trabalhador do Hospital das Clínicas da } \\
\text { Universidade Federal de Minas Gerais }\end{array}$ \\
\hline SINAN - & Sistema de Informação de Agravos de Notificação \\
\hline SINPAS - & Sistema Nacional de Previdência e Assistência Social \\
\hline SM\&T - & Saúde Mental e Trabalho \\
\hline SOSP - & Serviço de Orientação e Seleção Profissional \\
\hline ST - & Saúde do Trabalhador \\
\hline SUS - & Sistema Único de Saúde \\
\hline SVS/MS - & Secretaria de Vigilância em Saúde do Ministério da Saúde \\
\hline TMC - & Transtornos Mentais e do Comportamento Relacionados ao Trabalho \\
\hline UBS - & Unidade Básica de Saúde \\
\hline UEMG - & Universidade do Estado de Minas Gerais \\
\hline UFMG - & Universidade Federal de Minas Gerais \\
\hline UFRGS - & Universidade Federal do Rio Grande do Sul \\
\hline UFRJ - & Universidade Federal do Rio de Janeiro \\
\hline UNB - & Universidade Federal de Brasília \\
\hline UNE - & União Nacional dos Estudantes \\
\hline UNICAMP - & Universidade Estadual de Campinas \\
\hline
\end{tabular}




\section{SUMÁRIO}

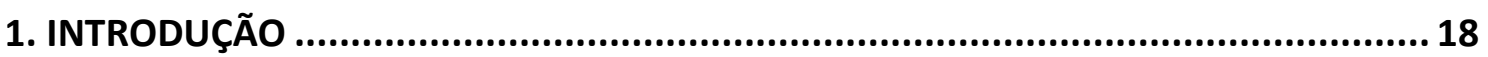

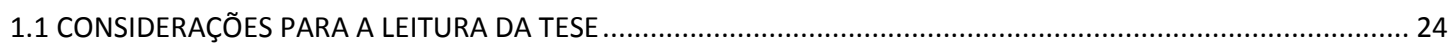

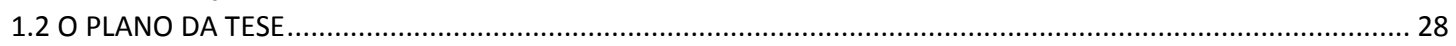

2. CONSIDERAÇÕES TEÓRICO-METODOLÓGICAS ................................................32

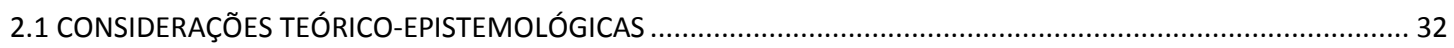

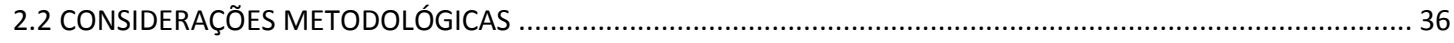

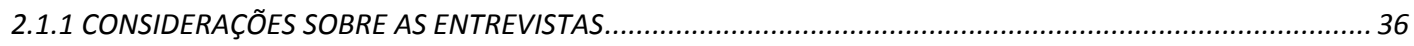

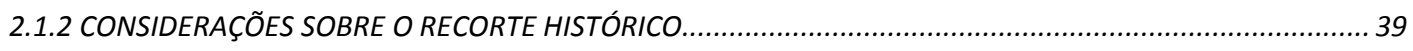

3. ASPECTOS POLÍTICOS E SOCIOECONÔMICOS ......................................................42

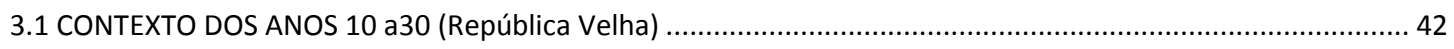

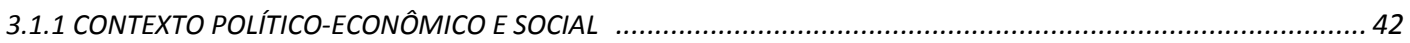

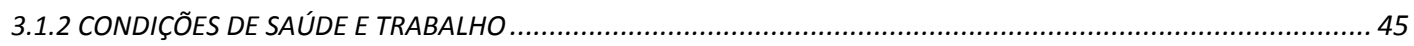

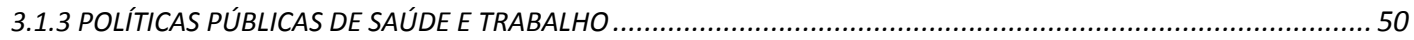

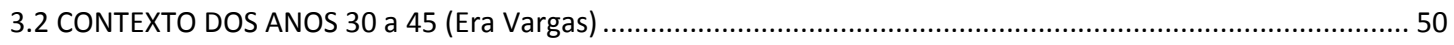

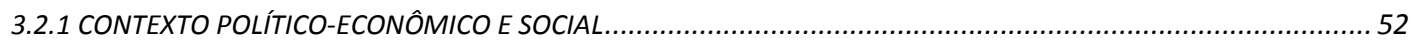

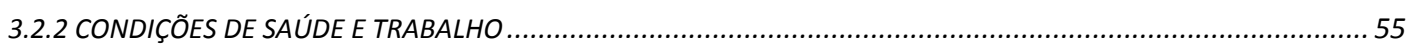

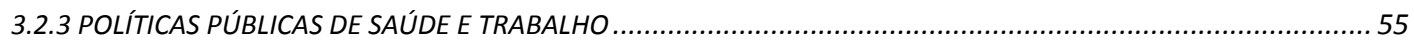

3.3 CONTEXTO DOS ANOS 46 a 64 (4a República ou República Populista) ............................................................ 59

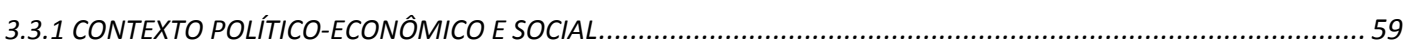

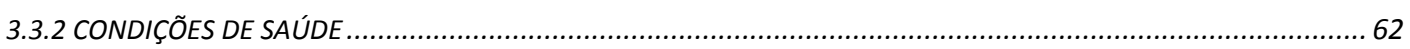

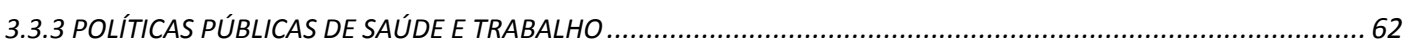

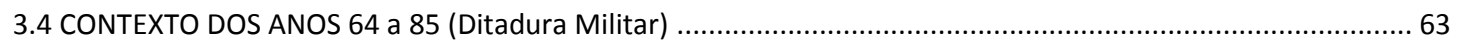

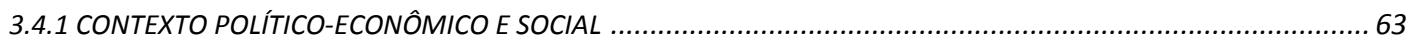

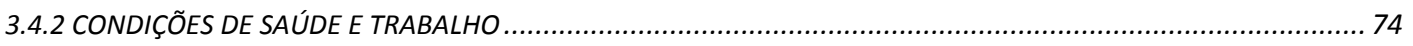

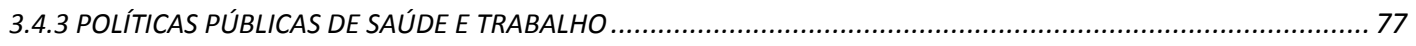

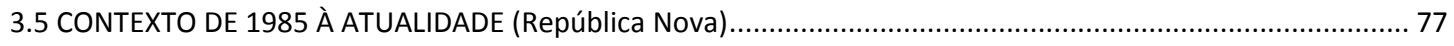

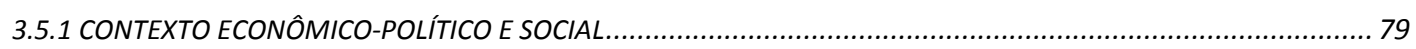

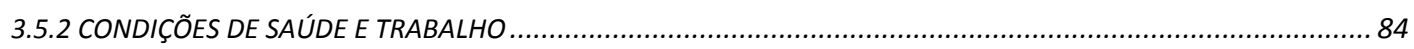

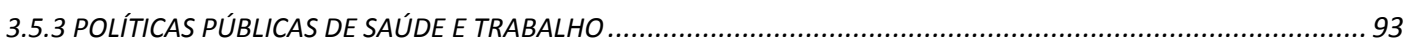

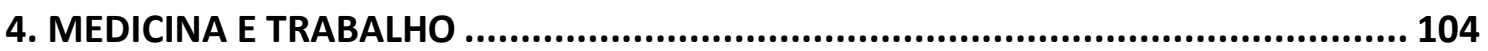

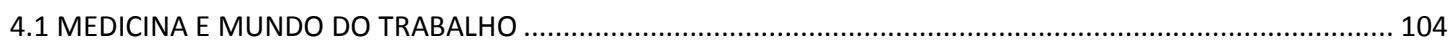

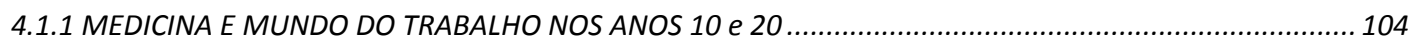

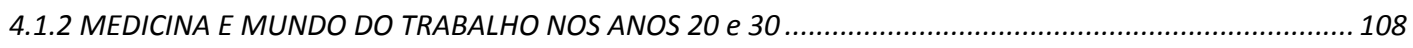

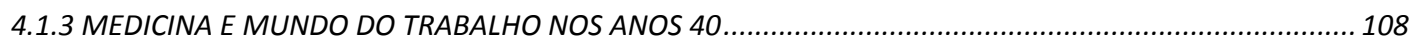

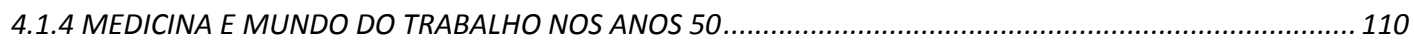

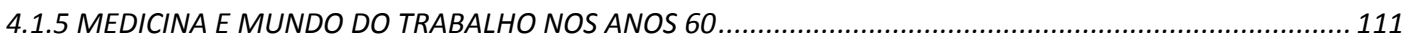

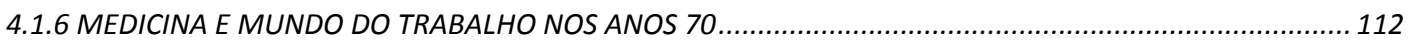

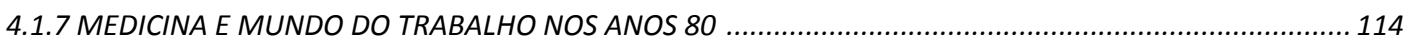

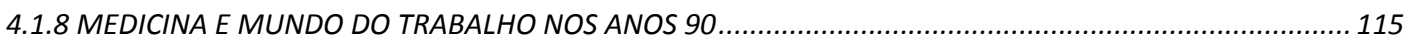

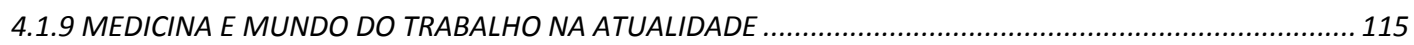

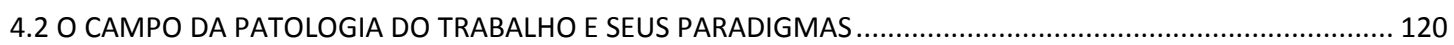

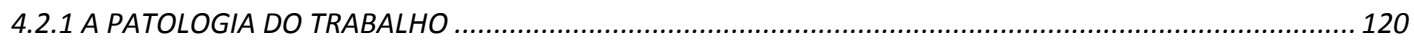

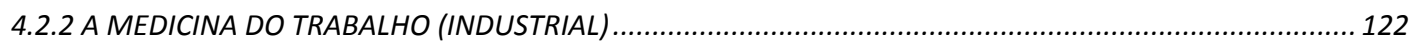

4.2.2.1 Abordagens / Paradigmas correlacionados ............................................................................... 122

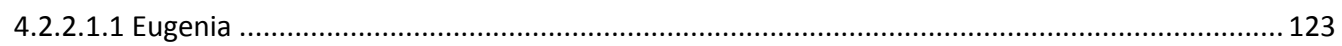

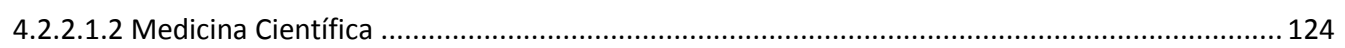

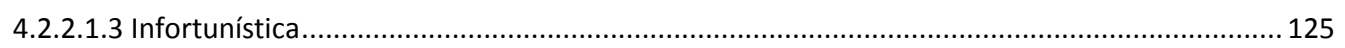

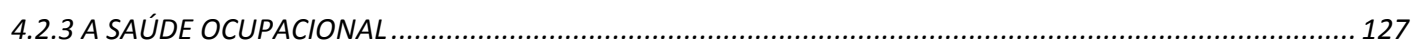

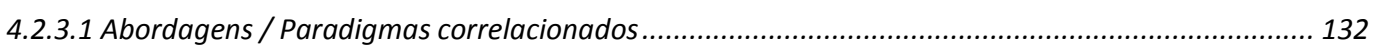

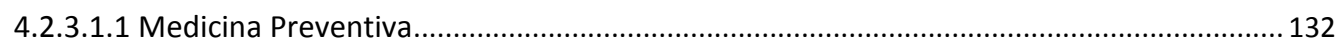


4.2.3.1.2 Ergonomia Tradicional ou Escola Anglo-Saxônica .............................................................. 134

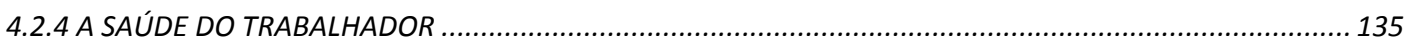

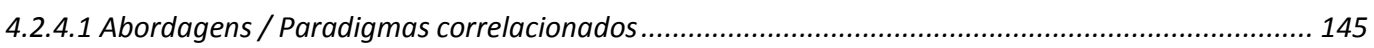

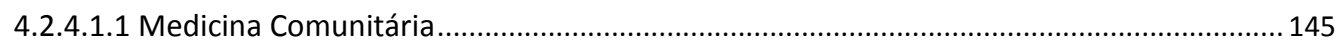

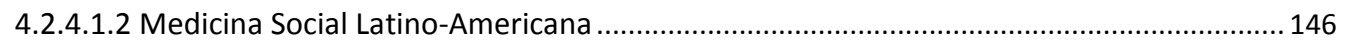

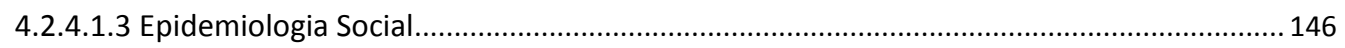

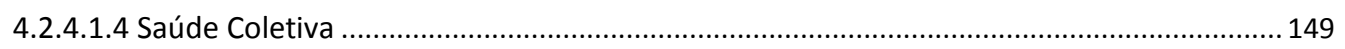

4.2.4.1.5 Ergonomia Situada ou Escola Francesa................................................................................. 152

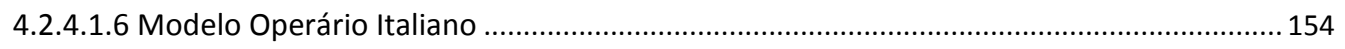

5. PSICOLOGIA E TRABALHO …….................................................................... 156

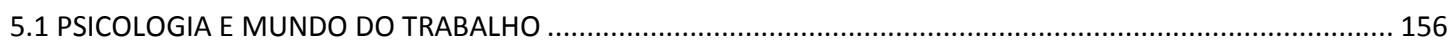

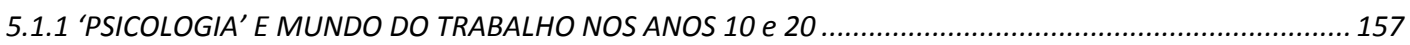

5.1.2 'PSICOLOGIA' E MUNDO DO TRABALHO NOS ANOS 20 e 30 ................................................................. 159

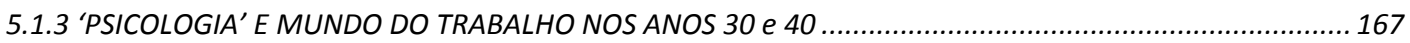

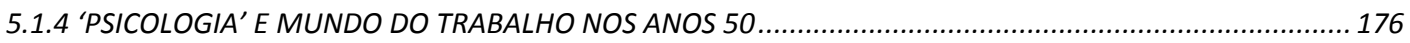

5.1.5 PSICOLOGIA E MUNDO DO TRABALHO NOS ANOS 60 e 70 .................................................................... 179

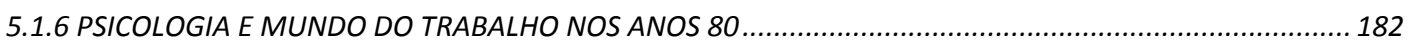

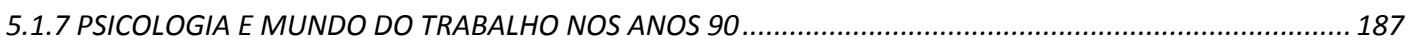

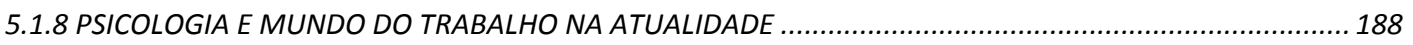

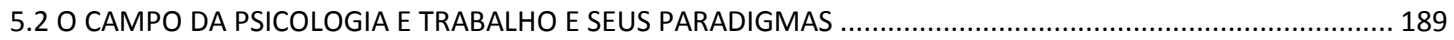

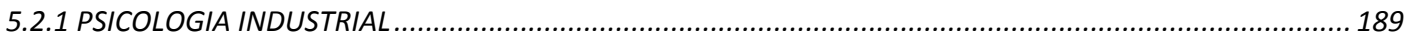

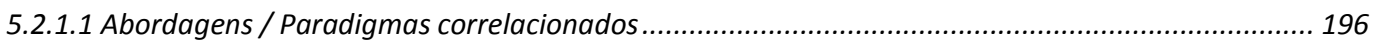

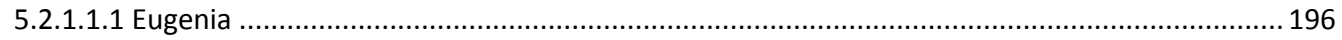

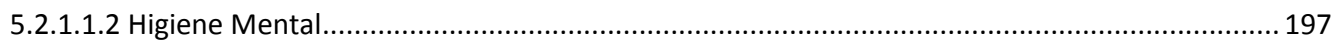

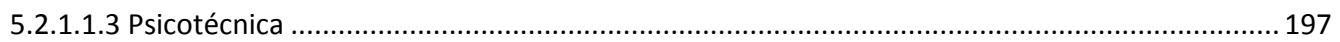

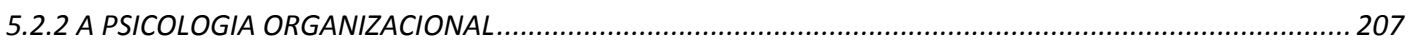

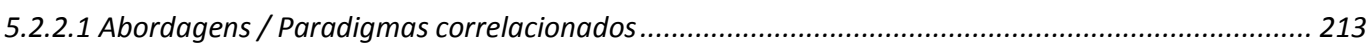

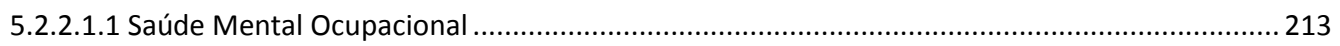

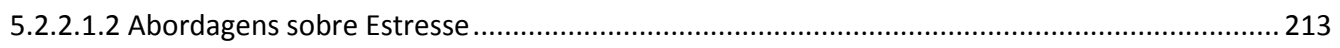

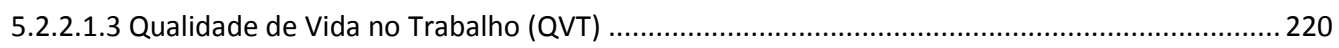

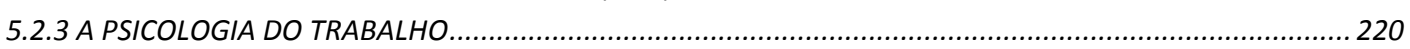

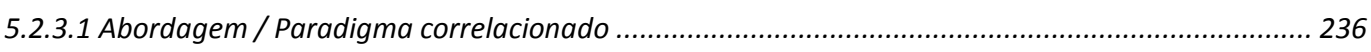

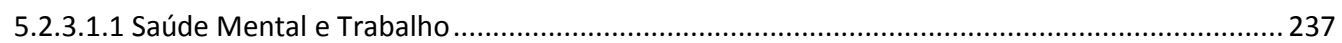

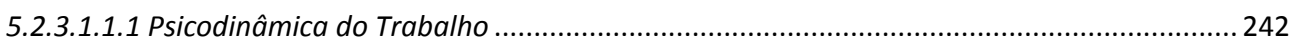

5.2.3.1.1.2 Modelos que adotam o conceito de desgaste mental........................................................ 244

5.2.3.1.1.3 Abordagens de base epidemiológica e/ou diagnóstica .................................................... 246

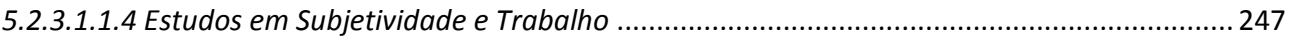

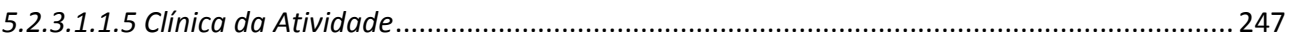

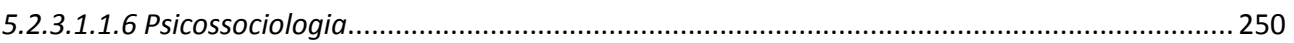

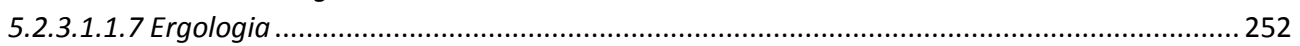

\section{OS TRANSTORNOS MENTAIS E DO COMPORTAMENTO RELACIONADOS AO}

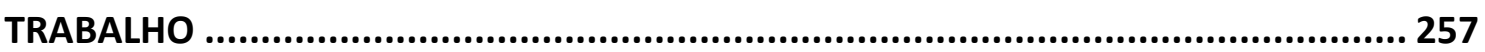

6.1 OS TRANSTORNOS MENTAIS E DO COMPORTAMENTO RELACIONADOS AO TRABALHO: DEFINIÇÃO E

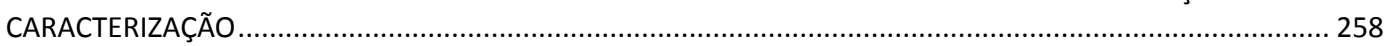

6.2 O MORAL, O MENTAL, O PSÍQUICO E SUAS RELAÇÕES COM O TRABALHO ……………………………........ 272

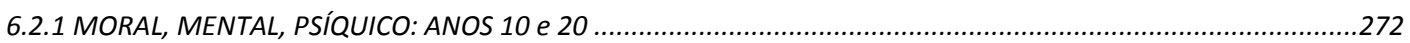

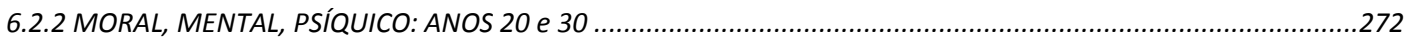

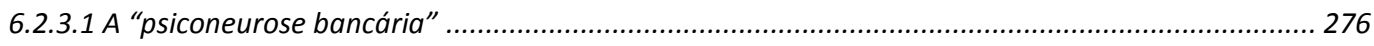

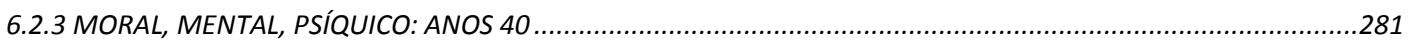

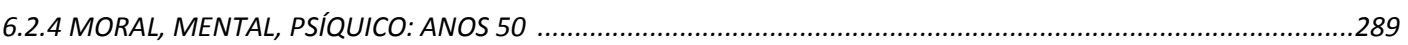

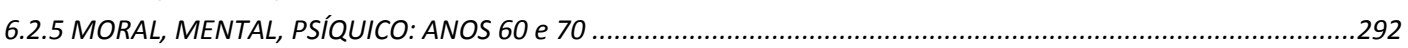

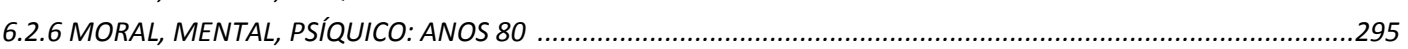

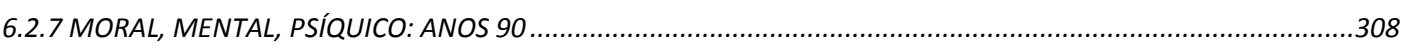


6.3 OS TRANSTORNOS MENTAIS E DO COMPORTAMENTO RELACIONADOS AO TRABALHO NA ATUALIDADE .... 312

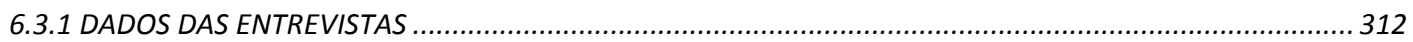

6.3.1.1 Em que momento / condições as discussões sobre as relações entre saúde mental e trabalho ganhariam visibilidade.

6.3.1.2 Atores importantes na discussão / reconhecimento dos Transtornos Mentais e do

Comportamento Relacionados ao Trabalho (TMC)...

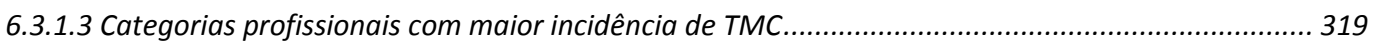

6.3.1.4 Aumento do reconhecimento e do "adoecimento" em T TMC..................................................... 319

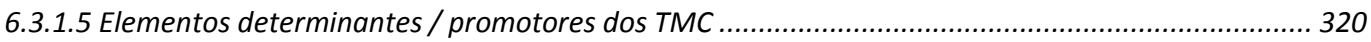

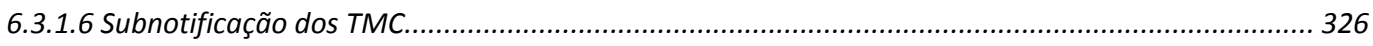

6.3.1.7 Caracterização dos TMC o como doença 'comum' '.................................................................. 327

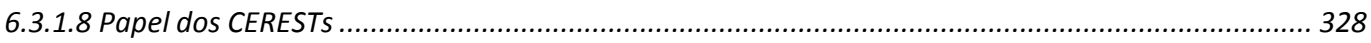

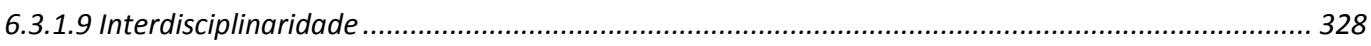

6.3.1.10 Concepções / noções sobre a categoria trabalho presentes no campo ........................................ 329

6.3.1.11 Estabelecimento do nexo ou relação com o trabalho dos T TMC ................................................ 331

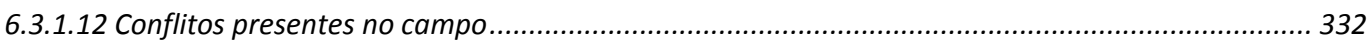

6.3.1.13 Dificuldades da atuação no campo da Saúde do Trabalhador e com os TMC .............................. 335

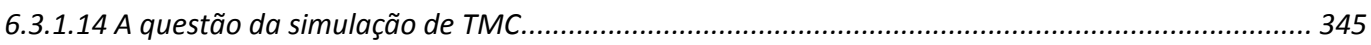

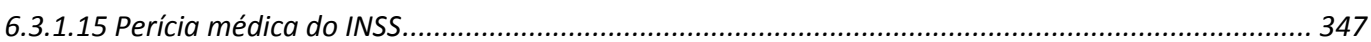

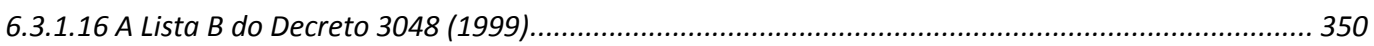

6.3.1.17 Questões conceituais e terminologias usadas com relação aos TMC na Lista B........................... 354

6.3.1.18 Manual "Doenças relacionadas ao trabalho: manual de procedimentos para os serviços de saúde" .... 356

6.3.1.19 NTEP - Nexo Técnico Epidemiológico Previdenciário (2007) ....................................................... 356

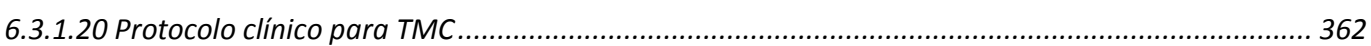

6.3.1.21 Papel e importância da Psicologia no campo da saúde e trabalho................................................ 367

6.3.1.22 Principais desafios no campo da Saúde do Trabalhador e quanto aos TMC.................................. 371

6.3.1.23 Principais avanços no campo da Saúde do Trabalhador e quanto aos TMC................................. 375

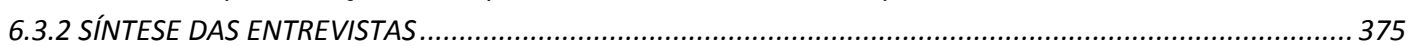

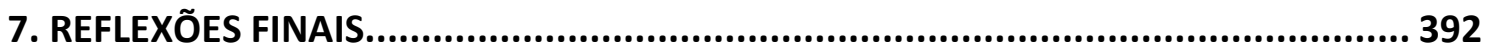

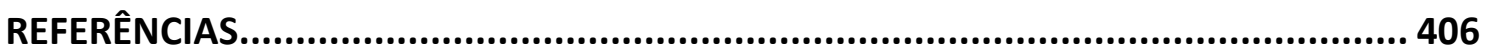

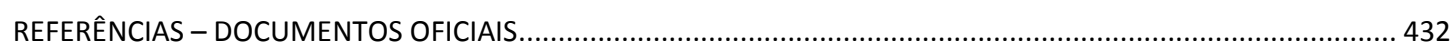

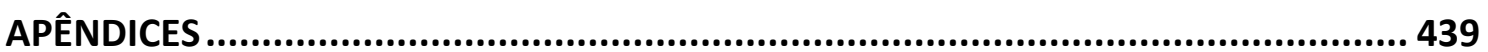

Apêndice A - Informações sobre as entrevistas e entrevistados .................................................................. 440

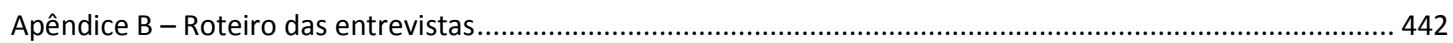

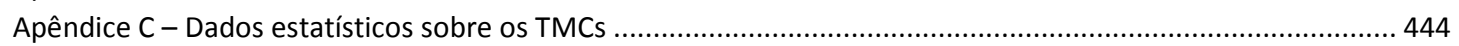

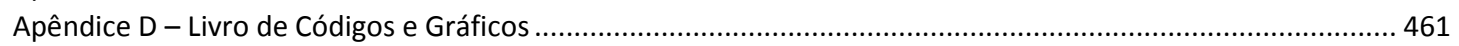

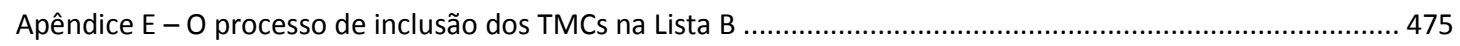

Apêndice $\mathrm{F}-\mathrm{O}$ processo de construção do protocolo para TMCs ................................................................... 477

Apêndice G - As Conferências Nacionais de Saúde do Trabalhador (CNST) ..................................................... 479

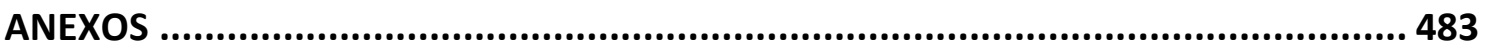

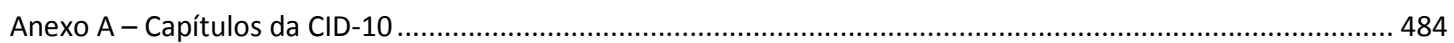

Anexo B - Transtornos Mentais e do Comportamento Relacionados com o Trabalho (Grupo V da CID-10)........ 485

Anexo C - Benefícios Acidentários Relacionados ao Trabalho ......................................................................... 488

Anexo D - Normas Regulamentadoras de Segurança e Saúde no Trabalho do Ministério do Trabalho................ 490

Anexo E - Psicólogo Especialista em Psicologia Organizacional e do Trabalho.................................................... 493 


\section{INTRODUÇÃO}

Para melhor situar a proposta de trabalho que se buscou desenvolver nessa tese de doutorado, gostaria de apresentar um pouco de minha trajetória e sua relação com a temática do trabalho (e da saúde e trabalho).

Venho de uma família em que quase todos os homens - inclusive meu pai - eram operários: do lado paterno, além de meu pai e meu avô, sete de meus oito tios trabalharam em indústria (na mesma siderurgia, a maior de Belo Horizonte); do lado materno, dois de meus quatro tios - um deles na mesma fábrica que meu pai -, os outros dois permanecendo no trabalho agrícola, em sua cidade natal. Nasci e morei boa parte de minha vida no Barreiro, região em que se concentra a maioria das instalações industriais de Belo Horizonte. Esse bairro (que é anterior à fundação de Belo Horizonte) veio a crescer, e se tornar uma das regiões mais populosas da cidade em virtude dessa alta concentração de instalações industriais, sendo a primeira a fábrica onde a maioria de minha família trabalhou. Ainda hoje essa fábrica é a maior empresa e a maior empregadora da região. Crescendo nesse ambiente, minha infância (minha vida) foi marcada pelos casos e "causos" que meus familiares contavam a respeito de seu trabalho.

Meu curso de graduação (Psicologia, na UFMG) pautou-se pela ênfase em disciplinas ligadas à Psicologia do Trabalho e Psicologia Organizacional. Os estágios que cursei envolviam atividades direta ou indiretamente ligadas à área. Minhas atividades de pesquisa (como bolsista de iniciação científica e de aperfeiçoamento, ou assistente de pesquisa contratada, ou voluntária) também o foram, notadamente na área de Saúde Mental e Trabalho.

A compreensão e o debate sobre as importantes relações entre o trabalho e a saúde mental desde cedo, em minha formação, tiveram destaque, determinando fortemente, de forma direta ou tangencial, minhas posteriores escolhas profissionais e teóricas - destacando-se o aperfeiçoamento em Saúde Mental e Trabalho, a atuação profissional que embasou minha dissertação de mestrado e, agora, o doutorado. Na graduação, no início dos anos 90, tive a oportunidade de acompanhar de forma 
próxima o intenso debate que as relações entre trabalho e saúde mental suscitavam, debate ainda "pioneiro" em certo sentido à época, como se verá neste trabalho. Ainda na graduação, tive oportunidade de conviver, estudar e trabalhar com profissionais representativos dessa discussão, participar como pesquisadora de campo de um estudo nacional também "pioneiro" sobre as relações entre trabalho e saúde mental de professores, ${ }^{1}$ e acompanhar também de perto a "epidemia" das LER (Lesões por Esforços Repetitivos), tanto em pesquisas ${ }^{2}$ como na atuação profissional no Centro de Referência em Saúde do Trabalhador (CERSAT) / Barreiro (Belo Horizonte).

Na trajetória acadêmica, após a conclusão da graduação, cursei um aperfeiçoamento em Saúde Mental e Trabalho, aprofundando estudos e discussões na temática. Iniciei também as atividades de docência em ensino superior, às quais venho me dedicando desde então. Em 2001, ingressei no mestrado em Sociologia da UFMG.

Profissionalmente, no período de 1997 a 2001, trabalhei como estagiária, e posteriormente psicóloga voluntária, no CERSAT, atuação sobre a qual comentarei (mais detalhadamente) a seguir.

Dediquei-me também a atividades de consultoria empresarial, onde a abordagem norteadora era de cunho psicossociológico. As atuações aconteceram em organizações públicas e privadas, atividades que foram descontinuadas quando de meu envolvimento com a extensão universitária, inicialmente como técnica, depois como assessora e, atualmente, como coordenadora geral de extensão. ${ }^{3}$ Atualmente, além

\footnotetext{
1 Pesquisa realizada em 1997/1998 pelo Laboratório de Psicologia do Trabalho da Universidade de Brasília, financiado pela Confederação Nacional dos Trabalhadores em Educação, que investigou mais de 52 mil sujeitos em 1.440 escolas de todo o país e que resultou na publicação, em 1999, pela editora Vozes, do livro "Educação - Carinho e Trabalho: Burnout, a síndrome da desistência do educador, que pode levar à falência da educação", organizado por Wanderley Codo.

2 Como, por exemplo, a pesquisa coordenada por José Newton Garcia de Araújo, "As representações sobre a LER e seus efeitos nas políticas de enfrentamento, vigilância, prevenção, tratamento e reabilitação", de 1999, financiada pelo CNPq.

3 Esse envolvimento progressivo, extremamente absorvente, é uma das razões do "hiato" temporal entre a conclusão do mestrado (em 2004) e o ingresso no doutorado (em 2011). Em 2010, antes do ingresso no doutorado (e já pensando em fazê-lo), tive a oportunidade de cursar uma disciplina ministrada pelo professor Francisco Antonio de Castro Lacaz, da UNIFESP ("Estado, Globalização, Reestruturação Produtiva e Saúde no Trabalho"). Nessa disciplina, se reafirmou e ganhou novos contornos meu interesse pelo campo de estudos da Saúde do Trabalhador, em especial da Saúde Mental e Trabalho, estimulando a retomada de minha formação acadêmica.
} 
das atividades extensionistas que coordeno, leciono no ensino superior, destacando-se minha atuação no curso de Psicologia, no qual supervisiono diversas práticas de estágio em saúde e trabalho.

No CERSAT/Barreiro, ${ }^{4}$ onde trabalhei por quatro anos, minha atuação consistia de ações de vigilância em Saúde do Trabalhador em empresas e atendimentos individuais, psicodiagnósticos e grupos de acompanhamento a usuários do serviço, sobretudo no atendimento a portadores de LER (Lesões por Esforços Repetitivos). Essa intensa participação no serviço levou-me à indagação sobre meu próprio papel e atuação como profissional de saúde, repensando as contradições e tensões entre os diferentes modelos de prática médica que presenciava em meu cotidiano, buscando compreender suas inter-relações, interdeterminações e lançar sobre elas outro olhar, buscando também certo distanciamento para problematizar noções e categorias como corpo, doença/saúde, dor, entre outras, até então percebidas como "naturais", dadas, da ordem dos fatos, e não como também construídas (inclusive nas práticas cotidianas de atendimentos), relacionais. Um olhar para o campo da saúde e trabalho, que pudesse fornecer outros elementos de análise e crítica, outras reflexões, tomando como foco as práticas e discursos dos profissionais de saúde. Essa outra abordagem do campo da saúde foi grandemente auxiliada pela perspectiva socioantropológica que busquei desenvolver em meu mestrado em Sociologia (UFMG).

A dissertação foi, ao mesmo tempo, a realização e o fruto desse distanciamento, na medida em que busquei na perspectiva socioantropológica outros modelos interpretativos, diferenciados de minha atuação em Psicologia e, em certa medida, foi também uma aproximação aprofundada, de outra ordem. O tema central da dissertação foi a discussão do processo de construção social das LER, investigando como as LER se constituíram como doenças. ${ }^{5}$ A abordagem desenvolvida foi a de tomar

\footnotetext{
4 O CERSAT/Barreiro é ligado ao SUS e à Secretaria Municipal de Saúde de Belo Horizonte, sendo suas atividades dirigidas à época pela Coordenação de Saúde do Trabalhador da citada Secretaria.

5 Como aponta Sato (2001, p. 149), “Essas lesões demandam a criação de práticas nos serviços públicos de saúde por parte de diversos profissionais de saúde [...], obrigando-os a criar uma linguagem de interface para trabalharem com as LER, sem que se percam as especificidades de suas formações de origem." E prossegue:

[...] para muito além de um nome que designa uma determinada patologia, ela [LER] expressa uma série de significados construídos na dinamização de processos sociais, mediante diversos desafios e questionamentos: do
} 
a LER como um caso representativo das doenças do trabalho, como categoria de estudo e objeto de intervenção.

As LER, como relatado por diversos autores, ${ }^{6}$ envolviam, além das questões ligadas à corporalidade e "materialidade" da doença, aspectos psicossociais. O campo "psi" sempre esteve a elas ligado, como o apontam os mencionados estudos. Esse envolvimento com as LER e com o campo teórico da Saúde Mental e Trabalho (tanto no atendimento aos trabalhadores, naquela época, como em minha prática como professora universitária e supervisora de estágios na área) despertou meu interesse pela indagação de como teriam se constituído, como categoria, os Transtornos Mentais e do Comportamento Relacionados ao Trabalho.

Esse interesse se deveu, à época, às observações cotidianas que fazíamos sobre os quadros de transtornos / sofrimento / distúrbios psíquicos que frequentemente acompanhavam os diagnósticos de LER. Um intenso debate se estabelecia sobre se os fatores "psicossociais" / psicológicos observados eram "causa" ou "consequência" da instalação do quadro de LER. ${ }^{7}$ Até mesmo no CERSAT, onde predominava uma abordagem mais pautada pela corrente teórica da Saúde do Trabalhador, frequentemente as pacientes portadoras de LER (a grande maioria dos casos atendidos no serviço) eram alcunhadas de "donas tristes", por apresentarem, além da LER, quadros poliqueixosos, que incluíam, por vezes, hipertensão, problemas cardíacos, diabetes e, na maioria dos casos, transtornos/sofrimento/distúrbios psíquicos. Havia a percepção, pelos profissionais da equipe, de que as LER e seu tratamento

conhecimento acumulado e da prática informada pelas diversas áreas do conhecimento; das práticas costumeiras por parte das gerências das empresas, dos trabalhadores, do movimento sindical, dos profissionais de saúde e da academia (SATO, 2001, p. 151).

${ }^{6}$ Conferir, entre outros: Almeida (1995a, 1995b); Alves (1997); Alves (2001); Araújo (1997, 2001); Araújo e Nunes (1997); Araújo et al. (1997, 1999); Baird (1996); Bammer e Martin (1988, 1992, 1996); Chiesa et al. (2002); Dwyer (2000); Galery (1998); Glina et al. (2001); Guimarães e Grubits (1999); Jardim e Silva Filho (1997); Lima (1996a, 1997, 2000); Lima (2001); Lima e Oliveira (1995); Merlo (2002); Merlo et al. (2000); Merlo, Jacques e Hoefel (2001); Monteiro (1997); Nunes e Mendes (2002); Oliveira e col. (1997); Orso et al. (2001); Pêgo, Carneiro e Almeida (1997); Pennella (2001); Pinheiro, Troccoli e Carvalho (2002); Pintos (1992); Sato (2001); Sato e col. (1993); Settimi et al. (2000a, 2000b, 2000c, 2000d, 2001); Settimi e Silvestre (1995); Verthein (2001); Verthein e Minayo-Gomez (2000a, 2000b, 2001).

7 A esse respeito, conferir, por exemplo: Almeida (1995a, 1995b); Alves (2001); Araújo (1997); Bammer e Martin (1988, 1992, 1996); Lima (1995, 1997); Lima e Oliveira (1995); Lucire (1986, 1988, 2003a, 2003b). 
ultrapassavam a clínica médica, eram também "coisa de psicólogo" ou, por vezes, apenas "coisa de psicólogo". Além das questões inerentes à origem da doença, havia também as decorrentes do sofrimento causado pelas intensas e constantes dores físicas, pelas limitações para atividades da vida diária e as decorrentes das rupturas introduzidas pelo afastamento (temporário ou permanente) do trabalho. ${ }^{8}$ Nossa própria presença no serviço - eu e outro psicólogo, também voluntário - devia-se à demanda da equipe de uma abordagem psicossocial para o enfrentamento da "epidemia" de LER atendida pelo serviço: em 1988, 84\% do total de casos atendidos; em 2000, 86\%; em 2002, 78\% e em 2003, 75\% (ALVES, 2004). Essa intensa experiência vivida no CERSAT, no atendimento das LER, só acentuou meu (já grande) interesse pelos agora chamados Transtornos Mentais e do Comportamento Relacionados ao Trabalho.

Apesar do meu interesse por eles estar sempre presente em minhas leituras e atuação profissional, a proposta de trabalho originalmente pensada para o doutorado era a de uma abordagem mais ampla sobre as doenças relacionadas ao trabalho, sendo os Transtornos Mentais e do Comportamento Relacionados ao Trabalho um caso específico que iluminasse essa discussão.

Contudo, a vivência na disciplina cursada na UNIFESP com o professor Francisco Lacaz, as disciplinas cursadas no doutorado, ${ }^{9}$ a convivência e frequentes debates com o grupo de orientandos de Leny Sato, minha pertinência de origem e inserção no campo foram moldando (ou definindo) minhas inquietações teóricas para a delimitação de um problema/objeto do campo "psi" - os Transtornos Mentais e do Comportamento Relacionados ao Trabalho. Do campo "psi" e de outros campos, na medida em que não se estão discutindo questões intrapsíquicas ou similares, mas um fenômeno eminentemente sócio-histórico, intrinsecamente relacionado ao trabalho.

Também contribuem para esse interesse a complexidade das discussões referentes aos Transtornos Mentais e do Comportamento Relacionados ao Trabalho, inclusive com concepções teóricas em controvérsia, e os crescentes e expressivos números de casos

\footnotetext{
8 Fenômeno chamado por Seligmann-Silva (1994) de "psicopatologia do afastamento".

9 “História, Memória e Temporalidade", com o professor José Antônio Vasconcelos (FFLCH/USP) e "A Memória das Testemunhas", com a professora Ecléa Bosi (IP/USP).
} 
diagnosticados nos últimos anos, que os colocam como a terceira causa no país de concessão de benefícios previdenciários, como auxílio-doença (referente a afastamento do trabalho por período superior a 15 dias) ${ }^{10}$ e aposentadorias por invalidez.

Embora a discussão teórica sobre a temática da saúde mental e trabalho venha ocorrendo no Brasil desde o início da década de 1980 (SATO; BERNARDO, 2005), é de 1999 o Decreto $\mathrm{n}^{\circ}$ 3.048, que trata do regulamento da Previdência Social, reconhecendo 12 categorias diagnósticas de transtornos mentais e do comportamento relacionados ao trabalho (ocasionados por agentes etiológicos de natureza química, bem como decorrentes da organização do trabalho). A publicação desse decreto e mudanças subsequentes na legislação previdenciária brasileira (que serão discutidas na tese) fazem com que o número de casos diagnosticados e passíveis de benefícios previdenciários do tipo acidentário (relacionados ao trabalho) aumente exponencialmente, e que o debate a respeito dos transtornos mentais e do comportamento relacionados ao trabalho ganhe novos contornos.

Além disso, os transtornos mentais e do comportamento são apontados como de difícil caracterização "objetiva e 'científica', até porque a medicina ainda não consegue lidar bem com eles" (MENDES, 2005, apud SILVA, 2011, p. 6); há dificuldades de se estabelecer o nexo causal entre os quadros de adoecimento e o trabalho, bem como "dificuldades decorrentes da interdisciplinaridade que envolve esta temática" (SELIGMANN-SILVA, 2005, p. 301).

O problema de pesquisa desta tese seria, então, investigar como, historicamente, e a partir de quais relações entre representações e práticas, começam a se reconhecer como categoria os "Transtornos Mentais e do Comportamento Relacionados ao Trabalho".

Como objetivos específicos, busca-se compreender como essa categoria diagnóstica passa a fazer parte das políticas públicas - e notadamente, da legislação - referentes

\footnotetext{
10 Recentemente foi publicada pela Presidência Medida Provisória (MP) que redefine esse prazo para 30 dias (Medida Provisória $n^{\circ}$ 664, de 30 de dezembro de 2014. Altera as Leis $n^{\circ} 8.213$, de 24 de julho de $1991, n^{\circ} 10.876$, de 2 junho de 2004, $n^{\circ} 8.112$, de 11 de dezembro de 1990, e a Lei $n^{\circ} 10.666$, de 8 de maio de 2003). Contudo, essa MP e seus efeitos / desdobramentos, dado seu caráter muito recente, não foram contemplados na tese.
} 
à relação saúde/trabalho, ${ }^{11}$ como também discutir de que forma os Transtornos Mentais e do Comportamento Relacionados ao Trabalho implicam e são implicados no aparecimento de uma estrutura conceitual voltada a seu tratamento. Busca-se também situar a discussão sobre os Transtornos Mentais e do Comportamento Relacionados ao Trabalho no contexto das relações entre Medicina e trabalho e seus diferentes paradigmas - a Medicina Industrial (do Trabalho), a Saúde Ocupacional e a Saúde do Trabalhador - , bem como os paradigmas referentes ao campo psi implicados - Psicologia Industrial, Psicologia Organizacional, Psicologia do Trabalho e como se dá sua inserção e posicionamento nesse campo.

\subsection{CONSIDERAÇÕES PARA A LEITURA DA TESE}

A discussão dos Transtornos Mentais e do Comportamento Relacionados ao Trabalho é temática complexa, que envolve concepções teórico-políticas distintas/polêmicas, num campo em que estão presentes contradições e tensões entre diferentes concepções a respeito do trabalho, da saúde e do "mental" / "psíquico". Nesse sentido, faz-se importante deixar claras as premissas a partir das quais meus interesses técnicopráticos e de pesquisa se orientam e que motivaram a escrita desta tese, as abordagens teóricas às quais me filio e que serão apresentadas neste trabalho. A perspectiva a partir da qual discuto e considero as relações entre saúde e trabalho é a da Saúde do Trabalhador, especificamente participando desse campo a partir dos olhares da Psicologia do Trabalho e da Saúde Mental e Trabalho, ${ }^{12}$ e do conceito de determinação social do processo saúde-doença.

Outra questão a esclarecer é o porquê da utilização do termo "trabalhador" em detrimento de "operário" na maior parte desse trabalho, mesmo que a maioria da bibliografia consultada (sobretudo a que debate o período dos anos 10 aos anos 70) utilize "operário". Gradualmente, como se discutirá nesta tese, as tecnologias de organização do trabalho concebidas para o contexto fabril vão se estender, ainda no

\footnotetext{
11 Ou, como coloca Silva (2011), "entender como esse grupo diagnóstico foi incluído na agenda das políticas públicas no campo da Saúde do Trabalhador".

12 Essa é a perspectiva que também orienta as práticas desenvolvidas no CERSAT / Barreiro, onde atuei, e que ainda norteia minha prática como supervisora de estágios em um curso de graduação em Psicologia.
} 
início do século $\mathrm{XX}$, para outros contextos laborais (como os analisados por Bertolli Filho, 1993). E quando se fala do trabalhador, o foco de análise desta tese é o trabalhador urbano.

Inegavelmente o trabalhador rural constitui importante objeto de estudo, no que tange aos Transtornos Mentais e do Comportamento Relacionados ao Trabalho. Bastaria apenas considerar, por exemplo, sua exposição aos agrotóxicos (conhecidos agentes etiológicos). Contudo, até os anos 80, quando começa (rapidamente) a declinar, o contingente de trabalhadores urbanos industriais vai progressivamente aumentar em percentuais, alcançando o auge nos anos 70. Também é para o trabalho urbano (notadamente o industrial) que os discursos teórico-científicos aqui estudados foram originalmente voltados.

Quanto às subdivisões temporais (cronológicas) dos capítulos, têm por objetivo a organização do texto e sua leitura, bem como assinalar mudanças de paradigmas ou concepções no campo científico ou transformações político-econômico-sociais. Contudo, deve-se registrar que esse recurso didático não pretende confinar os acontecimentos/eventos discutidos em uma camisa de força temporal, uma vez que se discutem processos históricos, que muitas vezes têm suas primeiras manifestações em períodos anteriores aos demarcados no texto, e estendem sua influência aos períodos seguintes. Também se observam, nesse sentido, ressurgimentos ou retomadas de discursos e práticas, em determinados momentos, representativos ou típicos de períodos anteriores aos assinalados.

Nesta análise de recorte histórico não se busca apresentar uma visão linear, contínua ou teleológica (em termos do campo científico), como se discutirá no Capítulo 2. Portanto, os períodos indicados devem ser tomados como referência, não como "continentes". Por esse motivo, também, às vezes se apresentam marcações temporais que aparentemente se superpõem, como "anos 10 e 20" e "anos 20 e 30". Com isso se busca indicar a coexistência ou a transição de determinadas formações discursivas no campo científico ou nos processos sociopolíticos.

Até o Capítulo 6, "Transtornos Mentais e do Comportamento Relacionados ao Trabalho", não se usará essa terminologia. Como se discutirá nesta tese, parte-se do princípio de que as diferentes terminologias empregadas ao longo da história - 
distúrbio, sofrimento, transtorno, de ordem moral, mental, psíquica - mobilizam diferentes representações sobre saúde e doença, etiologia, diagnóstico e tratamento. Essas representações e nomenclaturas evocam quadros clínicos e sintomatológicos descritos, estudados e mesmo vivenciados de forma diferenciada. A terminologia Transtornos Mentais e do Comportamento Relacionados ao Trabalho só será utilizada, dessa forma, após seu reconhecimento legal por meio do Decreto $n^{\circ} 3.018$, de 1999.

Além de serem a Saúde do Trabalhador, a Psicologia do Trabalho e a Saúde Mental e Trabalho as abordagens às quais me filio teoricamente, o que se discute também nesta tese - por vezes diretamente, por vezes tangencialmente - é o embate no campo de saúde e trabalho entre concepções epistemológicas, teóricas, políticas e práticas distintas - aqui agrupadas / discutidas em dois polos - Saúde do Trabalhador / Psicologia do Trabalho / Saúde Mental e Trabalho e Medicina do Trabalho-Saúde Ocupacional / Psicologia Industrial - Psicologia Organizacional/QVT-Estresse.

Como se discutirá, o polo hegemônico nos meios empresariais e serviços de medicina de empresa é o segundo. Na rede privada constituída pelos serviços assistenciais próprios das empresas, clínicas ou serviços de medicina de grupo e de seguro saúde, "cooperativas médicas, entidades filantrópicas, profissionais liberais em seus consultórios particulares, destacando-se os Serviços Especializados em Segurança e Medicina do Trabalho (SESMT)" (DIAS, 1995, p. 75), há o predomínio dessa abordagem. O discurso pericial (do INSS ou dos peritos "particulares" convocados pela Justiça do Trabalho) também é fortemente por ela informado. Esse polo possui ampla produção teórico-técnica, ampla repercussão midiática e muitas vezes conforma o senso comum. Essa abordagem é muito presente e atuante no campo, e é, em parte, desse embate que esta tese trata.

O outro polo - Saúde do Trabalhador/Psicologia do Trabalho/Saúde Mental e Trabalho - está mais presente na academia (universidades), movimento sindical e na rede pública de serviços de saúde, "onde se destacam [...] os Centros de Referência em Saúde do Trabalhador [CERESTs] e os Serviços Especializados existentes nos Hospitais Universitários" (DIAS, 1995, p. 75). A própria área responsável pela formulação de políticas públicas no Ministério da Saúde (Coordenação Geral de Saúde do Trabalhador 
- CGSAT) é denominada "Saúde do Trabalhador" (e não Medicina do Trabalho-Saúde Ocupacional).

Por opção metodológica, a partir dos anos 80, a vertente Medicina do Trabalho-Saúde Ocupacional / Psicologia Industrial - Psicologia Organizacional / QVT-Estresse só será abordada como contraponto às proposições / conceitos / práticas da vertente Saúde do Trabalhador / Psicologia do Trabalho / Saúde Mental e Trabalho. Mesmo incorrendo no risco de uma abordagem mais superficial ao não inventariar com tanto destaque a multiplicidade da primeira vertente, esta é uma tese essencialmente calcada e orientada para a discussão dos Transtornos Mentais e do Comportamento Relacionados ao Trabalho a partir e por meio das abordagens da Saúde do Trabalhador, Psicologia do Trabalho, Saúde Mental e Trabalho. São os movimentos, lutas, embates, conquistas desse polo que mais interessam a essa tese, em razão das concepções de saúde e doença, de processo de saúde e doença, de atuação multi/interdisciplinar, de participação dos trabalhadores que permeiam - ao menos discursivamente - a atual política pública de Saúde do Trabalhador do país e os equipamentos a ela destinados, como os CERESTs, e cuja emergência como movimento e atuação (produção de pesquisas, reivindicações sindicais, reivindicações por políticas públicas, atuação na reforma sanitária) propiciam (temos como hipótese) condições de possibilidade para o reconhecimento legal dos Transtornos Mentais e do Comportamento Relacionados ao Trabalho, atuando seus representantes como protagonistas nesse processo.

Neste trabalho, foi priorizada a atenção a períodos "pretéritos", notadamente a primeira metade do século XX. Essa opção se deveu a algumas razões, mesmo que o resultado do trabalho possa parecer, no final, desigual no tratamento dos períodos analisados. Primeiramente, há uma vasta e rica produção bibliográfica nacional sobre as relações entre saúde e trabalho, notadamente a partir dos anos 80/90. Essa produção, por sua vez, vem sendo objeto de análise de diversas dissertações e teses que discutem a temática, algumas delas consultadas para a elaboração deste trabalho. Por outro lado, a perspectiva de realizar uma "genealogia" dos Transtornos Mentais e do Comportamento Relacionados ao Trabalho exigiria uma perspectiva que focasse aspectos pretéritos desse campo discursivo. A escolha pelo início da análise recaiu 
sobre o início do século $\mathrm{XX}$, dado o contexto sociopolítico-econômico (discutido no Capítulo 3). Contudo, deve-se destacar que esta escolha, como outras, é arbitrária, uma vez que seria impossível delimitar a "origem" ou ponto inicial de determinado campo discursivo. Por se tratar de temática até então desconhecida para mim (no que tange às formulações da Medicina e da Psicologia), houve maior dedicação ao trabalho de pesquisa e garimpo de informações sobre as décadas iniciais do século XX e, proporcionalmente, menor a períodos históricos mais recentes e correndo o risco, dessa forma, de apresentar análise ainda mais lacunar.

Em virtude do tema central desta tese, os Transtornos Mentais e do Comportamento Relacionados ao Trabalho, são enfatizadas discussões que trazem a doença, a perturbação, o transtorno ou o sofrimento mental ou psíquico relacionado ao trabalho. Contudo, deve-se destacar que, no processo saúde-doença, o trabalho também pode atuar como promotor de saúde e realização; dimensão estruturante do trabalho seria "portadora de identidade e conformadora da subjetividade", apresentando "formas de vida em movimento no trabalho, na plasticidade humana na cena laboral" (ARAÚJO, 2011, p. 332).

Outra questão não abordada, dados os limites impostos a todo trabalho de pesquisa, é a discussão a respeito da "doença dos nervos", sempre tangenciada, e que guarda íntima relação com a discussão dos Transtornos Mentais e do Comportamento Relacionados ao Trabalho. ${ }^{13}$

\subsection{O PLANO DA TESE}

Feitas essas considerações, propõe-se um trabalho de análise nesta tese a partir da seguinte organização:

No capítulo 2, Considerações teórico-metodológicas, busca-se explicitar como minha leitura teórica informa os fenômenos pesquisados, quais as premissas a partir das quais se deu a construção do problema de pesquisa, e de como o campo da saúde - e da saúde mental - constitui objeto de pesquisa. Discutem-se também os procedimentos metodológicos utilizados na construção da tese.

\footnotetext{
13 A esse respeito, conferir a obra seminal de Luiz Fernando Dias Duarte, Da vida nervosa das classes trabalhadoras urbanas (1988).
} 
Nos capítulos 3 (Aspectos Políticos e Socioeconômicos), 4 (Medicina e Trabalho) e 5 (Psicologia e Trabalho), escrevem-se/narram-se panoramas históricos, ainda que lacunares, de campos ou dimensões que possuem sua especificidade própria, suas estratégias de legitimidade (no caso das ciências), que correm de forma independente, mas que mantêm relações de interdeterminação sem, contudo, se fundirem/subsumirem uns aos outros.

Os capítulos 4 (Medicina e Trabalho) e 5 (Psicologia e Trabalho) são subdivididos em duas seções. Na primeira, busca-se traçar esse panorama histórico na perspectiva da discussão das aproximações desses campos científicos com o mundo do trabalho; na segunda seção, apresentam-se paradigmas ou modelos teóricos que percorrem, influenciam, determinam essas aproximações. Essas seções também podem ser lidas de forma independente.

Esses modelos ou paradigmas científicos convocados ao campo não se restringem ou resumem a ele; diferentes arranjos teóricos-discursivos vão se configurando, sem que se configure uma "convivência pacífica" ou sucessão natural - são por vezes conflitantes - sendo a cada momento convocados de formas diferentes, com propósitos e interesses político-teóricos distintos. Esses modelos ou paradigmas não se atêm, dessa forma, a uma determinação histórico-temporal, como a esboçada por motivos prático-didáticos na tese.

No capítulo 6, a proposta é discutir os Transtornos Mentais e do Comportamento Relacionados ao Trabalho, tratados como tema com múltiplos atravessamentos e desdobramentos, um "campo de acontecimentos" (FOUCAULT, 1995a, p. 180), um ponto de encontro ou convergência (entre outros) das medicinas, das psicologias, políticas de Estado, produção acadêmica, atuação dos serviços de saúde e dos movimentos dos trabalhadores, de transformações políticas e econômicas e do contexto produtivo. Esse capítulo se divide, por sua vez, em três seções: na primeira, são trazidas informações a seu respeito, dados e estatísticas sobre sua incidência e os quadros nosológicos que os compõem. Na segunda seção, é traçado um panorama cronológico (ainda que lacunar) de como as relações entre trabalho e saúde/doença mental vêm sendo abordadas, tratadas, apreendidas a partir do início do século XX; as concepções de saúde/doença, de causalidade e nexo implicadas; os diversos grupos de 
interesse e os profissionais "legitimamente" envolvidos na questão. Por fim, na terceira seção, retoma-se a discussão iniciada no primeiro plano, buscando problematizá-los na atualidade ${ }^{14}$ em diversas dimensões, a partir dos dados das entrevistas realizadas no trabalho de campo.

Por fim, no capítulo 7, "Reflexões Finais", faz-se um balanço do percurso seguido e dos resultados encontrados, além de se estabelecer uma reflexão a respeito das implicações políticas decorrentes das escolhas metodológicas.

Nos Apêndices, encontram-se informações sobre as entrevistas e entrevistados (Apêndice A), o roteiro das entrevistas semiestruturadas (Apêndice B), dados estatísticos sobre os Transtornos Mentais e do Comportamento Relacionados ao Trabalho (Apêndice C) e o livro de códigos e gráficos resultantes do tratamento dos dados do trabalho de campo (Apêndice D), um relato sobre o processo de inclusão dos Transtornos Mentais e do Comportamento Relacionados ao Trabalho na Lista B do Decreto 3048 (Apêndice E), um relato sobre o processo de construção do protocolo para Transtornos Mentais e do Comportamento Relacionados ao Trabalho (Apêndice F) e uma descrição dos principais aspectos discutidos em cada uma das Conferências Nacionais de Saúde do Trabalhador (Apêndice G).

Nos anexos, encontram-se os Capítulos da CID-10 (Anexo A), a relação dos Transtornos Mentais e do Comportamento Relacionados com o Trabalho e seus respectivos agentes etiológicos (Anexo B), a caracterização dos Benefícios Acidentários Relacionados ao Trabalho (Anexo C), relação das Normas Regulamentadoras de Segurança e Saúde no Trabalho do Ministério do Trabalho e Emprego (Anexo D), bem como a Definição do Conselho Federal de Psicologia da especialidade Psicologia Organizacional e do Trabalho (Anexo E).

Nos Capítulos 3 a 5, em se tratando de elementos, concepções, domínios que interdeterminam, apresentam-se algumas possibilidades ou alternativas de leitura da tese.

\footnotetext{
14 Diferentemente dos Capítulos 4 e 5, a questão dos Transtornos Mentais e do Comportamento Relacionados ao Trabalho na atualidade não é debatida na mesma seção em que se traça o panorama histórico; por se constituir no objeto central da tese, será tratada em seção específica.
} 
- Uma leitura linear dos Capítulos 3, 4 e 5, seguindo a ordem das seções dos capítulos, podendo ser lidos de forma independente e não sequencial.

- Uma leitura temporal dos Capítulos 3, 4 e 5, por décadas ou períodos históricos afins, podendo ser lidos de forma independente e não sequencial.

- Uma leitura dos capítulos 4 e 5 pautada pelos modelos teóricos que conformam o campo, tendo como pares correspondentes Medicina do Trabalho-Psicologia Industrial, Saúde Ocupacional-Psicologia Organizacional, Saúde do Trabalhador-Psicologia do Trabalho. 


\section{CONSIDERAÇÕES TEÓRICO-METODOLÓGICAS}

Uma prática científica que se esquece de se pôr a si mesma em causa não sabe, propriamente falando, o que faz (BOURDIEU, 1989, p.35).

Nesse capítulo, busca-se explicitar como a leitura teórica informou os fenômenos pesquisados, quais as premissas a partir das quais se deu a construção do problema de pesquisa, e como o campo da saúde - e da saúde mental - se constituiu como objeto de pesquisa. Discutem-se também os procedimentos metodológicos utilizados na construção da tese.

\subsection{CONSIDERAÇÕES TEÓRICO-EPISTEMOLÓGICAS}

Propõe-se investigar como práticas políticas, econômicas e sociais fazem parte das condições de emergência e funcionamento de discursos científicos, no caso, sobre os Transtornos Mentais e do Comportamento Relacionados ao Trabalho, buscando a compreensão do processo de construção social da doença. Pretende-se tratar o tema "metodologicamente como um campo dinâmico de disputas e analisá-lo enquanto conjunto de discursos e de práticas inter-relacionados" (CARRARA, 1996, p. 288). Em sua pesquisa sobre a construção social das doenças venéreas, em especial a sífilis, o autor delimitou esse campo em dois níveis diferenciáveis:

a) o nível do campo científico ligado à doença, com seus vários grupos socioprofissionais, seus acordos e divergências teóricos, as relações de reciprocidade e de subordinação que mantêm entre si e em sua articulação com forças presentes em outros espaços sociais, as relações entre o campo médico-científico e o campo social envolvente.

b) o nível das estratégias de legitimação do trabalho dos profissionais da saúde, discutindo tanto os recursos presentes em seu próprio meio quanto os provenientes de outras esferas (políticas, econômicas, jurídicas etc.). Busca-se apontar como representações de saúde e doença são engendradas também no debate entre os diversos grupos de interesse desse campo, sendo produto também de determinações econômicas e político-ideológicas. 
Busca-se neste trabalho discutir como as "doenças", especificamente aquelas relacionadas ao trabalho (no caso, os Transtornos Mentais e do Comportamento Relacionados ao Trabalho), refletem, além de critérios diagnósticos, aspectos mais abrangentes. Tratar-se-ia, então, de uma proposta de análise do conhecimento produzido sobre os Transtornos Mentais e do Comportamento Relacionados ao Trabalho e a construção dessa categoria.

Para caracterizar os diversos grupos de interesse envolvidos na questão, toma-se aqui, como definição de campo, a proposta por Bourdieu (1989): um espaço multidimensional em que se organizam relações de poder e de dominação, onde se travam lutas concorrenciais em torno de seu capital específico, cujo estado se define, a cada momento, a partir das relações de força entre seus protagonistas - agentes ou instituições, cujas representações variam de acordo com sua posição e com os interesses a ela associados. A estrutura do campo, num dado momento da história, mostraria as relações de força entre os agentes. Cada campo é dotado de um móvel de disputa específico e tem uma história própria.

O campo científico, segundo Bourdieu (1989), é o lugar de um jogo concorrencial onde o objeto de disputa é o monopólio da autoridade científica. Ou seja, "o monopólio da competência científica, compreendida como capacidade de falar e agir legitimamente que é socialmente outorgada a um agente determinado" (BOURDIEU, 1989, p. 122-123).

No estudo em questão, propõe-se uma análise do campo científico ligado às doenças do trabalho, com seus vários grupos socioprofissionais, seus acordos e divergências teóricas, a diversidade de discursos (representações e posturas político-ideológicas) e de práticas deles decorrentes, bem como das ações dos atores sociais envolvidos. Como coloca Carvalho (2011, p. 33), entende-se aqui o discurso como produção social, pois "é somente no interior das relações sociais de produção que um discurso científico ${ }^{15}$ pode ser entendido em profundidade e até mesmo 'julgado'”.

Nesse sentido, a análise se aproxima da perspectiva enunciada por Foucault:

\footnotetext{
15 “Um saber se define por possibilidades de utilização e de apropriação oferecidas pelo discurso. Há saberes que são independentes das ciências [...]; mas não há saber sem uma prática discursiva definida, e toda prática discursiva pode definir-se pelo saber que ela forma" (FOUCAULT, 1995a, p. 206).
} 
Quando [a análise] se dirige a um tipo singular de discurso [...] é para estabelecer, por comparação, seus limites cronológicos: é também para descrever, ao mesmo tem tempo que eles e em correlação com eles, um campo institucional, um campo de acontecimentos, de práticas, de decisões políticas. [...] Mas pode também, por uma espécie de aproximação lateral [...], utilizar várias positividades distintas, cujos estados concomitantes são comparados durante um período determinado e confrontados com outros tipos de discurso, que tomaram o seu lugar em uma determinada época. (FOUCAULT, 1995a, p. 180).

Como aponta Foucault (1995a, p. 197), quando se afirma que certa formação discursiva substituiu outra ${ }^{16}$, trata-se de uma transformação nas relações que não altera, necessariamente, todos os seus elementos, conceitos, ou que "todo um mundo de objetos, enunciações, escolhas teóricas absolutamente novas, [surja] já armado e organizado em um texto que o situaria de uma vez por todas". Procura-se aqui demonstrar como, no caso dos Transtornos Mentais e do Comportamento Relacionados ao Trabalho, concepções diversas de Medicina, Psicologia, trabalho, causalidade, saúde e doença coexistem, se opõem e se superpõem. Pretende-se também situar a discussão sobre essas doenças relacionadas ao trabalho no contexto da discussão da constituição da medicina do trabalho como disciplina e de seus diferentes paradigmas, aqui caracterizados como Medicina Industrial (do Trabalho), Saúde Ocupacional e Saúde do Trabalhador (Capítulo 4). Também estão em questão a Psicologia e seus também diferentes paradigmas, como são convocados ao campo, e como se dá sua inserção e posicionamento nesse campo (Capítulo 5).

Em outra vertente, Dwyer (2000, p. 139) situa que o "aparecimento" (identificação) de uma doença do trabalho teria duas faces: o aumento das atividades que a produziriam e o seu reconhecimento que, por sua vez, alimentaria os relatos e suas notificações.

Outra questão que se coloca é a que se refere à produção do adoecimento. Grimberg (1988 apud OLIVEIRA, 2007) assinala a dupla produção de fenômenos relacionados à saúde ao distinguir duas dimensões, as condições de produção dos processos de saúde-doença e as condições de sua representação e ação social e institucional. Dessa forma, diz que saúde e doença seriam "emergentes das condições de trabalho e de vida de uma formação social", e também que "constituem, ao mesmo tempo, uma

\footnotetext{
16 Como os diferentes paradigmas sobre as relações entre Medicina e trabalho e Psicologia e trabalho, ou concepções de saúde, de causalidade, e mesmo sobre os Transtornos Mentais e do Comportamento Relacionados ao Trabalho.
} 
construção teórico-prática social e historicamente produzida, resultante de diferentes práticas sociais" (GRINBERG, 1988, apud OLIVEIRA, 2007, p. 20).

Essa abordagem das condições de produção dos processos de saúde-doença teria aproximações com a teoria da determinação social da doença, na qual a forma como se organiza a produção da vida em sociedade determinaria diferentes formas de viver, adoecer e morrer, para os diferentes grupos sociais. Esse conceito compreende a relação saúde-doença como um processo social, determinado pela forma de vida - as relações do homem consigo mesmo, dos homens entre si, com a sociedade e com a natureza, interações que passam pela forma como o homem produz o seu trabalho, construindo e transformando a sociedade (FRIAS JUNIOR, 1999). O estudo do processo saúde-doença do trabalhador deveria considerar, para Souza e Veras (1983), como condicionantes básicos desse processo as condições gerais de vida, as relações de trabalho e o próprio processo de trabalho. A interação homem-trabalho e com as condições de vida e de trabalho determinaria a divisão da sociedade em classes, que apresentariam características comuns de viver, adoecer e morrer (MENDES, 1988).

A compreensão do processo saúde-doença só poderia ser atingida se ele fosse ligado ao contexto social, pois o trabalho se relacionaria aos "elementos essenciais que definem a inserção social específica e que determinam as 'condições ambientais' diante das quais emergem os modos de andar a vida" de cada ser humano (LAURELL; NORIEGA, 1989, p. 103). Seu eixo básico seria o conceito de processo de trabalho, analisado a partir das unidades de produção e visto como determinante para o desgaste, os riscos e o quadro de morbidade dos trabalhadores (MINAYO, 2010). ${ }^{17}$

A Medicina Social Latino-Americana ${ }^{18}$ proporia, segundo Lacaz (1996), uma visão do conceito de trabalho que incorporaria a ideia de processo de trabalho não restrita a

\footnotetext{
17 Para Minayo (2010, p. 128),

O paradigma ancorado no conceito de processo de trabalho (principalmente de caráter industrial) vem demandando mudanças conceituais e de abrangência de objetos para dar conta dos problemas trazidos pela globalização, pelas novas formas de produção e por uma série de outros fatores. Dentre eles, é fundamental destacar a predominância contemporânea dos trabalhadores do setor de serviços e seus problemas específicos, em detrimento do setor industrial a partir do qual foi construído o paradigma marxista de saúde e trabalho.
}

18 Uma discussão sobre a Medicina Social Latino-Americana é realizada na seção 4.2.4.1.2. 
uma perspectiva ambiental de fatores/agentes de risco e externo ao trabalhador, e sim “como uma 'categoria' explicativa que se inscreveria nas relações sociais de produção existentes entre o capital e o trabalho" (LACAZ, 1996, p. 23). O processo de trabalho seria "um dos elementos-chave para a compreensão dos determinantes da saúde do trabalhador, já que permite desentranhar de que forma se constitui o nexo biopsíquico dessa coletividade" (LAURELL; NORIEGA, 1989, p. 106).

\subsection{CONSIDERAÇÕES METODOLÓGICAS}

Realizou-se um estudo eminentemente qualitativo, com pesquisa bibliográfica e documental, pois o tipo de análise proposta, da construção conceitual dos Transtornos Mentais e do Comportamento Relacionados ao Trabalho, requer ampla consulta a esses dados que objetiva, analogamente à análise de Lacaz (2007, p. 93), "garimpar os enunciados, as noções, as regras, as instituições que constroem práticas e saberes sobre as relações trabalho-saúde".

Visando complementar e confrontar os dados levantados nas pesquisas bibliográfica e documental, foram realizadas entrevistas individuais com atores - ligados às áreas sindical, de pesquisa, de prevenção, de tratamento - com destacada participação no campo da Saúde do Trabalhador e, em especial, contribuições para a discussão dos Transtornos Mentais e do Comportamento Relacionados ao Trabalho.

\subsubsection{CONSIDERAÇÕES SOBRE AS ENTREVISTAS}

O trabalho de campo contou com entrevistas individuais semiestruturadas, realizadas com profissionais ligados à área sindical, à academia (pesquisa) e à rede de saúde (SUS). Até o exame de qualificação, a proposta metodológica era a de se realizar um estudo eminentemente baseado em pesquisa bibliográfica e documental. Desde algum tempo, a orientadora da tese já vinha sugerindo que a investigação com entrevistas poderia ser enriquecedora ou redefinidora para o trabalho e, em certo sentido, a encarava como "ferramenta" complementar ou auxiliar para a "coleta de dados". 
Após o rico debate ocorrido no exame de qualificação, ${ }^{19}$ a perspectiva sob a qual encarava as entrevistas se transformou. Para além das ricas sugestões de nomes a serem entrevistados, o que se descortinou foi a possibilidade de, ao estudar um fenômeno relativamente recente como os Transtornos Mentais e do Comportamento Relacionados ao Trabalho (do ponto de vista de seu reconhecimento legal), polêmico, móvel de disputas no campo médico e "psi"' (como se discutirá na tese), de conversar com personagens que atuaram como testemunhas (no sentido de Eclea Bosi) - ou mesmo protagonistas - desta história. Relatos de quem a acompanhou, viveu, pensou, protagonizou, atuou e/ou ainda o faz cotidianamente em suas práticas.

A opção metodológica pela realização de entrevistas levou a algumas considerações sobre seu caráter de "narrativa", discutidas a seguir. As entrevistas realizadas, mesmo que não constituam propriamente entrevistas de história de vida (ou mesmo de história oral), na medida em que abordam a vivência e a agência dos sujeitos envolvidos, abordam também, necessariamente, aspectos biográficos.

Como coloca Bosi (2004b), os testemunhos vivos de uma época [ou tema] auxiliam "fazer emergir uma visão do mundo", carregada de ideologias e mitos de classes e grupos. Um trabalho de reinterpretação do passado seria pautado também "em função dos combates do presente e do futuro". Nos termos de Pollak (1992, p. 10), "toda organização política, por exemplo - sindicato, partido etc. -, veicula seu próprio passado e a imagem que ela forjou para si mesma". O denominador comum das memórias, bem como as tensões entre elas, seria a definição do consenso social e dos conflitos num determinado momento conjuntural. Haveria uma memória coletiva produzida no interior de um grupo, com poder de difusão, que se alimenta de imagens, sentimentos, ideias e valores que dão identidade àquele mesmo (BOSI, 2004b). O conjunto das lembranças seria também uma construção social do grupo em que a pessoa vive e onde coexistem elementos da escolha e rejeição em relação ao que será lembrado. E prossegue:

Quando um grupo trabalha [...] em conjunto, há uma tendência de criar esquemas coerentes de narração e de interpretação dos fatos, verdadeiros "universos de discurso", "universos de significado", que dão ao material de

\footnotetext{
${ }^{19}$ Agradeço novamente aos professores Francisco Antônio de Castro Lacaz e Maria Elizabeth Antunes Lima pelas generosas contribuições ao trabalho durante a banca de qualificação.
} 
base uma forma histórica própria, uma versão consagrada dos acontecimentos. O ponto de vista do grupo constrói e procura fixar a sua imagem para a história (BOSI, 2004a, p. 67).

De certa forma, foi o que ocorreu nesta tese, uma vez que todos os entrevistados, à exceção do historiador (Claudio Bertolli Filho) pertencem e são atuantes no campo da Saúde do Trabalhador. Mesmo com o risco de introduzir um viés na pesquisa, ao não entrevistar profissionais filiados a outras abordagens que discutam a temática das relações saúde/saúde mental-trabalho, esta escolha deveu-se ao fato de que, além de ser a perspectiva à qual também me filio, a Saúde do Trabalhador constitui a abordagem predominante nas políticas públicas de saúde e trabalho, orientando as práticas do Sistema Único de Saúde (SUS), na Rede Nacional de Atenção Integral à Saúde do Trabalhador (RENAST) e nos Centros de Referência em Saúde do Trabalhador (CERESTs). É também a abordagem à qual se filiam grupos de pesquisadores que, tinha-se como hipótese, poderiam ter promovido ou subsidiado as discussões que ensejaram as mudanças na legislação, e alguns representantes desses grupos foram entrevistados.

Os profissionais entrevistados foram: Andréa Maria Silveira (médica, UFMG), Andréia De Conto Garbin (psicóloga, CEREST, Secretaria de Saúde de Santo André), Claudio Bertolli Filho (historiador, UNESP-Bauru), Edith Seligmann-Silva (psiquiatra, USP, FGV), Elizabeth Costa Dias (médica, UFMG), Gilberto Salviano da Silva (assessor - Secretaria de Saúde da CUT), Heleno Rodrigues Corrêa Filho (médico epidemiologista, UNICAMP, UNB), Jandira Maciel da Silva (médica, UFMG), Luiz Carlos Brant (psicólogo, UFMG), Maria da Graça Corrêa Jacques (psicóloga, UFRGS), Maria Maeno (médica, FUNDACENTRO), Maria Regina Greggio (psicóloga, CEREST Contagem), Sílvia Rodrigues Jardim (psiquiatra, UFRJ), Wanderley Codo (psicólogo, UNB). ${ }^{20}$

Foi necessário trabalhar com número relativamente restrito de entrevistados, compensado por sua ampla experiência e vivência, e que muito contribuíram para a compreensão do objeto da tese. Das entrevistas originalmente previstas, não foi possível entrevistar representantes do DIESAT e do INSS. Previa-se também uma entrevista com a professora Maria Elizabeth Antunes Lima, personagem de destaque

\footnotetext{
20 A relação das entrevistas realizadas, período de realização e dados biográficos sumários dos
} entrevistados encontram-se no Apêndice A, e o roteiro de entrevista (semiestruturada), no Apêndice B. 
na história da Saúde Mental e Trabalho no Brasil. Contudo, como havia o interesse de que ela compusesse a banca examinadora do trabalho, decidiu-se pela não realização da entrevista. Problemas técnicos limitaram a duração e alcance/aprofundamento das entrevistas com Elizabeth Costa Dias e Maria Maeno, mas foi possível complementar as informações com a vasta bibliografia publicada por ambas.

Após sua transcrição, as entrevistas foram analisadas pelo método da análise de conteúdo. Como coloca Triviños (1987, p. 159), esse método se prestaria para o estudo "das motivações, atitude, valores, crenças, tendências". Como orientam Kelle (2002) e Triviños (1987), primeiramente procedeu-se à organização do material (pré-análise), por meio de leitura exploratória das entrevistas - leitura flutuante - com o objetivo de iniciar a identificação, a partir dos objetivos e conceitos-chave da tese, das unidades básicas de análise (conceitos), caminhando para o desenvolvimento de categorias (códigos e "famílias"). Depois, procedeu-se à descrição analítica, na qual se classificaram as falas dos entrevistados como expressões e variações das ocorrências dos conceitos identificados, e o tratamento dos dados (as entrevistas) a partir do software de análise qualitativa ATLAS.ti versão 6. ${ }^{21}$ Foram construídas categorias de análise ("famílias"), constituídas por agrupamentos de códigos que direcionavam para o entendimento de uma mesma questão. ${ }^{22}$ Por fim, procedeu-se à interpretação e análise desses dados.

\subsubsection{CONSIDERAÇÕES SOBRE O RECORTE HISTÓRICO}

A análise propõe um recorte histórico do campo de relações entre trabalho-saúde, em especial trabalho e saúde mental, para compreender, no que tange aos Transtornos Mentais e do Comportamento Relacionados ao Trabalho, os processos de transformação e as lutas travadas entre os diversos grupos de interesse envolvidos.

Para delinear esse recorte, não foi possível a busca sistemática (ou in loco) de fontes primárias. Originalmente, pensou-se em uma pesquisa em arquivos como, por

\footnotetext{
${ }^{21}$ Agradeço novamente a Jayane Maia pela inestimável ajuda na classificação e tratamento dos dados, e na utilização do ATLAS.ti.

22 As "famílias" construídas na pesquisa são apresentadas no Apêndice D — Livro de Códigos e Gráficos.
} 
exemplo, o Arquivo Edgard Leuenroth - Centro de Pesquisa e Documentação Social da Unicamp. Contudo, atrasos no cronograma da pesquisa, bem como a redefinição do trabalho de campo (e da própria tese) após o exame de qualificação, priorizando a realização de entrevistas, inviabilizaram essas consultas.

Dada essa impossibilidade, ganharam espaço os chamados "informantes": não aqueles que seriam "os organizadores e/ou proprietários da documentação", mas "as personagens que, tematizadas na documentação, atuam de formas analiticamente relevantes no campo 'imaginário' que o pesquisador constrói a partir da interlocução com as fontes" (FREHSE, 2005, p. 137). Como exemplos, podem-se citar autores/informantes de relevada importância para o recorte histórico dos Transtornos Mentais e do Comportamento Relacionados ao Trabalho, como Afrânio Peixoto e Leon Walther, expoentes da discussão nos anos 40. Cabe ressaltar que, na perspectiva adotada neste trabalho, "o sujeito do discurso não seria a pessoa que realiza um ato de fala ou o autor de um texto, mas aquele que poderia usar [...] determinado enunciado por seu treinamento, por seu lugar institucional, por sua competência técnica" (FOUCAULT, 1995b, p. 171). Nesse sentido, essas personagens - cuja via de acesso é a produção bibliográfica que deixaram, ou as análises de outros pesquisadores a respeito - constituem-se "porta-vozes" de certas formações discursivas. ${ }^{23}$

Como coloca Carvalho (2011), analisar formações discursivas implicaria buscar compreender historicamente as forças que participam de sua criação, construção, produção e reprodução. Para Foucault (1995b), a constituição histórica de um campo discursivo não se daria via acontecimentos cumulativos e lineares, mas sim por continuidades e rupturas, contradições e controvérsias.

Na mesma linha, Autuori (2009) destaca que história não é uma sucessão de acontecimentos lineares identificáveis e passíveis de uma única ordenação lógica; nesse sentido, uma mesma história poderia ser construída de diferentes perspectivas.

23 Cabe destacar que Frehse (2005) realiza seu trabalho de pesquisa e consulta de arquivos em instituições de conservação de documentação; nesta tese refere-se metaforicamente ao "arquivo" como o resultado ou produto da pesquisa documental (e bibliográfica) realizada, porém não nessas instituições. 
Por essa razão, reitera-se, o delineamento proposto da trajetória histórico-conceitual das relações entre saúde mental e trabalho para a compreensão da constituição dos Transtornos Mentais e do Comportamento Relacionados ao Trabalho como categoria. Já as categorizações (sobretudo cronológicas) elaboradas devem ser tomadas como referências, escolhas arbitrárias, pois seria impossível delimitar a "origem" ou ponto inicial (ou final) de determinado campo discursivo. Por essa razão, também, este trabalho é simultaneamente fruto de escolhas (teóricas) e de limitações da autora, e não se pretende uma abordagem histórica stricto sensu, ou uma análise histórica exaustiva que esgotasse a questão, o que seria, de toda forma, impossível.

Nesse sentido, trata-se de uma busca de apreensão do presente, ou, nos termos de Clot (2009, p. 14): «On soumet inévitablement le passé aux préocupations d'aujourd'hui. On comprend le passé par le présent. On comprend donc aussi le présent par le passé $»{ }^{24}$

Ou, como bem colocado por um dos entrevistados, um historiador:

Buscar o enfoque histórico de um saber é a maturidade desse próprio saber. A Psicologia, ela chegou a um ponto em que ela começa a se questionar e ela precisa olhar para o seu próprio passado. E não é mais, por exemplo, eu historiador, o não psicólogo, chegar lá para estudar a Psicologia, é o psicólogo buscando o saber. [...]

Nós também estamos nos voltando à perspectiva histórica com o objetivo de explicar quais condicionantes nos levaram a chegar ao ponto em que nós nos encontramos atualmente. [...]

De um lado, nós temos a maturidade, a complexidade de um saber, e em outra perspectiva você tem [...] esses próprios profissionais [que] já se sentem, de certa forma, incomodados por alguns dos caminhos trilhados pelo saber que eles professam. Então eles tentam explicar algumas questões do presente, em especial o futuro (BERTOLLI FILHO, 2014, entrevista).

\footnotetext{
${ }^{24}$ Submete-se inevitavelmente o passado às preocupações do hoje. Compreende-se se o passado por meio do presente. Por conseguinte, compreende-se também o presente por meio do passado [tradução nossa].
} 


\section{ASPECTOS POLÍTICOS E SOCIOECONÔMICOS}

Como exposto por Rocha e Nunes (1993, p. 80), a retomada do processo histórico permitiria "dar concretude ao conceito de determinação social do processo saúdedoença" e "a compreensão da situação atual, suas contradições e perspectivas, cujas raízes encontram-se na teia da história". Optou-se neste capítulo por seguir a mesma divisão temporal utilizada pelos autores. Aqui, porém, começa-se a análise já no século XX: anos 10-30 (República Velha), anos 30-45 (Era Vargas), anos 45-64 (Segunda República), anos 1964-1985 (Ditadura Militar), incluindo também, de 1985 aos dias atuais, a República Nova. Pretende-se discutir, referentemente a esses períodos históricos, aspectos gerais quanto ao contexto econômico, político e social, condições de trabalho, de vida e saúde, bem como políticas públicas de saúde/trabalho, na medida em que permitiriam elucidar "a articulação entre o contexto econômico, as ações da sociedade civil (em especial dos movimentos dos trabalhadores), as ações de Estado e as condições de saúde" (ROCHA;NUNES, 1993, p. 81).

\subsection{CONTEXTO DOS ANOS 10 a 30 (República Velha)}

\subsubsection{CONTEXTO POLÍTICO-ECONÔMICO E SOCIAL 25}

Importantes impulsos para a industrialização do país teriam sido a substituição do trabalho escravo (abolição da escravatura, em maio de 1888) pelo trabalho livre, sobretudo do imigrante, bem como a proclamação da República em novembro de 1889. Os investimentos em infraestrutura ligados à cafeicultura, como as ferrovias, foram fundamentais, também, para o processo de industrialização do país (GERAB; ROSSI, 1997). A economia cafeeira teria engendrado as condições necessárias para o

\footnotetext{
25 Os presidentes do período foram: Rodrigues Alves, de 1902 a 1906; Afonso Pena, de 1906 a 1909 e que faleceu durante o mandato, sendo sucedido pelo vice-presidente Nilo Peçanha, de 1909 a 1910; Hermes da Fonseca, de 1910 a 1914; Venceslau Brás, de 1914 a 1918; Rodrigues Alves, reeleito para o mandato de 1918 a 1922, faleceu antes de tomar posse, vítima da gripe espanhola, sendo substituído pelo vice-presidente Delfim Moreira entre 1918 e 1919, uma vez que a Constituição da época exigia a convocação de novas eleições; Epitácio Pessoa, de 1919 a 1922; Artur Bernardes, de 1922 a 1926; Washington Luís, de 1926 a 1930; e Júlio Prestes, eleito, mas que não assumiu em razão da Revolução de 1930, exercendo o governo, até a posse de Getúlio Vargas, a Junta Governativa Provisória de 1930.
} 
início do processo de industrialização: capitais disponíveis, mecanização do beneficiamento, malha ferroviária, formação de um mercado livre de trabalho (LUCA, 2001). Para Rocha e Nunes (1993, p. 84), o que caracterizou o crescimento industrial do período até os anos 30 foi seu “caráter não integrado e relativamente 'espontâneo', em 'surtos'".

No período do final do século XIX até a II Guerra Mundial, as racionalizações do trabalho sustentadas por Taylor, Ford e Fayol dariam a tônica da relação entre eficiência e produtividade (VERTHEIN; MINAYO-GOMEZ). A isso

[...] combinava-se com um alto grau de mecanização [...], o que ampliava a produtividade do trabalho. [...] $\mathrm{O}$ aumento da produtividade do trabalho era também alcançado através da intensificação da cadência das máquinas e da coação extraeconômica e violenta (castigos corporais, ameaças, dispensas do emprego, multas, rígida disciplina do trabalho etc.) (FOOT HARDMAN; LEONARDI, 1982, p. 135).

Do começo do século XX até a década de 20, o principal elemento de formação da mão de obra urbana, sobretudo industrial-operária, foi a imigração. Nos principais centros urbanos da época, Rio de Janeiro e São Paulo, "era elevadíssima a porcentagem de estrangeiros nos diferentes ramos industriais" (FOOT HARDMAN; LEONARDI, 1982, p. 141).

Muitos desses imigrantes foram trazidos ao país para o trabalho nas lavouras, notadamente da cafeicultura e paulatinamente foram se deslocando para os centros urbanos. ${ }^{26}$ No Rio de Janeiro e São Paulo, a predominância de operários imigrantes até 1920 foi, segundo Decca (1991, p. 11), "uma característica fundamental da classe trabalhadora e [que] nos ajuda a compreender melhor suas manifestações socioculturais".

Ao longo das três primeiras décadas do século $X X$, tiveram destaque as associações beneficentes e de socorros mútuos. Essas entidades objetivavam assegurar aos seus associados, mediante pequenas contribuições mensais, "tratamento médico, medicamentos, auxílios a doentes, vítimas de acidentes de trabalho, inválidos e velhos." (LUCA, 2001, p. 34). Já as associações operárias - sindicatos, ligas e uniões -

\footnotetext{
${ }^{26}$ Nesse período, observou-se rápido crescimento da população urbana, o que favoreceu a emergência de uma classe média (ROCHA; NUNES, 1993).
} 
eram compostas por pequeno número de trabalhadores de uma empresa ou ofícios, com foco em reivindicações salariais e melhoria de condições de vida; as negociações se davam diretamente com os empregadores e evitando vínculos com partidos políticos (ROCHA; NUNES, 1993). No início do século XX, as principais reivindicações dos trabalhadores teriam se voltado para as condições de trabalho (duração da jornada, idade mínima, trabalho noturno, repouso remunerado, trabalho de menores e mulheres) e para os ambientes de trabalho, chamando atenção ao impacto dessa "revolução industrial" sobre a saúde e a vida dos trabalhadores (MENDES, 1995, p. 13).

De 1901 a 1914 ocorreram 129 greves. Em 1917, houve greves em quase todos os setores industriais por melhores condições de salário, que prosseguiram em 1919. Nos anos 10-20, houve sistemática perseguição aos sindicatos e jornais operários e prisão dos principais líderes. A atitude do patronato e dos poderes públicos de rejeição às reivindicações da população operária teria resultado, no início do século, assim como no fim da Primeira Guerra Mundial, em uma série de grandes greves violentamente reprimidas (ROUQUIÉ, 1991). Datam desse período as greves de 1907, 1912 e as grandes greves de 1917-1920 - mais de duzentas, somente nos estados de São Paulo e Rio de Janeiro (MENDES, 1995). Dentre as principais reivindicações do operariado, encontrava-se a jornada de oito horas diárias. Desde o início do século XX, registram-se greves pleiteando a redução da jornada de trabalho. Decca (1991) destaca que, embora em algumas dessas greves tenham sido firmados acordos no sentido da fixação da jornada em oito horas diárias, comumente esses acordos eram rompidos por proprietários e industriais.

Em 1917, tanto nacional quanto internacionalmente observou-se a emergência de um movimento operário vigoroso, caracterizado tanto pelo número de greves quanto pelo surgimento de novos sindicatos (DUTRA, 1988). Dentre outros fatores que concorreram para esse crescimento, destacam-se:

A conjuntura criada pela Primeira Guerra Mundial (1914-1918) propiciou oportunidades de crescimento para a indústria brasileira, que tinha de suprir necessidades não mais atendidas pela produção europeia. A escassez de produtos provocada pela guerra acarretou um aumento significativo no custo de viela, fato que penalizava não apenas os operários, mas também as camadas médias urbanas. Os 
pequenos aumentos salariais estiveram longe de acompanhar a escalada dos preços (LUCA, 2001, p. 37-38).

Em julho de 1917, realizou-se uma greve geral em São Paulo, que parou a cidade e conseguiu "entrar para a história como um dos primeiros enfrentamentos de caráter classista no Brasil a obter grande repercussão" (GERAB; ROSSI, 1997, p. 27). Decca (1991, p. 17) destaca que essa greve "talvez tenha sido uma das mais importantes mobilizações operárias relacionadas à questão das condições de vida", na medida em que extrapolou o âmbito exclusivamente operário e converteu-se em "grande movimentação popular, de enorme alcance político": às reivindicações por melhores condições de trabalho somaram-se as pela "melhoria das condições de consumo das camadas mais pobres da população paulista".

Contudo, os resultados alcançados por esses movimentos foram avaliados por Luca (2001, p. 38) como "bastante modestos":

Conquistas obtidas a duras penas, como redução da jornada de trabalho, aumentos salariais, limitação do trabalho feminino e infantil, abolição de multas, dispensas de supervisores e mestres eram suprimidas na primeira conjuntura desfavorável aos operários. A própria greve, tática essencial do movimento, acabou sendo eficientemente utilizada pelos órgãos de repressão, que prendiam e deportavam os mais combativos, causando constantes baixas na liderança, depredavam sindicatos e fechavam os jornais operários. Os patrões podiam contar com a pronta presença das forças policiais para proteger suas empresas dos "agitadores".

Rouquié (1991, p. 152) destaca que, apesar de seu número reduzido, a classe operária impôs-se rapidamente como um ator social com o qual se deveria contar. Para esse autor, as próprias características do emprego operário "conferem a suas lutas para melhorar as condições de vida muito duras uma eficácia e um alcance, pelo menos políticos, terríveis".

Em 1921, foi aprovada uma lei de repressão ao anarquismo, proposta pelo senador Adolfo Gordo. Essas ações contra os elementos mais ativos do movimento operário teriam restringido significativamente as possibilidades de ação do movimento. Luca (2001) destaca como particularmente dura a repressão na presidência de Artur Bernardes (1922-1926), quando vigorou o estado de sítio, com suspensão de garantias constitucionais, restrição da liberdade de imprensa e dos direitos individuais e 
considerável aumento dos poderes presidenciais. Somente no final da década de 20 é que teria ocorrido o ressurgimento da atividade sindical e política. Para Luca (2001), mesmo com a constante perseguição imposta aos anarquistas, comunistas, socialistas e suas respectivas agremiações, eles seguiram desempenhando papel importante até a imposição da Lei de Segurança Nacional, em 1935.

O ano de 1929 foi marcado pela grande depressão econômica. No Brasil, em particular, o crack (a quebra) da Bolsa de Nova lorque teria levado a uma grande instabilidade na área financeira, bem como ao agravamento da crise do café (GERAB; ROSSI, 1997). Somado à crise econômica de 1929 e ao processo inflacionário, havia também dificuldades nas relações com o mercado internacional e agravaram-se a proletarização de grande contingente de trabalhadores e as disputas entre a nova burguesia urbana-industrial, o Estado e a oligarquia cafeeira (MOTTA, 2004, p. 104). Em 1929, também ocorriam eleições presidenciais. A campanha da Aliança Liberal, que se opunha à candidatura oficial de Júlio Prestes, uniu-se a militares e oligarcas

dissidentes e, apesar do apoio popular, não conseguiu superar nas urnas o candidato do governo. Entretanto, pela força das armas, Getúlio Vargas derrubou o presidente Washington Luís, em fim de mandato (GERAB; ROSSI, 1997, p. 28).

\subsubsection{CONDIÇÕES DE SAÚDE E TRABALHO}

No começo do século XX, nas grandes cidades ou mesmo nas de pequeno ou médio porte, ocorriam frequentes epidemias, devidas ao acelerado crescimento urbano, de modo geral sem infraestrutura condizente. Como aponta Decca (1991, p. 57), “Embora as grandes epidemias se tornassem mais raras a partir da década de 1920, o estado sanitário de cidades como São Paulo e Rio de Janeiro, por exemplo, continuou bastante ruim até os anos 30 e 40".

Outro aspecto a se destacar no período é a respeito das condições de moradia dos trabalhadores, sobretudo operários. Observou-se uma relativa concentração geográfica em "bairros fabris e operários, ou de vilas proletárias contíguas a grandes complexos industriais" (FOOT HARDMAN; LEONARDI, 1982, p. 149). Como mostra Decca (1991, p. 57), nesses bairros e vilas, "não havia saneamento básico, fiscalização, 
rede de esgotos, água encanada, sendo os poços construídos muito próximos das fossas; tudo isso e as habitações inadequadas faziam com que ali a contaminação fosse maior e a mortalidade infantil mais alta que nos outros bairros". E prossegue: "Se adicionarmos o dado da alimentação insuficiente ou deficiente, não causa espécie que entre o operariado e seus filhos fossem mais elevados os índices de febre tifoide, disenteria, sarampo, lepra, meningite cérebro-espinhal, tuberculose". No início do século, o habitat operário típico era o cortiço (ROUQUIÉ, 1991): frequentemente devido ao alto custo de moradia e baixos salários, as famílias operárias viviam em habitações coletivas, como os cortiços.

\footnotetext{
A habitação coletiva e precária do proletariado em São Paulo era vista fora dos meios operários como fonte de tuberculose, alcoolismo, vícios, como geradora de inveja e ódio da sociedade, como ambiente desastroso para a infância e mulheres, como formadora de péssimos hábitos, que prejudicavam a disciplina nas escolas e o trabalho nas fábricas e oficinas. A solidariedade do operariado e sua organização frente às árduas condições de vida era avaliada como desastrosa e socialmente perigosa (DECCA, 1987, p. 72).
}

No que tange às condições de trabalho, os trabalhadores urbano-industriais enfrentaram, desde os fins do século XIX e inícios do século XX, condições de trabalho bastante penosas (DECCA, 1991, p. 13). Rocha e Nunes (1993) comparam as condições de vida e trabalho da época com as observadas na Inglaterra no período da Revolução Industrial: condições de trabalho muito precárias, longas jornadas de trabalho, emprego de mulheres e menores, alta incidência de acidentes de trabalho não indenizados.

As condições de trabalho nas grandes e pequenas empresas eram geralmente muito ruins. Como aponta Luca (2001, p. 27), de modo geral as fábricas e oficinas instalavamse em espaços insalubres e, muitas vezes, improvisados, sem ventilação ou iluminação adequadas e sem proteção para engrenagens das máquinas, "o que era causa de inúmeros acidentes".

Rouquié (1991) mostra como, no início do século XX, as jornadas de trabalho de doze a quatorze horas ou mais eram normais. Decca (1991) também chama atenção nesse sentido, destacando que as jornadas variavam de 10 a 14 horas por dia, por vezes se prolongando ainda mais. Esse aumento e a manutenção de jornadas de trabalho extensas foram uma constante no período, "mesmo após as vitórias parciais 
conseguidas pela classe operária, em particular com a greve geral pela jornada de oito horas, em 1907" (FOOT HARDMAN; LEONARDI, 1982).

Além das extensas jornadas de trabalho, de frequentemente os trabalhadores não tinham direito a descanso semanal remunerado, férias, à licença remunerada para tratamento de saúde ou aposentadoria por velhice ou invalidez (FOOT HARDMAN; LEONARDI, 1982; DECCA, 1991; LUCA, 2001). Decca (1991) destaca que algumas leis começaram a ser elaboradas e aplicadas pontualmente a partir da década de 20, como a lei sobre acidentes de trabalho (Lei $\mathrm{n}^{0} 3.734$ de 1923); a lei Eloy Chaves, sobre aposentadorias e pensões (Decreto $n^{\circ} 4.682$ de 1923) e a lei de férias (Decreto $n^{\circ}$ 17.496 de 1926).

Como assinala Luca (2001), a lei de férias era considerada por muitos empresários como adequada para empregados no comércio, escritórios e bancos, mas "nefasta para o operário fabril", como o demonstra o texto de 1926 de Otávio de Pupo Nogueira, industrial e então secretário-geral da FIESP (Federação das Indústrias de São Paulo):

\footnotetext{
Que fará um trabalhador braçal durante quinze dias de ócio? Ele não tem o culto do lar, como ocorre nos países de climas inóspitos e padrão de vida elevado [...]. O lar não pode prendê-lo e ele procurará matar as suas longas horas de inação nas ruas. A rua provoca com frequência o desabrochar de vícios latentes e não vamos insistir nos perigos que ela representa para o trabalhador inativo, inculto, presa fácil dos instintos subalternos que sempre dormem na alma humana, mas que o trabalho jamais desperta. [...] Nos limitaremos a dizer que as férias operárias virão quebrar o equilíbrio de toda uma classe social da nação, mercê de uma floração de vícios, e talvez, de crimes que esta mesma classe não conhece no presente (VIANNA apud LUCA, 2001, p. 42).
}

Ao aumento das jornadas de trabalho, combinava-se a utilização em grande escala do trabalho de menores e mulheres (GERAB; ROSSI, 1997), submetendo, como apontam Foot Hardman e Leonardi (1982, p. 135, 136), "por completo a família proletária às condições da produção fabril". O trabalho das mulheres e crianças era procurado pelo patronato por ser mais barato (ROUQUIÉ, 1991). Violências sexuais contra meninas e mulheres por parte dos mestres e contramestres eram denunciadas rotineiramente na imprensa operária (GERAB; ROSSI, 1997).

A regulamentação do trabalho de mulheres e crianças esteve entre as principais reivindicações dos trabalhadores nos anos 10-20. Referentemente ao trabalho do 
menor, ocorreu em São Paulo, por meio da reforma do Código Sanitário em 1917, e em âmbito federal com o Código de Menores de 1927 (Decreto $n^{\circ}$ 17.943-A). Luca (2001) destaca que "insistia-se na importância da fábrica para afastar o menor das ruas", exemplificando com um trecho do relatório da Associação Comercial do Rio de Janeiro (1910):

\begin{abstract}
A lei que limita o trabalho de menores pode ser, em teoria, defensável. Mas praticamente no nosso país é absurda e criminosa [...]. Os menores precisam de tutela, mas não essa tutela da vadiagem, da criminalidade, que é o que esta lei faz tirando os menores do trabalho, para fazê-los perambular pelas ruas. [...] É que o Estado não tem nem pão, nem casa, nem dinheiro, nem escola para aqueles a quem a fábrica dá tudo isso e mais o estímulo, a suficiência da ação moral (GOMES, apud LUCA, 2001, p. 26).
\end{abstract}

Contudo, como apontam Luca (2001) e Rouquié (1991), as regulamentações referentes ao trabalho do menor eram geralmente ignoradas. Rouquié (1991, p. 153), cita, como exemplo, uma greve realizada em 1922, em São Paulo, contra os maus-tratos infligidos em certas fábricas às crianças, que trabalhavam muito além das oito horas legalmente autorizadas à época (ROUQUIÉ, 1991, p. 153).

Como até a década de 30 praticamente inexistia legislação sobre as relações trabalhistas, o que imperavam eram os regulamentos internos elaborados pelas fábricas para controlar o trabalho e resolver possíveis questões e conflitos (DECCA, 1991, p. 14). Esses regulamentos se destacavam de modo geral por sua rigidez, pela imposição da disciplina e mesmo multas ou castigos físicos por faltas ou "atos julgados condenáveis" cometidos no ambiente de trabalho.

Também eram estritamente supervisionados horários e o ritmo de trabalho. Pequenos erros ou "atos sem importância" poderiam implicar multas altas que diminuíam ainda mais os salários operários (como aponta a autora, "Havia trabalhadores que chegavam a receber no fim do mês apenas dois terços dos seus salários") (DECCA, 1991, p. 15).

Conviviam, com a rígida disciplina de trabalho, castigos corporais, ameaças, dispensas de emprego, multas (GERAB; ROSSI, 1997, p. 41, 42). Destacam-se também a rigidez e agressões físicas dos chefes e mestres contra menores.

Cada fábrica tinha um aspecto fosco e hostil de presídio, com seus guardas de portão fardados e armados, operários e operárias submetidos a vexatórias revistas e humilhantes observações, quando não recebiam ameaças de toda sorte (GERAB; ROSSI, 1997, p. 41) 
Como bem descreve Dean (1971, apud ROCHA; NUNES, 1993, p. 89),

As fotografias ocasionais de revezamento de turmas numa ou noutra fábrica nos exibem uma horda de espectros descarnados e andrajosos, apinhados à saída, precedidos de crianças descalças e raquíticas, com os rostos inexpressivos voltados para a câmera ou para o chão.

\subsubsection{POLÍTICAS PÚBLICAS DE SAÚDE E TRABALHO}

O Estado começaria a intervir nas relações de trabalho a partir de 1919, em virtude de pressões dos trabalhadores (após as grandes mobilizações de 1917 e 1918), bem como de pressões internacionais. De acordo com Simão (1966, apud ROCHA; NUNES, 1993, p. 86), "a maior atenção dada pelo Estado aos problemas concernentes às condições de trabalho e de assistência social nessa área, após a Primeira Guerra Mundial, ocorreu na medida em que a sociedade urbana se projetava no quadro econômico, social e político do país". No final dos anos 10, é assinado o Tratado de Versalhes e cria-se o Bureau Internacional do Trabalho (posteriormente, Organização Internacional do Trabalho). Os países capitalistas centrais pressionariam os periféricos para o enfrentamento da "problemática social e trabalhista", também em virtude da revolução soviética, "à qual era necessário responder no plano ideológico e das realizações sociais" menores (ROCHA; NUNES, 1993, p. 86).

Nesse contexto, surgiu a primeira lei sobre o Acidente do Trabalho (Lei $n^{0} 3.734$, de 1919) que, contudo, seria frequentemente burlada. Como mostra Sousa (2012, s/p), a caracterização do acidente do trabalho dependia da constatação de quatro requisitos: "evento súbito, violento, involuntário e externo. A doença ocupacional, por sua vez, era aquela "contraída exclusivamente pelo exercício do trabalho'". Surgiu também a primeira lei sobre Previdência Social (Decreto $n^{\circ} 4.682$ de 1923, "Lei Eloy Chaves"), que estabelecia as primeiras Caixas de Aposentadorias e Pensões, voltadas inicialmente apenas para ferroviários, marítimos e portuários, trabalhadores essenciais à economia agroexportadora de café. Essas Caixas tinham natureza civil-privada, sendo sua gestão realizada por representantes dos empregadores e dos empregados.

Em termos de política de Estado, a higiene do trabalho foi considerada, a partir da Reforma Carlos Chagas (do início dos anos 20), uma atribuição da saúde pública, sob 
responsabilidade, até 1930 , do Departamento Nacional de Saúde Pública, órgão integrante do Ministério da Justiça e Negócios Interiores. Institucionalmente, foi criada em 1923, com o Regulamento Sanitário Federal decorrente dessa Reforma, uma Inspetoria de Higiene Industrial no âmbito do Departamento Nacional de Saúde Pública, que lá permaneceram até 1930 (MENDES, 1995).

A concepção que imperava era de que pertenceriam à esfera pública apenas os problemas individuais que ameaçassem o restante da população ou a ordem econômica e social vigente; com isso, duas vertentes se delinearam no desenvolvimento dos serviços de atenção à saúde: a saúde pública e a medicina previdenciária. Como aponta Ponte (2010d), começou a se operar uma crescente separação entre a área da saúde pública e o atendimento médico individualizado propiciado pela medicina previdenciária, que persistiria ao longo da maior parte do século XX. A saúde pública seria financiada pelos recursos do Tesouro Nacional, e a medicina previdenciária, durante longo período, pela contribuição de empregados, patrões e consumidores (que participavam da formação dos fundos de seguridade social de maneira indireta e sem direito aos benefícios do sistema, uma vez que as empresas repassavam parte dos encargos que Ihes cabiam para os custos finais de seus produtos e serviços).

As intervenções do Estado tinham caráter esporádico e muitas vezes localizado, com predomínio de ações coletivas sobre as de assistência médica individual, e concentravam-se em São Paulo, Minas Gerais e Capital Federal (Rio de Janeiro). Algumas empresas forneciam serviços médicos aos trabalhadores dentro da empresa, embora os custos (ou parte deles) fossem repassados aos trabalhadores, por meio de descontos salariais (ROCHA; NUNES, 1993). 


\subsection{CONTEXTO DOS ANOS 30 a 45 (Era Vargas)}

\subsubsection{CONTEXTO POLÍTICO-ECONÔMICO E SOCIAL}

A Era Vargas compreende o governo de Getúlio Vargas, iniciado em 1930 e com término em 1945, e se divide em três períodos distintos: Governo Provisório (19301934), Governo Constitucional (1934-1937) e Estado Novo (1937-1945).

- Governo Provisório (1930-1934): Getúlio Vargas, candidato da Aliança Liberal (chapa de oposição que reunia setores das classes médias e grupos oligárquicos dissidentes de Minas Gerais, Rio Grande do Sul e de alguns estados do Nordeste), após ser derrotado nas eleições para a Presidência da República pelo representante das forças políticas de São Paulo, Júlio Prestes, "assume o poder através de um movimento armado. A Revolução de 30 [...] derruba o governo do paulista Washington Luís e põe fim à chamada República Velha ou República Oligárquica" (PONTE, 2010d, p. 130).

- Governo Constitucional (1934-1937): após o processo constituinte de 1933 e a promulgação da Constituição de 1934, Getúlio Vargas se tornou presidente constituído de modo legal, eleito de forma indireta pela própria Assembleia (PONTE, 2010d).

- Estado Novo (1937-1945): em novembro de 1937, quando já tinha sido iniciada a campanha da sucessão presidencial, Vargas, com o apoio da cúpula militar e promovendo um clima de anticomunismo após o levante comunista fracassado de 1935, promoveu um golpe que implantou o Estado Novo. O Congresso Nacional foi fechado, os partido políticos foram extintos e foi outorgada uma nova Constituição ao país. O Estado Novo se caracterizou politicamente como uma ditadura pessoal, organizada por meio de um Estado centralizado e forte e ideologicamente afinado com o fascismo, "em particular na defesa de um Estado tutor da sociedade, na crítica à democracia parlamentar, à pluralidade partidária e à representação autônoma de interesses". Vargas adotou o corporativismo como doutrina oficial do regime, que durou até 29 de outubro de 1945, quando ocorreu sua deposição (PONTE, 2010d). 
Do ponto de vista econômico, o período caracterizou-se pelo desenvolvimento industrial via substituição de importações, associando o crescimento da produção à expansão do consumo do mercado interno (ROCHA; NUNES, 1993).

Observava-se a criação de novas indústrias, a expansão da siderurgia e a criação do Conselho Nacional do Petróleo.

Do ponto de vista político, o período marcou-se incialmente pela Revolução de 1930, que levou à presidência Getúlio Vargas, que nela permaneceu até 1945. Rocha e Nunes (1993, p. 98) caracterizam a Era Vargas em dois momentos distintos: “Até 1937, onde existia uma crise de hegemonia devido à disputa de diferentes classes na sucessão da oligarquia cafeeira, e após 1937 [Estado Novo], um período com características ditatoriais".

Nesse período, houve maior intervenção do Estado no estabelecimento de políticas sociais que objetivariam assegurar o processo de industrialização e o controle dos movimentos dos trabalhadores.

As reivindicações dos trabalhadores no período versavam sobre o tema da Previdência Social, acidentes de trabalho, salários e jornadas de trabalho.

Como aponta Luca (2001), mesmo com a dura repressão imposta aos sindicatos nos anos 10 e 20 (anarquistas, socialistas e, depois de 1922, comunistas, e suas agremiações), um importante papel foi por eles desempenhado até a imposição da Lei de Segurança Nacional, em 1935.

Segundo Foot Hardman e Leonardi (1982, p. 289), extirpar a função política dos sindicatos operários foi uma das principais reações ao movimento dos trabalhadores pelo Estado após 1930. Contudo, essa reação só teria se efetivado, "após sete anos de acirrado enfrentamento de classes" com o Estado Novo (a partir de 1937). Os autores destacam a luta dos anarcossindicalistas contra o processo de destruição da antiga estrutura sindical livre e autônoma construída durante a República Velha.

O controle do movimento sindical iniciou-se em 1930, por meio do Decreto $\mathrm{n}^{0} 19.443$, que criou o Ministério do Trabalho, Indústria e Comércio, o qual passou a ser o responsável pelo controle da aplicação das leis sociais. Em 1931, o Decreto $n^{\circ} 19.770$ regulamentou a sindicalização de classes patronais e operárias, tendo por base 
princípios corporativos, como a colaboração do sindicato na resolução de conflitos e a obediência a critérios e exigências para seu reconhecimento, por parte do Ministério do Trabalho, e para a filiação do trabalhador a ele. Também se vedava a "propaganda ideológica" no sindicato. ${ }^{27} \mathrm{O}$ movimento sindical autônomo, composto por socialistas e anarcossindicalistas, não aceitou essa lei, e houve baixa procura pelo reconhecimento por parte do Ministério (ROCHA; NUNES, 1993; DUTRA, 1988).

Nesse decreto, assim passou a ser definido o sindicato: “Art. $5^{\circ}$. [...] orgãos consultivos e technicos no estudo e solução, pelo Governo Federal, dos problemas que, economica e socialmente, se relacionarem com os seus interesses de classe" (BRASIL, 1931), e não como órgãos de representação de interesses patronais e dos trabalhadores. O mesmo decreto estabelecia também que os sindicatos deveriam ser oficialmente reconhecidos pelo Ministério do Trabalho, Indústria e Comércio, recém-criado, para que seus filiados pudessem ter acesso a benefícios como direito a férias e acesso à legislação previdenciária, o que se dava mediante estrita obediência às exigências estabelecidas pelo ministério (PONTE, 2010d, p. 134).

Já no período constitucional do governo Vargas (após sua eleição pela Assembleia Nacional Constituinte), surgiu uma nova legislação sindical por meio do Decreto 24.694 de 1934, que instituiu a pluralidade sindical, apesar de manter as disposições que atrelavam os sindicatos ao Estado, com perda de sua autonomia (DUTRA, 1988).

Em 1935, o Congresso Nacional aprova a Lei de Segurança Nacional (Lei $n^{\circ} 38$ de 1935), a "Lei Monstro"28 a retomada do movimento operário e sua expressão política só seriam novamente possíveis com a derrocada do Estado Novo, com formas diferentes das existentes até 1930/35 (DECCA, 1991).

Em 1937, com a implantação do Estado Novo, uma nova Constituição foi promulgada, determinando que apenas sindicatos reconhecidos regularmente pelo Estado

\footnotetext{
27 Pelo decreto, só seriam reconhecidos os sindicatos compostos por pessoas que exercessem profissões idênticas, similares ou conexas (art. $1^{\circ}$ ), permitindo-se a criação de uma "federação regional" ou de base estadual, sendo que cinco federações poderiam constituir uma confederação de base nacional (art. $3^{\circ}$ ). Entretanto, só poderia haver uma organização de cúpula operária: a Confederação Brasileira do Trabalho.

28 A Lei de Segurança Nacional, apelidada de "Lei Monstro" pela oposição ao regime, definia o que constituía crime da ordem política e social contra o Estado (CÂMARA..., 2008).
} 
poderiam ter representação legal. O Decreto $n^{0} 1402$ (de 1939) instituiu a unidade sindical, ou monopólio da representação sindical, bem como o imposto sindical e a intervenção sobre os sindicatos. O imposto sindical compulsório favorecia, por sua vez, a manutenção de serviços assistenciais (médico e jurídico) pelos sindicatos (ROCHA; NUNES, 1993).

\subsubsection{CONDIÇÕES DE SAÚDE E TRABALHO}

Segundo Rocha e Nunes (1993), as condições de vida e saúde eram precárias; a esperança de vida, ao nascer, em 1940, era de 42,2 anos, e a mortalidade infantil, em 1941, era de 202,33 em 1000 nascidos vivos. Os autores informam que as doenças infecciosas e parasitárias corresponderam, em 1930, a 45,7\% das mortes, e em 1940, a $43,5 \%$.

Comuns até os anos 30, doenças pestilenciais, como febre amarela, varíola e lepra, dariam lugar às "doenças de massa" (verminose, esquistossomose, desnutrição, etc.), que estariam diretamente associadas às condições de vida da população rural e das camadas urbanas mais desfavorecidas (MONTERO, 1985).

As condições de trabalho continuavam precárias, com grande incidência de acidentes de trabalho. Grandes empresas manteriam serviços médicos com caráter curativo para assistência médica a seus empregados (ROCHA; NUNES, 1993).

Quanto ao regime de trabalho, aparentemente, por volta de 1934, o mais "comum" era de oito horas diárias, mas "exceções" ainda vigentes reafirmariam as dificuldades conhecidas de sua implantação efetiva, como lutas dos trabalhadores no período de 1927-1934 para a obtenção do cumprimento da legislação já estabelecida (inclusive da lei das oito horas de trabalho), que também apontariam a lentidão com que o regime estabelecido em lei foi incorporado na prática (DECCA, 1987).

\subsubsection{POLÍTICAS PÚBLICAS DE SAÚDE E TRABALHO}

Até 1930, as ações sanitárias eram de responsabilidade do nível local, por meio de unidades chamadas Departamentos, Serviços ou Direções Sanitárias; em 1930, houve 
sua centralização no Ministério dos Negócios da Educação e Saúde Pública (criado e regulamentado pelos Decretos $n^{0} 19.402$, de 1930, e 19.560, de 1931). Até os anos 30, as atividades de saúde pública, incluídas as de higiene industrial, se concentravam no Departamento Nacional de Saúde Pública, ligado ao Ministério da Justiça e Negócios Interiores. A criação de ministérios fez com que as ações do Departamento fossem divididas; a higiene e segurança do trabalho passaram a ser responsabilidade do Ministério do Trabalho, Indústria e Comércio, e a saúde pública, do Ministério dos Negócios da Educação e Saúde Pública (ROCHA; NUNES, 1993).

Criaram-se os Institutos de Aposentadoria e Pensões (IAPs) para categorias profissionais de trabalhadores urbanos, que tinham participação do Estado na administração e gerenciamento dos recursos. Rocha e Nunes (1993) chamam atenção para seu duplo caráter: de resposta a reivindicações preexistentes dos trabalhadores e, ao mesmo tempo, mecanismo de controle desses trabalhadores. Já a Previdência, nesse período, teria como características a redução dos benefícios e prestação de serviços (se comparados aos da década de 20), ainda que estendidos a trabalhadores anteriormente não contemplados, e participação do Estado na administração e custeio, embora apenas teoricamente, como ressaltam os autores. Categorias com maior capacidade reivindicativa conseguiam garantir o fornecimento de assistência médica, enquanto os industriários, que correspondiam a cerca de $50 \%$ da população dos institutos não recebiam esse tipo de serviço.

Os Institutos, organizados por categoria profissional, favoreceriam um vínculo entre sindicato e sistema previdenciário, um "clientelismo" dentro dos sindicatos, desde pequenos favores, "como obtenção de internação", a manipulação de verbas e empregos públicos (ROCHA; NUNES, 1993, p. 101). Para a concessão da aposentadoria ordinária, a legislação estabelecia tempo de serviço e idade mínima (exemplo, 30 anos de serviço e idade acima de 50/55 anos e, depois, 60 anos). ${ }^{29}$

A partir dos anos 30, segundo Rocha e Nunes (1993), o Estado passou a intervir nas relações de trabalho, como intermediário entre empregadores e empregados, de duas formas: 1) por meio do controle do movimento sindical, atrelando-o ao Estado; 2) por

\footnotetext{
${ }^{29}$ Vale lembrar que, no período, a esperança de vida, ao nascer, era de 42,2 anos.
} 
meio de legislação trabalhista, visando à atuação a respeito de condições de vida e trabalho.

Em 1931, foi criado o Departamento Nacional do Trabalho (Decreto $n^{\circ}$ 19.671), composto por duas seções: 1) organização, higiene e segurança e inspeção do trabalho; 2) previdência social, patrocínio operário e atuariado (ROCHA; NUNES, 1993). Em 1934, as questões ligadas à segurança do trabalho se tornaram responsabilidade da Inspetoria de Higiene e Segurança do Trabalho, dentro do Departamento Nacional do Trabalho. Essa Inspetoria se transformou, em 1938, em Serviço de Higiene e Trabalho e, em 1942, em Divisão de Higiene e Segurança do Trabalho (ROCHA; NUNES, 1993).

O Decreto-Lei n 399 (de 1938), que implantou o salário mínimo, também criou o adicional de insalubridade (AI), vinculado a percentual do salário mínimo (10\%, $20 \%$ ou 40\%), determinando a elaboração de quadro de indústrias insalubres (ROCHA; NUNES, 1993).

Em 1934, surgiu a segunda lei relacionada a acidente de trabalho (Decreto $n^{\circ} 24.637$ ), que estendeu o conceito de acidente, abrangendo doenças profissionais atípicas, definindo-o como "toda lesão corporal, perturbação funcional, ou doença produzida pelo exercício do trabalho ou em consequência dele" (SOUSA, 2012, s/p). Também se atribuía ao empregador a responsabilização de danos causados aos empregados.

Em 1944, foi promulgada a terceira lei acidentária (Decreto-Lei $\left.n^{\circ} 7.036\right)$, "considerada [...] a Lei mais completa quanto à proteção dos trabalhadores e seus dependentes" (ROCHA; NUNES, 1993, p. 106). A lei promoveu outra ampliação do conceito de acidente do trabalho, ao adotar a teoria da concausa; ${ }^{30}$ pois se retira do conceito de acidente do trabalho a causa única e exclusiva para a lesão. A lei determinava a obrigação, para o empregador, de proporcionar a seus empregados a máxima segurança e higiene no trabalho, prevendo, também, a obrigação dos empregados de cumprir as normas de segurança determinadas pelo empregador. Também se instituiu

\footnotetext{
30 Art. $3^{\circ}$ : “Considera-se caracterizado o acidente, ainda quando não seja ele a causa única e exclusiva da morte ou da perda ou redução da capacidade do empregado, bastando que entre o evento e a morte ou incapacidade haja uma relação de causa e efeito" (BRASIL, 1944).

"A teoria da concausa pode ser entendida como outra causa que em conjunto com acidente ou a doença primeira, concorre para o resultado, ou seja, ela não deflagra ou interrompe o processo da doença, apenas reforça/intensifica a mesma" (SILVA, 2011, p. 143).
} 
a "obrigação para o empregador de formalizar o seguro contra os riscos de acidente perante a instituição previdenciária de filiação do empregado" (SOUSA, 2012, s/p).

Em 1943, por meio do Decreto-Lei $n^{0} 5.452$, foi criada a Consolidação das Leis do Trabalho (CLT), que reuniu legislação relacionada à organização sindical, previdência social, proteção ao trabalhador e justiça do trabalho (esta, criada na Constituição de 1934). O Capítulo $V$ da CLT dispunha sobre as normas de segurança e medicina do trabalho $^{31}$ e representou a base para as Normas Regulamentadoras de Saúde e Segurança do Trabalho estabelecidas em 1978 (ROCHA; NUNES, 1993).

Lacaz (1996) denomina "saúde como razão instrumental" essa ação do Estado na saúde visando aumentar a capacidade produtiva dos indivíduos, primeiramente por meio do Ministério do Trabalho, Indústria e Comércio e depois do Ministério do Trabalho e Previdência Social, "com total omissão do Ministério da Saúde" (situação que só começou a se modificar a partir da VIII Conferência Nacional de Saúde, em 1986).

Bernardo e Garbin (2011) ressaltam que, desde a década de 1930 até a estruturação do SUS, a assistência à saúde da população trabalhadora não dizia respeito à saúde pública e era atribuição das empresas e da Previdência Social. O caráter fragmentário e corporativo da previdência social, na medida em que se vinculava a prestação de serviços médicos e assistenciais à contribuição trabalhista regulamentada, terminaria por excluir boa parte da população brasileira dos benefícios do sistema, além de não se estender a grande parte das zonas rurais do país, fortemente marcadas por relações trabalhistas bastante precárias do ponto de vista legal (PONTE, 2010d). Também não haveria uniformidade entre os Institutos no oferecimento dos benefícios aos seus associados ou nas exigências e critérios de concessão.

\footnotetext{
31 O Capítulo V da CLT contém as seguintes seções: da inspeção prévia e do embargo ou interdição; dos órgãos de segurança e de medicina do trabalho nas empresas; do equipamento de proteção individual; das medidas preventivas de medicina do trabalho; das edificações; da iluminação; do conforto térmico; das instalações elétricas; da movimentação, armazenagem e manuseio de materiais; das máquinas e equipamentos; das caldeiras, fornos e recipientes sob pressão; das atividades insalubres ou perigosas; da prevenção da fadiga; das outras medidas especiais de proteção; das penalidades (BRASIL, 1943).
} 


\subsection{CONTEXTO DOS ANOS 46 a 64 (4ạ República ou República Populista)}

\subsubsection{CONTEXTO POLÍTICO-ECONÔMICO E SOCIAL}

O período se caracterizou por grande crescimento da industrialização, uma nova etapa do processo de substituição de importações. Entre 1920 e 1960, enquanto a população teve um aumento de $231,6 \%$, a população operária aumentou 579,2\% (ROCHA; NUNES, 1993).

Na década de 1950, teria ocorrido um surto econômico mundial e independente de regimes econômicos, que Hobsbawm (1995) chamou de "Era de Ouro". Segundo o autor, "a Era de Ouro foi um fenômeno mundial, embora a riqueza geral jamais chegasse à vista da maioria da população do mundo" (HOBSBAWM, 1995, p. 255). O Brasil viveria nessa época seu segundo surto de industrialização, com indústrias de base e, posteriormente, indústrias de bens de consumo duráveis - o automóvel seria uma marca desse período (ROUQUIÉ, 1991).

Esse surto econômico foi em grande parte movido por uma revolução tecnológica, que teria multiplicado a capacidade produtiva da economia mundial, tornando possível uma divisão de trabalho internacional muito mais elaborada e sofisticada. De início, isso teria se limitado em grande parte ao conjunto das chamadas "economias de mercado desenvolvidas". Os países em desenvolvimento mais dinâmico no Terceiro Mundo, na década de 1950, teriam optado pela industrialização segregada e planejada, substituindo sua própria produção pela importação de manufaturas.

Até 1955, o processo de industrialização privilegiou a indústria nacional; no governo de Juscelino Kubitschek (1956-1960), iniciou-se a abertura ao capital estrangeiro (ROCHA; NUNES, 1993). Com a política desenvolvimentista de Kubitschek, "Era preciso dedicar um volume crescente de trabalho para produzir bens de produção; produzir mais artigos de exportação; construir Brasília e a rede de transportes que a interligasse com os principais centros urbanos do país" (SINGER, 1976, apud ROCHA; NUNES, 1993, p. 110).

A partir da década de 1960, começou a surgir uma economia cada vez mais transnacional, uma "economia mundial" que, "na verdade não tem base ou fronteiras 
determináveis, e que estabelece, ou antes impõe, limites ao que mesmo as economias de Estado muito grandes e poderosos podem fazer" (HOBSBAWM, 1995, p. 272). No início da década de 1970, uma economia transnacional já teria se tornado uma força global efetiva.

O processo de industrialização desde 1945 vinha produzindo considerável movimento migratório do campo para a cidade. No governo de Kubitschek, essa migração se intensificou - no Rio de Janeiro, por exemplo, observou-se (ao comparar os censos de 1950 e 1960) um crescimento populacional de 100 mil habitantes por ano, e São Paulo teve sua população duplicada.

Em termos políticos, após a queda do Estado Novo, o país vivia processo de redemocratização (ROCHA; NUNES, 1993) e de rápida urbanização.

Em dezembro de 1945, foram realizadas eleições à Presidência da República, sendo vencidas pelo general Eurico Dutra, apoiado pelo Partido Social Democrático, comandado pelos interventores estaduais durante o Estado Novo (FREIRE, s/d). 0 pleito seguinte foi vencido por Getúlio Vargas, que iniciou em 1951 seu segundo governo. Em agosto de 1954, Vargas se suicidou, assumindo a presidência o vice, Café Filho. Em 1956, foi eleito presidente Juscelino Kubitschek e vice, João Goulart (Jango). Em 1961, foi eleito presidente Jânio Quadros e vice, Jango. Em 25 de agosto de 1961, Quadros renunciou. Jango, em visita oficial à China, sofreu resistências dos militares para assumir a presidência. Visando contornar a crise sucessória, Goulart decidiu aceitar a fórmula parlamentarista proposta pelos militares e assumiu a presidência (PAULA, s/d). Em janeiro de 1963, em plebiscito popular, foi determinada a volta ao presidencialismo (KORNIS, s/d). Em 31 de março de 1964, ocorreu o golpe militar que determinou o afastamento de Jango da presidência (FERREIRA, s/d).

O papel do estado se ampliou, aumentando o número de serviços e benefícios oferecidos pela Previdência Social. Para Rocha e Nunes (1993, p. 111), "pretendia-se com isso suavizar as tensões sociais com o estabelecimento de políticas sociais de caráter populista. O modelo populista esgota-se durante o governo JK e no período 1960-1964". 
No período de 45 a 64, sob a democracia populista, grande parte dos sindicatos "foram colocados como sócios do Estado e, nessa condição, pensavam resolver os problemas dos trabalhadores. Eles continuavam sob o controle do Estado pela legislação, que permitia a intervenção nos sindicatos e mantinha o imposto sindical" (ROCHA; NUNES, 1993, p. 110). A Constituição de 1946 não teria alterado a legislação sindical, permanecendo a estrutura sindical atrelada por meio de controles políticos e econômicos ao Estado. O Estado oferecia, como expõem Rocha e Nunes (1993), respostas pontuais a reivindicações dos trabalhadores, como, por exemplo, o adicional de periculosidade de $30 \%$ do valor dos salários, concedido por meio da Lei $n^{\circ} 2.573$ (de 1955) a trabalhadores em contato permanente com inflamáveis.

No governo de Kubitschek, em 1960, o Brasil viveu a Greve de Paridade, que reuniu 700 mil trabalhadores em todo o Brasil, reivindicando paridade aos militares no reajuste de salários (MOTTA, 2004). O presidente, em fim de mandato, ameaçou usar do Estado de Sítio para reprimir os trabalhadores (MATTOS, 2004).

Já no governo João Goulart, os trabalhadores obtiveram algumas vitórias significativas, tais como o décimo terceiro salário, em 1962 (Lei $n^{\circ}$ 4.090), e um reajuste salarial de $80 \%$ em 1963, após uma greve em São Paulo que envolveu diversas categorias profissionais e mobilizou cerca de 700 mil trabalhadores (GERAB; ROSSI, 1997). Já para Kornis (s/d), o aumento visaria assegurar o apoio das lideranças sindicais e das bases trabalhadoras à volta ao presidencialismo, no plebiscito do mesmo ano.

No governo João Goulart, o movimento sindical urbano foi muito atuante. Antes de Jango tomar posse, houve greve geral decretada pelos líderes sindicais em reação ao impasse criado pelos ministros militares à posse do vice-presidente por ocasião da renúncia de Jânio Quadros. Em 1962, também foi organizada greve que reivindicava o retorno do presidencialismo. O governo Jango foi marcado por inúmeras greves, motivadas por reivindicações salariais e para pressionar o governo a realizar as reformas de base (KORNIS; MONTEIRO, s/d). Gomes (s/d) afirma que "o governo Goulart foi um dos marcos na história do movimento sindicalista brasileiro, na medida em que nesses anos as ações sindicais, inclusive as greves, ampliaram e explicitaram a participação dos sindicatos nas grandes questões da política nacional”. Já em 1964, com os rumores de um possível golpe para depor o presidente, o movimento sindical 
foi um dos responsáveis pelo comício popular realizado no dia 13 de março na Central do Brasil, no Rio de Janeiro, o Comício das Reformas, que reuniu 150 mil pessoas. Apesar das tentativas de conter o movimento golpista, em 31 de março, os militares afastaram Jango da presidência. O governo militar interveio nas organizações sindicais, e seus principais líderes foram presos (GOMES, s/d).

\subsubsection{CONDIÇÕES DE SAÚDE}

A esperança de vida ao nascer, em 1950, era de 45,6 anos e, em 1960, de 51,3 anos; observa-se redução da mortalidade infantil, de 170,2 em 1.000 nascidos vivos para 102,41 em 1964. Em 1950, as mortes por doenças parasitárias e infecciosas representavam 35,9\%, caindo para 25,9\% em 1960; já as doenças do aparelho circulatório representavam $14,2 \%$ do total de mortes em 1950, e 21,5\% em 1960, indicando início de mudança do padrão de saúde-doença, com a tendência de declínio das doenças infecciosas e parasitárias e aumento das crônico-degenerativas, relacionadas com o desenvolvimento industrial (ROCHA; NUNES, 1993).

\subsubsection{POLÍTICAS PÚBLICAS DE SAÚdE E TRABALHO}

No final dos anos 50, houve aumento de prestação de assistência médica, em virtude das pressões crescentes por cuidado médico, que acompanhariam o desenvolvimento industrial (ROCHA; NUNES, 1993).

O fornecimento da assistência médica passou a ser um serviço prestado pela Previdência Social, que construiu ambulatórios e hospitais próprios (ROCHA; NUNES, 1993). Conforme Pontes (2010f, p. 147), no campo da saúde, embates opunham defensores da subordinação da assistência médica a um conceito de saúde pública "que superasse o corporativismo e englobasse saúde pública e medicina previdenciária", e aqueles que defendiam a manutenção da separação entre tais setores.

Em 1953, o Ministério da Saúde foi transformado em ministério autônomo, e sua estrutura compreendia as Divisões: 1) Campanhas Nacionais; 2) Assistência Materno- 
Infantil; 3) Assistência Hospitalar; 4) Assistência a Psicopatas; 5) Saúde dos Portos; 6) Fiscalização do Exercício Profissional; 7) Fiscalização Antivenérea nas Fronteiras; 8) Delegacias Federais de Saúde (ROCHA; NUNES, 1993).

Uma discussão do período, segundo Rocha e Nunes (1993), era se o desenvolvimento industrial seria suficiente para resolver os problemas sociais (incluídos os da saúde), criando-se na época a teoria do círculo vicioso da pobreza-doença.

Em 1960, foi promulgada a Lei $n^{\circ}$ 3.087, a Lei Orgânica da Previdência Social (LOPS) e, em 1963, no governo João Goulart, o Estatuto do Trabalhador Rural (Lei $n^{\circ} 4.212$ ). A LOPS uniformizou os direitos a benefícios e serviços dos segurados de todos os Institutos e garantia:

1) aos segurados: auxílio-doença, aposentadoria por invalidez, aposentadoria por velhice, aposentadoria especial, aposentadoria por tempo de serviço, auxílio-natalidade, pecúlio, assistência financeira; 2) aos dependentes: pensão, auxílio-reclusão, auxílio-funeral e pecúlio; 3) aos beneficiários em geral: assistência médica, assistência alimentar, assistência habitacional, assistência complementar, assistência reeducativa e de readaptação profissional (ROCHA; NUNES, 1993, p. 114).

Contudo, como destacam os autores, esses direitos garantidos na legislação não eram assegurados na prática.

\subsection{CONTEXTO DOS ANOS 64 a 85 (Ditadura Militar)}

\subsubsection{CONTEXTO POLÍTICO-ECONÔMICO E SOCIAL 32}

No plano político, em 1974, a crise econômica e a piora das condições de vida levaram à votação maciça na oposição ao regime militar (ROCHA; NUNES, 1993). Essa derrota eleitoral do governo teria forçado medidas adotadas para "mudança lenta, gradual e segura" e a "transição controlada" pelo presidente Ernesto Geisel (15/03/74 a

32 Durante o regime militar (01/04/1964 a 15/03/1985), os presidentes do período foram: Ranieri Mazzilli (interino, presidente do Congresso), de 2 a 15 de abril de 1964; Humberto Castelo Branco, de 15 de abril de 1964 a 15 de março de 1967; Artur da Costa e Silva, de 15 de março de 1967 a 31 de agosto de 1969; Aurélio de Lira Tavares, Augusto Rademaker e Marcio de Souza Melo (Junta Governativa Provisória de 1969), de 31 de agosto a 30 de outubro de 1969; Emilio Garrastazu Medici, de 30 de outubro de 1969 a 15 de março de 1974; Ernesto Geisel, de 15 de março de 1974 a 15 de março de 1979; João Figueiredo, de 15 de março de 1979 a 15 de março de 1985. 
15/03/79), como a substituição do Al-5, em janeiro de 1979, "por um conjunto de medidas denominadas salvaguardas constitucionais" (REIS, 2010, p. 221). Contudo,

\begin{abstract}
Na lógica de uma "transição controlada" para o regime democrático não estava previsto que as ruas e praças do país viessem a ser ocupadas por diversos movimentos de protesto e de contestação às políticas da ditadura militar, forçando o governo, e também a oposição liberal, a aceitar uma ampliação da agenda política relacionada com os rumos da redemocratização do país. Com efeito, o que se observa desde os anos de 1970 é um processo de fortalecimento da chamada sociedade civil, que, afastada do espaço da "grande política", procurava [...] agir coletivamente e politizar um conjunto de questões relacionadas ao cotidiano da vida nas grandes cidades, ocupando praças, igrejas, bares, escolas, e transformandoos, em espaços públicos de "reorganização política e de oposição ao regime" (REIS, 2010, p. 222).
\end{abstract}

Em 1980, teve fim o bipartidarismo instituído em 1965; em 1982, houve eleições diretas para governador (suspensas desde 1966) e, na sequência, um grande movimento que reivindicava eleições diretas para presidente da República (CARVALHO, 2011).

O movimento civil de reivindicação por eleições presidenciais diretas no Brasil ocorrido em 1983-1984 ficou conhecido como "Diretas Já". Em junho de 1983, ocorreu em Goiânia a primeira manifestação popular em favor das eleições diretas. No mesmo ano, enquetes de opinião pública revelavam o interesse da população pelas eleições diretas para presidente. Em 27 de novembro de 1983, PMDB, PT, PDT, a Comissão de Justiça e Paz da Arquidiocese de São Paulo, a Central Única dos Trabalhadores (CUT), o Congresso das Classes Trabalhadoras (CONCLAT), a União Nacional dos Estudantes (UNE), "num total de aproximadamente setenta entidades", organizaram o primeiro grande ato público em defesa das eleições diretas, na Praça Charles Muller, em São Paulo. Seguiram-se diversas manifestações, e os comícios se espalharam por todo o país. No Rio de Janeiro, em 10 de abril de 1984, um comício reuniu cerca de um milhão de pessoas na Candelária; seis dias depois foi seguido pelo de São Paulo, no Vale do Anhangabaú, que reuniu um milhão e quinhentas mil pessoas.

A proposta de eleições diretas para a Presidência da República se deu por meio de apresentação de emenda constitucional (Emenda Dante de Oliveira) a ser votada pelo Congresso Nacional. Em abril de 1984, poucos dias antes dessa votação, o presidente João Figueiredo (15/03/79 a 15/03/85) impôs, por meio do Decreto $n^{\circ} 89.566$, medidas de emergência que proibiam concentrações públicas e estabeleciam a censura prévia 
dos meios de comunicação, além de outras ações restritivas (REIS, 2010). A emenda foi rejeitada em 1984. Em 1985, por meio de eleição indireta (via Colégio Eleitoral), foi eleito Tancredo Neves que, falecendo antes de assumir, foi substituído pelo VicePresidente, José Sarney (15/03/85 a 15/03/90).

No plano econômico, Rocha e Nunes (1993, p. 122) dividem o período em duas fases: a de 64-74 e após 74. A fase 64-74 corresponderia ao "milagre econômico"; a justificativa para o crescimento econômico associado a arrocho salarial seria a de que seria preciso "deixar o bolo crescer para então dividir". Após 74, iniciou-se período de crise econômica interna e internacional.

O crescimento econômico foi acompanhado de arrocho salarial e intenso controle sobre o movimento sindical: os militares intervieram nos sindicatos e prenderam seus líderes. Foram instituídas Leis de Greve (lei $n^{\circ} 4.330$, de 1964) e criou-se o FGTS (Fundo de Garantia por Tempo de Serviço), que gerou a perda da estabilidade no emprego (ROCHA; NUNES, 1993).

Começou a surgir, sobretudo a partir da década de 1960, uma economia cada vez mais transnacional, ou seja, um sistema de atividades econômicas para as quais os territórios e fronteiras de Estados não constituíam extremos; passou a existir uma "economia mundial" que não teve base ou fronteiras determináveis, e que estabeleceu - ou antes, impôs - limites ao que mesmo as economias de Estados grandes e poderosos poderiam fazer. Em dado momento do início da década de 1970, uma economia transnacional assim tornou-se uma força global efetiva, que continuou a crescer durante as décadas de crise após 1973. Três aspectos dessa transnacionalização seriam particularmente destacáveis: as empresas transnacionais (conhecidas como "multinacionais"), a nova divisão internacional do trabalho e o aumento de financiamento offshore (externo) (HOBSBAWM, 1995).

Em decorrência das transformações dos processos de trabalho, como a terciarização da economia dos países mais industrializados e a transferência de indústrias de países industrializados para países em desenvolvimento, as classes operárias teriam acabado, sobretudo após a década de 1990, tornando-se vítimas das novas tecnologias, principalmente os trabalhadores não qualificados das linhas de produção em massa, que podiam ser mais facilmente substituídos por maquinário automatizado. À medida 
que as grandes décadas de boom econômico de 1950 e 1960 dariam lugar a uma era de dificuldades econômicas mundiais nos anos de 1970 e 1980, a indústria não mais se expandiria no velho ritmo que "inchara" as forças de trabalho, ${ }^{33}$ mesmo quando a produção passou a depender menos de mão de obra. A produção dispensaria trabalhadores mais rapidamente do que a economia de mercado seria capaz de gerar novos empregos. Além disso, processos acelerados pela competição global, pelo arrocho financeiro dos governos, pela predominância da ideia de livre mercado pressionavam em favor da transferência de emprego para formas empresariais de maximização de lucros, sobretudo para empresas privadas (HOBSBAWM, 1995, p. 404).

As transformações da sociedade brasileira na década de 70 , o esgotamento das possibilidades do chamado "milagre econômico" e a descensão do regime militar que sustentava esse modelo produziram, de um lado, uma forte crise econômica, que acentuou a dependência do país a mercados externos, e a desigualdade na distribuição de renda da população, e, de outro, contribuíram para o processo de redemocratização, que resultaria nos anos 80 no retorno das eleições diretas e na criação de novos partidos (L'ABBATE, 2003). O surgimento de um "novo sindicalismo" ocorreria em paralelo com o reaparecimento "às claras" da esquerda tradicional e criação de novos partidos operários, como o Partido dos Trabalhadores (PT) (ROUQUIÉ, 1991).

Com o acesso dos militares ao poder, a legislação do trabalho do Estado Novo teria sido aplicada num sentido extremamente restritivo, sobretudo durante os primeiros anos do novo regime (ROUQUIÉ, 1991). No Brasil, a abertura política e o enfraquecimento do regime militar deram um novo dinamismo ao movimento sindical, até então controlado pelo poder estatal. Onde as "velhas estruturas industriais" floresceram no fim do século XX, como no Terceiro Mundo recém-industrializado ou em economias industriais socialistas (indústrias ainda marcadamente fordistas), seriam grandes as semelhanças com o entreguerras, ou mesmo com o mundo industrial

33 Rouquié (1991, p. 171) destaca o que chamou de "políticas industriais voluntaristas" que teriam provocado, num certo período, um crescimento dos empregos industriais e assemelhados, como a citada época do "milagre" econômico (anos 70 ), em que o número de trabalhadores da indústria teve um aumento de $90 \%$. 
ocidental pré-1914, até mesmo no surgimento de poderosas organizações sindicais, como a automobilística, em São Paulo, ou de estaleiros navais, em Gdansk (HOBSBAWM, 1995).

Outra característica marcante da segunda metade do século XX foi o que Hobsbawm (1995) chamou de "morte do campesinato". Na América Latina, a porcentagem de camponeses teria se reduzido à metade em vinte anos na Colômbia, no México e no Brasil (1960-80). Nesses países, no fim da II Guerra Mundial, os camponeses formavam metade, ou a maioria absoluta, da população ocupada. Já em 1970, não haveria na América Latina, à exceção dos pequenos Estados centro-americanos, um único país em que os camponeses não fossem minoria. Como consequência, o mundo da segunda metade do século XX tornou-se urbanizado como jamais fora.

O movimento migratório gerou um aumento populacional nos centros urbanos, que experimentaram um crescimento sem precedentes. Entre 1960 e 1980, o êxodo rural brasileiro movimentou cerca de 27 milhões de pessoas, "encontrando-se entre os maiores movimentos populacionais observados na história mundial" (PONTE, 2010e). O país, que até os anos de 1960 tinha 55\% da sua população nas áreas rurais, passou a apresentar nas duas décadas seguintes um perfil demográfico eminentemente urbano, que em 1980 respondia por aproximadamente $70 \%$ do total de habitantes (GERAB; ROSSI, 1997, p. 49).

Ao contrário das populações do campo, as classes operárias industriais não teriam sofrido abalos demográficos até que, na década de 1980, começaram visivelmente a declinar. Com exceção dos EUA, onde a porcentagem de pessoas empregadas na manufatura passou a declinar a partir de 1965, e muito nitidamente após 1970, as classes operárias industriais vinham permanecendo estáveis, mesmo nos velhos países industriais, constituindo cerca de um terço da população empregada (HOBSBAWM, 1995). No Brasil, a classe operária aumentou significativamente. Na época da euforia e do "milagre" econômico, entre 1970 e 1976, o número de trabalhadores da indústria (incluindo as indústrias extrativistas) passou de 2,6 a 4,9 milhões de pessoas, num aumento de 90\% (ROUQUIÉ, 1991; ROCHA; NUNES, 1993).

Outras transformações importantes ocorreram nos processos de trabalho, sobretudo a partir da década de 70: a terciarização da economia dos países mais industrializados, 
com a diminuição da participação do setor secundário (indústria) na economia e crescimento da participação do setor terciário (serviços), e a consequente mudança no perfil de mão de obra efetivamente empregada. Além disso, começou e acentuou-se o processo (de transferência de indústrias de países industrializados para países em desenvolvimento, sobretudo de indústrias responsáveis por maior impacto ambiental ou agravos à saúde, e de indústrias que requereriam mão de obra não muito especializada e de baixa tecnologia, as chamadas "maquiladoras" (MENDES; DIAS, 1991). ${ }^{34}$ Segundo Hobsbawm (1995, p. 276),

\begin{abstract}
Era natural que a indústria se transferisse de locais de mão de obra cara para outros onde ela era barata assim que isso se tornasse possível e economicamente viável, e a (previsível) descoberta de que a força de trabalho não branca era pelo menos tão qualificada e educada quanto a branca iria ser um bônus extra para as indústrias de alta tecnologia.
\end{abstract}

Também ocorreu, crescentemente, a implantação de novas tecnologias, sobretudo as de automação e informatização, que introduziram drásticas transformações na organização do trabalho. Essas tecnologias permitiram, a um só tempo, a redução do contingente de trabalhadores empregados, ganhos em produtividade e controle da produção. ${ }^{35}$

Após o golpe militar de 1964, que deixou aos trabalhadores pouco ou nenhum espaço de ação, a não ser "o trabalho silencioso no interior das fábricas e tentativas pontuais de contestação" (SANTANA, 1999, p. 104), o sindicalismo mais progressista voltou à cena, reivindicando a ampliação de espaços de representação dos interesses da classe trabalhadora.

Em 1964, proibiu-se o direito de greve (Lei $n^{\circ} 4.330$ ); as negociações salariais entre os sindicatos e patrões foram substituídas por decretos do governo, que passou a fixar os índices de aumentos salariais; a estabilidade após 10 anos de emprego foi substituída pela lei que instituiu, em 1966, o Fundo de Garantia por Tempo de Serviço (FGTS),

\footnotetext{
34 Como expõem Gerab e Rossi (1997, p. 50), "em 1967, começou-se a substituir o parque industrial nacional por indústrias transplantadas dos Estados Unidos e da Europa. Apesar de 'modernas' para a realidade brasileira, essas indústrias eram obsoletas nos seus países".

35 Mendes e Dias (1991, p. 345) identificam, nesse movimento, o ressurgimento do taylorismo, mais sofisticado, "através de dois de seus princípios básicos: o da primazia da gerência (via apropriação do conhecimento operário e pela interferência direta nos métodos e processos), e o da importância do planejamento e do controle do trabalho".
} 
permitindo demissões em contrapartida ao pagamento de uma indenização no valor de 40\% do FGTS (Lei ${ }^{\circ} 5.107$, de 1966) (AGUENA, 2006).

No Brasil, as greves operárias de 1968 teriam um claro sentido de confronto à ditadura militar, que cerceava a liberdade e autonomia sindicais quanto à política econômica fundada na superexploração do trabalho. Essas greves seriam uma resposta dos trabalhadores ao golpe militar de 1964, que desencadeou profunda repressão à esquerda, notadamente ao PCB (Partido Comunista Brasileiro) e ao sindicalismo. A ditadura militar também decretou a ilegalidade de todos os partidos políticos, criando somente dois oficiais (Arena e MDB); interveio em diversos sindicatos, proibiu a deflagração de greves, decretou a ilegalidade da CGT (Central Geral dos Trabalhadores), da UNE (União Nacional dos Estudantes), do PCB e demais partidos da esquerda (ANTUNES; RIDENTI, 2007).

Entre 1964 e 1968, os trabalhadores tiveram seus salários reduzidos em mais de 30\% (RUY, 2010b). Desde 1967, o governo promulgou as Leis do Arrocho, como a nova norma dos reajustes salariais era conhecida pelos militantes (GIANNOTI, 2008).

Em outubro de 1967, no estado de São Paulo, mais de 40 dos principais sindicatos criaram o Movimento Intersindical Antiarrocho (MIA), que visou pressionar o governo a acabar com o arrocho salarial e programou a realização de cinco concentrações, até o dia $1^{\circ}$ de maio de 1968 (RUY, 2010b).

Em 1968, ocorreram diversas manifestações e revoltas no país: operárias, estudantis, feministas, dos negros e dos movimentos ambientalistas, entre outras. Em Contagem (região industrial na Grande Belo Horizonte - MG) e Osasco (região industrial na Grande São Paulo), articulavam-se novos núcleos de esquerda, vinculados ao movimento operário católico de esquerda e militantes e simpatizantes de organizações políticas à esquerda do Partido Comunista Brasileiro (PCB) (ANTUNES; RIDENTI, 2007).

Em 13 de dezembro de 1968, foi decretado pelo regime militar o Ato Institucional número 5 (Al-5), conhecido como "o golpe dentro do golpe", no qual

[...] oficializou-se o terrorismo de Estado, que prevaleceria até meados dos anos 70. O Congresso Nacional e as Assembleias Legislativas estaduais foram colocados temporariamente em recesso e o governo passou a ter plenos poderes para suspender direitos políticos dos cidadãos, legislar por decreto, julgar crimes políticos em tribunais militares, cassar mandatos eletivos, 
demitir ou aposentar juízes e outros funcionários públicos etc. Simultaneamente, generalizavam-se as prisões de oposicionistas, o uso da tortura e do assassinato, em nome da manutenção da "segurança nacional", considerada indispensável para o "desenvolvimento" da economia, do que se denominaria mais tarde "milagre brasileiro" (ANTUNES; RIDENTI, 2007, p. 87).

E prosseguem:

Inúmeros estudantes, operários, intelectuais, políticos e outros oposicionistas dos mais diversos matizes foram presos, cassados, torturados, mortos ou forçados ao exílio, após a edição do Al-5. Rígida censura foi imposta aos meios de comunicação e às manifestações artísticas. O regime militar dava fim à luta política e cultural do período, reprimindo duramente qualquer forma de oposição. "Anos de chumbo" viriam a suceder o "ano rebelde" de 1968.

O Al-5 restringiu ainda mais as liberdades políticas no país. O movimento operário passou então a se organizar no chão das fábricas, por meio de grupos clandestinos e reivindicações específicas (AGUENA, 2006).

O movimento operário, depois das derrotas de Osasco e Contagem em 1968, teria refluído fortemente, tendo vários de seus quadros incorporados à luta armada (ANTUNES; RIDENTI, 2007).

Apesar das reações violentas do regime, observa-se ao longo dos anos 70 um processo de fortalecimento do movimento social organizado que, "por meio de associações como greves dos "braços cruzados, máquinas paradas", organizaram-se por locais de produção em paralisações de curta duração", que tinham como principal reivindicação maiores índices de reajuste salarial, o que significava o questionamento da "política salarial e trabalhista da ditadura" (Reis, 2010, p. 226).

Um novo impulso grevista iniciou-se em 1978, com meio milhão de trabalhadores em greve e, em 1979, com 3 milhões (AGUENA, 2006). As greves de 1978 surgiram no setor metalúrgico, mas se estenderam ao serviço público (médicos, professores), trabalhadores rurais, entre outros. A mobilização pela reposição salarial desencadeou uma "avalanche de greves" (RUY, 2010a): em 1978, foram deflagradas 118 greves e, dez anos depois, elas passaram a somar 2.188.

As greves dos metalúrgicos do $A B C$ paulista serviriam de referência política para uma série de movimentos grevistas no Brasil, com movimentos que abrangeriam dos operários industriais aos funcionários públicos. Desencadeou-se uma luta salarial de 
"caráter generalizante", que envolveu uma série de categorias assalariadas, e surgiram fóruns intersindicais. Uma série de eventos e greves gerais e greves por categorias, ou por empresas, atingiram as mais diversas categorias profissionais (ALVES, 2000).

Em março de 1979, a onda grevista cresceu, sendo deflagrada a greve geral dos metalúrgicos do $A B C$ paulista, agora organizada de fora por meio de piquetes. $O$ governo decretou a intervenção nos sindicatos e as diretorias foram cassadas. Ao contrário do que se pensava, a greve ganhou novo impulso. As assembleias no estádio da Vila Euclides, em São Bernardo do Campo (SP), extrapolavam várias vezes a capacidade das arquibancadas. Sob a liderança de Lula36, o $1^{\circ}$ de Maio unitário reuniu 100 mil pessoas (AGUENA, 2006). A reação da ditadura foi violenta, com centenas de prisões de trabalhadores e líderes sindicais, intervenção nos sindicatos e cassação das lideranças mais combativas, com o uso de violência policial contra os grevistas, além de demissões e listas negras (REIS, 2010). Após 41 dias de greve, foi negociada a volta das lideranças cassadas (AGUENA, 2006).

A expressão política desse movimento, deflagrado em maio de 1978 no $A B C$, seria a criação de uma nova esquerda - como o PT, Partido dos Trabalhadores - e outras organizações de esquerda e, em 1983, da CUT (Central Única dos Trabalhadores), ao lado de outras organizações intersindicais, como o CONCLAT, ${ }^{37}$ que originaria a CGT (ALVES, 2000).

No fim dos anos 70, começou a despontar o "Novo Sindicalismo", mais voltado para a autonomia dos sindicatos em relação ao Estado, que propunha negociação direta entre empresários e trabalhadores, buscava retirar o caráter assistencialista dos sindicatos e que teve seu marco nas greves de 1978 em indústrias metalúrgicas de São Bernardo do Campo, nas quais se negociou diretamente a elevação dos salários em acordo coletivo.

\footnotetext{
36 Luiz Inácio Lula da Silva, metalúrgico, presidente à época do Sindicato de Metalúrgicos de São Bernardo do Campo e Diadema, futuro Presidente da república.

37 Num período relativamente curto (1978-1983) e marcado por intensa mobilização sindical e particularmente grevista, o Brasil viu surgirem duas tendências bem marcadas de ação sindical, consubstanciadas, a partir de 1983, em duas centrais sindicais de abrangência nacional: a Central Única dos Trabalhadores (CUT) e a Coordenação Nacional da Classe Trabalhadora (CONCLAT), mais tarde tornada Central Geral dos Trabalhadores (CGT). A partir de estratégias e orientações político-sindicais distintas, essas duas correntes passaram a reivindicar e a disputar entre si a condição de representantes dos trabalhadores frente ao Estado, ao sistema político e ao patronato (CARDOSO; COMIN, 1997, p. 167).
} 
O crescimento das negociações coletivas propiciou espaço para negociação de modificações em condições de trabalho e avanços em conquistas asseguradas por lei (ROCHA; NUNES, 1993).

O que veio a ser denominado de "novo sindicalismo" nos anos 80 caracterizou-se por uma nova prática sindical, de organização da base, da construção da intervenção operária nos locais de trabalho, considerada uma das principais debilidades do sindicalismo brasileiro. Jácome Rodrigues, ao tratar do sindicalismo nos anos 80 , observou a "presença significativa" na vida nacional da organização dos empregados nos locais de trabalho, com a denominação de comissões de fábrica, comissões de empresa, conselho de representantes dos funcionários, comissões de garagem etc. (ALVES, 2000, p. 117).

Iniciou-se uma atuação mais organizada e sistemática nas questões ligadas à relação saúde-trabalho. Em 1979, foi criada uma Comissão Intersindical de Saúde do Trabalhador, que organizou duas Semanas de Saúde do Trabalhador (SEMSAT). Em 1980, criou-se o Departamento Intersindical de Estudos e Pesquisas de Saúde e dos Ambientes de Trabalho (DIESAT), que promoveu ao longo dos anos 80 cursos, seminários e publicações sobre temas ligados à relação saúde-trabalho (ROCHA; NUNES, 1993; LACAZ, 1996; FRIAS JUNIOR, 1999).

Nos anos 80, no contexto da redemocratização, ganharam fôlego novas práticas sindicais em saúde, "traduzidas em reivindicações de melhores condições de trabalho [...] no bojo da emergência do novo sindicalismo" (MENDES, 1995, p. 26). Desempenharam importante papel nesse cenário "as assessorias técnicas sindicais, estudando os ambientes e condições de trabalho, levantando riscos e constatando danos para a saúde; decodificando o saber acumulado, num processo contínuo de socialização da informação; resgatando e sistematizando o saber operário, vivenciando, na essência, a relação educador-educando".

Rocha e Nunes (1993, p. 128) agrupam a mudança de postura do movimento sindical com relação à luta pela saúde em 5 frentes de trabalho: ${ }^{38}$

\footnotetext{
38 Lacaz (1996, p. 13) diz que, a partir de influência do Modelo Operário Italiano desde o final dos anos 70, inicia-se processo de "luta pela melhoria das condições de trabalho e em defesa da saúde no trabalho, no sentido de superar o estágio economicista das reivindicações pelo recebimento dos adicionais de insalubridade, o que ficou conhecido como 'monetização do risco'”.
} 
1) atuação mais eficiente das CIPAs, procurando cipeiros vinculados aos sindicatos e tirando o caráter "fantasma" das CIPAs; 2) criação de Departamentos de Saúde e Trabalho nos sindicatos, com a contratação de técnicos; 3) realização de debates, seminários, cursos, visando difusão da informação sobre os riscos à saúde para desenvolver a consciência e mobilização dos trabalhadores; 4) inclusão de cláusulas que resultem na melhoria das condições de trabalho nos acordos coletivos; 5) participação ativa nas mudanças jurídico-institucionais no processo de Reforma Sanitária.

Já os itens de saúde das negociações coletivas incluiriam questões relacionadas à

[...] garantia de emprego a empregados acidentados após retorno da Previdência Social, complementação do auxílio-doença; aceitação dos atestados médicos e odontológicos fornecidos por profissionais dos sindicatos; métodos de proteção coletiva do trabalho; fornecimento de equipamentos de proteção individual e uniforme; realização de exame médico periódico; envio de cópia das comunicações de acidente de trabalho (CAT) ao sindicato; eleições e garantia de emprego aos membros da CIPA, informação sobre os riscos, avaliações ambientais, participação na introdução de novas tecnologias etc. (ROCHA; NUNES, 1993, p. 129).

Contudo, deve-se destacar que uma grande parcela dos sindicatos continuou se pautando pelas premissas do assistencialismo e pelas reivindicações de adicionais de insalubridade e de periculosidade.

Rocha e Nunes (1993, p. 129) apontam como fatores que dificultariam a atuação mais efetiva do movimento sindical em relação às questões de saúde e trabalho: estrutura institucional com falta de autonomia sindical; órgãos centralizados e com ações desintegradas; baixos salários; falta de estabilidade no emprego. "Esses dois últimos fatores fazem com que as lutas tenham de ser centradas nos reajustes salariais para garantir a sobrevivência; ao lado disso, o medo da demissão faz com que os trabalhadores omitam doenças".

Outro importante movimento do período no período foi o chamado "movimento sanitário", que se iniciou nos anos 70 e teve papel destacado na resistência ao regime militar brasileiro, característico da alta politização da questão da saúde no país, que passou a reivindicar a criação do SUS (Sistema Único de Saúde) (L'ABBATE, 2003).

No final dos anos 70, viviam-se também momentos de intensas discussões e mobilizações em torno da Reforma Sanitária, as quais se balizavam pela luta por acesso à saúde e pelos princípios da Conferência de Alma-Ata (SILVEIRA et al., 2013). Em 1978, realizou-se na cidade de Alma-Ata a Conferência de "Atenção Primária em Saúde -Saúde Para Todos no Ano 2000", na qual se estabeleceu a atenção primária à 
saúde como a estratégia fundamental para se tentar alcançar a meta de Saúde para Todos na passagem para o século XXI. Já em 1975, a Assembleia Mundial de Saúde, órgão máximo de deliberação da OMS, tinha estabelecido que a implementação de sistemas nacionais de atenção primária deveria ser considerada a primeira prioridade (PIRES-ALVES; FALLEIROS, 2010). Na Conferência de 1978, ficou expressa pela "Declaração de Alma-Ata" a "necessidade de levar a atenção à saúde o mais próximo possível do lugar onde residem ou trabalham as pessoas". Em 1979, a Assembleia Mundial de Saúde tratou da necessidade de maior atenção à saúde dos trabalhadores, por meio do desenvolvimento de programas especiais dirigidos àquele grupo da comunidade (LACAZ, 1996).

Dias (1993, p. 148) destaca a atuação e o trabalho desenvolvidos pelo Centro Brasileiro de Estudos sobre Saúde (CEBES) e pela Associação Brasileira de Pós-Graduação em Saúde Coletiva (ABRASCO), que teriam "catalisado a contribuição dos sanitaristas para a luta dos trabalhadores".

\subsubsection{CONDIÇÕES DE SAÚDE E TRABALHO}

A esperança de vida ao nascer, em 1970, era de 52,8 anos e, em 1977, de 57,9 anos (com diferenças regionais marcantes: em São Paulo, era de 64,5 anos, e no Nordeste, de 49,1 anos). Quanto à mortalidade infantil, de 102,41 em 1.000 nascidos vivos em 1964 passou-se para 108,68 em 1970; no Recife, esses números corresponderiam a 125,6 em 1964 para 229,9 em 1973 (83\% de aumento). Essa alta mortalidade estaria associada, para Rocha e Nunes (1993), às precárias condições de vida (habitação, alimentação, saneamento). Para Ponte (2010e, p. 186), o crescimento das cidades, "aliado às precárias condições de vida a que foi submetida a população de baixa renda, alocada em áreas destituídas de estrutura sanitária e sofrendo os efeitos da desnutrição", alterou o quadro epidemiológico do país, "revelando, em sua face mais visível, o recrudescimento das doenças transmissíveis e o aumento da mortalidade infantil".

Em 1970, as mortes por doenças parasitárias e infecciosas representavam 15,7\%, e as doenças do aparelho circulatório, $24,8 \%$ do total de mortes, observando-se tendência 
de aumento de morte por doenças cardiovasculares e carcinomas (ROCHA; NUNES, 1993).

Em 1973, as causas mais frequentes de afastamento do trabalho com concessão de benefício pela Previdência Social foram: 1) neuroses; 2) osteoartrites; 3) hipertensão benigna; 4) epilepsia; 5) esquizofrenia; 6) tuberculose pulmonar. O primeiro grupo de doenças mais frequentes para a concessão de aposentadorias foram as cardiovasculares; o segundo, doenças mentais, que teriam aumentado em virtude da migração da população rural para a periferia das grandes cidades e perdas salariais dos trabalhadores (ROCHA; NUNES, 1993, p. 125, grifo nosso).

Apontam-se condições de saúde precárias, com associação de doenças ditas de desenvolvimento, como cardiovasculares e mentais, com a presença de elevado índice de doenças infecciosas, algumas delas endemias rurais (como doença de Chagas) que se expandiram para os centros urbanos. Esse duplo perfil de morbimortalidade sugeriria, para Rocha e Nunes (1993), a associação de padrões de adoecimento ligados a precárias condições de vida a padrões de adoecimento da população trabalhadora, nos quais predominariam doenças cardiovasculares, mentais, degenerativas e acidentes/doenças de trabalho.

Segundo Lacaz (1996), o quadro de deterioração das condições de trabalho e seus reflexos sobre a saúde-doença se expressariam na cada vez maior ocorrência de acidentes do trabalho e de doenças profissionais. Esse quadro só passaria a ser mais conhecido a partir de 1966, com a centralização administrativa das informações pela Previdência Social após a criação do Instituo Nacional de Previdência Social (INPS), sendo de 1968 a publicação oficial das primeiras estatísticas nacionais relativas aos acidentes e doenças do trabalho.

O período foi marcado pela extensão da jornada de trabalho, aumento do número de horas extras, do ritmo e do número de acidentes do trabalho (LACAZ, 1996). No início dos anos 70, o Brasil era considerado o país recordista em acidentes de trabalho, ${ }^{39}$ sendo considerados pelo Estado como associados ao processo de desenvolvimento econômico do país. Cohn et al. (apud ROCHA; NUNES, 1993) contestam esse

39 Os números do período de 1971 a 1995 podem ser observados na Tabela 1 - Acidentes do trabalho registrados por espécie / Brasil. 
posicionamento, analisando que a mão de obra não cresceu na mesma proporção do ritmo de acidentes; no período, teria havido intensificação do processo de trabalho, degeneração das condições de trabalho, em associação a arrocho salarial e controle das ações sindicais (ROCHA; NUNES, 1993). Valorizavam-se Campanhas de Prevenção de Acidentes de Trabalho, atribuindo a culpa pelos acidentes aos trabalhadores (ROCHA; NUNES, 1993).

As entidades sindicais, até 1977, teriam atuado na prevenção de acidentes por meio de participação em congressos, seminários, cursos. Nesse ano, no XVI CONPAT (Congresso Nacional de Prevenção dos Acidentes de Trabalho), teriam proposto modificações na CIPA (Comissão Interna de Prevenção de Acidentes) para que fosse um “prolongamento do sindicato no interior da empresa” (ROCHA; NUNES, 1993, p. 127).

A atuação do governo referente aos altos índices de acidentes se deu no âmbito da criação de cursos de medicina do trabalho e engenharia de segurança para ampliação dos Serviços de Medicina e Segurança das empresas, e a promulgação de nova lei de acidentes de trabalho, a Lei $n^{\circ} 6.367$, de 1976 (ROCHA; NUNES, 1993).

Nessa lei, determinou-se que o salário dos primeiros 15 dias após o acidente fosse pago pela empresa, e após o $16^{\circ}$ dia, pela Previdência. Rocha e Nunes (1993) chamam atenção para o fato de que, após essa orientação, os acidentes leves, com poucos dias de afastamento, muitas vezes deixaram de ser registrados; o sub registro poderia ser comprovado pela redução do número total de acidentes, mas não dos de maior gravidade nem dos óbitos decorrentes. Também foi eliminado o pagamento de pecúlio por pequenas perdas sem repercussão na atividade profissional, que correspondia a $80 \%$ do montante de benefícios pagos. Outra mudança foi o reconhecimento de apenas 21 agentes causadores de doenças profissionais; todas as outras doenças passaram a necessitar de comprovação de nexo causal com o trabalho para concessão de benefícios e adquiriram caráter de excepcionalidade (ROCHA; NUNES, 1993). 40

\footnotetext{
40 Rebouças (1979, apud ROCHA; NUNES, 1993, p. 128) afirma que "doenças resultantes das condições de trabalho, como bronquite, varizes, hérnias, espondilopatias, reumatismos etc. deixaram de ter o amparo legal, afastou-se a viabilidade de cerca de $90 \%$ das demandas acidentárias por doenças ocupacionais".
} 


\subsubsection{POLÍTICAS PÚBLICAS DE SAÚDE E TRABALHO}

No período 1964-1974, prevaleceu a assistência médica individualizada em relação a medidas de saúde coletiva. Em 1966, aconteceu a fusão dos Institutos de Aposentadoria e Pensão (Decreto $n^{0} 72$ ), por meio da criação do Instituto Nacional de Previdência Social (INPS), que uniformizou benefícios, serviços e contribuições (ROCHA; NUNES, 1993).

A partir de 74, sobretudo a partir de 78, ampliou-se a agenda social do Estado. Incrementaram-se as atividades assistencialistas da Previdência Social, ampliando cobertura e benefícios, e foram adotadas medidas, como a criação do Ministério da Previdência e Assistência Social (Lei $n^{\circ}$ 6.025, de 1974), e ampliação de benefícios, como salário-maternidade e amparo previdenciário para maiores de 70 anos e inválidos (ROCHA; NUNES, 1993).

Em relação à saúde pública, até o final dos anos 70 , sua ação se restringiria a controle de endemias, campanhas de imunização, programas de suplementação alimentar e assistência materno-infantil, dirigindo-se à população em geral, sobretudo a de baixa renda. Já a medicina previdenciária se ampliaria desde o fim da década de 50, assumindo a predominância a partir de meados dos anos 60, e se voltaria principalmente para o fornecimento de assistência médica individual à população trabalhadora (ROCHA; NUNES, 1993).

A Lei $n^{\circ} 6.036$ (1974) desdobrou o Ministério do Trabalho e Previdência Social em Ministério do Trabalho e Ministério da Previdência e Assistência Social. Dessa forma, a prevenção de acidentes de trabalho e Segurança e Medicina do Trabalho eram atribuições do Ministério do Trabalho, e o pagamento de benefícios e a assistência médica, seriam da competência do Ministério da Previdência e Assistência Social (ROCHA; NUNES, 1993).

No início dos anos 70, as premissas da Medicina do Trabalho-Saúde Ocupacional subsidiaram a formulação das definições de uma política governamental do Regime 
Militar, conforme previam as Portarias $n^{0} 3.236$ e $3.237^{41}$ de 27 de julho de 1972.420 momento se caracterizava, do ponto de vista sócio-político-econômico, pela elevada ocorrência de acidentes de trabalho, indicadores das "precárias e nocivas condições de trabalho envolvendo a exposição a substâncias perigosas, jornadas de trabalho extenuantes, alto número de horas-extras, ritmo alucinante, baixos salários, instabilidade no emprego e repressão sindical" (LACAZ, 1996, p. 74).

Em 1974, foi lançada pelo Ministério do Trabalho e seu "braço político-ideológico" como diz Lacaz (1996) - , a Fundacentro, ${ }^{43}$ uma Política de Higiene e Segurança do Trabalho do Estado, tendo nos Serviços Especializados de Engenharia de Segurança e Medicina do Trabalho sua "ponta-de-lança". O elevado número de acidentes do trabalho iria desencadear, por parte do Estado, grande estratégia campanhista, cabendo à Fundacentro o papel de "epicentro operacional" do movimento campanhista. Lacaz (1996) aponta como se delineou uma aliança entre Estado e empresariado, aliança que engendraria o discurso que nortearia a estratégia campanhista. As metas dessa campanha - a queda do número absoluto de acidentes do trabalho - foi "alcançada", como destaca o autor, por meio de manipulação de estatísticas, facilitada pela mudança legal introduzida com a nova Lei de Acidentes do Trabalho de $\mathrm{n}^{\circ} 6.367$ de 1976, que abole direitos e benefícios anteriormente garantidos aos trabalhadores segurados pela Lei $n^{\circ} 5.316$ de 1967.

Em 1975, a Lei $n^{\circ} 6.229$ dispôs sobre a organização do Sistema Nacional de Saúde e, em 1978, a Lei $n^{\circ}$ 6.439, sobre o Sistema Nacional de Previdência e Assistência Social (SINPAS), estruturas que perduraram na década de 80. Ao Ministério da Saúde

41 A Portaria $n^{\circ} 3.237 / 72$ sofreu várias alterações, mas nenhuma que modificasse de forma substancial seus objetivos, até que foi revogada em 1978, com a revisão do Capítulo V da CLT (Lei $n^{\circ}$ 6.514/77) e a edição da Portaria $n^{\circ} 3.214 / 78$, quando os temas regulamentados passaram a ser objeto específico da NR 4 - Serviços Especializados em Segurança e Medicina do Trabalho (SESMT) (ABPA, 2014).

42 Comemora-se, desde então, a data de 27 de julho como "Dia Nacional de Prevenção de Acidentes do Trabalho".

43 O início dos anos 70 marca um período de expansão da Fundacentro. A Fundação foi criada em 1966 com apoio da OIT a partir de ideias de técnicos ligados ao Serviço Social da Indústria (SESI), à Faculdade de Saúde Pública e à Associação Brasileira de Prevenção de Acidentes (ABPA), tendo como inspiração institutos de higiene e segurança do trabalho da Europa. Começou efetivamente a funcionar em 1969, e em 1974 foi vinculada ao Ministério do Trabalho, crescendo suas atribuições e atividades (Fundacentro, 2014). Para Lacaz (1996, p. 76), a instituição constitui elemento fundamental "na estratégia do governo brasileiro em sua busca de relações de legitimidade junto à sociedade e ao movimento sindical de trabalhadores no campo da segurança, higiene e medicina do trabalho". 
competiria reformular a política nacional de saúde e promover ações voltadas para interesses coletivos; ao Ministério da Previdência e Assistência Social, o atendimento médico-assistencial individualizado (por meio do INAMPS - Instituto Nacional de Assistência Médica e Previdência Social) e pagamento de benefícios previdenciários (por meio do INPS - Instituto Nacional de Previdência Social);44 ao Ministério do Trabalho, a competência quanto à higiene e segurança do trabalho, com foco em prevenção (ROCHA; NUNES, 1993).

No início dos anos 80, ocorreu uma série de mudanças na assistência médica previdenciária, por meio de Resoluções, Portarias, Documentos e Planos. Além de introduzir mudanças no sistema, objetivava-se também a contenção de despesas e a reversão gradual do modelo assistencial existente. Essas mudanças contribuíram para a entrada da rede pública na assistência da clientela de pacientes previdenciários antes não atendidos por ela, especialmente trabalhadores segurados da Previdência Social (LACAZ, 1996).

\subsection{CONTEXTO DE 1985 À ATUALIDADE (República Nova)}

\subsubsection{CONTEXTO ECONÔMICO-POLÍTICO E SOCIAL 45}

No governo de Sarney, foram lançados quatro planos econômicos de combate à inflação: Plano Cruzado, de 1986 (que previa a adoção de congelamento geral de preços por doze meses e gatilho salarial - reajuste sempre que a inflação alcançasse 20\%); Plano Cruzado II, em novembro de 1986; Plano Bresser, em 1987 e Plano Verão, em janeiro de 1989. Os partidos políticos foram legalizados em 1985 e, em 1986, foi convocada a Assembleia Nacional Constituinte, composta por deputados e senadores

\footnotetext{
44 A arrecadação, fiscalização e cobrança se dariam por meio do Instituto de Aposentadorias e Pensões da Previdência Social (IAPAS).

45 Os presidentes do período 1985 a 2015 foram: Tancredo Neves, eleito indiretamente para o mandato de 1985 a 1990, faleceu antes de tomar posse, sendo sucedido pelo vice-presidente José Sarney; Fernando Collor de Melo, eleito para o mandato de 1990 a 1995, sofreu impeachment e foi substituído, de 1992 a 1995, pelo vice-presidente Itamar Franco; Fernando Henrique Cardoso, eleito para o mandato de 1994 a 1998 e reeleito de 1999 a 2002; Luiz Inácio Lula da Silva, eleito para o mandato de 2002 a 2006 e reeleito de 2007 a 2011; Dilma Rousseff, eleita para o mandato de 2010 a 2014 e reeleita para o mandato (em exercício) de 2015 a 2018.
} 
eleitos em 1986. A Assembleia foi instalada em fevereiro de 1987 e, em outubro de 1988, promulgada a nova Carta Constitucional. Também em 1988 foram realizadas eleições municipais e, em 1989, a eleição presidencial.

Fernando Collor de Mello foi o primeiro presidente eleito por voto popular após o regime militar. Seu governo foi marcado pela redução dos impostos de importação, liberação do câmbio, abertura da economia ao capital estrangeiro, privatizações e três planos econômicos de combate à inflação: Plano Collor I e II e "Plano Marcílio". Também em seu governo ocorreu o "confisco das poupanças" (confisco dos depósitos bancários superiores a cinquenta mil cruzeiros por um prazo de dezoito meses) e o retorno do cruzeiro como moeda (substituindo o cruzado novo). Em 1992, sofreu impeachment, renunciou à presidência e foi substituído pelo vice-presidente Itamar Franco. Como expõe Lima (2011, p. 163), "a abertura da economia, levando à liberação crescente das importações, obrigou as empresas nacionais a inovar rapidamente suas tecnologias e a aderir às políticas de gestão da produção e do pessoal, consideradas como mais avançadas, a fim de se tornarem mais competitivas".

Itamar Franco, em 1993, substituiu o cruzeiro pelo cruzeiro real. Em seu governo, realizou-se plebiscito sobre a forma de governo do Brasil, que definiu a permanência do sistema presidencialista. Em 1994, lançou o Plano Real.

Fernando Henrique Cardoso, ministro da Fazenda de Itamar Franco, assumiu a presidência em 1994, sendo reeleito (após mudança da Constituição) em 1999. A política econômica de seu primeiro governo priorizou a estabilização de preços; já em segundo mandato teve início a crise econômica internacional. Em seu governo, foram conduzidas as maiores privatizações da história do país, e teve início a terceirização de serviços e de empregos públicos em áreas consideradas não essenciais. Segundo Lima (2010, p. 287), seus dois mandatos (1995-1998 e 1999-2002) "foram marcados, principalmente, pela sobrevalorização da moeda, elevação inédita da taxa de juros, redução dos gastos públicos na área social, dependência científica e tecnológica e reforma da aparelhagem estatal".

Foi sucedido pelo governo Lula, eleito em 2002 e reeleito em 2006, cuja gestão se caracterizou pela estabilidade econômica e geração de empregos formais. Em 2007, foi 
eleita Dilma Rousseff, a primeira mulher a ser eleita chefa de Estado e de governo no Brasil.

Desde meados dos anos 80 , observar-se-ia crescente reestruturação produtiva do capital, fragmentação do mundo do trabalho, subordinação dos Estados periféricos a políticas de ajuste econômico (CARVALHO, 2011). A década de 1990 se caracterizou por um consenso neoliberal, favorável à implementação do programa de estabilização, ajuste e reformas institucionais do Fundo Monetário Internacional e do Banco Mundial, "assim como de suas diretrizes de abertura irrestrita da economia, desregulamentação comercial e financeira, desregulação do mercado de trabalho e enxugamento do Estado, com a privatização das empresas estatais e demissões em massa" (LIMA, 2010, p. 279). Observou-se redução do número de trabalhadores na indústria, notadamente na indústria de transformação, e o crescimento do setor de serviços ou "terciarização da economia" (DIAS, 1993). Ainda nos anos 80-90, teriam destaque algumas características (DIAS, 1993): busca por saldo positivo na balança comercial para pagamento da dívida externa; estagnação econômica; inflação crescente; virtual falência do Estado. Esses fatores teriam trazido, como consequência, desemprego, empobrecimento da população e deterioração na atenção a necessidades básicas como saúde, habitação, educação, saneamento, transporte.

Antunes (2007) chama o período de "desertificação neoliberal": período marcado pela mundialização e financeirização dos capitais; pragmática desenhada pelo Consenso de Washington (desregulamentações nas mais distintas esferas do mundo do trabalho e da produção); reestruturação produtiva no universo industrial e de serviços, consequência da nova divisão internacional do trabalho; subcontratação e terceirização da força de trabalho; transferência de plantas e unidades produtivas (empresas passaram a buscar, além de isenções fiscais, níveis mais rebaixados de remuneração da força de trabalho e força de trabalho sem experiência sindical e política).

Já Leite (2003) caracteriza o início dos anos 90 como momento de abertura dos mercados até meados da década, quando a estabilização da moeda introduziu uma nova etapa no processo. No final dos anos 90 , com o controle do processo inflacionário e a estabilização da moeda, haveria retomada de projetos de mais longo prazo para as 
empresas e um novo fôlego para o processo de reestruturação produtiva, especialmente nos setores mais competitivos.

Outro importante aspecto apontado por Leite (2003, p. 97) diz respeito às consequências da reestruturação produtiva e terceirização da produção quanto a condições de trabalho e saúde ao longo da cadeia produtiva e suas repercussões no movimento sindical. A divisão do trabalho entre as empresas gerou uma realidade em diferentes realidades, conforme se percorre a cadeia, no que tange a "trabalho repetitivo e desqualificado, aumento dos ritmos, intensificação do controle, perda de benefícios, diminuição dos níveis salariais, precarização do emprego, elevação de incidência de doenças profissionais, entre outros", o que, segundo a autora, representa também uma ameaça para o sentimento de pertencer a um coletivo.

Franco, Druck e Seligmann-Silva (2010, p. 233), analisam que, na esteira da terceirização, ocorreram sucessivas mudanças na legislação que liberaram a empresa das contrapartidas sociais referentes aos direitos trabalhistas. Por sua vez, o enfraquecimento dos sindicatos levaria a um "processo de judicialização das questões sociais (do trabalho), conferindo uma importância suprema à instância jurídica, em particular ao Ministério Público do Trabalho e aos Tribunais Regionais do Trabalho".

Clot (apud LIMA, 2011, p. 162) afirma que se estaria passando de uma prescrição taylorista das operações para uma prescrição da subjetividade, pois "a prescrição calculável da tarefa está em declínio e os fins se ampliam para o sistema. Sua realização é exposta agora à regulação das equipes, por sua vez, mais dependentes dos estilos pessoais e dos motivos comuns, dos valores e da ética dos coletivos". As empresas buscariam desenvolver estratégias gerenciais para obtenção da adesão dos trabalhadores às novas exigências de qualidade e de produtividade, "já que o sucesso na implantação de certos procedimentos exige a aceitação dos princípios que lhes servem de base", não se tratando de acaso "o aumento das discussões em torno das questões relativas à implicação, à motivação e ao envolvimento dos empregados".

Outro aspecto importante nesse contexto refere-se ao desemprego. Pochmann (2001, apud VIZZACCARO-AMARAL, 2011, p. 62) amplia a definição de desemprego, considerando duas situações: o desemprego aberto e o desemprego oculto. Para o autor, o desemprego aberto é aquele que corresponderia "aos trabalhadores que 
procuram ativamente por uma ocupação, estando em condições de exercê-la imediatamente e sem desenvolver qualquer atividade laboral", indicando concorrência no interior do mercado de trabalho em torno do acesso às vagas existentes. Já o desemprego oculto corresponderia ao subemprego e outras formas de sobrevivência, envolvendo os trabalhadores "que fazem "bicos" para sobreviver e também procuram por trabalho, assim como aqueles que deixam de buscar uma colocação por força de um mercado de trabalho extremamente desfavorável (desemprego oculto pelo trabalho precário e pelo desalento) ".

No plano sindical, ao longo da década 1980, o chamado "Novo Sindicalismo" alcançou os mais altos indicadores de sindicalização, de organização e de greves de toda a história do movimento operário nacional. Isso foi acompanhado por um amplo reconhecimento social e político dos sindicatos laborais. O número de conflitos coletivos levados adiante pelos sindicatos foi crescente até 1989, o que fez com que o Brasil chegasse a apresentar cerca de quatro mil greves por ano, assumindo então o posto de segundo país em número de greves no mundo, segundo a Organização Internacional do Trabalho. As negociações coletivas de trabalho implicaram a ampliação do número de cláusulas negociadas. Na década de 1970, as categorias profissionais apresentavam, em média, cerca de 12 cláusulas negociadas, passando, na década de 1980, para algo em torno de 50 (POCHMANN, 2005).

Mesmo marcada como um período de constituição de assessorias em Saúde do Trabalhador em sindicatos, a década de 90 também se por caracterizou por "enormes dificuldades para a sua sobrevivência" (SILVEIRA et al., 2013, p. 220). O movimento mundial de reestruturação produtiva e a terceirização ampliada da produção resultaram na precariedade das condições de trabalho e na fragilidade das ações de classe e de resistência individual (RIBEIRO, 2008). Diversos autores discutem os impactos da reestruturação produtiva para a atuação dos sindicatos. O quadro geral das transformações decorrentes da reestruturação impôs graves perdas aos sindicatos, com dificuldades de negociação e perda do poder regulatório, redução da abrangência das convenções coletivas, introdução da flexibilização do trabalho e descentralização das negociações para o âmbito das empresas (LEITE, 2003). Isso também implicou diferentes sindicatos, fragmentação dos associados entre eles, e a contratação sob 
outras "denominações" na carteira de trabalho, fragilizando ainda mais os vínculos sindicais, bem como na discriminação dos terceirizados pela empresa contratante do núcleo "estável" e terceirizados (FRANCO; DRUCK; SELIGMANN-SILVA, 2010).

O desemprego estrutural teria repercutido na organização dos sindicatos, deslocando seu foco de atuação para a preservação de postos de trabalho, "deixando em segundo plano as condições em que o mesmo é executado" (DIAS; HOEFEL, 2005, p. 820). Acrescentam Minayo-Gomez e Thedim-Costa (1999, p. 414):

\begin{abstract}
As negociações coletivas voltam-se prioritariamente para os trabalhadores do quadro funcional das empresas e as reivindicações têm como foco central a manutenção do emprego e o posicionamento frente às propostas de redução da jornada de trabalho, com a consequente diminuição de salário, como alternativa de incorporação, sob contratos precários, de mão de obra desempregada. Os próprios interesses dos trabalhadores terceirizados, submetidos às mais desfavoráveis formas de contratação e de condições de trabalho, raramente são contemplados.
\end{abstract}

\title{
3.5.2 CONDIÇÕES DE SAÚDE E TRABALHO
}

Os processos de reestruturação produtiva intensificados nas últimas décadas do século XX foram marcados por diversas particularidades, como aponta Chauí (2001). Nesse contexto, o desemprego tornou-se estrutural, deixando de ser acidental ou decorrente de crises conjunturais; essa exclusão se daria, sobretudo, em consequência da automação e pela alta rotatividade da mão de obra, que se tornaria rapidamente obsoleta e desqualificada, em razão de mudanças tecnológicas. O setor de serviços expandiu-se enormemente, e observou-se grande fragmentação e dispersão na produção em todas as suas etapas, com compra de serviços do mundo inteiro e "o desmantelamento das operações em linha de montagem e dos grandes estoques de produtos duráveis" (CHAUÍ, 2001, p. 19). Contudo, como aponta Leite (2003), em vez de uniformizar as estruturas produtivas nas várias regiões do mundo, o processo de globalização pressupõe formas de integração diferenciadas dos países na economia global, com caminhos distintos dos vários países, contrariamente a um modelo uniforme de desenvolvimento.

Verifica-se a terceirização ampliada e extensiva das operações (RIBEIRO, 2008) e "a fragmentação do trabalho em tarefas terceirizadas" (CHAUÍ, 2001, p. 20). Essa divisão 
do trabalho entre as empresas conduz a uma realidade em que as implicações dos novos conceitos de produção são muito diferenciadas entre as várias empresas da cadeia produtiva. Como consequências, poder-se-ia observar um processo de deterioração ao longo das cadeias, abarcando trabalho repetitivo e desqualificado, aumento dos ritmos, intensificação do controle, perda de benefícios, diminuição dos níveis salariais, precarização do emprego, elevação de incidência de doenças profissionais, entre outros fatores (LEITE, 2003).

Dentre as principais transformações ocorridas nos processos de trabalho, encontramse a flexibilização da produção, com deslocamento de mão de obra para o mercado informal e exploração mais intensiva da mão de obra formalmente empregada, bem como a incorporação acelerada de automação à produção. Essas transformações desencadearam mudanças no mercado de trabalho, como a complexidade de postos de trabalho, demandando cada vez mais especialização e aperfeiçoamento da mão de obra, o aumento nas exigências de qualidade e produtividade e novas demandas de gestão sobre a produção geradas pelos novos sistemas produtivos. A esses fatores, agregam-se os baixos salários, o receio de demissão e do desemprego, concorrendo para que, cada vez mais, expandam-se as jornadas de trabalho, as pressões por produtividade, ritmos e controles das atividades (CHIESA et al., 2002).

Como aponta Lacaz (2000), algumas das principais características da reestruturação produtiva são relativas à organização ${ }^{46}$ e divisão do trabalho; são seus subprodutos o desemprego, a ampliação do trabalho parcial, a precariedade das relações de trabalho e dos direitos trabalhistas. Flexibilizaram-se as relações de trabalho, por meio da terceirização, demissões em massa, programas de demissão voluntária, que

46 Segundo Dejours,

Por condição de trabalho é preciso entender, antes de tudo, ambiente físico (temperatura, pressão, barulho, vibração, irradiação, altitude etc.), ambiente químico (produtos manipulados, vapores e gases tóxicos, poeiras, fumaças etc.), o ambiente biológico (vírus, bactérias, parasitas, fungos), as condições de higiene, de segurança, e as características antropométricas do posto de trabalho (DEJOURS, 1992, p. 25).

E prossegue, ressaltando a diferença entre condições e organização do trabalho:

Por organização do trabalho designamos a divisão do trabalho, o conteúdo da tarefa (na medida em que ele dela deriva), o sistema hierárquico, as modalidades de comando, as relações de poder, as questões de responsabilidades etc. (DEJOURS, 1992, p. 25). 
configurariam estratégias de ajuste econômico das empresas numa conjuntura de inovações tecnológicas, concentração de capital e "descolamento entre base material da economia e acumulação" (FRANCO, 2002, p. 216). Já a terceirização intensa introduziu formas distintas de trabalho sob contratos que não garantiam direitos; essa distinção iria além do contrato de trabalho, refletindo-se nas condições de trabalho e nos modos distintos de tratamento, sempre inferiores, para com os subcontratados (RIBEIRO, 2008).

Nesse movimento mundial de reestruturação produtiva, a adoção de práticas de gestão "modernas", a terceirização ampliada da produção e a manutenção de setores industriais de elevado risco resultam na precariedade das condições de trabalho e na fragilidade das ações de classe ${ }^{47}$ e de resistência individual (RIBEIRO, 2008).

Nas últimas décadas, evidenciaram-se grandes transformações na "dinâmica de emprego e da composição da força de trabalho urbana e agrícola", como aponta Ribeiro (2008): redução do trabalho industrial, crescimento do setor de serviços, subcontratação, degradação das relações formais de emprego, desemprego, aumento do trabalho precarizado, da informalidade e da exclusão social. Observa-se, no Brasil, como destacam Minayo-Gomez e Thedim-Costa (1999), um processo de pauperização, inclusive entre trabalhadores integrados ao mercado de trabalho, fruto da insegurança, instabilidade e precariedade nos vínculos laborais. ${ }^{48}$ Essa degradação das

\footnotetext{
47 Diversos autores discutem os impactos da reestruturação produtiva para a atuação dos sindicatos. 0 quadro geral das transformações decorrentes da reestruturação impôs graves perdas aos sindicatos, com dificuldades de negociação e perda do poder regulatório, redução da abrangência das convenções coletivas, introdução da flexibilização do trabalho e descentralização das negociações para o âmbito das empresas (LEITE, 2003). O desemprego estrutural repercute na organização dos sindicatos, deslocando seu foco de atuação para a preservação de postos de trabalho, "deixando em segundo plano as condições em que o mesmo é executado" (DIAS; HOEFEL, 2005, p. 820). Acrescentam Minayo-Gomez e Thedim-Costa (1999, p. 414): "As negociações coletivas voltam-se prioritariamente para os trabalhadores do quadro funcional das empresas e as reivindicações têm como foco central a manutenção do emprego e o posicionamento frente às propostas de redução da jornada de trabalho, com a consequente diminuição de salário, como alternativa de incorporação, sob contratos precários, de mão de obra desempregada. Os próprios interesses dos trabalhadores terceirizados, submetidos às mais desfavoráveis formas de contratação e de condições de trabalho, raramente são contemplados".
}

48 Como apontam Antunes e Pochmann (2007), observa-se uma forma de reprodução da pobreza, cada vez mais concentrada no segmento da população ativa no mercado de trabalho (pessoas desempregadas e com ocupação precária). No passado, a pobreza estaria mais relacionada ao segmento inativo da população (crianças, idosos, doentes, pessoas com deficiência etc.); ter acesso à ocupação no mercado de trabalho era condição quase suficiente para superar o limite da pobreza absoluta. Nos últimos anos, a taxa de pobreza no país vem diminuindo, principalmente em virtude das políticas sociais de atenção aos inativos de mais idade (como a ampliação da cobertura da Previdência Social e a Lei 
condições materiais de vida foi agravada pela ausência de mecanismos de proteção social - o crescimento do setor informal implicou a perda de direitos trabalhistas e previdenciários historicamente conquistados pelos trabalhadores (DIAS; HOEFEL, 2005). O desemprego associado à terceirização, à precarização e à informalização implicou a perda dos direitos sociais e da estabilidade trazida pelo salário e pelo emprego, expressando relações de trabalho muito mais precárias e instáveis ligadas ao trabalho informal e temporário (NARDI; TITTONI; BERNARDES; 2002). Também cabe apontar a chamada "psicopatologia do desemprego" (SELIGMANN-SILVA, 1994), que atingiria não apenas os trabalhadores fora do mercado de trabalho, mas também os que se incluíam no mercado em condições de precarização e instabilidade. A reestruturação brasileira configurou para o mercado de trabalho um cenário de regressão e precariedades, no que tange ao nível de emprego, ao grau de formalização do trabalho e aos rendimentos reais (LEITE, 2003).

Entre os principais impactos desse processo no mundo do trabalho, Lino e Dias (s/d) destacam: a introdução de novas tecnologias, como a automação e a robótica, substituindo o trabalho humano e reduzindo o número de postos de trabalho; a diminuição das atividades de manufatura e o crescimento do setor de serviços; aumento dos níveis de desemprego em várias partes do mundo; aumento da intensidade e duração do trabalho - aceleração de ritmos, diminuição de pausas, aumento das responsabilidades dos trabalhadores; aumento do trabalho domiciliar, em tempo parcial e sazonal; diminuição dos níveis de remuneração pelo trabalho realizado.

Essa mudança de cenário transformou inclusive a relação do trabalhador com sua produção e suas "ferramentas" de trabalho, o maquinário. Para Oliveira (1997), as inovações tecnológicas, 49 buscando a otimização da produção "a todo custo",

Orgânica de Assistência Social) e aos menores (como programas de transferência de renda vinculados à educação e à erradicação do trabalho infantil). Dessa forma, a maior participação no total dos pobres do país se concentraria na população ativa, sobretudo os desempregados e ocupados precariamente no mercado de trabalho.

49 Sobre os impactos das inovações tecnológicas, Carneiro (1997, p. 71) considera que

Alguns estudos sobre os impactos sociais das inovações tecnológicas, organizacionais e gerenciais sobre a força de trabalho e seu novo perfil 
gerariam um mau relacionamento do trabalhador com a máquina e mesmo com a produção: há uma pulverização, fragmentação das tarefas, restrições nas variedades de movimentos e uma condensação em movimentos repetitivos, o que leva cada trabalhador a ter uma reduzida participação no produto final.

Esse "novo mundo do trabalho" teria consequências que se expressam na saúde pela degradação das condições de trabalho, associadas à assunção de novas tecnologias, que fazem conviver situações "antigas" e "novas" e que associam a exposição a fatores clássicos de risco, "novos" riscos e cargas, introduzidos pelas inovações organizacionais. Observa-se uma alta frequência de acidentes de trabalho (incluindo o efeito da degradação das vias nos acidentes de trajeto e na mortalidade); uma grande ampliação de doenças ocupacionais, além de uma gama de afecções ligadas ao trabalho não configuradas como tais pelas instituições médicas; o surgimento de problemas ligados a enfermidades do desenvolvimento industrial e urbano (RIBEIRO, 2008). Esses "novos regimes de trabalho" potencializariam "agentes agressivos" preexistentes e trariam novos agentes de distintas naturezas - físicos, químicos, ergonômicos, organizacionais (FRANCO, 2002).

Como expõe Lacaz (2000), as empresas, nesse novo contexto, passaram a colocar exigências contraditórias no que tangia à saúde, como intensificação dos ritmos, maior conhecimento e controle do trabalho, criatividade e polivalência e critérios de avaliação mais rígidos. Ou, em outros termos, como colocam Lacaz e Sato (2006), demanda-se um trabalhador mais participativo, escolarizado e polivalente; essa polivalência, contudo, seria vivida de modo ambíguo, uma vez que se expressaria na forma de aumento das responsabilidades, maior carga de trabalho e "menor" autonomia.

concluem que o trabalho fragmentado, linear, padronizado e repetitivo vem sendo substituído por novos métodos, caracterizados por maior integração e flexibilidade. Entretanto, a observação e o estudo dos processos de trabalho, principalmente na realidade brasileira, evidenciam que essas mudanças não são lineares nem homogêneas, pelo fato de ocorrerem em contexto de acirrada concorrência intercapitalista, em períodos de crise e estagnação econômica, no mundo moderno. O Brasil, como país de capitalismo tardio e periférico, insere-se nesse processo de forma dual: de um lado, encontramos sistemas de alta tecnologia, organizados segundo padrões flexíveis, tecnologias avançadas etc.; de outro, setores atuando segundo a lógica fordista e taylorista, atendendo, ambos, uma lógica comum que é a da acumulação. 
Antunes (2007) também descreve os contornos desse "novo tipo de trabalho" que, como diz, muitas vezes é mistificado pela denominação "colaborador": demanda-se um profissional "polivalente" e "multifuncional", que opere várias máquinas (diferente do trabalhador na empresa taylorista e fordista, especializado), no que chama de "desespecialização multifuncional"; há uma intensificação dos ritmos, tempos e processos de trabalho; ocorre uma ampliação do trabalho imaterial50 (chamado no discurso empresarial de "sociedade do conhecimento"); verifica-se uma intensificação de formas de extração do trabalho; ampliam-se as terceirizações 51 ; metamorfoseiamse as noções de tempo e de espaço. Como aponta o autor, o processo de reestruturação produtiva teria recuperado temáticas propostas pela própria classe trabalhadora, como sua inteligência, iniciativa e capacidade organizacional; observouse uma progressiva exploração da imaginação, dos dotes organizativos e da capacidade de cooperação dos trabalhadores (ANTUNES, 2009).

A informatização e automação transformariam o trabalho em gestão de um fluxo contínuo de informações; para Gorz (2005, p. 17), "o operador deve 'se dar' ou 'se entregar' de maneira contínua a essa gestão do fluxo; ele tem de se produzir como sujeito para assumi-lo". O trabalho não seria mais mensurável segundo padrões e normas preestabelecidas; o desempenho repousaria sobre a implicação subjetiva do

50 "Aumenta a importância da informação, do trabalho imaterial, em contraposição ao conceito tradicional de trabalho, centrado na ideia de transformação da natureza” (LIEDKE, 2002, p. 345).

51 "Vários tipos de terceirização têm sido detectados desde os anos 1980, abrangendo velhas e novas modalidades: o trabalho a domicílio - seja a forma tradicional, com a subcontratação de trabalhadores autônomos, em geral sem contrato formal, prática recorrente nos setores tradicionais da indústria, seja a forma de teletrabalho no domicílio, [...] ou indústria de aparelhos eletrônicos, ou áreas de venda e assistência técnica de várias empresas [...]; as redes de empresas fornecedoras de componentes e peças (típica da indústria automobilística); a subcontratação de serviços de apoio e periféricos; a subcontratação de empresas ou trabalhadores autônomos em áreas produtivas e nucleares (manutenção); a quarteirização, empresas contratadas para gerir contratos com as terceiras [...]. Nos últimos 15 anos, a terceirização cresceu em todos os setores no Brasil, nas seguintes formas: estágios (em empresas e bancos estatais), cooperativas (destacadamente na área de saúde) e externalização de serviços públicos (da administração direta) para empresas privadas. No setor privado, além das cooperativas, destacam-se o novo trabalho a domicílio (teletrabalho) e as "empresas-filhotes" ou "PJs" [pessoas jurídicas] (empresas do eu sozinho), que descaracterizam completamente as relações trabalhistas. Essa nova terceirização - ao deixar de ser uma prática marginal e periférica - conduz a uma profunda metamorfose social, tornando-se estratégia central na gestão das empresas e principal via de flexibilização dos contratos e de controle sobre os trabalhadores" (FRANCO;DRUCK; SELIGMANN-SILVA, 2010, p. 233). 
trabalhador (ou "motivação", no jargão gerencial). O modo de realizar tarefas não poderia mais ser formalizado ou prescrito, a prescrição incidindo sobre a subjetividade, "precisamente isso que somente o operador pode produzir ao "se dar" à sua tarefa. As qualidades impossíveis de demandar, e que dele são esperadas, são o discernimento, a capacidade de enfrentar o imprevisto, de identificar e de resolver problemas" (GORZ, 2005, p. 18). O trabalho imaterial, então, para o autor, repousaria sobre as capacidades expressivas e cooperativas desses trabalhadores. E prossegue: "O que as empresas consideram como "seu" capital humano é, pois, um recurso gratuito, uma "externalidade" que se produz sozinha, e que continua a se produzir, e da qual as empresas apenas captam e canalizam a capacidade de se produzir" [grifo do autor]. Outra questão importante é a que apontam Nardi, Tittoni e Bernardes (2002): a produção de tecnologias é uma forma de organização do saber, inscrita em relações de poder; a informatização definiria parâmetros de exclusão de formas de saber que não possuam referência nos códigos e nos sistemas digitalizados.

A reestruturação produtiva colocaria uma necessidade de um novo "modelo" de trabalhador, capaz de lidar com tecnologias e processos mais flexibilizados, exigindo também, dele, maior flexibilização, 52 incorporando experiências dos trabalhadores à base técnica e enriquecendo tarefas, mas exigindo também sua sujeição e adaptação de seu desejo aos objetivos da empresa; o objetivo das novas formas de gestão seria a gestão das subjetividades, por meio da internalização das metas e objetivos da empresa, negando a exploração da força de trabalho e o conflito capital/trabalho. 0 trabalhador, transformado em "colaborador", teria sua solidariedade clássica destruída pela competição interna, pela individualização dos salários e pela transformação das relações entre pares em relações entre clientes (NARDI; TITTONI; BERNARDES; 2002). Como aponta Brandão Junior (2000), os dispositivos e processos psicológicos e psicossociais utilizados como forma de pressionar os trabalhadores seriam de várias ordens - mecanismos de trabalho, gestão dos afetos realizados pelos serviços de "Recursos Humanos" e formas mais sofisticadas de controle, como a

\footnotetext{
52 Nardi, Tittoni e Bernardes (2002), citando Enriquez, discutem a "perversidade" que permearia as novas formas de gestão, com exigência da criação de personalidades "as if", adaptáveis ao extremo, de acordo com as mudanças na organização.
} 
introjeção da dominação - com importante peso para sua vida psíquica, em termos de cansaço físico, mental e de tensão.

Elío e Rodríguez (2007) apresentam como consequências das mudanças ocorridas nos processos produtivos em decorrência do neoliberalismo, globalização, flexibilização e precarização das relações de trabalho, terciarização da economia nos processos produtivos e de trabalho o surgimento de novas exigências laborais ou a agudização de antigas, a carência, diminuição ou desaparecimento de muitos componentes básicos para o desenvolvimento do trabalho humano, o estresse agudo e crônico e a fadiga, como elementos mediadores da patologia vinculada às novas formas de organização do trabalho, e a patologia vinculada a essas mudanças. As novas condições de trabalho e saúde impostas pela "modernização" das economias gerariam, no médio prazo, maior controle sobre riscos físicos e químicos de certo tipo de indústrias ou sobre a prevenção de acidentes causados por condições deficientes de segurança, mas provocariam condições de trabalho muito mais alienantes e danosas e trariam, em contrapartida, condições mais estritas, exigentes e desumanizantes de trabalho, acompanhadas de um controle rigoroso das decisões relacionadas ao trabalho, individualização das tarefas, problemas, demandas e condições coletivas de saúde. As formas de agressão e de controle sobre os indivíduos tornaram-se mais complexas e sutis, perpassando por relações sociais de dominação interiorizadas e espaços da subjetividade invadidos por práticas coercitivas, abertas ou sutis e, "mais recentemente, ditas 'participativas' e 'consensuais'" (FRANCO, 2002, p. 215).

As consequências desse "novo mundo do trabalho" para a saúde se expressariam na degradação das condições de trabalho, associada à introdução de novas tecnologias, que fariam conviver lado a lado situações "antigas" e "novas", associando a exposição de fatores clássicos de risco a novos riscos introduzidos pelas inovações organizacionais (RIBEIRO, 2008). Os novos regimes de trabalho potencializariam, então, "agentes agressivos" preexistentes e a eles somariam novos agentes (FRANCO, 2002).

No regime de trabalho taylorista, como aponta Lacaz (2000), os indicadores mais diretos da nocividade e de exploração do trabalho eram os relacionados a acidentes típicos e doenças ocupacionais (decorrentes de efeitos de materiais e agentes de risco 
existentes nos ambientes de trabalho). No fordismo, aliando a automação imposta ao trabalho a importantes mudanças na jornada de trabalho, produziu-se uma mudança no perfil da morbimortalidade. Surgiram novos fatores de desgaste: o predomínio de movimentos estereotipados e repetitivos, o trabalho por turnos alternados (com implicações como transtornos gastrointestinais, distúrbios do sono etc. e sobre a vida social e familiar do trabalhador). Aumentam os riscos físico-químicos, intensificou-se o ritmo de trabalho, e as técnicas de gestão provocaram a fadiga física e mental dos trabalhadores (COHN; MARSIGLIA, 1993).

No contexto da automação, ramos de produção, como a química, a petroquímica e a metalúrgica, exporiam o trabalhador a objetos de trabalho de alta periculosidade, bem como exporiam aos riscos as populações circunvizinhas à planta industrial. Os trabalhadores vivenciariam formas de organização do trabalho que os submeteriam a condições de imobilidade, associadas à monotonia e exigência de grande concentração de sua parte, gerando situações de grande tensão. "A redução da exigência de esforço físico do trabalhador vem acompanhada, assim, de significativo desgaste psíquico do trabalhador expresso em sintomatologias de fadiga, estresse e demais patologias psicossomáticas e nervosas" (COHN; MARSIGLIA; 1993, p. 72).

Franco, Druck e Seligmann-Silva (2010, p. 232) discutem o que chamam de precarização da saúde dos trabalhadores. Essa precarização se expressaria em uma fragilização (orgânica, existencial e identitária) dos "indivíduos pela organização do trabalho com intensificação da multiexposição", acrescida, entre outros fatores, por limitações impostas nas empresas nos cuidados com a saúde, como defasagens de treinamento de informação sobre os riscos entre trabalhadores "contratados" e terceirizados; diluição de responsabilidades em relação a acidentes, adoecimentos e falhas na prevenção; predomínio de medidas de proteção individual em detrimento de proteção coletiva e políticas preventivas.

As autoras também chamam atenção, no que tange à organização do trabalho, em todos os setores de atividades, para as "metas inalcançáveis" e pelos ritmos intensos de trabalho. A pressão de tempo somar-se-ia à intensificação do controle e ao medo da demissão, conduzindo à intensificação do trabalho. A esses fatores também se acrescentam os exíguos tempos destinados a pausas no trabalho, repouso, 
recuperação do cansaço, bem como a rotatividade no trabalho, "entre diversas empresas, com tipos diferentes de contratos". Para Franco, Druck e Seligmann-Silva (2010, p. 231), "estas e outras características da organização do trabalho potencializam a multiexposição aos agentes físicos, biológicos, químicos, ergonômicos e organizacionais, favorecendo sofrimento e processos de adoecimento".

Outras relevantes questões que se apresentam dizem respeito ao que Lima (2011b, p. 166) chama de aumento das desigualdades sociais. As mudanças vividas no mundo do trabalho se sustentariam, na maioria dos casos, com políticas de redução de pessoal, levando ao crescimento do desemprego ou do trabalho precarizado: 53

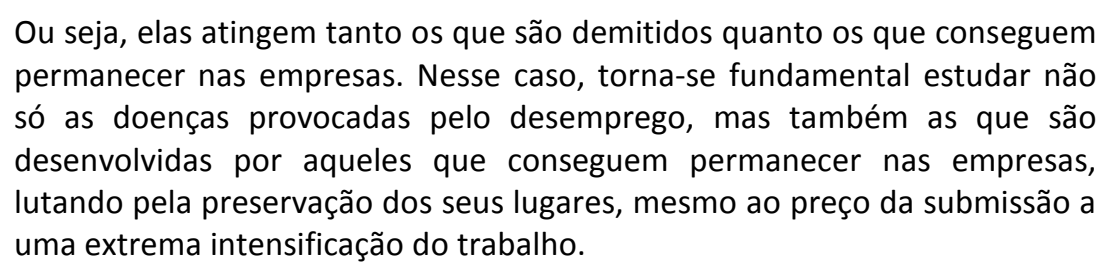

Ou, como colocam Franco, Druck e Seligmann-Silva (2010, p. 234),

\begin{abstract}
No âmbito de uma sociedade salarial - a despeito da destruição do emprego - o trabalho ainda se mantém como referência para a construção das identidades sociais [...]. Delineia-se, portanto, uma era de precarização global que consolida a perda da razão social do trabalho, com sérios impactos no imaginário social, gerando violência e adoecimentos, caracterizando uma condição de vulnerabilidade e desfiliação social.
\end{abstract}

\title{
3.5.3 POLÍTICAS PÚBLICAS DE SAÚdE E TRABALHO
}

Agravou-se a desigualdade de acesso a serviços de saúde, e grandes contingentes populacionais ficam excluídos ou são atendidos de modo insuficiente (DIAS, 1993).

Nos anos 80, moléstias inicialmente diagnosticadas como tendinites e tenossinovites passaram a ser reconhecidas, em 1986, como doenças de origem ocupacional. 0 reconhecimento da "tenossinovite do digitador" e outras lesões por esforços repetitivos se deu por intermédio da Portaria do Ministério da Previdência e Assistência Social $n^{\circ}$ 4.062, de 6 de agosto de 1987. Como diz Teixeira (2012, p. 117),

53 Franco, Druck e Seligmann-Silva (2010, p. 232) destacam que a condição de terceirizado ou empregado no regime de contrato temporário imporia aos trabalhadores uma condição de maior sujeição a "condições aviltantes e (in)suportáveis de trabalho". 
"tanto no [...] INSS como no sistema de saúde, o reconhecimento como agravo relacionado ao trabalho foi gradativo, decorrente da ativa participação de profissionais da saúde, dos Centros de Referência de Saúde do Trabalhador [...] e do movimento sindical".

Nos anos 90, observou-se o desfinanciamento do Sistema Único de Saúde e a deterioração dos serviços públicos; observou-se também a reconfiguração da relação público-privada, pois entidades filantrópicas e as sem fins lucrativos passaram a ser privilegiadas em detrimento dos hospitais contratados. Ocorreu também uma reforma da previdência social, incluíram-se novos mecanismos de privatização dos serviços sociais públicos, com a criação da figura jurídica das organizações sociais e houve focalização das ações do Estado no atendimento de demandas sociais básicas. "A grande massa da população brasileira [...] continua a depender do SUS, que, carente de recursos, e com um sistema administrativo ainda indefinido, não atende aos princípios propostos". A Lei ${ }^{\circ}$ 9.637, de 1998, ou Lei das Organizações Sociais, deu início à "flexibilização" do Sistema Único de Saúde, "ao permitir a mudança da natureza jurídica das instituições públicas de direito público para direito privado". Já nos anos 2000, houve aprofundamento da relação público-privado na política nacional de saúde; "ao contrário das expectativas de reversão do processo de privatização e de transformação do modelo assistencial, assistiu-se à edição de novas políticas de apoio e/ou tratamento fiscal diferenciado para os produtores privados de saúde" (LIMA, 2010, p. 304).

Pautando-se pela premissa do "conhecimento compartilhado" entre técnicos e trabalhadores, as políticas públicas subsidiadas pelo campo da Saúde do Trabalhador deveriam ter gestão participativa dos trabalhadores, estabelecendo-se uma "nova e complexa rede de poderes e forças" no que se denominou, em especial no estado de São Paulo, Programas de Saúde dos Trabalhadores (PSTs) (LACAZ, 1996, p. 12), cujas equipes eram em grande parte formadas por profissionais oriundos do Movimento Sanitário. A proposta original desses serviços era de funcionamento como polos facilitadores/difusores para que a rede de saúde atentasse para as especificidades do trabalho no processo saúde/doença (BERNARDO; GARBIN, 2011). 
Em 1988, nas eleições para os governos municipais, candidatos com plataformas de perfil mais democrático e popular foram eleitos em importantes cidades; vislumbravase, como coloca Lacaz (1996), a possibilidade de que tais municípios assumissem a questão da municipalização da saúde e a saúde dos trabalhadores por meio de programas, como os PSTs (Programas de Saúde dos Trabalhadores) muitos desses municípios gerenciaram serviços de saúde dos trabalhadores, criando Centros de Referência em Saúde dos Trabalhadores (CRSTs ou CERSATs). ${ }^{54}$

Para Bernardo e Garbin (2011, p. 107), essas "experiências, apesar de isoladas, foram fundamentais para a inclusão dessa área programática no capítulo de Saúde da Constituição Federal de 1988 e na lei que regulamenta o SUS". No início dos anos 90, observou-se a incorporação de unidades de referência em saúde do trabalhador nas redes de saúde de diversos municípios, que posteriormente vieram a ser denominados Centros de Referência em Saúde do Trabalhador (CERESTs) (SATO; LACAZ; BERNARDO, 2006). Em 1993, Frias Junior (1999) destaca que já eram 161 os Programas de Saúde do Trabalhador organizados ou em fase de organização no Brasil.

O início dos anos 90, então, trouxe a incorporação de unidades de referência em saúde do trabalhador nas redes de saúde de diversos municípios brasileiros, posteriormente denominadas CERESTs (Centros de Referência em Saúde do Trabalhador). Essas unidades utilizavam abordagem clínico-epidemiológica e de planejamento na busca pela atenção em todos os níveis de prevenção, visando ao conhecimento dos determinantes da saúde, com a participação de trabalhadores organizados - os agentes seriam, então, as equipes multiprofissionais e os trabalhadores (SATO; LACAZ; BERNARDO, 2006, p. 283).

Lacaz (1996, p. 39) vai destacar como a "efervescência das modificações que vinham ocorrendo no setor saúde" teriam culminado, em 1986, com patrocínio do Ministério da Saúde, na realização VIII Conferência Nacional de Saúde (VIII CNS), "a qual foi preparada nos vários estados do país mediante intenso processo de participação e arregimentação de forças políticas que já se articulavam anteriormente na luta pelas

\footnotetext{
54 Dentre eles, o CERSAT Barreiro (Belo Horizonte), onde atuei como voluntária, inaugurado em 1993 na gestão do então prefeito Patrus Ananias.
} 
eleições diretas para presidente da República, na busca da ruptura completa com o Regime Militar". ${ }^{55}$

Para Frias Junior (1999, p. 8), a VIII CNS teria sido o evento que marcou os princípios filosóficos do SUS. "Tanto é, que foi convocada para aquele mesmo ano a I Conferência Nacional de Saúde do Trabalhador, que, ao congregar de modo inédito, sindicalistas, técnicos da área de saúde e de outras afins, universidades e comunidade em geral, lançou [...] as bases para um novo caminhar".

Mesmo que isoladas, as experiências dos PSTs teriam sido fundamentais para a inclusão da área programática da Saúde do Trabalhador no capítulo de Saúde da Constituição Federal de 1988 e na lei que regulamenta o SUS:

Os dispositivos constitucionais definem a Saúde do Trabalhador como um conjunto de ações de atenção, promoção, prevenção e proteção à saúde que visa à recuperação e à reabilitação da saúde dos trabalhadores. Assim, a partir de então, o adulto passou a ter o direito de ser visto pela saúde pública: em sua condição de trabalhador, o que implica conhecer a situação de trabalho, ou seja, não apenas o processo de produção em si, mas também o processo de produção e (re)-produção das relações sociais de produção (BERNARDO; GARBIN, 2011, p. 107).

A nova Constituição Brasileira, promulgada em 1988, introduziu um conceito ampliado de saúde, entendida como direito de cidadania e garantida pelo Estado, ${ }^{56}$ mediante políticas sociais e econômicas que visassem "a redução do risco de doenças e de outros agravos, e ao acesso universal e igualitário às ações e serviços para sua promoção, proteção e recuperação, em uma rede regionalizada e hierarquizada, constituindo o Sistema Único de Saúde" (DIAS, 1993, p. 149).

Como destaca Dias (1993, p. 149), a saúde dos trabalhadores está contemplada em diferentes trechos da Constituição, destacando-se:

- a definição do direito universal à saúde;

- a relevância emprestada às ações e serviços públicos de saúde;

\footnotetext{
55 Para uma análise aprofundada sobre a VIII Conferência Nacional de Saúde e da I, II e III Conferências Nacionais de Saúde do Trabalhador, conferir Silva (2011) e Ramminger e Nardi (2007). No Apêndice G, encontra-se uma descrição dos principais aspectos discutidos em cada uma das Conferências Nacionais de Saúde do Trabalhador.

56 Art. 196. "A saúde é direito de todos e dever do Estado, garantido mediante políticas sociais e econômicas que visem à redução do risco de doença e de outros agravos e ao acesso universal e igualitário às ações e serviços para sua promoção, proteção e recuperação" (BRASIL, 1988).
} 
- a constituição do Sistema Único de Saúde, integrando os serviços e ações em uma rede hierarquizada, regionalizada, descentralizada, com atenção integral e participação da comunidade;

- a participação do setor privado de forma complementar, mediante contrato de direito público;

- a obrigação do empregador de indenizar o trabalhador vítima de acidente de trabalho, quando incorrer em dolo ou culpa, na vigência do seguro contra acidentes do trabalho.

O artigo 200 estabelece entre as atribuições do Sistema Único de Saúde "executar as ações de vigilância sanitária e epidemiológica, bem como as de saúde do trabalhador" e "colaborar na proteção do meio ambiente, nele compreendido o do trabalho" (BRASIL, 1988). Dias (1993, p. 150) informa que essa transferência da área da Segurança e Saúde dos trabalhadores do Ministério do trabalho para a Saúde teria sido alvo de polêmica e "acirradas discussões dos representantes das corporações profissionais e culminaram com a ambiguidade e superposição das atribuições".

Dentre os instrumentos legais previstos constitucionalmente, e que disciplinam temas relacionados à saúde do trabalhador, Dias (1993) destaca a Lei Orgânica de Saúde (Lei $n^{\circ} 8.080$, de 1990), a Lei Orgânica de Seguridade Social (Lei $n^{\circ} 8.212$, de 1991) e a lei que dispõe sobre planos de benefícios da Previdência Social e acidentes de trabalho (Lei $n^{\circ} 8.213$, de 1991).

A Lei Orgânica de Saúde (Lei $n^{\circ}$ 8.080, de 1990), para Dias (1993, p. 150), representaria o resgate do papel da saúde pública. Especificamente com relação à saúde do trabalhador, estabelece como competências do SUS a coordenação e execução de ações referentes à assistência a trabalhadores vítimas de acidentes de trabalho ou de doença profissional/do trabalho; à realização de estudos, pesquisas, avaliações, controles de riscos e agravos potenciais à saúde existentes no processo de trabalho; à normalização da fiscalização e controle de condições de produção, extração, armazenamento, transporte e manuseio de substâncias, produtos, máquinas e equipamentos que apresentem riscos à saúde do trabalhador; à avaliação do impacto sobre a saúde da introdução de novas tecnologias; à informação a trabalhadores e empregadores sobre riscos para a saúde existentes em processos de trabalho, divulgando resultados de estudos, avaliações e fiscalizações realizados em locais de trabalho. A Lei Orgânica da Saúde introduz nas leis orgânicas municipais questões 
relativas à saúde dos trabalhadores, que possibilitam maior autonomia de ação do nível local, sobretudo no que tange às ações de vigilância em saúde.

A Lei Orgânica de Seguridade Social (Lei $n^{\circ} 8.212$, de 1991) teria como destaques (DIAS, 1993): manutenção da responsabilidade do empregador pelo atendimento médico ao trabalhador acidentado nos primeiros 15 dias após a ocorrência do acidente; oferta de atendimento não diferenciado, no SUS, para vítimas de outros acidentes e doenças com relação ao acidentado do trabalho e ao portador de doença do trabalho; garantia de estabilidade no emprego, por um ano, ao acidentado do trabalho quando de seu retorno às atividades; garantia ao trabalhador, seus dependentes, sindicato e médico de fazer a Comunicação de Acidente de Trabalho quando a empresa o recusar; estabelecimento de tipos de benefícios acidentários e critérios para sua concessão e base de cálculo57 (auxílio-doença ou B-91, aposentadoria por invalidez ou B92, pensão por morte ou B93, auxílio-acidente ou B94); transferência para o empregador do ônus do financiamento do seguro de acidentes no trabalho, com taxas variáveis a partir do grau de risco da empresa.

Em 1992, por meio dos Decretos $n^{\circ} 503$ e 509, se reestruturam as competências do Ministério da Saúde, do Trabalho e da Previdência Social, passando a competir (DIAS, 1993):

- Ministério da Saúde: coordenação da Política Nacional de Saúde do Trabalhador; identificação e controle de riscos para a saúde dos trabalhadores, por meio de vigilância sanitária; intervenção sobre o dano à saúde dos trabalhadores, por meio da atenção na rede de serviços de saúde.

- Ministério do Trabalho: o trabalho e sua fiscalização; mercado de trabalho e política de empregos; política salarial. Já a diretriz de "planejar, coordenar, normatizar, orientar e supervisionar as ações e atividades na área de segurança e de saúde do trabalhador" representariam, como aponta Dias (1993, p. 153), superposição com a atuação do SUS definida pela Lei Orgânica da Saúde.

- Ministério da Previdência Social: a previdência social e a previdência complementar.

Em 1999, por meio da Portaria $n^{\circ} 1.339$ do Ministério da Saúde e do Decreto $n^{\circ} 3.048$ (Aprova o Regulamento da Previdência Social e dá outras providências), apresentaramse princípios norteadores para o diagnóstico das doenças relacionadas ao trabalho, a partir de lista com mais de 200 tipos de doenças classificadas como relacionadas ao trabalho e seus respectivos agentes etiológicos; nessa lista, há um conjunto de 12

\footnotetext{
${ }^{57}$ Que podem ser consultados no Anexo C.
} 
categorias diagnósticas do Grupo V da CID-10, os chamados Transtornos Mentais e do Comportamento Relacionados ao Trabalho (SILVA, 2011).

A partir de 2002, o Ministério da Saúde efetivou a institucionalização de uma Política Nacional de Saúde do Trabalhador mediante portaria ( $\left.n^{\circ} 1.679\right)$, que criou a Rede Nacional de Atenção Integral à Saúde do Trabalhador (RENAST) com o objetivo de "integrar a rede de serviços do SUS, voltados à assistência e à vigilância, para o desenvolvimento das ações de saúde do trabalhador" (BERNARDO; GARBIN, 2011, p. 107). Essa estratégia se efetivou principalmente por meio de incentivo financeiro aos municípios e estados para a criação de Centros de Referência em Saúde do Trabalhador (CERESTs), "que devem desempenhar a função de suporte técnico, de coordenação de projetos e de educação em saúde para a rede do SUS da sua área de abrangência". Essas unidades contam com uma equipe mínima definida em portarias do Ministério da Saúde, cujo número de profissionais varia de acordo com sua esfera de atuação (estadual ou regional) e da dimensão de sua área de abrangência (CFP, 2008, p. 23); a RENAST também prevê "a inserção da Saúde do Trabalhador na atenção básica e nos níveis de maior complexidade do sistema de saúde, a implementação de ações de vigilância e promoção em Saúde do Trabalhador e a criação de uma rede de serviços sentinela" direcionada para o acompanhamento dos setores produtivos que se destacam na determinação de agravos à saúde dos trabalhadores.

A RENAST é composta por cerca de 200 Centros Estaduais e Regionais de Referência em Saúde do Trabalhador e por mais de mil unidades de saúde que "identificam, investigam e notificam os casos de doenças, agravos e/ou acidentes relacionados ao trabalho (Rede Sentinela)" (NARDI; RAMMINGER, 2012, p. 381).

Os Centros de Referência em Saúde do Trabalhador (CERESTs), de abrangência regional e em todo o país, são implantados com as seguintes atribuições, de acordo com o Ministério da Saúde (TEIXEIRA, 2012, p. 117):

[...] capacitar a rede de serviços de saúde, apoiar as investigações de maior complexidade, assessorar a realização de convênios de cooperação técnica, subsidiar a formulação de políticas públicas, apoiar a estruturação da assistência de média e alta complexidade para atender aos acidentes de trabalho e agravos contidos na Lista de Doenças Relacionadas ao Trabalho e aos agravos de notificação compulsória citados na Portaria GM/MS n 777 de 28 de abril de 2004. 
Compete ao aos profissionais do CEREST se articular com os demais serviços da rede do SUS que possuem interfaces com a Saúde do Trabalhador, orientando e fornecendo fornecer retaguarda, para que os agravos à saúde relacionados ao trabalho possam "ser atendidos em todos os níveis de atenção do SUS, de forma integral e hierarquizada. Esse suporte deve se traduzir pela função de inteligência, acompanhamento e práticas conjuntas de intervenção especializada, incluindo ações de vigilância e formação de recursos humanos" (DEUSDEDIT JUNIOR, 2014, p. 115).

A Portaria $n^{\circ} 777$ do Ministério da Saúde, publicada em 2004, prevê a notificação de várias doenças relacionadas ao trabalho, de forma compulsória, sendo os profissionais que prestam assistência ao trabalhador obrigados a realizar a notificação no Sistema Nacional de Agravos de Notificação (SINAN), independentemente de vínculo empregatício e de existência de incapacidade (SILVA, 2011). Essa notificação pressupõe a articulação das ações dos CERESTs com a rede de saúde (BERNARDO; GARBIN, 2011).

A Portaria seria um avanço, na medida em que os dados de adoecimento no trabalho baseavam-se apenas nas informações do INSS a partir das Comunicações de Acidente do Trabalho (CAT), de preenchimento obrigatório nos casos de trabalhadores regidos pela Consolidação das Leis do Trabalho (CLT) (BERNARDO; GARBIN, 2011). A emissão da CAT deveria ser feita pela empresa e implicaria o reconhecimento, por parte da empresa, de que as condições de trabalho a que estavam submetidos seus trabalhadores seriam responsáveis pelo adoecimento ou acidente. Muitas vezes, a emissão da CAT não ocorria (SILVA, 2011).

Em 2006, foi promulgada a Lei $\mathrm{n}^{0} 11.430$, que entrou em vigor em abril de 2007, e instaurou o Nexo Técnico Epidemiológico Previdenciário (NTEP), mudando o sistema de registros de acidente e doença relacionada ao trabalho. Além dos casos nos quais há emissão da CAT, passaram a serem considerados também os casos com suspeita de nexo entre a doença com o trabalho (casos presumidos), por meio do cruzamento de informações epidemiológicas entre a doença e o ramo da atividade da empresa no qual o trabalhador exerce suas atividades (Código Nacional de Atividades Econômicas - CNAE). As doenças relacionadas ao trabalho passaram a ser estabelecidas pelo "nexo técnico epidemiológico", no qual os conceitos de prevalência e incidência das doenças passam a ser considerados pela Previdência Social para a concessão dos 
benefícios acidentários (SILVA, 2011; ALBUQUERQUE-OLIVEIRA, 2010). A partir da vigência do NTEP foi possível observar nas estatísticas da Previdência Social aumento expressivo do número de doenças relacionadas ao trabalho sem emissão de CAT (os casos presumidos).

O estabelecimento do nexo causal passou a ocorrer de forma automática e de forma independente da emissão da CAT pela empresa. "As empresas, por sua vez, caso não aceitassem os resultados da definição pelo sistema do NTEP, da relação causal entre as doenças e a atividade laboral, poderiam contestar os resultados" (SILVA, 2011, p. 180). Contudo, para isso, precisariam apresentar comprovações de que as condições de trabalho a que seus funcionários eram submetidos não seriam as causadoras da doença (cabendo à empresa o "ônus da prova").

Além disso, instituiu-se o chamado Fator Acidentário Previdenciário (FAP), que visa instrumentalizar a flexibilização prevista no SAT - Seguro de Acidentes de Trabalho (SAT). As alíquotas do Seguro Acidente de Trabalho (SAT, Lei $n^{0} 10.666$ de 2003) são pagas pelas empresas tomando como base seu ramo de atividade econômica, a partir de sua classificação na CNAE (Classificação Nacional de Atividades Econômicas) e considerando o grau de risco envolvido (leve, médio, grave). Após o Decreto $\mathrm{n}^{\circ} 6.042$ (2007), tomando por base o histórico dos benefícios concedidos pelo INSS entre 2000 e 2004, as empresas foram reclassificadas em razão da sinistralidade dos acidentes e passaram a ser taxadas de acordo com o grau de sinistralidade, por meio da medição da frequência, gravidade e custo dos acidentes e doenças ocupacionais de cada uma. $O$ Fator Acidentário de Prevenção (FAP) é um coeficiente que vai de 0,5 a 2,0 e que é multiplicado pelo Grau de Risco da empresa (ALBUQUERQUE-OLIVERIA, 2010; MELO; PRADO, 2009).

A introdução do NTEP e do FAP deram início a debates sobre a metodologia entre empresas, sindicatos patronais e de trabalhadores, comunidade científica, e mesmo Ação Direta de Inconstitucionalidade (ADI) como, por exemplo, a ADI $n^{\circ} 3931$, pela Confederação Nacional da Indústria, e a $A D I n^{\circ} 4.397$ pela Confederação Nacional do Comércio (SILVA, 2011).

A Política Nacional de Segurança e Saúde do Trabalhador (PNSST), regulamentada pelo Decreto $n^{0} 7.602$ (2011), foi elaborada em conjunto pelos Ministérios do Trabalho e 
Emprego, da Previdência e Assistência Social e da Saúde, com a finalidade de "promoção da saúde e a melhoria da qualidade de vida do trabalhador e a prevenção de acidentes e de danos à saúde advindos, relacionados ao trabalho ou que ocorram no curso dele, por meio da eliminação ou redução dos riscos nos ambientes de trabalho" (BRASIL, 2011).

Em 2012, por meio da Portaria $n^{\circ}$ 1.823, o Ministério da Saúde instituiu a Política Nacional de Saúde do Trabalhador e da Trabalhadora, que tem como finalidade:

[...] definir os princípios, as diretrizes e as estratégias a serem observados pelas três esferas de gestão do Sistema Único de Saúde (SUS), para o desenvolvimento da atenção integral à saúde do trabalhador, com ênfase na vigilância, visando à promoção e à proteção da saúde dos trabalhadores e à redução da morbimortalidade decorrente dos modelos de desenvolvimento e dos processos produtivos (MS, 2012).

Devem se destacar, no plano das políticas públicas e legislação que, quase mais de 30 anos depois da VIII Conferência Nacional de Saúde e das primeiras Conferências Nacionais de Saúde do Trabalhador, essa política programática apresenta hoje um alto grau de institucionalização, mas muitos desafios antigos persistem e novos se apresentam:

O termo movimento, que antecede a expressão reforma sanitária, é de fundamental importância para pensarmos sobre os processos em curso, pois o SUS e seus programas específicos estão em permanente transformação e não há garantia de estabilidade em relação aos avanços políticos e científicos dos últimos anos. As resistências conservadoras presentes nos jogos de saber e poder do campo [...] da Saúde do Trabalhador estão bem presentes no cotidiano, seja pelo retorno de velhas práticas, seja pela desmobilização política (NARDI; RAMMINGER, 2012, p. 376).

Bernardo e Garbin (2011, p. 107) fazem uma reflexão parecida, quando apontam que, diferentemente das equipes dos primeiros PSTs, integradas por "militantes", "que tendiam a ter um olhar crítico para o processo saúde-doença-trabalho", os novos serviços criados após a RENAST "contam com profissionais que não necessariamente tinham interesse pela área e, não raro, sequer a conheciam anteriormente".

Destacam-se também três significativas mudanças recentemente propostas, todas ainda em análise ou votação pelo Congresso Nacional.

- Em dezembro de 2014, o governo publicou duas Medidas Provisórias, de $n^{\circ} 664$ (Altera as Leis $n^{\circ} 8.213$, de 24 de julho de 1991; $n^{\circ} 10.876$, de 2 junho de 2004; 
$\mathrm{n}^{\circ} 8.112$, de 11 de dezembro de 1990; a Lei $\mathrm{n}^{\circ} 10.666$, de 8 de maio de 2003) e $\mathrm{n}^{\circ} 665$ (Altera a Lei $\mathrm{n}^{\circ}$ 7.998, de 11 de janeiro de 1990, que regula o Programa do Seguro-Desemprego, o Abono Salarial e institui o Fundo de Amparo ao Trabalhador (FAT); altera a Lei $\mathrm{n}^{0} 10.779$, de 25 de novembro de 2003, que dispõe sobre o seguro-desemprego para o pescador artesanal, e dá outras providências). Em vigor, essas Medidas ainda não foram votadas no Congresso.

- A chamada "Lei da Terceirização" - o Projeto de Lei n 4.330 de 2004, de autoria de Sandro Mabel, que "dispõe sobre os contratos de terceirização e as relações de trabalho deles decorrentes", que permitiria às empresas terceirizar sua atividade-fim - foi recentemente aprovada pela Câmara dos Deputados e aguarda apreciação pelo Senado Federal

- Também está em discussão no Congresso a Proposta de Emenda Constitucional $\mathrm{n}^{\circ}$ 451, de 2014, de autoria de Eduardo Cunha, que "Insere inciso XXXV e altera o parágrafo único do art. $7^{\circ}$ da Constituição Federal" - "Inclui como garantia fundamental, plano de assistência à saúde, oferecido pelo empregador em decorrência de vínculo empregatício, na utilização dos serviços de assistência médica". Essa emenda obrigaria os empregadores brasileiros a garantirem aos seus empregados serviços de assistência à saúde, excetuados os trabalhadores domésticos, em conflito com o capítulo da seguridade social e a seção da saúde e seus dispositivos. 


\section{MEDICINA E TRABALHO}

Pretende-se, neste capítulo, propor a construção de uma história parcial das relações da medicina com o mundo do trabalho e seus diferentes modelos (Medicina do Trabalho/Industrial, Saúde Ocupacional, Saúde do Trabalhador), como um campo dinâmico de disputas, discursos e de práticas inter-relacionados, fundamental para a compreensão dos Transtornos Mentais e do Comportamento Relacionados ao Trabalho.

\subsection{MEDICINA E MUNDO DO TRABALHO}

Busca-se, nesta seção, traçar um panorama ainda que lacunar, das relações da medicina com o mundo do trabalho dos anos 10 (século XX) à atualidade.

\subsubsection{MEDICINA E MUNDO DO TRABALHO NOS ANOS 10 e 20}

No Brasil, de acordo com Lacaz (1996), as preocupações originais da medicina teriam se dirigido para além das questões individuais, voltando-se desde o final do século XIX para intervenções sobre o "corpo urbano" e ações de controle sobre o meio ambiente (LACAZ, 1996, p. 12). No início do século XX, como destaca o autor, ainda predominava a economia eminentemente agroexportadora (notadamente o café), e as prioridades eram o saneamento de portos e estradas de ferro, as vias de transporte e escoamento da produção agrícola. O foco de atenção seria o ataque às doenças transmissíveis, sobretudo as de manifestação epidêmica, que teriam impactos na saúde da população e na ordem econômica (PONTE, 2010c).

Nas cidades, o crescimento urbano acelerado e de modo geral desacompanhado de infraestrutura condizente favorecia a ocorrência de frequentes epidemias, e eram altos os índices de febre tifoide, disenteria, sarampo, lepra, meningite cérebroespinhal, tuberculose (DECCA, 1991). Mendes (1995) destaca que a atenção se voltava para as doenças de quarentena, que limitavam o comércio (como a cólera, a peste e a febre amarela), e para as doenças que reduziam a produtividade (entre as doenças que 
incidiam diretamente na produção, estavam o impaludismo, o tifo exantemático e a ancilostomose). Embora as epidemias tenham se tornado mais raras a partir dos anos 20, o estado sanitário das cidades continuou bastante precário até os anos 30 e 40 (DECCA, 1991).

Nesse cenário, ganharam destaque medidas de imunização (vacinação) e campanhas sanitárias ${ }^{58}$ voltadas para o saneamento do meio urbano, "considerado o principal implicado na causação das doenças pestilenciais, particularmente das cidades portuárias, como o Rio de Janeiro, que tinham posição estratégica na vigência da economia agrário-exportadora" (LACAZ, 1996, p. 13). Destacavam-se também as concepções oriundas da "era bacteriológica", 59 segundo as quais "poder-se-ia eliminar as doenças através de medidas de higiene ou pela vacinação" (LACAZ, 1996, p. 13), predominando "a ideia de que para cada doença existe um agente etiológico" (MENDES, 1995, p. 11). Urgia também "sanear o meio, dessecando pântanos, afastando cemitérios, organizando e limpando o espaço urbano das aglomerações e da estagnação dos fluxos do ar, da água e dos homens" (MARQUES, 1995 apud PONTE, 2010a, p. 54). 60

Nesse contexto, ganham destaque concepções teóricas ligadas ao movimento higienista, em cuja concepção, de modo geral, a desorganização e mau funcionamento sociais seriam as causas das doenças, cabendo à Medicina "refletir e atuar sobre seus componentes naturais, urbanísticos e institucionais, visando neutralizar todo perigo possível" (MANSANERA; SILVA, 2000, p. 118).

\footnotetext{
58 As ações do sanitarismo "campanhista" visavam ao combate de endemias tais como a peste, a cólera, a varíola, dentre outras (SILVA, 2011). A esse respeito, conferir: Ponte (2010a) e Ponte, Kropf e Lima (2010).

59 Concepções oriundas do aperfeiçoamento da tecnologia médico-sanitarista desenvolvida pelos Institutos Butantã e de Bacteriologia no final do século XIX, e dos resultados obtidos pelos estudos de patologia tropical (MONTERO, 1985).

60 Numa atuação cuja "matriz" seria a descrita por Foucault quando, ao tratar das origens da Medicina Social, discorre sobre o que chamou de Medicina Urbana, que surgiria na França, no final do século XVIII, e teria como suporte a urbanização. Essa medicina urbana consistiria essencialmente em analisar lugares de acúmulo e amontoamento que poderiam provocar doenças ou se tornarem fontes de formação e de difusão de fenômenos epidêmicos ou endêmicos, e controlar a circulação, essencialmente da água e do ar, donde a necessidade de abrir largas avenidas, de organizar os corredores de ar e água (FOUCAULT, 1995b).
} 
Na França, o movimento higienista orientou-se no sentido de "melhorar o estado de saúde das populações, de lutar contra a degenerescência dos indivíduos e contra as psicopatias" (NASSIF, 2005, p. 80) por meio de ações profiláticas, bem como para a atuação nas questões de saúde dos trabalhadores, com a criação de serviços médicos em empresas e da cadeira de Medicina do Trabalho (BILLIARD, 1996; NASSIF, 2005).

No início do século XX, no Brasil, as fábricas e oficinas, espaços privados, ainda não constituíam objeto de intervenção estatal, voltando-se as ações para as condições gerais de vida. Predominava nos trabalhadores um perfil de morbimortalidade caracterizado pelas chamadas "doenças dos trabalhadores", sendo as relações trabalho-doença subsumidas a exposições, em determinadas ocupações, a agentes químicos, físicos e biológicos, objetos de duas abordagens:

1. da Medicina Legal que vai ocupar-se dos nexos de causalidade entre doença e os riscos inerentes à ocupação dos indivíduos, o que permite pensar em doenças e acidentes específicos, mais tarde configurando o campo da Infortunistica do trabalho;

2. da Higiene, preocupada com as causas e a prevenção de seus efeitos e que, uma vez aplicada à fábrica, constitui-se na higiene do trabalho ou, com o advento da produção em escala, na higiene industrial (LACAZ, 1996, p. 13, grifos do autor).

Informadas por essas abordagens, gradualmente as estratégias desenvolvidas pela saúde pública se deslocaram do controle sanitário e da ênfase sobre as doenças infecciosas-pestilenciais para estratégias de "controle social, instruído pela Higiene Industrial", centradas no indivíduo, como a seleção e acompanhamento de pessoal, e controle do "fator humano", que estaria na origem dos acidentes e doenças no trabalho (LACAZ, 1996, p. 14).

Desde os inícios dos anos 20 , a higiene e a saúde pública passaram a ter estatuto "científico", e sua atuação em relação ao operariado, um caráter técnico-racional; conferiu-se importância crescente ao conhecimento especializado e técnico, onde o tom eugênico ${ }^{61}$ se fez presente. Estudos acadêmico-científicos começaram a ser publicados, nos quais se encontram descrições das causas da insalubridade e seus agentes físicos, químicos e biológicos e das "moléstias profissionais específicas" por eles provocadas. Contudo, a tônica desses estudos marcava-se pela "ignorância e

\footnotetext{
61 Uma discussão sobre a Eugenia é realizada na seção 4.2.2.1.1.
} 
indisciplina" do operariado, que parecia, muitas vezes, "constituir 'causa direta' da insalubridade, que deveria ser sanada, como as outras, por recursos técnico-científicos e administrativos, no caso, pela educação higiênico-sanitária" (DECCA, 1987). ${ }^{62}$

Os meios operários eram vistos como extremamente perniciosos para a "moral e disciplina do trabalho", focos de agitação e revolta social; hábitos de lazer eram considerados vícios, e a recreação, "improdutiva". O trabalho do menor foi muitas vezes social e moralmente justificado, pois os retiraria de meios "malsãos" e viciados; menores "doentes e raquíticos" constituiriam, como adultos, "maus operários e maus elementos e consequentemente revoltados e indolentes", justificando assim, por meio de ideais eugênicos ligados à produtividade e ao trabalho, estudos realizados e soluções propostas para a proteção da infância pobre e operária nas décadas de 20 e 30 (DECCA, 1987, p. 64).

As preocupações eugênico-higienistas também se estenderiam à "mentalidade" dos trabalhadores. O país, em processo de industrialização, precisaria "produzir" trabalhadores com mentalidade propícia ao novo modo de produção em desenvolvimento, processo do qual participaram ativamente os profissionais ligados à psiquiatria e à higiene mental (CARVALHO, 1999). Como aponta o autor, "a principal estratégia discursiva era deslocar o eixo da discussão, encerrando no domínio das ciências médica e psicológica questões relativas ao processo de produção do capital", reduzindo problemas coletivos e de luta política às dimensões individual e psíquica, que encontravam nos conceitos de desequilíbrio ou doença mental, inaptidão e inadaptação suas principais categorias explicativas (CARVALHO, 2011, p. 36). 63

62 A propaganda higiênica e a educação higiênico-sanitária preconizada em estudos e pesquisas desenvolvidos pelos serviços públicos de saúde podem ter tido eficiência no controle do operariado por meio da imposição de normas para sobrevivência em ambientes declaradamente hostis e agressivos à saúde, mas

[...] se revelaram inócuas para a melhoria da saúde da população pobre e trabalhadora, uma vez que os problemas sociais de fundo se recolocavam de maneira cada vez mais grave com o crescimento urbano e industrial. Por outro lado, a "ignorância higiênico-sanitária" do proletariado urbano, afirmada em vários foros, deslocava as questões básicas referentes à sua saúde, sustentando programas às vezes delirantes em suas intenções educativas (DECCA, 1987, p. 85-86).

63 Uma discussão sobre a Higiene Mental é realizada no Capítulo 5, Psicologia e Trabalho. 


\subsubsection{MEDICINA E MUNDO DO TRABALHO NOS ANOS 20 e 30}

Desde o início do século XX, vinham se desenvolvendo, como aponta Lacaz (1996), duas abordagens voltadas para as "doenças dos trabalhadores": a Medicina Legal (Infortunística) ${ }^{64}$ e a Higiene Industrial. Em 1930, as ações vinculadas a agravos relacionados com o trabalho passaram a ser responsabilidade do recém-criado Ministério do Trabalho, Indústria e Comércio, por meio da Inspetoria de Hygiene e Segurança do Trabalho do Departamento Nacional do Trabalho, o que, para Lacaz (1996, p. 17), iria "retirar da Saúde Pública o papel de 'velar' pela higiene do trabalho". Contudo, como destaca o autor, as possibilidades de intervenção dos órgãos de Estado eram limitadas, uma vez que os principais problemas seriam objeto da ação do "centro de saúde da indústria". O empresariado também criava no período seus órgãos representativos, como o Centro das Indústrias de São Paulo (CIESP), fundado em 1928, e o Instituto de Organização Racional do Trabalho (IDORT), criado em 1931.

Na passagem dos anos 20 para os anos 30, começou-se a privilegiar a ação no espaço privado da fábrica, visando aos indivíduos e à sua adaptação às exigências da produtividade preconizadas pela "organização científica do trabalho" e ao gerenciamento da força de trabalho na perspectiva das "relações industriais", por meio da prevenção e seleção de mão de obra.

Mendes (1995, p. 23) também aponta como se observa, a partir da década de 30, um deslocamento (ou retorno) do olhar clínico para o olhar epidemiológico, "voltado ao estudo do comportamento da morbidade e da mortalidade de trabalhadores, enquanto 'classe', categorias ou profissões específicas".

\subsubsection{MEDICINA E MUNDO DO TRABALHO NOS ANOS 40}

Nos anos 40, ganhou destaque a "medicina do comportamento" que, incluindo a psicotécnica, "firmou-se como dispositivo abalizado para a dissecação e julgamento da rotina e das disfunções que caracterizavam o cotidiano industrial" (BERTOLLI FILHO, 1993, p. 40). O autor dá destaque especial ao clínico Raul Rocha, funcionário do

\footnotetext{
64 Uma discussão sobre a Infortunística é realizada na seção 4.2.2.1.3.
} 
Departamento de Assistência Médico-Social da Secretaria de Saúde do Rio de Janeiro, que diz em um de seus livros: "a medicina voltada para as questões industriais buscava afinar-se com os interesses do governo de Getúlio Vargas, declarando seus objetivos: 'dar completa eficiência ao trabalho e, ao mesmo tempo, poupar e preservar o trabalhador' e com isto 'economizar material, trabalho e dinheiro'" (ROCHA, 1940 apud BERTOLLI FILHO, 1993, p. 40). Pautado por essas premissas, a medicina do comportamento mesclou conceitos oriundos da psicologia e da ergonomia, da sociologia e da economia "para ensinar que o 'fator anátomo-fisiológico' individual também denominado 'substrato orgânico' - não poderia ser alterado pela medicina que, em compensação, contava com um arsenal de conhecimentos sólidos e eficientes para corrigir a 'ação mental' do agrupamento operário".

No final dos anos 40, a segurança e as condições de trabalho na indústria eram ainda bastante desfavoráveis, a despeito da Consolidação das Leis do Trabalho (CLT). O discurso de prevenção começou a ser adotado pelo empresariado nos anos 40; contudo, a ênfase ainda recaía nas práticas de seleção (aptidão ou inaptidão dos trabalhadores) (LACAZ, 1996).

Mesmo não sendo obrigatórios, os serviços médicos de empresa começam a ganhar importância, como demonstra Lacaz (1996, p. 33), citando a Declaração de Princípios publicada nos Anais do Congresso Brasileiro dos Problemas Médicos Sociais de ApósGuerra (1947):

[...] manifestam-se coletivamente pela industrialização e pela democracia... [e] são favoráveis à criação de serviços médicos nas indústrias e de centros de reabilitação de acidentados, comportando equipamentos de ortopedia, cirurgia e fisioterapia. Seu interesse é tanto na prevenção através dos serviços como na readaptação com a participação médica... Seu ponto de vista sobre a questão do acidente é direcionado pela sua prática profissional.

No pós-guerra, foram introduzidas significativas mudanças no contexto produtivo, como novos equipamentos, novos processos industriais, novos materiais, novos produtos químicos; observou-se o aumento da complexidade das relações entre trabalho e relativas à saúde, devido ao avanço tecnológico dos novos processos de trabalho e rearranjos na divisão internacional do trabalho (LACAZ, 1996; MENDES; DIAS, 1991). 
A abordagem da Medicina do Trabalho65 e da Higiene teria se revelando incapaz, segundo Mendes e Dias (1991), de lidar eficazmente com essas questões, impondo a necessidade de uma abordagem que incorporasse noções, instrumentos e técnicas fornecidos por outros campos de atuação profissional - como a psicologia, a sociologia, a economia, a engenharia - delineando a abordagem conhecida como Saúde Ocupacional, descrita por Lacaz (1996, p. 33) como "conceitualmente melhor acabada e construída". Colocou-se a necessidade de atuação multiprofissional, analisando e intervindo nos ambientes de trabalho; e, "com isso, assume a hegemonia das influências no Brasil, o modelo dos EEUU de Higiene Industrial e Saúde Ocupacional" .66

\subsubsection{MEDICINA E MUNDO DO TRABALHO NOS ANOS 50}

Estreitaram-se os contatos com especialistas norte-americanos em Higiene Industrial e, em São Paulo, criou-se o Serviço de Higiene Industrial do SESI. Em meados dos anos 50 , tiveram lugar estudos sobre as patologias do trabalho mais prevalentes em razão dos riscos, e

[...] concretiza-se como uma estratégia a organização e utilização de serviços médicos que, ao lado de atuarem no atendimento individual-clínico, também assumiriam atividades relacionadas ao campo da medicina do trabalho, tendo importante papel que alia o estudo das causas de absentismo, à seleção de pessoal e à análise das doenças e acidentes ocupacionais (LACAZ, 1996, p. 35).

Lacaz destaca que, nos anos 50, empresas de grande porte, algumas estatais e multinacionais, começaram a investir na manutenção de serviços de assistência médica próprios, independentes do setor estatal, "a ser[em] desenvolvido[s] por uma secção médica no interior das empresas" (TEIXEIRA; OLIVEIRA, 1978 apud LACAZ, 1996, p. 38). Esses Serviços de Medicina de Empresa objetivariam o controle e a seleção dos trabalhadores e teriam importante papel no desenvolvimento de metodologia e elaboração de inquéritos de higiene industrial nas cidades do Rio de Janeiro e São

\footnotetext{
65 Uma discussão sobre a Medicina do Trabalho é realizada na seção 4.2.2.

66 Uma discussão sobre a Saúde Ocupacional é realizada na seção 4.2.3.
} 
Paulo, envolvendo avaliação dos ambientes e condições de trabalho e exame médico dos trabalhadores.

Mendes e Dias (1991) destacam no cenário internacional a recomendação 112 da Organização Internacional do Trabalho (OIT), de 1959, que designa como "serviço de medicina do trabalho" um serviço organizado nos locais de trabalho ou em suas imediações destinado a:

\footnotetext{
Assegurar a proteção dos trabalhadores contra todo o risco que prejudique a sua saúde e que possa resultar de seu trabalho ou das condições em que se efetue; contribuir à adaptação física e mental dos trabalhadores, em particular pela adequação do trabalho e pela sua colocação em lugares de trabalho correspondentes às suas aptidões; contribuir ao estabelecimento e manutenção do nível mais elevado possível do bem-estar físico e mental dos trabalhadores (MENDES; DIAS, 1991, p. 341).
}

Lacaz (2007) localiza em meados nos anos 50 a realização de inquéritos sobre doenças do trabalho como dermatoses, pneumoconioses, intoxicações por chumbo - as últimas, bastante frequentes na emergente indústria automobilística. O autor aborda entrevista realizada com Bernardo Bedrikow, médico formado em saúde pública e higiene do trabalho em Harvard nos anos 50, professor decano de Medicina do Trabalho na Faculdade de Ciências Médicas da Santa Casa de São Paulo até os anos 80 e um dos fundadores do ambulatório de doenças profissionais do SESI de São Paulo, nos anos 50. Bedrikow relata que o primeiro lugar em número de atendimentos era ocupado pelas dermatoses ocupacionais e,

[em] segundo lugar a intoxicação por chumbo [...] Por causa da indústria automobilística. Foi período do crescimento desordenado da indústria automobilística. Aquele negócio heroico de fazer 100 caminhões por dia. E cada caminhão, cada ônibus levava 10 a $12 \mathrm{~kg}$ de chumbo [...] derretido no maçarico. Isto representou esta verdadeira epidemia: 1.000 casos de intoxicação em um curto espaço de tempo. Tudo bem documentado! (BEDRIKOW apud LACAZ, 2007, p. 101).

\subsubsection{MEDICINA E MUNDO DO TRABALHO NOS ANOS 60}

Já nas décadas de 50 e 60 observa-se a grande ampliação de funções da Medicina do Trabalho e da Higiene Industrial, com uma crescente preocupação com o tratamento 
dos traumatismos, por se tratarem agora passíveis, por lei, 67 de indenização. Isso levou os departamentos médicos das indústrias a uma ampliação de sua atuação

[...] do terreno cirúrgico para o médico, abarcando também o controle dos problemas de engenharia sanitária e de segurança industrial. Com o tempo incorporam-se outras funções [...] os exames de saúde na admissão e os periódicos, a colocação segundo a vocação, o controle médico e técnico dos acidentes e das doenças profissionais (FERRARI SAN MARTIN apud LACAZ, 1996, p. 13).

Segundo Lacaz (2000, p. 155), observou-se um progressivo grau de automação na indústria, associado a importantes mudanças nas formas de organização das jornadas de trabalho, como o regime de turnos alternados, o que veio a produzir mudanças no perfil de morbimortalidade. No final dos anos 60, essas mudanças se associaram, segundo o autor, ao "aumento do absenteísmo, da insatisfação no trabalho, das operações tartaruga como maneiras de resistência ao controle fordista. São sinais do esgotamento desta forma de gestão, divisão e organização do trabalho".

\subsubsection{MEDICINA E MUNDO DO TRABALHO NOS ANOS 70}

No início dos anos 70, o momento se caracterizava pela elevada ocorrência de acidentes de trabalho. Nesse momento, o Banco Mundial sinalizou o corte de financiamentos para o Brasil, caso o quadro de acidentes de trabalho não fosse revertido. Segundo estimativas da época, 1,7 milhão de acidentes ocorriam anualmente e $40 \%$ dos profissionais sofriam lesões (ABPA, 2014; TRT 20, 2013). As Portarias regulamentavam a formação técnica em Segurança e Medicina do Trabalho, resultando, dessa forma, na atualização do artigo 164 da CLT, que trata da composição de CIPA (TRT-20, 2013).

Como destaca Lacaz (1996), o número de acidentes do trabalho teve evolução acelerada do final dos anos 60 até meados dos 70. Já no tocante às doenças profissionais, apresentaram-se números baixíssimos, o que indicaria um sub-registro pelas empresas e a ausência de uma política assistencial e preventiva, como se observa na Tabela 1, a seguir.

\footnotetext{
67 Decreto-Lei no 7.036 de 1944.
} 
Tabela 1 - Acidentes do trabalho registrados por espécie / Brasil - 1971 a 1995

\begin{tabular}{|c|c|c|c|c|c|c|c|}
\hline \multirow{2}{*}{ ANO } & \multicolumn{2}{|c|}{ ACIDENTES-TIPO } & \multicolumn{2}{|c|}{$\begin{array}{c}\text { DOENÇAS } \\
\text { PROFISSIONAIS }\end{array}$} & \multicolumn{2}{|c|}{ ACIDENTES DE TRAJETO } & \multirow{2}{*}{$\begin{array}{c}\text { TOTAL } \\
\text { № }\end{array}$} \\
\hline & № & $\%$ & № & $\%$ & № & $\%$ & \\
\hline 1971 & 1.308 .335 & 98,33 & 4.050 & 0,31 & 18.138 & 1,36 & 1.330 .523 \\
\hline 1972 & 1.479 .318 & 98,31 & 2.389 & 0,16 & 23.016 & 1,53 & 1.504 .723 \\
\hline 1973 & 1.602 .517 & 98,15 & 1.784 & 0,12 & 28.395 & 1,73 & 1.632 .696 \\
\hline 1974 & 1.756 .649 & 97,77 & 1.839 & 0,10 & 38.273 & 2,13 & 1.796 .761 \\
\hline 1975 & 1.869 .689 & 97,57 & 2.191 & 0,12 & 44.307 & 2,31 & 1.916 .187 \\
\hline 1976 & 1.692 .833 & 97,07 & 2.598 & 0,15 & 48.394 & 2,78 & 1.743 .825 \\
\hline 1977 & 1.562 .957 & 96,79 & 3.013 & 0,19 & 48.780 & 3,02 & 1.614 .750 \\
\hline 1978 & 1.497.934 & 96,55 & 5.016 & 0,32 & 48.551 & 3,13 & 1.551 .501 \\
\hline 1979 & 1.338 .525 & 96,12 & 3.823 & 0,26 & 52.279 & 3,62 & 1.444 .627 \\
\hline 1980 & 1.404 .531 & 95,92 & 3.713 & 0,25 & 55.967 & 3,82 & 1.464 .211 \\
\hline 1981 & 1.215 .539 & 95,68 & 3.204 & 0,25 & 51.722 & 4,07 & 1.270 .465 \\
\hline 1982 & 1.117 .832 & 94,85 & 2.766 & 0,23 & 57.874 & 4,91 & 1.178 .472 \\
\hline 1983 & 943.110 & 94,03 & 3.016 & 0,30 & 56.989 & 5,68 & 1.003 .115 \\
\hline 1984 & 901.238 & 93,73 & 3.283 & 0,34 & 57.054 & 5,93 & 961.575 \\
\hline 1985 & 1.010 .340 & 93,73 & 4.006 & 0,37 & 63.515 & 5,89 & 1.077 .861 \\
\hline 1986 & 1.129 .152 & 93,46 & 6.014 & 0,52 & 72.693 & 6,29 & 1.207 .859 \\
\hline 1987 & 1.065 .912 & 93,73 & 6.382 & 0,56 & 64.830 & 5,70 & 1.137.124 \\
\hline 1988 & 927.424 & 93,42 & 5.029 & 0,51 & 60.284 & 6,07 & 992.737 \\
\hline 1989 & 732.635 & 92,64 & 6.600 & 0,83 & 51.592 & 6,52 & 790.827 \\
\hline 1990 & 632.012 & 91,12 & 5.217 & 0,75 & 56.343 & 8,12 & 693.572 \\
\hline 1991 & 587.760 & 91,72 & 6.331 & 0,98 & 46.698 & 7,28 & 640.790 \\
\hline 1992 & 449.754 & 92,20 & 7.718 & 1,59 & 30.312 & 6,21 & $487.784 *$ \\
\hline 1993 & 386.025 & 90,41 & 11.111 & 2,60 & 29.824 & 6,98 & $426.960 * *$ \\
\hline 1994 & 350.210 & 90,19 & 15.270 & 3,93 & 22.824 & 5,88 & 388.304 \\
\hline 1995 & 374.700 & 88,34 & 20.646 & 4,87 & 28.791 & 6,79 & $424.137^{* * *}$ \\
\hline
\end{tabular}

Fonte: Lacaz, 1996, p. 371.

Notas:

* Dados parciais. Faltando: PR abr. a dez.; AC jul. a dez.; MT e SE out. a dez.

** Dados parciais. Faltando: MS maio a dez.; MA jun. a dez.; AM, RN,SC e RO jul. a dez.; AL e CE out. a dez.; RJ nov. e dez.; RS abr. a dez.; DF jun. a dez.

*** Dados parciais. Faltando: MA out. a dez.; RS jan. a dez.; DF ago. a dez.

Embora desde o final dos anos 40 já existissem serviços médicos de empresa, eles só se tornaram obrigatórios com a Portaria $n^{\circ} 3.237$, e novamente pela Portaria $n^{\circ} 3.406$ de 1975, reformulada pela Portaria $n^{\circ} 3.214$ de 1978 que, em sua Norma Regulamentadora (NR) 4, dispõe sobre a criação dos Serviços Especializados em Engenharia de Segurança e Medicina do Trabalho (SESMT). 
Os SESMTs eram "Serviços de Saúde" que levavam a medicalização para dentro dos locais de trabalho, o que constituiria, para Lacaz (1996, p. 76), a "delegação às empresas da tutela da saúde dos trabalhadores". A Saúde do Trabalhador68 se proporia a reverter essa inversão, levando para o âmbito dos serviços de saúde pública a atenção, prevendo a participação coletiva dos trabalhadores e a apropriação de informações como elemento para controle da sua saúde.

Nesse outro polo de enunciação, a Saúde do Trabalhador começou a se colocar como contraponto aos saberes e práticas da Saúde Ocupacional-Medicina do Trabalho, inspirada pela Medicina Social Latino-Americana, pela Saúde Pública e pela Saúde Coletiva. ${ }^{69}$ A discussão sobre realidades mais complexas, para além das doenças profissionais clássicas, como é o caso das "doenças relacionadas ao trabalho", ganhou espaço (LACAZ, 1996, p. 23).

\subsubsection{MEDICINA E MUNDO DO TRABALHO NOS ANOS 8070}

A emergência da Saúde do Trabalhador como campo teórico-prático ocorre a partir dos anos 80 , no contexto da luta pela redemocratização do país, de novas práticas sindicais em saúde, traduzidas em reivindicações de melhores condições de trabalho - no bojo da emergência do Novo Sindicalismo - e de denúncias às políticas públicas e ao sistema de saúde, incapazes de dar respostas às necessidades de saúde da população, em especial dos trabalhadores (MENDES, 1995, p. 26).

Como diz Lacaz (1996), o início dos anos 80 foi um momento histórico em que uma série de elementos concorreu para que se criassem na rede pública os Programas de Saúde do Trabalhador, articulados também com o "Movimento Sanitário" na luta pela Reforma Sanitária.

Em texto no qual resenha o livro "De que adoecem e morrem os trabalhadores", publicado em 1984 pelo Departamento Intersindical de Estudos e Pesquisas de Saúde e

\footnotetext{
68 Uma discussão sobre a Saúde do Trabalhador é realizada na seção 4.2.4.

69 Uma discussão sobre a Saúde Coletiva é realizada na seção 4.2.4.1.4.

70 Nesta seção, será tratada essencialmente a perspectiva da Saúde do Trabalhador, por se tratar da abordagem teórica à qual me filio e que informa o campo teórico-prático objeto desta tese.
} 
dos Ambientes de Trabalho (DIESAT), ${ }^{71}$ Vorcaro (1988, p. 37) apontava como dificuldades ou impeditivos para o reconhecimento da extensão dos danos à saúde causados pelas condições de trabalho o ainda baixo número de publicações em Saúde Coletiva, as leis que favoreciam o sub-registro de doenças e acidentes e as várias facetas da organização e administração dos serviços públicos de assistência.

Como explicita Souto (2003, p. 229),

O que se observou na época foi uma série de procedimentos e recomendações que geraram, por um lado, iniciativas conflitantes que implicaram em desperdício de esforço intelectual e de bens materiais e, por outro lado, a inexequibilidade de se implementarem certas ações por falta de infraestrutura técnica a lhe dar o apoio que era necessário.

Vorcaro (1988, p. 37) também aponta como a situação de capitalismo tardio e o desenvolvimento e industrialização internos descompassados determinariam um perfil de morbidade em que as patologias diferem e coexistem, desde as "doenças de carência" até as psicossociais, "típicas dos países mais desenvolvidos, onde o avanço tecnológico dos meios de produção tende a tornar cada vez menos aparente a relação de causa e efeito entre trabalho e enfermidade".

Também em 1988, Mendes mostrava que, além da contribuição das doenças profissionais específicas à morbidade de trabalhadores, mais importante seria a contribuição inespecífica do trabalho ou da ocupação (as doenças relacionadas ao trabalho). O autor discutiu a alta frequência da hipertensão arterial, das doenças respiratórias crônicas, das doenças do aparelho locomotor, dos distúrbios mentais e estresse, alguns constituindo também causa importante de incapacidade naquele momento.

\subsubsection{MEDICINA E MUNDO DO TRABALHO NOS ANOS 90}

O início dos anos 90 teria trazido a incorporação de unidades de referência em saúde do trabalhador às redes de saúde de diversos municípios brasileiros, unidades posteriormente denominadas CERESTs (Centros de Referência em Saúde do Trabalhador). Essas unidades utilizam abordagem clínico-epidemiológica e de

\footnotetext{
${ }^{71}$ RIBEIRO; LACAZ,1984.
} 
planejamento na busca pela atenção em todos os níveis de prevenção, visando ao conhecimento dos determinantes da saúde, com a participação de trabalhadores organizados - os agentes seriam, então, as equipes multiprofissionais e os trabalhadores (SATO; LACAZ; BERNARDO, 2006, p. 283).

Simultaneamente, a chamada Lei Orgânica da Saúde (Lei n 8.080, de 1990) introduziu nas leis orgânicas municipais questões relativas à saúde dos trabalhadores, que possibilitaram maior autonomia de ação do nível local, sobretudo no que tange às ações de vigilância em saúde.

Deve-se destacar, contudo, que mesmo que as discussões do campo da Saúde do Trabalhador e as progressivas mudanças na legislação incorporem essa abordagem às políticas públicas em saúde, a perspectiva da Medicina do Trabalho-Saúde Ocupacional tem destacado papel, sobretudo no meio empresarial.

A perspectiva de que a doença ou acidente de trabalho são provocados pelo trabalhador também mantém sua forte pregnância, como pode-se exemplificar em obras como a de Souto (2003). Ao mesmo tempo em que louva as "novas regulamentações de proteção à saúde do trabalhador", pois "saúde não se constitui num bem unicamente individual, mas acima de tudo em patrimônio coletivo da Nação", Souto (2003, p. 231, grifo nosso) afirma que

\begin{abstract}
Ninguém ignora também que existam muitos empregados que não fazem por onde receber os benefícios que a lei lhes proporciona. São resistentes às medidas preventivas implantadas e são os primeiros, quando alguma coisa Ihes acontece, a lançar a culpa indevidamente sobre a empresa, passando a procurar imerecidas vantagens pecuniárias através de ações trabalhistas e civis.
\end{abstract}

\title{
4.1.9 MEDICINA E MUNDO DO TRABALHO NA ATUALIDADE
}

A atualidade é marcada pela atuação em Medicina do Trabalho-Saúde Ocupacional nas empresas, serviços de medicina do trabalho (próprios ou terceirizados), peritos (contratados privadamente) e alguns setores do INSS; já na saúde pública, pelos setores da academia e movimentos sindicais, como também pela atuação em Saúde do Trabalhador. 
Discutem-se, a seguir, impactos trazidos pelas novas tecnologias de gestão, reestruturação produtiva, terceirização, terciarização, precarização do trabalho vividas desde o final dos anos 70, mas intensificadas nos anos 80 e, sobretudo, de 90 em diante, para as condições de vida e saúde dos trabalhadores.

A incorporação de novas tecnologias e técnicas gerenciais aos processos de trabalho modificou o perfil de saúde, enfermidade e sofrimento dos trabalhadores; essas mudanças se expressariam no aumento de incidência de enfermidades como as LER/DORT (Lesões por Esforços Repetitivos / Distúrbios Osteomusculares Relacionados ao Trabalho), câncer, enfermidades "malcaracterizadas" como estresse, fadiga física e mental e outras expressões de sofrimento relacionadas ao trabalho. Essas "novas" enfermidades conviveriam com outras já bastante conhecidas, como a silicose e as intoxicações por metais pesados e agrotóxicos.

Quanto às mudanças do perfil patológico dos trabalhadores, um novo perfil se configuraria com prevalência de agravos marcados por doenças crônicas, como as cardiocirculatórias, psicossomáticas, cânceres e musculoesqueléticas, às quais se agregam mortes por excesso de trabalho - karoshi - e enfermidades neurológicas ligadas ao estresse (LACAZ, 2000; RIBEIRO, 2008).

Em 1988, Mendes já apontava que, além da contribuição das doenças profissionais específicas à morbidade de trabalhadores, mais importante seria a contribuição inespecífica do trabalho ou da ocupação (as doenças relacionadas ao trabalho). 0 autor discute a alta frequência da hipertensão arterial, das doenças respiratórias crônicas, das doenças do aparelho locomotor, dos distúrbios mentais e estresse, alguns constituindo também causa importante de incapacidade naquele momento. Em estudo de 2002, realizado junto ao INSS de Porto Alegre, Boff, Leite e Azambuja (2002) apontam como as três primeiras causas de incapacidade identificadas os acidentes e violências, as doenças osteomusculares e as doenças mentais. Para Noriega (1993), as repercussões mais importantes para a saúde dos trabalhadores se centrariam nas enfermidades psíquicas e psicossomáticas, como estresse agudo e crônico e a fadiga. Laurell (1993) também considera o estresse a reação de adaptação mais típica da sociedade contemporânea, gerando mal-estares como tensão nervosa e fadiga crônica. 
O perfil epidemiológico do adoecimento dos trabalhadores reflete essas mudanças (DIAS; HOEFEL, 2005). Lino e Dias (s/d) sistematizam as ocorrências de morbidade/mortalidade em três categorias de problemas relacionados ao trabalho, agrupadas em: "padrões antigos", nos quais a morbidade/mortalidade relacionada ao trabalho está bem definida; "novos perfis ou padrões", típicos de países altamente desenvolvidos; e "padrões mistos ou em mosaico", presentes em muitos dos países desenvolvidos e em desenvolvimento. Esses padrões podem ser observados no Quadro 1, a seguir:

Quadro 1 - Ocorrências de morbidade/mortalidade em categorias de problemas relacionados ao trabalho

\begin{tabular}{|c|c|c|}
\hline $\begin{array}{l}\text { a) "Antigos padrões/perfis } \\
\text { dos problemas de saúde- } \\
\text { doença dos trabalhadores" }\end{array}$ & $\begin{array}{l}\text { b) "Novos padrões/perfis dos } \\
\text { problemas de saúde-doença dos } \\
\text { trabalhadores" }\end{array}$ & $\begin{array}{l}\text { c) "Padrões/perfis dos problemas de saúde- } \\
\text { doença dos trabalhadores, de transição" }\end{array}$ \\
\hline $\begin{array}{l}\text { Alta incidência de acidentes } \\
\text { do trabalho, com tendência } \\
\text { ascendente }\end{array}$ & $\begin{array}{l}\text { uncia de acidentes do } \\
\text { u tendência }\end{array}$ & $\begin{array}{l}\text { tre } \\
\text { as }\end{array}$ \\
\hline $\begin{array}{l}\text { Alta incidência de acidentes } \\
\text { fatais }\end{array}$ & $\begin{array}{l}\text { Baixa ir } \\
\text { fatais }\end{array}$ & $\begin{array}{l}\text { identes do } \\
\text { setores e }\end{array}$ \\
\hline $\begin{array}{l}\text { Alta incidência de doenças } \\
\text { profissionais clássicas } \\
\text { (silicose, benzenismo, etc.), } \\
\text { com baixo número de casos } \\
\text { notificados/registrados }\end{array}$ & $\begin{array}{l}\text { Doençã } \\
\text { reduzic }\end{array}$ & $\begin{array}{l}\text { as profissionais } \\
\text { rescente de } \\
\text { grandes diferenças }\end{array}$ \\
\hline $\begin{array}{l}\text { Exposições } \text { a } r \text { altas } \\
\text { concentrações de agentes } \\
\text { tóxicos e poluentes, com } \\
\text { efeitos agudos e de curta } \\
\text { latência }\end{array}$ & $\begin{array}{l}\text { Surgimento de outros efeitos dos } \\
\text { agentes das doenças } \\
\text { profissionais: câncer, efeitos } \\
\text { neurocomportamentais e sobre } \\
\text { a reprodução; exposições a baixa } \\
\text { dosagem, levando a efeitos } \\
\text { crônicos e de longa latência }\end{array}$ & $\begin{array}{l}\text { s } \\
\text { efeitos } \\
\text { das } \\
\text { ação de } \\
\text { ão a } \\
\text { s e }\end{array}$ \\
\hline $\begin{array}{l}\text { Presença de outras doenças } \\
\text { relacionadas ao trabalho, } \\
\text { porém não reconhecidas nos } \\
\text { aspectos legais e } \\
\text { epidemiológicos }\end{array}$ & $\begin{array}{l}\text { Aumento da incidência de } \\
\text { doenças relacionadas ao } \\
\text { trabalho (estresse, hipertensão, } \\
\text { LER, doenças mentais) com alta } \\
\text { prevalência }\end{array}$ & $\begin{array}{l}\text { "doenças relacionadas ao trabalho", pc } \\
\text { difícil reconhecimento pelas segurador } \\
\text { ausência de políticas e programas para }\end{array}$ \\
\hline $\begin{array}{l}\text { Morbidade } r \text { geral } \\
\text { caracterizada por predomínio } \\
\text { de doenças infecciosas e } \\
\text { parasitárias, desnutrição e } \\
\text { carenciais }\end{array}$ & $\begin{array}{l}\text { Mortalidade e morbidade geral } \\
\text { marcadas por doenças crônico- } \\
\text { degenerativas }\end{array}$ & $\begin{array}{l}\text { Padrões mistos de morbidade e mortalidade } \\
\text { geral, caracterizados pela coexistência das } \\
\text { doenças infecciosas, parasitárias e carenciais e } \\
\text { das crônico-degenerativas e da violência, } \\
\text { caracterizando duplo perfil epidemiológico }\end{array}$ \\
\hline
\end{tabular}

Fonte: Lino e Dias, [s/d], p.5-6. 
O quadro apresentado reforça a constatação de Lacaz (2000) de que, em países periféricos, coexistem processos de trabalho arcaicos e modernos, ${ }^{72}$ levando à ocorrência de um perfil híbrido, no qual os nexos de causalidade com o trabalho tornam-se mais complexos e onde anteriormente não eram cogitados ou desvalorizados devem ser colocados em pauta (como a própria listagem de Transtornos Mentais e do Comportamento Relacionados ao Trabalho apontaria). ${ }^{73}$ Essa realidade contraditória traria consigo um novo perfil de morbimortalidade dos trabalhadores. Além das doenças e acidentes associados à organização taylorista/fordista, verifica-se tendência de mudança do perfil em que predominam doenças não reconhecidas como do trabalho (ou até recentemente não reconhecidas). Lino e Dias ( $\mathrm{s} / \mathrm{d}$ ) também discutem essa questão, apontando como a coexistência do duplo padrão de produção se reflete no duplo perfil de morbimortalidade, no qual antigas doenças profissionais, como as intoxicações por chumbo, mercúrio, a silicose e outras doenças pulmonares e altos índices de acidentes do trabalho, convivem com uma ocorrência elevada de casos de Lesões por Esforços Repetitivos, câncer e o sofrimento mental.

Na mesma perspectiva, vem a discussão de Lima (2011b), ao afirmar que, embora os resultados dos diversos estudos realizados sobre os impactos dessas mudanças na saúde dos trabalhadores não sejam concludentes, ainda assim fornecem sólidas "pistas" a respeito. A intensificação do trabalho teria como consequência o aumento das LER (Lesões por Esforços Repetitivos), que lideram as estatísticas sobre doenças ocupacionais, seguidas pelos transtornos mentais, como a fadiga nervosa, a síndrome do pânico e os quadros depressivos, entre outros. A autora ainda destaca o aumento dos acidentes de trabalho (sobretudo entre trabalhadores terceirizados), dos quadros de alcoolismo, de ansiedade e do índice de suicídios que atingem certas categorias profissionais. Conclui, então, que, embora as estatísticas careçam de precisão, é possível afirmar que as mudanças no mundo do trabalho que vêm se operando desde

\footnotetext{
72 O processo de globalização pressupõe formas de integração diferenciadas dos países na economia global, e o fenômeno da terceirização implica processos de deterioração das condições de trabalho ao longo da cadeia produtiva (LEITE, 2003).

${ }^{73}$ Lista B do Decreto $n^{\circ}$ 3048, de 1999.
} 
os anos 80 forjam um novo perfil de adoecimento em diversas categorias profissionais. Nos termos da autora,

\begin{abstract}
Algumas doenças podem ser mais facilmente relacionadas com tais mudanças do que outras, mas o fato inegável (e que a história das doenças ocupacionais nos ensina) é que, ao ser transformado nosso modo de trabalhar - ou nosso modo de "andar a vida", como colocam muito bem Laurell e Noriega [...] -, transforma-se também o tipo de desgaste que sofremos e, portanto, nossa forma de viver, adoecer e morrer (LIMA, 2011b, p. 166).
\end{abstract}

As mudanças no mundo do trabalho também repercutiriam no que Franco, Druck e Seligmann-Silva (2010, p. 232) chamam de tempos sociais do trabalho - ritmos, intensidade, regimes de turnos, hora extra, banco de horas -, que estariam em "contradição com os biorritmos dos indivíduos, gerando acidentes e adoecimentos, destacando-se [...] o crescimento de dois grupos de patologias - o das LER/DORT e o dos transtornos mentais".

Deve-se destacar a importância da discussão concernente aos impactos dos processos produtivos, em especial no contexto da reestruturação produtiva, para a saúde dos trabalhadores, uma vez que as doenças relacionadas ao trabalho envolvem ou afetam não apenas a corporalidade (ou a saúde mental) dos trabalhadores, mas também sua vida moral, seus sentimentos e sua autorrepresentação, já que o processo de adoecimento repercutiria em múltiplas dimensões da experiência vivida: na saúde, como doenças muitas vezes incapacitantes para atividades não apenas de trabalho, mas da própria vida cotidiana; na vida profissional, com o afastamento e/ou prejuízo da capacidade laborativa, e toda a carga valorativa advinda desse afastamento/prejuízo para segmentos da população (auto)valorizados em termos dessa capacidade; e na própria autoimagem, sendo recorrentes, após a instalação das doenças, rupturas e conflitos identitários, bem como os fenômenos chamados por Seligmann-Silva (1994) de "psicopatologia do afastamento", entre outros.

\title{
4.2 O CAMPO DA PATOLOGIA DO TRABALHO E SEUS PARADIGMAS
}

Busca-se nesta seção estabelecer uma discussão sobre o campo da "Patologia do Trabalho" (nos termos de Mendes, 1995), a partir da análise de seus principais 
paradigmas/modelos (Medicina do Trabalho/Industrial, Saúde Ocupacional, Saúde do Trabalhador) e de abordagens / paradigmas correlacionados.

\title{
4.2.1 A PATOLOGIA DO TRABALHO
}

De acordo com Mendes (1995), o conhecimento da disciplina por ele chamada Patologia74 do Trabalho (ou das relações saúde-trabalho) se constrói em razão de determinantes "macro", como os de natureza econômica, política e tecnológica, mas também de determinantes "micro", fortemente incidentes sobre o modo de pensar, de investigar, de agir. A medicina seguiria acompanhando as mudanças e exigências dos processos produtivos, e dos movimentos sociais, transformando suas práticas, incorporando novos enfoques e instrumentos de trabalho (MENDES; DIAS, 2000). Nos termos de Mendes e Dias (2000: s/p):

\begin{abstract}
A Revolução Industrial, iniciada na Inglaterra no século XVIII, desencadeando transformações radicais na forma de produzir e de viver das pessoas e, portanto, de seu adoecer e morrer, deu novo impulso à Medicina do Trabalho. Desde então, acompanhando as mudanças e exigências dos processos produtivos e dos movimentos sociais, suas práticas têm se transformado, incorporando novos enfoques e instrumentos de trabalho, em uma perspectiva interdisciplinar, delimitando o campo da Saúde Ocupacional e, mais frequentemente, da Saúde dos Trabalhadores.
\end{abstract}

Essas mudanças e exigências dos processos produtivos e dos movimentos sociais implicam transformações da prática, que serão discutidas a seguir, a partir da análise dos paradigmas/modelos da patologia do trabalho (Medicina Industrial/do Trabalho, Saúde Ocupacional, Saúde do Trabalhador), tomando-a como um campo dinâmico de disputas, discursos e de práticas inter-relacionados, fundamental para a compreensão dos Transtornos Mentais e do Comportamento Relacionados ao Trabalho.

\footnotetext{
74 De pathos, sofrimento, doença e logos, estudo (MENDES, 1995, p. 5).
} 


\subsubsection{A MEDICINA DO TRABALHO (INDUSTRIAL)}

A medicina do trabalho constituiria essencialmente uma atividade médica, ${ }^{75}$ e sua prática se daria tipicamente nos locais de trabalho, chamando a si a tarefa de cuidar da "adaptação física e mental dos trabalhadores", na tentativa de sua colocação em tarefas ou postos de trabalho correspondentes às suas aptidões. Essa adaptação, contudo, uma vez que restrita à intervenção médica, consistia na seleção de candidatos a vagas de emprego e a atividades "educativas". Conferia-se à medicina do trabalho o papel de "contribuir ao estabelecimento e manutenção do nível mais elevado possível do bem-estar físico e mental dos trabalhadores", papel próprio, segundo Mendes e Dias (1991, p. 342), da concepção positivista da prática médica.

O modelo da medicina do trabalho, essencialmente centrado na figura do médico, pauta-se pela teoria da unicausalidade: para cada doença, haveria um respectivo agente etiológico correspondente. Segundo esse modelo, a prática médica no ambiente de trabalho se concretizaria no isolamento de riscos específicos e na atuação sobre suas consequências, associando os quadros sintomáticos encontrados a uma doença legalmente reconhecida. Como frequentemente as doenças originadas no trabalho só seriam percebidas em estágios avançados, até por apresentarem, muitas vezes, em suas fases iniciais, sintomas comuns a outras patologias, era difícil, sob essa ótica, identificar os processos que as geraram, bem mais amplos que a mera exposição a um agente exclusivo. A rotatividade da mão de obra representava um obstáculo a mais nesse sentido (MINAYO-GOMEZ; THEDIM-COSTA, 1997).

Segundo Mendes e Dias (1991), a expectativa de promover a "adaptação" do trabalhador ao trabalho, assim como a da manutenção de sua saúde, refletiria a influência do pensamento mecanicista na medicina. O pensamento mecanicista iria sustentar também, no campo da administração, o desenvolvimento dos princípios da

\footnotetext{
75 Nos termos de Lacaz (1996, p. 16), “A Medicina do Trabalho, ao se apoiar na clínica e na abordagem individual, dá ao médico e apenas a ele o estatuto da legitimidade de quem fala e é o domínio por excelência da 'disciplina'".
} 
"Administração Científica do Trabalho",76 que teriam encontrado na medicina do trabalho importante aliado na consecução de sua finalidade última, a produtividade.

\subsubsection{Abordagens / Paradigmas correlacionados}

A seguir, apresentam-se abordagens/paradigmas correlacionados à Medicina do Trabalho/Industrial.

\subsection{Eugenia}

Como enunciam Mansanera e Silva (2000, p. 119), eugenia foi o termo cunhado por Francis Galton, fisiologista inglês, "para designar a ciência que trata dos fatores capazes de aprimorar as qualidades hereditárias da raça humana. Afirmava ele que os seres humanos, assim como os animais, poderiam ser melhorados através da seleção artificial". O movimento eugênico teria repercutido fortemente junto aos intelectuais brasileiros nas primeiras décadas do século $X X$, em um cenário marcado por grandes transformações sociais: a abolição da escravidão e a migração de ex-escravos para as cidades, a imigração (sobretudo europeia), migração de camponeses para as cidades, bem como os efeitos econômicos da industrialização, que agravavam, como destacam os autores, as tensões sociais do período.

Para os eugenistas, "o brasileiro não tinha podido promover o desenvolvimento harmônico do país, porque o calor e a mistura com raças inferiores tinham-no tornado preguiçoso, ocioso, indisciplinado e pouco inteligente. Infelizmente, nada podia ser feito contra o clima. Em contrapartida, o problema racial ainda podia ser resolvido" (COSTA, 1989, apud MANSANERA; SILVA, 2000, p. 120).

A questão racial ganhou força durante a I Guerra Mundial (1914-1918) e imediatamente após com o surgimento de movimentos nacionalistas que a enfatizavam. "Nesse projeto de construção de uma nova ordem nacional - na qual a

\footnotetext{
76 Segundo Taylor (1911/1990, p. 42), as bases da Administração Científica do trabalho seriam os estudos de fisiologistas sobre "resistência do animal humano" e os estudos de engenheiros, que determinam a que "fração de cavalo-força corresponderia à potência do homem".
} 
concepção que via nas doenças um problema crucial para a construção da nacionalidade foi se tornando hegemônica - a ciência e, sobretudo, a medicina desempenharam papel fundamental" (CARVALHO, 2010, p. 100).

No Brasil, esses movimentos se organizaram sob a forma de "Ligas", reunindo representantes da elite intelectual, econômica e política do país (CARVALHO, 2010). Um exemplo é a Sociedade Eugênica de São Paulo, fundada em 1918, pautada pela adoção do ideal do melhoramento da raça pelos médicos, que, embora tenha durado pouco tempo, "seus ideais permaneceram mobilizando muitos médicos, principalmente os psiquiatras, que viam na eugenia a possibilidade de colaborarem com medidas de combate ao considerado grave problema da composição racial brasileira" (MANSANERA; SILVA, 2000, p. 121).

O eugenismo se constituiu como forte influência nas práticas de higiene e educação sanitária até meados dos anos 40; "para os higienistas sociais, interessava a possibilidade, apontada pelo eugenismo, de utilização de todos os conhecimentos no sentido de melhorar física, mental e racialmente as futuras gerações brasileiras", e concebiam que havia excesso de pessoas no planeta, constituído por "gente de baixa categoria física, psíquica e intelectual, que comia e não produzia, e que, sem trabalhar, agitava-se nocivamente, perturbando o equilíbrio social'. Isso seria "consequência da civilização, que permitiu a anulação dos preceitos básicos que garantiam a vitória dos melhores, impedindo o acúmulo de incapazes e de nocivos à coletividade" (MANSANERA; SILVA, 2000, p. 121).

\subsubsection{Medicina Científica}

A medicina científica teria surgido, segundo Nascimento Sobrinho $(1995, s / p)$, no "período formativo do capitalismo monopolista, entre o final do século XIX e o início do século $X X$, que teria se confrontado, então, com duas exigências básicas: aumentar a acumulação de capital e legitimar a ordem social".

Em decorrência das lutas dos movimentos sociais, que levaram políticos e legisladores a introduzirem medidas legais de controle das condições e ambientes de trabalho, limites haviam sido impostos à duração da jornada de trabalho, tornando-se 
necessário para o aumento da produtividade o recurso a diversas áreas de saber, dentre elas a medicina, que contribuiria com estudos sobre o rendimento do corpo humano, sua proteção e "restauração", de modo a maximizar a produção. Propostas como a Administração Científica do Trabalho de Taylor (1911/1990), baseadas no aproveitamento ótimo das capacidades e resistências tanto físicas quanto psicológicas dos trabalhadores, viriam a se apoiar fortemente em conhecimentos produzidos pela medicina.

Para Nascimento Sobrinho (1995, p. 37-38), os elementos estruturais da medicina científica seriam

[...] o mecanicismo, o biologicismo, o individualismo, a especialização, a exclusão das práticas alternativas, a concentração de recursos humanos, a tecnificação do ato médico, a ênfase na medicina curativa. Aplicam-se, dessa forma [...] a medicina de reprodução da força de trabalho e de controle social.

Segundo Montero (1985, p. 42), somente a partir do aperfeiçoamento da tecnologia médico-sanitarista e dos resultados obtidos pelos estudos de patologia tropical, a medicina científica começaria a impor-se no Brasil, sobretudo nos grandes centros urbanos, como forma terapêutica eficiente e hegemônica, concomitantemente ao processo de industrialização do país.

\subsection{Infortunística}

No Brasil, a "infortunística" constituiu-se em viés que, segundo Mendes (1995, p. 1415), impregnou fortemente a medicina do trabalho,

[...] quer pela ideia subjacente, sempre presente, do infortúnio, isto é, da infelicidade, da desventura, da desgraça, da falta de sorte, quer pela ideia de risco inerente ao trabalho, que sempre impregnou o conceito legal de agravos à saúde relacionados ao trabalho - ambos os conceitos servindo para, de alguma forma, escamotear a análise da gênese desses eventos - e, ainda, pela questão do nexo causal, fundamental na lógica da Medicina Legal e da Medicina do Seguro.

A infortunística é a "parte da Medicina Legal que estuda os infortúnios ou riscos industriais, sejam agudos, físicos e químicos, propriamente acidentes do trabalho, sejam subagudos ou crônicos, tóxicos e biológicos, as doenças profissionais" (PEIXOTO 
et al. apud MENDES, 1995, p. 15). Bertolli Filho (1993) vai caracterizá-la como uma área de confluência de várias especialidades, voltada para o estudo das condições materiais de trabalho e das possibilidades de o ambiente das máquinas constituir-se em fator de risco para a saúde.

Assim como na Europa, o deslocamento do eixo da "patologia do trabalho" para o lado da "medicina do seguro" teria provocado, no Brasil, o estreitamento da óptica das “doenças profissionais", equivalentes aos "acidentes do trabalho" (MENDES, 1995, p. 14).

Bertolli Filho (1993, p. 38) situa as primeiras tentativas acadêmicas cujo objetivo era a análise do trabalho sob a perspectiva médico-legal no grupo ligado ao psiquiatra Afrânio Peixoto, que reclamava para o médico (mais do que para o advogado) as tarefas de "'avaliação e disciplinarização' do operariado urbano, sendo a Psicotécnica a área do saber 'plenamente capacitada para selecionar os operários', 'corrigir' os faltosos e, em continuidade, garantir um melhor rendimento do trabalho industrial".

Afranio Peixoto, Flaminio Fávero e Leonídio Ribeiro publicaram em 1926 a obra "Medicina Legal dos Acidentes de Trabalho e das Doenças Profissionaes", na qual, segundo Bertolli Filho (1993), fixaram-se as bases nacionais da infortunística e "ficaram estabelecidos os fundamentos jurídicos e hipocráticos de análise da mão de obra integrada ao processo de produção e também dos acidentados no recinto industrial". Em 1934, Peixoto, Fávero, Ribeiro e João de Barros Barreto publicaram o livro "Accidentes do Trabalho", no qual é veiculada a concepção de infortúnio que será a tônica da Medicina do Trabalho e a da Higiene Industrial - a ideia "da infelicidade, da desventura, da desgraça, da falta de sorte [e] [...] de risco inerente ao trabalho" (apud MENDES, 1995, p. 15).

Como destaca Lacaz (1996), tais concepções atuariam no sentido da naturalização dos agravos à saúde no trabalho, tratados como fatalidades, aliados à propensão individual aos acidentes e ao trabalho considerado como inevitavelmente nocivo à saúde. Essas concepções também repercutiriam na justificativa do Ministério do Trabalho, Indústria e Comércio à $3^{\mathrm{a}}$ Lei de Acidentes do Trabalho (Decreto-Lei $\mathrm{n}^{\circ} 1.036$ de 1944, Reforma da Lei de Acidentes do Trabalho), elaborada por comissão de advogados da qual Fávero era participante: "Não interessa pesquisar a causa nem o responsável. 0 
acidente deve ser considerado como um risco inerente ao exercício da profissão" (MENDES, 1995 apud LACAZ, 1996, p. 16).

\subsubsection{A SAÚDE OCUPACIONAL}

Mendes (1995, p. 22-23) aponta como, a partir da década de 30, operou-se na medicina um deslocamento (ou retorno) do olhar clínico para o olhar epidemiológico. Os fatores decisivos para esse deslocamento seriam:

- Primeiramente, a entrada de pesquisadores externos à estrutura constituída pelo Estado, pela medicina do trabalho (nas empresas), e pela medicina do seguro, pesquisadores esses ligados a instituições acadêmicas e de pesquisa. Diferentemente da Primeira República (até 1930), onde a pesquisa e a produção do conhecimento teriam ocorrido principalmente no interior dos institutos de pesquisa do Estado (sobretudo nos institutos de pesquisa em saúde pública), e da República Nova (1930-1945), onde a pesquisa seria expressão de uma política corporativista e paternalista, por meio da presença ostensiva do Ministério do Trabalho, a partir de 1945 amplia-se o leque de atores, que viriam "da própria organização do capital, por exemplo, por meio do Serviço Social da Indústria (SESI) ou da Associação Brasileira para a Prevenção de Acidentes (ABPA)" ou diretamente das empresas, via serviços médicos de empresa (medicina do trabalho); e da universidade, por meio das faculdades de Direito, de Engenharia, de Medicina e de Saúde Pública.

- A segunda força seria decorrente do instrumental de abordagem: na medida em que quadros mais "dramáticos" de adoecimento iam desaparecendo, "como resultado das modificações dos processos de trabalho, substituição de tecnologias ou melhoramento das condições e dos ambientes de trabalho", outras técnicas de investigação seriam requeridas. Muitos dos danos à saúde não poderiam, segundo o autor, ser "vistos na observação clínica e individual, caso a caso", mas poderiam ser detectados em populações de trabalhadores por meio de técnicas epidemiológicas.

- O terceiro fator seria de natureza demográfica: com o aumento da expectativa de vida da população, efeitos de longo prazo, tardios, começariam a ser detectados.

- A quarta mudança diz respeito a mudanças nos critérios utilizados para definir os danos à saúde. Cada vez mais, tornar-se-ia impossível restringir às "doenças profissionais" o território dos danos à saúde produzidos pelo trabalho, pela percepção de que os impactos sobre a morbimortalidade dos trabalhadores se davam de forma "inespecífica" e intrometidos na nosologia "comum". Observa-se uma passagem da categoria das "doenças profissionais" às "doenças relacionadas com o trabalho".

Surgiu, então, o conceito de "doenças relacionadas com o trabalho", ou melhor, "outras doenças relacionadas com o trabalho", já que as ditas "doenças profissionais" 
também o seriam (MENDES, 1995). Segundo o Comitê de Especialistas da OMS (Organização Mundial de Saúde),

[...] doenças relacionadas com o trabalho [...] pode ser um termo apropriado para descrever agravos outros que, em adição às doenças profissionais legalmente reconhecidas, ocorrem em trabalhadores quando o ambiente ou as condições de trabalho contribuem significativamente para a ocorrência de doenças, porém em graus variados de magnitude (OMS apud MENDES, 1995, p. 25).

Desenvolveu-se o conceito de, entre as doenças do trabalho, lato sensu, separar as tecnopatias ou doenças profissionais das mesopatias, estas adquiridas ou desencadeadas "em função de condições especiais em que o trabalho é realizado e com ele se relacionem diretamente" (MENDES, 1995, p. 15). ${ }^{77}$ Grande parte da produção do conhecimento, sobretudo entre as décadas de 30 e 60, seria focada sobre as "mesopatias", tanto por sua frequência, em relação às "doenças profissionais", quanto por representarem a maior demanda sobre o seguro de acidentes de trabalho. ${ }^{78}$ Como enfatiza o autor, havendo a necessidade, nas "mesopatias", de terem seu "nexo causal" determinado, "é possível entender como elas tenham mobilizado [e ainda mobilizem] legistas e advogados, por muito tempo".

Em 1950, um Comitê Misto OIT-OMS elaborou a seguinte definição de Saúde Ocupacional:

A Saúde Ocupacional tem como objetivos: a promoção e manutenção do mais alto grau de bem-estar físico, mental e social dos trabalhadores em

\footnotetext{
77 As doenças ocupacionais, na legislação brasileira, eram equiparadas aos acidentes de trabalho típicos, sendo igualmente amparados, e se subdividem em (C. OLIVEIRA, 1997, p. 23):

- Doenças profissionais ou tecnopatias: um agente provoca as agressões, quaisquer que sejam as atividades desempenhadas, desde que as condições de trabalho ou o contato ensejem esta agressão, ou seja, são desencadeadas pelo exercício peculiar a determinadas atividades (como, por exemplo, as intoxicações por metais pesados, como chumbo, manganês e mercúrio). A doença desenvolvida é a mesma, tem as mesmas características e o agente é conhecido.

- Doenças do trabalho ou mesopatias: produzidas pelas condições de trabalho, pelas condições especiais em que o trabalho é realizado.

78 Ponte (2010d, p. 117) discute como as doenças degenerativas foram incorporadas, a partir dos anos 50 , às

[...] reivindicações dos trabalhadores em prol da instituição de mecanismos de seguridade social, como aposentadorias e pensões. A incorporação da atenção à saúde na agenda de negociações entre empregados e empregadores gerou arranjos que paulatinamente se configuraram como uma nova vertente da assistência médica no Brasil, desta vez associada ao complexo previdenciário que começava a se constituir.
} 
todas as ocupações; a prevenção [...], de desvios de saúde causados pelas condições de trabalho; a proteção dos trabalhadores em seus empregos, dos riscos resultantes de fatores adversos à saúde, a colocação e manutenção do trabalhador adaptadas às aptidões fisiológicas e psicológicas, em suma: a adaptação do trabalho ao homem e cada homem à sua atividade (OIT/OMS apud LACAZ, 1996, p. 31).

A partir dessa definição, Lacaz (1996) discute como os conceitos de Saúde Ocupacional e Medicina do Trabalho se associam, uma vez que quaisquer tentativas de conceituar medicina do trabalho necessariamente devem se situar com relação a essa definição de Saúde Ocupacional proposta pelo Comitê. A partir dessa definição, em 1959 surgiu a Recomendação $\mathrm{n}^{\circ} 112$ da OIT, relativa à criação dos "Servicios de Medicina del Trabajo en los lugares de empleo".

Algumas das bases conceituais que subsidiam a Saúde Ocupacional e the conferem cientificidade seriam as ideias de História Natural da Doença, oriunda da Medicina Preventiva e da Epidemiologia; de Limite de Tolerância, proveniente da Higiene Industrial e da Toxicologia; de Adaptação, originária da Ergonomia tradicional ${ }^{79}$ (LACAZ, 1996). A Medicina Preventiva ${ }^{80}$ proveria as bases sobre as quais se enuncia esse conceito de Saúde Ocupacional, uma vez que se utilizam termos como prevenção, proteção, riscos, adaptação, visando à intervenção na saúde dos trabalhadores. Como aponta o autor, "o paradigma da causalidade dos agravos à saúde dá-se pela precedência das condições de trabalho, numa visão a-histórica e descontextualizada das relações econômicas, político-ideológicas e sociais que influem nos nexos entre trabalho e saúde-doença" (LACAZ, 2007a, p. 759).

No Brasil, a adoção e o desenvolvimento da Saúde Ocupacional deram-se mais tardiamente. Apesar de algumas ações importantes, marcos, como a criação da Fundação Centro Nacional de Segurança, Higiene e Medicina do Trabalho (Fundacentro), ou a regulamentação do capítulo $V$ da Consolidação das Leis do Trabalho (CLT), ${ }^{81}$ foi mantida na legislação a essência de uma prática medicalizada,

\footnotetext{
79 Uma discussão sobre a Ergonomia Tradicional ou Escola Anglo-Saxônica é realizada na seção 4.2.3.1.2

80 Uma discussão sobre a Medicina Preventiva é realizada na seção 4.2.3.1.1.

81 Como apontam Mendes e Dias (1991, p. 344), "Sobretudo nas normas relativas à obrigatoriedade de equipes técnicas multidisciplinares nos locais de trabalho (NR 4) e na avaliação quantitativa de riscos ambientais e adoção de 'limites de tolerância' (NRs 7 e 15)". NR 7: Programa de Controle Médico de Saúde Ocupacional (PCMSO); NR 15: Atividades e Operações Insalubres (ver Anexo D: Normas Regulamentadoras de Segurança e Saúde no Trabalho do Ministério do Trabalho e Emprego).
} 
individualizada, característica do modelo da medicina do trabalho, e que, além disso, atenderia apenas a trabalhadores do mercado formal de trabalho (MENDES; DIAS, 1991). Do ponto de vista institucional, a marca mais característica da saúde ocupacional no Brasil seria, para Mendes (1995x), a criação da Fundacentro (Lei $\mathrm{n}^{\circ}$ 5.161, de 21 de outubro de 1966) e sua instalação em 1969. A Fundacentro, acrônimo mantido nas posteriores modificações do nome dessa Fundação,82 seria a busca de uma versão nacional dos modelos de "institutos de saúde ocupacional" desenvolvidos no exterior a partir da década de 50.

O modelo da Saúde Ocupacional consagrou-se, sobretudo nas grandes empresas, com a organização de equipes cada vez mais multiprofissionais, e com ênfase na Higiene Industrial. Sua estratégia seria intervir nos locais de trabalho buscando controlar os riscos ambientais, refletindo-se nessa postura a influência das escolas de saúde pública, nas quais tais questões já vinham sendo tratadas. O ensino e a pesquisa dos problemas de saúde ocupacional encontram seu apogeu na metade do século $X X$ (MENDES; DIAS, 1991). O modelo da Saúde Ocupacional contemplaria uma proposta mais interdisciplinar, buscando relacionar o ambiente de trabalho e o corpo do trabalhador, pautando-se pela teoria da multicausalidade: um conjunto de fatores de risco é analisado e avaliado na produção do agravo à saúde. Essa avaliação teria como base a clínica médica, mas também contemplaria fatores ambientais e biológicos de exposição e efeito (MINAYO-GOMEZ; THEDIM-COSTA, 1997x).

Lacaz (1996, p. 22) ressalta que as principais estratégias de intervenção se resumiriam a "adaptar/adequar o ambiente e as condições de trabalho dentro dos parâmetros preconizados para a média dos trabalhadores 'normais' em termos de suscetibilidade individual a tais agentes e fatores de risco". Os exames admissionais e periódicos realizados pelos serviços médicos das empresas desempenhariam esse papel, na medida em que selecionavam apenas os trabalhadores mais hígidos ou com maior capacidade de suportar as condições de trabalho, e excluíam aqueles que apresentavam desvio da "normalidade".

Algumas das críticas dirigidas ao modelo da Saúde Ocupacional referem-se ao fato de

\footnotetext{
82 Fundação Centro Nacional de Segurança, Higiene e Medicina do Trabalho; atual Fundação Jorge Duprat Figueiredo de Segurança e Medicina do Trabalho.
} 
que as medidas que deveriam assegurar a saúde do trabalhador, em seu sentido mais amplo, acabariam por restringir-se a intervenções pontuais sobre os riscos mais evidentes. Segundo Minayo-Gomez e Thedim-Costa (1997), a ênfase recairia sobre a utilização de equipamentos de proteção individual (EPIs), em detrimento dos que poderiam significar proteção coletiva (equipamentos de proteção coletiva ou EPCs). Atuando essencialmente sobre o indivíduo, com privilégio do diagnóstico e tratamento de problemas eminentemente orgânicos, "com uma visão empirista e positivista trazida da clínica", pouco espaço se abriria para a subjetividade e a percepção do trabalhador, tratado como paciente e objeto da ação técnica (LACAZ, 1996, p. 22).

Normatizaram-se as formas de trabalhar consideradas seguras, 83 imputando-se aos trabalhadores os ônus por acidentes e doenças, concebidos como decorrentes da ignorância e da negligência, o que, segundo Minayo-Gomez e Thedim-Costa (1997), se caracterizaria como uma penalização aos trabalhadores, e consolidou-se a tese do chamado "ato inseguro". ${ }^{84}$ Durante décadas, alicerçada na teoria de que a maioria dos acidentes de trabalho teria como causa o "ato inseguro" do acidentado, ocorreu o processo que Ribeiro (1997) chamou de culpabilização, que técnicos patronais e do governo sustentavam e difundiram, nas semanas internas de prevenção de acidentes, nos congressos promovidos pelo Ministério do Trabalho, nos cursos de segurança e medicina do trabalho e nos de formação de técnicos e "cipeiros" (integrantes das CIPAs - Comissões Internas de Prevenção de Acidentes das empresas). ${ }^{85} \mathrm{~A}$ tese do "ato inseguro" ainda hoje ecoa nos discursos de trabalhadores e profissionais de saúde, mas fazia-se necessário um olhar para as condições de trabalho, pois apenas o "ato inseguro" não explicaria a ocorrência de cerca de vinte e cinco milhões de acidentes em duas décadas. Nos anos 70, o Brasil ostentava o título de "campeão mundial" dos acidentes de trabalho (BOHADANA, 1983; PICALUGA, 1983a, 1983b; RIBEIRO, 1997).

\footnotetext{
83 O que, segundo Minayo-Gomez e Thedim-Costa (1997), conformaria apenas um quadro de prevenção simbólica.

${ }^{84}$ A respeito da discussão da "propensão ao acidente" e do "ato inseguro", conferir Andrew Szasz (Accident proneness: The career of an ideological concept - 1984) e Fábio de Oliveira (A Construção Social dos Discursos sobre o Acidente de Trabalho - 1997).

${ }^{85}$ Ver Lacaz (1996) e Ribeiro e Lacaz (1984).
} 
A abordagem da Medicina do Trabalho-Saúde Ocupacional apresentaria limites conceituais-epistemológicos que implicariam, por exemplo, na não apreensão das questões ligadas à organização/divisão do trabalho, como ritmo, duração da jornada, trabalho em turnos, divisão e conteúdo das tarefas, hierarquia, dentre outros. Sua abordagem das relações trabalho-saúde/doença privilegiaria concepções cartesianas do corpo como máquina exposta a agentes e fatores de risco, considerando as consequências do trabalho para a saúde como resultantes da interação do corpohospedeiro com tais agentes (LACAZ, 1996).

O modelo de Saúde Ocupacional foi cada vez mais problematizado, sobretudo quanto a atingir os objetivos que se propôs alcançar, em primeiro lugar, porque teria mantido o referencial da medicina do trabalho "mecanicista". A proposta de trabalho interdisciplinar, de equipes multiprofissionais, muitas vezes revelou-se uma justaposição desarticulada de atividades e especialidades, permeada por conflitos de natureza corporativista. Além disso, a produção de conhecimentos e tecnologias de intervenção, essencial à capacitação dos quadros para atuação nesse modelo, não acompanhou o ritmo das transformações nos processos de trabalho (MENDES; DIAS, 1991). Nesse contexto de questionamentos do modelo da Saúde Ocupacional, começou a constituir-se a abordagem da Saúde do Trabalhador.

\subsubsection{Abordagens / Paradigmas correlacionados}

A seguir, apresentam-se abordagens/paradigmas correlacionados à Saúde Ocupacional.

\subsection{Medicina Preventiva}

Após o término da II Guerra Mundial, consolidou-se uma tendência de mudanças de enfoque em saúde pública e medicina preventiva, iniciando-se nos países industrializados e difundindo-se para outros países nos anos subsequentes (NASCIMENTO SOBRINHO, 1995). 
A medicina preventiva elaborou uma crítica à prática médica então vigente nas suas características de especialização, tecnificação, biologismo, individualismo e inadequação dos profissionais à realidade da população. Discursivamente, operaria uma ruptura com a higiene, afirmando-se como disciplina independente, aglutinando disciplinas como epidemiologia, ciências sociais e administração sanitária (NASCIMENTO SOBRINHO, 1995).

Para Pires-Alves e Falleiros (2010), a Medicina Preventiva, originária dos Estados Unidos em meados dos anos 40 , seria uma tentativa de se fazer frente aos crescentes custos da atenção curativa e, ao mesmo tempo, à separação entre as esferas da saúde pública e da saúde individual, propondo-se a reorientar a formação médica com o objetivo de estimular uma atitude preventiva, epidemiológica, social, educativa e de equipe. A medicina preventiva teria incorporado a multiprofissionalidade ao modelo original de Medicina do Trabalho, que passou a configurar no Brasil uma área mais abrangente, a Saúde Ocupacional (FRIAS JUNIOR, 1999).

No final da década de 50, realizaram-se seminários internacionais patrocinados pela OPAS (Organização Pan-Americana de Saúde), tentativas de reprodução do movimento preventivista na América Latina, que repercutiram no Brasil (NASCIMENTO SOBRINHO, 1995). Na América Latina, a difusão dessa proposta se deu por meio da criação, em meados dos anos 50, de departamentos de medicina preventiva nas faculdades de medicina, contando com o apoio técnico e financeiro da OPAS e de fundações norteamericanas, como Kellogg, Rockfeller e Ford. Em 1968, com a reforma do ensino superior, esses departamentos se tornariam obrigatórios nos cursos de medicina (PIRES-ALVES; FALLEIROS, 2010).

Segundo Arouca (apud NASCIMENTO SOBRINHO, 1995, p. 38), “o movimento da Medicina Preventiva e Social é uma leitura liberal e civil dos problemas de saúde". Essa proposta consistiria numa prática ideológica, na medida em que implicaria um "movimento de reforma médica e numa prática discursiva que tomava como objetos, de um lado, a prática e a educação médica e, do outro, a saúde e a doença".

Pires-Alves e Falleiros (2010, p. 168) apontam críticas à proposta:

Para seus críticos, a medicina preventiva revestiu-se de sensíveis contradições: propôs-se redefinir as responsabilidades do médico mantendo 
a natureza do seu trabalho; ampliar seu espaço social, preservando a organização hospitalar e dos consultórios privados; desenvolver a preocupação social, mantendo o exercício médico como uma atividade de troca; diminuir o custo da atenção médica, mantendo, todavia, um cuidado médico excessivamente técnico; e melhorar as condições de vida das populações, preservando a estrutura social.

\subsection{Ergonomia Tradicional ou Escola Anglo-Saxônica 86}

Após a I Guerra Mundial, a ergonomia teria se desenvolvido nos países europeus, de onde se expandiu para todos os países industrializados. No período de 1940 a 1965, notadamente nos Estados Unidos, os maiores investimentos ainda estiveram voltados para a ergonomia militar (OLIVEIRA, 2002a).

Alinhada com os pressupostos do modelo da Saúde Ocupacional, consolidou-se a ergonomia tradicional ou escola anglo-saxônica, desenvolvida nos modelos das proposições de Human Factors e Human Engineering, e muito divulgada no Brasil entre médicos (fisiologistas) do trabalho e desenhistas industriais. Conhecida como human factors, essa escola "surgiu formalmente com a criação da Human Factors Society em 1957" (OLIVEIRA, 2002a, p. 92) e procurou integrar à concepção do ambiente de trabalho os chamados "fatores humanos", por meio dos conhecimentos de fisiologia e psicologia, "de modo a bem adaptar esse ambiente de trabalho ao homem", utilizando-se bastante de pesquisas em laboratório e, "a partir desses estudos, procura transferir os resultados ao posto de trabalho". Sua principal preocupação seria o estudo do chamado sistema homem/máquina.

Essa escola se caracterizaria, em geral, segundo F. LIMA (1997b, p. 313), como uma disciplina aplicada, isto é, "procura definir princípios de concepção das situações de trabalho, numa forma diretamente utilizável pelos engenheiros, que respeitem os limites psicofisiológicos do homem". Seus conhecimentos de base são, em particular, a Fisiologia e a Psicologia, a partir das quais se formulam regras práticas que orientam os projetos de postos de trabalho ergonômico, regras essas geralmente reunidas e divulgadas em manuais.

${ }^{86}$ Terminologia usada por F. Lima (1997b). Jacques (2003) vai chamar essa corrente de russa/anglosaxã. 
Sua ênfase em "riscos ergonômicos" e "condições antiergonômicas de trabalho" levaria à concepção de novos mobiliários e equipamentos que privilegiariam as condições físicas de trabalho. Um de seus críticos, Ferreira (apud F. LIMA, 1997b) aponta sua perspectiva reducionista da situação de trabalho, chamando-a de "ergonomia das cadeiras". A escola anglo-saxônica seria definida numa dupla relação de exterioridade:

1) O trabalho (ou "o homem que trabalha e enquanto trabalha") não constituiria objeto de conhecimento; os conhecimentos e regras aplicadas, oriundas de outras disciplinas, teriam um caráter normativo.

2) O saber produzido "constitui-se em propriedade de um especialista que prescinde da participação [...] dos próprios trabalhadores" para realizar suas análises e propor soluções, o que se refletiria numa intervenção e observação que tomaria o trabalhador como objeto, não recorrendo à sua experiência ou vivência. A aplicação dos resultados, por sua vez, seria caracterizada como pontual e definitiva, na medida em que se limitaria a prescrever instruções aos trabalhadores ("de como devem se sentar, regular as cadeiras, fazer pausas ou ginásticas") (F.LIMA, 1997b, p. 313).

\subsubsection{A SAÚDE DO TRABALHADOR}

Lacaz (1996) caracteriza a Saúde do Trabalhador como uma prática teórica (geração de conhecimento) e como prática política e ideológica (visando superar relações de poder e a conscientização dos trabalhadores). Como indica o autor (2007a), esse campo de práticas e conhecimentos se contrapõe aos conhecimentos e práticas da Medicina do Trabalho-Saúde Ocupacional, objetivando superá-los.

Esse campo se constitui "a partir de conceitos originários de um feixe de discursos dispersos formulados pela Medicina Social Latino-Americana, relativos à determinação social do processo saúde-doença; pela Saúde Pública, em sua vertente programática e pela Saúde Coletiva ao abordar o sofrer, adoecer, morrer das classes e grupos sociais inseridos em processos produtivos" (LACAZ, 2007a).

A Saúde do Trabalhador como objeto de estudo e seu desenvolvimento posterior associam-se fortemente à maturação do processo de industrialização e ao modo particular que esse processo assume na América Latina, como: sua rapidez; a grande variedade/heterogeneidade de processos de trabalho (sob a égide da nova divisão internacional do trabalho), que implicariam um perfil diferenciado de 
morbimortalidade ("duplo padrão" de riscos no trabalho);87 os efêmeros "milagres econômicos" vividos por Argentina, Brasil, Chile, México; as profundas mudanças da estrutura de classes, como a "morte do campesinato" e o surgimento de uma classe operária industrial jovem (LACAZ, 1996).

A partir dos anos 70, iniciaram-se estudos e pesquisas em morbimortalidade, programação em serviços de saúde e questões teórico-metodológicas que passaram a incluir o aporte das ciências sociais (LACAZ, 1996). O campo de conhecimento denominado Saúde do Trabalhador, como outros em Saúde Coletiva, requereria, segundo Minayo-Gomez e Thedim-Costa (2003, p. 134), a mediação explícita ou implícita do corpo conceitual das ciências sociais e humanas. Esse aporte, segundo os autores, retiraria o "caráter eminentemente higienista conferido à relação trabalhosaúde", a partir do momento em que o trabalho seria "concebido como uma categoria social [...] resultado de um emaranhado de relações econômicas, sociais, políticas e tecnológicas que se realizam de forma conflituosa e interdependente".

A emergência da Saúde do Trabalhador no Brasil teria início sobretudo a partir da década de 80, no contexto da transição democrática, e em sintonia com transformações do mundo ocidental (MENDES, 1995):

- Denúncia de políticas públicas e do sistema de saúde, avaliados como incapazes de dar respostas às necessidades de saúde da população, e dos trabalhadores, em especial.

- Surgimento de novas práticas sindicais em saúde, traduzidas em reivindicações de melhores condições de trabalho, por meio das CIPAs, na esteira da emergência do Novo Sindicalismo.

Para Lacaz (2007a, p. 758), a configuração do campo da Saúde do Trabalhador se constituiria por três "vetores": a produção acadêmica, a programação em saúde na rede pública e o movimento dos trabalhadores, sobretudo nos anos 80 , quando seu discurso assumiria "caráter mais propositivo junto ao Estado". A construção do campo da Saúde do Trabalhador surge também como uma reivindicação do movimento sindical e dos técnicos de saúde ligados à reforma sanitária, expressando uma

\footnotetext{
87 Riscos "antigos" e "novos".
} 
profunda discordância com o modelo da prática da Medicina do Trabalho - Saúde Ocupacional (NARDI, 2002).

$\mathrm{Na}$ implementação desse modo de lidar com as questões de saúde relacionadas ao trabalho, teria sido decisivo o papel desempenhado pelas assessorias técnicas sindicais, como o DIESAT, "estudando os ambientes e condições de trabalho, levantando riscos e constatando danos para a saúde; decodificando o saber acumulado, num processo contínuo de socialização da informação; resgatando e sistematizando o saber operário, vivenciando, na essência, a relação educadoreducando" (MENDES, 1995, p. 26).

As universidades também teriam contribuído no campo das ideias, por meio de uma prática teórica enfocada para questões relativas ao processo saúde e doença em sua relação com o trabalho, e na pesquisa (MENDES, 1995, p. 26). Iniciou-se um movimento de estudos e pesquisas da temática nos Departamentos de Medicina Preventiva e Social, fortemente influenciados pelos referenciais da Medicina Social Latino-Americana, aliando a abordagem da determinação social do processo saúde/doença às contribuições das ciências sociais. Com o surgimento de grupos identificados com o movimento pela Reforma Sanitária, começaram a ser formados em cursos de Residência Médica em Medicina Preventiva e/ou Social médicos sanitaristas com formação em área de concentração em Saúde Ocupacional-Medicina do Trabalho (LACAZ, 1996). No referencial maior da universidade, da escola médica e dos hospitais universitários, também teriam se destacado os ambulatórios especializados no atendimento da patologia do trabalho, como o Ambulatório de Medicina do Trabalho da UNICAMP (funcionando desde 1978) e o Ambulatório de Doenças Profissionais do Hospital das Clínicas da UFMG88 (inaugurado em 1984), apoiado pela Fundacentro e em convênio com o INPS/INAMPS (MENDES, 1995).

Também os técnicos de instituições públicas, como as universidades e institutos de pesquisa, a rede de serviços de saúde e de fiscalização do trabalho, teriam contribuído

\footnotetext{
88 A esse Ambulatório são ligadas Elizabeth Costa Dias, Andrea Maria Silveira e Jandira da Silva Maciel (entrevistadas para esta tese). Para um aprofundamento da atuação e história do Ambulatório de Doenças Profissionais do Hospital das Clínicas da UFMG, atualmente chamado Serviço Especial de Saúde dos Trabalhadores, conferir Silveira et al. (2013).
} 
para o desenvolvimento da área de Saúde do Trabalhador, por meio da capacitação profissional, da produção de conhecimento, da prestação de serviços e da fiscalização das exigências legais (MENDES, 1995). Na rede pública de serviços de saúde, Dias (1995, apud LACAZ, 1996) destaca que, apesar de o sistema de saúde vir atendendo trabalhadores ao longo de sua existência, a atenção à saúde dos trabalhadores como prática diferenciada emergiria nos anos 80 , no contexto do processo de reorganização política e social do país, vinculada particularmente à Reforma Sanitária Italiana. Concretizadas nos Programas de Saúde do Trabalhador (PST) na rede pública de serviços de saúde, essas experiências se consolidaram no texto constitucional de 1988 e se regulamentaram pela Lei Orgânica da Saúde (Lei nº 8.080) de 1990.

Os organismos internacionais também influenciaram a gênese da Saúde do Trabalhador: a OPAS, lançando em 1984 o documento "Programa de Acción en la Salud de los Trabajadores" (Programas de Ação em Saúde dos Trabalhadores), e o Comitê misto OIT-OMS, lançando em 1985 a Convenção 161 e a recomendação 171 sobre Serviços de Saúde no Trabalho (FRIAS JR, 1999; SATO; LACAZ; BERNARDO, 2006). O documento da OPAS traz diretrizes para a implantação de programações em saúde na rede pública de serviços sanitários e embasou a diretriz adotada pela OIT, que pressupõe "ampla participação dos trabalhadores, a atuação em equipes multiprofissionais e a sua implementação principalmente a partir de políticas públicas" (OIT, 1985 apud LACAZ, 1997, p. 9).

Segundo Mendes (1995, p. 25), uma "heterogênea combinação de filósofos, cientistas sociais, políticos, planejadores, engenheiros, profissionais de saúde e outros, junto com os trabalhadores e suas organizações" estaria engajada na transformação progressiva da organização do trabalho e das respectivas tecnologias e meio ambiente de trabalho.

Para Deusdedit Junior (2014, p. 97), a especificidade do campo da Saúde do Trabalhador se daria em duas direções: 1) a consideração do lugar ocupado pelo trabalho na compreensão dos fenômenos humanos, incluído aí o processo saúde/doença, direção que conferiria os fundamentos teórico-filosóficos ao campo; 2) o reconhecimento de que certos agravos à saúde têm relação direta (e/ou indireta) com o trabalho, considerando as "especificidades desses agravos (causas, evolução, 
tratamento, prevenção etc.), o que justificaria, portanto, um campo específico de estudos". Pensar em Saúde do Trabalhador implicaria, então

[...] pensar sobre as diversidades epidemiológicas dos agravos à saúde dos trabalhadores, que variam desde as doenças provocadas pela introdução das novas tecnologias e pela organização do trabalho, passando pelas "contaminações" por cancerígenos, solventes [...] e metais pesados; pela surdez de milhares de operários dos mais diversos ramos da produção; pela silicose [...], pelo gravíssimo problema das intoxicações por agrotóxicos [...] e acidentes com máquinas agrícolas nas atividades rurais, até chegar aos efeitos para a saúde do trabalho escravo de menores e mulheres (LACAZ, 1997, p. 8, grifos do autor).

A Saúde do Trabalhador teria como características básicas (MENDES, 1995):

- A busca da compreensão das relações (do nexo) entre o trabalho e a saúde-doença dos trabalhadores, que por sua vez se refletiria sobre a atenção à saúde prestada.

- A possibilidade/necessidade de mudança dos processos de trabalho - das condições e dos ambientes de trabalho - em direção à "humanização do trabalho".

- O exercício de uma abordagem multidisciplinar e intersetorial das ações que buscaria a superação "da compreensão e intervenções estanques e fragmentadas sobre a questão".

- A participação dos trabalhadores, percebidos como capazes de contribuir com seu conhecimento para o avanço da compreensão do impacto do trabalho sobre o processo saúde-doença e para intervenções políticas.

O modelo da Saúde do Trabalhador apareceria em práticas diferenciadas em diferentes momentos e regiões, mantendo, contudo, alguns princípios: busca do reconhecimento dos saberes dos trabalhadores, questionamento das alterações nos processos de trabalho (sobretudo a adoção de novas tecnologias), exercício do direito à informação e à recusa ao trabalho perigoso ou arriscado à saúde (MENDES, 1995).

Por Saúde do Trabalhador, Nardi (2002, p. 283) define um "conjunto de conhecimentos oriundos de diversas disciplinas, tais como: medicina social, saúde pública, saúde coletiva, clínica médica, medicina do trabalho, sociologia, epidemiologia social, 89 engenharia, psicologia, entre outras tantas". O termo Saúde do Trabalhador surgiria no Brasil no bojo do movimento pela Reforma Sanitária no Brasil, sobretudo a partir da década de 1980 , tendo a Reforma Sanitária Italiana ${ }^{90}$ como um exemplo

\footnotetext{
89 Uma discussão sobre a Epidemiologia Social é realizada na seção 4.2.4.1.3.

90 Conforme Mattos e Freitas (1994 apud DEUSDEDIT JUNIOR, 2014, p. 101),
} 
inspirador. A união dos esforços de técnicos de saúde ligados às universidades, ao Ministério da Saúde e às Secretarias de Saúde municipais e estaduais, juntamente com os trabalhadores, dentro da emergência do Novo Sindicalismo (ROUQUIÉ, 1991), teriam estabelecido as bases do movimento (NARDI, 2002).

Para Nardi (2002, p. 284), trata-se da

[...] construção de um saber e de uma prática interdisciplinares que se diferenciam de uma ação centrada no conhecimento médico ou nos saberes divididos em compartimentos (engenharias, psicologia, medicina, enfermagem, serviço social etc.), na forma de uma equipe de técnicos das várias profissões.

O objeto da Saúde do Trabalhador se definiria como o processo saúde e doença, em sua relação com o trabalho (MENDES; DIAS, 1991, p. 345) que, por sua vez, seria entendido como um "espaço de dominação e submissão do trabalhador pelo Capital, mas, igualmente, de resistência, de constituição e do fazer histórico dos trabalhadores". ${ }^{91}$ A categoria trabalho surgiu como momento de condensação dos espaços individual (corporal) e social, reformulando-se as relações entre o social e manifestações patológicas. Ao criticar o modelo médico vigente, buscava-se a compreensão de que

A Reforma Sanitária Italiana, criada pela Lei 833 de 23/09/78, que instituiu o Serviço Sanitário Nacional na Itália, foi fortemente influenciada pelas contribuições de Oddone, quando propôs o "Modelo Operário Italiano". Esse Modelo "tinha como premissas a formação de grupos homogêneos, a experiência ou subjetividade operária, a validação consensual e a não delegação, possibilitando assim a participação dos trabalhadores nas ações de planejamento e controle da saúde nos locais de trabalho, não delegando tais funções aos técnicos e valorizando a experiência e o conhecimento operário existente.

Uma discussão sobre Modelo Operário Italiano é realizada na seção 4.2.4.1.6

91 Minayo-Gomez e Thedim-Costa (1997, p. 27) prosseguem, em sua análise contextual das práticas de Saúde do Trabalhador:

$\mathrm{Na}$ interseção das relações e técnicas que o configuram, se expressa o conflito de interesses entre o trabalho e o capital, que, além de ter sua origem na propriedade dos meios de produção e na apropriação do valorproduto realizado, consuma-se historicamente através de formas diversas de controle sobre o próprio processo de produção. Esse controle exercido no interior das unidades produtivas, por meio de velhos ou novos padrões de gestão da força de trabalho, respectivamente, taylorismo, fordismo e neotaylorismo, pós-fordismo, toyotismo, redunda na constituição de coletivos diferenciados de trabalhadores e de uma multiplicidade de agravos potenciais à saúde. 
[...] a medicina não apenas cria e recria condições materiais necessárias à produção econômica, mas participa ainda da determinação do valor histórico da força de trabalho e situa-se, portanto, para além dos seus objetivos tecnicamente definidos (DONNANGELO, 1979 apud MINAYOGOMEZ; THEDIM-COSTA, 1997, p. 25).

A saúde do trabalhador é assim definida por Minayo-Gomez e Thedim-Costa (1997, p. 25):

\begin{abstract}
Em síntese, por Saúde do Trabalhador compreende-se um corpo de práticas teóricas interdisciplinares - técnicas, sociais, humanas - e interinstitucionais, desenvolvidas por diversos atores situados em lugares sociais distintos e informados por uma perspectiva comum. Esta perspectiva é resultante de todo um patrimônio acumulado no âmbito da Saúde Coletiva, com raízes no movimento da Medicina Social Latino-Americana e influenciado pela experiência italiana. $O$ avanço científico da Medicina Preventiva, da Medicina Social e da Saúde Pública, durante os anos 60 e o início da década de 70, ao suscitar o questionamento das abordagens funcionalistas, ampliou o quadro interpretativo do processo saúde-doença, inclusive em sua articulação com o trabalho.
\end{abstract}

Minayo-Gomez e Thedim-Costa (1997) definem o campo da saúde do trabalhador como uma "zona de empatia", para a qual confluiriam estudos disciplinares diversos, abrigando diferentes aproximações e uma grande variedade de estudos e práticas, "mesmo na ausência de uma adequada precisão conceitual sobre o caráter da associação entre saúde e trabalho e o processo saúde-doença". A área da saúde do trabalhador teria, no Brasil, uma conotação própria, "reflexo da trajetória que lhe deu origem e vem constituindo seu marco referencial, seu corpo conceitual e metodológico" (MINAYO-GOMEZ; THEDIM-COSTA, 1997, p. 22). Ainda segundo esses autores, a área "a princípio é uma meta, uma vontade que entrelaça trabalhadores, profissionais de serviços, técnicos e pesquisadores, por premissas nem sempre explicitadas". Seu pilar fundamental seria um compromisso com a mudança do quadro de saúde da população, propondo também ações políticas, jurídicas e técnicas. Essa compreensão teria surgido num contexto caracterizado pela confluência de movimentos sociais e políticos, de novas estratégias de ação influenciadas/influenciando a produção intelectual.

Essa prática teria, no Brasil, uma natureza "anti-hegemônica" (RIBEIRO, 1997), por fundamentar-se na participação dos trabalhadores nas estratégias de melhoria e transformação dos processos de trabalho. As possibilidades de êxito das ações são relacionadas à incorporação dos trabalhadores como coparticipantes nas decisões 
relativas a seu trabalho e sua saúde, e exercendo controle social sobre as medidas que Ihes são destinadas.

Deusdedit Junior (2014) caracteriza a história da Saúde do Trabalhador no Brasil em dois grandes momentos, um primeiro, marcado por intensa participação dos movimentos dos trabalhadores e "omissão do Estado", e um segundo, "em que se nota uma maior presença do poder público no estabelecimento de políticas voltadas aos trabalhadores":

- O primeiro período marcou-se por uma "efervescência dos movimentos sindicais"; o Estado "ainda insiste na omissão ou permissão das práticas ineficazes de transformação dos espaços de trabalho" (DEUSDEDIT JUNIOR, 2014, p. 99), no qual "apenas o esforço isolado de profissionais que se articulam em programas de saúde do trabalhador, centros de referência e atividades de vigilância realmente efetivas abre um rastro de luz nesse universo sombrio", e mesmo sua atuação é marcada pela descontinuidade (MINAYO-GOMEZ; THEDIM-COSTA, 1997, p. 23-24). Alguns avanços são observados na configuração da participação do Estado na implementação de políticas públicas voltadas para a saúde dos trabalhadores, embora de forma fragmentada e descontinuada (DEUSDEDIT JR., 2014, p. 99).

- O segundo período traz uma participação mais explícita do Estado, a partir do final dos anos 80, a partir da inserção do conceito de saúde na Constituição Federal de 1988 e na Lei Orgânica de Saúde (Lei n 8.080) de 1990 (MENDES, 1995; MENDES, 2002; NARDI, 2003)

No Brasil, marcos fundamentais referentes a tais mudanças teriam sido a realização da VIII Conferência Nacional de Saúde e da I Conferência Nacional de Saúde dos Trabalhadores (1986), tidas como momentos culminantes de mobilização popular, e a afirmação do modelo da Saúde do Trabalhador no campo institucional, por meio da IX Conferência Nacional de Saúde e da II Conferência Nacional de Saúde do Trabalhador (1994). A consolidação deste modelo nos termos legais teria ocorrido com a inserção do conceito de saúde na Constituição Federal de 1988 e na Lei Orgânica de Saúde (Lei $\mathrm{n}^{\circ}$ 8.080) de 1990 (MENDES, 1995; MENDES, 2002; NARDI, 2003). A saúde passaria a ser percebida não mais apenas por sua ausência, mas como

[...] resultante das condições de alimentação, educação, salário, meio ambiente, trabalho, transporte, emprego, lazer e liberdade, acesso à propriedade privada da terra e acessos aos serviços de Saúde (BRASIL, 1988, grifo nosso).

Em seus marcos legais, a denominação Saúde do Trabalhador surge incorporada na Lei Orgânica de Saúde (1990), que estabelece sua conceituação e define as competências 
do Sistema Único de Saúde neste campo. No artigo VI desta lei, encontra-se a seguinte definição de "Serviços de Saúde do Trabalhador":

[...] conjunto de atividades que se destina, através de ações de vigilância epidemiológica e vigilância sanitária, à promoção e proteção da saúde dos trabalhadores, assim como visa à recuperação e reabilitação da saúde dos trabalhadores submetidos aos riscos e agravos advindos das condições de trabalho (BRASIL, 1988).

Uma importante marca simbólica seria a modificação da denominação dos serviços de atenção à saúde de "Serviços Especializados em Medicina do Trabalho" e/ou "Saúde Ocupacional" para serem chamados de "Serviços de Saúde do Trabalhador", como é o caso dos PSTs (Programa de Saúde do Trabalhador), de São Paulo; CERSAT (Centro de Referência em Saúde do Trabalhador), de Belo Horizonte; do CESAT (Centro de Saúde do Trabalhador), de Salvador; do CRST (Centro de Referência em Saúde do Trabalhador), de São Paulo, dentre outros (NARDI, 2002).

Uma das práticas que mais se destacam em Saúde do Trabalhador é a da vigilância em saúde. Segundo Mendes (1995, p. 26), a vigilância não é

[...] uma mera ação de produção de informação, mas, fundamentalmente, é a intervenção sobre determinantes e condicionantes de problemas de enfrentamento contínuo que incorpora, ainda, ações de caráter individual. Esses problemas são escolhidos pelo alto impacto que têm nas condições de existência de grupos populacionais em microáreas específicas e pela possibilidade de intervir sobre eles.

A vigilância em Saúde do Trabalhador, no âmbito da saúde pública, é concebida por Minayo-Gomez e Thedim-Costa (2003, p. 134) como uma prática articulada de ações voltadas para o controle de atividades, riscos e agravos, tendo por referência a relação entre processo de trabalho e saúde, englobando diversos níveis de intervenção (empresas, ramos de atividade, territórios) e diferentes órgãos do poder público e instituição da sociedade civil.

Em Saúde do Trabalhador, segundo Sato (1996, p. 491), busca-se o diagnóstico das condições de trabalho e saúde, no sentido de eleger prioridades para eliminação de determinantes e condicionantes de problemas de saúde, a partir do conhecimento dos trabalhadores. A noção de vigilância teria pelo menos duas posições:

- Por meio do conceito de vigilância à saúde, buscar-se-ia ampliar as responsabilidades dos serviços de saúde, incluindo não apenas o atendimento aos 
danos e controle de determinados riscos, mas também o controle das condições de vida e determinantes ambientais do processo saúde-doença.

- Outra, que buscaria preservar certas características específicas dos sistemas de vigilância epidemiológica, mesmo assumindo a necessidade de ampliação de seu raio de ação.

Ainda segundo Sato (1996), seria buscando romper essa dicotomia e a dispersão das ações em saúde que a primeira posição teria se voltado para a noção de vigilância, consoante com a proposta por Mendes et al. (1993 apud SATO, 1996, p. 490) de uma prática interdisciplinar informada pelo modelo epidemiológico, "que articula, sob a forma de operações, um conjunto de processos de trabalho relativos a situações de saúde a preservar, riscos, danos e sequelas, incidentes sobre indivíduos, famílias, ambientes coletivos...".

O recorte privilegiado em Saúde do Trabalhador é o de uma ação em saúde motivada pelo conhecimento dos trabalhadores. Por meio do conceito de problema, buscar-se-ia o conhecimento dos trabalhadores sobre a relação saúde-trabalho, conhecimento considerado legítimo para acionar ações de vigilância, e não apenas uma "requisição carregada de valores político-ideológicos pois, na definição de problema, na definição de prioridades e de estratégias para atuar sobre seus determinantes e condicionantes, todos os atores sociais devem participar" (SATO, 1996, p. 491).

Outro aspecto relevante é a análise das relações entre o conhecimento do trabalhador e as explicações e valores correntes da sociedade. Lidar com o conhecimento do trabalhador requereria atenção ao contexto no qual este se construiu, e à realidade à qual pretende atribuir significado.

Apesar de estar definida e normatizada em textos legais, seguindo os princípios da universalidade, equidade e integralidade, bem como o controle social das políticas e dos serviços de atenção à saúde dentro do Sistema Único de Saúde (SUS), a implantação do modelo proposto para a Saúde do Trabalhador ainda enfrentaria a resistência dos setores hegemônicos da Medicina do Trabalho e da Saúde Ocupacional (NARDI, 2002). Estes segmentos estariam enraizados nos serviços médicos das empresas e nas associações profissionais (VASCONCELLOS apud NARDI, 2002). 
As principais críticas advindas dos setores tradicionais da Medicina do Trabalho, da Saúde Ocupacional e da Engenharia de Segurança em relação à Saúde do Trabalhador seriam referentes ao excesso de influência das ciências sociais, e a um envolvimento ideológico à esquerda de seus defensores, por representarem uma proposta estatizante e socializante para a prática da medicina (NARDI, 2002).

\subsubsection{Abordagens / Paradigmas correlacionados}

A seguir, apresentam-se abordagens/paradigmas correlacionados à Saúde do Trabalhador.

\subsection{Medicina Comunitária}

Na década de 60, eclodiram movimentos de direitos civis e conflitos sociais, voltandose prioritariamente às populações dos guetos, ensejando práticas como a da Medicina Comunitária (oriunda dos EUA), que se difundiu, na década de 70, para a América Latina com o apoio da OMS e da Organização Pan-Americana de Saúde (OPAS). Implantando-se nas cidades, dirigiu-se para as chamadas "populações marginais urbanas" (BOHADANA, 1983).

A Medicina Comunitária caracterizou-se pela implantação de programas de extensão da cobertura dos serviços de saúde, destacando-se os que mobilizaram amplamente agentes da comunidade para a atenção aos cuidados básicos de saúde, como na China socialista. Nos EUA, a Medicina Comunitária surgiu nos anos 60, no contexto de tensões aguçadas pelo crescente desemprego e subemprego, e de emergência de movimentos de direitos civis e inclusão social, fazendo parte das políticas desenvolvidas para dar resposta a essas tensões, por meio de programas assistenciais destinados à contenção da pobreza. Os programas de medicina comunitária tinham como alvo e objetivo prestação de serviços à coletividade, sobretudo (em seu início) às populações rurais, posteriormente às populações dos guetos, mobilizando recursos e mão de obra locais e estimulando a participação dos usuários no controle e na gestão dos serviços. No contexto internacional, esse movimento culminou em $1977 \mathrm{com}$ as 
metas de Saúde para Todos no Ano 2000, estabelecidas pela OMS, e na definição em 1978 (Conferência Internacional de Alma-Ata) da Atenção Primária à Saúde como principal estratégia para alcançar esse objetivo (PIRES-ALVES; FALLEIROS, 2010).

A Medicina Comunitária se apresentaria também sob outras denominações, como cuidados primários de saúde, atenção primária, medicina rural e outras. Esse modelo buscou incorporar temáticas oriundas da economia e da sociologia, como produtividade, diminuição dos custos, extensão de coberturas e participação comunitária (NASCIMENTO SOBRINHO, 1995).

\subsection{Medicina Social Latino-Americana}

Como aponta Lacaz (1996), uma nova abordagem das relações trabalho-saúde/doença emergiu a partir das contribuições da Medicina Social Latino-Americana, que discutiu o processo de trabalho (como processo de produção de bens e serviços e de valor) a partir da concepção marxista que o coloca como categoria central para se compreender a relação trabalho e processo saúde-doença (CFP, 2008, p. 16). Essa discussão foi fortemente embasada por contribuições das Ciências Sociais, no campo da chamada Saúde Coletiva, “onde aparece ora como 'área temática', ora como espaço estruturado de práticas teóricas e programáticas" (LACAZ, 1996, p. 23).

Para Lacaz (2007a, p. 759), ao buscar compreender o processo saúde-doença,

[...] a Medicina Social Latino-Americana apreende-o através do processo de trabalho, categoria explicativa que se inscreve nas relações sociais de produção estabelecidas entre capital e trabalho. E, conforme a acepção marxista, aqui o trabalho é, ontologicamente, a ação do homem sobre a natureza para modificá-la e transformá-la e a si mesmo não sendo, portanto, externa ao homem. Tal ação vai ocorrer sobre o objeto de trabalho, mediante os instrumentos de trabalho, configurando o próprio trabalho e suas diferentes formas de organização, divisão, valorização, características de cada formação social e modo de produção, o que imprime um caráter histórico ao estudo das relações trabalho-saúde e, consequentemente, do adoecimento pelo trabalho.

Essa abordagem permitiria constituir uma visão do trabalho para além do ambiente e seus agentes e da saúde como uma adaptação, situando-a em uma perspectiva em que biológico e psíquico constituiriam um nexo indissociável, e cujo desequilíbrio se expressaria em distúrbios, classificados como doenças, acidentes ou mal-estares e 
incômodos, ou mesmo a não expressão de capacidades, que se somariam às doenças ocupacionais clássicas e acidentes do trabalho (LACAZ, 1996).

Outra diferença introduzida pela Medicina Social Latino-Americana seria a visão dos trabalhadores como sujeitos sociais e políticos, agentes de mudanças, com capacidade para transformar e interferir em sua realidade de trabalho, e saberes e vivências acumulados que possibilitariam a construção de metodologias de intervenção sobre essa realidade (LACAZ, 1996).

\subsection{Epidemiologia Social}

Um modelo profundamente inspirador da abordagem da Saúde do Trabalhador foi o da Epidemiologia Social, sobretudo a partir das formulações de Laurell e Noriega (1989). A análise proposta pela Epidemiologia Social é a da avaliação dos impactos dos ambientes de trabalho e das formas de organização e gestão do trabalho na vida dos trabalhadores, a partir da determinação histórica e social dos processos de saúde e doença (NARDI, 2002).

Laurell e Noriega consideram o processo saúde-doença não apenas como um processo biopsíquico mas também como um processo social, considerado na sua relação com o contexto histórico específico em que se dão as relações humanas (DEUSDEDIT JUNIOR, 2014). Assim,

[...] a exploração do nexo biopsíquico humano historicamente específico requer necessariamente a construção de um novo objeto de conhecimento, dado que este nexo não é passível de ser pensado nem estudado da perspectiva do objeto "saúde-doença", estabelecido pela medicina dominante, e menos ainda da perspectiva do objeto "doença" (LAURELL; NORIEGA, 1989, p. 111).

No intuito de se distanciarem do conceito de risco, ${ }^{92}$ que consideravam insuficiente para a apreensão global da lógica do processo de trabalho, já que se baseava em um esquema monocausal e dizia respeito aos "elementos isolados entre si e isolados da

92 Para Breilh (1994, p. 98), o conceito de risco se define como a contingência, proximidade ou probabilidade de um dano, e dificilmente poderia dar conta do caráter contraditório do trabalho, que não seria nem absolutamente destrutivo, nem absolutamente benéfico; esse conceito estaria associado a uma noção restritiva e estática dos elementos nocivos do trabalho. 
dinâmica global do processo de trabalho (DEUSDEDIT JR., 2014), Laurell e Noriega (1989) utilizaram-se da categoria cargas de trabalho (física, química, mecânica, fisiológica) que interagem dinamicamente entre si e com o corpo do trabalhador.

Segundo Wisner (1987, s/p),

Todas as atividades, inclusive o trabalho, têm pelo menos três aspectos: físico, cognitivo e psíquico. Cada um deles pode determinar uma sobrecarga. Eles estão inter-relacionados e é bastante frequente, embora isso não seja necessário, que uma forte sobrecarga de um dos aspectos seja acompanhada de uma carga bastante alta nos dois outros domínios.

Posteriormente, Noriega (1993 apud BRANDÃO JUNIOR, 2000) passou a atribuir às exigências, ou requerimentos decorrentes da organização do trabalho e das atividades do trabalhador, importante papel na conformação dos perfis de saúde-doença dos coletivos de trabalhadores, distinguindo-as dos riscos relacionados aos objetos e meios de trabalho. Noriega buscou desvelar na organização real do trabalho as estratégias adaptativas intersubjetivas, de defesa/oposição, que seriam latentes na tensão entre a procura de prazer/reconhecimento dos sujeitos e os constrangimentos externos impostos, independentemente de suas vontades, pelas situações de trabalho (MINAYO-GOMEZ; THEDIM-COSTA, 1997).

Os conceitos de carga de trabalho e desgaste são propostos para analisar as mediações entre o processo de trabalho e o processo saúde-doença coletivo. As cargas de trabalho se definem

[...] como los elementos del proceso laboral que interactúan dinámicamente entre sí y con el cuerpo del trabajador produciendo aquellos cambios en los procesos biopsíquicos que se manifiestan como desgaste, entendido éste como pérdida de capacidades biopsíquicas, potenciales o efectivas. Este concepto permite, entonces, hacer una lectura específica de los elementos del proceso laboral que se relacionan directamente con la salud-enfermedad colectiva (LAURELL, 1993, p. 21). 93

A especificidade do conceito carga permitiria distinguir os elementos do processo de trabalho que poderiam transformar os processos corporais e psíquicos e analisar como interatuam e modulam entre si. As cargas se agrupariam como as que teriam

93 [...] como os elementos do processo de trabalho que interatuam dinamicamente entre si e com o corpo do trabalhador, produzindo mudanças nos processos biopsíquicos que se manifestam como desgaste, entendido como perda de capacidades biopsíquicas, potenciais ou efetivas. Esse conceito permite, então, fazer uma leitura específica dos elementos do processo de trabalho que se relacionam diretamente com a saúde-doença coletiva [tradução nossa]. 
materialidade externa ao corpo (físicas, químicas, biológicas, mecânicas) e as que adquiririam materialidade, apenas, por meio do corpo humano, ao transformar seus processos (cargas fisiológicas e psíquicas) (LAURELL, 1993). O conceito de desgaste complementaria o de carga, ao consignar as transformações negativas, originadas na interação dinâmica das cargas, nos processos biopsíquicos humanos, se definindo como a perda da capacidade, potencial e/ou efetiva, corporal e psíquica (LAURELL, 1991, p. 260). As cargas de trabalho representariam um modo específico de vivenciar o trabalho, não podendo ser confundidas com o objeto dele ou com o esforço físico: seriam a expressão da vivência do trabalhador com relação ao contexto de trabalho, sendo dada sua dimensão pelo próprio trabalhador (LEMOS, 2005). Contudo, é importante apontar que o conceito suscita diversos questionamentos teóricos, como o de Breilh, aqui reproduzido:

[...] de todos los procesos epidemiológicos vinculados al trabajo, tal vez los únicos a los que corresponde el término carga es al trabajo muscular: cargas estáticas y dinámicas de los músculos o a cualquier circunstancia que implique una tensión funcional. [...] aplicar exclusivamente carga a lo mental, empobrece tremendamente la idea de proceso de deterioro. Podría usárselo para dar cuenta de los problemas de tensión neurofisiológica por sobre estimulación o subestimulación, pero no agota el conjunto de procesos del sufrimiento-protección mental que implica el trabajo en distintos contextos (BREILH, 1994, p. 99). ${ }^{94}$

Outra questão, discutida por Deusdedit Junior (2014, p. 81) se refere ao processo de singularização da doença: a abordagem não permitiria avançar na discussão de por que, submetidos às mesmas condições e organização do trabalho, alguns trabalhadores adoeçam, e outros, não.

\subsection{Saúde Coletiva}

A expressão Saúde Coletiva é considerada por L’Abbate (2003, p. 266) “uma invenção tipicamente brasileira", surgida no final da década de 70, na perspectiva de constituir

94 De todos os processos epidemiológicos vinculados ao trabalho, talvez os únicos aos quais corresponda o termo carga seja o trabalho muscular: cargas estáticas e dinâmicas dos músculos ou qualquer circunstância que implique uma tensão funcional. [...] aplicar exclusivamente carga ao mental empobrece enormemente a ideia de processo de desgaste. Poder-se-ia usá-lo para dar conta dos problemas de tensão neurofisiológica por super ou subestimulação, mas não esgota o conjunto de processos de sofrimento-proteção mental que implica o trabalho em distintos contextos [tradução nossa]. 
um paradigma que permitisse uma articulação entre as diferentes instituições do campo da saúde. Compreenderia um conjunto complexo de saberes e práticas envolvendo desde organizações que prestam assistência médica à população até instituições de ensino e pesquisa, compreendendo práticas técnicas, científicas, culturais, ideológicas, políticas e econômicas.

As transformações da sociedade brasileira na década de 70, o esgotamento das possibilidades do chamado "milagre econômico" e a descensão do regime militar que sustentava esse modelo produziram, de um lado, uma forte crise econômica, que acentuou a dependência do país a mercados externos e a desigualdade na distribuição de renda da população e, de outro, contribuíram para o processo de redemocratização que resultaria, nos anos 80 , no retorno das eleições diretas e na criação de novos partidos (L'ABBATE, 2003).

Profissionais da Saúde Pública e da Medicina Preventiva, que, segundo L'Abbate (2003), sempre tiveram significativa presença na cena política brasileira (por meio de organizações de caráter científico e/ou sindical), passaram a defender o Sistema Único de Saúde (SUS). O chamado "movimento sanitário" teve papel destacado na resistência ao regime militar brasileiro, característico da alta politização da questão da saúde no país.

Em associação com os movimentos de afirmação da saúde como direito social e expansão da cobertura dos sistemas de saúde, desenvolveu-se essa abordagem, enfatizando as insuficiências de um enfoque estritamente biológico, e apoiando-se na ideia de que "a estrutura social e as condições de vida, assim como os elementos culturais e simbólicos, constituíam determinações sociais da doença, e que a plena reforma da saúde só se daria nos marcos de um processo de transformação da sociedade" (PIRES-ALVES; FALLEIROS, 2010, p. 170); a política se constituiria então como elemento fundamental para a compreensão da saúde e da doença e para "o estabelecimento de novas práticas de saúde que valorizavam o papel dos sujeitos individuais e coletivos".

A formulação teórico-conceitual proveniente da Medicina Preventiva e Social sobre as relações saúde-trabalho se articularia em uma nova prática sanitária, que buscaria no "social" a determinação dos agravos à saúde dos trabalhadores (LACAZ, 1996). Esse 
movimento crítico culminaria, no Brasil, com as formulações da Saúde Coletiva que, segundo Pires-Alves e Falleiros (2010, p. 170), deveria ser compreendida como

- uma corrente de pensamento;

- um movimento social;

- um espaço de prática concreta, de caráter necessariamente multidisciplinar, que acentuava o foco na dimensão social das formas de adoecimento e da organização dos serviços de saúde e que aprofundava a ruptura com a tradição médica de cunho essencialmente biomédico.

Donnangelo (apud L'ABBATE, 2003, p. 267) define a saúde coletiva como

[...] uma delimitação aproximada do campo [da saúde] não através de definições formais, mas [considerando] como ponto de partida, que a posição ocupada pela saúde coletiva no contexto das práticas sanitárias brasileiras se expressa atualmente em um conjunto de tendências de ampliação e recomposição de seu espaço de intervenção ou, correspondentemente, de seu campo de saber e prática.

A Saúde Coletiva vai se marcar pela incorporação de uma noção de trabalhador diferente da adotada pela Saúde Ocupacional-Medicina do Trabalho, nas quais é visto de forma passiva: como hospedeiro e paciente. Na Saúde Coletiva, considera-se o trabalhador como

[...] sujeito de mudanças, com saberes e vivências sobre seu próprio trabalho, compartilhadas coletivamente, [...] com capacidade de transformar e interferir em sua realidade de trabalho, mediante a reivindicação de direitos e participação no controle da nocividade do trabalho; na definição consensual de prioridades de intervenção e na construção de metodologias de intervenção sobre a realidade vivida (SATO; LACAZ; BERNARDO, 2006, p. 283).

Na década de 70, verificaram-se transformações quanto ao aumento do consumo de serviços médicos, dado o aumento do número de trabalhadores com direito à assistência médica previdenciária, transformações que teriam penetrado as escolas médicas e resultado numa produção acadêmica com utilização intensa do instrumental técnico-metodológico das ciências sociais, sobretudo o marxista. Produziram-se estudos epidemiológicos sobre o processo saúde-doença da população e estudos de políticas de saúde. A reorganização do atendimento à saúde e o redirecionamento da produção acadêmica teriam ensejado a necessidade de repensar os nomes pelos quais era conhecido o campo da saúde: "polícia médica", "medicina social”, "saúde pública", "medicina preventiva", "medicina comunitária", "saúde comunitária", bem como algumas dicotomias como "medicina preventiva x curativa", "medicina individual $\mathrm{x}$ 
social", "saúde pública x assistência médica individual". Tais denominações e oposições suporiam diversidades teóricas, históricas e ideológicas (L'ABBATE, 2003).

Ao introduzir a contribuição das ciências sociais na compreensão da saúde do trabalhador, o campo da saúde coletiva teria estabelecido, segundo Minayo-Gomez e Thedim-Costa (2003, p. 126), uma

[...] ruptura com as concepções hegemônicas da medicina do trabalho e da saúde ocupacional que, dentro de uma perspectiva positivista, formulam articulações simplificadas entre causa e efeito, desconsiderando a dimensão social e histórica do trabalho e do processo saúde/doença.

E prosseguem: "o novo marco ultrapassa, também, uma visão ambiental estreita aos locais de trabalho que, sob uma compreensão unicausal, vincula uma doença a um agente", ou, quando extrapola essa concepção, avançando para um enfoque multicausal, o qual "continua a interpretar a doença como resultante de um grupo de fatores de risco", entendendo-se a dimensão social como uma variável socioeconômica individual, um mero componente dentre outros (MINAYO-GOMEZ; THEDIM-COSTA, 2003, p. 126).

\subsection{Ergonomia Situada ou Escola Francesa ${ }^{95}$}

A Ergonomia Situada se apoiaria em uma abordagem voltada ao estudo de campo, à observação e à análise da atividade de trabalho em execução real (OLIVEIRA, 2002a, p. 92).

Baseada em princípios compartilhados com o modelo da Saúde do Trabalhador, a corrente da Ergonomia Situada tem como base a distinção entre tarefa prescrita e atividade real. Trabalho prescrito seria o que é determinado, que é pré-escrito para ser executado pelos trabalhadores; já o trabalho real é o trabalho realmente executado (OLIVEIRA, 2002b).

Essa distinção, dada a variabilidade das condições de trabalho, ocorreria, sobretudo, em situações que exigissem a interferência constante dos trabalhadores para manter a

\footnotetext{
95 Terminologia usada por F. Lima (1997b). Jacques (2003) vai chamar essa corrente de franca/latino-
} americana. 
continuidade da produção, ou mesmo prevenir eventos acidentários (MINAYOGOMEZ; THEDIM-COSTA, 1997; WISNER, 1987). Seu objetivo geral se confundiria com o da ergonomia tradicional - "adaptar o trabalho ao homem" sem, contudo, deixar de apresentar diferenças teóricas, epistemológicas e práticas fundamentais (F. LIMA, 1997b), em especial pelo fato de não constituir uma disciplina aplicada, desenvolvendo seus próprios métodos e conceitos centrados na análise da atividade de trabalho.

A atividade real de trabalho (F. LIMA, 1997b, p. 314) seria a "forma [...] como os homens se comportam efetivamente nas situações de trabalho concretas, e não como eles deveriam se comportar". Possuiria uma metodologia particular, a Análise Ergonômica do Trabalho (AET), abordagem que visa à aquisição de conhecimento sobre o funcionamento e as situações de trabalho, tornando possível compreender os seus determinantes (VILELA; ASSUNÇÃO, 2004). ${ }^{96}$

A perspectiva é de que melhorias ergonômicas seriam sempre relativas, devendo ser contínuas, dado o caráter dinâmico e complexo das situações de trabalho. Nessa abordagem, uma intervenção ergonômica implica necessariamente a participação dos trabalhadores, tanto na análise quanto na implementação e controle dos resultados dos estudos. Para F. Lima (1997b, p. 315), a escola francesa, por contraposição à anglosaxã, se definiria numa dupla relação de interioridade:

- Por desenvolver seus conhecimentos a partir da análise da atividade concreta de trabalho, exigiria conhecer "por dentro [...] tanto o comportamento do homem quando trabalha, quanto os determinantes da situação em que ele trabalha".

- Essa análise pressuporia a compreensão da “lógica [...] imanente ao comportamento de um homem específico numa situação de trabalho específica", fundando-se não em "conhecimentos genéricos dos administradores ou engenheiros sobre como a produção deve funcionar, mas sobre a experiência dos próprios trabalhadores de como ela realmente funciona". Isto requereria o desenvolvimento de métodos específicos para privilegiar a participação voluntária e cooperativa dos trabalhadores observados [grifo do autor].

Esse enfoque traria uma contribuição singular (MINAYO-GOMEZ; THEDIM-COSTA, 1997), na medida em que postula uma investigação que objetiva à formulação de propostas de transformação.

\footnotetext{
96 Conferir Wisner (1987), Guerin et al (2001), Falzon (2007), Abrahao et al (2009).
} 


\subsection{Modelo Operário Italiano}

O chamado Modelo Operário Italiano (MOI) teve ampla repercussão no movimento da Saúde do Trabalhador. Uma de suas premissas metodológicas é a interlocução com os trabalhadores, considerados depositários de um saber emanado da experiência e sujeitos essenciais quando se visa a uma ação transformadora. O reconhecimento desse saber/poder seria o sustentáculo do "Modelo Operário Italiano", que emergiu no final dos anos 70, e que tinha como foco particular a mudança e o controle das condições de trabalho nas unidades produtivas (MINAYO-GOMEZ; THEDIM-COSTA, 1997).

O pressuposto básico desse modelo seria a "não delegação", pelos trabalhadores, a outros, daquilo que diria respeito à sua saúde, elaborando pautas de negociação que visassem intervir sobre os riscos baseados numa metodologia de conhecimento desses problemas. Partindo da "subjetividade/experiência operária", trabalhava-se com os "grupos homogêneos de risco", classificando os achados em "grupos de risco" e procedendo à "validação consensual" (SATO, 1996). Essa não delegação se expressaria por uma recusa em transferir para técnicos ou mesmo representantes sindicais as tarefas de sistematização dos conhecimentos dos grupos homogêneos (submetidos às mesmas condições de trabalho), e a validação consensual seria resultante da discussão coletiva das avaliações que pautariam os processos reivindicatórios (MINAYO-GOMEZ; THEDIM-COSTA, 1997).

Segundo Laurell e Noriega (1989, p. 88),

[...] a concepção que se perfila mais claramente nos textos [do Modelo Operário Italiano] é a subjetividade - experiência operária, como conhecimento latente acumulado, resultado do viver e atuar numa determinada realidade, cujo poder é o grupo homogêneo, ou seja, a coletividade que compartilha dessa realidade.

A etapa posterior do modelo, a construção do Mapa de Risco, quando os dados coletados são categorizados nos "grupos de risco", é criticada por Laurell e Noriega (1989), pois estes seriam criados a partir de conhecimentos em medicina, engenharia, ergonomia, dentre outras áreas, "procedimento taxonômico" que apontaria uma contradição do modelo, "pois ao mesmo tempo que se enfatiza a potencialidade da 
subjetividade de um modo diferente da ciência formal, ordena a experiência no mesmo molde desta" (LAURELL; NORIEGA, 1989, p. 87).

Sato (1996, p. 492) partilha dessas críticas, e entende ser necessário

[...] um maior aprofundamento sobre a epistemologia do conhecimento prático que possa nortear a ação de vigilância à saúde a partir da identificação dos problemas pelos trabalhadores. Isso possibilitará [...] pensar nas limitações que se encontram ao atuar apenas a partir dele [MOI], pois [...] a visibilidade do conhecimento dos trabalhadores é diferente daquela alcançada pelo conhecimento científico.

Paradigmático à época em que foi concebido, esse modelo serviria, para MinayoGomez e Thedim-Costa (1997), de contraponto "a formas hegemônicas de construção de conhecimento e intervenção nos locais de trabalho", mesmo se confrontadas potencialidades e limitações de um enfoque centrado na experiência-subjetividade operária. 


\section{PSICOLOGIA E TRABALHO}

No Brasil, falar sobre como a Psicologia tem tomado os fenômenos do mundo do trabalho para construir seus objetos de estudo implica reconhecer $e$ configurar os diversos olhares que se apresentam, como num caleidoscópio. E a partir dele é que se pode identificar os limites, as perspectivas, os obstáculos e os desafios que se apresentam para a Psicologia do Trabalho (SATO, 2013, p. 99).

Busca-se neste capítulo traçar um panorama (ainda que lacunar) das relações da Psicologia com o mundo do trabalho, dos anos 10 (século XX) à atualidade, bem como estabelecer uma discussão sobre o campo de relações e imbricamentos da Psicologia e do trabalho a partir da análise de seus principais paradigmas/modelos (Psicologia Industrial, Psicologia Organizacional, Psicologia do Trabalho) e de abordagens/paradigmas correlacionados.

A inserção da Psicologia no campo da saúde e trabalho não se fez de forma unívoca. Primeiramente, porque a própria Psicologia, como ciência, é múltipla - poder-se-ia falar de "psicologias". Também coube a ela, historicamente, um papel secundário, como ciência "paramédica". Spink (2009, p. 34) vai mais longe, ao dizer que "merecem realce [...] a hegemonia do modelo médico na definição do objeto de investigação e a ausência de paradigmas verdadeiramente psicológicos para o estudo do processo saúde/doença". Disciplinas como a Psicologia, a Enfermagem, a Fisioterapia, a Terapia Ocupacional e o Serviço Social, entre outras, mesmo tendo reconhecidamente construído um "discurso próprio" sobre saúde e doença, teriam se constituído como "ciências" ou "profissões da saúde"97 ou paramédicas, tributárias da concepção hegemônica do discurso (bio)médico.

97 A respeito de sua caracterização oficial como profissionais de saúde, conferir a Resolução 287, publicada em 8 de outubro de 1998: "O Plenário do Conselho Nacional de Saúde, [...] considerando [...] a importância da ação interdisciplinar no âmbito da saúde; e o reconhecimento da imprescindibilidade das ações realizadas pelos diferentes profissionais de nível superior, constitui um avanço no que tange à concepção de saúde e à integralidade da atenção [e relaciona] as seguintes categorias profissionais de saúde de nível superior para fins de atuação do Conselho: 1. Assistentes Sociais; 2. Biólogos; 3. Biomédicos; 4. Profissionais de Educação Física; 5. Enfermeiros; 6. Farmacêuticos; 7. Fisioterapeutas; 8. Fonoaudiólogos; 9. Médicos; 10. Médicos Veterinários; 11. Nutricionistas; 12. Odontólogos; 13. Psicólogos e 14. Terapeutas Ocupacionais". 
Prado Filho e Trisotto (2007) discutem, a partir das contribuições de Foucault, a Psicologia como disciplina da norma. A Psicologia surgiria presa a imperativos epistemológicos positivistas, "como saber de fronteira, sem território próprio, formando-se nos interstícios da biologia com as ciências humanas e sociais, tomando métodos emprestados de outras ciências". Seu caráter normativo também era acentuado, "saber que gira em torno do par 'função $X$ norma', reafirmando sua vocação como 'Psicologia do normal', que lida com 'problemas de ajustamento'”98 (p. 11).

Os autores também denunciam as "técnicas psi como práticas sutis de poder, com forte suporte científico, apoiadas num argumento de cientificidade": como ciência, ou antes, como conjunto de saberes e práticas sobre o sujeito, a Psicologia teria o poder, socialmente reconhecido, de enunciar a subjetividade, mas essa enunciação sempre se daria como sujeitos da norma, a ela remetidos, "marcando e nomeando os desvios em termos de médias, curvas, condutas adequadas ou não, sancionadas ou não, quando não, patologizadas"99 (PRADO FILHO;TRISOTTO, 2007, p. 11).

Como aponta Spink (2009, p. 29), “A psicologia, em um primeiro momento, entra para o rol das profissões ditas 'da saúde' através da transposição de um know how técnico - derivado da experiência clínica - sem a contrapartida do questionamento desta transposição de técnicas de uma esfera para outra".

\subsection{PSICOLOGIA E MUNDO DO TRABALHO}

No Brasil, as relações da "Psicologia" com o "mundo do trabalho" começaram a se estabelecer no início do século XX, inicialmente por meio da "Higiene Mental". Essas relações são coincidentes com a "construção" e autonomização, como ciência, da própria Psicologia.

\footnotetext{
98 "Este conceito de "ajustamento" também merece atenção: ausente, hoje, do vocabulário psi, deve-se lembrar que durante muitos anos ao longo da primeira metade do século passado [século XX] ele reinou soberano nos discursos psicológicos." (PRADO FILHO; TRISOTTO, 2007, p. 8).

99 "Basta um passeio pelos domínios da psicometria, com seus recursos à estatística, disciplina comparativa, com suas amostragens e "curvas normais" [...] - esta "matemática política", conforme Foucault - para que a psicologia mostre-se como saber ao mesmo tempo normatizante e normalizador" (PRADO FILHO; TRISOTTO, 2007, p. 11).
} 
As primeiras instituições de ensino de graduação em Psicologia foram fundadas no Brasil nos anos 50, e a pós-graduação, nos anos 60, quando a profissão foi regulamentada, sendo o Conselho da categoria e o código de ética instituídos nos anos 70.

\subsection{1 'PSICOLOGIA' E MUNDO DO TRABALHO NOS ANOS 10 e 20}

No Brasil, ainda no século XIX, o ensino de Psicologia trouxe referências a Wundt e William James. A reforma de ensino Benjamin Constant (1890), pautou a educação pelos princípios positivistas, tendo como meta a educação cientificista; essa mesma reforma desmembraria a disciplina Filosofia em Filosofia e Psicologia Lógica, e a de Pedagogia em Pedagogia e Psicologia, aparecendo pela primeira vez o ensino da Psicologia como disciplina autônoma. Conforme Motta (2004), a partir dessa reforma, o Estado tomou para si a função educadora, já visando à industrialização do país.

A industrialização, como diz Carvalho (2011, p. 41), teria sido o grande leitmotiv para o desenvolvimento da Psicologia como disciplina científica no Brasil. Nesse contexto, marcada pela "subordinação aos interesses do capital", foi se afirmando como ciência e produzindo "dispositivos discursivos e práticos que incrementavam a sua afirmação e legitimação científica".

Como aponta Jacques (2007), no início do século XX, observou-se uma crescente aproximação da Psicologia com princípios naturalistas e evolucionistas. No cenário norte-americano, os estudos assumiriam uma tendência pragmática, aliada à grande demanda do setor industrial crescente, orientando os estudos e as práticas da psicologia, tanto no trabalho como campo de aplicação. A implantação do modelo taylorista-fordista em larga escala teria representado a "aproximação definitiva da psicologia com o mundo do trabalho", na perspectiva da aplicação dos conhecimentos e das técnicas psicológicas às relações de trabalho, sobretudo no que tange aos efeitos da fadiga em sua relação com a produtividade (JACQUES, 2007, p. 114). Para a autora, a publicação em 1913 do livro de Hugo Münsterberg - Psychology and Industrial Efficiency - marcaria formalmente a criação da chamada Psicologia Industrial. 
A implantação do modelo taylorista-fordista também teria contribuído para dar visibilidade aos efeitos do trabalho sobre o psiquismo dos trabalhadores. Como mostra Jacques (2007), o próprio Henry Ford teria demonstrado preocupação com problemas decorrentes das rotinas de trabalho demandadas por esses processos de trabalho, e a identificação das linhas de montagem fordistas como fontes de sofrimento "psíquico" ou "mental" dos trabalhadores é tema do primeiro número do “Journal of Mental Hygiene", de 1917.100

A Psicologia, nesse cenário, ocupou-se da avaliação/mensuração das diferenças individuais e do desenvolvimento de métodos e técnicas psicológicas de seleção de pessoal (aplicadas posteriormente à avaliação de desempenho e ao treinamento), na busca do "homem certo para o lugar certo" para aumentar a produtividade dos trabalhadores (JACQUES, 2007).

\subsection{2 'PSICOLOGIA' E MUNDO DO TRABALHO NOS ANOS 20 e 30}

Nos anos 20, os princípios que redefiniam o processo de produção e da organização do trabalho nos Estados Unidos e na Europa vieram a se combinar no Brasil com a necessidade de expansão da capacidade produtiva (BERTOLLI FILHO, 1993). Nesse sentido, as chamadas "ciências do comportamento" reivindicavam uma participação ativa na vida social:

\footnotetext{
Ninguém pode dispensar seus valiosos serviços e não existe campo de atividade humana em que ela [Higiene Mental] não possa penetrar. A sua esfera de ação alcança todos os lugares em que o homem se encontra [...] No lar, na escola, na fábrica, na caserna, no hospital, na igreja, nos subterrâneos, nos transportes aéreos, nos submarinos e nos cárceres, onde quer que se encontre um cérebro humano existe oportunidade para o seu emprego (LOPES, 1944 apud CARVALHO, 2010, p. 107).
}

Nesse contexto, ganhou proeminência a atenção aos "aspectos psíquicos" da formação da força de trabalho, no intuito de se produzirem trabalhadores hígidos do ponto de vista mental, produtivos e "conformados", isto é, com o máximo de força de trabalho e o mínimo de força política (CARVALHO, 1999). É recorrente a metáfora que comparava o homem a uma máquina psicofísica que deveria atingir um funcionamento ótimo: "O

100 Uma discussão sobre a Higiene Mental é realizada na seção 5.2.1.1.2. 
homem não trabalha, sinão muito raramente, como um motor physico na agitada e constante vida das fabricas: trabalha e operará cada vez mais como um apparelho psyco-physiologico" (PENAFIEL, 1925, apud CARVALHO, 1999, s/p). Nos termos de Walther (1929, p. 47),

A industria contemporânea vem assignalando, ao factor psychico, no trabalho do operário, importância cada vez mais accentuada. O homem não funcciona, desde há muito, e senão raramente, como motor physico. Elle trabalha como apparelho pysicho-physico. [...] Por conseqüência, o trabalho industrial não pode ser tratado, unicamente, como ramo da mecânica, applicada às sciencias naturaes; nelle figura um elemento psychico, que deve ser tomado na mais alta consideração.

Nesse sentido, foi sobre o "fator humano" que as ações e intervenções se concentraram, sobretudo no que tangia à seleção de pessoal e orientação e instrução profissional, atuando como "produtora de tecnologia auxiliar à aplicação dos princípios tayloristas da administração e racionalização do trabalho" (MOTTA, 2004, p. 112). A colocação de Lourenço Filho bem representa esses ideais:

\begin{abstract}
A racionalisação do trabalho, iniciada com Taylor, passa a apresentar assim novos aspectos. E ella se complica ainda mais com a preoccupação do bem estar dos que trabalham. No esforço de revisão dos processos de producção, bem depressa se verificou que a technica tinha de appellar não só para as sciencias physico-chimicas como para as sciencias biológicas do homem. A physiologia e a psychologia foram chamadas a cooperar na organisação das fabricas, para maior efficiencia econômica e melhoria das condições do trabalho operário. $E$ as primeiras tentativas tiveram logo êxito surprehendente. Especialistas da physiologia e da psyschologia trabalham hoje, em grande numero de paizes, e o resultado de seus esforços dão matéria a uma vasta e proveitosa bibliographia. Por ella se accentúa, cada vez mais, a conviç̧ão de que, para produzir muito e barato, não basta o apuro technico do machinario, o aproveitamento dos resíduos e a divisão das tarefas. É preciso a adaptação psycho-physiologica do trabalho ao homem, e a adaptação do motor humano ao trabalho (LOURENÇO FILHO, 1929, p. 3).
\end{abstract}

As atenções se voltaram, então, para as personalidades ou mentalidades individuais, na busca da compreensão do "fator humano". Como bem observa Carvalho (2011, p. 36), "processo de trabalho e organização do trabalho e suas relações com a saúde/subjetividade dos operários [...] não existiam como objeto de estudo do campo que envolvia psiquismo e trabalho em sua formação inicial", sendo objeto da atenção a personalidade individual, sob a aura de uma perspectiva de modernidade e progresso caras aos ideais positivistas. 
Para lidar com as personalidades ou mentalidades individuais, os métodos seriam preventivos ou curativos, sempre de ordem médica, observando, classificando, categorizando e intervindo sobre os "desviantes" ou "inadaptados". Quanto a estes, toda uma produção discursiva calcada nas noções de aptidões naturais, elemento psíquico, normalidade e anormalidade, orientação e seleção foi se produzindo (CARVALHO, 1999) para, nos termos de Penafiel, "collocar methodicamente a experiencia technica, medico-psychologica, a serviço do Commercio e da Industria moderna" (PENAFIEL, 1925 apud CARVALHO, 2011, p. 35).

O "elemento psychico" deveria, então, constituir objeto de estudo da higiene mental no mundo do trabalho, bem como o esgotamento das "energias nervosas ou physicas" dos trabalhadores, entendidos como distúrbios individuais, aqueles relacionados à personalidade do indivíduo, cabendo à Higiene Mental o controle e a reparação do desgaste (mental) da força de trabalho. Embora houvesse algum reconhecimento sobre a contribuição dos "officios insalubres" e das más condições de vida como causas de debilidade orgânica, adoecimento e morte dos trabalhadores não constituíam objeto de interesse da higiene mental (CARVALHO, 1999, 2011)..$^{101}$

A Higiene Mental, na medida em que implicava a "produção" do indivíduo trabalhador e mesmo numa sociedade do trabalho, ofereceria uma contribuição para o equacionamento técnico dos conflitos sociais, uma vez que atribuía ao desequilíbrio ou doença mental, inaptidão e inadaptação os entraves ao processo de ordenação social. Nesse sentido, os 'inadaptados' seriam aqueles cujo "apparelho psycophysiologico" não estivesse a serviço da produtividade industrial. ${ }^{102}$

101 É exemplar a declaração de Penafiel a respeito: "A Liga de Hygiene Mental têm que deixar de lado a influencia exercida por habitações malsans ou uma nutrição insufficiente. E até no que concerne á fadiga que certos trabalhos causam principalmente ao systema nervoso [... ] o papel daquella Liga [LBHM] deve cifrar-se [...] no estudo, sobretudo, do elemento psychico que envolve taes problemas" (PENAFIEL, 1925 apud CARVALHO, 2010, p. 103).

102 Como nas declarações da época trazidas por Carvalho (2010, p. 107):

Faustino Esposel acreditava "piamente no effeito de um tal systema de formação moral como prophylactico das psycho-neuroses ou mesmo do nervosismo sem rotulo, de distúrbios elementares do systema nervoso, que fazem; distúrbios esses que podem gerar paixões, crimes, idéias extremistas, reinvindicadoras ou Revolucionárias" (ESPOSEL, 1925). 
Como bem aponta Carvalho (1999, s/p), “operava-se um deslocamento do eixo de problematização, trazendo para o domínio das ciências médica e psicológica questões econômicas e sociais relativas ao processo de produção; questões, portanto, de luta política num contexto de conflitos de classe": problemas coletivos de ordem conjuntural e da ordem da luta de classes eram reduzidos à dimensão individual e psíquica. O autor também chama atenção para o que denomina de "duplo deslocamento epistemológico": a redução das questões econômicas, políticas e sociais relativas ao processo de produção ao "dominio psychologico", ao mesmo tempo que se restringia o "dominio psychologico" à esfera do indivíduo, do mundo privado (CARVALHO, 2010, p. 103).

Nesse momento, um exemplo desse duplo deslocamento seria a concepção sobre a propensão ao acidente. Como destaca Lacaz (1996), uma teoria em voga nos países europeus e nos Estados Unidos, e difundida no Brasil, era a da propensão ou susceptibilidade individual a acidentes (e mesmo a doenças) de trabalho. Barreto (1929, apud LACAZ, 1996, p. 15), então Secretário Geral do Departamento Nacional de Saúde Pública, assim se pronunciou sobre o tema em um congresso médico:

\footnotetext{
A Doutrina da interferência, em muitos accidentes, de uma verdadeira susceptibilidade individual, [que] hoje assenta em base solida, firmada sobretudo pelas verificações conduzidas pelo Industrial Fatigue Research Board, da Inglaterra.

Greenwood, primeiramente, em 1919, Newbold, cinco annos mais tarde mostraram por methodos estatisticos que, como diferem os individuos em altura, em peso, na força muscular ... tambem divergem na predisposição aos accidentes.
}

As estratégias para resolução dos "problemas" seriam intervenções de ordem médicopsiquiátrica, de base eugênico-higienista e preventivista, e de orientação e seleção profissionais (CARVALHO, 1999).

A partir do conhecimento das "qualidades psychicas do indivíduo", seria possível prover "um lugar para cada homem e cada homem no seu lugar", a partir de variáveis como sua forma de trabalhar, seu esforço dinâmico, a duração das pausas na sua

Oscar de Souza assinalava o valor do trabalho como terapêutica e como profilaxia das doenças nervosas funcionais e defendia que "a felicidade da vida é o trabalho livremente acceito como um dever" (LBHM, 1929). 
"actividade" - variáveis consideradas dependentes de suas qualidades psíquicas (CARVALHO, 2010). Como diz Walther (1929, p. 50),

\begin{abstract}
Taes são os dois problemas da adaptação do operário ao trabalho. A [...] Techno-psychologia industrial diz respeito à adaptação do trabalho ao operário. Os problemas, que surgem aqui, são os seguintes: 1 . A adaptação de uma funcção industrial ao operário, por meio da divisão do trabalho, no interior da fabrica, e que exigirá que se tenha em conta a constituição psychophysica de cada trabalhador. 2. A adaptação do próprio processo do trabalho. [...]

Depois de ter escolhido o homem capaz de se consagrar, com proveito, a determinada tarefa, é preciso ensinar-lhe a maneira de fazer esse trabalho. Esse ensino deve adaptal-o à nova tarefa com o menor esforço e no mais curto tempo que fôr possível. Para isso, elle terá de ser conformado às leis psychologicas.
\end{abstract}

Ainda na perspectiva de promover a melhor adaptação do homem ao trabalho, um processo fundamental era o de seleção. Para isso, ganharam destaque novas fórmulas de recrutamento do operariado. Afrânio Peixoto destaca que "a morosidade na realização das tarefas produtivas, os acidentes de trabalho e os conflitos que pontuavam o cotidiano das indústrias deviam-se, em conjunto, à atuação dos "degenerados morais" imprudentemente integrados à linha de produção"; nesse sentido, se impunha como necessária a adoção de "critérios racionais" para a seleção dos trabalhadores, uma vez que os ambientes de trabalho poderiam ser espaços "em que se viciam todos os meios de vida, facilitam-se todas as ocasiões de agressão e nocividade naturais, aumentadas ainda agora pela rotina, prejuízo e má educação do proletariado, mal alimentado, malvestido, mal alojado, viciado pelo álcool e pelo fumo" (PEIXOTO, 1922, apud BERTOLLI FILHO, 1993, p. 38).

Esses critérios racionais deveriam, para melhor promover a adaptação, considerar as aptidões e "disposições" dos trabalhadores:

\footnotetext{
A seleção operaria visa escolher, para determinado trabalho, o homem que possua disposições psychicas e physicas indispensáveis à sua pratica, de modo satisfatório. Os homens differem muito entre si, por suas aptidões innatas. Cada qual não pode cumprir certo trabalho do mesmo modo. Alguns são mais ou menos dotados; outros, completamente incapazes. Trata-se em cada caso de escolher o mais aquinhoado. Dahi, a importância do problema de seleção (WALTHER, 1929, p.50).
}

O lema norte-americano "The right man in the right place" (o homem certo no lugar certo) balizou as ações do empresariado na promoção da seleção e ajustamento do 
trabalhador, e os nomes de Frederick Taylor, Henry Fayol e Henry Ford se tornaram "menções obrigatórias nos pronunciamentos dos "capitães" da indústria nacional", dada a necessidade de organização científica/racional do trabalho (BERTOLLI FILHO, 1993, p. 38).

\begin{abstract}
Adaptar o operário ao trabalho - eis a condição primordial da organisação racional do trabalho obreiro. E o primeiro passo para essa adaptação consiste, do ponto psychologico, na verificação das aptidões requeridas para o trabalho industrial, que se tenha em vista: isto é, na seleç̧ão profissional. Trata-se de collocar cada homem no posto em que possa trabalhar nas melhores condições possíveis, no posto em que possa dar rendimento optimo, com mínimo esforço. Comprehende-se que isto interessa tanto o operário quanto a empreza que o occupe. De nada servirão as tentativas para augmentar o rendimento operário, pela divisão racional do trabalho, por sua normalisação ou por outros methodos, se essa condição, a selecção do operário, não for anteriormente preenchida (WALTHER, 1929, p. 53)
\end{abstract}

Provas de capacidade mental poderiam determinar aptidões e uma seleção mais "eficaz", dessa forma funcionando, como destaca Carvalho (2010, p. 105), como um dispositivo de triagem médico-moral para isolar os indivíduos considerados nocivos à produtividade industrial; o estudo do "factor psycho-physiologico" do indivíduotrabalhador asseguraria a associação entre os "typos intellectuaes (ou mentaes)" e os "typos de trabalho industrial". O autor transcreve a classificação dos "typos de operarios", descritos em "um dos livros de cabeceira" dos higienistas brasileiros (L'hygiène mentale d'ouvrier, de Stocker): "a) o typo feliz, perfeitamente ajustado ao meio e com excellente capacidade de trabalho; b) o typo "medio", cujas deficiencias adaptativas se traduzem por inquietação e sentimento de infelicidade; c) o typo "claudicante" ou falho, que acaba pela doença, ou pela rebeldia".

Além das preocupações com a adaptação, a questão da fadiga, num contexto de "universalidade do taylorismo como forma de organização e divisão do 'trabalho industrial moderno'”, ganhou cada vez mais proeminência (LACAZ, 1996, p. 18). Tratase aqui não mais da fadiga relacionada às extensas jornadas de trabalho ou às exigências de esforço físico, tão comum anteriormente (e ainda observável em diversos setores/indústrias). Como refere Barreto (1929 apud LACAZ, 1996, p. 18),

O problema da fadiga é sabidamente dos que mais preocupam os hygienistas industriaes. Si é verdade que a introdução, incessantemente crescente, de machinismos reduz a solicitação do esforço muscular, também é certo que surgem outras causas de fadiga, com a orientação nova que assume o trabalho industrial moderno. A velocidade que se consegue na 
produção exige atenção incessante do operador [...] acaba cansando tambem a monotonia de uma mesma operação, que se repete milhares de vezes ao dia, ocorrencia tão frequente hoje na industria moderna. As posições fixas, as forçadas [...], os movimentos inúteis ou arythmicos que se executam, os ruidos [...] são outras tantas causas provadas de fadiga, que a hygiene evita com a mudança de trabalho para os operarios [...], pelo estudo racional dos movimentos uteis para cada operação. [...] A duração bem regrada do trabalho diário e semanal, com o estabelecimento cuidadoso das pausas, cujo numero e duração [...] vão se estabelecendo mercê de investigações que se empreendem com rigoroso determinismo cientifico, são outros recursos a restringirem a fadiga industrial.

Ou, como indicado por Penafiel (apud CARVALHO, 2010, p. 105), a prevenção da fadiga se produziria "pela conservação e a reparação das forças", sendo os métodos propostos os de "reconforto physico" e de "reconforto psychico ou moral". Carvalho (2010) chama atenção para o fato de que, aí, não se estabelece diferença conceitual entre os termos "moral" e "mental".

Mesmo quando se reconhecem as duras condições de trabalho impostas, ou "que o capitalismo é implacável" (PENAFIEL, 1925 apud CARVALHO, 2010, p. 105), a fadiga, que levaria ao "empobrecimento" da "energia potencial" na vida do operário e poderia ser de natureza física, moral ou intelectual, era encarada sob a perspectiva de "falta de resistência individual”. Ou, nos termos de Walther (1929, p. 160, grifo nosso):

É a «(vulnerabilidade à fadiga» que caracterisa os indivíduos. Indivíduos de typo diverso, quanto a fatigabilidade, não podem ser submettidos ao mesmo rythmo de producção, sem graves prejuízos para a saúde e distúrbios no rendimento geral do trabalho. As empresas que não levem em conta essas differenças individuaes, podem obrigar todos seus operários a uma disciplina uniforme: mas não conseguirão tirar de cada operário seu rendimento máximo. 103

Outra questão apontada por Walther (1929, p. 150) é a da busca "individual" de combater os efeitos da fadiga:

E, para combater a fadiga profissional, [...] cada individuo tem querido resolver o problema a seu modo, empiricamente, e as mais das vezes

103 Deve-se destacar que, mesmo tratando da questão da fadiga na perspectiva da "vulnerabilidade", de ordem individual, Walther expressa argumentos de certa forma dissonantes do discurso "dominante" aqui retratado: "Na construcção de qualquer machinario ou ferramenta, o ponto de partida deve ser o homem. É a machina que se deve adaptar a elle e não elle à machina" (WALTHER, 1929, p. 150). 
usando de meios que diminuem as forças physicas em lugar de accrescel-as. Toda gente procura excitantes de toda espécie, o álcool, 104 o tabaco, etc.

Uma "solução parcial" para a questão da fadiga e, sobretudo, da monotonia foi apresentada por Walther (1929, p. 193): "dentro de certos limites", poderia ser sanada pela orientação e seleção profissionais. "Indicando trabalho monótono aos que não soffram com elle, ficarão attenuadas, em parte, as conseqüências desagradáveis do trabalho das fabricas, sobre o homem em geral. [...] Será sempre difficil encontrar actividade variada, em que se possa colocar o operário refractario à monotonia". 105

Fazendo uma análise do discurso e do campo científico do período, Carvalho (1999, 2011) identifica como, na década de 20, eram explícitas as referências ao trabalho como fim, e ao papel da higiene mental na "construção de uma sociedade do trabalho". A partir de meados da década de 30, esse discurso começou a se transformar, predominando, cada vez mais, a dimensão da ciência e da tecnologia. Não teria se produzido uma descontinuidade na ordem do discurso, mas "mudanças de superfície" na formulação de novos objetos, conceitos e estratégias, "que apenas encobriam a formação anterior, revestindo-a de novas expressões e atribuindo-lhe maior valor" (CARVALHO, 1999, s/p). Os problemas do mundo do trabalho passariam, cada vez mais, a ser expressos sob o viés da técnica, sendo as soluções para seu enfrentamento os dispositivos técnico-científicos, notadamente "da tecnologia científica psicológica". Os conceitos de "saúde mental" e de "higiene mental" com frequência começariam a aparecer de forma complementar; por "saúde mental" se entendendo uma "condição" ótima a ser preservada e (re)produzida, e "higiene mental", como meio ideal para sua consecução. Observa-se uma crescente sofisticação da produção conceitual, que, tornando o campo cada vez mais especializado, o limitaria "ao homem de ciência"; desenvolveram-se dispositivos técnicos (como testes

\footnotetext{
104 Cabe destacar que, na perspectiva higienista, o alcoolismo era entendido como uma doença moral; em vez de considerar as condições socioeconômicas como relacionadas ao alcoolismo, esse era tomado como "causa de degeneração moral e social da sociedade" (MANSANERA; SILVA, 2000, p. 128).

105 Para Walther (1929, p. 191),

O trabalho nas fabricas é monótono por sua própria essência, tende fatalmente para uma automatisação cada vez maior e mais completa. [...] A fabricação em massa, a acceleração da produção acarreta sempre maior divisão do trabalho; faz desapparecer, para o individuo, toda a variedade na actividade profissional. Dahi, a monotonia do trabalho industrial, com o que vem a soffer grande parte da população operaria.
} 
psicológicos, por exemplo) e discussões teórico-metodológicas, que confeririam mais cientificidade e legitimidade aos estudos e discursos.

Dataria dessa época, por exemplo, a disputa estabelecida entre médicos, pedagogos e advogados para obtenção da legitimidade na aplicação das "ciências do comportamento" na boa prática de seleção de quadros e de sua conduta para a indústria (BERTOLLI FILHO, 1993), bem como na criação de instituições que iriam consubstanciar tais discursos (LACAZ, 1996).

Para Carvalho (1999, s/p), "Foi através da eugenia106 e da higiene mental como referentes conceituais básicos que trabalho e psiquismo se encontraram, configurando objeto e campo específicos, respectivamente 'indivíduo/força de trabalho' e sua 'psicologia' e 'trabalho e higiene mental'".

\subsection{3 'PSICOLOGIA' E MUNDO DO TRABALHO NOS ANOS 30 e 40}

Bertolli Filho (1993) situa, no Brasil, a entrada da psicologia e da vertente "comportamental" da medicina no contexto da necessidade de modernização das relações de trabalho, primeiramente como auxiliares nos processos de seleção de mão de obra e na análise "psicológica" do operariado.

A Psicologia, ou as ciências, ou "medicina do comportamento" foram inicialmente convocadas para as tarefas de seleção e avaliação do operariado (por meio da psicotécnica), para medidas "inibidoras da presença dos inadaptados" ou de "correção" da ação mental, "higiene mental" e disciplinarização, ou ainda para a avaliação da capacidade para o trabalho, visando ao ajustamento do trabalhador ao ordenamento fabril. Contribuíram também para a avaliação dos transtornos mentais ${ }^{107}$ (causadores ou resultantes de acidentes de trabalho) e para a avaliação da concessão (ou não) de indenizações por possíveis danos à saúde provocados por acidentes. Paulatinamente avançou para a prevenção e tratamento das moléstias.

\footnotetext{
106 Uma discussão sobre a Eugenia é realizada na seção 5.2.1.1.1.

107 "Um [...] campo de intervenção das "ciências do comportamento" nas questões originadas pela produção dava-se através da análise dos operários que apresentavam possíveis "transtornos mentais", causadores ou resultantes de acidentes que comprometiam a existência do indivíduo e dos seus companheiros de labuta" (BERTOLLI FILHO, 1993, p. 45).
} 
Mesmo nesse cenário, diferentes polos de análise já se configurariam, permitindo que "vozes diferenciadas se mesclassem" (BERTOLLI FILHO, 1993). Também chama atenção para o fato de que essa presença não poderia ser analisada ou entendida apenas como "reflexo dos interesses apadrinhados pelas elites patronais" (p. 51), demarcando também uma busca por "estratégias "científicas" de percepção dos eventos individuais e coletivos que, centrados no corpo, incentivavam a modernização da trama coletiva". Segundo o autor, no final dos anos 40, as "ciências do comportamento" já teriam firmado sua presença nos debates sobre a organização e o gerenciamento do trabalho.

Nos anos 40, observa-se o aprofundamento da utilização de dispositivos técnicocientíficos, notadamente "da tecnologia científica psicológica", nos termos de Carvalho $(1999,2011)$. Os testes psicológicos e a psicometria ganharam cada vez mais espaço, na perspectiva de que se apresentavam como meios "neutros" e "objetivos" de avaliação da força de trabalho (MOTTA, 2004).

A multiplicação dos estudos, enfoques e perspectivas de entendimento do proletariado urbano acirraria as disputas pela legitimidade na aplicação das "ciências do comportamento", fazendo com que "especialmente os médicos, mas também os pedagogos, os advogados e os cientistas sociais reclamassem para si o título de psicólogos, se não de psiquiatras e psicanalistas". Processo ainda lento nos anos 30, nos anos 40 ganhou projeção a "'medicina do comportamento' que, incluindo a psicotécnica, firmou-se como dispositivo abalizado para a dissecação e julgamento da rotina e das disfunções que caracterizavam o cotidiano industrial" (BERTOLLI FILHO, 1993, p. 39).

O autor destaca como representativo do discurso da psicotécnica108 no período o trabalho do clínico Raul Rocha que, em suas obras, indicou que a "medicina voltada para as questões industriais buscava afinar-se com os interesses do governo de Getúlio Vargas", declarando seus objetivos: "dar completa eficiência ao trabalho e, ao mesmo tempo, poupar e preservar o trabalhador" e, com isso, "economizar material, trabalho e dinheiro". Mesclando princípios da psicologia, ergonomia, da sociologia e da

108 Uma discussão sobre a Psicotécnica é realizada na seção 5.2.1.1.3. 
economia, afirmava que "fator anátomo-fisiológico" individual, ou "substrato orgânico", não poderia ser alterado pela medicina que, em compensação, "disporia de conhecimentos sólidos e eficientes para corrigir a 'ação mental' do agrupamento operário" (ROCHA, 1949, apud BERTOLLI FILHO, 1993, p. 40).

Bertolli Filho (1993, p. 42) destaca a percepção "médica", no período, das "atividades produtivas como fruto do relacionamento harmonioso entre operários e industriais, e os serviços sociais, dádiva dos 'gerentes modernos'". Apregoava-se a "solidariedade" 109 como meio para o fim dos conflitos entre operários e patrões; já os serviços sociais seriam "provas flagrantes do despojo e das boas intenções do grupo dirigente" e "todo conjunto de obras feitas ou auspiciadas pela indústria, destinadas a elevar o nível de dedicados obreiros e empregados, e que têm uma influência indireta sobre a capacidade produtiva" (FÁVERO, 1947, apud BERTOLLI FILHO, 1993, p. 44). Assim, o que se esperava dos trabalhadores era uma postura de humildade e agradecimento pelos "privilégios" recebidos de seus empregadores, uma vez que não se constituíam como obrigatoriedade legal ou necessários para bom funcionamento das unidades fabris.

Já os indivíduos "revoltosos" ou "inadaptados" deveriam ser evitados por meio de seleção criteriosa dos empregados, uma vez que, rejeitando os direcionamentos e ordenamentos do sistema fabril, se revelariam indivíduos "perigosos"; "perigosos" também seriam os trabalhadores que "insistiam" em cobrar indenizações indevidas após serem acidentados no trabalho (BERTOLLI FILHO, 1993).

Nesse sentido, visando promover novas formas de relacionamento entre os empregados e seus superiores, pautadas pela "ausência de conflito", e que garantissem lucratividade nos negócios, contribuiriam os recursos oferecidos pela psicotécnica. Como coloca Bertolli Filho, (1993, p. 40-41):

Elaboradora do modelo perfeito do "bom trabalhador", as "ciências do comportamento" ampliavam suas perspectivas, anunciando também o

109 Já em 1927, Claparède, no prefácio à obra de Léon Walther, vai apregoar o princípio da "solidariedade": "Capaz de collocar-se em pontos de vista apparentemente contradictorios, comprehendeu ele [Léon Walther], desde logo, que qualquer trabalho humano, digno desse nome, não pode prescindir da mais estreita solidariedade entre os interesses do capital e do trabalho (tidos como oppostos) e obedecer, a um só tempo, às exigências da natureza humana e da producção" (CLAPARÈDE, 1929, p. 7, grifo nosso). 
paradigma do "patrão moderno". Como tal, entendia-se o administrador de empresa que acompanhava seus empregados praticamente desde o nascimento, para isto criando escolas onde, desde os primeiros anos de vida, a força de trabalho em estado potencial deveria ser disciplinada e orientada vocacionalmente sendo que, no decorrer deste processo, seriam dispensados todos os aprendizes que se mostrassem avessos à faina cotidiana, à submissão às ordens, à vida em conjunto e à demonstração de solidariedade em relação ao grupo patronal.

No campo discursivo e de práticas da Higiene Mental, a tônica ainda era a consideração de que esta constituía o melhor meio para "o estudo sistematizado do homem e do seu meio, as suas reações ao meio tumultuoso e atordoante em que trabalha, a filtragem do bom elemento mental, a avaliação de sua capacidade de resistência" (CAVALCANTI, 1944 apud CARVALHO, 2011, p. 38). E prossegue Cavalcanti:

\footnotetext{
São os pesares e as preocupações que dão as grandes estatísticas de desorganizados mentais, de esgotados, neurastênicos e psicastênicos. A organização científica do trabalho não poderá ser perfeita sem a assistência profilática do sistema nervoso do trabalhador. A higiene mental seleciona, valoriza e faz de indivíduos fracassados momentâneos ótimos trabalhadores.
}

Mesmo permanecendo vigente a perspectiva de que a melhor prática era apenas "colocar o indivíduo no lugar que lhe compete", tornava-se cada vez mais difícil a desconsideração das "forças exteriores" que atuavam e debilitavam o indivíduo no mundo do trabalho. Como aponta Carvalho (2011, p. 38), "o discurso tangenciava a contradição, mas insistia no psicologismo individualista".

Nos anos 40, consolidaram-se ou criaram-se entidades voltadas para a "organização racional do trabalho". O IDORT (Instituto de Organização Racional do Trabalho) funcionou como elemento catalisador para a constituição de diversos grupos, institutos e órgãos congêneres. As orientações do IDORT e dessas instituições foram adotadas ao longo dos anos 30 e 40, definindo uma lógica de "organização racional" do trabalho e dos perfis dos agentes ligados à produção, notadamente dos trabalhadores (MOTTA, 2004; BERTOLLI FILHO, 1993).

Nos anos 40, foram fundados órgãos, como Instituto de Psicologia, ABNT (Associação Brasileira de Normas Técnicas), ABPA (Associação Brasileira de Prevenção de Acidentes), Conselho de Higiene e Segurança do Trabalho, Instituto de Administração, FGV (Fundação Getúlio Vargas), DASP (Departamento Administrativo do Serviço 
Público), ISOP (Instituto de Seleção e Orientação Profissional) e o SOSP (Serviço de Orientação e Seleção Profissional), entre outros (MOTTA, 2004). Bertolli Filho (1993) destaca que a sugestão de estudo e acompanhamento "científico" dos trabalhadores ganhou adesão do empresariado nacional, originando entidades como o SENAI (Serviço Nacional de Aprendizagem Industrial), o SENAC (Serviço Nacional de Aprendizagem Comercial) e o SESI (Serviço Social da Indústria).

Essas entidades teriam desenvolvido atividades no campo da Psicologia e especialmente da psicotécnica, numa linha de atuação similar à dos industriais americanos (responsáveis pelo patrocínio de organizações, como o National Institute of Industrial Psychology e o Tavistock Institute of Human Relations). O ano de 1946 marcou a inauguração de um setor de orientação psicotécnica pelo SESI e logo depois, pelo SENAC, que trouxe novamente ao Brasil o professor Léon Walther (com seu discípulo, Pierre Weil) como diretor de pesquisas motivadas pelo "comportamento operário". Destaque-se que essas organizações também foram chamadas de “escritórios de Psicologia Industrial” (BERTOLLI FILHO, 1993).

Já o processo de "seleção científica" e acompanhamento médico periódico dos trabalhadores, que se iniciou nos anos 20 e 30, ganhou projeção nos anos 40 pela prática da "medicina do comportamento", que incluía a psicotécnica, e que se utilizou de conhecimentos que visavam à correção da "ação mental" dos trabalhadores (LACAZ, 1996, p. 30). A "medicina do comportamento" multiplicava suas estratégias de conhecimento dos trabalhadores. Um exemplo citado por Bertolli Filho (1993, p. 41) é o do médico Arlindo Ramos, que postulava que, "mesmo para os 'cargos de responsabilidade', o importante não seria tanto a aplicação de 'testes de inteligência", mas sim de exames que poderiam assinalar a existência de distúrbios pré-psicóticos, facilitando a operação de alijamento dos 'doentes' do mundo da produção".

Bertolli Filho (1993) destaca que, como a educação continuada dos trabalhadores não se configurava como prioridade, tornavam-se cada vez mais necessários rígidos testes para sua admissão. Pelas premissas da psicotécnica, o primeiro passo consistia no levantamento dos dados individuais, a partir de extensos roteiros de questões cujas 
respostas eram registradas em fichas específicas, 110 por um "psicólogo" treinado na "triagem científica" da força de trabalho. Outra importante etapa consistia em descrições detalhadas da vida do "candidato", construindo uma "história de vida" que, analisada, resultaria ou não na contratação do trabalhador. Além disso, realizavam-se exames médicos dos candidatos, "exame de temperamento e personalidade" e testes de seleção. ${ }^{111}$ No caso de candidatos à contratação em casas bancárias ou lojas comerciais, nas quais havia maior possibilidade de roubo, os testes de seleção eram ainda mais exigentes; sugeria-se mesmo a utilização do "Polígrafo de Keller".112

E qual seria, para os "psicologistas", o tipo ideal de trabalhador que esses processos almejavam selecionar?

Segundo as instruções do Dr. Rocha, o operário modelo era aquele que, tanto em condições propícias quanto adversas (como por exemplo, em ambientes marcados por calor ou ruído em escala excessiva) estava capacitado para atuar satisfatoriamente no processo produtivo, sentença que incluía o bom rendimento do trabalho e a irrestrita obediência às ordens emanadas pela chefia da empresa. Em contraposição, o servidor "inadaptado" era aquele que, por "fatores intelectuais, morais e afetivos" pervertia o recinto de labuta grupal, mostrando-se negligente, despreocupado, preguiçoso e por isto insuflador do descontentamento coletivo e causador de acidentes comprometedores do bom funcionamento da fábrica (BERTOLLI FILHO, 1993, p. 43).

Destaque-se que os "psicologistas" buscavam estender sua atuação para além do processo de seleção, "com o objetivo de acompanhar a integração dos funcionários no processo de produção de mercadorias e na prestação de serviços". Partindo da premissa de que o trabalhador "sempre pode produzir mais do que realmente faz", propunham seu "julgamento contínuo", buscando estabelecer estratégias corretivas

110 "Essas fichas, se preenchidas integralmente, revelavam-se uma minuciosa fonte de informações sobre o operário, sua família e seus amigos, incluindo aí a idade de seus pais ao casarem e as "tendências psicológicas" dos progenitores do trabalhador" (BERTOLLI FILHO, 1993, p. 41).

111 Chega ao Brasil, no período, o psiquiatra espanhol Emílio Mira Y Lopez. Criador de vários testes psicométricos, como o teste de psicodiagnóstico miocinético (PMK), largamente utilizado no Brasil, por exemplo, para exames de avaliação para concessão de carteira de habilitação de condutores de veículos, foi partícipe da construção do ISOP.

112 "Dispositivo empregado desde a década de 20 pela polícia norte-americana e por isto conhecido como "revelador de mentiras". Este mecanismo permitia o registro da pressão arterial, da respiração e do reflexo psicogalvânico do entrevistado, em situações tensas propositadamente suscitadas durante o exame. Graças a essa estratégia, a medicina acreditava poder descobrir as "perturbações emotivas" frequentes nos portadores de "personalidades psicopatas", excluindo da lista de eventuais contratados os indivíduos cujas respostas ou reações corporais sugerissem "anormalidade mental"" (BERTOLLI FILHO, 1993, p. 42). 
dos empregados "desajustados", classificados como "neuróticos que fracassaram socialmente" e, portanto, perigosos para a comunidade laboriosa. Uma vez que o emprego da "higiene mental" não alcançasse os resultados almejados, caberia demitir o trabalhador "mentalmente perturbado" (BERTOLLI FILHO, 1993, p. 43).

Contudo, essas propostas destoavam dos interesses imediatos do empresariado; poucas empresas se dispuseram a arcar com os altos custos que a abrangência das orientações prescritas pelos "psicólogos"/psicologistas representavam; some-se a isso o fato de que a mão de obra barata e abundante permitia pronta substituição dos trabalhadores "inadaptados" (BERTOLLI FILHO, 1993). ${ }^{113}$

Como bem analisado por Bertolli Filho (1993), além da seleção e acompanhamento da mão de obra, outra importante vertente de atuação e intervenção das "ciências do comportamento" nas questões originadas pela produção era a análise dos trabalhadores que apresentavam possíveis "transtornos mentais", fossem eles causados por ou resultantes de acidentes de trabalho.

Sobretudo após a instituição da Justiça do Trabalho, em 1939, "psicólogos" e "psiquiatras" foram recrutados para atuação como peritos em processos judiciais motivados por pedidos de indenizações movidos pelos operários acidentados. Bertolli Filho (1993) analisa como, nesse momento, especialistas em "comportamento industrial" tenderam a se voltar para a psicanálise. Contudo, esse campo epistemológico se apresentaria como frágil e lacunar face às exigências jurídicas: a ausência de um "quadro nosológico" amplo e "comprovado" segundo as exigências da lógica positivista imperante levaria advogados e mesmo ampla parcela da comunidade médica a questionarem a validade dos laudos preparados a partir dessa abordagem. Assim, muitos "psicanalistas" teriam recorrido à orientação da "escola" liderada pelo médico, político e industrial paulista Antônio Carlos Pacheco e Silva, que apresentava as "patologias mentais" como resultado de disfunções glandulares ou de traumatismo

113 Como coloca Bertolli Filho (1993, p. 43),

Até mesmo a burocracia estatal, representada a partir de 1938 pelo Departamento Administrativo de Serviço Público (DASP), mostrou-se pouco disposta a acatar critérios rígidos de seleção dos servidores públicos, impondo apenas o 'exame abalizado' dos 'aparelhos fisiológicos' e principalmente do aparelho visual, concedendo pouca atenção aos dados de ordem psicológica dos candidatos, dispensando-os de interrogatórios mais prolongados. 
físico. Dessa forma, a partir de um "referencial concreto" - o agravo corporal - os peritos em "psicologia industrial" teriam mais segurança para declarar o trabalhador como merecedor (ou não) de indenização e de aposentadoria, temporária ou permanente. Outra vertente, não se alinhando a essa orientação que situava os "comportamentos inadaptados" como produtos de "traumas orgânicos", atribuía a causação do acidente em questão exclusivamente à condição "anormal" da personalidade do trabalhador (BERTOLLI FILHO, 1993, p. 45).

Quando instados a elaborarem laudos de avaliação de trabalhadores que requeriam indenizações em razão de danos à saúde, os "peritos", de modo geral, eram concordes no "diagnóstico da existência de traumatismos físicos favorecedores do desenvolvimento de 'neuroses de responsabilização' dos patrões pelo acidente de trabalho, sentimento rotulado pela medicina como 'sinistrose', 'neurose de renda', 'neurose de desejo' e 'indenizofilia'” - "patologia" que acometia os trabalhadores acidentados e contava com definição única: "um delírio pleitista, querelante, de reivindicação" (BERTOLLI FILHO, 1993, p. 45).

As publicações, sobretudo de cunho psicanalítico, passaram a abrir espaço para a análise do comportamento tido como característico entre os trabalhadores acometidos pela moléstia "sinistrose". Bertolli Filho (1993) atribui à incapacidade da clínica geral em verificar a veracidade das queixas apresentadas pelos trabalhadores acidentados a oportunidade para os "psicanalistas" intervirem na questão. Como peritos designados para a solução do impasse médico-legal, buscariam estabelecer nexos causais entre o "infortúnio" e a "afecção nervosa ou mental" que reduzia ou anulava a capacidade produtiva do trabalhador.

Nesse cenário, a tendência predominante seria declarar o reclamante como um "simulador", que buscava assim extorquir as companhias seguradoras, e negar os pedidos de indenização ou, por vezes, declarar a inexistência de evidências que subsidiassem decisões legais.

Um exemplo da tendência a apresentar as "patologias mentais" como resultado de disfunções glandulares ou de traumatismo físico é trazido pelo artigo "A perícia médica nos casos de simulação em infortunística", tese apresentada no Primeiro Congresso Brasileiro de Direito Social pelo médico e perito Antônio Leão Bruno e publicada em 
1941, no qual busca estabelecer diretrizes para a conduta pericial. Bruno define a simulação em infortunística como sendo:

[...] o conjunto de manifestações conscientes e artificiais por via das quais se concretiza a vontade do empregado para iludir terceiros (o médico, o empregador, as companhias de seguros, advogados, juízes, curadores especiais das vítimas de acidentes do trabalho, etc.), tendo em vista obter determinadas vantagens (BRUNO, 1941, p. 9).

A atenção do médico legista não deveria se fixar tão somente no estado de saúde atual do ferido ou do doente ou do "pseudoacidentado. Deveria estar também voltada para o estado de saúde anterior, para os antecedentes pessoais ou hereditários e, ainda, para a constituição individual do examinando" (BRUNO, 1941, p. 14, grifo nosso).

No final dos anos 40, as "ciências do comportamento" consolidaram sua participação nos debates acerca da organização e gerenciamento do trabalho. Como coloca Bertolli Filho (1993, p. 51), o projeto psicotécnico, aliado à avaliação "psicológica" dos trabalhadores, sobretudo os acidentados, criou condições para novos mecanismos de controle dos trabalhadores, mecanismos que atribuíam as contradições do cotidiano e as reivindicações dos trabalhadores acidentados a comportamentos "desajustados", e que visavam "a ampla subordinação da força de trabalho às necessidades e ao ritmo intenso da produção fabril".

Carvalho (2011, p. 41) destaca como, no Brasil, especialmente após a II Guerra Mundial, esse "território especial de pesquisas e de intervenções" constituiu o que ele chama de PIO - Psicologia Industrial e Organizacional.

Lacaz (1996, p. 17) chama atenção para como, no encontro das "ciências do comportamento" com a profissiografia, pautado pelo discurso da adaptação, da seleção e do acompanhamento periódico e da prevenção, se encontravam presentes as noções norteadoras do conceito de Saúde Ocupacional que surgiria cerca de 20 anos depois, a partir de formulação da OIT/OMS: "a Saúde Pública aplicada aos ambientes de trabalho e seus trabalhadores, na busca da adaptação do homem ao trabalho, da prevenção dos riscos do trabalho e, de forma não dita, da seleção dos mais hígidos e capazes".

Nesse contexto, uma ressalva importante é apresentada por Bertolli Filho (1993, p. 51), no sentido de que os pronunciamentos dos médicos e "psicólogos" não fossem 
entendidos apenas "enquanto reflexos dos interesses apadrinhados pelas elites patronais". Ao mesmo tempo em que produziriam e legalizariam posicionamentos que imputariam a responsabilidade pelos acidentes de trabalho e as enfermidades profissionais aos próprios trabalhadores, buscar-se-ia também "estabelecer estratégias 'científicas' de percepção dos eventos individuais e coletivos que, centrados no corpo, incentivavam a modernização da trama coletiva".

\subsection{4 'PSICOLOGIA' E MUNDO DO TRABALHO NOS ANOS 50}

As chamadas "ciências do comportamento" como campo de pesquisas e de intervenções acerca da organização e gerenciamento "psicológico" do trabalho constituíram termos discursivos no Brasil, no final dos anos 40 e início dos anos 50, cada vez mais sob o registro da "Psicologia Industrial".

A Psicologia Industrial teria sua "marca formal" de criação nas publicações de Hugo Münsterberg, em 1913 e 1914 (WALTHER, 1929; JACQUES, 2007). Embora no exterior pareça ter sido consagrado o uso da terminologia até o final dos anos 70 (como em várias obras citadas consultadas para esta tese), no Brasil, até os anos 50, os termos "medicina do comportamento", "ciências do comportamento", "higiene", "higiene industrial" e "higiene mental" predominavam nas publicações analisadas. A higiene industrial ainda pautaria as discussões e análises, sobretudo no que tangia a postos ou ambientes de trabalho, mas observavam-se crescentemente as publicações de obras nacionais (ou traduzidas) com a terminologia Psicologia Industrial. Mesmo os profissionais se identificaram, cada vez mais, como psicólogos (e menos como psicologistas, tecnopsicologistas, psicotecnologistas, cientistas do comportamento e outras denominações empregadas até então).

Nos anos 50, ganhou influência a Escola das Relações Humanas, de Elton Mayo - o chamado "Movimento das Relações Humanas" viveu seu auge nos EUA nesse período (CARVALHO, 2011). Os estudos de Mayo, como coloca Jacques (2007, p. 114), marcaram o reconhecimento dos fatores psicológicos como decisivos para o aumento da produtividade dos trabalhadores; deles derivariam a aplicação dos estudos sobre 
motivação, satisfação no trabalho, clima e cultura organizacionais e "uma prática psicológica aplicada aos variados contextos empresariais (não só às indústrias)".

A orientação dos trabalhos se pautaria pela busca de proporcionar a melhoria das relações humanas no trabalho industrial visando "a harmonia entre os empregados e empregadores, através dos Supervisores, de imediato, e o aumento da produtividade, em seguida, como efeito" (ASSIS, 1954, p. 68). A harmonia entre o capital e o trabalho seria "mais um problema afetivo que econômico porque a solução deste é uma consequência da solução daquele". Essa perspectiva adaptacionista e que negava o conflito balizaria a maior parte da produção do período.

A adaptação do homem ao trabalho deveria ser buscada e promovida por todos os meios; trabalhadores adaptados teriam maior "automatização dos movimentos e atitudes próprias de cada atividade", trabalhando com mais rapidez, perfeição do trabalho e produtividade. Sendo o "hábito do trabalho uma obrigação social, deve ser transmitido como um dos elementos da herança social, como costume, como tradição [...] desde cedo através das atividades próprias da infância e da adolescência". Na vida adulta, deveria ser proporcionado "um aprendizado racional que livre o trabalhador da aquisição de movimentos desnecessários e mesmo nocivos" (ASSIS, 1954, p. 43).

A atuação dos gerentes para a adaptação do trabalhador e a promoção de "hábitos" adequados não se restringiriam aos limites da empresa; deveria o gerente "atingir o lar do seu subalterno, o emprego de suas horas de lazer, a sua atitude nos órgãos de classe, a sua saúde, numa tentativa, enfim, de conhecê-lo em todos os aspectos da sua personalidade para bem compreender as suas reações no trabalho" (ASSIS, 1954, p. 5).

Começariam a ganhar destaque estudos sobre motivação como meio para a consecução de maior produtividade: “A boa produtividade se consegue com o operário interessado no seu trabalho, nele encontrando motivo ou motivos para gastar a sua energia sem desperdício, para dispensar esforço voluntário" (ASSIS, 1954, p. 5).

A fadiga continuaria ocupando lugar de destaque nas discussões do período. Debates sobre seus efeitos e meios profiláticos eram abundantes; as medidas mais comumente sugeridas para evitá-la e aos "efeitos fisiológicos e psíquicos que repercutem de maneira desfavorável [...] sobre o desenvolvimento do trabalho do indivíduo" 
abordavam análise da jornada/introdução de repousos intercalares, treino, adaptação do instrumental ao trabalho/preparo do ambiente de trabalho (de cunho "higiênico"), estudo dos movimentos profissionais e a onipresente "seleção científica dos trabalhadores" (STERSA, 1959, p. 99).

A seleção continuaria sendo vista como o meio mais adequado de identificação de aptidões e "disposições" psíquicas e físicas para o trabalho, para que ele fosse desempenhado do modo mais satisfatório. "Selecionando o trabalhador, procura-se assim colocar cada operário no posto em que possa trabalhar nas melhores condições possíveis, com ótimo rendimento e dispêndio de mínimo esforço" (STERSA, 1959, p. 33). Como etapas de avaliação, eram recomendadas a análise de antecedentes pessoais e "familiares e hereditários", a realização de exames físicos e laboratoriais, bem como "exame mental". Dessa forma, a seleção também cumpriria o papel de "eliminar os predispostos aos acidentes de trabalho" e os "sensibilizados às doenças profissionais":

[A] seleção inicial, além de eliminar os predispostos aos acidentes de trabalho, descobre os elementos sensibilizados às doenças profissionais, desclassificando os que apresentem deficiências muito acentuadas ou incompatibilidade para o posto desejado (STERSA, 1959, p. 41, grifo nosso).

Além da seleção adequada e "científica", outro recurso para a promoção da adaptação do homem ao trabalho e o melhor aproveitamento de suas aptidões era o da orientação profissional, "método científico que visa informar o indivíduo sobre as aptidões que ele possui e designar a carreira em que se exijam as aptidões assim verificadas" (STERSA, 1959, p. 33).

Destaca-se ainda, no cenário dos anos 50, a criação do primeiro curso universitário de Psicologia do Brasil (1953) na Pontifícia Universidade Católica do Rio de Janeiro (PUCRJ) e de seu Instituto de Psicologia Aplicada (IPA), em breve secundado por diversos outros (MOTTA, 2004, p. 153). 114.

\footnotetext{
114 Também nos anos 50 se registra na França a publicação do artigo "A neurose das telefonistas" por Le Guillant et al. (1956/1984), um importante marco no campo de estudos da saúde/doença mental em seus vínculos com o trabalho (JACQUES, 2007, p. 114). Le Guillant, psiquiatra francês, foi um dos primeiros a utilizar a expressão "psicopatologia do trabalho", cunhada por Paul Sivadon, também psiquiatra francês (LIMA, 1998, 2006; CLOT, 2010), vai demonstrar a existência de uma relação entre o contexto laboral e a frequência e a gravidade dos distúrbios mentais apresentados pelos trabalhadores (JACQUES, 2007, p. 114).
} 


\subsubsection{PSICOLOGIA E MUNDO DO TRABALHO NOS ANOS 60 e 70}

A regulamentação ou reconhecimento da profissão do psicólogo era uma reivindicação dos "psicólogos" ou "psicologistas" (denominação que constava na proposta apresentada ao Congresso Nacional por Lourenço Filho), que se mobilizavam desde o final dos anos 40 e, mais notadamente, nos anos 50, com destacada participação dos profissionais associados à psicotécnica. Como já apontado anteriormente, buscava-se a "autonomia científica" do campo; "especialmente os médicos, mas também os pedagogos, os advogados e os cientistas sociais [reclamariam] para si o título de psicólogos" (BERTOLLI FILHO, 1993, p. 39).

Por fim, um projeto encaminhado pela Associação de Psicólogos de São Paulo foi acompanhado pelo deputado Adaucto Lucio Cardoso e, depois de discutido e aprovado no Congresso, se transformou na Lei, adotando a denominação "psicólogo". A Psicologia foi então reconhecida no Brasil como profissão pela Lei 4.119 de 1962, sancionada pelo Presidente da República, João Goulart (MOTTA, 2004). ${ }^{115}$ A autora registra que, em julho de 1962, um mês antes da promulgação dessa lei, realizou-se, na França, uma Conferência Internacional promovida pela American Psychological Association e pela International Union of Scentific Psychology, na qual o Brasil foi representado. Nessa Conferência, apenas três países - Canadá, Egito e Estados Unidos - de um total de 20, já possuíam algum tipo de legislação que regulamentasse a atividade do psicólogo sendo, contudo, legislações parciais. Dessa forma, o Brasil seria um dos primeiros países do mundo a aprovar a regulamentação da profissão do psicólogo, e talvez o primeiro a fazê-lo em todo o território nacional.

Tornou-se, então, necessária a regulamentação dessa Lei. Nomeou-se uma comissão de psicólogos que, juntamente com o Conselho Federal de Educação, trabalhou para fixar o currículo mínimo e a duração do curso de Psicologia; essa regulamentação ocorreu em 1964, por meio do Decreto $n^{0}$ 53.464. Ficou então estabelecida a formação do psicólogo em três diferentes níveis: licenciatura (formação do professor de Psicologia) e bacharelado (formação do pesquisador), ambas com quatro anos de

115 O Conselho Federal de Psicologia e os Conselhos Regionais de Psicologia foram criados pela Lei 5.766, de 1971; o Código de Ética Profissional dos Psicólogos do Brasil foi publicado no Diário Oficial da União em 1979 (MOTTA, 2004). 
duração; formação do psicólogo, com o foco na atuação profissional, com duração de cinco anos (MOTTA, 2004).

Também se estabeleceram, não sem conflitos, as "fronteiras" entre a atividade do médico e a do psicólogo, seus respectivos domínios. Azzi (1966 apud MOTTA, 2004, p. 213) aponta que a maior "luta" no tocante à definição "destes limites de reserva de mercado foi a psicanálise, a forma de psicoterapia que é objeto de luta mais acirrada entre psicólogos e médicos [a que mais cresceu]". Outra recomendação foi a da constituição de uma organização dos psicólogos "à semelhança do CRM, para os médicos, ou da OAB, para os advogados", o que ocorreu na década de 70.

Após a regulamentação da profissão, aumentaram cada vez mais os cursos de psicologia em nível universitário. Também se operou um deslocamento; no então cenário em que prevalecia a Psicologia voltada para a educação ou para a psicometria/Psicologia aplicada, observou-se o crescimento da psicologia "clínica", para a qual os cursos de formação dedicaram atenção cada vez maior (MOTTA, 2004).

No início dos anos 70, foram criados pela Lei $\mathrm{n}^{0} 5.766$ de $1971^{116}$ o Conselho Federal de Psicologia (CFP) e os Conselhos Regionais de Psicologia (CRPs), definindo em seu primeiro artigo:

Art. 1을 criados o Conselho Federal e os Conselhos Regionais de Psicologia, dotados de personalidade jurídica de direito público, autonomia administrativa e financeira, constituindo, em seu conjunto, uma autarquia, destinados a orientar, disciplinar e fiscalizar o exercício da profissão de Psicólogo e zelar pela fiel observância dos princípios de ética e disciplina da classe (BRASIL, 1971).

Após a regulamentação da profissão ocorrida nos anos 60, nos anos 70 expandiu-se 0 número de cursos de graduação em Psicologia, e começou também a expansão da pósgraduação stricto sensu. Na década de 70, após a instituição dos Conselhos Federal e Regionais de Psicologia e a regulamentação da profissão da profissão ainda nos anos 60, observou-se um momento de reconhecimento e "institucionalização" da Psicologia como campo científico autônomo.

${ }^{116}$ A Lei $n^{\circ} 5.766$ foi posteriormente regulamentada pelo Decreto $n^{\circ} 79.822$, de 1977. 
Nos anos 60, observou-se um grande número de pesquisas e artigos voltados à formação de quadros de "chefia" e "gerenciais" (CARVALHO, 2011, p. 41).

Mesmo sendo ainda comuns as publicações que se referiam à Psicologia Industrial, o final dos anos 60 e, notadamente, os anos 70 se marcaram pela consolidação do discurso da Psicologia Organizacional117. Como coloca Carvalho (2011, p. 44),

Dos anos 1970 para cá, foi notável o desenvolvimento técnico-discursivo da propriamente dita "Psicologia Organizacional", tendo ampliado sua área de alcance no mundo do trabalho: ao saber voltado para recrutamento, seleção e orientação profissionais some-se todo um investimento em treinamento, avaliação, desenvolvimento e gestão de pessoal, organização do trabalho, ergonomia.

Retomando explanação de Lacaz $(1996$, p. 17) já referida, manteve-se o discurso da adaptação, da seleção e do acompanhamento periódico, da prevenção, consubstanciado pelo conceito de Saúde Ocupacional da formulação da OIT/OMS: "a Saúde Pública aplicada aos ambientes de trabalho e seus trabalhadores, na busca da adaptação do homem ao trabalho, da prevenção dos riscos do trabalho e, de forma não dita, da seleção dos mais hígidos e capazes".

No final dos anos 70 e início dos anos 80, começaram a surgir estudos e pesquisas que buscavam a compreensão da relação entre trabalho e saúde mental, numa perspectiva que introduziu uma ruptura com as premissas da Psicologia Industrial e Organizacional.

\footnotetext{
O recurso ao materialismo dialético constituiu-se numa importante transformação metodológica para a compreensão das relações entre processo saúde-doença mental e processo de trabalho, visando à apreensão dos determinantes psicoafetivos, socioculturais e político-econômicos inerentes ao processo de trabalho e de seus efeitos na saúde dos trabalhadores (CARVALHO, 2011, p. 47).
}

Carvalho (2011, p. 48) faz menção a alguns trabalhos do período que, preocupados com as relações entre Saúde e Trabalho, tangenciaram questões pertinentes aos debates em Saúde Mental do Trabalhador, além de "estudos antropológicos que, usando a categoria de 'doenças dos nervos' exploram as relações entre sofrimento, trabalho e condições de vida do ponto de vista da classe trabalhadora".

117 Uma discussão sobre a Psicologia Organizacional é realizada na seção 5.2.2. 
Os anos 70 - apesar de ainda serem frequentes as referências à Psicologia Industrial - marcaram-se pela consolidação do discurso da Psicologia Organizacional, ainda hoje hegemônica no mundo do trabalho.

O final da década foi marcado pela luta pela redemocratização do país, de novas práticas sindicais em saúde, traduzidas em reivindicações de melhores condições de trabalho, no bojo da emergência do Novo Sindicalismo (MENDES, 1995, p. 26). Nesse contexto, ganharam destaque as discussões sobre a determinação social do processo saúde-doença e começou a se delinear a Saúde do Trabalhador como campo teórico-prático. Começou também o delineamento dos campos da Psicologia do Trabalho118 e da Saúde Mental e/no/do Trabalho'119.

\subsubsection{PSICOLOGIA E MUNDO DO TRABALHO NOS ANOS 80}

Como já discutido, o início dos anos 80 foi marcado pela intensificação dos movimentos de redemocratização do país, pela consolidação de novas práticas sindicais em saúde, traduzidas em reivindicações de melhores condições de trabalho, pelo acirramento de discussões em torno da reforma sanitária, entre outros movimentos políticos e sociais.

Cada vez mais ganharam espaço discussões sobre a determinação social do processo saúde-doença e se constituiu a Saúde do Trabalhador como campo teóricoprático, bem como os campos da Psicologia do Trabalho e da Saúde Mental e/no/do Trabalho.

Contudo, deve-se frisar que o modelo da Psicologia Organizacional continuou prevalente no meio empresarial, constituindo-se como o modelo teórico-prático (paradigma) dominante nesse meio (e mesmo em diversos espaços de formação em Psicologia). Abordagens pautadas pelo modelo da Psicologia Organizacional priorizavam Programas de Qualidade de Vida no Trabalho120 e de combate ao

\footnotetext{
118 Uma discussão sobre a Psicologia do Trabalho é realizada na seção 5.2.3.

119 Uma discussão sobre a Saúde Mental e Trabalho é realizada na seção 5.2.3.1.1.

120 Uma discussão sobre a Qualidade de Vida no Trabalho (QVT) é realizada na seção 5.2.2.1.3.
} 
estresse. ${ }^{121}$ Esses programas teriam a saúde (e a saúde mental) como objeto, partindo de uma perspectiva individualizante, ou "psicologizante", desconsiderando-se o papel desempenhado pelos contextos de trabalho (SATO, 2010; PRILLELTENSKY, 1994).

A formação em Psicologia, no Brasil, apresentaria na época (e mesmo hoje) duas tendências nas áreas de Saúde e de Trabalho/Organizações, segundo Sato, Lacaz e Bernardo (2006, p. 283): a primeira, de "formar profissionais para a prática clínica liberal", e a segunda, "de tratar a temática do trabalho e organizações na perspectiva da gestão de recursos humanos em que a ótica da saúde praticamente não comparece".

Introduziu-se, então, a partir dos anos 80, e mais notadamente a partir dos anos 90, uma tensão entre essas duas abordagens.

No começo dos anos 80, observou-se o início de estudos e pesquisas que buscavam discutir as relações entre trabalho e saúde mental.

Entre 1981 e 1983, a psiquiatra Edith Seligmann-Silva coordenou uma pesquisa sobre condições de vida e de trabalho e suas repercussões sobre a saúde mental de trabalhadores industriais siderúrgicos em Cubatão (SP). Carvalho (2011) destaca como as categorias "condições de vida" e "condições de trabalho" aparecem como centrais nesse estudo. Seligmann-Silva (1988, p. 14) também chama atenção, no mesmo estudo, tanto para as condições de trabalho e condições gerais de vida muito difíceis, que geralmente se tornam adoecedoras, como para o fato de que os trabalhadores, nessas condições, "manifestam resistências admiráveis contra estas condições".

Carvalho (2011, p. 48) relaciona alguns trabalhos do final dos anos 70 e início dos anos 80 que tangenciaram questões pertinentes aos debates em Saúde Mental do Trabalhador. Seligmann-Silva (1988, p. 13) também chama atenção para dois estudos: o de Yone de Souza Grossi com trabalhadores de extração de ouro, e outro, de Maria Cecília Minayo, com trabalhadores de extração de ferro, nos quais se destacam o sofrimento mental desses trabalhadores, "relacionado à dominação vivenciada, dentro

121 Uma discussão a respeito das abordagens sobre estresse é realizada na seção 5.2.2.1.2. 
de processos de trabalho, e marcado por uma exploração inaudita, como ainda existem em muitos lugares do Brasil".

No início dos anos 80, também se destacou a participação de trabalhadores/movimento sindical na discussão das relações entre trabalho e sofrimento mental; a tônica das discussões do movimento sindical, contudo, era a questão salarial e, como coloca Seligmann-Silva (1988, p. 16),

[...] fica restando pouco espaço para a questão da saúde e, em particular, da saúde mental. Mas é uma batalha que está sendo levada adiante já, por vários Sindicatos e pelo DIESAT. E é impressionante a sensibilização que se observa a nível dos próprios trabalhadores, em qualquer categoria profissional, quando o assunto é abordado. Quando se toca nessas questões, eles reconhecem os problemas que sentem e vivem no seu cotidiano de trabalho e de vida.

Mesmo não ocupando espaço central na agenda do movimento sindical, destacam-se nesse sentido os pioneiros estudos empreendidos pelo DIESAT (Departamento Intersindical de Estudos e Pesquisas de Saúde e dos Ambientes de Trabalho) a partir de demandas colocadas pelos próprios trabalhadores. Esses estudos foram conduzidos por equipes multidisciplinares, em conjunto com os trabalhadores. As pesquisas realizadas com bancários e metroviários contaram com a participação da psiquiatra Edith Seligmann-Silva, da psicóloga Leny Sato, da socióloga Agda Aparecida Delía e do médico Francisco Antônio de Castro Lacaz; já a pesquisa realizada com aeronautas, contou com a participação do psicólogo Wanderley Codo entre seus integrantes (SELIGMANN-SILVA, 1988, 2014; CODO, 2014). Também em uma publicação do DIESAT encontra-se a noção de neurose vinculada ao contexto de trabalho. Trata-se de obra produzida por representantes sindicais como resultado de debates realizados pelo DIESAT no período de 1979 a 1984. As doenças mentais também foram apontadas como a mais frequente, e quase única, causa da aposentadoria por invalidez, abaixo dos 40 anos (RIBEIRO; LACAZ, 1984; SILVA, 2011).

A participação dos trabalhadores nos estudos e pesquisas sobre sua saúde/saúde mental é vista pelos pesquisadores dos campos teórico-epistemológicos Saúde do Trabalhador/Psicologia do Trabalho/Saúde Mental e Trabalho como condição imprescindível para sua realização. Segundo Seligmann-Silva (1988, p. 14), 
Não é possível estudar psicopatologia do trabalho sem escutar os depoimentos dos trabalhadores sobre suas vivências relacionadas ao cotidiano laboral. Infelizmente, só agora se iniciam em nosso país - e mesmo assim, ainda em poucas Faculdades de Psicologia ou Medicina aulas e estudos referidos ao assunto.

Sato, Lacaz e Bernardo (2006) identificam a aproximação da Psicologia com os problemas de saúde do trabalhador nos anos 80, em São Paulo, a partir de dois caminhos distintos: a atuação em um órgão sindical de pesquisa em saúde e trabalho, o DIESAT, e a atuação nos serviços de saúde pública. Esses caminhos teriam fornecido à Psicologia dois eixos temáticos importantes: o planejamento em saúde e a "pesquisa de processos de trabalho que explicassem o sofrimento, as doenças, os acidentes de trabalho e os modos construídos pelos trabalhadores para lidar com os riscos no trabalho" (SATO; LACAZ; BERNARDO, 2006, p. 283).

A inserção da Psicologia no DIESAT teria oportunizado o conhecimento dos problemas percebidos como importantes por trabalhadores e direções sindicais, desencadeando ações de pesquisa, de assessoria em avaliação de condições de trabalho e de formação em saúde. Outro importante elemento era a atuação em equipes multidisciplinares, compostas por médicos, engenheiros, advogados, ergonomistas, sociólogos, psicólogos (SATO; LACAZ; BERNARDO, 2006).

Já na atuação na saúde pública, as atividades desenvolvidas pelos psicólogos seriam primeiramente norteadas pelas diretrizes dos Programas de Saúde do Trabalhador (PSTs), ${ }^{122}$ posteriormente dos Centros de Referência em Saúde dos Trabalhadores (CRSTs, CERSATs, CERESTs). Essa atuação demandaria formas de atuação que operacionalizassem a noção de atenção à saúde, que incluía ações de prevenção primária, assistência e promoção da saúde, numa perspectiva que ultrapassasse os aspectos biológicos, incorporando o psíquico e o social. Sato, Lacaz e Bernardo (2006, p. 284) destacam que, quando surgiram os primeiros PSTs, quase não havia pesquisas em Psicologia que discutissem a saúde no trabalhador na perspectiva da Saúde Pública. Dessa forma, essa prática em unidades de saúde da rede pública teria trazido importante colaboração ao "levar essa temática para a reflexão da Universidade".

122 Em meados da década de 1980, foram criados os primeiros Programas de Saúde do Trabalhador (PST) por alguns municípios e estados (CFP, 2008, p. 19). 
Outro movimento fortemente presente nos anos 80 foi o da Reforma Psiquiátrica / Luta Antimanicomial, que visava "o gradual fechamento dos manicômios e a criação de serviços substitutos capazes de garantir a continuidade do tratamento fora dos muros hospitalares" (RIBEIRO, 2009 apud DEUSDEDIT JUNIOR, 2014, p. 106), que oportunizassem a transição de um modelo centrado no hospital para um modelo de atenção comunitário. Como destaca Deusdedit Junior (2014), a forma como as políticas de Saúde Mental estão organizadas hoje no país está diretamente relacionada à Reforma Psiquiátrica.

O final dos anos 70 e começo dos anos 80 também se marcaram por questionamentos metodológicos de psicólogos sociais de orientação epistemológica marxista, "em busca de uma ciência comprometida com a transformação social" (LANE; SAWAIA, 1995 apud CARVALHO, 2011, p. 49). Textos de Psicologia que questionavam a dimensão da subjetividade no mundo do trabalho apareciam sob a rubrica "Psicologia Social" ou mesmo "Psicologia Social Comunitária"; criou-se uma Equipe de Psicologia SócioHistórica na Faculdade de Ciências Humanas e da Saúde da Pontifícia Universidade Católica de São Paulo (PUC-SP) e promoveu-se a divulgação da chamada "psicologia sócio-histórica" (CARVALHO, 2011).

Em 1984, a partir de temas discutidos pelo Programa de Pós-Graduação em Psicologia da PUC-SP, publicou-se o livro "Psicologia Social: O homem em movimento", organizado por Silvia Lane e Wanderley Codo. Nesse livro, entre outros textos já "clássicos" hoje, destacam-se (para os propósitos dessa tese), dois de autoria de Wanderley Codo. O primeiro, "O fazer e a consciência" (CODO, 1984/1994b), discute a relação trabalho-trabalhador sob uma orientação marxista; o segundo, "O papel do psicólogo na organização industrial (notas sobre o 'lobo mau' em psicologia)" (CODO, 1984/1994a), derivado de sua tese de doutorado, "A Transformação do Comportamento em Mercadoria" (1981), é uma contundente discussão da Psicologia Industrial e da atuação dos psicólogos. Para Jacques (2014) e o próprio Codo (2014), esse texto teria sido um "divisor de águas" nas discussões sobre o trabalho, em Psicologia. Uma crítica que fazem Codo $(1988,2014)$, Codo, Sampaio e Hitomi (1993) e Lima (1998) sobre a produção acadêmica à época se refere à "ausência da categoria trabalho" não apenas na psicanálise, mas na Psicologia, em geral. 
Outro fator significativo para a abertura do campo da Saúde do Trabalhador à Psicologia, segundo Jacques (2003) e Ramminger e Nardi (2007), foram as deliberações da VIII Conferência Nacional de Saúde (CNS) e a I Conferência Nacional de Saúde do Trabalhador (CNST), realizadas em 1986, e consolidadas na Constituição Brasileira de 1988 e na Lei Orgânica da Saúde de 1990. Essas deliberações buscavam a ruptura com o modelo teórico centrado no conhecimento médico, propondo ações integradas e interdisciplinares.

Outro marco seria a publicação, em 1987, do livro de Christophe Dejours, "A loucura do trabalho". Lima (1998; 2013) destaca a importância dessa publicação para a discussão das relações entre trabalho e saúde mental no país e sua visibilidade, "possibilitando o seu aprofundamento e incentivando os pesquisadores a aperfeiçoarse e a desenvolver estudos dentro da nova especialidade que se delineava" (1998, p. 10). Carvalho (2011) também aponta como as ideias desenvolvidas a partir da proposta de Dejours encontraram espaço crescente no meio acadêmico, sobretudo a partir dos anos 90, influenciando artigos, dissertações e teses que passaram a enfocar o "sofrimento psíquico" e suas relações com a organização do trabalho. ${ }^{123}$

\subsubsection{PSICOLOGIA E MUNDO DO TRABALHO NOS ANOS 90}

Os anos 90 seriam marcados pelo contexto da chamada reestruturação produtiva, pela terciarização da economia e pela precarização e terceirização do trabalho. Em termos de políticas de pessoal, viriam a se tornar palavra-chave o discurso de flexibilidade, formação contínua e competitividade (CARVALHO, 2011), e começariam a se introduzir demandas de capacitação e manutenção da empregabilidade pelos trabalhadores (JACQUES, 2013).

Algumas mudanças se observaram no discurso, como destaca Sato (2010), com a adoção de expressões como "gestão de pessoas", "área de people", "empowerment", entre outras. Apresentou-se também uma sofisticação do discurso psicológico sobre absenteísmo e rotatividade, que passariam a estar associados a "índices de satisfação

\footnotetext{
123 A obra de Dejours, sua influência e as críticas a respeito são discutidas na seção Saúde Mental e Trabalho (5.2.3.1.1) e, mais especificamente, na seção Psicodinâmica do Trabalho (5.2.3.1.1.1).
} 
no trabalho"; aprimoraram-se os mecanismos de recrutamento, seleção, treinamento e gerenciamento de crises (CARVALHO, 2011).

As políticas de pessoal passariam a desempenhar impacto cada vez maior na subjetividade e na caracterização da sociabilidade dos trabalhadores (SELIGMANNSILVA,2013; LIMA, 1996b). Programas de manejo de estresse e de Qualidade de Vida no Trabalho se tornariam cada vez mais frequentes, mobilizando a contribuição da Psicologia Organizacional (CARVALHO, 2011). Começou a se estruturar, inclusive em termos de uma associação nacional, a abordagem da POT (Psicologia Organizacional e do Trabalho), que, pelas áreas de atuação e temáticas propostas, apresentaria intrínseca ligação com a Psicologia Organizacional. ${ }^{124}$

Quanto às abordagens pautadas pela Psicologia do Trabalho e pela Saúde Mental e Trabalho, observa-se grande crescimento nos anos 90, com o desenvolvimento de pesquisas na academia e a prática realizada nos programas ou centros de referência em saúde do trabalhador. Intensificou-se o debate a respeito das relações entre trabalho e saúde mental, "explicitando a contraposição aos modelos nos quais o trabalho se encontra alijado da análise da subjetividade e dos processos relativos à saúde mental" (ARAÚJO, 2011, p. 326). Essas relações seriam também evidenciadas pela visibilidade que as Lesões por Esforços Repetitivos (LER) adquiriram, em razão da "epidemia" observada nos anos 90, que incitou discussões sobre manifestações complexas de adoecimento (MAENO, 2013). ${ }^{125}$

\subsubsection{PSICOLOGIA E MUNDO DO TRABALHO NA ATUALIDADE}

Quanto às abordagens pautadas pela Psicologia do Trabalho e pela Saúde Mental e Trabalho, observa-se após os anos 90 a consolidação, como um dos campos possíveis da atuação na saúde pública, nos serviços de atenção à Saúde do Trabalhador, como os CERESTs, tomando o trabalho como objeto de política em saúde pública (SATO, 2013). Jacques (2007) destaca como uma das possibilidades abertas por essa inserção a discussão/estabelecimento do nexo causal entre o trabalho e o adoecimento mental;

\footnotetext{
124 Discussão que será retomada na seção 5.2.3, Psicologia do Trabalho.

125 Questão que será mais explorada no Capítulo 6.
} 
Sato (2013) destaca a abertura de espaço de atuação e investigação. Deve-se ressaltar, contudo, não ser a inserção nos CERESTs a única possibilidade de atuação.

Ainda sobre a atuação em Saúde do Trabalhador, em 2008 o Conselho Federal de Psicologia, por meio de seu Centro de Referência Técnica em Psicologia e Políticas Públicas (CREPOP), publicou documento com referências e diretrizes para a atuação do psicólogo na Saúde do Trabalhador, no âmbito da saúde pública. Segundo o documento,

\footnotetext{
O principal aspecto que se procurou evidenciar [...] é a importância de articular o mundo do trabalho, contexto, condições e relações de trabalho e suas repercussões na saúde dos trabalhadores, evitando explicações de cunho individualista e culpabilizante para fenômenos que se apresentam coletivos e de cunho essencialmente social (CFP, 2008, p. 48).
}

Seligmann-Silva et al. (2010) destacam como a globalização, a mundialização da precarização social, as inovações tecnológicas e as novas formas de gestão produziriam rápidas transformações no mundo do trabalho, mudanças que, para as autoras, não teriam despertado a atenção do "pensamento tradicional das áreas da Medicina do Trabalho, da Saúde Ocupacional e da Psicologia"; também não teriam despertado a atenção o trabalho como mediador de integração social, com importância na constituição da subjetividade. A Medicina do Trabalho e a Saúde Ocupacional continuariam priorizando as condições de trabalho - os aspectos físicos, mecânicos, químicos e biológicos dos ambientes laborais - como fatores de risco à saúde dos trabalhadores. Já a Psicologia, aqui entendida como a Psicologia Organizacional, concentraria sua atenção "nos aspectos intrassubjetivos e, quando muito, estende-se aos intersubjetivos. Os aspectos sociais, econômicos e organizacionais, assim como os processos psicossociais em suas repercussões sobre a subjetividade do trabalhador, são minimizados ou ignorados" (SELIGMANN-SILVA et al., 2010, p. 187).

\subsection{O CAMPO DA PSICOLOGIA E TRABALHO E SEUS PARADIGMAS}

Nesta seção, busca-se estabelecer uma discussão sobre o campo de relações entre Psicologia e Trabalho, a partir da análise de seus principais paradigmas/modelos (Psicologia Industrial, Psicologia Organizacional e Psicologia do Trabalho) e de abordagens/paradigmas correlacionados. Aponta-se também sua vinculação ou 
relação com a "Patologia do Trabalho" e seus diferentes modelos (Medicina Industrial, Saúde Ocupacional, Saúde do Trabalhador).

Objetiva-se tratar a questão como um campo dinâmico de disputas, discursos e de práticas inter-relacionados, fundamental para a compreensão dos Transtornos Mentais e do Comportamento Relacionados ao Trabalho.

\subsubsection{PSICOLOGIA INDUSTRIAL}

Concomitantemente ao desenvolvimento da medicina industrial, no início do século $\mathrm{XX}$, aumentaram as demandas de controle da produção em massa e do trabalho. É nesse contexto que as práticas da Psicologia ligadas ao trabalho assumiram seu contorno de Psicologia Industrial, surgindo atreladas aos interesses da indústria e instrumentalizando alguns pressupostos do taylorismo (SAMPAIO, 1999).

Em 1911, Taylor publicou o livro "Princípios da Administração Científica", no qual buscou estabelecer diretrizes para uma "ciência" da gestão do trabalho, cujos objetivos seriam otimização e o controle do trabalho, combate ao desperdício, redução do tempo de produção e aumento do ritmo de trabalho, por meio do planejamento e da racionalização máxima das operações realizadas pelos trabalhadores. ${ }^{126}$

Para a racionalização da produção, seria imprescindível a análise do trabalho e das tarefas de cada trabalhador. Dessa forma, seria possível "desenvolver para cada elemento do trabalho individual uma ciência que substitua os métodos empíricos" e "selecionar cientificamente, depois treinar, ensinar e aperfeiçoar o trabalhador" (TAYLOR, 1911/1990, p. 40). Já a finalidade do planejamento seria "caracterizar qual o trabalho que deve ser feito, como deve ser feito esse trabalho, onde e por quem deverá ser executado e, finalmente, quando deverá ser feito" (TAYLOR, 1911/1990, p. 18). Assim, seria possível alcançar: " $1^{\circ}$ - Desenvolvimento de uma verdadeira ciência.

\footnotetext{
126 Entre os "mecanismos" ou elementos da Administração Científica, Taylor (1911-1990, p. 94) elenca: "estudo do tempo, com os materiais e métodos para realizá-lo corretamente"; "chefia numerosa e funcional e sua superioridade sobre o velho sistema do contramestre único"; "padronização dos instrumentos e material usados na fábrica e também de todos os movimentos do trabalhador para cada tipo de serviço"; "necessidade duma seção ou sala de planejamento"; "uso da régua de cálculo e recursos semelhantes para economizar tempo"; "sistema de rotina".
} 
$2^{\circ}$ - Seleção científica do trabalhador. $3^{\circ}$ - Sua instrução e treinamento científico. $4^{\circ}$ Cooperação íntima e cordial entre a direção e os trabalhadores" (TAYLOR, 1911/1990, p. 95).

Nesse contexto, tornou-se primordial para a consecução desses objetivos a seleção rigorosa e "científica", por meio da qual se poderia colocar "o homem certo no lugar certo" (the right man in the right place), na perspectiva do posto de trabalho, lugar onde suas aptidões poderiam ser mais bem aproveitadas e possíveis desvios ou inadaptações, evitados. Descreve Silva (2011, p. 101) o lugar da Psicologia neste processo:

[...] os métodos e os instrumentos da Psicologia e da Psicologia Industrial complementam os objetivos do taylorismo, formando trabalhadores para o novo tipo de trabalho e os novos níveis de uso da sua força de trabalho, e eliminando aqueles que não se conformassem a estas normas e padrões.

Com a introdução de medidas legais que impunham limites à duração da jornada de trabalho (mesmo que nem sempre observados), tornava-se cada vez mais necessário o aproveitamento ótimo das capacidades e resistências tanto físicas quanto mentais dos trabalhadores, que viriam a se apoiar fortemente em conhecimentos produzidos pela medicina (fisiologia, higiene) e pela "Psicologia". ${ }^{127}$

Lacaz (1996, p. 35) cita como "descrição acabada" do taylorismo a seguinte passagem de Barreto (1929), em que se entrelaçam o discurso da adaptação e da seleção de pessoal para permitir aos

[...] tayloristas ter a organização perfeita: seres humanos ajustados às exigências minuciosamente descritas dos postos de trabalho ... dentro do

127 Como descrito por Weber (1922/1999, p. 362):

A disciplina descansa aqui [na oficina capitalista] completamente numa base racional, calculando em grau decrescente, com a ajuda de métodos de medição adequados, o ótimo de rentabilidade de cada trabalhador individual, do mesmo modo que se faz com um meio de produção material. O máximo triunfo festeja [...] o adestramento e treinamento racional do trabalho produtivo, baseado nestes cálculos, no sistema americano do scientific management, o qual chega às últimas consequências da mecanização e do disciplinamento da empresa. O aparelho psicofísico do homem é aqui completamente adaptado às exigências do mundo externo, do instrumento, da máquina ou, em uma palavra, da função, despojado de seu ritmo dado por sua própria estrutura orgânica e submetido a um novo ritmo que, depois da análise sistemática das funções de cada músculo e da criação de uma ótima economia das forças, corresponde perfeitamente às condições do trabalho. 
esquema taylorista, a melhora da atividade humana no trabalho pode conseguir-se [...] procurando a seleção dos trabalhadores e formando-os adequadamente [...] (BARRETO, 1929 apud LACAZ, 1996, p. 35).

Um pressuposto do taylorismo, amplamente acolhido na Psicologia Industrial, foi a "lei da fadiga": buscava-se determinar, "cientificamente", o limite de esforço, medindo assim as possíveis cotas de produção dos trabalhadores (RAMOS, 1948).

Assis (1954, p. 7) assim define a Psicologia Industrial: "o estudo dos problemas psicológicos do trabalho industrial, da adaptação do operário ao trabalho, da seleção e orientação profissional, da adaptação do trabalho ao operário, da segurança no trabalho". Inicialmente voltada para a seleção e colocação de pessoal (the right man in the right place), a Psicologia Industrial inicia nos anos 20 seus trabalhos de orientação vocacional (baseados na Psicometria) e estudos sobre condições de trabalho e higiene, visando ao aumento da produtividade. Baseava-se ainda fortemente no estudo da organização formal, estruturada pelas técnicas de prescrição da execução do trabalho (STERSA, 1959).

A atuação prioritária da psicologia industrial se daria nos postos de trabalho, não se envolvendo com a estrutura das organizações (estudo e atuação no ambiente, na perspectiva do posto de trabalho).

Como destaca Prilleltensky (1994, p. 3), a perspectiva da Psicologia Industrial implicava que "se os trabalhadores têm problemas, eles devem mudar alguma coisa dentro deles próprios, não nas condições de trabalho - uma implicação que é inteiramente congruente com a bem conhecida ideologia da "culpabilização da vítima'". Isso ficaria bem claro, por exemplo, em investigações sobre acidentes de trabalho: "O operário acidentado não deverá receber somente cuidados médicos em relação a seus ferimentos, mas deverá ser bem estudado a fim de verificar quais as causas psíquicas que o levaram a se acidentar" (STERSA, 1959, p. 158, grifo nosso).

Após a II Guerra Mundial, destacam-se estudos sobre seleção (baseada na psicometria), avaliação de desempenho, treinamento, condições de trabalho e liderança. Como coloca Carvalho (2011, p. 43), 
cientificidade e, consequentemente, mais legitimidade, aos estudos e discursos.

O período pós II Guerra Mundial marcou-se por diversos órgãos e entidades dedicados ao estudo e pesquisa da "organização racional" do trabalho e dos perfis dos agentes ligados à produção, notadamente dos trabalhadores, entre eles o Instituto de Seleção e Orientação Profissional (ISOP), fundado em 1947, dentro da Fundação Getúlio Vargas (FGV). Para Pierre Weil (1972, apud Carvalho, 2011, p. 41), “Oito de agosto de 1947 [data de fundação do ISOP] talvez seja a data mais importante na história da Psicologia Industrial no Brasil".

Em 1949, foi organizada no ISOP, por seu então diretor, Mira y López, a publicação dos "Arquivos Brasileiros de Psicotécnica" que, segundo Carvalho (2011), foi tão importante para a Psicologia Industrial como os "Archivos Brasileiros de Hygiene Mental" teriam sido para a Higiene Mental do Trabalho. Em 1969, a publicação passou a ser denominada "Arquivos Brasileiros de Psicologia Aplicada", "acompanhando as transformações metodológicas que levaram - em nível nacional e internacional - a se compreender a intrínseca ambiguidade e inadequação do termo psicotécnica" (SEMINÉRIO, 1972 apud CARVALHO, 2011, p. 42). Em pesquisa realizada nos Arquivos Brasileiros de Psicotécnica de 1949 a 1969, Carvalho (2011) identifica que os trabalhos eram agrupados em duas grandes denominações: "Psicologia do Trabalho" e "Orientação Profissional". Sob a denominação Psicologia do Trabalho, os temas mais encontrados foram "análises profissiográficas", "grupos profissionais-pesquisas", "seleção", "reabilitação-readaptação" e "prevenção dos acidentes". O autor destaca ainda a influência da psicologia experimental e comportamental norte-americana e da psicofisiologia nesse período.

Outro elemento importante para a compreensão da Psicologia Industrial foi a contribuição da Escola de Relações Humanas. Na década de 20 do século XX, surgiu uma nova corrente na administração, em reação à escola clássica/taylorista, chamada de Escola das Relações Humanas, interessada em outros fatores ligados à produção, ampliando o escopo da investigação da organização formal para a informal, baseada nas relações de grupo. Inicialmente considerada capaz de "preencher um lapso técnico da administração clássica", essa corrente não propôs mudanças substanciais nos 
processos de produção, sendo facilmente incorporada pelo contexto taylorista (SAMPAIO, 1999).

O "Movimento das Relações Humanas" teve seu auge nos EUA na década de 1950 e enfatizava a "importância dos fenômenos psicossociais de relacionamento humano para o desempenho das pessoas [...] nas situações organizacionais e de trabalho", pondo em evidência "aspectos psicossociais na determinação do rendimento do fator humano no trabalho" (HESKETH, 1979, apud Carvalho, 2011, p. 42). Como destaca Carvalho (2011, p. 42),

A Escola de Relações Humanas produziu a ideia de fator humano como "recursos humanos" a serem explorados. Nos estudos sobre acidentes de trabalho, adquire uma dimensão negativa e aparece associado à ideia de falha ou erro cometido pelo trabalhador.

Motivados pela Escola de Relações Humanas, também se desenvolviam, nessa época, estudos sobre motivação, comunicação e comportamento de grupo. A perspectiva era a da promoção da melhoria dos relacionamentos entre os empregados, sendo negados (e mesmo considerados patológicos) os conflitos.

Contudo, desde o pós-guerra, com as alterações do cenário socioeconômico, as empresas começaram a buscar transformações nas práticas e modelos que, até então, haviam bem servido à organização clássica da produção. Adaptadas segundo algumas contribuições da Escola das Relações Humanas, essas práticas já não seriam percebidas como suficientes para subsidiar a produtividade das empresas (SAMPAIO, 1999), ensejando a busca/construção de outros modelos de práticas, dentre eles a Psicologia Organizacional.

Segundo Tiffin e McCormick (1958/1975a, p. 7), até a década de 40, a ênfase dominante da Psicologia Industrial foi dada à seleção e colocação de pessoal, com ênfase na construção e utilização de testes para essa finalidade. Nos últimos anos da década de 40 e início da década de 50, a atenção se voltou para as relações humanas na indústria, sobretudo no que tangia à "interação grupal, processos de supervisão e liderança, processos de comunicação e pelos aspectos relacionados com as atitudes e o moral do empregado". Essa ênfase, por sua vez, teria levado à maior consideração de programas de avaliação e aperfeiçoamento administrativos. Já a ênfase a processos administrativos teria levado ao interesse pelas considerações 
organizacionais, como pesquisas referentes a estruturas organizacionais e a outros aspectos das organizações.

As aproximações entre o modelo da Medicina do Trabalho e a prática da Psicologia Industrial são várias. Ambas basearam suas premissas e proposições em representações do homem fortemente influenciadas pelo individualismo, pelo mecanicismo e pelo biologicismo.

No que tange à reprodução da força de trabalho, basilar para a Medicina do Trabalho, a Psicologia Industrial veio contribuir com estudos sobre a "resistência do animal humano" e sobre a determinação científica de limites de esforço (sobretudo quanto ao problema da fadiga), visando também ao estabelecimento de cotas de produção para os empregados.

A Psicologia Industrial se consolidou como forte aliada da atuação da Medicina e Higiene do Trabalho. Com base nas premissas tayloristas de buscar 0 aproveitamento ótimo das capacidades e resistências físicas e mentais, bem como nos objetivos da Medicina do Trabalho de promover a adaptação física e mental ao trabalho, em particular pela adequação do trabalhador e sua colocação em postos de trabalho correspondentes às suas aptidões, a Psicologia Industrial teria contribuído com trabalhos de seleção e colocação da mão de obra no posto de trabalho (sobre o qual recai toda a ênfase) avaliado como o mais adequado (the right man in the right place), por meio de práticas, como a avaliação psicométrica e, em menor grau, da orientação vocacional.

Ambas, Medicina do Trabalho e Psicologia Industrial, partilhariam a percepção do conflito nas empresas/organizações como de natureza patológica, que deveriam ser evitados por processos de avaliação (física e/ou mental) e colocação de pessoal. À obrigatoriedade de o trabalhador passar pelo crivo e julgamento de aptidão para o trabalho, constituindo o exame médico uma exigência legal para o acesso ao posto de trabalho, somou-se o trabalho psicométrico de seleção da Psicologia Industrial. 


\subsubsection{Abordagens / Paradigmas correlacionados}

A seguir, apresentam-se abordagens/paradigmas correlacionados à Psicologia Industrial.

\subsection{Eugenia}

Na França, do final do século XIX/início do século XX, o movimento higienista orientouse no sentido de "melhorar o estado de saúde das populações, de lutar contra a degenerescência dos indivíduos e contra as psicopatias" (NASSIF, 2005, p. 80) por meio de ações profiláticas, bem como para a atuação nas questões de saúde dos trabalhadores, com a criação de serviços médicos em empresas e da cadeira de Medicina do Trabalho (BILLIARD, 1996; NASSIF, 2005). A orientação do movimento é essencialmente eugenista, na medida em que se definiam "tipos humanos" que melhor poderiam ser utilizados pela organização racional do trabalho (NASSIF, 2005) - o que também se verificou no Brasil, onde o discurso da Higiene Mental articulava psiquiatria, psicologia e eugenia. Uma definição de eugenia, por Renato Kehl, seria a de

[...] sciencia da boa geração [...]. Para a consecução de seus desígnios seleccionistas estabelece a seleção dos genitores [...]. Destaca-se o que diz respeito à esterilisação dos individuos inaptos para as boas procreações, degenerados somato-psychicos [...] incluindo entre estes os leprosos, loucos, idiotas, epilepticos, cancerosos, nefríticos, tuberculosos, prostitutas, vagabundos [...] A esterilisação dos degenerados e criminosos constitue uma das medidas complementares da politica eugenica, a qual estabelece, precipuamente, o exame de sanidade pré-nupcial, o impedimento à paternidade indigna, à procreação, em summa, de cacoplastas e desgraçados (KEHL, 1925 apud CARVALHO, 2010, p. 101).

Outras expressões de base eugênica se aplicariam à "eugenia psíquica" ou "mental", como a de "euphrenia", proposta por Mirandolino Caldas. Para ele, a disciplina seria dividida em "euphrenia genealogica", ou "estudo das linhagens (pedigrees) psychiatricas e psychologicas", e "euphrenia medico-pedagogica", mais voltada à formação da "bôa cerebração" (CALDAS, 1932 apud CARVALHO, 2010, p. 114).

Como coloca Jurandir Freire Costa (1979, apud MANSANERA; SILVA, 2000, p. 123), a prevenção eugênica destinava-se a formar um indivíduo brasileiro mentalmente sadio, 
"Mas esse brasileiro deveria ser branco, racista, xenófobo, puritano, chauvinista e antiliberal".

\subsubsection{Higiene Mental}

[Durante a República Velha, no contexto da industrialização, produziu-se um cenário favorável à] proliferação de tecnologias e para o trabalho de especialistas que investigavam sobre a saúde dos imigrantes, a situação sanitária dos portos, o dia a dia das cidades, a higiene infantil, os hábitos $e$ costumes populares, a eugenia ou "ideal de branqueamento" do povo brasileiro, o trabalho fabril (MANSANERA; SILVA, 2000, p. 117).

Interessavam aos dirigentes republicanos o controle higiênico dos portos e cidades, a avaliação da capacidade da força de trabalho e políticas demográfico-sanitárias que contemplassem a questão racial. Nesse sentido, como apontam os autores, o discurso médico-higiênico teria acompanhado esse processo de transformação política e econômica da sociedade brasileira (crescente industrialização e urbanização), expressando o pensamento de uma parte da elite dominante.

Como destaca Carvalho (2011, p. 36), foi nessa perspectiva e com esse compromisso de classe social que a medicina-psiquiatria passou a enfocar os aspectos "psíquicos" da força de trabalho. O objetivo dos "neuro-higienistas" era a "produção de trabalhadores hígidos do ponto de vista mental, produtivos e conformados, isto é, com o máximo de força de trabalho e o mínimo de força política: operários fortes e dóceis ${ }^{128 "}$.

A atuação higienista não deveria se restringir a "distúrbios", mas se estender à prevenção das "perturbações", tanto individual quanto coletivamente. É emblemático, nesse sentido, o discurso do psiquiatra Ernani Lopes no I Congresso Médico Paulista, de 1916:

\footnotetext{
Quem lance um olhar sobre o desenvolvimento da pshychiatria nos últimos tempos reconhecerá que essa sciencia já não se ocupa em exclusivo com o tratamento dos alienados durante a sua internação. Cada vez mais se verifica a necessidade que há da intervenção do psychiatra em numerosos casos de vida social. Si nos dedicassemos a fazer o estudo da mentalidade dos individuos socialmente desclassificados, encontrariamos as mais das vezes as causas de não exito em perturbações bem caracterizadas do dominio psychico.
}

\footnotetext{
128 Dócil, aqui, na perspectiva foucaultiana: “É dócil um corpo que pode ser submetido, que pode ser utilizado, que pode ser transformado e aperfeiçoado" (FOUCAULT, 1999, p. 118).
} 
Na Alemanha, sobrettudo, encontramos demonstrações diversas de que scientistas e homens administradores já compreenderam o alcance desse sério problema. Assim, é qui em várias sociedades de beneficiência e de assistência às classes pobres, discute-se com frequencia, sob o ponto de vista psychiatrico, varias questões que outrora eram vistas apenas sob um criterio estritamente moralistico (LOPES, 1925, apud MANSANERA; SILVA, 2000, p. 118-119).

Durante a Primeira Guerra Mundial e nos anos subsequentes, surgiram nacional e internacionalmente movimentos que problematizavam a noção de nacionalidade e davam destaque à questão racial, a maioria numa perspectiva eugênica de "desenvolvimento das forças nacionais" e de "melhoria racial". Esses movimentos, que no Brasil se organizaram em torno de "ligas" que reuniam representantes da elite intelectual e política do país, teriam sido responsáveis pela criação do Departamento Nacional de Saúde Pública, em 1923 (CARVALHO, 1999).

Em 1923, Gustavo Riedel fundou no Rio de Janeiro a Liga Brasileira de Higiene Mental (LBHM), considerada a instituição mais expressiva da psiquiatria eugenista e higienista, para a produção, circulação e consolidação do discurso da psiquiatria higienista brasileira a partir da década de 1920 (MANSANERA; SILVA, 2000; CARVALHO, 1999, 2010). Como destaca Carvalho (1999, s/p), sendo dirigida por psiquiatras e composta de membros da elite da classe médica brasileira e de juristas e educadores, ${ }^{129}$ a LBMH tornou-se o grande centro de propaganda em favor da "hygidez mental", cujo objetivo era a elaboração de programas de higiene mental baseados na noção de prevenção eugênica. ${ }^{130}$ Destaca-se, a partir de seus estatutos, um de seus fins: a "realização de

129 Carvalho (1999, s/p.) detalha a composição da Liga:

Seria importante notar que o quadro de membros honorários da LBHM possuía representantes da elite política e econômica. Esse grupo contava não só com o presidente da República, Arthur Bernardes, mas também com três ministros de Estado (Felix Pacheco, João Luiz Alves e Pires e Albuquerque), dois senadores (Conde de Frontin e José Euzebio), dois deputados (Carlos Maximiliano e Clementino Fraga), o prefeito do Distrito Federal (Alaor Prata), dois Conselheiros Municipais (Cesario de Mello e Mario Piragibe), um representante do funcionalismo público (Pereira Junior) e três representantes da indústria e comércio (Guilherme Guinle, Affonso Vizeu e Antônio Gomes Pereira). Caldas (1930) destaca o papel pioneiro e decisivo de Juliano Moreira, Ernani Lopes e Gustavo Riedel, fundador da LBHM e seu primeiro presidente. Além destes, Henrique Roxo, Plinio Olinto, Mauricio de Medeiros, Afranio Peixoto e Faustino Esposel são apontados como grandes dirigentes das primeiras campanhas em favor da "prophylaxia mental". Afranio Peixoto, Medeiros e Carlos Penafiel são especialmente citados por suas atuações na Câmara Federal.

130 Como coloca Caldas (1932 apud MANSANERA;SILVA, 2000, p. 122), 
um programa de higiene mental e de eugenética no domínio das atividades individuais, escolares, profissionais e sociais" (MANSANERA; SILVA, 2000, p. 127). Por meio de "Boletins e prospectos de propaganda", a LBHM se propunha a "diffundir nas camadas populares as normas de hygiene neuro-psychica já sancionadas pela unanimidade dos especialistas" (LBHM, 1925 apud CARVALHO, 2010, p. 106). Em 1925, a LBHM inaugurou sua publicação periódica, os "Archivos Brasileiros de Hygiene Mental" (ABHM). Carvalho (1999) destaca que a publicação, além de servir como órgão de difusão e propaganda dos preceitos da higiene mental, também favoreceu intercâmbio científico em termos nacionais e mesmo internacionais; em seu editorial de outubro de 1929, posiciona-se "como órgão official da Liga Brasileira de Hygiene Mental, tem uma grande e nobre missão a realizar: órgão de doutrina e de combate". O primeiro artigo original dos ABHM a tratar especificamente da "influencia do elemento psychico no trabalho humano" foi o publicado em 1925 por Carlos Penafiel, "O elemento psychico no trabalho humano: a Liga de Hygiene Mental e os novos horizontes da Saude Publica" (CARVALHO, 2010).

Em 1923 realizou-se o I Congresso Brasileiro de Higiene, no qual os participantes estabeleceram como objetivo "proteger higienicamente a coletividade, em nome da ordem e contra a anarquia do liberalismo, dos ideais igualitários, da promiscuidade e decadência urbanas". Seriam, então, suas atribuições a criação de hábitos "sadios" e o combate às "taras sociais", que levariam à realização "das grandes aspirações sanitárias do Estado: a robustez do indivíduo e a virtude da raça" - tarefa difícil em "uma grande nação com uma raça inferior, eivada pela mestiçagem, como eram os brasileiros" (MANSANERA; SILVA, 2000, p. 119).

Reivindicava-se, então, que se impedisse ou restringisse a entrada de imigrantes, sobretudo os que não fossem brancos; quanto aos brancos, apenas deveriam ser aceitos os que "possuíssem características superiores da raça": a raça branca seria "a única, sem exceção, que uma vez selecionada, convém à assimilação da nossa sub-

[...] quem quer que acompanhe, de perto, o grande movimento da hygiene mental no mundo, haverá de notar que os ingentes esforços dos neurohygienistas se vão orientando não somente no sentido da conservação da saúde psychica, mas tambem e sobretudo, no sentido da extincção das eivas hereditarias, de modo que a mentalidade das novas gerações possa, cada vez mais se aproximar do padrão psychologico ideal. 
raça, que innegavelmente evolui para o typo branco, ainda que impuro, o qual já lhe é predominante" (OLIVEIRA, 1932, apud MANSANERA; SILVA, 2000, p. 133).

Os ideais eugênico-higienistas, tendo em vista a consecução de seu projeto de busca e construção de homens hígidos e sadios, voltam-se então para as escolas. Difundia-se a ideia de que, na escola, se deveriam formar homens orientados para profissões adequadas, sem vícios e sem patologias mentais, que pudessem dessa forma viver em equilíbrio psíquico no meio social. A importância da escola/educação para a higienização social era fundamental no projeto higienista, pois não estaria a serviço apenas da transmissão de ensinamento, mas na avaliação dos alunos: "higienistas se questionavam se valiam os esforços dispendidos na alfabetização de uma grande massa de débeis mentais e desiquilibrados" (MANSANERA; SILVA, 2000, p. 215). Como apontam os autores, o sistema de ensino, na perspectiva da "escola nova",131 acolheu iniciativas favoráveis à utilização de testes mentais nas escolas, que auxiliariam na seleção dos alunos e na formação de turmas homogêneas do ponto de vista intelectual.

Verthein e Minayo-Gomez (2001, p. 462) analisam como, no Brasil, observa-se uma vinculação psiquiatria-Estado em um projeto de profilaxia social, desenvolvido a partir da elaboração do Regulamento/Código Sanitário Federal de 1923 (Departamento Nacional de Saude Pública) e das premissas que subsidiariam a criação da Liga Brasileira de Higiene Mental (LBHM). Esses regulamentos incluem no âmbito da saúde pública as questões de higiene industrial e profissional e a precaução contra a presença do "perigo genético das raças impuras". A higienização, fundamentada na teoria da degenerescência psíquica, tomava como alvo de assepsia o que era identificado como conduta "antissocial": trabalhadores, mendigos, prostitutas, alcoólatras. Os autores destacam como, progressivamente, tanto no discurso quanto nas práticas da medicina mental, o objeto central de atenção passou a ser o operariado urbano.

\footnotetext{
${ }^{131}$ A obra de Léon Walther teve sua tradução para o português e seu prefácio elaborados por Manuel Bergström Lourenço Filho que, inicialmente se dedicando à "psychotechnica" no contexto industrial, posteriormente alcançou projeção nacional como um dos mentores do movimento escolanovista (BERTOLLI FILHO, 1993).
} 
Os higienistas concebiam que as atitudes "anti-higiênicas" e "antissociais" decorriam, majoritariamente, da má adaptação ao trabalho (MANSANERA; SILVA, 2000, p. 131). Um exemplo analisado pelos autores seria o artigo publicado em 1929 nos ABHM por Faustino Esposel, "Do valor da orientação profissional em hygiene mental": o operário que exercesse contra sua vontade sua profissão, ou que não tivesse aptidão para exercê-la, ficaria em "estado depressivo", que poderia levá-lo aos vícios e aos "venenos sociais", sugerindo ser tênue a passagem da vadiagem ao crime, adquirindo o trabalho um valor profilático:

[...] a alegria no trabalho vale como um dos bons elementos, da prophilaxia das pertubações mentaes. [...] Pois certamente augmentará a produção nacional e crescerá a fortuna publica se cada cidadão trabalhar satisfeito, e exercendo o mister para o que tem aptidões naturais (ESPOSEL, 1929, apud MANSANERA; SILVA, 2000, p. 127).

Outro exemplo citado por Carvalho (1999, s/p) é um artigo publicado por Ernani Lopes nos ABHM em 1930, onde o autor discorre sobre as consequências da inaptidão do operário "ao seu officio": "ou o individuo reage por uma depressão que anniquila os restos de aptidão que ainda possua, ou, ao contrário, pela hypertrophia do proprio eu, o que o torna intratavel e antipathico". Também se encontram nesse texto referências quanto aos efeitos do processo de trabalho no "psychismo": são enfocadas as "causas de reacções psychopatologicas ligadas ás condições physicas, ao rhytmo e á duração do trabalho"; aponta-se que trabalho prolongado em "ambientes" superaquecidos poderia produzir "perturbações mentaes"; que ritmos intensos de trabalho associados à responsabilidade do operário no processo levariam ao aumento de "neurasthenia" — indicando, assim, a possibilidade de produção de "disturbios psychicos" associados ao trabalho. ${ }^{132}$ Como profilaxia e mesmo terapêutica para se evitar ou curar distúrbios psíquicos/mentais no trabalho, dever-se-ia "aconselhar distracções sadias e outros derivativos para o operario cujo desprazer no trabalho origina disturbios psychoneuroticos" e era "das organizações de hygiene mental [que deveria partir] o exemplo da selecção profissional" (LOPES, 1930 apud CARVALHO, 1999, s/p). Carvalho (1999,

\footnotetext{
132 Outra passagem ilustrativa dessa premissa é observada na obra de Ernani Lopes: "sem duvida, ha-de, em parte, encontrar-se nesse estado de morbidade nervosa a explicação das faceis revoltas e adopção de doutrinas extremistas por parte da laboriosa classe dos graphicos, em nosso Brasil"; quanto às greves, "devem ser consideradas [...] como reacções de defesa de inadaptaveis" (LOPES, 1930 apud CARVALHO, 1999, s/p).
} 
$s / p)$, a propósito dessa publicação, considera-a seminal no sentido de abrir "caminho para a problematização de uma psicopatologia do trabalho ou, se quisermos ser mais precisos, de uma psicopatologia do indivíduo trabalhador", numa enunciação “'psicologizante', que reduzia a dimensão política do conflito a disfunções da ordem do psiquismo 'individual'".

As concepções higienistas teriam impulsionado um discurso de subordinação do trabalho à dimensão "technica, medico-psychologica". Atuando na seleção, recrutamento, orientação e treinamento dos trabalhadores, na perspectiva de "adaptar o homem ao trabalho", teria favorecido também a difusão da psicologia experimental ("psychotechnica") no país. Os conflitos e movimentos coletivos de "insubordinação" eram interpretados como resultantes de "perturbação mental" ou "morbidade nervosa" de trabalhadores inadaptados, que eram tratados como "psicopatas" - quem sofria de patologia mental - ou "desequilibrados", potencialmente doentes. O "elemento psíquico" no trabalho humano constituía objeto de investigação e intervenção tendo em vista perspectivas adaptativas: "Saude mental', naquele momento, não significava um campo de saberes e práticas, mas sim um estado ou condição mental supostamente passível de se produzir (e reproduzir) 'mecanicamente' pelo método disciplinar" (CARVALHO, 2011, p. 38-39).

O movimento higienista teria repercutido tão fortemente, como observam Mansanera e Silva (2000, p. 123), que pode ser observado na Constituição de 1934, que em seu artigo 138 informava que "incumbe à União, aos Estados e aos Municípios, nos termos das leis respectivas":

a) assegurar amparo aos desvalidos, criando serviços especializados e animando os serviços sociais, cuja orientação procurarão coordenar; b) estimular a educação eugênica; c) amparar a maternidade e a infância; d) socorrer as famílias de prole numerosa; e) proteger a juventude contra toda exploração, bem como contra o abandono físico, moral e intelectual; f) adotar medidas legislativas e administrativas tendentes a restringir a natalidade e a morbidade infantis; e de higiene social, que impeçam a propagação de doenças transmissíveis; g) cuidar da higiene mental $e$ incentivar a luta contra os venenos sociais (BRASIL, 1934, grifo nosso).

Duarte (1998) também destaca como a literatura comprometida com a vulgarização dos saberes médicos, abundante e influente a partir do movimento higienista, influiu 
na medida em que o sistema do "nervoso" sustentaria por longo período os discursos médicos intervenientes em nossa sociedade.

A partir de meados dos anos 30, o discurso higienista, na análise de Carvalho (2011, p. 37), teria sofrido algumas modificações, mas "de superfície",

[...] como reflexo de um predomínio cada vez mais acentuado, no âmbito discursivo, da dimensão tecnológico-científica sobre a dimensão da moral e da política. Os textos passaram a abordar especificidades das técnicas de orientação e seleção profissionais. Enfatizava-se a dimensão da "psychotechnica", seu objeto de estudo e sua metodologia.

\subsection{Psicotécnica}

No contexto da industrialização, tornava-se necessário "produzir novas práticas de ensino e de profissionalização, fazer do brasileiro um novo trabalhador apto ao atual tipo de trabalho". Para esse fim, as ações deveriam se desdobrar em duas vertentes: a seleção da força de trabalho e a psicotécnica, "como ciência básica capaz de selecionar os trabalhadores pelas aptidões através da análise das tarefas, da análise das tendências e disposições de cada candidato" (MOTTA, 2004, p. 104).

Segundo Lacaz (1996), dado o interesse pela seleção da força de trabalho e de seu acompanhamento no trabalho, visando ao controle do "factor humano" quanto a acidentes e doenças no trabalho, era imprescindível que, em sua admissão, houvesse uma avaliação "científica" da sua capacidade física e mental de trabalho. A ferramenta ideal para esse fim seria a psicotécnica, "ancorada nas chamadas ciências do comportamento e capaz de medir as capacidades individuais e escolher o trabalhador mais adaptado para cada posto de trabalho". A preocupação com a organização racional e científica da produção se apresentava como recurso técnico-científico para aumentar a produtividade e o lucro, mas também para combater a "natural indolência" do trabalhador brasileiro (MOTTA, 2004, p. 104).

A Psicotécnica ofereceria "medidas científicas, estatísticas, cálculos, instrumentos científicos neutros e suficientemente confiáveis", que garantiriam a promoção de "um trabalhador cientificamente adequado às exigências de máxima eficiência com o 
mínimo de resistência" (MOTTA, 2004, p. 102, grifo da autora). ${ }^{133}$ Seria ainda um instrumento auxiliar para "A seleção de pessoal que permitiu aos tayloristas ter a organização perfeita: seres humanos ajustados às exigências minuciosamente descritas dos postos de trabalho", permitindo encontrar, na variabilidade, "as regularidades [...] que regem o comportamento de seus 'objetos naturais' [...] as leis que governam ditos objetos naturais" (BARRETO, 1925 apud LACAZ, 1996, p. 15). Ou, nos termos de Walther,

\begin{abstract}
Com a organisação verdadeiramente scientifica sahiremos do campo da rotina e do arbitrário. A admissão dos operários, sua selecção e divisão do trabalho segundo suas capacidades - operar-se-ão por methodos precisos. O progresso da psychologia applicada tem permitido examinar os indivíduos do ponto de vista de suas aptidões profissionaes. A pratica dos testes, notadamente, promete resultados muito perfeitos. Desse modo começamos a entrar na selecção scientifica (WALTHER, 1929, p. 57).
\end{abstract}

Nessa perspectiva, nos anos 20, o empresariado patrocinou a vinda ao Brasil de Henri Piéron (professor da Sorbonne) e de Léon Walther ${ }^{134}$ (professor da Universidade de Genebra), que ministraram cursos no ensino dos conceitos básicos da psicotécnica, que se apresentava como síntese das "ciências do comportamento" aplicada à realidade industrial. Paralelamente foram criadas entidades representativas, como o Centro das Indústrias do Estado de São Paulo (CIESP), de 1928, e institutos para desenvolvimento de pesquisas, como o Instituto de Organização Racional do Trabalho (IDORT), em 1931 (MOTTA, 2004; BERTOLLI FILHO, 1993).

Motta (2004) chama atenção para estudos de Fisiologia, Psicotécnica, Psicologia, Higiene Mental e do Trabalho que se desenvolveram, desde início da década de 20, a partir do Instituto de Higiene e da Escola Politécnica. Uma das vertentes se dedicava a analisar a adaptação psicofísica do homem à máquina, tendo como meta aumentar o

\footnotetext{
133 Os desdobramentos da psicotécnica e dos princípios tayloristas também se fariam presentes na educação. Em 1925, na Escola Normal da Praça, com a visita do psicólogo Henri Pièron, "foram desenvolvidos ensaios em torno de Orientação Profissional, Psicologia e Pedagogia. Essas inovações pedagógicas tiveram desdobramentos na renovação do ensino, tendo como um dos principais educadores adeptos da novidade Lourenço Filho" (MOTTA, 2004, p. 102).

134 León Walther, especialista em Psicologia Industrial, veio ao Brasil ministrar cursos e conferências patrocinados pela "Associação Comercial de São Paulo", em 1929 (MOTTA, 2004). Sua obra, traduzida e publicada no Brasil em 1929, foi assim prefaciada por Claparède: "princípio da racionalização do trabalho, caldeado ao profundo calor da sympathia pelo operário - Taylor corrigido pela psychologia tal é, nos parece, em suma, a obra de León Walther, tão benéfica quanto engenhosa" (CLAPARÈDE, 1929, p. 7, grifo nosso).
} 
rendimento do trabalho, diminuir a fadiga e os riscos de acidentes, estudos que teriam sido aplicados em 1923 no Liceu de Artes e Ofícios, onde se criou um Curso de Mecânica Prática. Esse curso, considerado pela autora "precursor do IDORT", teria sido pioneiro no uso da Psicotécnica para a seleção de aprendizes e profissionais mecânicos. Em 1925, o curso teria se ampliado tanto que se transformou na Escola Profissional Mecânica, pautada pela aplicação de métodos psicotécnicos e exames de aptidões.

A Psicotécnica se diferenciaria da Tecnopsicologia, que seria, nos termos de Walther $(1929$, p. 47),135 "a applicação da psychologia à technica do trabalho. [...] Seu domínio é exclusivamente technico e se limita à maneira de trabalhar". Dessa forma, a Tecnopsicologia se dedicaria à adaptação da máquina e do ambiente fabril ao homem, e a Psicotécnica, à adaptação do homem à máquina (MOTTA, 2004).

Para Walther (1929),136 a organização científica e a Psicotécnica permitiriam identificação de aptidões, a seleção e admissão dos trabalhadores, e a divisão do trabalho segundo suas capacidades, visando a "mais eficiente utilização do elemento humano", por meio da análise científica (Psicotécnica):

O objectivo visado pela analyse psychologica do trabalho é o de dar conta das aptidões que intervenham na realisação de um trabalho considerado. Facilmente percebemos que os differentes trabalhos da fabrica fazem appello a differentes funcções psychicas; ou que se appellam para as mesmas aptidões o fazem em grau differente.

Para chegar à descoberta das aptidões requeridas num determinado trabalho industrial, a analyse scientifica appella, simultaneamente, para muitos methodos. São elles os seguintes: Inquérito: conversação ou questionário. Observação. Composição de uma lista provisória das aptidões suppostas como necessárias a determinado trabalho. Organisação dos meios destinados a descobrir ou verificar as aptidões (testes). Verificação experimental e mathematica das aptidões provisoriamente estabelecidas (WALTHER, 1929, p. 59-60).

\footnotetext{
135 Será mais destacada a contribuição da obra de Léon Walther, uma vez que, no Brasil, "fez escola", em sua passagem pelo país no final dos anos 20 e em seu retorno, no final dos anos 40 .

136 É curioso encontrar na obra de Walther (1929) críticas a Münsterberg e a Taylor. Com relação a Taylor, afirma que "Acreditamos mesmo que a sciencia actual tenha ultrapassado o taylorismo, senão em todas as questões por elle abordadas, ao menos na maior parte dos problemas que pretende resolver" (ibid., p. 22) e "Taylor se nega a crer que o methodo mais racional do trabalho seja encontrado pelo próprio operário" (ibid., p. 25). Já sobre Münsterberg, escreve: "Tanto a obra de Dill Scott, como a de Münsterberg, tem hoje valor histórico, apenas. Foram ultrapassadas de muito" (ibid., p. 19).
} 
Por meio da Psicotécnica, o elemento humano ou psíquico inadequado poderia ser identificado, ou diagnosticado, pois, como coloca Carvalho (2010), se apresentaria como "sintoma". Já as "boas" qualidades mentais poderiam ser valorizadas e mesmo prescritas, produzidas e reproduzidas, a partir de orientações médico-pedagógicas e psicológicas. Um exemplo de "programa" de ação científica nesse sentido é o apresentado por Carlos Penafiel:

As tres diretrizes principaes dessa ordem de investigações devem relacionar-
se, segundo as melhores autoridades no assumpto, com as tres questões
praticamente mais importantes para o homem de negócios e para o
industrial em procura de bons colaboradores e operarios uteis: 1- Como
conhecer as qualidades mentaes que fornecerão o melhor rendimento para
os trabalhos a executar; 2- Que condições psychologicas asseguram o
melhor e o mais considerável rendimento de trabalho; 3- Que meios
educativos elevarão ao maximo as faculdades de que a Industria e o
Commercio têm necessidade (PENAFIEL, 1925, apud CARVALHO, 2010, p.
104).

A busca da legitimação das proposições da Psicotécnica por meio de argumentos de sua cientificidade, bem como a busca de aplicação, não apenas ao contexto fabril, pode ser exemplificada pelo prefácio de Lourenço Filho à edição brasileira da obra de Léon Walther:

Nada mais característico de nossa época que a applicação da sciencia a toda actividade humana. Essencialmente experimentalista e pragmático, o homem de hoje tudo procura submetter ao domínio da experiência systematizada, à verificação e controle scientifico. Essa tendência se manifesta mesmo no campo social, nas novas formas de educação, de prevenção do crime, de organisação tributária. Mas é ainda no terreno econômico que encontra seus mais prementes problemas (LOURENÇO FILHO, 1929, p. 3).

Observaram-se, crescentemente, investimentos em estudos pormenorizados das funções psicomotoras, sensoriais, cognitivas e intelectuais do trabalhador, numa produção conceitual cada vez mais sofisticada, que tendia a tornar o campo cada vez mais especializado, "onde somente o homem de ciência poderia penetrar" (CARVALHO, 2011, p. 37). 


\title{
5.2.2 A PSICOLOGIA ORGANIZACIONAL
}

Como define Jacques (2007, p. 114), o surgimento da Psicologia Organizacional está ligado à noção de organização, "enquanto entidade ontológica", como objeto da Psicologia. Em 1972, Bergamini (p. 41) apontava:

[...] é notável o crescente interesse das empresas brasileiras na procura de novas técnicas especializadas em avaliação, desenvolvimento, adaptação e compensação de seus recursos humanos [...]. Essas aspirações dos homens de empresas estão vitalizando o desenvolvimento da área mais nova de especialização da Psicologia, aquela que diz respeito aos aspectos psicológicos da organização empresarial.

A Psicologia Organizacional não representaria uma ruptura com as premissas da Psicologia Industrial: apesar de apresentar variações no que tange ao "objeto" construído, conservaria certa "regularidade discursiva e convergência em relação ao objetivo, finalidade social, compromisso ético-político, alvo das ações, bases teóricas e elementos discursivos" (CARVALHO, 2011, p. 43). Carvalho (2011) vai mesmo chamar essa abordagem de PIO - Psicologia Industrial e Organizacional, pois

\begin{abstract}
No que diz respeito aos objetivos, ao objeto e à relação sujeito-objeto de investigação, a tônica geral desses textos é essencialmente a mesma que caracteriza a produção discursiva desde os anos 1920. Referindo-se às funções do psicólogo na empresa, Bergamini (1972) [...] sustenta que ele deve "assegurar condições cientificamente favoráveis ao ajustamento do homem [...] e a partir do estudo de condições físicas ambientais, atingir o assessoramento das grandes linhas das políticas empresariais". Lourenço Filho $(1969,1971)$ também era claro quanto à clientela e finalidade social: o papel do ISOP era desenvolver "importantes trabalhos de pesquisa, destinados, em especial, a atender a grandes setores da organização do trabalho no Brasil” (CARVALHO, 2011, p. 51). ${ }^{137}$
\end{abstract}

A Psicologia, a Ergonomia e a Profissiografia, com seu estatuto de cientificidade, continuariam a possibilitar empregar o "homem melhor adaptado para determinada função, evitando insatisfações e afastando os inadequados" (LACAZ, 1996, p. 15). Referindo-se às funções do psicólogo na empresa, Bergamini indicava que ele deveria

137 Carvalho (2011, p. 52) vai mais além, pois, para ele, não haveria ruptura discursiva entre as abordagens da "PIO" e da Higiene Mental:

[...] no que tange às dimensões do objeto, das referências teóricoconceituais, dos objetivos imediatos e do compromisso de classe social [...] não chega a haver ruptura ou descontinuidade entre os discursos HMT [Higiene Mental do Trabalho] e PIO [Psicologia Industrial e Organizacional], mas tão somente 'desenvolvimento', uma sofisticação discursiva e técnica. 
"assegurar condições cientificamente favoráveis ao ajustamento do homem [...] e a partir do estudo de condições físicas ambientais, atingir o assessoramento das grandes linhas das políticas empresariais". Quanto à sua atuação, diz que

[...] a ação do psicólogo visa o verdadeiro ajustamento do homem consigo mesmo, com o grupo social em que desenvolve suas atividades de trabalho e com as circunstâncias ambientais que o envolvem, buscando alcançar a produtividade como [...] necessária consequência desse ajustamento e autorrealização (BERGAMINI, 1972, p. 41)

Já Zanelli (1986, s/p.) define o objeto de trabalho da atuação em Psicologia Organizacional como

[...] as relações entre as condições de ajus-tamento da organização em seu ambiente, das relações de interdependência de seus subsistemas e os fatores que determinam tais relações - isto tudo no que concerne especificamente aos recursos humanos.

Segundo Sampaio (1999), a Psicologia Organizacional se organizaria na medida em que os profissionais dirigiriam o "olhar" anteriormente voltado para o estudo e análise dos postos de trabalho (premissa para "colocar o homem certo no lugar certo"), passando a abranger também a discussão das estruturas da organização. $O$ autor considera essa prática apenas uma ampliação dos objetivos de estudo da Psicologia Industrial, na medida em que os psicólogos continuariam atrelados aos problemas de produtividade nas empresas. Seu caráter instrumental teria supervalorizado as teorias comportamentais na Psicologia, que maximizariam a influência do ambiente no comportamento humano, minimizando, por exemplo, influências intrapsíquicas, reduzidas ao âmbito da satisfação e dos estudos de motivação.

Privilegiaram-se, ainda segundo Sampaio (1999), propostas de mudança planejada das organizações, como o Desenvolvimento Organizacional (DO) e Desenvolvimento Gerencial (DG). A perspectiva seria a da redução e evitação de conflitos e a ênfase, na preparação de mão de obra (Desenvolvimento Interpessoal - DI), técnicas sociométricas, treinamento e desenvolvimento de Recursos Humanos (RH), dinâmica de grupo norte-americana, Análise Transacional. Sua orientação "prescritiva e tecnocrática" conferiria à sua prática um caráter de engenharia social.

A dimensão do poder, até então não tematizada, passaria a ser discutida como "relações de poder na organização", embora delimitada a espaços restritos e reduzida 
a "estilos negativos de direção"; "conflitos intergrupais e interpessoais"; "relacionamento interpessoal deficiente"; entraves à competitividade e ao desempenho organizacional (SAMPAIO, 1999). As dinâmicas de grupo passam a ser utilizadas como meios de identificação de indivíduos que não fossem capazes de lidar de "forma saudável" com a competição ou que pudessem extrapolar no exercício do poder. Como bem destaca Carvalho (2011, p. 45), “o conceito de 'relações humanas' ganha sentido mais amplo à medida que a relação indivíduo-contexto organizacional vai sendo construída como objeto de estudo e intervenção".

O contexto discursivo passou a articular noções como "clima", "cultura" e "saúde organizacional", cabendo ao psicólogo atuar na produção de um "bom" clima organizacional, "contornar" as contradições e mediar conflitos, intervindo na cultura organizacional sem transformá-la. A partir dos anos 70, observa-se um "desenvolvimento técnico-discursivo" da Psicologia Organizacional, que amplia sua área de atuação. Para além das atividades de recrutamento, seleção e orientação profissionais, ganham espaço práticas ligadas a treinamento, avaliação, desenvolvimento e gestão de pessoal, organização do trabalho, ergonomia, comunicação organizacional. Aprimoram-se os mecanismos de recrutamento, seleção e treinamento, bem como de "gerenciamento de crises" e de "índices de satisfação no trabalho"; desenvolve-se um novo discurso psicológico sobre o absenteísmo e a rotatividade de pessoal (CARVALHO, 2011).

Programas de saúde (ou Saúde Mental Ocupacional138) e de Qualidade de Vida no Trabalho fazem parte da agenda da Psicologia Organizacional, sendo apontados como obstáculos à sua consecução a conformação da cultura organizacional e o clima de conflito e competição entre grupos. "Esses programas, não raro, convertem-se em dispositivos atenuadores da tensão, em controladores do chamado estresse ocupacional" (CARVALHO, 2011, p. 45).

As mudanças introduzidas pelo contexto de reestruturação produtiva demandariam uma atuação pautada pelo discurso da flexibilidade, da formação contínua e da

138 Uma discussão sobre a Saúde Mental Ocupacional é realizada na seção 5.2.2.1.1. 
multifuncionalidade e uma sofisticação dos conceitos e dispositivos da Psicologia Organizacional (CARVALHO, 2011, p. 44).

Prilleltensky (1994, p. 5) chama atenção para duas premissas da Psicologia Organizacional: 1) a empresa é basicamente um empreendimento livre de conflitos de classe e 2) a psicologia organizacional é uma ciência social. A primeira premissa partiria de um pressuposto implícito de que empresários e empregados trabalhariam pelos mesmos objetivos, mascarando contradições fundamentais entre os interesses de ambas as partes. Nesse contexto, o conflito seria tratado em uma linguagem psicológica, oposta a uma linguagem de classe. "O conflito é visto como o resultado de mal-entendidos psicológicos, não como o resultado de uma distribuição desigual de poder". Já a segunda premissa partiria de uma "doutrina tecnocrática [que] trata todos os problemas humanos como problemas técnicos".

Outras questões apontadas por Prilleltensky (1994) seriam referentes aos mecanismos da Psicologia Organizacional de manutenção do status quo: a) personalização de conflitos, b) a abordagem cooperativa, c) profissionalização de decisões gerenciais. A personalização dos conflitos partiria da atribuição dos problemas dos trabalhadores a causas internas. Já a abordagem "cooperativa" se basearia em estratégias de controle que não despertassem resistências, ou de "poder suavizado". Na profissionalização das decisões gerenciais, ao profissionalizar o processo de tomada de decisões, a organização se beneficiaria por desviar as atenções da arena política.

Nesse sentido também há a análise de Lima (1996b, p. 31) sobre as "novas políticas de $\mathrm{RH}^{\prime}, 139$ que teriam como características, "utilização de conceitos das ciências humanas: as novas formas de gerenciamento querem ser vistas como 'científicas', deixando 'de ser um campo de amadores"', e a valorização do consenso: "para evitar os conflitos e melhor administrar as contradições, essas novas políticas tentam sempre construir uma 'comunidade de trabalho' consensual, além de alcançar a adesão dos trabalhadores aos princípios, valores e objetivos da organização".

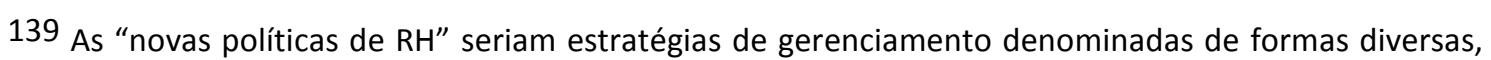
como "gerenciamento estratégico participativo", "gerenciamento de terceiro tipo", "pós-fordismo" (LIMA, 1996b, p. 23). 
Lima (1996b) destaca como elementos centrais dessas políticas o discurso de participação, iniciativa, inovação e maior liberdade, ao mesmo tempo em que apregoam conformidade às normas, consenso e adesão ao projeto proposto pela empresa. O controle seria um elemento central dessas políticas, contudo, mais que pela imposição de ordens e proibições (substituídas, em grande parte, por normas e princípios), ele se daria pela adesão e interiorização das regras.

Essas políticas de gestão, segundo Lima (1996b), exerceriam influência sobre a economia psíquica, e demandariam um trabalhador as if (como se), " um sujeito que se adapte a qualquer forma de comportamento mais adequada para a conquista do sucesso individual" (NARDI; RAMMINGER, 2012, p. 384). Na mesma linha, afirma Enriquez (1996, p. 10):

[...] [as políticas de gestão operariam] através da organização de uma gestão do afetivo - senão do inconsciente - dos membros da organização, suscita[ndo] neles uma paixão pela empresa e o desenvolvimento de um imaginário da performance e da excelência. Ela [a organização] se serve, então, de ideias e teorias formuladas por pesquisadores em ciências humanas, para desviá-las para melhor seduzir e impulsionar, não somente seus gerentes, mas todo o conjunto de seu pessoal, a uma identificação com os valores da empresa.

Sato (2013, p. 102), a partir de discussão de trabalho de Pulido-Martínez (2007), também aborda o papel que o discurso psicológico, especificamente o da Psicologia Organizacional, desempenharia na construção da subjetividade do trabalhador:

[...] a psicologia produzida no hemisfério norte adentra os países do sul e se apresenta como discurso que norteia a construção da subjetividade, de modo a operar uma subjetividade "em desenvolvimento" para outra que seria "moderna" e necessária para se alcançar o desenvolvimento nacional.

Lima (2002, p. 126) chama atenção para avaliações de cunho moralista (ou de viés nitidamente psicologizante) feitas por psicólogos organizacionais sobre situações que enfrentam no seu dia a dia, afirmando que, "quase sempre, desconhecem os problemas para os quais são convocados a propor soluções". E prossegue:

Assim, são comuns as tentativas de rotular as pessoas como "irresponsáveis", "sem compromisso com a empresa e com os resultados do seu trabalho" ou "difíceis no trato pessoal", quando a análise mais aprofundada das situações traz à tona problemas graves na organização do trabalho e que são, em grande medida, responsáveis pelas atitudes adotadas por essas pessoas. O impacto mais nefasto de tudo isso sobre a realidade parece-nos mais do que evidente: o desconhecimento do que 
efetivamente está ocorrendo conduz a diagnósticos equivocados e, portanto, a ações inadequadas.

Já Seligmann-Silva et al. (2010a, p. 187) destaca que, embora a globalização, as inovações tecnológicas e as novas formas de gestão tenham promovido rápidas transformações no mundo do trabalho, "o pensamento tradicional das áreas da Medicina do Trabalho, da Saúde Ocupacional e da Psicologia dá pouca atenção para essas mudanças e para o aspecto do trabalho como mediador de integração social, seja pelo valor econômico, seja pelo valor cultural". A Medicina do Trabalho e a Saúde Ocupacional continuariam a se pautar pelo foco nos aspectos físicos, mecânicos, químicos e biológicos dos ambientes laborais como fatores de risco à saúde dos trabalhadores, enquanto que, na Psicologia, esse foco

[...] ainda se concentra nos aspectos intrassubjetivos e, quando muito, estende-se aos intersubjetivos. Os aspectos sociais, econômicos e organizacionais, assim como os processos psicossociais em minimizados ou suas repercussões sobre a subjetividade do trabalhador, são ignorados (SELIGMANN-SILVA, 2010a, p. 187).

As aproximações entre o modelo da Saúde Ocupacional e a prática da Psicologia Organizacional são várias. Ambas fortemente destacam a importância atribuída a fatores ambientais, como a relação ambiente de trabalho/satisfação (psicologia) e ambiente de trabalho/adoecimento (medicina), fatores ambientais tomados numa acepção estrita referindo-se essencialmente a dados "objetivos", biológicos, ergonômicos, químicos. A lógica subjacente é a da exposição a condições insatisfatórias/insalubres, fazendo-se necessárias medidas adaptativas e, sobretudo, normatizadoras.

Ganharam destaque, sobretudo no final da década de 70, projetos de normalização/padronização das relações interpessoais e dos processos de trabalho, como os sistemas de gerenciamento da "qualidade". A fuga aos padrões ou, mais exatamente, a ideia da inadaptação, dá a tônica para ações de contenção de problemas como agravos à saúde e conflitos. O conceito de "ato inseguro" também se respalda fortemente nessa ótica - o acidentado é o inadaptado, o individualmente desajustado. 
Surgem concepções de multidisciplinaridade e de atuação multiprofissional. Com a ampliação da noção de ambiente, não mais seria possível agir somente sobre o corpo do trabalhador, nem agir isoladamente: "diferentes disciplinas (engenharia, ergonomia, medicina, psiquiatria, psicologia etc.) investiram o seu olhar (cada qual com seu arsenal específico de saberes e práticas) sobre o trabalhador e sobre 0 ambiente de trabalho" (CARVALHO, 2011, p. 40).

\subsubsection{Abordagens / Paradigmas correlacionados}

A seguir, apresentam-se abordagens/paradigmas correlacionados à Psicologia Organizacional.

\subsection{Saúde Mental Ocupacional}

Prilleltensky (1994) situa como importante "ponto de partida" para a Psicologia Organizacional a Saúde Mental Ocupacional. Seligmann-Silva (1994), Sato e Bernardo (2005), Sato (2010) e Faiman (2012) discutem como, a partir da década de 20, nos EUA, iniciaram-se atividades chamadas de Saúde Mental Ocupacional.

Prilleltensky (1994) também situa as origens da Saúde Mental Ocupacional nos EUA na década de 20, a mesma época em que se iniciavam os experimentos de Hawthorne. Já em 1919, Southard teria conduzido, em Harvard, estudo sobre possíveis problemas psiquiátricos de trabalhadores demitidos, relatando que "60 por cento de mais de 4.000 casos atingiram o status de desempregados por meio de traços de incompetência social mais do que de incompetência ocupacional" (PRILLELTENSKY, 1994 , p. 3). O primeiro psiquiatra em tempo integral a trabalhar em uma empresa norte-americana foi contratado em 1922. Muitas empresas passariam a oferecer assistência à saúde mental de seus empregados por meio de programas de assistência.

De acordo com Seligmann-Silva (1994), os estudos sobre a temática surgem sob denominações como Psiquiatria Ocupacional, Saúde Mental Ocupacional e Psiquiatria Industrial. 
Como colocam Prilleltensky (1994) e Sato e Bernardo (2005), a Saúde Mental Ocupacional, como prática, privilegiaria a oferta de assistência psicoterápica aos trabalhadores; o trabalho, suas condições e sua organização seriam tomados apenas como pano de fundo dos problemas que demandavam essa assistência, e cálculos de custo-benefício seriam os argumentos para a oferta de psicoterapia.

Sato e Bernardo (2005, p. 870) consideram que a Saúde Mental Ocupacional, ao buscar a gênese dos problemas de saúde mental dos trabalhadores no universo intraindividual, contribuiria para construir a explicação que "culpabiliza a vítima".

Um exemplo de apresentação mais detalhada sobre a proposta da Saúde Mental Ocupacional pode ser encontrado em Lewis e Pearson (1960/1964); ainda na perspectiva da consideração da questão sob o prisma da análise de custo-benefício, afirmam os autores: "o custo combinado, para o comércio e indústria [norte] americanos, do alcoolismo, do absenteísmo, dos acidentes, da produção inferior ao padrão, e das contendas entre empregados e empregadores, devido a problemas emocionais e mentais, tem sido estimado em mais de três bilhões de dólares anuais" (LEWIS; PEARSON, 1960/1964, p. 61). E prosseguem:

\begin{abstract}
Quanta produtividade e eficiência operacional se têm irreparavelmente perdido por rivalidades neuróticas e ressentimentos dentro de uma empresa comercial? Quantas vezes tem falhado a comunicação intraorganizacional porque as partes eram tão incompatíveis temperamentalmente que nenhuma podia aceitar uma declaração ou uma ordem da outra independentemente de seu mérito ou razão? Quantas "operações-tartaruga", quantas greves de braços cruzados ou abertamente declaradas obedecem a causas derivadas de um pensamento ou comportamento irracionais por parte da gerência, da supervisão, dos subordinados ou dos representantes sindicais? Quantos negócios faliram, quantos empregos se perderam para sempre, porque houve gerentes incapazes de pensar realisticamente, ou que se opunham a inovações, apegando-se ao passado, ou que aderiam obstinadamente a normas de fabricação, de marcação de preços ou de distribuição reconhecidamente insensatas?
\end{abstract}

Nesse sentido, para os autores, a questão da "saúde emocional" seria um problema para o qual se deveria recorrer à assistência psiquiátrica. Como expõem os autores,

[...] de cada quatro trabalhadores nos Estados Unidos, um apresenta distúrbios da personalidade que vão desde a ansiedade e as doenças psicossomáticas até desordens mentais severos, como a esquizofrenia, que se estima afligir $1 \%$ das forças do trabalho. Tais perturbações [...] são as causas reais de muitas das dificuldades mais comuns dos empregados na indústria: alcoolismo, acidentes, resistência à autoridade, alta mobilidade de 
pessoal, faltas ao trabalho, reclamações crônicas. As doenças emocionais motivam mais absenteísmo do que qualquer outra doença, salvo o resfriado comum, e os psiquiatras acreditam que $70 \%$ dos que são dispensados por outras razões (brigas com os chefes, trabalho imperfeito) sofrem realmente de distúrbios emocionais (LEWIS; PEARSON, 1960/1964, p. 62).

\subsection{Abordagens sobre Estresse}

Mesmo que autores como Seligmann-Silva (1994, 2011), Glina et al. (2001), Jacques (2003) e Araújo (2011) considerem os estudos sobre estresse como abordagens relacionadas à Saúde Mental e Trabalho (ou, nos termos de Seligmann-Silva, Saúde Mental Relacionada ao Trabalho), entende-se neste trabalho que o campo da Saúde Mental e Trabalho (discutido na seção 5.2.3.1.1) possui características e pressupostos teórico-metodológicos distintos dessas abordagens sobre o estresse. Como se discutirá nessa seção, as ações de prevenção e intervenção das teorias sobre o estresse seriam voltadas essencialmente para o gerenciamento individual do estresse, baseadas em treinamento em habilidades cognitivo-comportamentais ou mudanças de hábitos / estilo de vida, numa perspectiva que individualiza a questão, sendo raras as medidas preventivas ou de atuação sobre o ambiente de trabalho ou sobre a organização. As abordagens em Saúde Mental discutidas na tese, embora apresentem uma série de divergências, possuem pontos de acordo como a discussão e análise das condições e organização do trabalho, e a consideração do trabalho como espaço estruturador da vida subjetiva, relacionado ao adoecimento e sofrimento mental. Além disso, a Saúde Mental e Trabalho possui estreita afinidade com o campo da Saúde do Trabalhador (sendo mesmo considerada por alguns autores, como se discutirá, uma subárea desse campo). Já os estudos sobre estresse apresentam, pelas questões expostas, maior afinidade com a Saúde Ocupacional e com os pressupostos da Psicologia Organizacional.

O conceito de estresse vem sendo cada vez mais utilizado, tanto no meio acadêmico quanto nos meios de comunicação e no dia a dia. Segundo Jacques (2003), essa popularização teria contribuído para o vínculo entre trabalho e saúde/doença mental. Essa popularização também se reflete no grande número de estudos publicados a 
respeito, e que não serão aqui revistos; apenas serão apresentados alguns de seus pressupostos, bem como algumas críticas ao conceito.

Seligmann-Silva (2011, p. 124) chama atenção para a hegemonia do conceito, presente nas "formulações adotadas pelos especialistas responsáveis por elaborar a categorização e as rubricas referentes a um amplo conjunto de distúrbios mentais, relacionados ao trabalho", na CID-10. Por outro lado, autores como Jacques (2003) e Carvalho (2011) destacam sua imprecisão conceitual e utilização não criteriosa. Segundo Jacques (2003, p. 101) o termo seria utilizado tanto para qualificar um estado de irritabilidade como um quadro de depressão grave. Além da polissemia conceitual, seria observada também "pouca clareza na distinção entre fatores estressores, coping e estresse propriamente dito, e entre estresse biológico, psicológico, social, ambiental, entre outros". Já para Carvalho (2011, p. 62), a utilização "indiscriminada” da teoria do estresse no âmbito das relações entre psiquismo e trabalho "transformou o conceito de estresse em uma espécie de "superconceito" que justificava, de forma reducionista, todo o sofrimento humano no mundo do trabalho".

O termo estresse, tomado da Física, teria sido aplicado originalmente aos fenômenos humanos em 1936 por Hans Selye, designando as reações do organismo mediante um esforço de adaptação a uma dada situação (PEREIRA, 2015). Selye assim designaria uma "síndrome geral de adaptação" constituída por três fases: reação de alarme, fase de adaptação, fase de exaustão; essa definição teria forte dimensão biológica, inclusive de pesquisas sobre os processos neuroendocrinológicos envolvidos (JACQUES, 2003). Uma vez diante de situações desencadeantes de estresse, consideradas estímulos estressores, os indivíduos devem produzir uma resposta que, se positiva, indica adequada adaptação; caso seja negativa (processo adaptativo inadequado), teria lugar a instalação do estado de estresse (PEREIRA, 2015). Já Bergamini e Tassinari (2008, p. 31) dizem que o estresse envolve dois eventos simultâneos: "um estímulo externo, chamado estressor, bem como a reação emocional e física a esse estímulo. Essas reações podem ser medo, ansiedade, diferenças de ritmo de respiração e do batimento cardíaco, tensão muscular e muitas outras".

De acordo com Seligmann-Silva (2011, p. 125), essa perspectiva inicial calcada em uma estrita visão fisiológica teria originado posteriormente direcionamentos diversos de 
pesquisa. Alguns pesquisadores teriam se dedicado a investigar os aspectos cognitivos envolvidos, sobretudo possibilidades de desenvolvimento de alternativas, por meio de aprendizagem, pelos indivíduos, de formas de lidar com os estressores, "logrando modos de adaptação e, portanto, de prevenção dos distúrbios da saúde". Outros teriam destacado em seus estudos a importância dos fatores sociais, tanto em sua atuação como estressores, quanto em sua atuação favorecendo possibilidades preventivas; especificamente nos estudos sobre estresse vinculado ao trabalho, "a identificação de fatores estressantes e os elementos situacionais configuradores de apoio social têm sido objeto de numerosas investigações".

O referencial cognitivo comportamental seria basilar para "o amplo campo das teorias sobre estresse psicológico e que sustentam os modelos de prevenção, diagnóstico e intervenção propostos", destaca Jacques (2003, p. 102). As intervenções pautam-se essencialmente por mudanças cognitivas, no sentido da indicação, para os indivíduos, da formulação de expectativas realistas e da reavaliação de crenças, além de recomendações de "tratamento comportamental visando à aprendizagem de novas reações diante dos estressores, e sugestões de busca de apoio por psicólogo ou psiquiatra, com uso de medicação conforme o caso" (PEREIRA, 2015, p. 53).

O estresse psicológico seria definido como uma relação entre a pessoa e o ambiente, avaliada como prejudicial ao seu bem-estar. Destaca-se "avaliação cognitiva da situação (o fator estressor), que determina por que e quando esta situação é estressora e para o esforço de enfrentamento, ou seja, a mudança cognitiva e comportamental diante do estressor" (JACQUES, 2003, p. 101). Já o conceito de coping seria "o conjunto de estratégias cognitivas e comportamentais utilizadas para avaliar e gerenciar as exigências internas e/ou externas, com base nas experiências pessoais e nas especificidades do estímulo".

Glina et al. (2001) destacam, no campo de estudos sobre estresse, autores escandinavos como Frankenhaeuser e Gardell, Kalimo, Levi, que definem estresse como um desequilíbrio entre as demandas do trabalho e a capacidade de resposta dos trabalhadores. Seligmann-Silva (2011, p. 126) chama atenção para uma perspectiva muito difundida a partir dos anos 80, o modelo tridimensional do ambiente psicossocial de trabalho de Karasek e Theorell, cuja análise se detém sobre três eixos 
básicos: 1) as exigências do trabalho; 2) os níveis de apoio social ao executante das tarefas; e 3) os níveis de controle do trabalhador sobre o próprio desempenho. Conforme Glina et al., a situação saudável de trabalho seria a que permitisse o desenvolvimento do indivíduo, alternando exigências e períodos de repouso com o controle do trabalhador sobre o processo de trabalho.

Araújo (2011) coloca que, da necessidade de uma abordagem específica da teoria do estresse referente ao mundo do trabalho, teriam sido cunhados termos como estresse ocupacional ou síndromes específicas, como a síndrome de burn-out que, no Brasil, tem sido objeto de várias investigações.

Jacques $(2003$, p. 103) chama atenção para a prudência necessária às generalizações das teorias sobre o estresse, sobretudo no que tange à síndrome de burn-out (ou síndrome de esgotamento profissional), "uma reação à tensão emocional crônica e que envolve três componentes: a exaustão emocional, a despersonalização e a diminuição do envolvimento pessoal no trabalho". Essa síndrome tem maior prevalência e reconhecimento entre profissionais da área de serviços e cuidadores. Jacques $(2003,2007)$ argumenta que, se é possível identificar e estabelecer uma associação da síndrome a determinadas categorias profissionais, o trabalho deveria ser considerado como tendo função constitutiva no adoecimento, e não apenas um fator desencadeante, como é tomado nessa abordagem. Nos termos da autora, "embora [haja] a consideração sobre a natureza do trabalho, o enfoque ainda dicotomiza a dimensão externa e interna em que a natureza do trabalho se apresenta como fonte de tensão individualmente experimentada pelo trabalhador" (JACQUES, 2003, p. 103).

As ações de prevenção e intervenção baseadas nas teorias sobre o estresse seriam voltadas essencialmente para o gerenciamento individual do estresse, por meio de mudanças cognitivas e comportamentais e práticas de exercícios físicos e relaxamento (JACQUES, 2003, p. 103). Dessa forma, o principal alvo seria o trabalhador, por meio de abordagens orientadas para, por exemplo, melhoria de habilidades para lidar com, resistir ou reduzir o estresse, chamadas por Kompier e Kristensen (2003, p. 41) "abordagens de vacinação contra estresse", baseadas em relaxamento ou treinamento em habilidades cognitivo-comportamentais. Essas intervenções também seriam, majoritariamente, do tipo "tamanho único", na medida em que pouco difeririam de 
mpresa para empresa. Como aponta Araújo (2011, p. 330), as abordagens adotadas não incorporariam, "de modo mais orgânico, a análise da organização, do ambiente e do processo de trabalho, mantendo-se nos limites das medidas de intervenção voltadas ao gerenciamento individual do estresse".

Outras estratégias de prevenção e intervenção se relacionariam à indicação de hábitos de vida mais saudáveis, bem como a implantação de programas de Qualidade de Vida no Trabalho (QVT), "focalizadas no gerenciamento dos trabalhadores e com menor ênfase nas condições de trabalho e, principalmente, na organização do trabalho" (JACQUES, 2003, p. 102). Kompier e Kristensen (2003, p. 41) consideram que essas intervenções seriam "primordialmente uma 'abordagem band-aid"', na medida em que estariam concentradas na redução do efeito, em detrimento da redução de estressores no trabalho. Essas intervenções, de natureza reativa, estariam concentradas em atividades como aconselhamento de trabalhadores "estressados", psicoterapia individual, relaxamento, biofeedback, sendo raras medidas preventivas ou de atuação sobre o ambiente de trabalho ou sobre a organização.

Para Kompier e Kristensen (2003), a ênfase nas abordagens individuais refletiria atitudes e valores do gerenciamento empresarial, de caráter individualista, atribuindo sucessos e fracassos organizacionais a características individuais das pessoas envolvidas, como fatores de personalidade, estilo de vida, eventos estressantes da vida ou responsabilidades e demandas da vida familiar. Como consequências, aponta-se o risco de considerar o trabalhador "culpado" por seus problemas de saúde, uma operação de "culpabilização da vítima", em que ameaças potenciais no ambiente de trabalho seriam negligenciadas e recomendações unilaterais, adotadas ("concentramse mais no indivíduo do que na mudança da condição estressante") (KOMPIER; KRISTENSEN, 2003, p. 43). Seligmann-Silva (2011) considera que, embora resultados dos tratamentos realizados sob a perspectiva do estresse possam ter alcançado resultados positivos, induziriam os trabalhadores a se responsabilizarem pelo próprio adoecimento, sem perceber sua dimensão coletiva.

Para Araújo (2011, p.331), dada a pouca importância atribuída à forma como o trabalho se estrutura e aos seus aspectos ambientais (condições concretas de trabalho) e organizacionais, as intervenções propostas apresentariam limitações para 
os problemas enfrentados em caráter mais duradouro, "uma vez que, não raro, apenas a aparência ou as manifestações mais evidentes das situações são focalizadas e redesenhadas, sem interferência sistemática nas estruturas que produzem as condições desfavoráveis no ambiente laboral".

Outras críticas se referem ao "psicologismo" dessas abordagens, discutindo o estresse como um fenômeno individual e subjetivo e promovendo "a explicação de eventos sociais por fatores psíquicos individuais" (KOMPIER; KRISTENSEN, 2003, p. 44). Os mesmos autores também criticam a perspectiva de que os estressores pudessem ser inerentes ao trabalho, ou que "alguns trabalhos são estressantes em si mesmos e que pode não ser muito realista reduzir ou eliminar todos esses fatores de risco", sem considerar que atividades de trabalho "não são 'dadas por Deus'"; são construídas, criadas, portanto, passíveis de serem recriadas.

\subsubsection{Qualidade de Vida no Trabalho (QVT)}

A terminologia Qualidade de Vida no Trabalho (QVT) vem sendo amplamente utilizada, inclusive no Brasil. Contudo, como destacam Lacaz (2000), Heloani e Capitão (2003) e Barros (2010), dada sua imprecisão conceitual, o termo vem sendo utilizado com diferentes conteúdos, significados e definições, e daria margem a uma diversidade de práticas nela contidas.

Barros (2010) destaca suas origens formais vinculadas ao desenvolvimento da abordagem sociotécnica, com um viés de humanização do trabalho, associada a maiores possibilidades de atuação do trabalhador em planejar e interferir nos processos de trabalho. Contudo,

[...] com o passar do tempo, as publicações mais atuais parecem ter cindido as partes "sócio" e "técnica", esquecendo as sugestões de interferência na técnica e detendo-se tão somente nas temáticas "especiais", a saber: a "humanização do trabalho" - ambiente agradável, estilo de vida saudável e melhoria nas relações interpessoais - sem considerar as propostas de desenvolvimento de autonomia no interior da dimensão técnica do trabalho. [...] As análises de conjuntura sociopolítica desses trabalhos costumam ater-se às caracterizações das modificações do mundo do trabalho no contexto da pós-modernidade, por vezes tratando de assuntos como flexibilização e carreiras sem fronteiras, por exemplo. 
Já Lacaz (2000, p. 153) situa sua origem no pós-guerra (II Guerra Mundial), como consequência da implantação do Plano Marshall para a reconstrução da Europa. A terminologia Qualidade de Vida no Trabalho (QVT), para Lacaz (2000, p. 153), daria margem a práticas que ora se aproximam da qualidade de processo e de produto, ora com esta se confundem. $\mathrm{O}$ autor destaca os diferentes enfoques assumidos ao longo do tempo: nos anos 60, haveria ênfase nos aspectos da reação individual do trabalhador às experiências de trabalho. Em sua vertente de trabalhar melhorias das condições e ambientes de trabalho, visando maior satisfação e produtividade, a QVT teria se iniciado nos anos 70, sendo vista como um movimento no qual expressões como "gerenciamento participativo" e "democracia industrial" seriam frequentemente adotados. Nos anos 80, "adquire importância como um conceito globalizante, na busca de enfrentar as questões ligadas à produtividade e à qualidade total'”' (LACAZ, 2000, p. 153). Seriam várias as definições da expressão QVT: algumas versariam sobre tecnologias e seu impacto; outras, sobre aspectos econômicos como salários e incentivos; outras, ainda, sobre elementos ligados à saúde física e mental, segurança e bem-estar.

A abordagem da QVT demandaria a mobilização de todos os trabalhadores da empresa para possibilitar o cumprimento das metas traçadas; nesse contexto, questões motivacionais e de satisfação com o trabalho ganhariam destaque (BARROS, 2010). Prilleltensky (1994, p. 10) exemplifica, ao problematizar os discursos gerenciais:

\footnotetext{
As promessas feitas aos trabalhadores pelos defensores da Qualidade de Vida no Trabalho retratam esses programas de maneira muito atrativa. Eles ofereceriam "oportunidade de realização de potenciais", "orgulho", "satisfação", "poder de tomar decisões" e assim por diante; mas para além desses pronunciamentos, permanece a questão básica para os sindicatos: Esses projetos beneficiam de fato os trabalhadores?
}

Ainda segundo Prilleltensky (1994, p. 10), esses programas seriam desenhados para "ajustar os trabalhadores ao trabalho e não o trabalho aos trabalhadores", configurando uma estratégia mais sutil, porém mais abrangente, de controle. Lacaz (2000, p. 153), na mesma linha, afirma que esses programas se caracterizariam "por envolver mecanismos de controle da percepção e subjetividade para enquadrar 
trabalhadores mediante engrenagens que visam introjetar as normas e metas da empresa". ${ }^{140}$

Como ressalta Lacaz (2000), ao mesmo tempo em que trariam um discurso que remeteria a mudanças na organização do processo de trabalho, as práticas "se preocupam muito pouco com as condições e organização do trabalho, na medida em que sua vertente individualista apenas incentiva a prática de hábitos de vida saudáveis", não atingindo as relações e a organização do processo de trabalho, centrais para a compreensão dos problemas atuais de saúde dos trabalhadores, pois "é na organização do trabalho, que implica a divisão de tarefas e delimitação das relações sociais de trabalho, que se deve buscar as restrições para a livre manifestação da saúde mental" (LACAZ, 2000, p. 155).

Já Sato (2010, p. 48) diz que esses programas tomam como objeto aspectos da saúde a partir de uma leitura individualizante, desconsiderando o papel desempenhado pelos contextos de trabalho no sofrimento dos trabalhadores. Essa leitura individualizante fomentaria uma orientação psicológica para os conflitos no local de trabalho; dessa forma, a cooperação seria mais fácil de ser atingida do que quando é colocada em termos políticos (PRILLELTENSKY, 1994). Também favoreceria a perspectiva de que é possível, por exemplo, o gerenciamento individual do estresse, sem colocar em causa as condições ou a organização do trabalho (PEREIRA, 2015).

Para Lacaz (2000, p. 153), a proposta da QVT visaria amalgamar interesses diversos e contraditórios, presentes nos ambientes e condições de trabalho, "interesses estes que não se resumem aos do capital e do trabalho, mas também aos relativos ao mundo subjetivo (desejos, vivências, sentimentos), aos valores, crenças, ideologias e aos interesses econômicos e políticos". Na medida em que encerrariam uma concepção clínica, voltada para a mudança de hábitos de vida, as práticas de QVT, para Lacaz (2000, p. 153) atribuiriam ao trabalhador a responsabilidade de se adaptar, "de

140 Heloani e Capitão (2003, p. 108) fazem análise semelhante:

Nas empresas pós-fordistas, signatárias do neoliberalismo, a matéria-prima principal são as pessoas; a moeda mais importante é o signo e o símbolo, e a manipulação dos processos psicodinâmicos constitui a principal tecnologia. Essas são algumas das ferramentas da empresa pós-moderna (se é permitido o neologismo). Substituíram o chicote, o supervisor e os testes psicológicos pela ilusão da integração e da participação. 
modo a otimizar sua qualidade de vida e de trabalho. Tal comportamento, não podemos esquecer, abre caminho para uma velha postura ideológica: a culpa da vítima pelo ato inseguro".

\subsubsection{A PSICOLOGIA DO TRABALHO}

Nesta tese, será utilizada a denominação Psicologia do Trabalho, inclusive para assinalar e reforçar que esta vertente vai se dedicar ao estudo do trabalho em todas as suas dimensões, para além da relação de emprego, aí incluídas temáticas "marginais", como trabalho escravo, trabalho infantil, trabalho "sujo", trabalho "informal"141 e/ou precarizado, sempre sob a perspectiva ou ponto de vista do trabalhador, demarcandose aí uma crucial diferença com relação à Psicologia Organizacional.

Contudo, deve-se observar que diversos autores, como Sato (2010, 2013), Spink (1996) e Jacques (2007), entre outros, consideram essa abordagem como uma "área" ou vertente da Psicologia Social, como se verá na discussão a seguir; Sato a chama de "Psicologia Social do Trabalho". A própria denominação da área de concentração do programa de doutorado da USP, ao qual esta tese se filia, é "Psicologia Social e do Trabalho". Muitos departamentos de institutos/cursos de Psicologia também assim se estruturam.

Historicamente, podem-se encontrar referências à Psicologia do Trabalho sem que distinções sejam feitas com relação à Psicologia Organizacional ou Industrial (já apresentadas na tese), como mostra Spink (1996):

O que hoje é chamado de Psicologia do Trabalho é uma lista de tópicos tão

\footnotetext{
141 Diversos estudos questionam a utilização do termo "informal", debate rico que, contudo, extrapola os limites desta tese. Apenas, a título de exemplo, segue o questionamento de Nouroudine (2011, p. 69), grifo nosso):

Se ['o trabalho que não é mais o trabalho' ou que não é emprego] designa o trabalho não mercantil e o trabalho informal por distinção (ou oposição) ao trabalho mercantil, então o 'trabalho que não é mais o trabalho' continua sendo, na realidade, um trabalho. Todavia, ele é diferente do trabalho mercantil, que, de acordo com uma postura etnocêntrica, supostamente constitui uma referência para a avaliação da natureza das atividades humanas. Mas, qualquer que seja o modo de trabalho dominante num coletivo de vida, uma análise da norma na atividade dita informal, do duplo ponto de vista do conceito e da experiência, permite sugerir que uma atividade humana socializada não pode ser verdadeiramente informal.
} 
vasta que perde qualquer significado específico e é difícil considerar como um conjunto. [...] cada item é o ponto de partida para um microuniverso de tendências, métodos de pesquisa, pressupostos teóricos e valores sociais demonstra que o termo psicologia do trabalho é tão descritivo quanto psicologia do fora-do-trabalho (SPINK, 1996, p. 174)

A própria inserção "institucional" no Conselho Federal de Psicologia como área de especialidade repercute essa indefinição e a reconhece como Psicologia Organizacional e do Trabalho (РОT) - sobre a qual se discutirá a seguir.

Outra questão a se considerar foi levantada por Leny Sato em uma reunião de orientação ${ }^{142}$, a de se levar em conta também o caráter regional ou institucional da diversidade de nomenclaturas para se referir a esse campo, identificado na USP e PUCSP como Psicologia Social do Trabalho e, na UFMG, de Psicologia do Trabalho, a título de exemplo.

Sem menosprezar as relevantes considerações de Sato $(2010,2013)$ para essa denominação - Psicologia Social do Trabalho -, com as quais estamos de acordo, será mantida nesta tese a denominação de Psicologia do Trabalho. Os temas de estudo da Psicologia Social não se atêm à dimensão do trabalho - embora esta tenha crucial importância -, voltando-se, também, para temas como relações de gênero, relações étnico-raciais, movimentos sociais, violência e direitos humanos, processos comunitários, entre outros. Busca-se, aqui, evidenciar a ênfase na categoria Trabalho. Em termos teórico-políticos, também serviria para evidenciar o tensionamento existente entre as abordagens da Psicologia do Trabalho e da Psicologia Industrial/Organizacional.

Após esses posicionamentos terminológicos, que refletem discussões de fundo epistemológico-prático, passa-se à discussão da área doravante chamada, nesta tese, Psicologia do Trabalho.

A Psicologia do Trabalho, segundo Lima (2002, p. 127), consistiria uma abordagem que visa conhecer e compreender as condições materiais e organizacionais do trabalho, bem como "o tipo de relação que os indivíduos estabelecem com tais condições, o sentido que atribuem às atividades que realizam, as pressões psicológicas que sofrem

142 SATO, Leny. (Instituto de Psicologia da Universidade de São Paulo). Comunicação pessoal, 2015. 
no trabalho e como se defendem das mesmas". A atividade deve ser sempre contextualizada e compreendida em seus determinantes históricos, sociais, econômicos e culturais.

Dessa forma, como coloca Sato (2000, p. 47), o desafio é pensar a "pessoa em contexto", a "pessoa em situação". Nesse sentido, a Psicologia ofereceria relevante contribuição para a compreensão da subjetividade do trabalhador, "sobretudo no que concerne às vivências de sofrimento no trabalho e às patologias dele decorrentes" (CFP, 2008, p. 23).

As concepções teóricas da Psicologia do Trabalho se contrapõem às da Psicologia Organizacional, na medida em que as concepções da Psicologia Organizacional não dariam conta "da multiplicidade e complexidade da constituição do humano e do seu psiquismo", na visão de Jacques (2007, p. 114), pois teriam uma perspectiva reducionista da compreensão do processo saúde/doença mental, um importante tema de estudo da Psicologia do Trabalho. Jacques aponta como, desde a segunda metade do século XX, a aplicação da Psicologia ao mundo do trabalho recebe críticas, como a de Fromm (1956 apud JACQUES, 2007, p. 114), sobre formas de emprego do conhecimento psicológico que "incrementam o empresário de utilidades sem comprometer-se com a situação do trabalhador".

Como coloca Sato (2013, p. 99), a Psicologia abrigaria vertentes teórico-metodológicas distintas, e expectativas também distintas sobre "o que o conhecimento por ela construído pode oferecer à sociedade". Por essa razão, entende que seria mais apropriado falar em "psicologias" e em "trabalhos". Essas leituras se relacionariam de modo conflituoso e tenso, nos termos definidos por Bourdieu (1989) como de configuração de um campo científico: um espaço de luta pela conquista de posições hegemônicas. Sato (2013) destaca ainda que os debates nesse campo seriam fortemente marcados pelas relações que a Psicologia mantém com os interesses do capital e dos trabalhadores. Para a autora $(2010,2013)$, quando se compreende que um campo científico, na acepção bourdiana do termo, conforma as relações entre Psicologia e trabalho, deve-se pensar na luta pela ocupação de posições mais privilegiadas nesse campo, mesmo que nem sempre essa luta se apresente de forma 
explícita (SATO 2013), e estar "sensível para reconhecer outras leituras e abordagens que não alcançaram posições centrais nesse campo" (SATO, 2010, p. 48).

Dessa forma, mais recentemente, duas perspectivas se delineariam para Psicologia quando toma o Trabalho e as Organizações como objeto de investigação e de práticas (SATO, 2010, p. 41). A primeira, historicamente conhecida como "a" Psicologia do Trabalho e das Organizações - e aqui referida como Psicologia Organizacional - que "abraçou problemas e interesses postos pelo corpo gerencial e pelo capital, articulando-se, por exemplo, com a administração e com a engenharia". A segunda, nos termos de Sato (2010), chamada de Saúde do Trabalhador - e aqui referida como Psicologia do Trabalho - traria os problemas humanos no trabalho como objeto e seria influenciada, entre outras abordagens, pela Psicologia Social, pela Medicina Social Latino-Americana e pela Saúde Coletiva. Embora ambas as perspectivas abordem fenômenos do mundo do trabalho e dos processos organizativos, cada uma delas teria construído sua trajetória de forma isolada e com poucos pontos de contato, no que tange a "referências teórico-metodológicas, as práticas e os loci nos quais essas práticas são exercidas" (SATO, 2010, p. 41). Assim, construiriam distintas leituras sobre a realidade, constituindo diferentes objetos e buscando interlocução com áreas do conhecimento e atores sociais também distintos, "os quais ocupam posições antagônicas e contraditórias no universo social e político, refletindo, assim, no tipo de relação entre essas duas vertentes" (SATO, 2010, p. 48).

Segundo Jacques (2007, p. 114), no exame da trajetória da Psicologia como área de aplicação, é possível reconhecer a prioridade dada às questões referentes à gestão de pessoal, bem como uma tendência hegemônica para a utilização de métodos e técnicas psicológicas com objetivos de classificação e adaptação dos trabalhadores, a partir de normas compatíveis com a acumulação do capital. Questões relacionadas à saúde/doença mental, por exemplo, não fariam parte do cotidiano de trabalho do psicólogo, como o ilustra a análise de Spink (1996) sobre os experimentos de Hawthorne (conduzidos por Elton Mayo), como a retirada de trabalhadoras da pesquisa em razão de reivindicações de melhores condições salariais, sendo por isso classificadas como neuróticas e passíveis de serem tratadas pela psiquiatria. 
Ainda nesse sentido, Lima (2013) chama atenção para a ideia, ainda fortemente veiculada, de que problemas no mundo do trabalho tenham sua origem em questões estritamente pessoais, levando a outra ideia que the seria complementar, a de que o modo de saná-los seria por meio de tratamento psicológico individual. ${ }^{143}$ Avaliações de cunho moralizante ou psicologizante tornariam comuns as abordagens das pessoas como "irresponsáveis", "sem compromisso com a empresa e com os resultados do seu trabalho" ou "difíceis no trato pessoal", quando, para Lima (2002, p. 124), "a análise mais aprofundada das situações traz à tona problemas graves na organização do trabalho e que são, em grande medida, responsáveis pelas atitudes adotadas por essas pessoas". ${ }^{144}$

Sato (2010, p. 42) discute como a perspectiva da Psicologia voltada para a gestão de recursos humanos terminaria por demarcar o campo de uma Psicologia voltada para as questões do trabalho e das organizações, mantendo-se hegemônica na atualidade. Algumas mudanças ou "metamorfoses" poderiam ser observadas em suas práticas sem, contudo, representar uma significativa alteração em termos de objetivos ou de concepção, não obstante as mudanças identificadas no discurso ou linguagem empregada: de "gestão de recursos humanos" para "gestão de pessoas", no emprego de palavras da língua inglesa como "área de people" e "empowerment", entre outras. Já no campo das práticas, a autora identifica que mudanças na gestão empresarial levariam a mudanças na forma como a Psicologia aí atua:

\footnotetext{
De um campo de aplicação que demanda da Psicologia apenas o conhecimento e o desenvolvimento de técnicas (de entrevista, de testes etc.), para um campo de pesquisa - uma vez que atualmente as atividades de gestão de recursos humanos estão migrando para as divisões, serviços, setores e equipes de trabalho - cabendo agora à Psicologia o papel de assessoria aos gestores (SATO, 2010, p. 42).
}

Já a outra vertente teórico-metodológica indicada por Sato (2010, p. 42) - em seus termos, "Psicologia Social do Trabalho" - tomaria "o mundo do trabalho como foco

\footnotetext{
143 E prossegue: "Com isso, corremos o sério risco de perder de vista a importante premissa defendida por Le Guillant (2006) ao propor que, antes das pessoas, é precisamente do trabalho que se deve cuidar em todos os sentidos do termo. E cuidando do trabalho não estaríamos, ao mesmo tempo, cuidando das pessoas que o realizam?" (LIMA, 2013, p. 93).

144 “O que só vem reforçar nossa convicção de que, quase sempre, [os psicólogos] desconhecem os problemas para os quais são convocados a propor soluções” (LIMA, 2002, p. 124).
} 
de estudos e problematização não tendo como preocupação inicial construir e delimitar um espaço de aplicação".

Em meados nos anos 80, essa vertente da Psicologia, tomando como interlocutora a Saúde Coletiva, teria participado da construção do campo interdisciplinar de teorias e de práticas denominado Saúde do Trabalhador, conformado pelo encontro do movimento sindical (Novo Sindicalismo) - "o ator que então se apresentava como a voz por parte dos trabalhadores" - com profissionais de saúde pública, com significativas contribuições da academia (SATO, 2010, p. 42). O objeto de estudo seria o processo saúde-doença, compreendido como um processo histórico, elegendo-se como categoria central o processo de trabalho, o que possibilitaria que a Psicologia passasse a se ocupar dos problemas que viviam os trabalhadores no dia a dia de trabalho.

Já informada pela perspectiva da Psicologia Social, essa vertente passaria a abordar "os problemas sociais e humanos no trabalho, presentes nos espaços organizacionais e fora dele", compreendendo fenômenos como identidade, processos de interação social, subjetividade. A contribuição da Psicologia Social permitiria um olhar para o trabalho e para processos organizativos do ponto de vista dos trabalhadores, “mostrando situações difíceis de serem vividas, estratégias e táticas criadas e utilizadas para com elas lidar" (SATO, 2013, p. 101). Contudo, como aponta a autora, embora essa vertente esteja há muito presente e tenha realizado diversos estudos e pesquisas que tomam o trabalho e os processos organizativos a partir de categorias como identidade, memória, representações e interações sociais, tem sido categorizada sob a denominação genérica de Psicologia Social, não sendo considerada como uma perspectiva da Psicologia do Trabalho e das Organizações. Sua hipótese é de que

[...] não tenham sido consideradas como uma perspectiva da Psicologia do Trabalho e das Organizações porque fogem a uma determinada concepção sobre a formação e a profissionalização em Psicologia, uma vez que é forte entre nós a dicotomia entre conteúdos e abordagens profissionalizantes e não profissionalizantes, cabendo àqueles apresentar modos e técnicas para intervir na realidade (SATO, 2010, p. 42).

Para Sato (2013, p. 99), o utilitarismo permearia a Psicologia Organizacional (em seus termos, "Psicologia Organizacional e do Trabalho"), cuja "missão" é gerar conhecimentos e instrumentos para intervir no trabalho, no que tange à gestão de 
recursos humanos, "respondendo a demandas gerenciais e ao desenvolvimento das condições para o processo de industrialização". Por não se orientarem por esse utilitarismo, os estudos e pesquisas da segunda vertente discutida (e aqui chamada Psicologia do Trabalho) não teriam sido reconhecidos como contribuições da Psicologia do Trabalho, mas como estudos de Psicologia Social, situando-se em uma perspectiva crítica da Psicologia Social "que situa o trabalho numa sociedade desigual, lidando com categorias que considerem as relações políticas"145. A autora também acredita que a perspectiva utilitarista tenha contribuído para o fato de "os estudos do trabalho na Psicologia Social terem ficado esmaecidos". Quanto a essa "psicologia aplicada", Sato (2000, p. 42) referenda ser essa "a vertente da Psicologia socialmente reconhecida e legitimada como sendo a Psicologia do Trabalho e Organizacional" (aqui tomada na acepção que se trabalha nesta tese, de Psicologia Organizacional). Entre outras razões, destaca o fato de essa abordagem ter construído "um espaço de aplicação dos conhecimentos da Psicologia e, sustentada nessa tecnologia, ter aberto um campo de atuação profissional reconhecido como um filão importante para os(as) psicólogos(as) no mercado de trabalho". ${ }^{146}$

Jacques (2007, p. 114) também aponta críticas a esse modelo hegemônico, considerando representativos os trabalhos de Codo (1984), Jacques (1989) e Spink (1996), entre outros, trabalhos ${ }^{147}$ que se aproximam do campo conceitual da Psicologia

\footnotetext{
145 Convém registrar que os dois textos de Wanderley Codo apontados como emblemáticos nos anos 80, e apresentados na seção 5.1.7 (Psicologia e mundo do trabalho nos anos 80), "O fazer e a consciência" (CODO, 1984/1994b) e "O papel do psicólogo na organização industrial (notas sobre o 'lobo mau' em psicologia)" (CODO, 1984/1994a), são publicados em um livro de Psicologia Social (Psicologia Social: O homem em movimento).

146 Numa entrevista, realizada em 2006 para a revista Cadernos de Psicologia Social do Trabalho, concedida aos professores Dulce Helena Penna Soares e Maria Chalfin Coutinho (UFSC), Henrique Caetano Nardi (UFRGS) e Leny Sato (USP), Yves Clot (CNAM - França) aponta como na França não foi tão prevalente a "psicologia do trabalho ligada à gestão de recursos humanos 'à americana'" (nos termos de Nardi). Em sua opinião, isso se deveu à presença da tradição da ergonomia francesa, a ergonomia da atividade, que se opunha (e opõe) à psicologia industrial, à psicotécnica e à psicologia dos recursos humanos, e ao desenvolvimento da psicopatologia do trabalho, com os trabalhos de Le Guillant e outros (CLOT, 2006).
}

147 Os trabalhos mencionados por Jacques (2007, p. 114), em ordem cronológica, são:

CODO, Wanderley. O papel do psicólogo na organização industrial (notas sobre o "lobo mau" em psicologia). IN: LANE, Sílvia Tatiana Maurer; CODO, Wanderley (org.) Psicologia social: O homem em movimento. São Paulo: Brasiliense, 1984.

JACQUES, Maria da Graça Corrêa. O contexto histórico como produtor e produto do conhecimento: A trajetória da psicologia do trabalho. Psicologia: Reflexão e Crítica, 4(1/2), 1989. 
Social fundamentada no materialismo histórico e que estimulam a aproximação da psicologia à área de Saúde do Trabalhador.

Sato (2010, p. 48) também observa como a vertente aqui identificada como Psicologia Organizacional busca manter a sua posição privilegiada "no campo da Psicologia do Trabalho por meio da adoção de uma noção que procura "amalgamar" e, portanto, descaracterizar as diferenças entre esta e a segunda vertente [na acepção que se trabalha nesta tese, a Psicologia do Trabalho]". Essa tentativa de amalgamação se operaria por buscas de "um acordo para a convivência pacífica entre ambas", notadamente por meio da noção de "Qualidade de Vida no Trabalho" (QVT). Na abordagem da QVT, "saúde/saúde mental têm importância, mas apenas como "recurso" necessário à garantia de continuidade da produção [...] e o enfoque recai na maior adaptação do trabalhador ao trabalho, por meio, inclusive, da mudança do estilo de vida", diferindo radicalmente da perspectiva da Saúde do Trabalhador.

Essa "amalgamação" que descaracteriza as diferenças entre as abordagens fica clara na própria definição da área de "Psicologia Organizacional e do Trabalho" feita pelo Conselho Federal de Psicologia. A Resolução do CFP no 2 de 2001 traz a definição das especialidades concedidas pelo CFP, entre elas a de Psicólogo Especialista das Organizações e do Trabalho. ${ }^{148}$ A título de exemplo, entre as possíveis ações desse profissional estariam:

Planeja e desenvolve ações destinadas a equacionar as relações de trabalho, o sentido de maior produtividade e da realização pessoal dos indivíduos e grupos inseridos nas organizações, estimulando a criatividade, para buscar melhor qualidade de vida no trabalho (CFP, 2001 , p. 10, grifo nosso).

O mesmo documento relaciona outras atuações para o psicólogo que, como se discute nesta tese, não se coadunam com princípios de promoção da produtividade ou da qualidade de vida no trabalho:

Desenvolve, analisa, diagnostica e orienta casos na área da saúde do trabalhador, observando níveis de prevenção, reabilitação e promoção

SPINK, Peter Kelvin. Organização como fenômeno psicossocial: Notas para uma redefinição da psicologia do trabalho. Psicologia \& Sociedade, 8(1), 1996.

${ }^{148}$ A definição da especialidade em Psicologia das Organizações e do Trabalho encontra-se na íntegra no Anexo E. 
de saúde. Participa de programas e/ou atividades na área da saúde e segurança de trabalho, subsidiando-os quanto a aspectos psicossociais para proporcionar melhores condições ao trabalhador (CFP, 2001, p. 11, grifo nosso).

Essa "amalgamação", acrítica ou estratégica, permeia a produção acadêmica na área da POT - Psicologia Organizacional e do Trabalho. A título de exemplo, uma obra de grande repercussão dessa abordagem, "Psicologia, Organizações e Trabalho no Brasil", de Zanelli, Borges-Andrade e Bastos (2004), traz 18 textos de diferentes autores, e apenas um, "Saúde Mental e Trabalho", de Codo, Soratto e Vasques-Menezes (2004), traz uma discussão identificada com as premissas da Psicologia do Trabalho. Para Zanelli e Bastos (2004, p. 478), nessa mesma obra, a estrutura do campo de atuação do psicólogo organizacional e do trabalho se subdividiria em vários subcampos, cada um deles integrado por um conjunto de atividades profissionais, nenhuma delas também identificada com a Psicologia do Trabalho.

Pesquisadores associados a essa abordagem encontram-se organizados na Associação Brasileira de Psicologia Organizacional e do Trabalho (SBPOT), que também subsidia um Grupo de Trabalho (GT) de Psicologia Organizacional e do Trabalho (POT) pertencente à Associação Nacional de Pesquisa e Pós-Graduação em Psicologia (ANPEPP) (SBPOT, 2015).

Quando perguntados sobre seu posicionamento a respeito dessa área "comum", alguns entrevistados desta tese assim se pronunciaram:

[...] a gente tem uma Sociedade Brasileira de Psicologia Organizacional e do Trabalho que nunca conseguiu dar conta bem dessa tensão que a gente tem entre duas categorias de organização do trabalho, tanto que houve uma discussão muito tempo, [...] é primeiro Psicologia do Trabalho e das Organizações ou vice-versa? Nada a ver! (JACQUES, 2014, entrevista).

A categoria trabalho é categoria da Psicologia Social. A Psicologia das Organizações é uma aplicação dos princípios da Psicologia. [...] São campos diferentes, e eu fico pensando: quanto da Psicologia, quantas tensões a gente tem? Mesmo dentro da própria prática clínica psicoterápica. [...] Eu acho que isso faz parte, nós temos que trabalhar com isso. A Psicologia não é homogênea, [...] ela é plural, ela é diversa, e eu acho que a gente tem de saber dialogar, e eu acho que esse é um exercício muito complexo para todos nós (JACQUES, 2014, entrevista).

Nós temos a Psicologia Organizacional e do Trabalho no mesmo campo [no Conselho Federal de Psicologia]. Eu penso que não deveria ficar, apesar de todas as discussões, [...] eu acho que o objeto é diferente, a gente deveria considerar de forma diferente. [...] não nego o papel dela [Psicologia Organizacional], mas eu acho que são campos diferentes (GREGGIO, 2014, entrevista). 
Talvez essa seja a principal diferença entre Psicologia Organizacional e Psicologia do Trabalho. É a ideia de que é o trabalhador que está em análise e não a organização que está em análise (CODO, 2014, entrevista).

A distância que se percorre entre as duas áreas [Psicologia Organizacional e Psicologia do Trabalho] é muito mais política que científica (CODO, 2014, entrevista).

Uma já mencionada crítica de Codo (1988), Codo, Sampaio e Hitomi (1993) e Lima (1998) sobre a produção acadêmica em Psicologia, sobretudo dos anos 70 e 80, se refere à "ausência da categoria trabalho" não apenas na Psicanálise, mas na Psicologia em geral. Lima (1996a) aprofunda essa crítica quando afirma que as categorias trabalho e saúde mental ainda não estavam "devidamente articuladas pela Psicologia" (LIMA, 1996a, p. 49). Outra questão apontada pela autora (LIMA, 1996a) seria a "distância entre as práticas dos psicólogos que atuavam em organizações e aquelas exercidas por psicólogos clínicos", afirmando que "o psicólogo do trabalho [organizacional] ainda não [havia incorporado] a questão da saúde mental à sua prática nas organizações, e o psicólogo clínico, por sua vez, não [estabelecia], em geral, um vínculo entre as queixas de seus clientes e de sua situação de trabalho" (LIMA, 1996a, p. 49).

Codo (2014) também formulou essa crítica em entrevista concedida para esta tese:

Na minha tese, eu fui fazer o levantamento, da literatura, e fiquei extremamente espantado com o fato de que não havia a categoria Trabalho na Psicologia. Eu terminei minha tese em 1981. Eu estou te falando de 1979, 1980. [...] E não tinha Trabalho. [...] Não tinha pesquisa por internet, então você usava o Psychological Abstracts. [...] Você chegava em Trabalho, o Psychological Abstracts te mandava para Personal, Departamento de Pessoal. [...] la para Pessoal, tinha lá como fazer Seleção, como fazer Treinamento, mas a categoria Trabalho rigorosamente não, não existia em Psicologia. Eu "fucei" para tudo quanto era lado, fui na [Psicologia] Clínica... E ninguém falava de Trabalho. E não havia literatura sobre Trabalho, a categoria Trabalho não existia na Psicologia. E eu acabei fazendo toda a minha tese em cima da ausência da categoria Trabalho. Se é o trabalho que nos transforma em ser humano, que nos hominiza, e se a Psicologia estuda o ser humano, como é que a Psicologia esquece da categoria central que forma o próprio ser humano? Essa para mim tinha sido uma descoberta mais importante do que o estudo de caso da fábrica, a questão da alienação etc. [objetos da tese]. Eu costumava brincar - eu escrevi isso, inclusive - que o homem, na Psicologia, é como um herói de telenovela: ele tem conflitos afetivos, sexuais, dramas familiares... Mas não trabalha (CODO, 2014, entrevista).

Como coloca publicação do Conselho Federal de Psicologia,

A forma como o trabalho é concebido [...] implica reconhecê-lo como categoria central na compreensão dos fenômenos humanos, em geral, 
incluindo, aí, os processos saúde/doença [...]. Isto significa dizer que o "trabalho deve ser entendido como 'o ponto de partida de toda tentativa de se compreender o homem, (pois) é ele que funda, produz e reproduz o ser social sempre como um outro" (CHASIN apud CFP, 2008, p. 44).

Em termos metodológicos, como orientação para a atuação do psicólogo do trabalho, Lima (2002) sugere que se aborde, da forma mais direta possível, as situações de trabalho; apenas após desvendá-las e compreendê-las, o psicólogo poderia agir sobre elas. Nesse sentido, deve-se buscar conhecer, da forma mais detalhada possível, as condições materiais e organizacionais do trabalho, o tipo de relação que os indivíduos estabelecem com essas condições, o sentido atribuído às atividades realizadas, bem como as pressões psicológicas presentes no trabalho e como os indivíduos delas se "defendem".

Lima (2002, p. 123) destaca que a abordagem deve ser "baseada no respeito às especificidades de cada situação e na rejeição a qualquer ideia apriorística sobre a mesma", pois, muitas vezes, a prática do psicólogo do trabalho (na acepção que se trabalha nesta tese, seriam os psicólogos organizacionais) e sua ação sobre a realidade seria baseada em pressupostos ou mesmo em preconceitos, com subsídios buscados nos manuais organizacionais e suas prescrições, "negligenciando toda a riqueza que proporciona o conhecimento das atividades reais, isto é, daquilo que efetivamente as pessoas fazem no seu cotidiano de trabalho". E prossegue:

Já são sobejamente conhecidas as demonstrações feitas pelos ergonomistas a respeito da distância inevitável entre o trabalho prescrito e o trabalho real. De acordo com os resultados obtidos pelos pesquisadores dessa área, se quisermos compreender de forma efetiva uma dada situação laboral temos de nos apoiar nessas duas dimensões, mas, sobretudo, naquela que nos remete à efetividade dos gestos e das vivências presentes no cotidiano daqueles que a vivem: o trabalho real.

Em termos de práticas investigativas, Sato (2013, p. 102) destaca que ainda predominam os estudos que, embora busquem tornar "visível a realidade do ponto de vista dos trabalhadores e das trabalhadoras", o fazem restritos à realidade dos que estão empregados, o que faz com que, "a rigor, tenhamos construído uma psicologia que focaliza o trabalho enquanto emprego". Mais recentemente, começaram no Brasil a realizar estudos sobre a situação de desemprego, que promoveriam a abertura para a discussão do trabalho informal, em suas diversas modalidades. Mesmo que a trajetória da Psicologia, na maioria dos seus estudos, tenha concebido o trabalho como 
emprego, ao se debruçar sobre a relação assalariada e as pessoas que estavam empregadas, a autora destaca que "o trabalho assalariado na sociedade brasileira sempre conviveu com outras modalidades de relação de trabalho, inclusive, infelizmente, com o trabalho escravo" (SATO, 2013, p. 105). Assim, embora tardiamente, em sua análise, a Psicologia (em seus termos, a Psicologia Social do Trabalho) tem se dedicado a estudar o desemprego e o espectro de atividades situadas no "circuito inferior da economia", o que inclui as "profissões esquecidas" (SATO, 2013, p. 95).

Em termos de atuação "prática", para Sato (2013), um campo que se configura mais recentemente para a atuação do psicólogo é o da Saúde do Trabalhador. Um dos pressupostos adotados pela vertente da Psicologia inserida no campo da Saúde do Trabalhador é o de tomar como central o direito à saúde e à cidadania; nesse sentido, a Psicologia Social da Saúde seria um rico campo de interface para a Psicologia do Trabalho. Jacques (2007, p. 115) destaca como fator primordial para essa aproximação Psicologia-Saúde do Trabalhador a "superação dos modelos hegemônicos das práticas de intervenção e regulação das relações entre saúde e trabalho agrupados como Medicina do Trabalho, Engenharia e Segurança e Saúde Ocupacional", na medida em que a atuação passa a se pautar por uma perspectiva interdisciplinar que abre espaço para a contribuição de outros campos disciplinares, como o da Psicologia. Condições de trabalho e organização do trabalho passam a ser focos de problematização da Psicologia, contextualizadas nas relações sociais de trabalho (SATO, 2013).

Ainda de acordo com Sato (2013, p. 102), a atuação em Saúde do Trabalhador traria à Psicologia a possibilidade de tomar o trabalho como objeto de política em saúde pública e abriria um novo espaço de atuação e de investigação, constatado pelo grande número de estudos sobre o tema, 149 "bem como de material produzido pelo e para o movimento sindical e trabalhadores". Como também assinala Jacques (2007), a inserção da Psicologia no campo da Saúde do Trabalhador abre um conjunto variado

\footnotetext{
149 A respeito da "volumosa" produção em Psicologia do Trabalho e, mais especificamente, Saúde Mental e Trabalho, observar as considerações de Lima (2013), discutidas na seção 5.2.3.1.1 (Saúde Mental e Trabalho).
} 
de possibilidades de atuação, destacando-se o estabelecimento do nexo causal entre o trabalho e o adoecimento mental.

A atuação da Psicologia do Trabalho no campo da Saúde Pública, especificamente em Saúde do Trabalhador, suscitou a publicação de orientações do Conselho Federal de Psicologia (CFP). Em 2008, por meio do Centro de Referência Técnica em Psicologia e Políticas Públicas (CREPOP), o CFP publicou o documento "Saúde do Trabalhador no âmbito da Saúde Pública: referências para a atuação do(a) psicólogo(a)". Participaram da Comissão de elaboração do documento as psicólogas Andréia De Conto Garbin, Leny Sato, Márcia Hespanhol Bernardo e Maria Elizabeth Antunes Lima. Em sua Introdução, o documento informa: "Este documento, que tem por objetivo oferecer referências para a atuação do psicólogo na área da Saúde do Trabalhador - no âmbito da Saúde Pública - é fruto de um trabalho coletivo que partiu de uma demanda da categoria, foi reconhecida pelo CFP e respondida por meio do CREPOP" (CFP, 2008, p. 13). Além de apresentar importantes discussões sobre marcos lógico-legais da Saúde do Trabalhador, sobre a Saúde do Trabalhador como política pública, sobre aspectos éticos e políticos relacionados à atuação do psicólogo na Saúde do Trabalhador e sobre a formação do psicólogo, o documento também traz orientações para a atuação do psicólogo em Saúde do Trabalhador, sumarizadas no Quadro 2, a seguir.

Quadro 2 - Atuação do psicólogo em Saúde do Trabalhador

(continua)

\begin{tabular}{|c|c|}
\hline Tipo de atuação & Diretriz / orientação \\
\hline $\begin{array}{l}\text { Atuação do } \\
\text { psicólogo em } \\
\text { Saúde do } \\
\text { Trabalhador }\end{array}$ & $\begin{array}{l}\text { A área de atenção à saúde dos trabalhadores insere-se no campo das práticas em } \\
\text { saúde coletiva, e o psicólogo poderá deparar-se com as questões do processo saúde- } \\
\text { doença em sua relação com o trabalho, independentemente do lugar em que esteja } \\
\text { atuando (p. 28). } \\
\text { As práticas [...] devem ser desenhadas a partir de [...] contínua atividade investigativa } \\
\text { que norteie a eleição de prioridades e que defina as formas de atuação. (p. 29) } \\
\text { Da mesma forma que a Saúde do Trabalhador enquanto política pública não se } \\
\text { restringe aos CERESTs, também a atuação do psicólogo [...] não pode ficar restrita a } \\
\text { essa unidade [...]. Ela deve ocorrer nos [...] diversos serviços do SUS, [...] como } \\
\text { unidades de atenção básica, ambulatórios de especialidades, CAPS, hospitais e } \\
\text { serviços de vigilância em saúde. (p. 29) }\end{array}$ \\
\hline $\begin{array}{l}\text { Notificação dos } \\
\text { agravos e riscos } \\
\text { para a saúde }\end{array}$ & $\begin{array}{l}\text { Embora as normas técnicas referentes à temática da saúde mental e trabalho } \\
\text { impulsionem o aperfeiçoamento das ações de registro e notificação dos transtornos } \\
\text { mentais, faz-se necessária a incorporação dessa prática no dia a dia do psicólogo a } \\
\text { partir da realização de um diagnóstico com o devido rigor ético e técnico. (p. 30) }\end{array}$ \\
\hline
\end{tabular}


Quadro 2 - Atuação do psicólogo em Saúde do Trabalhador

(conclusão)

\begin{tabular}{|c|c|}
\hline Tipo de atuação & Diretriz / orientação \\
\hline $\begin{array}{l}\text { Informação: } \\
\text { produção e } \\
\text { organização de } \\
\text { dados }\end{array}$ & $\begin{array}{l}\text { As informações dos serviços devem alimentar os sistemas de informação em saúde, } \\
\text { integrando os dados de saúde do trabalhador aos bancos de dados oficiais [como } \\
\text { Previdência Social e Ministério do Trabalho e Emprego], o que garantirá a ampla } \\
\text { difusão das informações e as disponibilizará para a sociedade. (p. 31) }\end{array}$ \\
\hline $\begin{array}{l}\text { Ações de } \\
\text { assistência e } \\
\text { promoção da } \\
\text { saúde: uma } \\
\text { abordagem } \\
\text { interdisciplinar }\end{array}$ & $\begin{array}{l}\text { O psicólogo deve sempre colaborar com a saúde dos trabalhadores, [...] sua prática } \\
\text { clínica não [deve] perder de vista a centralidade do trabalho na compreensão da } \\
\text { subjetividade humana. (p. } 31 \text { ) } \\
\text { É na abordagem interdisciplinar que se pode dar conta da amplitude dos problemas } \\
\text { de saúde relacionados ao trabalho. (p.31) } \\
\text { Os psicólogos têm participado da elaboração de diferentes modalidades terapêuticas } \\
\text { de atenção aos trabalhadores, dando especial destaque às atividades grupais com } \\
\text { portadores de doenças crônicas. (p. } 31 \text { ) }\end{array}$ \\
\hline $\begin{array}{l}\text { Análise dos } \\
\text { processos de } \\
\text { trabalho e } \\
\text { vigilância }\end{array}$ & $\begin{array}{l}\text { As ações de vigilância em Saúde do Trabalhador incluem a identificação, o controle e } \\
\text { a eliminação dos riscos nos locais de trabalho. Partindo de dados epidemiológicos, de } \\
\text { informações fornecidas pelos trabalhadores atendidos nas unidades de saúde e/ou } \\
\text { pelos sindicatos, além da bibliografia especializada, definem-se as prioridades de } \\
\text { atuação. O objetivo é identificar os riscos à saúde nos contextos de trabalho e indicar } \\
\text { modificações, visando à prevenção primária. (p. 33) }\end{array}$ \\
\hline $\begin{array}{c}\text { Educação em } \\
\text { saúde }\end{array}$ & $\begin{array}{l}\text { Desenvolvimento de cursos, seminários e estágios para técnicos, gestores e } \\
\text { trabalhadores, com a finalidade de capacitar técnicos integrantes das instâncias de } \\
\text { controle social e trabalhadores em geral, além de servir de modelo para as instâncias } \\
\text { municipais e regionais do SUS. Refere-se, ainda, à produção de conhecimento, [...] à } \\
\text { publicação de manuais, elaboração de artigos, organização de livros, apostilas e } \\
\text { audiovisuais técnicos. (p. } 35 \text { ) }\end{array}$ \\
\hline $\begin{array}{l}\text { O } \\
\text { estabelecimento } \\
\text { do nexo causal }\end{array}$ & $\begin{array}{l}\text { Um grande desafio que se apresenta ao psicólogo [...] consiste no estabelecimento do } \\
\text { nexo causal entre os transtornos mentais e os aspectos organizacionais do trabalho. } \\
\text { Embora tal questão não esteja [...] resolvida, para uma análise da categoria trabalho } \\
\text { como fator de risco para o desenvolvimento dos transtornos mentais e do } \\
\text { comportamento, conta-se com o [...] modelo proposto pelo Ministério da Saúde, em } \\
2001 \text { [Doenças relacionadas ao trabalho: manual de procedimentos para os serviços } \\
\text { de saúde. Coordenação Saúde do Trabalhador]. (p.35) } \\
\text { O nexo entre adoecimento/sofrimento psíquico e trabalho é uma atividade [...] na } \\
\text { assistência aos trabalhadores que [...] já tiveram sua saúde afetada pelo trabalho; [...] } \\
\text { a identificação de tais situações na atividade clínica do psicólogo deve ser vista [...] } \\
\text { como alerta para o desencadeamento de ações preventivas [...] [para] evitar que } \\
\text { outros trabalhadores permaneçam expostos às mesmas condições. (p. 38) }\end{array}$ \\
\hline
\end{tabular}

Fonte: CFP, 2008.

Destaquem-se ainda considerações desse documento sobre especificidades da relação

trabalho e saúde: "as especificidades da relação trabalho e saúde remetem a um

pensar e fazer diferenciados, pois envolvem aspectos da organização, processo e condições de trabalho, a compreensão da vivência subjetiva no trabalho e as repercussões para a saúde mental dos trabalhadores" (CFP, 2008, p. 13). 
As aproximações entre o modelo da Saúde do Trabalhador e a prática da Psicologia do Trabalho são várias. Ambas compartilham da premissa de que se deve buscar a participação dos trabalhadores para a promoção de mudança nos processos de trabalho, e destacam a importância do reconhecimento dos saberes dos trabalhadores.

Ambas também propõem uma ruptura com a perspectiva positivista de causa e efeito para agravos em saúde, física e/ou mental, buscando considerá-los em suas dimensões sociais e históricas, retirando o caráter adaptacionista conferido à relação trabalho e saúde.

A atuação de ambas se inscreve num contexto interdisciplinar e interinstitucional, fundamentais à proposta de atuação de promoção da mudança dos processos de trabalho, sejam visadas as condições ou a organização do trabalho.

Ambas compartilham uma representação do trabalho como uma categoria social resultante de um emaranhado de relações econômicas, sociais, políticas e tecnológicas, que se realizam de forma conflituosa e interdependente.

A intervenção da Saúde do Trabalhador sobre determinantes e condicionantes do processo de trabalho e saúde, bem como as ações de vigilância em saúde do trabalhador, contemplam aspectos "psíquicos", ou da atuação da Psicologia do Trabalho, questões de autorrepresentação e identitárias, conflitos psíquicos, dentre outros, numa perspectiva integrada, não hierarquizada, entre as duas áreas de atuação.

As relações de poder e os conflitos organizacionais fazem parte do escopo do trabalho de investigação do processo saúde e doença, em sua relação com o trabalho.

\subsubsection{Abordagem / Paradigma correlacionado}

A seguir, apresenta-se abordagem/paradigma correlacionado à Psicologia do Trabalho.

\subsection{Saúde Mental e Trabalho}


Em 1994, Seligmann-Silva (1994, p. 50-51) chamou de "Saúde Mental do Trabalho" um campo de estudos interdisciplinar, que teria como objeto central "a inter-relação entre o trabalho e os processos saúde/doença cuja dinâmica se inscreve mais marcadamente nos fenômenos mentais", caracterizando-se "tanto pelo enriquecimento dos eixos de análise quanto pela fixação de uma perspectiva em que as finalidades das investigações assumem diretrizes éticas".

Araújo (2011) destaca que o campo vem sendo impulsionado por estudos que enfocam o trabalho em sua relação com o processo de subjetividade, a contribuição do trabalho nos processos de adoecimento psíquico, bem como satisfação e capacidade para o trabalho.

A autora afirma que, para a constituição desse campo, teria sido necessário estabelecer rupturas com modelos dominantes "de concepção dos processos de construção de identidade, individual e coletiva, e de estruturação do processo de determinação de saúde/saúde mental e doença" que desconheceriam o trabalho como elemento ou espaço estruturador da vida subjetiva e desenvolveriam a análise dos processos de adoecimento e sofrimento mental considerando apenas os limites da família ou da sexualidade (ARAÚJO, 2011, p. 325). Na mesma linha, Carvalho (2011, p. 51) aponta a ruptura ou descontinuidade estabelecida pelo discurso da Saúde Mental e Trabalho com relação à Higiene Mental do Trabalho e à Psicologia Industrial e Organizacional, realizando "os mesmos deslocamentos éticos, políticos e epistemológicos que a Saúde do Trabalhador em relação aos modelos da Medicina do Trabalho e da Saúde Ocupacional".

Sato e Bernardo (2005) situam os estudos em Saúde Mental e Trabalho como uma subárea do campo da Saúde do Trabalhador; Athayde (2011) afirma que poderia se considerar uma subárea ou uma temática desse campo. Já Deusdedit Junior (2014, p. 77) caracteriza a Saúde Mental e Trabalho como um campo de fronteira entre outros dois campos, a Saúde do Trabalhador e a Saúde Mental, "tangenciando-os, mas nem por isso confundindo-se com eles". Por essa razão, os problemas que se apresentam seriam desafios na medida em que, no interior desses dois campos, esses problemas 
ainda não seriam devidamente tratados. ${ }^{150} \mathrm{Ou}$, como sugere Athayde (2011), uma alternativa seria explorar a questão considerando as relações entre os campos Saúde do Trabalhador e Saúde Mental e atenção psicossocial/estudos da subjetividade, “operando mais fecundamente 'entre"'.

Autores, como Codo (1988), relatam estudos e pesquisas realizados desde os anos 20 que seriam "precursores" da Saúde Mental e Trabalho como área. Contudo, para Seligmann-Silva (1994), seria no final dos anos 70 e começo dos anos 80 que as relações entre trabalho (processo de trabalho) e saúde mental (processo saúdedoença mental) teriam emergido como novo campo de estudos, "visando à apreensão dos determinantes psicoafetivos, socioculturais e político-econômicos inerentes ao processo de trabalho e de seus efeitos na saúde dos trabalhadores" (CARVALHO, 2011, p. 47).

Desde o final dos anos 80, o tema da Saúde Mental vai se tornando de interesse para pesquisadores, sobretudo depois da publicação, no Brasil, em 1987, da obra de Christophe Dejours, "A Loucura do Trabalho", que despertou intensos debates (DEUSDEDIT JUNIOR, 2014; LIMA, 2013). Lima (2013) também aponta o crescimento da área, verificável pela disseminação de grupos de pesquisa e pela quantidade considerável de publicações e produções acadêmicas (como dissertações e teses) voltadas para a temática.

Dada a complexidade envolvida na compreensão da articulação trabalho-saúde mental, a atuação em Saúde do Trabalhador demandaria um movimento teórico e uma ação interdisciplinares (NARDI; RAMMINGER, 2012).

Diversos autores, como Jacques (2003), Lima (2003, 2005) e Araújo (2011), chamam atenção para as divergências presentes no campo no que se refere ao papel desempenhado pelo trabalho. Para alguns autores, o trabalho seria estruturador e determinante para o adoecimento psíquico; para outros, atuaria como desencadeante

150 Se a Saúde do Trabalhador se configura como um campo ligado à Saúde Coletiva, o que pode implicar uma dificuldade em compreender o processo de singularização da doença, a Saúde Mental pode se deparar com uma dificuldade oposta, ao limitar-se aos casos individuais, desconsiderando (ou minimizando) a dimensão coletiva do adoecimento (DEUSDEDIT JUNIOR, 2014, p. 77). 
(ou "porta de entrada", ou "gatilho") para o adoecimento (ARAÚJO, 2011). Contudo, apesar dessas divergências, Araújo destaca como ponto comum

[...] na quase totalidade da produção, a discussão da importância de se trazer à cena a dimensão da vida no trabalho, explicitando a contraposição aos modelos nos quais o trabalho se encontra alijado da análise da subjetividade e dos processos relativos à saúde mental (ARAúJO, 2011, p. 326).

Outra divergência presente no campo se refere a "problemas conceituais, teóricos e metodológicos", problemas que podem ser percebidos desde a "própria definição do que se entende por adoecimento psíquico e seguem pelos aspectos ou marcadores que assinalariam/indicariam tal adoecimento" (ARAÚJO, 2011, p. 339). Outra divergência apontada é a que se refere ao estabelecimento ou determinação do nexo causal entre o trabalho e o adoecimento mental; para Jacques (2013, p. 246), isso seria devido ao fato de muitas teorias psicológicas não reconhecerem a categoria trabalho na etiologia da doença mental. 151

Dadas as divergências apontadas, ao analisar a produção teórica em Saúde Mental e Trabalho encontra-se grande diversidade "taxonômica", com agrupamentos, distinções e classificações de correntes distintas (ARAúJO, 2011).

Serão apresentadas algumas dessas "taxonomias", bem como um delineamento de algumas das abordagens teórico-metodológicas do campo sem, contudo, pretender estabelecer uma nova tipologia, por entender, como Jacques (2003, p. 99), "que qualquer classificação simplifica e engessa a questão"; tampouco se pretende "esgotar os diferentes referenciais teóricos e metodológicos propostos".

A apresentação dessas classificações e abordagens, ainda que de forma sumária, se faz necessária para a compreensão da diversidade de abordagens e perspectivas, por vezes antagônicas, presentes no campo da Saúde Mental e Trabalho. ${ }^{152}$

\footnotetext{
151 "A hegemonia do pensamento psicanalítico no campo 'psi' é uma das justificativas para a pouca importância conferida aos vínculos entre trabalho e saúde/doença mental que, embora presentes na obra freudiana, foram relegados a um segundo plano no campo conceitual da Psicanálise" (JACQUES, 2013, p. 246).

152 Essas divergências serão muito mencionadas pelos profissionais entrevistados nesta tese, como se pode observar na seção 6.3 .
} 
Uma primeira tipologia ou "taxonomia" é proposta por Seligmann-Silva (1994), na qual a autora distingue três referenciais teóricos ou, como coloca Jacques (2003), modelos teóricos em Saúde Mental e Trabalho: as teorias sobre estresse (work-stress), a Psicodinâmica do Trabalho e o modelo que adota o conceito de desgaste. Em trabalho mais recente, renomeia esses modelos como: teoria do estresse, perspectivas psicanalíticas e a noção de desgaste como abordagem integradora e ampliadora das demais (SELIGMANN-SILVA, 2011).

Jacques (2003) toma como critérios para sua tipologia o referencial teórico, a metodologia proposta e a inter-relação entre trabalho e o processo saúde/doença mental, distinguindo quatro grandes grupos de abordagens: as teorias sobre estresse, a Psicodinâmica do Trabalho, as abordagens de base epidemiológica e/ou diagnóstica e os estudos e pesquisas em subjetividade e trabalho. Estudos associados ao desgaste mental são incluídos pela autora em um ou outro dos conjuntos conforme a ênfase e abordagem metodológica.

Glina e colaboradores (2001) delineiam entre os modelos de explicação das relações entre Saúde Mental e Trabalho duas correntes: a Psicopatologia ou Psicodinâmica do Trabalho e os estudos que tratam da relação entre estresse e trabalho.

Para Tittoni (2002, p. 216), seriam dois os eixos constituídos por abordagens teóricometodológicas em saúde Mental e Trabalho, sendo um voltado para o "diagnóstico dos sintomas de origem psi e sua vinculação às situações de trabalho", com forte influência da epidemiologia; o outro se ocuparia das "representações dos trabalhadores e suas experiências no cotidiano de trabalho e nas situações de adoecimento", influenciado pelos conhecimentos produzidos pelas ciências sociais e pela psicanálise.

Araújo (2011, p. 327) distingue três correntes de pensamento no campo da Saúde Mental e Trabalho: a fundamentada na teoria do estresse; a vinda das ciências sociais, que privilegia aspectos relacionados às relações de poder; e a originária da teoria psicanalítica, que subsidia os estudos da Psicodinâmica do Trabalho.

Bendassolli e Soboll (2011) apresentam três vertentes de análise psicológica sobre as questões engendradas pelo trabalho: uma social, uma cognitivo-comportamental e uma clínica, sendo que apenas a última estaria relacionada ao campo da Saúde Mental 
e Trabalho. Com referência à vertente clínica, os autores apresentam quatro grandes modelos teóricos e de intervenção, que configurariam "clínicas do trabalho": Psicodinâmica do Trabalho, Clínica da Atividade, Psicossociologia e Ergologia.

Uma breve exposição sobre essas correntes/abordagens em Saúde Mental e Trabalho encontra-se esboçada a seguir. ${ }^{153}$

\subsection{Psicodinâmica do Trabalho}

A Psicodinâmica do Trabalho, abordagem que tem Christophe Dejours como o principal expoente, tornou-se difundida no Brasil a partir da publicação, em 1987, de seu livro "A loucura do trabalho: estudos de psicopatologia do trabalho" (JACQUES, 2003). Essa obra teria desempenhado um papel de destaque na discussão sobre as relações entre saúde mental e trabalho no Brasil - para Lima (1998), foi a partir dessa publicação que o interesse pela questão da saúde mental no trabalho teria se fortalecido e adquirido visibilidade. A ênfase dessa abordagem se centraria no privilégio concedido ao estudo da normalidade sobre a patologia. Essa ênfase teria ensejado posteriormente a substituição da terminologia Psicopatologia do Trabalho por Psicodinâmica do Trabalho, visando minimizar a importância dos aspectos psicopatológicos (JACQUES, 2003).

Sua atenção se voltaria para "o campo do sofrimento e do conteúdo, da significação e das formas desse sofrimento no âmbito do infrapatológico ou do pré-patológico" (JACQUES, 2003, p. 104). O sofrimento psíquico seria concebido como "uma vivência subjetiva intermediária entre a doença mental descompensada e o conforto (ou bemestar) psíquico", que levaria à utilização de "estratégias defensivas, construídas, organizadas e gerenciadas coletivamente" (DEJOURS; ABDOUCHELY, 1994, p. 124), defesas que seriam coletivamente elaboradas pelos trabalhadores no enfrentamento das situações de sofrimento no cotidiano laboral. O sofrimento seria experimentado, pelo trabalhador, por meio de sentimentos de insatisfação com relação ao conteúdo ergonômico e ao conteúdo significativo do trabalho, e de ansiedade (ARAÚJO, 2011).

\footnotetext{
153 Vale recordar que, como explanado na seção 5.2.2.1.2, "Abordagens sobre Estresse", nesta tese, as vertentes teórico-metodológicas subsidiadas pelas teorias sobre o estresse não estão sendo consideradas como pertinentes ao campo da Saúde Mental e Trabalho.
} 
A abordagem toma como referência os conceitos ergonômicos de trabalho prescrito e trabalho real, concedendo prioridade a aspectos relacionados à organização do trabalho. A psicanálise forneceria os aportes teóricos subjacentes à pesquisa e ao trabalho de interpretação, sendo o método proposto a escuta, a interpretação e a devolução; apresentam-se objeções ao uso de questionários e estudos epidemiológicos, sendo impostas restrições à observação do cotidiano de trabalho por priorizar-se a escuta do trabalhador (JACQUES, 2003). As intervenções propostas, pautadas no modelo clínico de diagnóstico e intervenção, se dirigiriam para a coletividade de trabalho, por meio da entrevista coletiva, e não indivíduos tomados isoladamente, contemplando aspectos da organização do trabalho a que os indivíduos estariam submetidos (JACQUES, 2003). No Brasil, algumas adaptações ao método foram introduzidas, como a realização do estudo na ausência de demanda por parte do coletivo de trabalhadores e a substituição das entrevistas coletivas por entrevistas individuais (ARAÚJO, 2011).

Na Psicodinâmica do Trabalho, o objetivo não seria o desvendamento da realidade do trabalho em suas dimensões físicas e cognitivas; seriam privilegiados os relatos das vivências subjetivas dos trabalhadores, sua fala sobre o trabalho, emoções e reações por ele desencadeados, ou, nos termos de Dejours, a dimensão do comentário (ARAÚJO, 2011; DEUSDEDIT JUNIOR, 2014).

Com referência ao papel desempenhado pelo trabalho no adoecimento psíquico, para a Psicodinâmica do Trabalho não haveria relação causal entre o trabalho e saúde mental; as doenças mentais dependeriam das estruturas de personalidade, adquiridas muito antes da entrada dos indivíduos no mundo produtivo (LIMA, 2004). O trabalho poderia constituir uma espécie de "porta de entrada" ou "gatilho", mas não assumiria papel determinante no processo de adoecimento (JACQUES, 2003). Como coloca Araújo (2011, p. 328), “o trabalho poderia, a partir de determinadas características, estabelecer o momento de expressão do sofrimento, mas não a sua forma - esta, sim, decorrente da estrutura psíquica do indivíduo".

Segundo Jacques (2003, p. 105), Dejours teria afirmado se afastar dos pressupostos psicanalíticos centrais "sob a justificativa de que sob a égide teórica de Freud, a única fonte de distúrbios é a dinâmica que se trava entre a repressão social e a sexualidade 
emergente". Contudo, como destaca a autora, para leitores da obra de Dejours, como M. Lima e Codo, os vínculos com os princípios psicanalíticos se manteriam, uma vez que "a concepção de sujeito é psicanalítica, a conceituação teórica é psicanalítica, as conclusões são psicanalíticas e a racional teórica em que as conclusões se apoiam é psicanalítica" (CODO, apud JACQUES, 2003, p. 105). Já Lima (2011a) aponta como o trabalho permaneceria uma categoria marginal, subordinada à subjetividade, objeto por excelência da Psicodinâmica do Trabalho. Lima (1998) também destaca que, não obstante a importância das publicações de Dejours para a discussão e pesquisa sobre as relações entre saúde mental e trabalho no Brasil, a pouca discussão em torno de outras abordagens em debate ou controvérsia com a Psicodinâmica do Trabalho teria introduzido um viés nas pesquisas e produções teóricas sobre a temática. Nos termos da autora,

[...] ao mesmo tempo em que essa publicação [o livro "A loucura do trabalho"] teve o inegável mérito de permitir que passássemos efetivamente a refletir sobre as questões que envolvem a relação entre saúde mental e trabalho, ela acabou por acarretar um novo problema, ao se colocar como portadora da melhor, senão a única, perspectiva válida nesse campo (LIMA, 2013, p. 94).

Lima (2011a) também critica a concepção de ciência e pesquisa da Psicodinâmica do Trabalho, na medida em que priorizaria o arranjo mental dos conceitos, um modelo teórico concebido pela via especulativa e que serviria para ordenar as evidências empíricas. Para Araújo (2011), com relação ao método, a ênfase no discurso dos trabalhadores poderia desconsiderar as condições objetivas em que se realizam as atividades laborais; o trabalho, compreendido apenas por meio de vivências subjetivas, o seria apenas parcialmente. A autora também aponta aspectos metodológicos de difícil operacionalização em contextos como o brasileiro - por exemplo, a realização da pesquisa apenas segundo a demanda dos trabalhadores ou as entrevistas envolvendo o coletivo de trabalhadores. Essas modificações e adaptações introduzidas na metodologia requereriam a avaliação de possíveis distorções que esses procedimentos possam ter introduzido no método utilizado.

\subsection{Modelos que adotam o conceito de desgaste mental}

De acordo com Seligmann-Silva et al. (2010, p. 189), a perspectiva centrada no conceito de desgaste teria como fundamento teórico o materialismo dialético e a 
perspectiva histórica, sendo um modelo associado a essa corrente e adotado no Brasil o do desgaste mental. Este, por sua vez, tomaria como base as noções de desgaste e cargas de trabalho propostas por Laurell (1986) e Laurell e Noriega (1989), noções vinculadas "à ideia de consumo do substrato e das energias vitais do trabalhador pelos processos de trabalho".

Segundo Glina et al. (2001, p. 608), o desgaste psíquico seria associado, por SeligmannSilva, à imagem de "mente consumida", em três esferas: 1) envolvendo quadros clínicos relacionados ao desgaste orgânico da mente (quer seja em decorrência de acidentes do trabalho, quer seja pela ação de produtos tóxicos); 2) envolvendo variações do "mal-estar", dentre as quais, a fadiga (mental e física) é uma das analisadas; 3) quando da verificação de desgastes que afetem a identidade do trabalhador, "ao atingir valores e crenças, que podem ferir a dignidade e a esperança". Os agravos à saúde mental seriam decorrentes de perdas ocasionadas pelo desgaste mental, perdas que poderiam assumir múltiplas dimensões: de ordem concreta, simbólica ou potencial; de natureza biológica, psíquica ou social, embora geralmente correspondam a articulações dessas três instâncias (ARAÚJO, 2011).

Uma perspectiva de análise fundamental seria, para Seligmann-Silva (2011), a que focaliza a dominação:

O desgaste é visualizado como produto de uma correlação desigual de poderes impostos sobre o trabalho e sobre o trabalhador, acionando forças que incidem no processo biopsicossocial saúde-doença. Ou melhor, uma correlação de poderes e forças em que o executante do trabalho se torna perdedor (SELIGMANN-SILVA, 2011, p. 123, grifos da autora).

Seligmann-Silva $(1994,2011)$ apresenta a noção de desgaste como opção conceitual integradora:

O modelo centrado no conceito de desgaste mental pode ser também tomado como um paradigma integrador se contemplado em face dos outros modelos teóricos considerados [na tipologia de Seligmann-Silva, teorias sobre estresse e Psicodinâmica do Trabalho], pois permite compreender as interações entre: a) os "fatores" ambientais e psicossociais objetivados pelos estudos do work-stress; b) o mundo subjetivo e a identidade [...] e as elaborações de sentido [...], aproximando-se, assim, da PDT [Psicodinâmica do Trabalho]; c) as diferentes esferas da vida social onde se desenvolvem relações de poder - que, quando desvantajosas para a integridade e estabilidade mental do trabalhador, acarretarão o desgaste (SELIGMANN-SILVA, 2011, p. 137). 


\subsection{Abordagens de base epidemiológica e/ou diagnóstica}

A abordagem de base epidemiológica e/ou diagnóstica das relações entre saúde mental e trabalho, segundo classificação de Jacques (2003), se caracterizaria pela incorporação de elementos teórico-metodológicos oriundos da Epidemiologia Social, como o modelo da determinação social da doença, e das ciências sociais (ARAÚJO, 2011).

Os estudos de cunho epidemiológico das relações entre saúde mental e trabalho estariam ligados, segundo Araújo (2011), ao crescimento do campo da saúde pública e da Saúde Coletiva no país, em especial com a criação de cursos de pós-graduação stricto sensu; esses cursos, por sua vez, teriam contribuído para a formação e qualificação de pesquisadores de diversas áreas de atuação profissional em saúde e trabalho, inclusive para os serviços de atenção à saúde do trabalhador das diferentes esferas do governo.

De acordo com Jacques (2003), as contribuições dessa abordagem permitiriam comprovar o caráter social do processo saúde/doença, e o trabalho se apresentaria como um fator constitutivo do psiquismo e do processo saúde/doença mental; as condições e contradições nas quais o trabalho é realizado determinariam os modos de adoecimento (ARAÚJO, 2011).

Essa abordagem lança mão da utilização de metodologias qualitativas e quantitativas, uma característica dos estudos de um dos precursores dos estudos sobre os vínculos entre saúde e doença mental e trabalho, Louis le Guillant (JACQUES, 2003). Essa perspectiva "pluridimensional" buscaria informações de todos os instrumentos disponíveis, como observações, questionários, entrevistas, fontes documentais e dados estatísticos (LIMA, 2002).

Para um dos autores de destaque dessa abordagem, Wanderley Codo, cujos estudos visam identificar quadros psicopatológicos associados a determinadas categorias profissionais, o trabalho seria uma dupla relação de transformação entre o homem e a natureza, geradora de significado; e "o sofrimento psíquico e a doença mental ocorrem quando, e apenas quando, afeta esferas da nossa vida que são significativas, geradoras e transformadoras de significado" (CODO, 2002, p. 174). Os estudos de Lima 
(2004) também revelariam a predominância de distúrbios mentais específicos em determinadas classes profissionais. Muitos dos estudos e pesquisas dessa abordagem priorizariam a "identificação de quadros psicopatológicos relacionados ao trabalho em que este se apresenta como constitutivo e não, tão somente, como fator desencadeante" (JACQUES, 2003, p. 109); o trabalho e seus elementos constituintes seriam estruturantes do conteúdo e da forma do sofrimento apresentado (ARAÚJO, 2011). Jacques (2007) também situa nessa abordagem os estudos que objetivam o estabelecimento do nexo causal entre transtornos mentais e trabalho.

Uma característica da abordagem, destacada por Araújo (2011), é a condução de estudos com base em demandas sindicais, ligando-se, segundo a autora, de modo significativo a lutas sindicais por melhores condições de trabalho. ${ }^{154}$

Uma crítica à abordagem exposta por Araújo (2011, p. 332) seria "o foco excessivo na doença, o que obscurece o olhar sobre a dimensão estruturante do trabalho, portadora de identidade e conformadora da subjetividade, ou a compreensão [...] da plasticidade humana na cena laboral".

\subsection{Estudos em Subjetividade e Trabalho}

Jacques (2003) classifica na categoria subjetividade ${ }^{155}$ e trabalho um leque de variados estudos e pesquisas. Em comum, visariam analisar o sujeito trabalhador, definido a partir de suas experiências e vivências adquiridas no mundo do trabalho, considerado para além de seu caráter técnico e econômico.

Analisam-se as relações entre saúde mental e trabalho tomando como base as experiências e vivências subjetivas, não se restringindo aos processos de adoecimento psíquico. O trabalho se constituiria como o eixo central para a compreensão da subjetividade humana (ARAÚJO, 2011); o campo da subjetividade e trabalho "constróise no tensionamento entre as dicotomias indivíduo-coletivo e objetivo-subjetivo"

\footnotetext{
154 Dois exemplos seriam o estudo de Codo e colaboradores, financiado pela Confederação Nacional dos Trabalhadores em Educação e anteriormente citado na tese (CODO, 1999); outro, estudo com vigilantes patrimoniais e do transporte de valores, fruto de parceria firmada entre o Sindicato dos Vigilantes de Minas Gerais, Ministério Público do Trabalho e pesquisadores da UFMG e da PUC-MG (VIEIRA; LIMA; LIMA, 2010).

155 Podem ser encontrados distintos conceitos de subjetividade, subjetivação e sofrimento. A esse respeito, conferir Brant e Minayo-Gomez (2011).
} 
(NARDI, TITTONI \& BERNARDES, 2002, p. 241). Dessa forma, essa abordagem considera que o trabalho pode estabelecer formas específicas de sofrimento (ARAÚJO, 2011).

Diversos aportes teóricos contribuem para a abordagem: pressupostos marxistas, que sustentam a concepção sobre a "determinação histórica dos processos de saúde/doença e seus vínculos com as condições de vida e de trabalho dos trabalhadores"; discussões de Canguilhem sobre saúde e doença, como sua distinção entre patologia e anormalidade, e seu conceito de saúde não restrito à ausência de doença; da psicologia social histórico-crítica, como os pressupostos da não dicotomia entre indivíduo e coletivo, subjetivo e objetivo; da psicanálise, ampliando o campo conceitual para além do intrapsíquico, concebendo o sujeito como vinculado às normas sociais (JACQUES, 2003, p. 110).

São de interesse desse enfoque as vivências, o cotidiano, os modos de ser sem privilégio de diagnósticos psicopatológicos. Os temas de estudos e pesquisas são diversos, como gênero, etnia, processo de trabalho, transformações tecnológicas e organizativas (JACQUES, 2003).

Como metodologia, Jacques (2003) aponta o privilégio de abordagens qualitativas, por meio de técnicas como observação, entrevistas individuais e coletivas, análises documentais. Segundo Tittoni (2002, p. 286), "as estratégias de discussões em grupo, de entrevistas coletivas, de pesquisa etnográfica, das diferentes estratégias para análise do discurso, mostram-se como formas importantes de agir sobre a produção de conhecimento em saúde mental e trabalho". Sato (2011) refere-se também à pertinência da abordagem etnográfica para os estudos em saúde mental e trabalho, a qual torna possível conhecer o "trabalho real" e como nele são operadas e vivenciadas formas de controle gerencial, bem como seus imprevistos, situações problemáticas, enfim, o cotidiano de trabalho real.

Privilegia-se a dimensão da experiência e das vivências dos trabalhadores, considerando-se as vivências de sofrimento e adoecimento sem que haja a ênfase em diagnósticos clínicos. Como colocam Nardi, Tittoni e Bernardes (2002, p. 245), as diferentes abordagens que "constroem o campo da subjetividade e trabalho, buscam as experiências dos sujeitos e as tramas que constroem o lugar do trabalhador, definindo modos de subjetivação relacionados ao trabalho". 
Como aponta Pereira (2015), também integram essa abordagem estudos que buscam analisar estratégias desenvolvidas pelos trabalhadores, como movimentos de resistência e ações individuais e coletivas que visam diminuir as pressões e conseguir espaços de manobra para si, como nos trabalhos de Sato (2002).

\subsection{Clínica da Atividade}

A Clínica da Atividade toma como fundamentos, em grande medida, as teorias de Vygotsky, Leontiev e Bakhtin (CLOT, 2011). Sua abordagem amplia o conceito de atividade, considerando o trabalho como atividade dirigida, histórica e processual (BENDASSOLLI; SOBOLL, 2011).

Para Clot (2007, p. 12), “o trabalho não é uma atividade entre outras. Ele exerce na vida pessoal uma função psicológica específica que se deve definir". As relações entre atividade e subjetividade estariam no centro da análise, sendo a subjetividade constituída na e pela atividade (LHUILLIER, 2011; BENDASSOLLI; SOBOLL, 2011): “o trabalhador constitui e é constituído por sua atividade, sendo ao mesmo tempo produtor e produto, estando presente a capacidade de afetar e de ser afetado" (SILVA; BARROS; LOUZADA, 2011, p. 194).

A atividade se efetivaria como elaboração, por parte do sujeito, de sua tarefa, redefinição que seria individual e coletiva. Contudo, deve-se considerar que o real da atividade é muito mais vasto que a atividade realizada; nesse sentido, o objeto da Clínica da Atividade não seria a atividade como tal, mas o desenvolvimento das atividades do sujeito e seus impedimentos (SILVA; BARROS; LOUZADA, 2011). Nos termos de Lhuillier (2011, p. 44), "a análise da atividade deve levar em conta também o que não se faz, o que não se pode fazer, o que se tenta fazer sem conseguir, o que se teria querido ou podido fazer, o que não se faz mais, o que se pensa ou o que se sonha poder fazer no futuro".

O sofrimento emergiria de uma atividade ou desenvolvimento impedido, que levaria a uma perda do "poder de agir": "a função psicológica do trabalho pode ser perdida quando ele, enquanto atividade concreta, não é mais uma fonte de alteridade, um centro de iniciativa e de criatividade" (CLOT, 2011, p. 78). 
Outra questão relevante se refere à compreensão do trabalho; o trabalhar seria sempre uma dimensão coletiva, sendo o trabalho um "exercício coletivo de ligação social com o real" (CLOT, 2011, p. 73), uma possibilidade de estabelecer engajamento em uma história coletiva. Nesse sentido, a análise do trabalho sempre se situaria diante dos estilos e dos gêneros: o gênero, uma "dimensão transpessoal do ofício", faria a inscrição das habilidades necessárias à realização de uma atividade, na história de um coletivo (habilidades essas que não poderiam ser isoladas do contexto social de seu uso); já os estilos seriam a reformulação dos gêneros, em situação (SILVA; BARROS; LOUZADA, 2011). A possibilidade de os trabalhadores se reconhecerem no que fazem, corresponderia à sua inscrição em uma história não apenas dos sujeitos envolvidos, mas na de um ofício, história que não pertenceria a ninguém, mas pela qual todos se sentiriam responsáveis (CLOT, 2011).

A Clínica da Atividade visaria promover uma transformação das situações de trabalho, tomando os trabalhadores como protagonistas dessa transformação (LIMA, 2013; DEUSDEDIT JUNIOR, 2015). Os principais métodos utilizados na Clínica da Atividade são a instrução ao sósia e a autoconfrontação cruzada, que visariam "produzir um deslocamento do trabalhador do lugar de quem cumpre suas tarefas, com um grau mais ou menos elevado de automatismos, para o lugar de quem observa e analisa seu próprio trabalho" (SILVA; BARROS; LOUZADA, 2011, p. 147).

Seu objeto seria o trabalho como atividade coletiva transformadora dos objetos e do outro (SILVA; BARROS; LOUZADA, 2011), e sua ênfase, na busca de instrumentos que viabilizem a compreensão da situação de trabalho real para aumentar o poder de agir do sujeito (BENDASSOLLI; SOBOLL, 2011). Nos termos de Clot (2011), "trata-se do

desenvolvimento do poder de agir sobre o mundo e sobre si mesmo, coletiva e individualmente". E prossegue: "criar um contexto para viver: é nessa condição que atividade e saúde são sinônimos" (CLOT, 2011, p. 72).

\subsection{Psicossociologia}

O principal interesse da Psicossociologia seriam a relação ou as reciprocidades entre o individual e o coletivo, o psíquico e o social, o particular e o geral (CARRETEIRO; BARROS, 2011; BENDASSOLLI; SOBOLL, 2011). Na tensão entre os sistemas sociais e as 
estruturas psíquicas, se articulariam o campo social, a conduta humana e a vida psíquica, sendo o vínculo social analisado a partir das transformações sociais empreendidas pelos sujeitos, e pelos rearranjos psíquicos engendrados a partir de suas experiências no mundo (PEREIRA, 2015).

Constituem-se, então, como objetos privilegiados da Psicossociologia a compreensão das relações interpessoais, dos processos grupais, das organizações e das instituições (LHUILIER, 2011). Grupos, organizações e instituições seriam mediadores da vida pessoal dos indivíduos. A organização envolveria "elementos técnicos e normativos, bem como uma dimensão simbólica (da cultura) e outra, imaginária (das representações compartilhadas)"; já as instituições se definiram como "um conjunto de signos e de símbolos, de representações e de regras, produtos das práticas das relações humanas" (BENDASSOLLI; SOBOLL, 2011, p. 11).

Outro aspecto a destacar se refere ao fato de que, na tradição psicossociológica, o trabalho não se constitui como objeto específico de investigação. Nos termos de Amado e Enriquez (2011, p. 101), "os sujeitos humanos não se encontram ligados apenas a uma função e a um trabalho, eles estão, em maior ou menor grau, ligados a um sistema mediador entre o indivíduo e a sociedade, o grupo, a organização ou a instituição". Ou seja, como colocam Carreteiro e Barros (2011), a relação-indivíduo sociedade seria a base de compreensão do mundo do trabalho e do sujeito trabalhador.

Um ramo da Psicossociologia, a Psicossociologia do Trabalho, tem se voltado mais para a discussão do trabalho; não se trataria de uma nova disciplina, mas de uma práxis, construída coletivamente, cujo eixo privilegiado de análise seriam os processos de resistência (PEREIRA, 2015).

Nesse sentido, embora a Psicossociologia não possua conceitos relativos ao trabalho como atividade e trabalho concreto, convocaria e promoveria diálogos com diversos campos disciplinares para a compreensão da complexidade do trabalho; um exemplo citado por Carreteiro e Barros (2011, p. 222) é a interface com a Ergonomia e a Ergologia, que permitiriam tomar o "trabalho real e as experiências dos trabalhadores como categorias importantes na compreensão da subjetividade, do desenvolvimento do sujeito e dos processos de sua participação social". 
Quanto ao aspecto clínico da Psicossociologia, Carreteiro e Barros (2011) destacam que o trabalho do psicossociólogo se faria, simultaneamente, em duas dimensões, a das transformações sociais e a dos remanejamentos psíquicos. A clínica, concebida de modo amplo, se voltaria para a produção de novos sentidos, nessa articulação entre as questões singulares e o contexto mais amplo (PEREIRA, 2015).

Como atuação privilegiada, se propõe a pesquisa/intervenção psicossociológica, um dispositivo de consulta e pesquisa, que visaria a um trabalho de elaboração coletiva (BENDASSOLLI; SOBOLL, 2011), realizada a partir de análises sociais de situações concretas (LHUILIER, 2011; CARRETEIRO; BARROS, 2011; AMADO; ENRIQUEZ, 2011). Pesquisadores ("interventores") e sujeitos pesquisados possuiriam o mesmo status de conhecimento, uma vez que são detentores de saberes específicos que, mesmo diferentes, são colocados, no processo, em termos de igualdade; rompe-se assim a concepção do pesquisador como um expert, visando ao estabelecimento de uma relação de cooperação (CARRETEIRO; BARROS, 2011).

\subsection{Ergologia}

A Ergologia, segundo Bendassolli e Soboll (2011), teria como projeto melhor conhecer o trabalho para intervir e transformá-lo, buscando contemplar as atividades humanas em todas as suas dimensões. A atividade ${ }^{156}$ é tomada no sentido de atividade interior: seria "o que se passa na mente e no corpo da pessoa no trabalho, em diálogo com ela mesma, com o seu meio e com os 'outros'" (TRINQUET, 2010, p. 96).

Como destaca Nourodine (2011, p. 78), em ergonomia da atividade (uma das abordagens que subsidia teoricamente a Ergologia), analisar o trabalho é estudar tanto o trabalho prescrito quanto o trabalho real, mas, sobretudo, a distância entre eles. Compreender o trabalho seria, então, dar conta "do sentido da atividade como gestão da distância que há entre o prescrito e as condições reais do trabalho".

Para a Ergologia, em qualquer atividade humana há normas elaboradas anteriormente à realização dessas atividades, as chamadas "normas antecedentes", conceito que

156 Deve-se destacar que, para a Ergologia, o trabalho é mais uma das formas de atividade humana: "A atividade de trabalho, entre todas as outras atividades humanas com as quais ela se comunica, não tem, de modo algum, o privilégio dessa dimensão dramática" [necessidade constante de renormatizações] (SCHWARTZ, 2011, p. 133). 
envolveria saberes relativamente estabilizados, como o prescrito, objetivos, regras, missões, entre outros, e os oriundos da experiência, como culturas de ofício, knowhow e valores. Durante a realização da atividade, considerando imprevisibilidades das situações de trabalho (como disfunções, por exemplo), os protagonistas do trabalho deveriam proceder a ajustes das normas antecedentes. O processo de construção, de correlação das normas antecedentes a características das situações de trabalho, no intuito de produzir normas mais adequadas às condições reais da atividade, é chamado de "renormalização". As normas antecedentes e as renormalizações seriam referências para a realização das atividades, bem como da distância entre normas e condições reais de trabalho; "Em Ergologia, o princípio epistemológico central na produção de saber sobre a atividade humana reside na dialética entre a norma antecedente e a renormalização" (NOUROUDINE, 2011, p. 79).

Seria impossível a existência de normas antecedentes totais ou "completas"; o trabalhar nunca se ateria à dimensão do prescrito. Dessa forma, "trabalhar é arriscar, fazer 'uso de si'" (SCHWARTZ, 2011, p. 191). ${ }^{157}$ Como coloca Pereira (2015), a ideia de uso de si se referiria à capacidade de o sujeito fazer escolhas (mesmo que inconscientes), usar suas capacidades e renormatizar. Nos termos de Trinquet (2010, p. 96),

\footnotetext{
Essa capacidade, que somente os humanos possuem, [que] permite-lhes usar de si mesmos como lhes convém. É uma liberdade [...] muito limitada pelas coerções inevitáveis, mas nunca há somente uma única melhor maneira de fazer as coisas. Pois, sempre há escolhas, por mais ínfimas que elas sejam. [...] Um ser humano sempre hesita porque é consciente e pode escolher, adaptar-se, atualizar e, portanto, inovar.
}

Essa impossibilidade de antecipação completa seria nociva à saúde, conceituada por Schwartz (2011, p. 138) como a "tentativa de redesenhar parcialmente o meio em que se vive, em função de suas próprias normas, elaboradas por sua história". Os riscos de acidente e adoecimento surgiriam quando a gestão se desse com base exclusiva na norma antecedente, "bloqueando as alternativas, sancionando as renormatizações, obstruindo as arbitragens" (PEREIRA, 2015, p. 44).

157 A esse respeito, Trinquet $(2010$, p. 96) afirma que "a evolução do trabalho corresponde a uma capacidade especificamente humana, que [...] Schwartz [...] chama de uso de si e que outros intitulam de auto-organização ou de poder de agir". 
A intervenção na ergologia teria como objetivo "incitar aqueles que vivem e trabalham a pôr em palavras um ponto de vista sobre sua atividade, a fim de torná-la comunicável e de submetê-la à confrontação de saberes" (SCHWARTZ, 2011, p. 162). Essa intervenção não poderia ser abordada apenas por peritos, mas somente por um coletivo onde certas condições de organização e funcionamento se fizessem presentes, que seriam encontradas no Dispositivo Dinâmico de Três Polos (DD3P). O polo dos saberes constituídos se referiria a conceitos, competências e conhecimentos disciplinares acadêmicos ou profissionais - saberes que, essencialmente, permitiriam elaborar o trabalho prescrito. Já o polo dos saberes investidos na atividade se referiria à experiência prática, recriadora de saberes por meio dos debates de normas (TRINQUET, 2010). As colaborações do primeiro polo (a colaboração entre as disciplinas) e as do segundo polo (a colaboração com os protagonistas do trabalho) só poderiam, por sua vez, funcionar e se constituir em face do terceiro polo, no qual se colocam duas exigências: ética e epistemológica. A exigência epistemológica postularia que a produção de saber sobre as atividades humanas requereria a colaboração de seus autores e sua abordagem em sua complexidade; a exigência ética postula uma concepção do sujeito humano "em que este aspira a ser produtor de suas próprias normas de vida" (NOUROUDINE, 2011, p. 81). Nos termos de Schwartz (2011, p. 163), "O terceiro polo que não designa interlocutores entre os dois primeiros polos: [mas sim] como pensar o trabalho e retrabalho por cada um dos saberes e conjuntos de valor dos outros".

A Ergologia, como colocam Athayde e Brito (2011), não teria como projeto se colocar como uma disciplina; seus conceitos e pontos de vista sobre a atividade seriam transversais a saberes, disciplinas e abordagens sobre o trabalho, com eles trabalhando em conjunto. Outro aspecto a destacar é a necessária pluridisciplinaridade da abordagem, visando apreender as múltiplas dimensões que constituem as atividades, bem como as normas e os processos de renormalização em ação (NOUROUDINE, 2011).

Das questões e convergências ou divergências metodológicas e conceituais em jogo nas correntes/abordagens em Saúde Mental e Trabalho apresentadas, duas serão aqui 
brevemente retomadas: as divergências no que dizem respeito à consideração da centralidade do trabalho como categoria fundante humana e ao papel por ele desempenhado do adoecimento mental.

Para a Psicodinâmica do Trabalho, o trabalho seria um fator desencadeante, uma espécie de "gatilho" ou "porta de entrada" no processo de saúde/doença mental; já o caráter constitutivo do trabalho no processo de saúde/doença mental seria comum às abordagens com base no modelo epidemiológico e/ou diagnóstico, aos estudos e pesquisas em subjetividade e trabalho e na Clínica da Atividade. Já a ausência de ênfase na patologia seria um aspecto comum entre as investigações em subjetividade e trabalho e a Psicodinâmica do Trabalho (JACQUES, 2003).

A perspectiva da centralidade do trabalho seria observada em abordagens como Clínica da Atividade, abordagens de base epidemiológica e estudos sobre subjetividade trabalho, e refutada pela Ergologia e Psicossociologia; já na Psicodinâmica do Trabalho, ao mesmo tempo em que se destaca o caráter privilegiado da categoria trabalho como mediadora entre o sujeito e o campo social, o enfoque principal dessa abordagem encontra-se nas dinâmicas intrassubjetivas (PEREIRA, 2015).

Jacques (2003) aponta que a complexidade da relação entre a saúde/doença mental e trabalho ensejaria extrapolar os limites de determinada abordagem, indicando pesquisadores com grande experiência que o fazem, admitindo o emprego de conceitos e de procedimentos metodológicos de origens diversas; contudo, para fazêlo, seria necessária reflexão e argumentação consistentes, e não apenas um empréstimo acrítico e ocasional. Como coloca Sato (2011), a opção pelo emprego de uma ou outra abordagem repousaria em condicionamentos diversos, como a natureza do objeto, o objetivo do estudo, a concepção sobre a realidade social condicionantes de ordem epistemológica e teórico-conceitual.

Contudo, como destaca Jacques (2003, p. 99), o que frequentemente se verificaria seria a imprecisão teórica e metodológica,

[...] o que produz tentativas ingênuas de combinar conceitos e técnicas com fundamentos epistemológicos diferentes. Constata-se, não uma tentativa de articular pressupostos diversos, mas, simplesmente, emprestar conceitos e técnicas sem uma reflexão sobre as diferentes concepções de homem, homem/sociedade, ciência e pesquisa que lhes fundamentam. 
Carvalho (2011, p. 46) observa nas produções teórico-práticas no campo da Psicologia do Trabalho e, mais notadamente, no da Saúde Mental e Trabalho, o que chama de textos "camaleônicos" ou "miméticos": textos produzidos sob as "rubricas" Psicologia do Trabalho e Saúde Mental do Trabalhador, mas que com elas "não guardam identidade [...] discursiva no que tange aos objetivos, finalidade social e compromisso ético ou de classe social". Em sua avaliação, são produzidos por "intelectuais ou técnicos que lançam mão de sofisticado e contemporâneo ferramental conceitual para atender aos objetivos organizacionais e empresariais", produzindo como resultado "um discurso inconsistente, mas de aparência complexa". O autor observa como conceitos como "modos de subjetivação" e "saúde do trabalhador" aparecem deslocados de seu sentido histórico-crítico, e a categoria trabalho sendo confundida com "emprego" e "alienada das dimensões histórica e ontológica ou deslocada do centro do debate".

Lima (2013) também chama atenção para publicações que colocam, lado a lado, autores de perspectivas teóricas as mais diversas, algumas mesmo antagônicas. A autora cita Chasin (2001) que, ao criticar o que chama de "falácia da equivalência" ou "pluralismo" entre as vertentes do pensamento, concluiu que isso se tornaria uma espécie de "camuflagem da ignorância ou um subterfúgio do oportunismo em teoria"; essa falácia acabaria se tornando "princípio de convivência ou de coabitação acadêmica, jamais critério de verdade ou meio de produção teórica da verdade, a não ser como verdade instrumental, pragmaticamente concebida" (CHASIN, 2001 apud LIMA, 2013, p. 96). 


\section{OS TRANSTORNOS MENTAIS E DO COMPORTAMENTO RELACIONADOS AO TRABALHO}

Busca-se neste capítulo estabelecer uma discussão sobre os Transtornos Mentais e do Comportamento Relacionados ao Trabalho, que se divide em três planos.

No primeiro plano, "Os Transtornos Mentais e do Comportamento Relacionados ao Trabalho: definição e caracterização", são trazidas informações a seu respeito, dados e estatísticas sobre sua incidência e os quadros nosológicos que os compõem.

No segundo plano, "O moral, o mental, o psíquico e suas relações com o trabalho", buscando a compreensão do processo de construção social dos Transtornos Mentais e do Comportamento Relacionados ao Trabalho e seu reconhecimento como doenças relacionadas ao trabalho, é traçado um panorama cronológico (ainda que lacunar) de como as relações entre trabalho e saúde/doença mental vêm sendo abordadas, tratadas, apreendidas a partir do início do século XX; as concepções de saúde/doença, de causalidade e nexo implicadas; os diversos grupos de interesse e os profissionais "legitimamente" envolvidos na questão.

Por fim, no terceiro plano, "Os Transtornos Mentais e do Comportamento Relacionados ao Trabalho na atualidade", a partir dos dados das entrevistas realizadas no trabalho de campo, retoma-se a discussão iniciada no primeiro plano, buscando problematizá-los na atualidade em diversas dimensões.

Os Transtornos Mentais e do Comportamento Relacionados ao Trabalho são tratados, nessa discussão, como tema com múltiplos atravessamentos e desdobramentos, um "campo de acontecimentos" (FOUCAULT, 1995a, p. 180), um ponto de encontro ou convergência (entre outros) das medicinas, das psicologias, políticas de Estado, produção acadêmica, atuação dos serviços de saúde e dos movimentos dos trabalhadores, de transformações políticas e econômicas e do contexto produtivo. 


\subsection{OS TRANSTORNOS MENTAIS E DO COMPORTAMENTO RELACIONADOS AO TRABALHO: DEFINIÇÃO E CARACTERIZAÇÃO}

Observa-se, casa vez mais, o interesse pelo debate sobre os vínculos entre trabalho, saúde e doença mental. Uma das razões para esse interesse é o crescente número, no Brasil e no mundo, de transtornos mentais e do comportamento relacionados ao trabalho. Segundo estimativas da Organização Mundial de Saúde, os Transtornos Mentais Menores acometiam, em 2001, cerca de 30\% dos trabalhadores ocupados, e os Transtornos Mentais Graves, cerca de 5 a 10\% (MS/OPAS, 2001). Os dados sobre a concessão de benefícios previdenciários no Brasil produzidos pelo INSS situavam esses transtornos como a terceira causa de concessão de benefícios previdenciários, como auxílio doença (referente a afastamento do trabalho por período superior a 15 dias) e aposentadorias por invalidez (MS/OPAS, 2001; JACQUES, 2003). Jacques $(2003,2007)$ destaca que, para essa visibilidade e interesse, contribuíram o número elevado de casos de depressão e suicídio entre a população rural (associados ao uso indiscriminado de agrotóxicos), bem como o crescente número de transtornos mentais diagnosticados entre trabalhadores que vivenciaram processos de reestruturação produtiva nos seus locais de trabalho.

No Brasil, os transtornos mentais e do comportamento foram reconhecidos como doenças relacionadas ao trabalho em 1999, por meio da Portaria 1339 do Ministério da Saúde, que publicou uma Lista de Doenças Relacionadas ao Trabalho e, por meio do Decreto 3048, que trata do regulamento da Previdência Social, nos quais foram discriminadas doze categorias diagnósticas e seus respectivos agentes etiológicos ou fatores de risco de origem ocupacional (constantes no Anexo B deste trabalho, com seus respectivos CIDs - códigos na Classificação Internacional de Doenças). Esses documentos definem a listagem dos transtornos mentais e do comportamento relacionados ao trabalho, "a ser adotada como referência dos agravos originados no processo de trabalho no Sistema Único de Saúde, para uso clínico e epidemiológico" (MS, 1999), na qual consta a relação de Transtornos Mentais e do Comportamento Relacionados ao Trabalho, sua codificação (no Grupo V - transtornos mentais e comportamentais - da CID 10) e os agentes etiológicos ou fatores de risco de natureza ocupacional (Quadro 3, a seguir): 
Quadro 3-Os transtornos mentais e do comportamento relacionados ao trabalho e os agentes etiológicos ou fatores de risco de natureza ocupacional

(continua)

\begin{tabular}{|c|c|}
\hline Doenças & Agentes etiológicos ou fatores de risco de natureza ocupacional \\
\hline $\begin{array}{l}\text { I - Demência em outras doenças } \\
\text { específicas classificadas em outros } \\
\text { locais (F02.8) }\end{array}$ & $\begin{array}{l}\text { - Manganês } \\
\text { - Substâncias asfixiantes: CO, H2S, etc. (sequela) } \\
\text { - Sulfeto de Carbono }\end{array}$ \\
\hline $\begin{array}{l}\text { II - Delirium, não sobreposto a } \\
\text { demência, como descrita (F05.0) }\end{array}$ & $\begin{array}{l}\text { - Brometo de Metila (X46.-; Z57.4 e Z57.5) (Quadro XIII) } \\
\text { - Sulfeto de Carbono (X49.-; Z57.5) (Quadro XIX) }\end{array}$ \\
\hline $\begin{array}{l}\text { III - Outros transtornos mentais } \\
\text { decorrentes de lesão e disfunção } \\
\text { cerebrais e de doença física (F06.-): } \\
\text { Transtorno Depressivo Orgânico } \\
\text { (F06.32); Transtorno Afetivo Misto } \\
\text { Orgânico (F06.33); Transtorno } \\
\text { Cognitivo Leve (F06.7) } \\
\text { III - Outros transtornos mentais } \\
\text { decorrentes de lesão e disfunção } \\
\text { cerebrais e de doença física (F06.-): } \\
\text { transtorno cognitivo leve (F06.7) } \\
\text { (Redação dada pelo Decreto n }{ }^{\circ} 3.265, \\
\text { de 1999) }\end{array}$ & $\begin{array}{l}\text { - Tolueno e outros solventes aromáticos neurotóxicos (X46.-; Z57.5) } \\
\text { (Quadro III) } \\
\text { - Chumbo ou seus compostos tóxicos (X49.-; Z57.5) (Quadro VIII) } \\
\text { - Tricloroetileno, Tetracloroetileno, Tricloroetano e outros solventes } \\
\text { orgânicos halogenados neurotóxicos (X46.-; Z57.5) (Quadro XIII) } \\
\text { - Brometo de Metila (X46.-; Z57.4 e Z57.5) (Quadro XIII) } \\
\text { - Manganês e seus compostos tóxicos (X49.-; Z57.5) (Quadro XV) } \\
\text { - Mercúrio e seus compostos tóxicos (X49.-; Z57.4 e Z57.5) (Quadro XVI) } \\
\text { - Sulfeto de Carbono (X49.-; Z57.5) (Quadro XIX) } \\
\text { - Outros solventes orgânicos neurotóxicos (X46.-; X49.-; Z57.5) }\end{array}$ \\
\hline $\begin{array}{l}\text { IV - Transtornos de personalidade e de } \\
\text { comportamento decorrentes de } \\
\text { doença, lesão e de disfunção de } \\
\text { personalidade (F07.-): Transtorno } \\
\text { Orgânico de Personalidade (F07.0); } \\
\text { Outros transtornos de personalidade e } \\
\text { de comportamento decorrentes de } \\
\text { doença, lesão ou disfunção cerebral } \\
\text { (F07.8) }\end{array}$ & $\begin{array}{l}\text { - Tolueno e outros solventes aromáticos neurotóxicos (X46.-; Z57.5) } \\
\text { (Quadro III) } \\
\text { - Tricloroetileno, Tetracloroetileno, Tricloroetano e outros solventes } \\
\text { orgânicos halogenados neurotóxicos (X46.-; Z57.5) (Quadro XIII) } \\
\text { - Brometo de Metila (X46.-; Z57.4 e Z57.5) (Quadro XIII) } \\
\text { - Manganês e seus compostos tóxicos (X49.-; Z57.5) (Quadro XV) } \\
\text { - Mercúrio e seus compostos tóxicos (X49.-; Z57.4 e Z57.5) (Quadro XVI) } \\
\text { - Sulfeto de Carbono (X49.-; Z57.5) (Quadro XIX) } \\
\text { - Outros solventes orgânicos neurotóxicos (X46.-; X49.-; Z57.5) }\end{array}$ \\
\hline $\begin{array}{l}\text { V - Transtorno Mental Orgânico ou } \\
\text { Sintomático não especificado (F09.-) }\end{array}$ & $\begin{array}{l}\text { - Tolueno e outros solventes aromáticos neurotóxicos } \\
\text { - Tricloroetileno, Tetracloroetileno, Tricloroetano e outros solventes } \\
\text { orgânicos halogenados neurotóxicos } \\
\text { - Brometo de Metila } \\
\text { - Manganês e seus compostos tóxicos } \\
\text { - Mercúrio e seus compostos tóxicos } \\
\text { - Sulfeto de Carbono } \\
\text { - Outros solventes orgânicos neurotóxicos }\end{array}$ \\
\hline $\begin{array}{l}\text { VI - Transtornos mentais e } \\
\text { comportamentais devidos ao uso do } \\
\text { álcool: Alcoolismo Crônico } \\
\text { (Relacionado com o Trabalho) (F10.2) }\end{array}$ & $\begin{array}{l}\text { - Problemas relacionados com o emprego e com o desemprego: } \\
\text { Condições difíceis de trabalho (Z56.5) } \\
\text { - Circunstância relativa às condições de trabalho (Y96) }\end{array}$ \\
\hline VII - Episódios Depressivos (F32.-) & $\begin{array}{l}\text { - Tolueno e outros solventes aromáticos neurotóxicos } \\
\text { - Tricloroetileno, Tetracloroetileno, Tricloroetano e outros solventes } \\
\text { orgânicos halogenados neurotóxicos } \\
\text { - Brometo de Metila } \\
\text { - Manganês e seus compostos tóxicos } \\
\text { - Mercúrio e seus compostos tóxicos } \\
\text { - Sulfeto de Carbono } \\
\text { - Outros solventes orgânicos neurotóxicos }\end{array}$ \\
\hline
\end{tabular}


Quadro 3-Os transtornos mentais e do comportamento relacionados ao trabalho e os agentes etiológicos ou fatores de risco de natureza ocupacional

(conclusão)

\begin{tabular}{|c|c|}
\hline Doenças & Agentes etiológicos ou fatores de risco de natureza ocupacional \\
\hline $\begin{array}{l}\text { VIII - Reações ao "Stress" Grave e } \\
\text { Transtornos de Adaptação (F43.-): } \\
\text { Estado de "Stress" Pós-Traumático } \\
\text { (F43.1) }\end{array}$ & $\begin{array}{l}\text { - Outras dificuldades físicas e mentais relacionadas com o trabalho: } \\
\text { reação após acidente do trabalho grave ou catastrófico, ou após assalto } \\
\text { no trabalho (Z56.6) } \\
\text { - Circunstância relativa às condições de trabalho (Y96) }\end{array}$ \\
\hline $\begin{array}{l}\text { IX - Neurastenia (Inclui "Síndrome de } \\
\text { Fadiga") (F48.0) }\end{array}$ & $\begin{array}{l}\text { - Tolueno e outros solventes aromáticos neurotóxicos } \\
\text { - Tricloroetileno, Tetracloroetileno, Tricloroetano e outros solventes } \\
\text { orgânicos halogenados } \\
\text { - Brometo de Metila } \\
\text { - Manganês e seus compostos tóxicos } \\
\text { - Mercúrio e seus compostos tóxicos } \\
\text { - Sulfeto de Carbono } \\
\text { - Outros solventes orgânicos neurotóxicos }\end{array}$ \\
\hline $\begin{array}{l}\text { X - Outros transtornos neuróticos } \\
\text { especificados (Inclui "Neurose } \\
\text { Profissional") (F48.8) }\end{array}$ & $\begin{array}{l}\text { - Problemas relacionados com o emprego e com o desemprego (Z56): } \\
\text { Desemprego (Z56.0); Mudança de emprego (Z56.1); Ameaça de perda } \\
\text { de emprego (Z56.2); Ritmo de trabalho penoso (Z56.3); Desacordo com } \\
\text { patrão e colegas de trabalho (Condições difíceis de trabalho) (Z56.5); } \\
\text { Outras dificuldades físicas e mentais relacionadas com o trabalho } \\
\text { (Z56.6) }\end{array}$ \\
\hline $\begin{array}{l}\text { XI - Transtorno do Ciclo Vigília-Sono } \\
\text { Devido a Fatores Não Orgânicos } \\
\text { (F51.2) }\end{array}$ & $\begin{array}{l}\text { - Problemas relacionados com o emprego e com o desemprego: Má } \\
\text { adaptação à organização do horário de trabalho (Trabalho em Turnos } \\
\text { ou Trabalho Noturno) (Z56.6) } \\
\text { - Circunstância relativa às condições de trabalho (Y96) }\end{array}$ \\
\hline $\begin{array}{l}\text { XII - Sensação de Estar Acabado } \\
\text { ("Síndrome de Burn-Out", "Síndrome } \\
\text { do Esgotamento Profissional") (Z73.0) }\end{array}$ & $\begin{array}{l}\text { - Ritmo de trabalho penoso ( } \mathrm{Z} 56.3 \text { ) } \\
\text { - Outras dificuldades físicas e mentais relacionadas com o trabalho } \\
\text { (Z56.6) }\end{array}$ \\
\hline
\end{tabular}

Fontes: Portaria 1339 de 1999 (MS, 1999); Decreto 3048 de 1999 (BRASIL, 1999a).

A partir de então, o reconhecimento do nexo causal entre trabalho e essas doenças passou a figurar em um maior número de trabalhos no campo da Saúde do Trabalhador (SILVA, 2011, p. 6). A promulgação dessas leis, por sua vez, ao mesmo tempo em que representa um significativo avanço, como apontam Glina et al. (2001, p. 608), traria o desafio de "reconhecer, diagnosticar e fazer o nexo causal dos transtornos mentais com o trabalho".

Como assinalam Silva (2011), Jacques (2003) e Nardi (1997), uma progressiva abertura às questões da saúde mental (e da Psicologia) no campo da Saúde do Trabalhador teve lugar nas propostas da VIII Conferência Nacional de Saúde e I Conferência Nacional de Saúde do Trabalhador, consolidadas na Constituição Brasileira de 1988 e na Lei Orgânica da Saúde de 1990. Começou a operar-se uma ruptura com modelos teóricos 
centrados no conhecimento médico, começando a serem propostas ações mais integradoras e multidisciplinares. ${ }^{158}$

A Portaria no 1.339 do Ministério da Saúde (MS, 1999) e o Decreto no 3.048 (BRASIL, 1999a) também configuram a necessidade de estabelecer relação causal entre o dano e/ou a doença e o trabalho (JACQUES, 2007, p. 112). Segundo o Manual do Ministério da Saúde (MS/OPAS, 2001) que toma como referência a Portaria 1339 e o Decreto 3048, intitulado "Doenças relacionadas ao trabalho: manual de procedimentos para os serviços de saúde", "o estabelecimento do nexo causal entre a doença e a atividade atual ou pregressa do trabalhador representa o ponto de partida para o diagnóstico e a terapêutica corretos, para as ações de vigilância e para o registro das informações" (JACQUES, 2007, p. 113).

Outra significativa mudança foi introduzida em 2006, com a publicação da Medida Provisória no 316, de 11 de agosto de 2006, convertida na Lei no 11.430, de 2006 (BRASIL, 2006), que institui o Nexo Técnico Epidemiológico Previdenciário (NTEP). O NTEP entrou em vigência em abril de 2007, por sua vez introduzindo mudanças no sistema de registro de acidentes e doenças relacionados ao trabalho (SILVA, 2011). Com a nova metodologia, passam a ser considerados também casos onde há suspeita de nexo entre a doença e o trabalho (casos presumidos), por meio do cruzamento de informações epidemiológicas sobre a incidência da doença e o ramo de atividade da empresa na qual o trabalhador atua (classificação da empresa na Classificação Nacional de Atividades Econômicas - CNAE).

Mesmo antes do estabelecimento da metodologia do NTEP, o número de casos de transtornos mentais e do comportamento relacionados ao trabalho vinha aumentando, sendo apontado por pesquisadores e pelo Ministério da Previdência e Assistência Social (SILVA, 2011). Barbosa-Branco, Albuquerque-Oliveira e Mateus (2013) analisaram os benefícios concedidos pelo INSS no ano de 2002, constatando que os transtornos mentais já se encontravam entre os "quatro maiores grupos de causas de benefícios concedidos a trabalhadores segurados 159 no Brasil", não se incluindo, nesses dados, o imenso contingente de trabalhadores do setor informal.

\footnotetext{
158 Como discutido nos capítulos 4 e 5.

159 Trabalhador segurado: inserido no mercado formal de trabalho e que contribui para o INSS.
} 
Wünsch Filho (2004, p. 110), ao analisar estatísticas de atendimentos de 1997 nos serviços de Saúde ao Trabalhador da cidade de São Paulo, identificou o "aparecimento explícito, embora discretamente, dos transtornos mentais", na ocasião, 2\% dos casos; $56 \%$ dos casos (trabalhadores dos setores formal e informal) referiam-se a doenças do sistema osteomuscular. Já nas estatísticas do INSS entre 2006 e 2008, os casos de depressão e transtornos mentais e do comportamento relacionados ao trabalho tiveram um crescimento de $0,4 \%$ para $3 \%$ no total de benefícios pagos como relacionados ao trabalho (SILVA, 2011).

Contudo, como aponta Silva (2011), com a nova metodologia prevista pelo NTEP (regulamentado pelo Decreto $n^{\circ} 6.042$, de 2007), observou-se, nas estatísticas da Previdência Social, expressivo aumento do número de Transtornos Mentais e do Comportamento Relacionados ao Trabalho sem emissão de CAT (Comunicação de Acidente de Trabalho), ou seja, casos presumidos. A autora exemplifica como, entre 2006 e 2007, aumentou o número de registros de diagnóstico de reação aguda ao estresse: em 2006, quando o registro das doenças relacionadas ao trabalho ocorria apenas com a emissão da CAT pelas empresas, foram registradas 395 ocorrências; em 2007, já com a nova metodologia em vigor, foram registrados 2.299 casos presumidos para o mesmo diagnóstico. A obrigatoriedade de emissão da CAT por parte da empresa ainda existe, contudo não se configura mais como instrumento exclusivo para estabelecimento do nexo das doenças com o trabalho, como anteriormente ocorria. Além disso, como coloca Jacques (2007, p. 112), "TAL medida inverte o ônus da prova em alguns casos ao determinar o registro automático como doença relacionada ao trabalho de determinadas patologias em função de altas incidências em determinados ambientes de trabalho".

Essa significativa mudança introduzida no sistema de registro de acidentes e doenças relacionadas ao trabalho pela nova metodologia do NTEP pode ser observada no Gráfico 1, a seguir. 
Gráfico 1 - Número de benefícios acidentários concedidos a segurados com transtornos mentais e do comportamento de 2006 a 2010

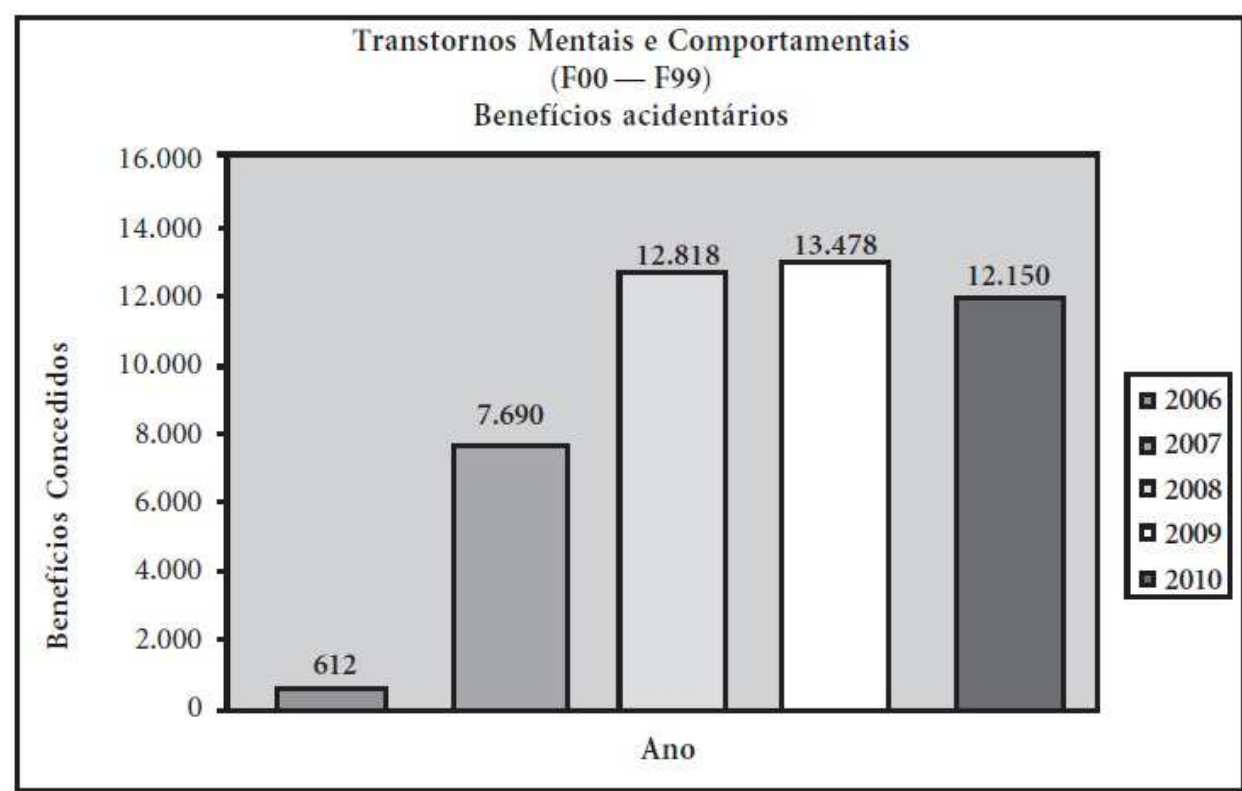

Fonte: Maeno, 2011, p 146.

O gráfico apresenta o somatório dos benefícios acidentários concedidos pelo INSS para Transtornos Mentais e do Comportamento Relacionados ao Trabalho entre 2006 e 2010 e permite observar como, de 2006 para 2007, o número de beneficios acidentários concedidos pelo INSS para esses transtornos passou de 612 casos em 2006 para 7.960 em 2007; 12.818 em 2008; 13.478 em 2009 e "queda" para 12.150 em 2010. Com relação aos benefícios concedidos em 2006, em 2007 houve um aumento de $1.156,7 \% .{ }^{160}$

Contudo, o número de benefícios por incapacidade temporária (acidentários e previdenciários ${ }^{161}$ ), no mesmo período, apresenta uma redução progressiva, a despeito do aumento no número de benefícios acidentários concedido, como se oberva no Gráfico 2, a seguir.

160 Se comparados os benefícios concedidos em 2006 com os concedidos em 2008, houve um aumento de $1.994,4 \%$.

161 Não relacionados ao trabalho. 
Gráfico 2 - Número de benefícios concedidos por incapacidade temporária (acidentários e previdenciários) aos segurados com transtornos mentais e comportamentais de 2006 a 2010

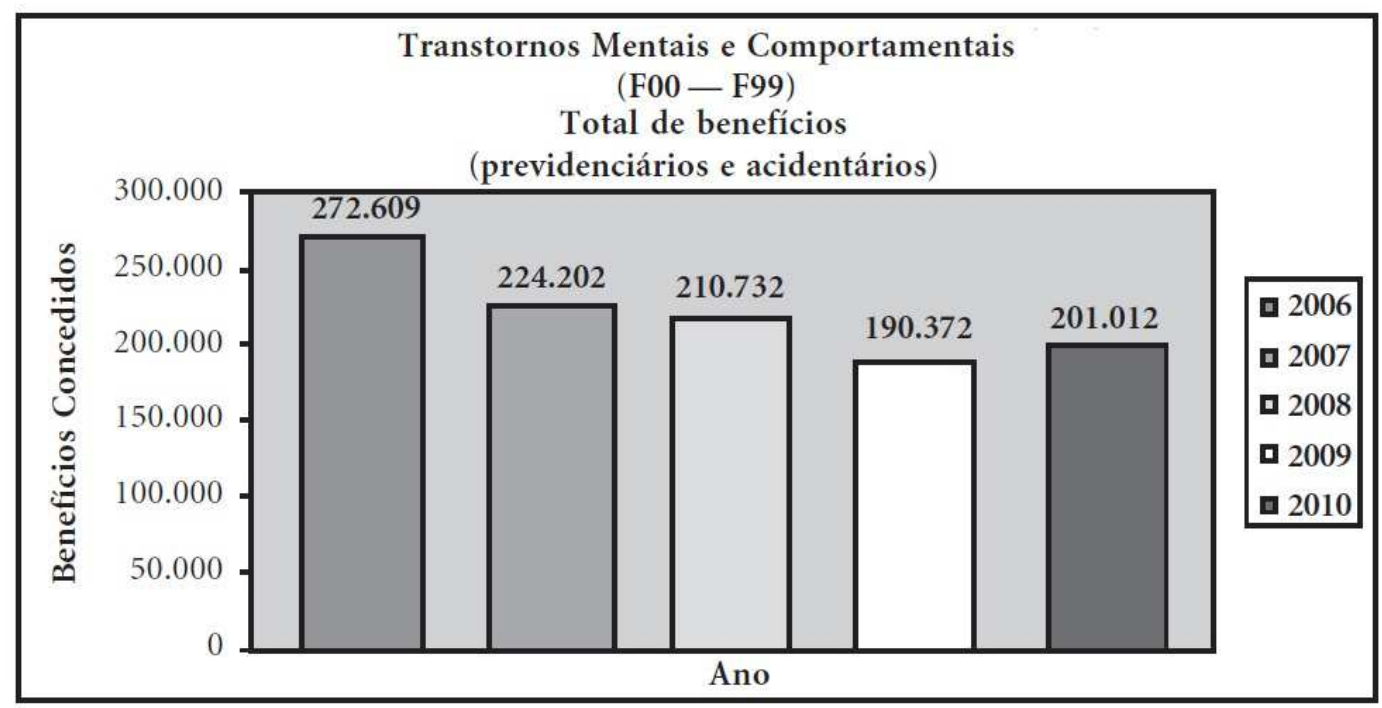

Fonte: Maeno, 2011, p. 147.

O gráfico apresenta o somatório dos benefícios previdenciários e acidentários concedidos pelo INSS para Transtornos Mentais e do Comportamento entre 2006 e 2010. Em 2006 são registrados 272.609 casos; em 2007, 224.202 casos, uma redução expressiva. Em 2008, são 210.732 casos; em 2009, 190.372 casos e, em 2010, 201.012 casos (pequeno aumento, numa tendência de redução expressiva). Observa-se simultaneamente um descréscimo dos benefícios previdenciários (doença comum B31), e um aumento dos benefícios acidentários (B91) ${ }^{162}$, exceto em 2010 , onde se observa um aumento de concessão de benefícios previdenciários e redução de benefícios acidentários $(9,6 \%)$ com relação ao ano anterior.

Segundo Maeno (2011, p. 146), os dados disponíveis mostram que após um notável aumento da concessão de benefícios acidentários aos segurados com transtornos mentais nos anos subsequentes à implementação do nexo técnico epidemiológico, vêse um declínio a partir de 2010. Observa-se também o decréscimo acentuado do número total de concessões de benefícios por incapacidade temporária aos segurados com transtornos psíquicos, "particularmente considerando-se que nada indica que os adoecimentos desses grupos tenham sofrido declínio em sua ocorrência e que a cobertura previdenciária venha aumentando nos últimos anos". Os transtornos

162 Os Benefícios Acidentários Relacionados ao Trabalho encontram-se descritos no Anexo C deste trabalho. 
mentais seriam a principal causa de incapacidade, morbidade e morte prematura em países de diferentes graus de desenvolvimento socioeconômico; assim, a diminuição de benefícios por incapacidade concedidos "deve ser analisada de forma aprofundada, pois pode representar um processo de exclusão de adoecidos do sistema de proteção da Previdência Social por meio da perícia médica, apoiada em diretrizes clínicas e sistema informatizado restritivos" (MAENO, 2011, p. 147). Ainda assim, os Gráficos 3 e 4 a seguir mostram como, em 2010, os transtornos mentais foram a $3^{\text {a }}$ causa de benefícios previdenciários concedidos, tanto na concessão de auxílio-doença, quanto na de aposentadorias.

Gráfico 3 - Auxílios-Doença - Previdenciários concedidos (B-31)*: Principais Grupos de Causas (CID-10, 2010)

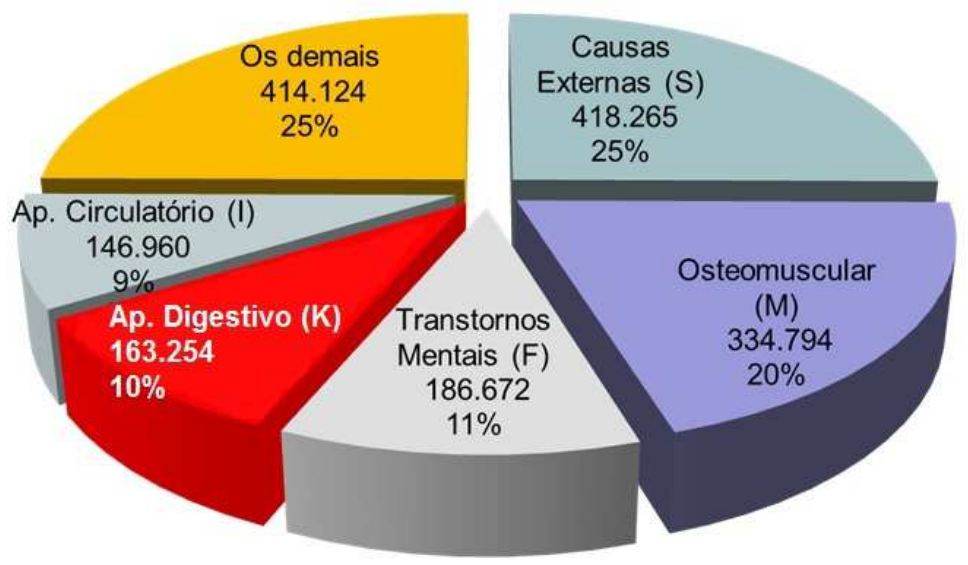

Fonte: Veiga, 2014, p. 4.

* Total: 1.664 .069 casos.

Gráfico 4-Aposentadoria por invalidez - Previdenciários concedidos*: Principais causas (CID10, 2010)

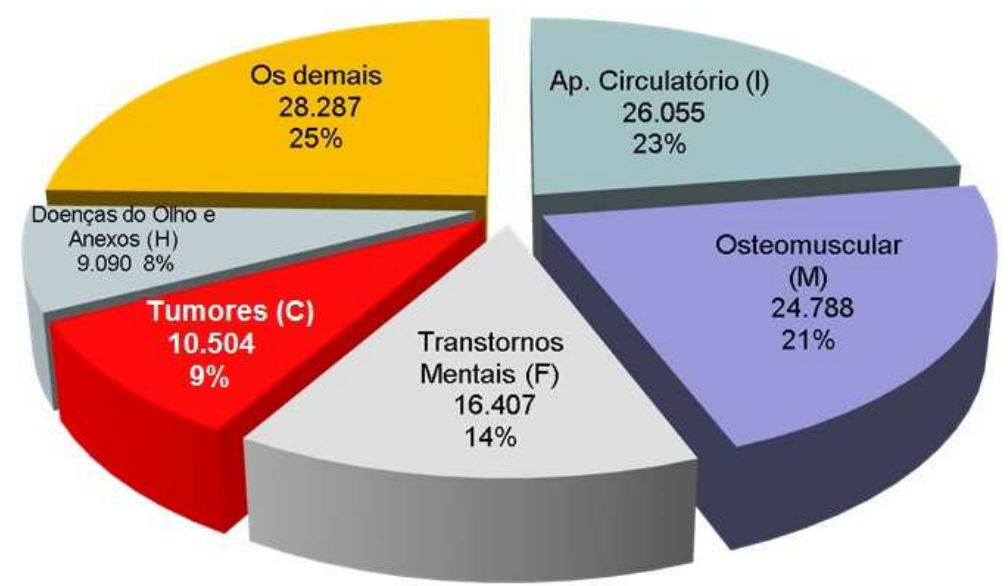

Fonte: Veiga, 2014, p. 5.

* Total: 115.131 casos. 
Nos benefícios previdenciários de auxílio-doença (doença comum) concedidos em 2010, os transtornos mentais corresponderam a $11 \%$ (186.672 casos, de um total de 1.664.069), correspondendo à $3^{\mathrm{a}}$ maior causa, após os agravos provocados por causas externas (25\% dos casos) e dos agravos do sistema osteomuscular e do tecido conjuntivo (20\%). Nos benefícios previdenciários (doença comum) por invalidez concedidos em 2010, os transtornos mentais corresponderam a 14\% (16.407 casos, de um total de 115.131), correspondendo à $3^{\mathrm{a}}$ maior causa, após as doenças do aparelho circulatório ( $23 \%$ dos casos) e dos agravos do sistema osteomuscular e do tecido conjuntivo (21\%).

Já no que tange aos dados de benefícios acidentários (relacionados ao trabalho), no período de 1999 a 2012 os Transtornos Mentais e do Comportamento Relacionados ao Trabalho correspoderam à $6^{\text {a }}$ causa geral de acidentes registrados, e à $3^{\text {a }}$ causa, se consideradas apenas as doenças relacionadas ao trabalho, como o mostra a Tabela 2 a seguir. ${ }^{163}$

A Tabela apresenta informações sobre acidentes do trabalho retiradas do sistema AEAT InfoLogo (Base de Dados Históricos de Acidentes do Trabalho da Previdência Social), no período de 1999 a 2012 (período disponibilizado para pesquisa), classificados por tipo de acidente (Típico com CAT - Comunicação de Acidente de Trabalho -, de Trajeto com CAT, Doença do Trabalho com CAT e sem CAT cadastrada no INSS), distribuídos por capítulo da CID-10.

163 A apresentação mais detalhada desses dados encontra-se na Tabela 3, no Apêndice C deste trabalho. 
Tabela 2 - Acidentes do trabalho por capítulo da CID (1999-2012)

\begin{tabular}{|c|c|c|c|c|c|}
\hline \multirow{2}{*}{$\begin{array}{l}\text { Agrupamento } \\
\text { CID }\end{array}$} & \multicolumn{4}{|c|}{$\begin{array}{c}\text { Total } \\
\text { Motivo / Situação }\end{array}$} & \multirow[t]{2}{*}{ Total } \\
\hline & TPCAT* & TRCAT** & DOCAT $^{* * *}$ & SECAT $* * * *$ & \\
\hline Capítulo XIX & 4.202 .669 & 838.677 & 19.540 & 398.342 & 5.459 .228 \\
\hline Capítulo XIII & 352.532 & 42.036 & 191.717 & 477.351 & 1.063 .636 \\
\hline Ignorado (ING) & 259.197 & 26.031 & 13.522 & 1.782 & 300.532 \\
\hline Capítulo XX & 130.844 & 36.358 & 862 & 735 & 168.799 \\
\hline Capítulo XXI 164 & 116.086 & 9.372 & 3.305 & 1.287 & 130.050 \\
\hline Capítulo V & 40.654 & 3.254 & 9.377 & 64.251 & 117.536 \\
\hline Capítulo VII & 76.837 & 1.834 & 850 & 6.332 & 85.853 \\
\hline Capítulo VI & 10.157 & 1.513 & 18.420 & 38.449 & 68.539 \\
\hline Capítulo VIII & 12.163 & 297 & 35.279 & 1.109 & 48.848 \\
\hline Capítulo XI & 10.514 & 949 & 2.809 & 21.677 & 35.949 \\
\hline Capítulo XII & 19.816 & 1.159 & 4.442 & 6.473 & 31.890 \\
\hline Capítulo IX & 8.098 & 1.451 & 2.193 & 20.088 & 31.830 \\
\hline Capítulo II & 15.846 & 1.908 & 956 & 4.430 & 23.140 \\
\hline Capítulo I & 9.314 & 654 & 2.329 & 10.238 & 22.535 \\
\hline Capítulo XVIII & 15.632 & 3.973 & 1.137 & 676 & 21.418 \\
\hline Capítulo X & 4.756 & 692 & 4.430 & 9.262 & 19.140 \\
\hline Capítulo XIV & 3.105 & 466 & 518 & 1.422 & 5.511 \\
\hline Capítulo XVII & 4.612 & 333 & 155 & 43 & 5.143 \\
\hline Capítulo III & 780 & 182 & 653 & 419 & 2.034 \\
\hline Capítulo IV & 871 & 124 & 167 & 848 & 2.010 \\
\hline Capítulo XV & 863 & 240 & 210 & 319 & 1.632 \\
\hline Capítulo XVI & 494 & 115 & 24 & 23 & 656 \\
\hline Total & 5.295 .840 & 971.618 & 312.895 & 1.065 .556 & 7.645.909 \\
\hline
\end{tabular}

Fonte: Produzida pela autora em pesquisa no Sistema AEAT InfoLogo - Base de Dados Históricos de Acidentes do Trabalho da Previdência Social, 2015. 165

Legenda: 166

*TPCAT — Típico, com CAT (Comunicação de Acidente de Trabalho): corresponde ao número de acidentes cuja Comunicação de Acidentes do Trabalho - CAT foi cadastrada no INSS. Não são contabilizados o reinício de tratamento ou afastamento por agravamento de lesão de acidente do trabalho ou doença do trabalho, já comunicados anteriormente ao INSS.

**TRCAT — Trajeto, com CAT: São os acidentes ocorridos no trajeto entre a residência e o local de trabalho do segurado e vice-versa.

***DOCAT — Doença do Trabalho, com CAT: corresponde à quantidade de acidentes ocasionados por qualquer tipo de doença profissional peculiar a determinado ramo de atividade constante na tabela da Previdência Social.

****SECAT - cadastrada no INSS. O acidente é identificado por meio de um dos possíveis nexos: Nexo Técnico Profissional/Trabalho, Nexo Técnico Epidemiológico Previdenciário (NTEP) ou Nexo Técnico por Doença Equiparada a Acidente do Trabalho. Essa identificação é feita pela nova forma de concessão de benefícios acidentários.

164 O Capítulo XXI possui um CID relacionado aos Transtornos Mentais e do Comportamento Relacionados ao Trabalho: Z73.0 - Sensação de Estar Acabado ("Síndrome de Burn-Out", "Síndrome do Esgotamento Profissional").

165 Disponível em: <http://www3.dataprev.gov.br/aeat>. Acesso em 16 jan. 2015.

166 Fonte: Renast Online. Disponível em: <http://www.renastonline.org/s\%C3\%A9rie-hist\%C3\%B3ricaacidentes-trabalho-inss>. Acesso em 16 jan. 2015. 
O Capítulo V (Transtornos mentais e comportamentais) representa $1,54 \%$ dos casos (117.536, de um total de 7.645.909), correspondendo à $6^{\text {a }}$ maior causa, após o Capítulo XXI (Fatores que influenciam o estado de saúde e o contato com os serviços de saúde), com 1,7\% dos casos, correspondendo à $5^{\text {a }}$ maior causa; o Capítulo XX (Causas externas de morbidade e de mortalidade), com 2,2\% dos casos, correspondendo à $4^{\text {a }}$ maior causa; CID ignorado/desconhecido (3,9\% dos casos), correspondendo à $3^{\mathrm{a}}$ maior causa; o Capítulo XIII (Doenças do sistema osteomuscular e do tecido conjuntivo, $14 \%$ dos casos), correspondendo à $2^{\text {a }}$ maior causa, e o Capítulo XIX (Lesões, envenenamento e algumas outras consequências de causas externas, $71,4 \%$ dos casos), $1^{\text {a }}$ causa.

Se consideradas apenas as doenças relacionadas ao trabalho (excluindo Lesões, envenenamento e algumas outras consequências de causas externas, Causas externas de morbidade e de mortalidade e CID ignorado/desconhecido), o Capítulo V Transtornos mentais e comportamentais corresponderia à $3^{\text {a }}$ maior causa (e as doenças do sistema osteomuscular e do tecido conjuntivo, à $1^{\text {a }}$ causa). Já os benefícios acidentários por incapacidade concedidos no período de 2008 e 2012, quando classificados por grupo de CID, apresentam os Transtornos Mentais e do Comportamento Relacionados ao Trabalho como a $3^{\mathrm{a}}$ causa de concessão do benefício e, se consideradas apenas as doenças relacionadas ao trabalho, a $2^{\text {a }}$ causa. Informações mais detalhadas a respeito dos benefícios acidentários (auxílio-doença e aposentadorias) concedidos no período podem ser encontradas no Apêndice C (Tabelas 4- Benefícios por Incapacidade concedidos, por CID; 5- Benefícios acidentários por Incapacidade concedidos por CID e percentual de cada grupo; 6Auxílios-Doença Acidentários concedidos por CID e percentual de cada grupo; 7Aposentadorias Acidentárias concedidas por CID e percentual de cada grupo).

Considerando-se apenas os Transtornos Mentais e do Comportamento Relacionados ao Trabalho, as informações sobre auxílio-doença acidentário do período de 1999 a 2012, distribuídas por diagnóstico, apresentam 56\% dos casos como de reações ao estresse e transtornos de adaptação, e 39\%, de episódios depressivos. Quanto aos Transtornos Mentais e do Comportamento Relacionados ao Trabalho decorrentes de acidentes de trabalho típicos registrados no mesmo período, os casos de reações ao 
estresse e transtornos de adaptação correspondem a 92\% dos casos, e os episódios depressivos, a 4\%. Informações mais detalhadas a respeito podem ser encontradas no Apêndice C (Tabelas 8-Acidentes do trabalho (Doença do Trabalho com CAT) por CID e percentual de cada grupo; 9- Acidentes do trabalho (Típico, com CAT) por CID e percentual de cada grupo).

No Apêndice $C$ também podem ser encontrados dados referentes às notificações ${ }^{167}$ de Transtornos Mentais e do Comportamento Relacionados ao Trabalho no SINAN Sistema de Informação de Agravos de Notificação: relação de agravos relacionados ao trabalho notificados no período de 2007 a 2001 (Figura 4 e Tabela 10); percentual das principais profissões, a partir da classificação da CBO - Classificação Brasileira de Ocupações - com Transtornos Mentais e do Comportamento Relacionados ao Trabalho notificados, no período de 2007 a 2013 (Gráfico 5).

Segundo o manual de procedimentos para os serviços de saúde sobre doenças relacionadas ao trabalho organizado pelo Ministério da Saúde do Brasil e pela Organização Panamericana de Saúde (MS/OPAS, 2001), a definição de disfunção e incapacidade causada pelos transtornos mentais e do comportamento, sejam eles relacionados ou não ao trabalho, é muito difícil. O documento relaciona parâmetros propostos pela American Medical Association (Associação Médica Americana), que organiza as disfunções causadas pelos transtornos mentais e do comportamento em quatro áreas:

1. Limitações em atividades da vida diária: que incluem atividades como autocuidado, higiene pessoal, comunicação, deambulação, viagens, repouso e sono, atividades sexuais e exercício de atividades sociais e recreacionais. 0 que é avaliado não é simplesmente o número de atividades que estão restritas ou prejudicadas, mas o conjunto de restrições ou limitações que, eventualmente, afetam o indivíduo como um todo;

2. Exercício de funções sociais: refere-se à capacidade do indivíduo de interagir apropriadamente e comunicar-se eficientemente com outras pessoas. Inclui

167 Os Transtornos Mentais e do Comportamento Relacionados ao Trabalho são agravos de notificação obrigatória no Sistema de Informação de Agravos de Notificação (SINAN); a respeito, ver as Portarias do Ministério da Saúde $n^{\circ} 777 / G M$, de 28 de abril de 2004 (Notificação compulsória de agravos à saúde do trabalhador); $n^{\circ} 104$, de 25 de janeiro de 2011 (Define as terminologias adotadas em legislação nacional, conforme o disposto no Regulamento Sanitário Internacional 2005 [RSI 2005], a relação de doenças, agravos e eventos em saúde pública de notificação compulsória em todo o território nacional e estabelece fluxo, critérios, responsabilidades e atribuições aos profissionais e serviços de saúde); $\mathrm{n}^{\circ}$ 1.271, de 6 de junho de 2014 (Define a Lista Nacional de Notificação Compulsória de doenças, agravos e eventos de saúde pública nos serviços de saúde públicos e privados em todo o território nacional). 
a capacidade de conviver com outros, tais como membros de sua família, amigos, vizinhos [...], motoristas de táxi ou ônibus, colegas de trabalho, supervisores ou supervisionados, sem alterações, agressões ou sem o isolamento do indivíduo em relação ao mundo que o cerca;

3. Concentração, persistência e ritmo: também denominados capacidade de completar ou levar a cabo tarefas. Estes indicadores ou parâmetros referem-se à capacidade de manter a atenção focalizada o tempo suficiente para permitir a realização cabal, em tempo adequado, de tarefas comumente encontradas no lar, na escola, ou nos locais de trabalho [...];

4. Deterioração ou descompensação no trabalho: refere-se a falhas repetidas na adaptação a circunstâncias estressantes. Frente a situações ou circunstâncias mais estressantes ou de demanda mais elevada, os indivíduos saem, desaparecem ou manifestam exacerbações dos sinais e sintomas de seu transtorno mental ou comportamental. [...] descompensam e têm dificuldade de manter as atividades da vida diária, o exercício de funções sociais e a capacidade de completar ou levar a cabo tarefas. Aqui, situações de estresse, comuns em ambientes de trabalho, podem incluir o atendimento de clientes, a tomada de decisões, a programação de tarefas, a interação com supervisores e colegas (MS/OPAS, 2001, p. 163).

É importante destacar, como o fazem Mendes e Dias (1991), que os trabalhadores compartilham dos perfis de adoecimento e morte (morbimortalidade) da população em geral, a partir de determinantes como idade, gênero, grupo social ou pertencente a grupo específico de risco, e também podem adoecer ou morrer por causas relacionadas ao trabalho, seja por consequência da profissão que exercem/exerceram, seja por condições adversas nas quais o trabalho é/foi realizado. Por isso, o perfil de morbimortalidade dos trabalhadores resulta da amalgamação desses fatores, que poderiam ser sintetizados em quatro grupos de causas:

- doenças comuns, aparentemente sem qualquer relação com o trabalho;

- doenças comuns (crônico-degenerativas, infecciosas, neoplásicas, traumáticas, etc.) eventualmente modificadas no aumento da frequência de sua ocorrência ou na precocidade de seu surgimento em trabalhadores, sob determinadas condições de trabalho;

- doenças comuns que têm o espectro de sua etiologia ampliado ou tornado mais complexo pelo trabalho. [...] doenças musculoesqueléticas e alguns transtornos mentais exemplificam esta possibilidade, na qual, em decorrência do trabalho, somam-se (efeito aditivo) ou multiplicam-se (efeito sinérgico) as condições provocadoras ou desencadeadoras destes quadros nosológicos;

- agravos à saúde específicos, tipificados pelos acidentes do trabalho e pelas doenças profissionais (MS/OPAS, 2001, p. 28).

A contribuição do trabalho para a alteração da saúde mental se daria a partir de uma gama de aspectos, que vão desde a exposição a agentes tóxicos até os relacionados à 
organização do trabalho, conforme relacionado no Quadro 3. Como aponta Jacques (2007, p. 113), a distribuição dos transtornos mentais e do comportamento relacionados ao trabalho na classificação de Schilling se complexifica, pois as teorias divergem sobre o papel do trabalho no processo de adoecimento mental, "considerando-o ou como determinante ou como fator desencadeante a partir de uma estrutura pré-existente. Além disso, os transtornos mentais têm uma etiologia multicausal em que conjuntos de diversos fatores interagem de modo complexo".

Além disso, há também dificuldades concernentes ao diagnóstico e estabelecimento do nexo com o trabalho dos Transtornos Mentais e do Comportamento Relacionados ao Trabalho, como apontado por Seligmann-Silva (1995, p. 289), que afirma:

[...] não existe um consenso que tenha permitido uma classificação dos distúrbios psíquicos vinculados ao trabalho, existe uma concordância da importância etiológica do trabalho, mas não a respeito do modo como se exerce a conexão trabalho/psiquismo de forma suficiente a permitir um quadro teórico. Os distintos modelos teóricos vêm trazendo dificuldades para a clínica e prevenção.

Outra dificuldade importante apontada por Glina et al. (2001, p. 608) refere-se à ausência, na Classificação Internacional das Doenças (CID), de um grupo de diagnósticos de distúrbios psíquicos relacionados com o trabalho. Esses fatores contribuiriam para a "complexidade inerente à tarefa de definir-se claramente a associação entre tais distúrbios e o trabalho desenvolvido pelo paciente". Outra questão apontada pelos autores, e que contribuiria para o não reconhecimento dos transtornos mentais e do comportamento relacionados ao trabalho, refere-se às próprias características dos distúrbios psíquicos, regularmente mascarados por sintomas físicos. A discussão sobre diagnóstico será retomada na terceira seção deste capítulo. 


\title{
6.2 O MORAL, O MENTAL, O PSÍQUICO E SUAS RELAÇÕES COM O TRABALHO
}

Nessa seção busca-se traçar um panorama (ainda que lacunar) de como as relações entre trabalho e saúde / doença mental vêm sendo abordadas, tratadas, apreendidas a partir do início do século XX.

\subsubsection{MORAL, MENTAL, PSÍQUICO: ANOS 10 e 20}

\begin{abstract}
O mal, a estafa profissional (surménage) é uma conseqüência das condições sociaes e econômicas da producção contemporânea. [...] Todavia, é forçoso dizer que o systema actual de producção, mais que qualquer outro talvez da historia econômica, consome as forças physicas e moraes do operário. 0 trabalho actual esgota os homens mais rapidamente do que o fazia, noutros tempos, a má habitação e a alimentação insufficiente. A percentagem dos homens declarados inaptos para o serviço militar na classe operaria é muito maior que a dos camponezes. É uma das provas de não serem dos melhores os nossos processos de trabalho. A causa disso está na super-producção da mão de obra fornecida pelas populações rurais. Esse «exercito de reserva industrialı, de que nos fala Karl Marx, leva a industria a considerar o operário, no conjunto de sua organisação, como um elemento de producção de segunda ordem. Ella cuida das machinas e da matéria prima, mas não se preoccupa com o operário. Ella pode substituil-o mais facilmente do que uma machina... Essa abundancia de mão de obra tem diminuído, porem, em proporções muito inquietadoras, mau grado a cessação de trabalho, persistente em muitos paizes. A carência de mão de obra qualificada faz-se sentir fortemente nos últimos tempos. (WALTHER, 1929, p. 150, grifos nossos).
\end{abstract}

A epígrafe acima, de Léon Walther (1929), poderia ser considerada um retrato do cenário do mundo do trabalho nos anos 10 e 20, sobretudo no que tange à saúde física (e mental) dos trabalhadores. O discurso sobre o "mental", em suas relações com o trabalho, no período, poderia ser delineado em duas chaves/vertentes: uma vertente "preventiva", ligada à higiene mental e à seleção, e outra, "adaptativa", buscando o ótimo rendimento do trabalhador, do "homem certo no lugar certo", evitando ou contornando aspectos como fadiga, monotonia e alcoolismo, que pudessem implicar em perdas nesse rendimento/produtividade.

De um lado, concepções higienistas e eugênicas consubstanciavam o discurso "técnico" introduzido pela organização "científica". Para o melhor rendimento, é 
necessário o homem certo no lugar certo, o que melhor se adapte às exigências do cargo (ou posto de trabalho), que apresente pouca (ou nenhuma) resistência, que possua boa capacidade de resistir à fadiga e à doença, ou antes, que não possua “propensão" a elas. ${ }^{168}$

O discurso eugênico e a necessidade de melhoramento (inclusive racial) da população (e dos trabalhadores) eram fortemente direcionados ao contingente de ex-escravos ou seus descendentes incorporados à mão de obra urbano - industrial, e ao grande contingente de imigrantes presentes no país no período, sobretudo em cidades como Rio de Janeiro (então capital do país) e São Paulo. Esse trabalhador urbano imigrante (como já discutido no capítulo 3), era muitas vezes politicamente organizado, e proliferaram os sindicatos e associações, de tendência, no período, majoritariamente anarcossindicalista; as duras condições de vida e trabalho suscitavam a organização de inúmeras greves no período.

A maneira de lidar com essas reivindicações por parte do empresariado pautava-se por classificá-las como manifestações de indivíduos descontentes, desequilibrados, querelantes, mal-adaptados, mal-ajustados, com "taras". Da parte do Estado, com repressão policial. ${ }^{169}$

Operava-se uma "conversão" de reivindicações políticas, salariais, de conflitos de classe em problemas da "ordem psíquica" desses indivíduos.

168 É famosa a passagem da obra de Taylor onde, ao descrever o perfil de trabalhador necessário para atividades mais repetitivas e/ou que requeiram força, preconize a necessidade de seleção de um "homem-boi":

Um dos primeiros requisitos para um indivíduo que queira carregar lingotes de ferro como ocupação regular é ser tão estúpido e fleumático que mais se assemelhe em sua constituição mental a um boi, que a qualquer outra coisa. Um homem de reações vivas e inteligentes é, por isso mesmo, inteiramente impróprio para tarefa tão monótona. No entanto, o trabalhador mais adequado para o carregamento de lingotes é incapaz de entender a ciência que regula a execução desse trabalho. É tão rude que a palavra percentagem não tem nenhuma significação para ele e, por conseguinte, deve ser treinado por homem mais inteligente no hábito de trabalhar de acordo com as leis dessa ciência, para que possa ser bem sucedido (TAYLOR, 1911/1990, p. 53, grifos nossos).

169 Os imigrantes poderiam ser expulsos do país, como vários o foram; imigrantes e brasileiros também eram enviados para colônias penais no norte do país, de onde poucos voltavam. Quanto aos demais, a estratégia consistia em dura repressão - policial ou por meio dos rígidos regulamentos das empresas - e "marcar" os indivíduos problema (GERAB; ROSSI, 1997). 
A higiene mental, que buscava a identificação - e mesmo a "produção" - do trabalhador com "hygidez mental", fortemente amparada no discurso eugênico, preconizava a "seleção" desses indivíduos, tanto no âmbito profissional como, mesmo, no âmbito social. A esse "saneamento" mental e social, se conjugavam medidas de cunho "técnico", preconizadas pela "organização científica" do trabalho: estudos de tempos e movimentos, a eliminação de tempos parados (as "ceras"), diminuindo a porosidade do trabalho, desenvolvimento de técnicas de seleção, uso da Psicotécnica.

A Psicotécnica seria o caminho considerado racional, "neutro" e científico para a seleção dos trabalhadores certos para os lugares certos e, tão importante quanto isso, para evitar aqueles que possuíssem tendências à má adaptação, à fadiga, ao conflito, à insubordinação, à doença, ao álcool, aos "vícios" (que poderiam ser potencializados pelo ambiente de trabalho).

Nesse sentido, pode-se dizer que uma operação de ortopedia social prevalecia quando se pensava nas relações entre o "mental" e o trabalho. O psíquico ou mental seria fator de predisposição à boa ou à má adaptação, sendo considerado no período predominantemente sob essa chave.

As terminologias mental e moral frequentemente se fundiam ou sobrepunham-se ao discurso médico/higienista. Carvalho (2010, p. 106) chama atenção para o fato de, naquele momento, não se estabelecerem diferenças conceituais entre os termos "moral" e "mental". O mental então se confundia/mesclava com o moral - moral pautado pela norma do trabalho: é normal e "são" apenas o indivíduo adaptado e que vive o trabalho como algo "natural".

[...] a alegria no trabalho vale como um dos bons elementos da prophylaxia das perturbações mentaes. [...] Pois certamente augmentará a produção nacional e crescerá a fortuna publica se cada cidadão trabalhar satisfeito, e exercendo o mister para o que tem aptidões naturais (ESPOSEL, 1929 apud MANSANERA; SILVA, 2000, p. 128).

Eventuais transtornos ou doenças, tanto físicos como "morais", diziam não das condições de vida ou trabalho, mas sim da constituição individual dos sujeitos. Os conceitos de "saúde mental" e de "higiene mental", com frequência, começariam a aparecer de forma complementar; por "saúde mental" se entendendo uma "condição" ótima a ser preservada e (re)produzida, e "higiene mental", como meio ideal para sua 
consecução. ${ }^{170}$ É importante compreender, nesse contexto, o que expressavam as noções de higiene e higidez:

\begin{abstract}
O termo "hygidez", muito usado pelos higienistas, é um substantivo que significa bom estado de saúde. Hígido seria aquele que tem "hygidez", que é sadio, são. É diferente de "hygiene": higidez deriva do grego hygiés (sadio, são) e higiene do grego hygieinós (termo mais ligado à ideia de asseio, limpeza). Por extensão, "hygidez mental" correspondia a um bom estado de "saúde mental". Contudo, é importante observar que o conceito, embora remeta a uma dimensão social, não corresponde ao de "saúde mental", tal como é hoje concebido. Não se pode confundir "saúde mental" com "hygidez mental", assim como não se pode confundir "prevenção higienista" com "promoção da saúde". São conceitos construídos em momentos históricos diferentes, baseados em representações distintas do social e pertencentes a registros discursivos diferenciados (CARVALHO, 1999, s/p).
\end{abstract}

É importante salientar, como o fez Walther na citação inicial desta seção, que a mão de obra abundante e barata permitia a rápida substituição dos indivíduos malajustados e mal-adaptados. Dada essa abundância, a ênfase no discurso da seleção baseada na psicotécnica ganharia maior adesão nas décadas seguintes.

Em suma, embora Seligmann-Silva $(s / d)^{171}$ chame atenção para o antigo interesse da psiquiatria (Psiquiatria Ocupacional) na questão do "mental" em suas relações/imbricações com o trabalho (mesmo ressalvando que "sempre houve obscurecimento do papel que é desempenhado, na gênese de transtornos mentais, pelas condições de trabalho e por certos modos de obter incremento de produtividade"), estudos como os de Carvalho $(1999,2010,2011)$ apontam que, nesse momento, moral e mental se misturam, "borram", confundem, e que possíveis transtornos mentais relacionados ao trabalho fossem percebidos sob o registro da tara, do vício ou da má adaptação - questões de ordem estritamente individual.

\footnotetext{
170 Ou mesmo como campo específico de saberes e práticas (CARVALHO, 1999, 2011).

171 Como coloca Seligmann-Silva (s/d, p. 64),

Numa perspectiva histórica vemos que o conhecimento da relação entre trabalho e alterações da Saúde Mental é bastante antigo. O reconhecimento da existência de uma psicopatologia no trabalho, igualmente, desde os anos 20 do século passado já mereceu publicações, seja no âmbito do que era denominado Psiquiatria Ocupacional ou, um pouco depois, já sob a designação de Psicopatologia do Trabalho. Nos estudos de psicopatologia, historicamente, sempre houve obscurecimento do papel que é desempenhado, na gênese de transtornos mentais, pelas condições de trabalho e por certos modos de obter incremento de produtividade, conforme foi bem analisado por Doray já há mais de 30 anos.
} 


\subsubsection{MORAL, MENTAL, PSÍQUICO: ANOS 20 e 30}

Observa-se um discurso cada vez mais "científico"; a técnica seria a justificativa racional para as intervenções na indústria visando à maior produtividade.

Como destacou Bertolli Filho (1993), não se poderia "resumir" toda a discussão científica da época a alianças com o patronato para o incremento da produção industrial e submissão dos trabalhadores; observar-se-ia também uma busca pela consolidação do(s) campo(s) científico(s) - higiene industrial, medicina do trabalho, higiene mental, psicotécnica, infortunística... - uma busca de legitimidade e "autonomia" como ciência, demarcando seus "territórios" e especificidades, distanciando-se do conhecimento leigo. Observa-se uma crescente sofisticação da produção conceitual, que, tornando o campo cada vez mais especializado, o limitaria "ao homem de ciência"; desenvolveram-se dispositivos técnicos (como testes psicológicos, por exemplo) e discussões teórico-metodológicas, que confeririam mais cientificidade e legitimidade aos estudos e discursos (CARVALHO, 2010, p. 106).

Começou a se operar mais fortemente a busca de cientificidade do discurso sobre o trabalho e o trabalhador, e a psicotécnica se apresentava como a principal via de apreensão do "mental", tanto na perspectiva de prevenção ("prophylaxia", nos termos higienistas) quanto na de seleção. A tônica ainda era a de responsabilização ou individualização das questões - dever-se-ia proceder à busca dos fatores "hereditários" ou constitucionais que levariam à má adaptação, à insatisfação, à baixa produtividade, ao adoecimento, ao alcoolismo.

A ideia de que se deveria formar o trabalhador, de cunho fortemente higienista, se apresentava na medida em que as atenções não deveriam se voltar apenas para o trabalhador adulto. A atuação também deveria se voltar para a educação, para a infância, para a formação de "hábitos" (mentais) saudáveis para o trabalho, de um futuro trabalhador mais adaptado/adaptável, menos "propenso" ao adoecimento, à insatisfação, à fadiga, ao uso do álcool.

A sobreposição moral/mental no nível discursivo foi se tornando mais diluída, encoberta (embora na prática ainda se observe); Carvalho (2011, p. 37) atribui essa mudança, que classifica como "de superfície", ao predomínio, cada vez mais 
acentuado, no âmbito discursivo, da dimensão tecnológico-científica sobre a dimensão da moral e da política.

Uma alusão às relações entre trabalho e depressão pode ser encontrada na obra de Walther (1929), onde o autor aponta como o trabalho pode provocar depressão e fadiga, quando sobreutiliza determinadas partes do corpo em detrimento de outras, primeiro, na forma de dores localizadas, posteriormente se estendendo ao "organismo inteiro" e provocando "perturbações nervosas":

O trabalho provoca a depressão e a fadiga, quando elle põe em jogo, de modo excessivo, certas partes do corpo, com exclusão das outras. Sem que o corpo esteja fatigado por inteiro, uma dor localisada é já percebida: essa dor previne o individuo de que a parte em trabalho começa a esgotar-se. Se o trabalho continua, o effeito torna-se geral, a fadiga se extende progressivamente a outros grupos de músculos, e invade o organismo inteiro, provocando perturbações nervosas mais ou menos graves e, às vezes, até a morte (WALTHER, 1929, p. 151).

Outro fator relacionado seria a monotonia, apontada por Walther como consequência da divisão do trabalho, na medida em que faz desaparecer a variedade na atividade profissional; apesar disso, as explicações deveriam ser buscadas nas diferenças individuais:

O trabalho nas fabricas é monótono por sua própria essência, tende fatalmente para uma automatisação cada vez maior e mais completa. [...] A fabricação em massa, a acceleração da produção acarreta sempre maior divisão do trabalho; faz desapparecer, para o individuo, toda a variedade na actividade profissional. Dahi, a monotonia do trabalho industrial, com o que vem a soffer grande parte da população operaria. Nem todos, no entanto, são sensíveis, do mesmo modo, a essa monotonia. Pesquisas recentes demonstram que os homens se comportam de modo differente, em face da uniformidade do trabalho nas fabricas (WALTHER, 1929, p. 191).

Uma questão central nas discussões do período é a sobre a fadiga. Walther (1929) chama atenção sobre as diferenças de rendimento e produtividade que se observam em trabalhadores fatigados. Contudo, além de uma breve discussão sobre a jornada de trabalho ideal (apontando oito horas diárias como o limite máximo a que se poderia submeter a resistência humana), o que norteia seu discurso sobre a fadiga é, ainda, a questão da propensão ou, em seus termos, a "vulnerabilidade".

É a «vulnerabilidade à fadiga» [...] que caracterisa os indivíduos. Indivíduos de typo diverso quanto a fatigabilidade não podem ser submettidos ao mesmo rythmo de producção sem graves prejuízos para a saúde e distúrbios no rendimento geral do trabalho (WALTHER, 1929, p. 160). 
Tratar-se-ia então de compreender as diferenças individuais para minorar a fadiga e obter a maior produtividade, entendendo a fadiga não como produto da organização do trabalho, mas como um fator individual de fragilidade, individualizando a discussão. Se compreendidas as "differenças individuaes", então, seriam possíveis alternativas "cientificas" para a questão da fadiga.

Outra discussão central nesse período é sobre o alcoolismo, uma vez que, tanto quanto a fadiga, interferiria diretamente na capacidade produtiva do trabalhador, e que poderia ser considerado uma ameaça para sua própria vida e para a dos colegas de trabalho, como pode se observar na seguinte passagem:

[...] os progressos da legislação social vão exigindo do operário hábil os costumes temperados, porque para contar-se com o trabalhador, para que ele não se mutile na machina que opera, tenha visão nitida, memoria viva, mãos firmes, trabalhe bem, em summa e não incorra em frequentes acidentes de trabalho, cumpre que seja sóbrio (BRAGA, 1930 apud MANSANERA; SILVA, 2000, p. 128).

Em vez de considerar as condições socioeconômicas em sua relação com o alcoolismo, o discurso médico-higienista o concebia como "uma doença moral, cujo remédio estaria na educação, e uma doença social, cujo remédio estaria na ordem" (MANSANERA; SILVA, 2000, p. 128) e causa de degeneração moral e social da sociedade.

O alcoolismo brasileiro, podemos affirmal-o em nome das estatisticas, é
muito mais grave e impressionante na realidade do que na apparencia. É o
alcoolismo das bebidas fortes e de baixo custo, é, pois, alcoolismo das
classes pobres, tal como se nos afigurava "a priori". [...] Não é, pois, o
alcoolismo dos abastados, cujas consequências só as victimas e os
descendentes attinge; não é o dos remediados que com os seus malefícios
se vêem a sós; é o alcoolismo do pobre, do trabalhador urbano e rural,
mourejando na officina ou no campo, e cujo valor physico é indispensável á
economia do paiz e cuja invalidez é um peso morto, que se pode auferir
pelas victimas nos manicomios, nos hospitaes, nas penitenciarias e nos
asylos, ou deambulando nas ruas, míseros derelictos humanos, fluctuando,
inuteis, na torrente da vida (LESSA, 1925, apud MANSANERA; SILVA, 2000, p.
128).

Além da "degeneração moral", outra possível causa para o alcoolismo estaria relacionada à "inaptidão" para exercer a profissão, ou seja, uma inadaptação ao trabalho. Esposel (1929 apud MANSANERA; SILVA, 2000, p. 127) chama atenção para o tédio, "o desgosto de quem exerce contra sua vontade alguma profissão, sem ter o mínimo de aptidão para exercê-la". Essa situação poderia levar o trabalhador aos 
vícios, aos "venenos sociais". Para enfrentar a questão, propunha a utilização de métodos "psicológicos" que avaliassem a personalidade (normal e anormal) tanto na seleção do trabalhador quanto antes, na orientação profissional, que poderia promover a "higiene" individual e coletiva.

Walther (1929) relaciona o alcoolismo à fadiga, que estaria na gênese da "busca de excitantes de toda espécie" como o álcool e o tabaco:

E, para combater a fadiga profissional, ao envez de aproveitar esses resultados [dos estudos científicos], cada individuo tem querido resolver o problema a seu modo, empiricamente, e as mais das vezes usando de meios que diminuem as forças physicas em lugar de accrescel-as. Toda gente procura excitantes de toda espécie, o álcool, o tabaco, etc. (WALTHER, 1929, p. 150).

Quanto aos acidentes de trabalho, Jacques (2013, p. 240) também chama atenção para o fato de que a noção de "propensão ao acidente" foi cunhada na década de 20, quando pesquisadores (tanto engenheiros como psicólogos) procuraram explicar a ocorrência de acidentes pelas diferenças individuais. "As primeiras inserções da dimensão subjetiva na análise dos acidentes de trabalho se referem a hipóteses de predisposição individual", e a noção de trabalhador "propenso" ainda se mantém, apresentando-se de diversas formas, como na noção de "ato inseguro".

\subsubsection{A "psiconeurose bancária" 172}

A "psiconeurose bancária" apresentou particularidades talvez únicas no cenário dos anos 30, como a relação que estabelece entre saúde física e mental e condições de trabalho, o envolvimento sindical em movimentos paredistas que incluíam em sua pauta de reivindicações mudanças para além das questões salariais, levando, juntamente com a tuberculose, à modificação da jornada de trabalho de uma categoria profissional e sua regulamentação pelo Estado configurando um caso singular, sobretudo se considerado o contexto e o discurso hegemônico de "responsabilização"

172 Somente na "reta final" da tese me deparei com a "psiconeurose bancária", discussão e investigação totalmente afins a este trabalho. Em pesquisas preliminares sobre a questão, foram identificadas poucas referências ou citações, indicando ser necessário um trabalho de investigação mais minucioso e aprofundado. Contudo, dada a minha chegada tardia ao tema, não foi possível seguir essa linha de investigação que, certamente, muito teria enriquecido este trabalho. 
do trabalhador pelo adoecimento (por má adaptação, vulnerabilidade, propensão, fraqueza moral etc.), e não relacionado às condições ou à organização do trabalho.

No cenário dos anos 30, destaca-se um caso apontado por Codo (1988, p. 20): “Em 1933 foi aprovada a jornada de 6 horas para os bancários, argumentando-se com bases na 'psiconeurose bancária'".

Naquele momento, o Sindicato Brasileiro de Bancários tinha como principais reivindicações a caixa de aposentadorias, o salário mínimo profissional e a redução da jornada de trabalho para seis horas; segundo Palmares (2010), a jornada era das 7h30 às $18 \mathrm{~h} 30$ no centro e das $7 \mathrm{~h}$ às $19 \mathrm{~h} 30$ nas zonas suburbana e rural. Até 1933 , segundo o ministro do Tribunal Superior do Trabalho Aloysio Corrêa da Veiga, os empregados em bancos estavam integrados ao regime de enquadramento sindical dos comerciários; desde 1923 os bancários se articulavam para criar uma categoria com identidade própria.

Em 1932, em Santos, ocorreu a primeira greve, reivindicando melhorias salariais e das condições sanitárias, dada a alta incidência de tuberculose na categoria (VEIGA, 2009, p. 17); de acordo com Pennella (2001, p. 103), em 1938, 23\% dos bancários de São Paulo eram portadores de tuberculose. Segundo Maeno (201-), na primeira metade do século XX os bancários eram acometidos por transtornos psíquicos então denominados "psiconeurose bancária". Pennella (2010, p. 103) cita, como exemplo, 259 casos de "psiconeurose bancária" diagnosticados no Rio de Janeiro, em 1938.

A greve de 1932 mobilizou nacionalmente a categoria, engajada na reivindicação do "horário higiênico", a jornada de seis horas diárias. Pareceres médicos justificavam a redução da jornada de trabalho dos bancários, "vítimas da tuberculose e da neurose" (PALMARES, 2010; VEIGA, 2009). Essa redução, segundo Veiga (2009, p. 18), se impunha em razão do "desgaste físico e mental provocado pela tarefa cotidiana de exercer função voltada ao recebimento e pagamento de grandes somas em dinheiro, onde a concentração para evitar incorreções causava um sofrimento maior". Vitoriosa, a greve levou à assinatura da lei (Decreto-Lei 23.322/1933), criando a jornada de trabalho dos bancários de seis horas diárias e 36 horas semanais (PENNELA, 2001; VEIGA, 2009; PALMARES, 2010). 


\subsubsection{MORAL, MENTAL, PSÍQUICO: ANOS 40}

No campo teórico-prático de análise do trabalho, os anos 40 se marcaram pela proeminência conquistada pela medicina do trabalho e higiene industrial, pela infortunística e pela psicotécnica, e pelas práticas de avaliação, recrutamento, seleção e "acompanhamento" (adaptação) da mão de obra cada vez mais orientada pela abordagem conhecida como Psicologia Industrial, juntamente com as "ciências do comportamento" ou "medicina do comportamento".

Segundo Carvalho (2011, p. 37), a partir do final da década de 30 e início dos anos 40, iniciaram-se estudos sobre categorias profissionais específicas e possíveis transtornos mentais a elas relacionados, citando, como exemplos, a "incidência das doenças mentais no magistério"; a seleção de pessoal para o "tráfego telefônico"; a incidência dos "distúrbios mentais" nos ferroviários; a "psiconeurose" como moléstia profissional dos bancários. ${ }^{173}$ Destaca, contudo, que a perspectiva desses estudos tratava, essencialmente, "da manutenção da ordem social e econômica por meio de um processo de vigilância e de seleção da força de trabalho".

Mesmo que esses estudos indicassem, em alguma medida, indícios de uma percepção de caráter mais "coletivo" em relação aos acidentes e doenças do trabalho, a tônica dominante no período foi a de análises baseadas na origem individual desses agravos e, em grande parte, responsabilizando os trabalhadores por sua ocorrência.

Os aportes teóricos da Psicanálise e da Infortunística - ou conjugados - começam a trazer outras percepções para o campo da análise dos acidentes e doenças do trabalho. Sustentada por determinada apreensão da teoria psicanalítica, uma linha de análise desses agravos, sobretudo os acidentes, de grande repercussão no período, atribuiria a neuroses ou outros distúrbios psíquicos as reivindicações de indenização por acidentes de trabalho sofridos (distúrbios conhecidos como sinistrose, neurose de renda, indenizofilia), como discutido por Bertolli Filho (1993).

173 Também não foi possível o aprofundamento dessas questões, que teriam enriquecido este trabalho. 
Como explica Silva (2011, p. 111), "sinistrose" foi um termo cunhado pelo médico neurologista francês Édouard Brissaud, visando descrever uma patologia que passou a ser considerada nas indenizações dos acidentes de trabalho na França a partir de uma lei de 1898, sendo, por essa razão, também conhecida como "enfermidade de Brissaud", e estaria relacionada "a uma forma de neurose decorrente de situação traumática, devido a acidentes do trabalho". A autora também registra como, na França, essa tese teria sido rejeitada por Charcot, uma vez que não acreditava ser possível distinguir "entre as neuroses ditas espontâneas e as atribuídas aos traumatismos" (CARVALHO; SEGRE, 1977 apud SILVA, 2011, p. 112), indicando a dificuldade em caracterizar sua vinculação ao trabalho.

Para Léon Imbert (apud SILVA, 2011, p. 112), a sinistrose seria a forma mais frequente de neurose relacionada com o trabalho, contudo, percebida como doença duvidosa, uma vez que poderia estar associada a qualquer outra doença - muitas vezes, à histeria - ou mesmo, em muitos casos, ser simulada com objetivos de indenização, sendo, por isso, muitas vezes denominada de "neurose de responsabilização" dos patrões, "neurose de renda", "neurose de desejo" e "indenizofilia" (BERTOLLI FILHO, 1993; JACQUES, 2006; SILVA, 2011).

Como destaca Bertolli Filho (1993, p. 46), apesar da pluralidade de denominações, essa patologia contava com uma definição similar: "um delírio pleitista, querelante, de reivindicação". O "quadro psicopatológico" da "sinistrose" é descrito com muita semelhança nas avaliações emitidas pelos peritos, no sentido de primeiramente classificarem os trabalhadores acidentados analisados como "bons trabalhadores" e "responsáveis pais de família"; após o acidente de trabalho, esses trabalhadores realizavam o tratamento médico e afirmavam não desejarem indenização. Quando considerados recuperados e "aptos" para retornarem ao trabalho, "perdiam o amor pelo trabalho", alegando incapacidade para o retorno, e percorriam centros hospitalares e clínicas particulares à procura da recuperação física, ao mesmo tempo em que, influenciados por "maus conselhos" dos colegas, passavam a se empenhar em obter indenização.

Silva (2011) considera a sinistrose um caso "emblemático", que retrataria como os transtornos psíquicos eram abordados na literatura das "ciências do comportamento": 
na maioria dos casos, tratar-se-ia de manifestações de caráter simulatório. Caso o trabalhador apresentasse quaisquer transtornos de ordem mental ou psíquica, esses seriam tratados como "efeito secundário" de acidente de trabalho ou outra doença desconhecida, sendo necessária a avaliação pericial para que se concedesse ou não indenização. Dessa forma, para Jacques (2006), as reivindicações de indenização pelos trabalhadores em razão de acidentes sofridos poderiam ser classificadas como decorrentes de "uma personalidade "anormal", com "neurose de responsabilização" dos patrões pelos acidentes.

Sendo assim, a avaliação pericial deveria buscar identificar se as reivindicações de indenização se baseavam em simulações ou se eram referentes a transtornos cuja origem se encontraria em traumas em decorrência do acidente. ${ }^{174}$ Ampla literatura no terreno da Infortunística foi produzida no período a respeito, reproduzindo-se, aqui, algumas diretrizes preconizadas por Bruno (1941) para a condução da análise pericial. Primeiramente, Bruno (1941, p. 9) informa sobre o que seria a simulação em infortunística:

[...] definimos a simulação em infortunística como sendo o conjunto de manifestações concientes e artificiais por via das quais se concretiza a vontade do empregado para iludir terceiros (o médico, o empregador, as companhias de seguros, advogados, juizes, curadores especiais das vítimas de acidentes do trabalho, etc), tendo em vista obter determinadas vantagens.

A seguir, esclarece sobre a "tipologia" geral da simulação; para ele, "de acordo com a nossa experiência e com a gravidade dos meios de que lança mão o simulador", haveria cinco tipos de simulação: 1) simulação verdadeira; 2) agravação voluntária; 3) imputação inexata (consciente ou inconsciente); 4) dissimulação; 5) exageração (BRUNO, 1941, p. 11).

Mais especificamente, o autor discorre sobre a atuação do perito em face da "simulação de perturbações neuropsíquicas". Primeiramente, o autor fez o alerta de que, em casos de perturbações nervosas possivelmente relacionadas a traumatismos, deveriam ser analisados os antecedentes pessoais, pois "muitas vezes, o perito mais experimentado poderá deparar com sérios obstáculos para formular juízo seguro, em

174 Como coloca Favero (1958 apud SILVA, 2011, p. 113), se se tratava de "perturbação mental resultante de grande abalo nervoso numa catástrofe". 
virtude do grande número de concausas em jogo e da influência preponderante da personalidade prepsicótica" (BRUNO, 1941, p. 15).

No que tange a essas "perturbações", deveria o perito estar atento, pois "não nos devemos esquecer que muito raro não é existir uma acentuada desproporção ou discordância entre as perturbações nervosas acusadas pelo paciente e a natureza do traumatismo" (BRUNO, 1941, p. 17). Para essas, perturbações, uma nova "tipologia" da simulação se delinearia. Os "cinco grandes grupos de simuladores da alienação mental" seriam:

Os simuladores de estados maníacos fazem-no desde os simples estados de excitação maníaca até os de mania com grande agitação. Fazem muito barulho, saltam e gritam, como se os demônios os tangessem, mas, quando acreditam que não estejam a ser observados, buscam repousar e adormecer calmamente...

Os simuladores de estados depressivos fingem-se atacados de profunda melancolia: silenciosos, quasi imóveis, parcos no comer - pensam que com essas atitudes conseguirão iludir o perito.

Os simuladores de estados delirantes ou paranoicos procuram imitar o delírio episódico dos degenerados e a paranoia. Ora fingem-se tomados de ideias de perseguição, ora alegam a existência de alucinações na verdade inventadas.

Os simuladores de episódios psicopáticos em fundo neuropático simulam ideias delirantes, maxime as de perseguição e de grandeza.

Os simuladores de estados confuso-demenciais procuram fingir que se acham desmemoriados, confusos, obnubilados, etc. (BRUNO, 1941, p. 15).

Não obstante sua recomendação de que "Quando estiverdes em presença dum caso difícil, embaraçoso, eu vos convido com empenho a não pensar desde logo na simulação" (BRUNO, 1941, p. 13), Bertolli Filho (1993, p. 47), nos chama atenção para o fato de que a tendência predominante "entre os estudiosos dos segredos do "comportamento industrial" era declarar o reclamante um "simulador", que "buscava extorquir as companhias seguradoras", e negar o pedido de indenização ou alegar insuficiência de evidências que pudessem embasar decisões caráter legal. ${ }^{175}$

175 o autor cita como exemplo o caso de um estivador que, sofrendo uma queda que lhe causou múltiplas fraturas, não acatou o parecer que o declarou apto para retornar ao trabalho, pois ainda apresentava uma série de sintomas, como dores, tonturas e perda parcial da audição. Examinado por vários médicos, o trabalhador "foi qualificado como mentor de um engodo contra seus patrões, já que 
"Psicólogos" e "psiquiatras" seriam recrutados para atuação como peritos nos processos judiciais movidos pelos trabalhadores acidentados; Bertolli Filho (1993, p. 45) destaca, como já mencionado no Capítulo 5, como esses especialistas em "comportamento industrial" tenderam a se voltar para a psicanálise ${ }^{176}$, buscando estabelecer nexos causais entre o "infortúnio" e a "afecção nervosa ou mental" que reduziam ou anulavam a capacidade produtiva do trabalhador.

Essa apreensão da teoria psicanalítica, contudo não atenderia as exigências jurídicas de um "quadro nosológico" amplo e "comprovado", o que levava ao questionamento dos laudos emitidos sob essa abordagem. Muitos "psicanalistas" recorreram então a uma "escola" que apresentava as "patologias mentais" como resultado de disfunções glandulares ou de traumatismo físico, como exemplificado nas diretrizes para a conduta pericial propostas por Bruno (1941). Em seu artigo, essa "escola" utilizou largamente termos afins à psicanálise, como "maníaco", "depressivo", "paranoico", "psicopático", mas percebe-se claramente a atenção a disfunções prévias ou traumatismos, como o demostram os títulos de algumas seções, como: "Sintomatologia das doenças e a influência etiológica dos traumatismos" e "Traumatismos e perturbações anteriores da saúde". Na seção dedicada às "Perturbações neuropsíquicas", é explícito na relação: “Quando nos defrontarmos com portadores de perturbações neuropsíquicas consequentes a traumatismos cranianos [...]" (BRUNO, 1940, p. 14).

Outra vertente, não se alinhando a essa orientação que situava os "comportamentos inadaptados" como produtos de "traumas orgânicos", atribuía a causação do acidente em questão exclusivamente à condição "anormal" da personalidade do trabalhador. Exemplificando essa vertente, Bertolli Filho (1993, p. 48-50) apresenta o caso de um serralheiro de 24 anos que, no espaço de um ano, sofreu 17 acidentes de pequena e média proporções. O médico designado pela companhia seguradora para a investigação desse alto número de ocorrências buscou conhecer a trajetória de vida e a "complexidade psicológica" do trabalhador, submetendo-o a entrevistas e testes,

nenhum dos clínicos encarregados do caso conseguiu encontrar "explicações científicas" para as constantes queixas apresentadas pelo paciente" (BERTOLLI FILHO, 1993, p. 47).

176 "Ramo da psicologia criado por Sigmund Freud [...] formado por um saber tão "prático" e eficiente quanto os demais setores da profissão médica" (MARCONDES, 1939 apud BERTOLLI FILHO, 1993, p. 45). 
cujos resultados, em termos da identificação dos traços de personalidade desse trabalhador foram "recalque da afetividade e da imaginação", "espírito seco, rígido, sem mobilidade, estereotipado em seus pequenos interesses", "ansiedade", "lógica não muito rigorosa" e ainda irritabilidade, fobias, dúvidas e sentimento de inveja. Em seguida, buscaram-se informações sobre sua trajetória de vida, experiências familiares e círculo de amigos. A partir desses dados, o médico elaborou uma "estrutura explicadora" para a ocorrência desses repetidos acidentes, em linhas gerais, elencando fatores como ter sido "criança mimada, superprotegida", ódio inconsciente pela figura materna, não só o "Complexo de Édipo" como também o "Complexo de Caim", "castração simbólica". Assim, os acidentes seriam agressões autoprovocadas para atrair a atenção dos pais: "o relacionamento deturpado com a mãe levou o paciente a substituir a figura da progenitora pela companhia seguradora, cobrando da empresa o aconchego e o carinho materno que supostamente o paciente não recebeu durante a infância", a personalidade "anormal" do trabalhador sendo o elemento exclusivo de explicação dos acidentes em série. Bertolli Filho ainda chama atenção para o fato de que esse trabalhador era totalmente cego do olho direito e tinha a visão muito prejudicada no outro olho, elemento desconsiderado na avaliação dos acidentes pelo perito face a suas "neuroses".

Não apenas os pedidos de indenização em razão de doenças e acidentes do trabalho poderiam ser atribuídos aos fatores de personalidade, mas os próprios agravos ou a "propensão" a eles poderiam ser explicados por essa interpretação/aplicação da teoria psicanalítica. Em última instância, os acidentes eram então provocados, muitas vezes, pelos trabalhadores, seja por desatenção ou por "propensão", não mais "moral", mas psíquica/neurótica.

Observa-se certa mudança no discurso explicativo sobre a "propensão" ou "vulnerabilidade", não mais (tão estreitamente) relacionados a taras ou degenerarão moral, mas a neuroses e outros transtornos ligados à história de vida do trabalhador: "perturbações emotivas", "personalidades psicopatas", "anormalidade mental", "personalidade anormal", "castração", "relacionamentos deturpados" eram termos recorrentes. Esse discurso, para Bertolli Filho (1993, p. 48), se traduziria em um 
"enfoque clínico que desmerecia as queixas dos operários e [na] "psicologização" desenfreada dos acidentados".

Observa-se, nesse sentido, uma passagem do registro do estritamente "moral" para o do psíquico/mental, embora, subjacente ao psíquico, a questão moral não tenha desaparecido. Como já apontado anteriormente, essa modificação seria de "de superfície", reflexo do predomínio cada vez mais acentuado - no âmbito discursivo da dimensão tecnológico-científica sobre a dimensão da moral e da política (CARVALHO, 2011, p. 37).

As explicações seriam, então, individualizadas e focadas nos trabalhadores, explicações que, para Jacques (2006, p. 241), ainda hoje persistem nos órgãos institucionais e no imaginário social ${ }^{177}$, o mesmo se verificando nas doenças relacionadas ao trabalho, "cujas explicações têm ainda um caráter moral, associadas à fraqueza, falta de vontade, preguiça, simulação". 178

A Psicotécnica era uma aliada privilegiada na avaliação dessas questões - das tendências psíquicas indesejadas, ou para auxiliar na identificação da simulação proposital ou da psiquicamente causada. Além disso, operaria como elemento auxiliar ou principal das práticas de recrutamento, seleção e acompanhamento de mão de obra da Psicologia Industrial em sua proposta de organização e gerenciamento "psicológico" do trabalho, ainda pautada pela busca dos adaptados/adaptáveis, dos "normais", e evitação de possíveis desvios ou inadaptações - vistos como causas não apenas de perdas de produtividade mas, também, de doenças e acidentes de trabalho.

177 Silveira (2013) chama atenção para a questão de, ainda hoje, encontrarem-se referências no meio médico e pericial à sinistrose:

Você está achando que é uma coisa da década de 40? Eles [os peritos] te falam que é sinistrose. A gente não usa a expressão, mas o conteúdo, o conceito, é o mesmo, que é uma invenção das pessoas, que são oportunistas que querem se beneficiar da seguradora, de explorar seguradoras, [...] é indústria das ações contra as empresas, isso aí, tem um punhado de gente que ainda fala isso. (entrevista)

178 A esse respeito, Jacques reproduz comentário de Elio Gaspari, em sua coluna no jornal Zero Hora, com o título de "Cuidado com as pedras desgovernadas", onde traz o relato um acidente elaborado pelo INSS: "Ao retornar de seu horário de almoço, o trabalhador Moacir Pereira Passos não enxergou uma pedra vindo em sua direção desgovernada e que bateu em sua cabeça" (GASPARI, apud JACQUES, 2013, p. 241). E prossegue, com ironia: "Estava voltando do almoço (logo, não trabalhando), não viu a pedra (distraído). Inocenta-se a pedra que estava desgovernada. Pedras governadas são aquelas que sabem desviar da cabeça de trabalhadores distraídos que insistem em almoçar". 
Os testes proporcionariam o meio "científico" e "neutro" para o "exame de temperamento e personalidade" (BERTOLLI FILHO, 1993, p. 42), permitindo à "perícia [...] estabelecer quais pessoas estavam aptas ou não para o trabalho" (FÁVERO, 1958 apud SILVA, 2011, p. 112). Bruno (1941) também destaca a importância de exames admissionais dos trabalhadores nos processos seletivos, citando "a lição do Mestre" Flaminio Favero:

\begin{abstract}
Muitas das dúvidas que a questão do estado anterior suscita na prática, poderiam ser em boa parte desviadas, exigindo-se, nas indústrias, exame prévio do candidato por meio do qual se estabelecesse, com o maior rigor possível, a capacidade de trabalho e o estado de saúde individual. Já se caminha para isso. Até lá, em cada caso concreto, os peritos, de acordo com os aplicadores da Lei, devem encarregar-se de minorar as dificuldades práticas, considerando que não há identidade absoluta de organismo humano, mas que cada indivíduo apresenta as suas taras, as suas miopragias especiais e particulares, como bem sabem, aliás, as companhias de seguros, na taxação dos seus clientes (FAVERO, apud BRUNO 1941, p. 15).
\end{abstract}

Registre-se que, mesmo que essas medidas preconizadas pelos "cientistas do comportamento" não fossem adotadas, ou não completamente, pelo empresariado, dado o cenário de mão de obra barata e farta versus o alto custo desses procedimentos, no nível do discurso científico observa-se uma consolidação dessas ideias e uma busca de constituição de um "campo/discurso psi" que se tornaria cada vez mais autônomo e dotado de legitimidade científica própria.

As chamadas "ciências do comportamento" como campo de pesquisas e de intervenções acerca da organização e gerenciamento "psicológico" do trabalho se constituíram em termos discursivos no Brasil, no final dos anos 40 e início dos anos 50, cada vez mais sob o registro da "Psicologia Industrial". 


\subsubsection{MORAL, MENTAL, PSÍQUICO: ANOS 50179}

O impulso de industrialização que o país viveu nos anos 50, com indústrias de base e, posteriormente, indústrias de bens de consumo duráveis, ampliaria a necessidade se obter desempenho e produtividade satisfatórios. Nos anos 50, empresas de grande porte, estatais e multinacionais começaram a investir na manutenção de serviços de assistência médica próprios, independentes do setor estatal, cujo objetivo seria o controle e a seleção dos trabalhadores, desempenhando também importante papel no desenvolvimento de metodologia e elaboração de inquéritos de higiene industrial (LACAZ, 1996, p. 38).

A seleção continuaria sendo vista como o meio mais adequado de identificação de aptidões e "disposições" psíquicas e físicas para o trabalho, para que fosse desempenhado do modo mais satisfatório. "Selecionando o trabalhador, procura-se assim colocar cada operário no posto em que possa trabalhar nas melhores condições possíveis, com ótimo rendimento e dispêndio de mínimo esforço" (STERSA, 1959, p. 33). Como etapas de avaliação, eram recomendadas a análise de antecedentes pessoais e "familiares e hereditários", a realização de exames físicos e laboratoriais, bem como "exame mental". Dessa forma, a seleção também cumpriria o papel de "eliminar os predispostos aos acidentes de trabalho" e os "sensibilizados às doenças profissionais", como se discutirá a seguir.

Os acidentes de trabalho e mesmo as enfermidades profissionais continuariam tendo sua responsabilidade imputada aos trabalhadores ou ao "fator humano". Stersa (1959, p. 111) afirma serem três os fatores que condicionariam os acidentes de trabalho. 0 primeiro, "causas imprevisíveis", os que ocorrem "apesar de todas as precauções tomadas por parte dos operários e dos patrões, mas são em número ínfimo" (estimado por ele em cerca de 2\%); o segundo fator seriam as "causas objetivas ou extrínsecas",

\footnotetext{
179 Da produção da "Psicologia Industrial" brasileira do período, foram destacadas duas publicações, por se tratarem de "manuais" utilizados em cursos "oficiais", patrocinados pelo Estado e/ou entidades representativas do empresariado. O de Benedito Assis, "Compêndio de Psicologia Industrial", publicado em 1954, resultou de um curso de 20 aulas ministrado sob o patrocínio do Departamento da Produção Industrial (DPI) da Secretaria do Trabalho, Indústria e Comércio do Estado de São Paulo. O de Olívio Stersa, "Higiene Industrial e Psicologia do Trabalho (noções elementares)", publicado em 1959, foi produzido para uso das Escolas Industriais, SESI, SESC, SENAI, SENAC e centros de aprendizagem industrial.
} 
ligadas às condições "de serviço" (condições de trabalho), como, por exemplo, maquinário desprotegido ou defeituoso, proteção insuficiente, condições ambientais de ruído, calor, umidade, entre outros. Somados, os dois primeiros fatores "concorrem em média com $20 \%$ das estatísticas de acidentes". O terceiro e último fator seriam as "causas intrínsecas ou subjetivas" do próprio operário e corresponderiam a "uma média de 88 a 90\% do total dos acidentes de trabalho". 180 Alguns dos componentes das "causas intrínsecas ou subjetivas" seriam:

1. Idade (os acidentes são mais frequentes nos jovens, diminuem em torno dos 40 anos e rareiam na velhice);

2. Falta de prática no serviço (são mais frequentes os acidentes na vigência dos primeiros dias de serviço);

3. Indisciplina (recusa do operário em usar os meios de proteção por considerá-los incômodos ou antiestéticos);

4. Distrações (determinadas por instabilidade emocional, tarefa muito monótona, conversa durante o trabalho);

5. Fadiga (são raros os acidentes no meio do dia);

6. Alterações somáticas (perturbações da visão, da audição, defeitos das extremidades);

7. Alterações na esfera psíquica (psicoses, neuroses, alcoolismo, epilepsia etc.) (STERSA, 1959, p. 111, grifos nossos).

Seria "evidente" a relação entre a higiene mental do trabalhador e sua participação nos acidentes de trabalho, que deveriam ser investigados para identificação das causas psíquicas que o promoveram. Quanto ao "perfil" do trabalhador propenso ao acidente, Stersa (1959, p. 158, grifos nossos) afirma que

\footnotetext{
Muitos acidentes ocorrem por perturbações da esfera psíquica, em indivíduos com desequilibrio na parte emocional. Alguns são alcoólatras ou epilépticos enquanto outros, sendo histéricos, desejam atrair a atenção alegrando-se em se apresentarem como vítima.

Há operários sem escrúpulos morais que, com a finalidade de obter indevidamente certas indenizações, fazem-se passar por vítimas de acidentes, simulando doença mental ou orgânica.

Há indivíduos que se acidentam repetidamente. Estudos em feitos mostram que são pessoas desajustadas e estão necessitando de melhor orientação.

As pessoas impulsivas, nervosas, desatentas, medrosas e insubordinadas são as mais sujeitas aos acidentes.
}

180 Note-se que o somatório de percentuais apresentado pelo autor ultrapassa os 100\%. 
Já no que tange às "moléstias profissionais", seriam duas as causas principais, nessa ordem: fatores predisponentes e fatores determinantes. Os fatores predisponentes consistiriam na suscetibilidade congênita, uma sensibilidade maior para esse ou aquele tóxico ou tipo de trabalho que todo indivíduo que adquire uma moléstia profissional deve ter. Por outro lado, não seria possível explicar porque alguns trabalhadores desempenhavam há anos determinada função sem nunca terem apresentado doenças específicas, enquanto outros, com muito menos tempo de trabalho, as adquiriam. Dessa forma, "a condição de suscetibilidade, sob a ação dos agentes determinantes [de diversas ordens], dará como consequência, a moléstia profissional" (STERSA, 1959, p. 127).

Assis (1954) também argumenta na perspectiva de, nos acidentes e doenças relacionados ao trabalho, considerá-los como relacionados a um perfil de trabalhador propenso, não por questões de suscetibilidade congênita, como o faz Stersa, mas pela má formação da personalidade; o meio (as condições em que o trabalho se realiza) pode atuar como "fator superveniente". Mesmo nesses fatores, destacam-se as explicações de cunho psíquico-individual:

\begin{abstract}
Sendo o adulto o resultado da infância e da adolescência, a maior parte dos seus desajustamentos tem a sua origem na má formação da personalidade e do caráter, naquelas primeiras etapas da vida. Tanto que são elas as épocas apropriadas à educação pela maior plasticidade do sistema nervoso, pela sua imaturidade, pelas outras condições naturais que possibilitam uma ação mais produtiva dos agentes responsáveis pela manutenção e progresso da vida da sociedade.

Fatores supervenientes, porém, podem exercer influência levando o indivíduo a desvios de comportamento normal, a desajustes, como causas relacionadas com a saúde, com distúrbios temperamentais, emocionais e de personalidade e com a atuação das forças do meio (ASSIS, 1954, p. 23, grifos nossos).
\end{abstract}

Mesmo que difiram quanto aos elementos que promoveriam essa propensão ou suscetibilidade - suscetibilidade congênita ou má formação da personalidade -, Stersa e Assis chegam ao mesmo ponto: a propensão ou suscetibilidade, em interação com o meio (que, como se pode perceber, desempenha um papel secundário), resultaria nos acidentes e doenças; dessa forma, operava-se a culpabilização dos trabalhadores pelos acidentes e doenças de que eram vítimas. Essa percepção foi se estendendo até os anos 70 (e mesmo até hoje), sustentando o discurso do ato 
inseguro. Também estão de acordo quanto ao melhor meio de identificação desses indivíduos "predispostos aos acidentes de trabalho" ou "sensíveis às doenças profissionais", a seleção:

[A] seleção inicial, além de eliminar os predispostos aos acidentes de trabalho, descobre os elementos sensibilizados às doenças profissionais, desclassificando os que apresentem deficiências muito acentuadas ou incompatibilidade para o posto desejado (STERSA, 1959, p. 41).

Mesmo sendo essa uma concepção de forte pregnância, observam-se abordagens teórico-práticas que, em alguma medida, não se filiam a essa abordagem estritamente individualizante das doenças e acidentes de trabalho. Como aponta Lacaz (2007, p. 101), em meados nos anos 50 foram realizados estudos que não se filiavam a essa perspectiva: inquéritos sobre doenças do trabalho, como dermatoses, pneumoconioses, intoxicações por chumbo (essas, em geral relacionadas à emergente indústria automobilística). ${ }^{181} \mathrm{Em}$ entrevista realizada com Bernardo Bedrikow, um dos fundadores, nos anos 50, do ambulatório de doenças profissionais do SESI de São Paulo, há o relato de que o primeiro lugar em número de atendimentos era ocupado pelas dermatoses ocupacionais e, em segundo lugar, a intoxicação por chumbo, cerca de "1.000 casos de intoxicação em um curto espaço de tempo". ${ }^{182}$

\subsubsection{MORAL, MENTAL, PSÍQUICO: ANOS 60 e70}

A Psicologia Organizacional difunde-se e, no final dos anos 70, começou a implantar as propostas de Desenvolvimento Organizacional e QVT - Qualidade de Vida no Trabalho. As abordagens, em termos da discussão e intervenção na relação entre trabalho e saúde mental, centravam-se em sua maioria no estresse numa perspectiva individualizante da questão, ou na chamada Saúde Mental Ocupacional. O discurso da propensão ou suscetibilidade vai aqui se configurar sob o conceito de ato inseguro.

\footnotetext{
181 Momento que coincide com a ascensão da abordagem da Saúde Ocupacional.

182 É importante destacar que, no Decreto $n^{\circ} 3048 / 1999$, na relação de agentes patogênicos causadores de doenças profissionais ou do trabalho, na seção referente aos Transtornos Mentais e do Comportamento Relacionados ao Trabalho, um dos agentes etiológicos ou fatores de risco de natureza ocupacional para "Outros transtornos mentais devidos a lesão e disfunção cerebral e a doença física" (F06) é o chumbo ou seus compostos tóxicos.
} 
No final dos anos 70, começou a se delinear como campo teórico-prático o da Saúde Mental e Trabalho.

Silva (2011) chama atenção para o fato de que até a década de 70 a maioria das ações do Estado, das pesquisas acadêmicas e das ações sindicais, se voltavam para os acidentes de trabalho e, em escala menor, para as doenças relacionadas ao trabalho; as doenças mentais relacionadas ao trabalho nesse período são chamadas pela autora de "doenças invisíveis".

Apoiando-se em estudos de Antonaz (2002), Silva (2011) argumenta que essa "invisibilidade" das doenças mentais relacionadas ao trabalho estaria associada à "noção prevencionista, que foi hegemônica no país, a partir da construção de um aparato governamental com a formação de instituições do Estado" voltadas para atuação quanto aos acidentes de trabalho, que ocorriam em elevadíssimo número, sobretudo nos anos 70 . Essa atuação seria pautada pela lógica de responsabilização dos trabalhadores pelos acidentes de trabalho, por meio de conceitos como o de ato inseguro.

Segundo Oliveira (2007, p. 20), ato inseguro e condição insegura são os conceitos oriundos da "teoria dos dominós", elaborada ainda na década de 1930 por Heinrich. Segundo essa teoria, o acidente seria causado por uma cadeia linear de fatores, "como uma sequência de dominós justapostos", que culminaria na lesão:

\footnotetext{
A primeira peça do dominó seria os "fatores sociais e ambientais prévios" responsáveis pela formação do caráter dos operários. A segunda peça, os comportamentos inadequados dos trabalhadores, frutos de características herdadas ou adquiridas. Esses comportamentos inadequados poderiam vir a constituir-se em atos inseguros, isto é, em comportamentos de risco que, juntamente com a presença de condições inseguras (atos e condições inseguros são a terceira peça do dominó), levariam à ocorrência do acidente e, por fim, à lesão (respectivamente a quarta e a quinta peças da sequência de dominós) (OLIVEIRA, 2007, p. 20).
}

Ao longo das décadas de 70 e 80, essas ideias teriam recebido forte difusão do Estado brasileiro, durante o chamado "milagre econômico", período marcado, de acordo com Oliveira (2007, p. 20), por intensa formação de técnicos nas áreas de higiene e segurança. A concepção sobre atos inseguros e condições inseguras teria se convertido em "discurso oficial", sendo retransmitida aos profissionais responsáveis pelas ações 
de prevenção de acidentes nas empresas do país - o que teria contribuído, segundo o autor, para o forte enraizamento dessas ideias no imaginário social brasileiro sobre os acidentes.

A tônica do discurso era "psicologizante", traduzida em preocupações com fatores humanos, seleção e treinamento. Nesse sentido, seria exemplar o discurso de um engenheiro durante o XV Congresso Nacional de Prevenção de Acidentes do Trabalho, realizado em 1976:

As raízes do problema residem na formação imperfeita dos homens. Os
acidentes não acontecem, são causados. Por falta de comunicação, por falta
de supervisão, por planejamento defeituoso, por erros humanos, tais como
agressão, distração, fadiga, indisciplina, arrogância ou avareza. Os
planejadores têm feito e estão fazendo tudo que podem para eliminar as
causas físicas e ambientais. Já sabemos como eliminar os riscos, ao preparar
os planos das fábricas, máquinas e processos, ao organizar os locais de
trabalho e ao estruturar os métodos de trabalho. Podemos recorrer à
ergonomia, para que a segurança acompanhe as máquinas e fábricas, ainda
no estágio de plantas e projetos. Mas, devido ao fator humano, os acidentes
continuam a acontecer (LIMA, 1976, apud OLIVEIRA, 2007, p. 20, grifo
nosso).

Como aponta Oliveira (2007, p. 20), esse modo de compreender o fenômeno tem como consequência "a culpabilização dos próprios trabalhadores pelos acidentes de que são vítimas". Embora, na atualidade, haja descrédito científico sobre essas concepções, "ainda é notável sua difusão no senso comum de empresários, profissionais da área e [mesmo] trabalhadores".

Segundo Carvalho (2011), foi somente no final dos anos 70 e início dos anos 80 que a discussão da relação trabalho e saúde mental sob outo prisma emergiu como um novo campo de estudos no Brasil, o que também refletiria uma tendência internacional, na medida em que processos de trabalho e transformações tecnológicas e organizacionais passariam a ser vistas como fontes geradoras de fadiga e tensão, e tratadas como objeto de investigação. Lacaz destaca que mesmo o perfil de morbimortalidade da população trabalhadora começaria a se alterar, em decorrência da automação e das mudanças nas formas de organização das jornadas de trabalho, como o regime de turnos alternados (LACAZ, 2000).

Carvalho (2011, p. 48) faz menção a alguns trabalhos do período (final dos anos 70, início dos anos 80 ) que, preocupados com as relações entre saúde e trabalho, 
tangenciariam questões pertinentes aos debates em saúde mental do trabalhador: Leite Lopes (1978), Costa (1979), Fischer (1980), Grossi (1981), Delgado (1983), entre outros. Já os trabalhos de Gueiros Souza (1980) e de Duarte (1982; 1986) seriam exemplos de "estudos antropológicos que, usando a categoria de "doenças dos nervos", exploram as relações entre sofrimento, trabalho e condições de vida do ponto de vista da classe trabalhadora". ${ }^{183}$

No final da década de 70, a Saúde do Trabalhador começaria a se colocar como contraponto aos saberes e práticas da Saúde Ocupacional-Medicina do Trabalho (LACAZ, 1996, p. 23). No campo da Psicologia, a Psicologia do Trabalho também começaria a fazê-lo com relação à Psicologia Industrial-Organizacional. Começaram a se desenhar as polaridades Saúde Ocupacional-Medicina do Trabalho/Saúde do Trabalhador, e Psicologia Industrial-Organizacional/Psicologia do Trabalho.

\subsubsection{MORAL, MENTAL, PSÍQUICO: ANOS 80184}

Em 1986 realizou-se a I Conferência Nacional de Saúde do Trabalhador, ${ }^{185}$ marcada por discussões que visavam formular conteúdos para a Política Nacional de Saúde do

183 Os trabalhos mencionados por Carvalho (2011, p. 48), em ordem cronológica, são:

LEITE LOPES, J. S. O vapor do diabo: o trabalho dos operários do açúcar. Rio de Janeiro: Paz e Terra, 1978.

COSTA, J.F. Ordem Médica e Norma Familiar. Rio de Janeiro: Graal, 1979.

BELTRÃO, J. P. Mulheres da castanha: um estudo sobre trabalho e corpo. Brasília: UnB, 1979 (mimeo).

FISCHER, F. M. Trabalho em turnos: alguns aspectos econômicos, médicos e sociais. Dissertação (Mestrado em Saúde Pública). São Paulo: USP, 1980.

GROSSI, Y.S. Mina de Morro Velho: a extração do homem, uma história de experiência operária: São Paulo: Paz e Terra, 1981.

DUARTE, L.F.D. Doença dos nervos: um estudo de representações e visões de mundo de um grupo de trabalhadores. IN: RODRIGUES, L.M. et al. Trabalho e cultura no Brasil. Brasília: ANPOCS/CNPq, 1982.

DELGADO, P. G. Mal-Estar na Indústria: Contribuição ao Estudo das Relações entre Saúde Mental e Condições de Trabalho. Dissertação (Mestrado em Psiquiatria). Rio de Janeiro: IPUB/UFRJ, 1983.

SANTOS, E.M. Frutos anônimos da exploração: o caso dos acidentes e intoxicações dos trabalhadores do abacaxi em Sapé - Paraíba. Dissertação de mestrado. Rio de Janeiro: ENSP/FIOCRUZ, 1985.

DUARTE, L.F.D. Da vida nervosa das classes trabalhadoras urbanas. Rio de Janeiro: Zahar, 1986.

184 A partir desta seção, serão analisadas mais detalhadamente as contribuições da Saúde do Trabalhador, da Psicologia do Trabalho e da Saúde Mental e Trabalho para a compreensão dos Transtornos Mentais e do Comportamento Relacionados ao Trabalho. As formulações teóricas da "vertente" da Saúde Ocupacional-Medicina do Trabalho e da Psicologia Industrial-Organizacional serão abordadas de forma mais sucinta, e apenas naquilo em que se opõem/contrapõem às proposições, conceitos e práticas da outra vertente (Saúde Mental e Trabalho). 
Trabalhador, os quais seriam posteriormente incorporados na Constituição Federal de 1988 e na Lei $n^{\circ} 8.080$, de 1990.

A Constituição Brasileira de 1988 introduziu um conceito ampliado de saúde, entendida como direito de cidadania e garantida pelo Estado, e estabeleceu a criação do Sistema Único de Saúde. A Lei Orgânica de Saúde (Lei nº 8.080) de 1990 estabelece como competência do SUS a coordenação e execução de ações referentes à Saúde do Trabalhador.

Nos anos 80, diversos municípios implementam PSTs (Programas de Saúde dos Trabalhadores) e Centros de Referência em Saúde dos Trabalhadores (CRSTs ou CERSATS).

Como já explanado, uma polarização começou a se delinear no final dos anos 70 e início dos anos 80, estendendo-se até a atualidade, entre Saúde Ocupacional-Medicina do Trabalho/Saúde do Trabalhador, e Psicologia Industrial-Organizacional/Psicologia do Trabalho.

Como já discutido também em capítulos anteriores, apresentou-se uma forte afinidade epistemológica, teórico-prática e política entre a Saúde Ocupacional-Medicina do Trabalho e a Psicologia Industrial-Organizacional, e entre a Saúde do Trabalhador e a Psicologia do Trabalho. O campo da Saúde Mental e Trabalho, discutido no capítulo 5, se constrói a partir de colaborações/aportes da Saúde do Trabalhador e da Psicologia do Trabalho, entre outros, para a busca da compreensão, estudo e intervenção nas questões ligadas ao sofrimento, desgaste ou transtorno mental/psíquico relacionado ao trabalho.

Nos anos 80 , programas de saúde e de qualidade de vida no trabalho começaram a fazer parte do discurso da Psicologia Organizacional. Contudo, essas abordagens, pautadas pela ênfase nos aspectos individuais e restrita discussão sobre papel desempenhado pelo contexto de trabalho, tenderiam a priorizar questões relacionadas

185 Uma síntese das discussões das Conferências Nacionais de Saúde do Trabalhador (CNST) encontrase no Apêndice G. 
à cultura organizacional e conflitos e competições entre grupos, apontados como os principais obstáculos para sua consecução (CARVALHO, 2011).

Dentre as principais contribuições do campo da Saúde Mental e Trabalho, então em conformação nos anos 80, destacam-se aqui algum estudos e pesquisas realizados no período, a participação dos sindicatos nas discussões relativas à saúde mental, a atuação dos PSTs e debates em torno do reconhecimento do sofrimento, desgaste ou transtorno mental/psíquico como relacionado ao trabalho.

Para Seligmann-Silva (1988, p. 14), antes que pela academia, a percepção das relações entre trabalho e sofrimento mental teria ocorrido por parte dos trabalhadores, "tanto que os estudos pioneiros do DIESAT (Departamento Intersindical de Estudos e Pesquisas de Saúde e dos Ambientes de Trabalho) surgiram a partir de demandas colocadas pelos próprios trabalhadores".

Já Silva (2011) e Camargo $(2010,2011)$ apontam como pioneiros os estudos de Seligmann-Silva, cuja tese de doutorado, em 1973, intitulava-se "Fatores socioculturais na doença"; destacam também relatório de pesquisa de 1981/1983, intitulado "As condições de trabalho e de vida e suas repercussões sobre a saúde mental de trabalhadores industriais", sobre estudo desenvolvido em Cubatão (e mencionado a seguir), realizado antes das pesquisas do DIESAT com as categorias dos bancários e metroviários (também mencionadas a seguir).

Na relação de teses e dissertações produzidas em São Paulo (no período de 1967 a 1995) analisadas por Lacaz (1996, p. 273) em sua pesquisa, encontram-se algumas, cujos títulos já apontam para relações entre trabalho e sofrimento/doença/transtorno mental (ou LER/DORT). ${ }^{186}$

Codo $(1988$, p. 21) também aponta que publicações com a temática saúde mental e trabalho vinham crescendo, e que os trabalhadores, com destaque para os bancários, à

\footnotetext{
186 Exemplos (LACAZ, 1996, p. 273):

- Trabalho Hospitalar e Sofrimento Psíquico (Tese, 1989);

- A Compreensão dos Trabalhadores Sobre o Processo Saúde-Doença no Âmbito do Trabalho: Estudo de Casos de Intoxicados por Chumbo em Bauru (Dissertação, 1989);

- Transtornos Mentais Entre Trabalhadores de Usina Siderúrgica (Dissertação, 1990);

- Um Estudo Sobre a Prevalência de Distúrbios Psiquiátricos Entre Sepultadores do Serviço Funerário de São Paulo (Dissertação, 1991).
} 
época, iniciavam processo de conscientização sobre os "riscos da 'loucura" (CODO, 1988; SILVA, 2011). Apesar do aumento do número de pesquisas e publicações, contudo, denuncia:

\begin{abstract}
As pesquisas e publicações denunciando o comprometimento da Saúde Mental e Trabalho proliferam, a consciência dos trabalhadores mais atingidos (como os bancários) admite sem surpresas o risco da "loucura" e, no entanto, nenhuma providência concreta a nível preventivo ou remediativo é tomada. Sobre a "doença mental" paira uma espécie de conluio do silêncio, a sociedade se cala, restringe a atuação aos consultórios e hospitais especializados, como a lepra há alguns anos, tudo se passa como se estivéssemos diante de uma realidade que envergonha a sociedade ou a família, a ser confinada, não apenas longe de nossos olhos, mas principalmente de nossas consciências (CODO, 1988, p. 21).
\end{abstract}

Segundo Cruz (2005), nos anos 80 foi realizado por Naomar de Almeida Filho estudo sobre a prevalência de desordens mentais entre trabalhadores de uma área industrial da região metropolitana de Salvador (Bahia).

Seligmann-Silva (1988) relata dois estudos relacionados com trabalhadores de extração mineral (mineiros), os já mencionados trabalhos de Maria Cecília Minayo (com trabalhadores de extração de ferro) e o de Yone de Souza Grossi (com trabalhadores de extração de ouro). Cita também (Seligmann-Silva, 2014) duas publicações por ela consideradas "pioneiras" do início dos anos 80: um estudo realizado por Pedro Gabriel Delgado, que teria utilizado dados produzidos por sua pesquisa realizada em Cubatão (relatada a seguir), e o de Maria Cristina Gueiros Souza. ${ }^{187}$

Por sua contribuição teórica e/ou histórica, serão destacados a seguir alguns estudos e pesquisas, realizados nos anos 80 , que visavam à compreensão, estudo e intervenção nas questões ligadas ao sofrimento, desgaste ou transtorno mental/psíquico relacionado ao trabalho.

- Pesquisa em Cubatão (1981-1983)

Cruz (2005) cita como pioneiro e referência para os trabalhos posteriores o estudo exploratório realizado por Edith Seligmann-Silva sobre a repercussão das condições de

187 DELGADO, P. G. Mal-Estar na Indústria: Contribuição ao Estudo das Relações entre Saúde Mental e Condições de Trabalho. Rio de Janeiro, Dissertação (Mestrado em Psiquiatria,) IPUB/UFRJ, 1983.

GUEIROS SOUZA, M. C. "Doença dos nervos” como estratégia de sobrevivência. Recife, mimeo, 1980. 
trabalho na saúde mental dos trabalhadores industriais de Cubatão e dos metalúrgicos em São Paulo, no qual foram investigados afastamentos do trabalho por problemas de saúde (denominados de "nervosismos"), identificando mecanismos de desgaste mental e da utilização, por parte dos trabalhadores, de defesas contra o sofrimento. Seligmann-Silva (1988), a respeito dessa investigação, informa que foram realizados estudos de casos de trabalhadores que haviam tido afastamento do trabalho por manifestações de distúrbio mental ou por doenças psicossomáticas, que teriam evidenciado "profunda associação entre o processo de adoecimento e o trabalho destas pessoas", associação que ocorre

[...] por inúmeras interações, nas quais participam tanto aspectos organizacionais (ritmos intensificados, jornadas prolongadas, insuficiência de pausas, controle coercitivo e permanente sofrimento pelos trabalhadores, além de outras características) quanto aspectos ambientais e às próprias condições de vida (SELIGMANN-SILVA, 1988, p. 15).

Nesse estudo, verificou-se que várias crises mentais agudas tinham sido desencadeadas por grandes aumentos de jornada de trabalho, originados por dobras de turno (com 16 horas de trabalho) ou aumento das horas extras. Além disso, nessas indústrias, a maioria dos operários trabalhava em regime de turnos alternados ou revezamento, "o que por si somente se constitui em um importante fator de risco, tanto para a saúde geral quanto para a psicossocial". Então, somavam-se o trabalho em turnos de revezamento, a exigências de maiores jornadas e de intensificação de ritmo de produção (na siderurgia) e o temor do desemprego, pois no período da pesquisa de campo (1981-1983) havia recessão econômica, o que "fazia com que as pessoas elevassem ao máximo seus esforços para aguentar as péssimas condições de trabalho existentes em seus empregos". Esses elementos resultavam em sobrecarga, exacerbação da fadiga e em crises mentais; "a situação também desembocava, para muitos, em hipertensão, enfarte, úlcera etc." (SELIGMANN-SILVA, 1988, p. 14; 2014). Em 1984, foi publicado pelo DIESAT o livro "De que adoecem e morrem os trabalhadores", organizado pelos médicos Herval Pina Ribeiro e Francisco Antônio de Castro Lacaz, cujos capítulos trazem textos produzidos a partir de eventos simpósios, seminários, Semanas de Saúde do Trabalhador (SEMSAT) - realizados entre 1979 e 1983 e organizados pelo movimento sindical. Entre as diversas questões 
debatidas no livro, destacam-se aqui as que trazem a discussão ou apontam relações entre trabalho e saúde mental.

No capítulo 3, "Acidentes de Trabalho", originado de simpósio sobre o tema realizado em 1981, discute-se e contesta-se "a versão oficial e dos empregadores que responsabiliza o 'ato inseguro' pela maioria deles, aprofundando a busca de suas causas determinantes" (RIBEIRO; LACAZ, 1984, p. 8).

Já o capítulo 4, "Horas Extras, Turnos e Ritmos de Trabalho", foi discutido e aprovado, em 1981, em fórum de debates sobre o tema promovido pelo DIESAT com participação de dirigentes e bases sindicais. Nesse texto, já se apontam, como problemas que os trabalhadores em turno alternado relatariam, distúrbios do sono, nervosos e digestivos, além da tensão nervosa que contribuiria para causar acidentes de trabalho. Já sobre as horas extras, discorre-se sobre a semelhança, em termos de desgaste para a saúde, com o sistema de trabalho em turnos:

[...] a perda de horas de repouso, a alteração do horário de refeições, aliada à própria tensão inerente ao trabalho em excesso, têm reflexos no comportamento, com aparecimento de irritabilidade fácil, nervosismo, consequentes do desgaste mental, responsável por muitos casos de internações em hospitais psiquiátricos (RIBEIRO; LACAZ, 1984, p. 100).

O capítulo 5 discute "Tóxicos na Indústria" (boletim do DIESAT publicado em 1982), e o capítulo 8, "Trabalho Rural, Acidentes e Doenças" (SEMSAT de 1983), ambos versando sobre intoxicações no trabalho e elencando efeitos das mesmas para a saúde física e mental.

Por fim, registra-se também, no capítulo 9, "Incapacidade, Trabalho e Previdência Social" (publicado em revista do DIESAT de 1984), análise das cinco patologias que respondiam à época por um terço dos casos de incapacidade para o trabalho. Ribeiro e Lacaz (1984, p. 191-192) informam serem as neuroses o diagnóstico mais frequente dos afastamentos temporários concedidos pelo INPS, e a causa mais frequente (quase única) da aposentadoria por invalidez abaixo dos 40 anos. Como colocam os autores, haveria um reconhecimento pela Previdência das origens e vínculos sociais das doenças mentais, omitindo, contudo,

[...] a relação, frequentemente mais estreita, entre o trabalho e as condições, ambientes, formas e relações de produção em que é exercido - 
e também fator determinante daquela e de outras doenças. O trabalho perigoso, insalubre, penoso, monótono, repetitivo; a aceleração do ritmo de produção, a antevisão do acidente, da invalidez e da velhice miserável; a perspectiva do desemprego, a burla constante aos mínimos direitos estabelecidos pela legislação, já injusta e arbitrária, fazem os trabalhadores tomarem consciência da exploração e a falta de perspectiva de revertê-la; os enlouquece. Quem não enlouqueceria? Assim, a doença mental não encontra resposta, quer a nível social, quer a nível médico ou previdenciário. Os que têm agravado seu quadro acabam sendo asilados, prática que cronifica a doença e os marginaliza de vez, levando-os à única opção presente: a aposentadoria (RIBEIRO; LACAZ, 1984, p. 192).

- Pesquisa com bancários - DIESAT (1984)

Seligmann-Silva $(1988,2014)$ faz um relato sobre pesquisa a respeito de condições de trabalho e saúde mental dos bancários, realizada em 1984 pelo DIESAT, solicitada ao órgão pelo Sindicato dos Bancários de Campinas e pela Federação dos Bancários de São Paulo, Mato Grosso do Sul e Paraná. O projeto foi construído por uma equipe multidisciplinar do DIESAT (composta pela psicóloga Leny Sato, pela socióloga Agda Aparecida Delía, pelo médico Francisco Antônio de Castro Lacaz e pela psiquiatra Edith Seligmann-Silva), conjuntamente com os bancários, e a pesquisa também foi conduzida conjuntamente. A demanda inicial estava relacionada com a implantação da "computadorização" (nos termos da autora). Com a informatização do setor bancário, ampliou-se o leque de serviços ofertados pelos bancos, o que implicou um volume muito maior e diversificado de tarefas para o caixa. Esses novos serviços possuíam particularidades e especificações diferentes, exigindo do caixa a memorização de um grande número de instruções e "resultando numa sobrecarga mental". As responsabilidades desse profissional também aumentaram muito com os novos serviços, demandando mais tempo para suas operações e consequente aumento das filas de usuários que, impacientes pelo atendimento, muitas vezes agrediam (verbalmente) os profissionais. Aliadas aos novos serviços, surgiam também maior pressão e exigências de qualidade de atendimento ao público (clientes). Nessa pesquisa, alguns dos achados são assim relatados:

Isto [o contexto acima descrito] os conduz a uma autorrepressão muito intensa que acaba sendo canalizada psicossomaticamente ou mesmo psiquiatricamente, em alguns casos. Num grande banco estatal, no decorrer de dois anos, os motivos psiquiátricos de afastamento atingiram um nível de $14,06 \%$ de todos os afastamentos por doença. O diagnóstico psiquiátrico mais frequente nesse mesmo banco foi o de depressão. Estudos de casos em bancários que haviam recebido esse diagnóstico demonstraram que a 
depressão havia se constituído reativamente a situações vinculadas estreitamente ao trabalho: vivência de desqualificação, frustração de projetos de carreira e de vida, esvaziamento de motivação, sensação de aprisionamento dentro de um cotidiano entediante (SELIGMANN-SILVA, 1988, p. 14).

- Pesquisa com metroviários de SP - DIESAT (1985) ${ }^{188}$

A pesquisa realizada pelo DIESAT com o Sindicato dos Metroviários de São Paulo, em 1985, também é relatada por Seligmann-Silva (1988). Da pesquisa participaram, além da equipe multidisciplinar de técnicos do DIESAT, representantes das várias escalas de horário e de linhas do metrô: "Sempre desenvolvemos a pesquisa em conjunto com os trabalhadores, porque devemos conhecer o processo de trabalho e, para tanto, devemos aprender como se dá esse processo a partir dos trabalhadores" (SELIGMANNSILVA, 1988, p. 15). Essa pesquisa foi realizada em espaço de tempo curto, uma vez que os metroviários levariam os resultados do estudo para negociações com a empresa, visando à redução da jornada e aumento das folgas. Como resultado da pesquisa, constatou-se que a jornada de 8 horas era excessiva, e as folgas, insuficientes para o repouso. A autora relata que a empresa havia solicitado pesquisa própria a outro grupo de pesquisadores, e que o conjunto dos resultados das duas pesquisas favoreceu os trabalhadores que, embora não tenham obtido a redução da jornada diária, conseguiram modificações na escala com menos períodos noturnos e aumento de folgas.

- Pesquisa com aeronautas -DIESAT (1985/1986)

Pesquisa realizada pelo DIESAT com o Sindicato dos Aeronautas, em 1985-1986, relatada por Codo (2014):

E [...] apareceu um estudo para fazer. Era com os aeronautas. Foi meu primeiro estudo em Saúde Mental e Trabalho propriamente dito. Metodologia participante e tal. [...] Criei um instrumento, aplicamos um instrumento para os aeroviários. Eles estavam brigando para ter quartos separados. Porque eles dormiam juntos, dois a dois. Quando eu ouvi essa reivindicação, lá dentro do DIESAT, eu falei: "isso é uma tolice". Com tanta coisa que tem para brigar, o cara vai querer dormir sozinho no quarto? [...] Frescura, onde já se viu? [...] Eu fui à primeira reunião, fui com a Edith Seligmann-Silva, mas depois a Edith não podia mais, eu fui sozinho, comecei

188 A entrevistada Silvia Rodrigues Jardim também realizou pesquisa com metroviários, no Rio de Janeiro, que serviu de base para sua tese de doutorado, "Processo de trabalho e sofrimento psíquico: o caso dos pilotos de trem de Metrô do Rio de Janeiro", defendida no Instituto de Psiquiatria da UFRJ em 1994. 
a ver que o problema era muito sério... O que acontece é que tem uma hierarquia militar, no avião. Não tem dois com o mesmo posto. Tem sempre um que manda no outro. Quando vão dois para o quarto, você leva a hierarquia para dentro do quarto, e você é um trabalhador de turno irregular. Aí eu fui para a literatura para estudar o trabalho do aeronauta, $e$ a coisa do turno me chamou a atenção. Fui fazer todo um trabalho sobre turno, e em turno irregular você tem problemas sérios de sono. É muito difícil você conciliar o sono. Tem hora que você dorme de dia, tem hora que você dorme de noite... E o que você tem que fazer para conciliar o sono? Você tem que criar todo um ritual. E você mantém esse ritual para poder induzir o sono. Ora, dormindo em dois, você não podia ter o ritual. Aí, [...] eles foram para a briga, dizendo que [...] tinham problema de saúde e que aquilo era um problema de aumento da jornada de trabalho. Então, se é pra dormir em dois, então tem que pagar hora extra. E ganharam. Passaram a dormir sozinhos (CODO, 2014, entrevista).

- Investigação em fábrica de cloro-soda do $A B C D$ (1987) e de fios de rayon (1986)

Sato, Lacaz e Bernardo (2006, p. 284) citam como um caso que teve repercussão de âmbito nacional, e no qual a Psicologia teria importante participação, o referente a uma fábrica que produzia cloro-soda da região do $A B C D$, a partir de uma demanda do Sindicato de Trabalhadores nas Indústrias Químicas em 1987 aos serviços de saúde pública em razão de alguns trabalhadores apresentarem sintomas compatíveis com intoxicação por mercúrio metálico.

Uma ação conjunta de instituições de pesquisa (Instituto de Saúde, Universidade de São Paulo, Fundacentro) e de serviços de saúde pública (PST do ABC Paulista, CRST de São Bernardo do Campo) foi planejada para avaliar as condições de trabalho e os trabalhadores afetados. Essa ação envolveu atuação interinstitucional e multiprofissional, com participação de médicos, engenheiros, psiquiatras e psicólogos, que elaboraram avaliações ambientais, clínicas, neuropsíquicas e laboratoriais. Psicólogos e psiquiatras elaboraram um protocolo de avaliação neuropsíquica (entrevista psiquiátrica e testes neuropsicológicos), para analisar os efeitos da exposição ao mercúrio metálico sobre a esfera neuropsíquica dos trabalhadores.

A partir dos resultados encontrados, foram definidos critérios para afastamento da exposição e tratamento dos trabalhadores, mudanças no ambiente de trabalho, bem como o afastamento dos trabalhadores da exposição e a aposentadoria de outros, por invalidez. Lacaz (1996) informa que, a partir da repercussão desse caso, a avaliação da esfera neuropsíquica de intoxicados por mercúrio metálico passou a compor os critérios diagnósticos de incapacidade da Previdência Social, "sendo aplicada a 
trabalhadores de outras fábricas, do setor metalúrgico e químico que, posteriormente, também foram afastados do trabalho". Diversas dissertações e teses de Engenharia, de Medicina e de Psicologia teriam registrado essa experiência.

Outro caso citado por Sato, Lacaz e Bernardo (2006, p. 285) foi o de uma indústria produtora de fios de rayon, cujos trabalhadores, em 1986, entraram em greve após sucessivos acidentes graves ocorridos na empresa. Além das condições de segurança, a greve também era motivada pela suspeita de que os trabalhadores estavam se intoxicando por dissulfeto de carbono. "Também nesse caso, a avaliação neuropsíquica foi fundamental para estabelecer o nexo causal entre os sintomas referidos e os riscos no ambiente de trabalho".

- Projeto Saúde Mental e Trabalho (PSM\&T) - USP Ribeirão Preto (1988-1992)

De 1988 a 1992 desenvolveu-se na Faculdade de Filosofia Ciências e Letras de Ribeirão Preto/USP (FFCLRP/USP) "um esforço de investigação interdisciplinar voltado para avaliação, crítica e constituição de uma metodologia de pesquisa em saúde mental e trabalho", o Projeto Saúde Mental e Trabalho (PSM\&T), que contou com apoio do Ministério da Saúde, do CNPq e da FAPESP. O PSM\&T "realizou investigações práticas" e se propôs "definir um desenho investigativo útil à consolidação da área de saúde mental e trabalho" (CODO; SAMPAIO; HITOMI, 2004, p. 1). Como relata Codo (2014):

Os primeiros [...] meses do Projeto Saúde Mental e Trabalho [foram] para estudar, afinal de contas, o que é isso. Isso implicou num texto que na minha avaliação, esse sim foi a melhor coisa que eu produzi até hoje, que fundou mesmo a questão da categoria trabalho na saúde mental. O livro se chamava Indivíduo, Trabalho e Sofrimento. ${ }^{189}$ Foi um livro que realmente implicou em um aprofundamento de Marx, tinha um psiquiatra no grupo, o Jackson Sampaio, que trouxe toda a discussão da clínica. O último texto do livro falava sobre saúde mental, o que é saúde mental. [...] Tínhamos uma definição de metodologia e tínhamos que encontrar um instrumento epidemiológico. E a escolha recaiu sobre o MMPI. [...] Porque o MMPI, ele é rigorosamente empírico, ele não tem teoria nenhuma por trás dele. Ele é construído na base de grupos de risco. [...] Por que qual é o outro instrumento? E eu teria que me ligar com a psicanálise, ou me ligar com o behaviorismo, ou me ligar com a fenomenologia, e eu queria me ligar com Trabalho, [...] com Saúde Mental do Trabalho. [...] Aí eu fui para a Inglaterra para aprender como é que mexe com essas coisas [dados]. [...] Na Inglaterra desenvolvi uma metodologia de análise, utilizando regressão logística. [No

189 CODO, Wanderley; SAMPAIO, José Jackson Coelho; HITOMI, Alberto Haruyoshi. Indivíduo, trabalho e sofrimento - uma abordagem interdisciplinar. Petrópolis: Vozes, 1992. 
retorno ao Brasil, publicou outro livro]. ${ }^{190}$ [...] Aí, pronto, o trabalho, o uso da metodologia se consolidou (CODO, 2014, entrevista).

- Edição temática da revista "Psicologia, Ciência e Profissão" (1988)

Em 1988, a revista Psicologia, Ciência e Profissão, publicação do Conselho Federal de Psicologia, apresentou edição intitulada "Como está a saúde mental do trabalhador?", na qual se discute a questão da saúde mental no Brasil enfatizando a análise do sistema de atendimento aos trabalhadores. Alguns dos artigos publicados nessa edição foram: "A política previdenciária oficial”, "Uma análise psicológica dos acidentes", "Por que os trabalhadores criaram o DIESAT", "Os vínculos entre condições de trabalho e saúde mental", "Saúde mental e trabalho: uma urgência prática", "Sobre a saúde mental do trabalhador em saúde mental".

Em seu Editorial, destacou-se como "o problema da saúde mental tem sido tratado como um verdadeiro tabu em nossa sociedade, a começar pelos poucos dados estatísticos oficiais disponíveis e pela enorme dificuldade que se tem para ter acesso aos mesmos" (Editorial..., 1988, p. 5). Apesar dessa situação, as informações sobre principais doenças incapacitantes que atingiam os trabalhadores relacionavam como as primeiras a hipertensão arterial e a neurose - mesmo se consideradas as falhas na produção desses dados, como: "a) o encaminhamento do doente depende do patrão; b) a maioria dos problemas de saúde com menos de 15 dias de "inativação" nem são encaminhados e registrados; c) nessas estatísticas, não estão incluídos os casos de subemprego, que representam de fato grande parcela dos trabalhadores".

O Editorial também problematizava a concepção de doença mental "veiculada nos meios de comunicação de massa, pelos técnicos e profissionais, geralmente psiquiatras de orientação mais conservadora", que a relacionam a fatores genéticos, "falhas" no desenvolvimento da personalidade, vida familiar pregressa, que constituiriam a gênese nos distúrbios psíquicos, sendo que apenas "recentemente [o texto é de 1988] começaram a surgir pesquisas e análises relacionando as próprias condições inadequadas de trabalho com o aparecimento dessas doenças". Apontaram-se também limitações do sistema de atendimento aos trabalhadores na área de saúde

190 CODO, Wanderley; SAMPAIO, José Jackson Coelho (org). Sofrimento Psíquico nas Organizações Saúde Mental \& Trabalho. Petrópolis: Vozes, 1995. 
mental, que cumpriria "a função de meramente excluir os não produtivos do sistema de produção, de modo a não causar prejuízos à empresa privada e poucos gastos ao Estado".

Por fim, o Editorial informava objetivar proporcionar "aos psicólogos uma compreensão mais clara dos problemas e [contribuir para a] construção de uma Psicologia mais comprometida com os interesses dos trabalhadores de nosso País", e levantava as seguintes questões:

[...] se as doenças mentais são as mais frequentes causas de aposentadoria por invalidez abaixo dos 40 anos e se neurose e hipertensão arterial são as duas doenças incapacitantes mais frequentes, com claros determinantes psicológicos, por que o psicólogo está praticamente ausente dessa importante área de atendimento da saúde? Como tem sido o processo de formação dos profissionais de Psicologia para atuarem na área de saúde mental? Temos atuado, mas comprometidos com quem? Que contribuição a categoria pode dar, visando ao planejamento e implantação de um sistema de saúde mental comprometido com o ponto de vista do trabalhador? (Editorial..., 1988, p. 5)

Outros importantes elementos contribuíram para o debate sobre as relações entre trabalho e saúde/doença mental no período.

\section{- Primeiros casos de LER}

De acordo com Seligmann-Silva et al. (2010b, p. 185-186), nas décadas de 80 e 90, além dos agravos já conhecidos, como como mortes e mutilações, intoxicações por vários produtos químicos, perdas auditivas, pneumopatias e dermatoses, os trabalhadores com LER/DORT "passaram a invadir os consultórios". Essas patologias acometiam trabalhadores cujas atividades laborais não exigiam altos gastos energéticos e sua etiologia não podia ser enquadrada nos fatores de risco tradicionais: físicos, químicos e biológicos. "Nesse contexto, ganhou força a discussão de que o trabalho e suas repercussões sobre a saúde dos trabalhadores deveriam ser analisados não somente no tocante às condições tradicionalmente abordadas, mas também aos seus aspectos organizacionais, ergonômicos e psicossociais" (SELIGMANN-SILVA et al.,2010b, p. 185).

- Debates em torno do reconhecimento do sofrimento, desgaste ou transtorno mental/psíquico como relacionado ao trabalho 
Em seu trabalho de análise das Conferências Nacionais de Saúde do Trabalhador (CNSTs), Silva (2011, p. 166) indica que, na I CNST, de 1986, questões referentes à saúde mental em sua relação com o trabalho não foram debatidas.

Contudo, os debates sobre a temática vinham sendo empreendidos, bem como sobre seu reconhecimento pela legislação como "doença profissional ou relacionada ao trabalho" na Constituição de 1988, como exemplifica artigo publicado por Wanderely Codo, a partir de uma apresentação em congresso (não informado no texto):

Trago a debate, neste fórum nacional, a proposta de que as Doenças Mentais sejam consideradas, para efeitos legais como Doença Profissional, enquadrando-a na lei n. 6.367, de 1976, ou seu equivalente a ser elaborada pela Constituinte, equiparando-a, portanto, como qualquer outra doença profissional ou do trabalho, a um acidente de trabalho, pois atualmente as doenças "psíquicas" não são atingidas por aquela legislação. A razão maior da existência desta mesa-redonda é a proximidade da Constituinte; nos interessa passar em revista a legislação sobre saúde/doença mental e contribuir ao debate (CODO, 1988, p. 21).

Para além das questões financeiras envolvidas nesse reconhecimento, "uma vantagem econômica [...] irrisória para o trabalhador quando acidentado", os elementos apontados por Codo (1988, p. 22) como centrais na questão seriam:

O possível enquadramento das doenças mentais como "doença profissional" arranca a discussão e o diagnóstico do foro privado e o remete a uma instância pública, necessariamente política.

1. Do ponto de vista do Trabalhador, deve fazer bem o reconhecimento de que sua loucura não é tão sua como parecia, é produto das suas condições objetivas de vida, ameaça de sua classe, portanto, pelo menos não haveria mais razões para escondê-la do mundo. Abre-se a possibilidade de reivindicações por um ambiente de trabalho psicologicamente sadio, arquitetam-se modos de aferição dos mesmos, enfim reduz-se a impotência perante o "stress" e a tensão no trabalho [...].

2. Do ponto de vista da empresa, haveria razões objetivas para uma maior preocupação com investimentos em mudanças na estrutura organizacional de trabalho, visando eliminar ou diminuir fatores de risco à saúde mental.

3. Do ponto de vista do Estado, mobilizar-se-ia, sob riscos de arcar com os prejuízos, para uma fiscalização dos ambientes de trabalho no que tange ao bem-estar psíquico, assim como investiria em pesquisas visando à detecção em caráter preventivo dos fatores de risco ou em modos alternativos de organização do trabalho nos casos em que o comprometimento mental já está detectado [...]

4. Do ponto de vista dos profissionais que fizeram da lide com a saúde mental sua profissão, seríamos convocados a emitir laudos, ou pelos tribunais, ou por representantes de trabalhadores, ou patronais. Veríamos necessariamente crescer as contribuições científicas que abordassem a loucura a partir das condições sociais concretas, nossas formulações se tornariam obrigatoriamente menos exotéricas. 
Por fim, reafirma:

Na outra face do infortúnio está o reconhecimento jurídico, portanto público, do caráter predatório do trabalho nestas relações de produção, e pelo avesso um instrumento importante de "conscientização" do trabalhador, no sentido de reapropriação do seu próprio corpo. Na medida em que expulsa da tragédia a ideologia da culpa individual, da incompetência. Quando a legislação de acidentes de trabalho consagra a responsabilidade do empregador, pode realizar o trânsito entre as representações individualistas e o caráter coletivo do trabalho, por isso da segurança no trabalho; uma visão coletiva da relação saúde-doença (CODO, 1988, p. 22).

\subsubsection{MORAL, MENTAL, PSÍQUICO: ANOS 90}

No polo Saúde Ocupacional-Medicina do Trabalho-Psicologia IndustrialOrganizacional, incrementam-se os estudos e práticas sobre estresse ocupacional e Qualidade de Vida no Trabalho.

Após a promulgação da Constituição de 1988 e da Lei Orgânica de Saúde de 1990, incorporaram-se unidades de referência em Saúde do Trabalhador às redes de saúde de diversos municípios brasileiros, posteriormente denominadas CERESTs. Em 1994, realizou-se a II Conferência Nacional de Saúde do Trabalhador, na qual aconteceram discussões específicas sobre as relações entre trabalho e saúde mental. Em 1999, por meio da Portaria $n^{\circ} 1.339$ (Ministério da Saúde) e do Decreto $n^{\circ} 3.048$, foram reconhecidos como relacionados ao trabalho vários agravos à saúde, chamados de Transtornos Mentais e do Comportamento Relacionados ao Trabalho. Em 2001, o Ministério da Saúde publicou um manual de procedimentos para os serviços de saúde, no qual, no capítulo 10, são discutidos os Transtornos Mentais e do Comportamento Relacionados ao Trabalho.

O campo de estudos da Saúde Mental e Trabalho observou grande disseminação de grupos de pesquisa e publicações e produções acadêmicas (como dissertações e teses) voltadas para a temática. Nessa produção, começou-se a observar grande diversidade de correntes teóricas, ${ }^{191}$ diversidade que repercute em divergências no que diz

\footnotetext{
191 Uma apresentação dessas correntes ou abordagens em Saúde Mental e Trabalho é realizada na
} seção 5.2.3.1.1. 
respeito à consideração da centralidade do trabalho como categoria fundante humana e ao papel por ele desempenhado do adoecimento mental.

Os anos 90, como já discutido, seriam marcados pelo contexto da chamada reestruturação produtiva, pela terciarização da economia e pela precarização e terceirização do trabalho, bem como pelos discursos de flexibilidade, formação contínua e competitividade.

Desde o final dos anos 80 , no contexto da reestruturação produtiva, ocorreram mudanças na organização do trabalho que levariam à flexibilização das concepções de tarefas e postos de trabalho (LACAZ, 2000); essa flexibilização representaria a necessidade de o trabalhador desempenhar diferentes tarefas, ser maleável em termos de horários e de abertura a mudanças, inclusive geográficas), no que Jacques (2013) chamou de "captação subjetiva" do trabalhador.

Lacaz (2000) destaca que o aprofundamento da automação e o avanço de novas tecnologias de informação e comunicação introduziriam uma sofisticação e dissimulação nos mecanismos de controle dos trabalhadores, mascarados sob as ideias de qualidade e de competitividade. O cenário de reestruturação produtiva também introduziria crescentes pressões por qualificação, cuja responsabilidade passaria a ser atribuída aos trabalhadores; pressões que, como Jacques (2013) mostra, estariam associadas ao conceito de empregabilidade, responsabilizando os trabalhadores por sua manutenção no mercado de trabalho. Nos termos da autora, "retoma-se a questão da culpabilização, agora pela expulsão do mercado, reforçada pelo contexto social, o que corrobora para a ocorrência de quadros depressivos associados às situações de subemprego e desemprego" (JACQUES, 2013, p. 244).

As empresas passariam a incorporar exigências consideradas contraditórias no que tange à saúde, como "maior intensidade do ritmo, maior controle e conhecimento do trabalho; polivalência e criatividade; maior liberdade de ação, reconhecimento maior do trabalho e critérios rígidos de avaliação" (LACAZ, 2000, p. 156). Ao mesmo tempo em que se exigiria um trabalhador mais participativo, mais escolarizado e mais polivalente, seriam aumentadas as responsabilidades, a carga de trabalho, e diminuída 
a autonomia. Essas relações e contradições se expressariam em quadros variados de queixas, com prevalência de mal-estar difuso, dificuldades para dormir e cansaço que não melhora com repouso. No âmbito da saúde mental, Jacques (2013) identifica referências de autores à "neurose da excelência" e à "síndrome do esgotamento profissional" como quadros sintomáticos típicos desse contexto. Já Lacaz (2000, p. 157) aponta que

\footnotetext{
Proliferam então as doenças cardiocirculatórias, gastrocólicas, psicossomáticas, os cânceres, a morbidade musculoesquelética expressa nas lesões por esforços repetitivos (LERs), às quais somam-se o desgaste mental e físico patológicos e mesmo as mortes por excesso de trabalho, além das doenças psicoafetivas e neurológicas ligadas ao estresse.
}

A década de 80 e, mais especialmente, a de 90, marcaram-se também pela alta incidência dos casos de LER: "nas décadas de 1980 e 1990 [...] os trabalhadores com afeç̧ões musculoesqueléticas, as LER/DORT passaram a invadir os consultórios" (SELIGMANN-SILVA et al. 2010, p. 185). Nos anos 90, segundo a Organização Mundial de Saúde (OMS), cerca de um em cada cem trabalhadores, apenas na região Sudeste brasileira, era portador de LER. Reconhecidas no Brasil pela Previdência Social desde 1987, as LER foram, nos anos 90 , as doenças relacionadas ao trabalho mais prevalentes dentre as registradas, segundo estatísticas do INSS referentes à população trabalhadora segurada (ALVES, 2004). Nesses quadros de adoecimento, a "etiologia não podia ser enquadrada nos fatores de risco tradicionais: físicos, químicos e biológicos", devendo ser considerados "os aspectos organizacionais, ergonômicos e psicossociais" do trabalho (SELIGMANN-SILVA et al., 2010, p. 186). Para Maeno (2013), a visibilidade que as LER tiveram teria contribuído para que o conceito da multicausalidade para manifestações complexas de adoecimento ganhasse força. Os casos de LER também teriam chamado atenção dos profissionais de pesquisa e assistência pelas repercussões na saúde mental dos trabalhadores acometidos, em razão do sofrimento mental, da dimensão da dor e das dificuldades em relação à (in) visibilidade que cercava esse grupo de doenças (SILVA, 2011, p. 167).

Crescia o número de pessoas que apresentavam transtornos psíquicos, chamando atenção de diversos setores ligados à saúde, ao judiciário, ao meio sindical, ao meio acadêmico, entre outros, e "a crescente demanda de pedidos de afastamento por problemas mentais dirigidos ao INSS também provocou a necessidade de se questionar 
os elementos do trabalho que poderiam estar na origem desses pedidos" (DEUSDEDIT JUNIOR, 2014, p. 19).

Deusdedit Junior (2014) também chama atenção para o crescimento que se observa, a partir dos anos 90, dos estudos que focavam os impactos deletérios da organização do trabalho na saúde dos trabalhadores; também cresceria o número de estudos em saúde mental e trabalho voltados para a discussão de bases teóricas-epistemológicas que os fundamentam, como categorias nosológicas e fundamentos teóricos que sustentam as investigações em saúde mental e trabalho.

Araújo (2011, p. 326) aponta que, na quase totalidade dessa produção, observa-se a discussão da importância de trazer à cena "a dimensão da vida no trabalho", em contraposição a modelos teóricos que não considerariam o trabalho na análise da subjetividade e nos processos relativos à saúde mental - aspecto que aglutinaria esses estudos em um mesmo "ponto de partida". Contudo, observam-se também divergências, sobretudo no que se refere ao papel desempenhado pelo trabalho no adoecimento psíquico, entendido por alguns autores como determinante ("determinados tipos ou características do trabalho seriam estruturadores de adoecimento psíquico"), por outros como desencadeante ("porta de entrada" para o adoecimento). 


\subsection{OS TRANSTORNOS MENTAIS E DO COMPORTAMENTO RELACIONADOS AO TRABALHO NA ATUALIDADE}

Nesta seção serão apresentados diversos aspectos que envolvem os Transtornos Mentais e do Comportamento Relacionados ao Trabalho - seu reconhecimento legal, como funciona a atenção à saúde para esses transtornos, relação CEREST $X$ atenção básica, relação com perícia médica, diagnóstico, nexo, entre outros. A apresentação tem como ponto de partida as categorias analíticas extraídas do material das entrevistas realizadas no trabalho de campo. Na primeira parte, serão apresentadas de forma categorizada as percepções dos entrevistados sobre o cenário atual da Saúde do Trabalhador, em especial dos Transtornos Mentais e do Comportamento Relacionados ao Trabalho. Na segunda parte, enfatizam-se e discutem-se algumas particularidades e desafios apresentados pelos entrevistados.

\subsubsection{DADOS DAS ENTREVISTAS}

Após a identificação das principais unidades básicas de análise (conceitos) do conteúdo das entrevistas, foram construídas categorias de análise ("famílias"), constituídas por agrupamentos de códigos que direcionam para o entendimento de uma mesma questão. As "famílias" construídas nessa análise e que balizarão esta seção estão relacionadas a seguir.

- Família 1: como o entrevistado caracteriza (ou qualifica) a atenção básica na relação com a Saúde do Trabalhador e com os Transtornos Mentais e do Comportamento Relacionados ao Trabalho TMCs.

- Família 2: atores que o entrevistado aponta como importantes no campo da Saúde do Trabalhador, sobretudo na discussão dos TMCs.

- Família 3: como o entrevistado caracteriza o campo da Saúde do Trabalhador em sua relação com os TMCs.

- Família 4: qual é a forma (ou o que é requerido), segundo o entrevistado, para a caracterização de uma doença "mental"' relacionada ao trabalho (para estabelecer o nexo).

- Família 5: como o entrevistado identifica as relações saúde/trabalho, e a percepção sobre a categoria trabalho presente no campo.

- Família 6: papel ou importância que o entrevistado relaciona aos Centros de Referência em Saúde do Trabalhador (CERESTs). 
- Família 7: conflitos que o entrevistado percebe como existentes no campo da Saúde do Trabalhador, sobretudo quanto aos TMCs.

- Família 8: desafios percebidos pelos entrevistados do campo da Saúde do Trabalhador, sobretudo quanto aos TMCs.

- Família 9: fatores, segundo os entrevistados, que determinam/promovem o "adoecimento" do trabalhador, sobretudo quanto aos TMCs.

- Família 10: dificuldades que o entrevistado aponta como limitadores para a atuação no campo da Saúde do Trabalhador, sobretudo quanto aos TMCs.

- Família 11: de onde vem o encaminhamento de trabalhadores adoecidos (sobretudo com TMCs).

- Família 12: motivo pelo qual o entrevistado se interessou pelo campo da Saúde do Trabalhador.

- Família 13: opiniões dos entrevistados quanto às listas B (Decreto 3048/1999) e C (Decreto 6957/2009).

- Família 14: opiniões dos entrevistados sobre o manual "Doenças relacionadas ao trabalho: Manual de procedimentos para os serviços de saúde".

- Família 15: opiniões dos entrevistados sobre o Nexo Técnico Epidemiológico Previdenciário (NTEP).

- Família 16: categorias profissionais citadas pelos entrevistados com maior incidência de TMCs.

- Família 17: opiniões dos entrevistados sobre a perícia do INSS.

- Família 18: opiniões dos entrevistados sobre o protocolo clínico para os TMCs.

- Família 19: opiniões dos entrevistados sobre o papel, a função, a importância da Psicologia no campo da Saúde do Trabalhador.

- Família 20: opinião dos entrevistados sobre a simulação de doença ligada ao trabalho, sobretudo nos TMCs.

- Família 21: divergências (ou sugestões de reflexão) citadas pelos entrevistados sobre terminologias usadas no campo da Saúde do Trabalhador.

- Família 22: em que momento o campo das relações entre saúde mental e trabalho e os TMCs ganhariam visibilidade, segundo o entrevistado.

- Família 23: pontos positivos/avanços do campo da Saúde do Trabalhador identificados pelo entrevistado.

As "famílias" de dados (conjuntos de temas ou códigos), e seus respectivos códigos (conjuntos de citações), bem como gráficos que mostram as incidências de respostas por código, encontram-se no Apêndice D - "Livro de Códigos e Gráficos". A seguir, serão apresentados e discutidos os principais temas ("códigos") obtidos na análise das entrevistas, bem como suas inter-relações, representadas no diagrama a seguir (Figura 1). 
Figura 1 - Diagrama dos principais temas das entrevistas e suas inter-relações

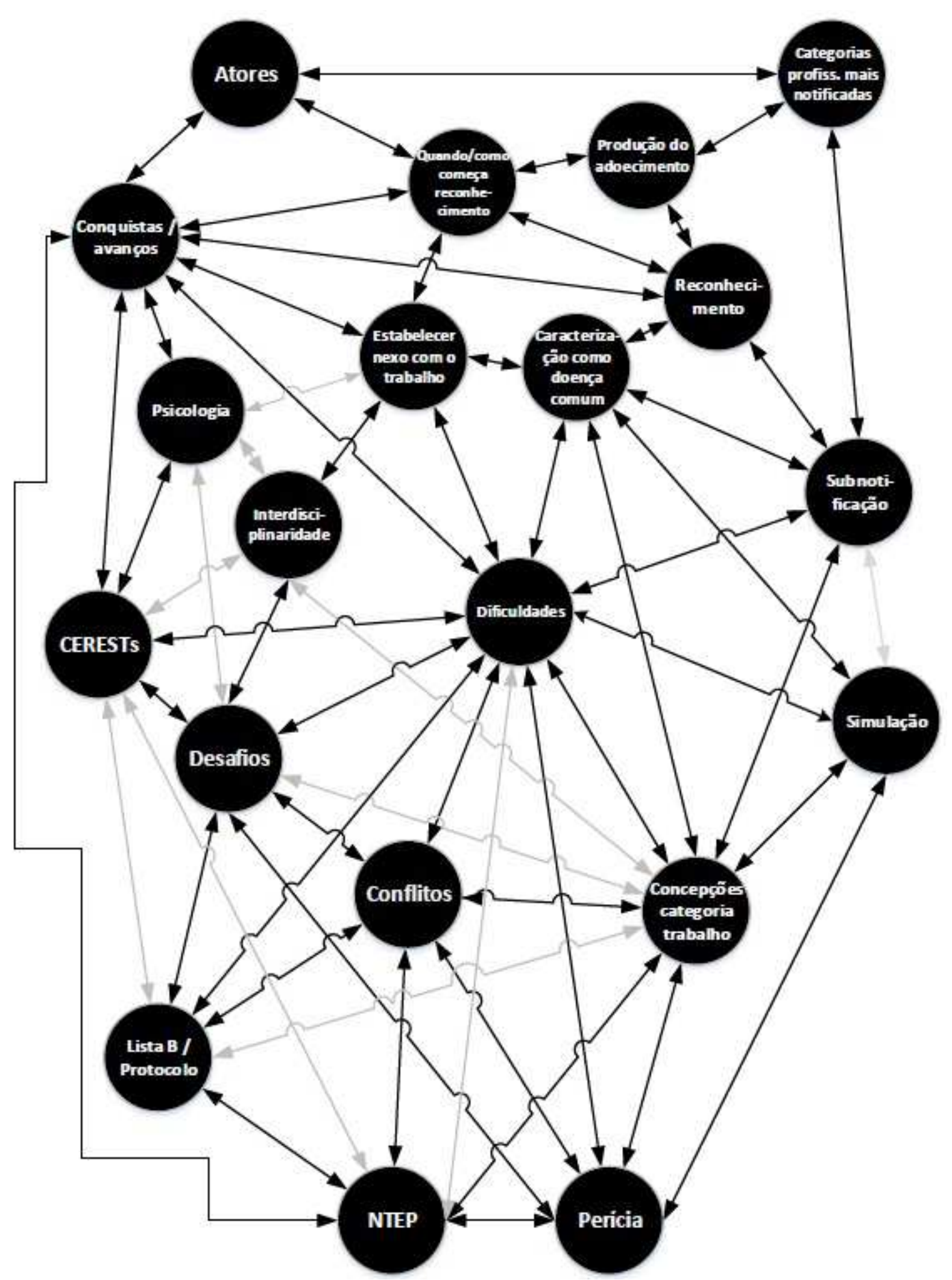

Fonte: produzido pela autora (dados da pesquisa), 2015. 


\subsubsection{Em que momento / condições as discussões sobre as relações entre saúde} mental e trabalho ganhariam visibilidade

Nas entrevistas realizadas para a tese, os entrevistados foram questionados a respeito de em que momento, ou em quais condições, as discussões sobre as relações entre saúde mental e trabalho teriam conquistado visibilidade.

A maioria dos entrevistados destacou a produção acadêmica e as pesquisas (da academia, dos sindicatos, dos serviços de saúde) que, como já discutido na seção 6.2, começam nos anos 80 e ganham impulso nos anos 90, como em algumas das falas abaixo reproduzidas:

Então você tinha uma discussão, tanto acadêmica com pessoas que reconheciam e [...] que estavam fazendo uma reflexão, um investimento intelectual muito grande em discutir como o trabalho gerava esse sofrimento mental, o transtorno mental (SILVEIRA, 2013, entrevista).

Tem alguns trabalhos na década de 80 que eu acho que são pioneiros [...]. Eu acho que é na década de 80 que devem ter começado, sistematicamente, pessoas a trabalharem essa relação saúde mental e trabalho (MAENO, 2014, entrevista).

Nós temos hoje uma produção teórica que nos permite entender melhor a questão de que os problemas mentais e de comportamento podem, sim, ter a ver com o constituinte trabalho (JACQUES, 2014, entrevista).

Ela [Edith Seligmann-Silva] solta um livro com os estudos dela e acaba também fundando a área aqui no Brasil. E os estudos com estresse já existiam aqui. (CODO, 2014, entrevista).

Muitos dos entrevistados também destacaram, como importante elemento para incitar a discussão sobre as relações entre saúde mental e trabalho, o surgimento das Lesões por Esforço Repetitivo (LER):

[...] essa discussão da saúde mental começa a emergir com mais força quando surge a epidemia de LER, os casos de transtornos osteomusculares relacionados ao trabalho (SILVEIRA, 2013, entrevista).

A gente estava naquela coisa de mostrar como as LER imprimiam os sofrimentos psíquicos, então a sintomatologia psíquica, de cansaço, depressão, irritabilidade, tristeza, tudo isso fazia parte do quadro das lesões por esforços repetitivos das LER. Quem tem LER tem sintomas psíquicos também (JARDIM, 2014, entrevista).

As lesões por esforços repetitivos deram esta luz [...] para a gente (MAENO, 2014, entrevista).

Isso que nós estamos chamando de sofrimento ou adoecimento mental, [...] eu percebo essa importância a partir do advento da LER. A gente encontra uma certa coincidência temporal.... Os estudiosos apontam isso e a gente observa isso também na prática, no cotidiano, que o advento da LER coincide com esse advento da saúde mental, ou do sofrimento mental, do adoecimento mental (SILVA, 2013, entrevista). 
A verdadeira "epidemia" [de LER] fez com que se reconsiderasse que apenas fatores individuais (ou mesmo ergonômicos) não explicavam suficientemente a questão. Foi um sinal de alerta, um ponto de inflexão na discussão (DIAS, 2013, entrevista).

A repercussão da obra de Christophe Dejours no Brasil também é mencionada por alguns entrevistados como fomentadora da discussão sobre as relações entre saúde mental e trabalho:

\begin{abstract}
Eu acho que teve um marco muito importante, pelo menos para a gente aqui em Minas, que foi quando 'A Loucura do Trabalho' foi traduzida para o português $e$ causou um grande impacto no métier, as pessoas passaram a estudar, o Dejours se transformou em uma personalidade, eu me lembro que no início da década de 90 ele veio a Belo Horizonte, nós organizamos um grande evento, vários colegas, inclusive, da área de Saúde Mental participaram, colegas que eram psiquiatras, e ai se começou a fermentar mais, a se discutir mais (SILVEIRA, 2013, entrevista).

Não havia na literatura uma discussão de psicopatologia. Quem começa a fazer isso é o Dejours na França. Ele lança um livro que é meio seminal, que se chama 'Psychopathologie du Travail'. E ele fala dentro do livro que não existe psicopatologia do trabalho. Não existe loucura no trabalho. Que a saúde mental, e a doença mental, é produzida pela infância e nunca pelo trabalho. Porque ele é um psicanalista, não é? [...] E o livro dele é traduzido muito rapidamente aqui para o Brasil (CODO, 2014, entrevista).
\end{abstract}

Sobre saúde mental e trabalho, no Brasil, foi [Christophe] Dejours quem deu força e visibilidade à discussão (SILVA, 2014, entrevista).

Outro autor mencionado por alguns entrevistados como relevante para instigar o debate sobre as relações entre saúde mental e trabalho é Louis Le Guillant:

Eu acho que o Le Guillant [...] é um marco importante. [...] A gente tem uma história dos autores franceses de começarem a entender que a saúde mental podia sim ter a ver com o trabalho. [...] Acho que [Le Guillant] é um marco importante, para dizer "Olha aqui, tem alguma coisa a ver" (JACQUES, 2014, entrevista).

O fundamental foi o estudo do Le Guillant sobre a neurose das telefonistas. Le Guillant era um feroz crítico do sistema capitalista e um pesquisador brilhante (CODO, 2014, entrevista).

O movimento da reforma psiquiátrica ou luta antimanicomial, concomitante, no contexto da luta pela redemocratização do país ao da reforma sanitária e da saúde do trabalhador, teria contribuído para a discussão das relações entre saúde mental e trabalho não em sua especificidade, mas na perspectiva de colocar "na agenda política" e em "outro cenário" a discussão sobre saúde/doença mental:

E é interessante que, quando a gente estava lutando pela redemocratização do Brasil, ao mesmo tempo que havia uma luta pela saúde, havia uma luta também pelo fim dos manicômios no Brasil (SILVA, 2014, entrevista).

É lógico que havia todo um empenho pela humanização da atenção à saúde do portador [de sofrimento mental], da pessoa com transtorno mental, mas eu não me lembro deles [movimento antimanicomial] terem feito a discussão política da 
relação entre o adoecimento e as condições de trabalho. [...] Mas é possivel, porque eles colocaram na agenda política o problema da doença mental, do transtorno mental. Porque eles conseguiram colocar na agenda, conseguiram dar visibilidade e eu acho que isso, digamos assim, abriu a estrada para outras demandas surgirem. Dá visibilidade e permite até que ela [saúde mental] seja discutida em outro cenário, que é o cenário do mundo do trabalho. Eu acho que sob essa dimensão, sim. Não que a questão da saúde mental no trabalho fosse item privilegiado da agenda, mas ao colocar a doença mental no cenário permite que ela seja identificada em outro cenário, que é o cenário do trabalho... (SILVEIRA, 2013, entrevista).

Outros fundamentais elementos apontados pelos entrevistados tanto para a discussão das relações entre saúde mental e trabalho, como para a constituição do campo da Saúde do Trabalhador, teriam sido o cenário de redemocratização do país, o movimento pela reforma sanitária, a realização da I Conferência Nacional de Saúde do Trabalhador, culminando na Constituição de 1988 e na criação do SUS (1990):

E é interessante que, quando a gente estava lutando pela redemocratização do Brasil, ao mesmo tempo que havia uma luta pela saúde [...] Luta contra a ditadura e pela redemocratização (SILVA, 2014, entrevista).

Acho que outro movimento importante foi a l Conferência de Saúde do Trabalhador, que dentro de toda aquela lógica que a gente estava, de querer reformular, de criar o SUS etc. (JACQUES, 2014, entrevista).

Eu acho que a Constituição [1988] e a Lei Orgânica da Saúde foram movimentos importantes (JACQUES, 2014, entrevista).

Por fim, Codo chama atenção para as discussões sobre estresse (que vinham desde os anos 70) como relevantes para instigar a discussão das relações entre saúde mental e trabalho:

[a] questão do trabalho como agente estressante. Isso teve uma evolução importante, e você pode atribuir à categoria estresse, a preocupação da saúde mental no trabalho (CODO, 2014, entrevista).

\subsubsection{Atores importantes na discussão / reconhecimento dos Transtornos Mentais e do Comportamento Relacionados ao Trabalho}

Nas entrevistas realizadas para a tese, os entrevistados foram questionados a respeito de quais seriam os atores importantes no campo da saúde do trabalhador, sobretudo na discussão dos transtornos mentais e do comportamento relacionados ao trabalho.

A participação mais destacada nas respostas dos entrevistados foi a atuação dos movimentos sindicais. Destacaram-se os sindicatos dos bancários (citados por cinco entrevistados) e de metalúrgicos e professores (citados por dois), como em algumas das falas reproduzidas a seguir: 
Naquele tempo [década de 80] existiam vários diretores de sindicatos diferentes, sensiveis às questões do trabalho e na saúde, e também alguns já percebendo a questão da saúde mental. E alguns percebiam muito. Até demandavam coisas (SELIGMANN-SILVA, 2014, entrevista).

A gente começou a sentir, [...] eu, [...] o pessoal do DIESAT, que era interessante discutir com os trabalhadores isso, porque não tinha disciplina de psicopatologia do trabalho na psiquiatria, nem na psicologia, na época não existia. Então a gente precisa[va] é ouvi-los. Aprender com eles. [...] Geralmente o pessoal do sindicato estava dentro do grupo [de pesquisa da universidade], também, para eles inclusive nos ajudarem a formular os roteiros de entrevistas (SELIGMANNSILVA, 2014, entrevista).

Eu acho que um ator importante nesse cenário foi o movimento sindical. Particularmente algumas categorias mais organizadas, que passaram a ter uma atuação mais sistemática no campo sindical, mas discutindo a saúde no trabalho e que passam a denunciar sistematicamente o adoecimento mental dos trabalhadores (SILVEIRA, 2013, entrevista).

[...] particularmente os bancários, porque talvez seja a categoria mais organizada e de melhor nível de escolarização que sofreu maior impacto das transformações dos processos cognitivos (DIAS, 2013, entrevista).

E para chegar nesse movimento de que os transtornos mentais virassem uma situação de notificação, nós tínhamos também já muita discussão dos próprios sindicatos, pressionando, nós tínhamos os casos já dos bancários, dos químicos, discutindo a questão da saúde mental. [...] Então alguns grupos de trabalhadores, algumas categorias iam representando bastante [...], essas questões. Apresentando [...] para a discussão, essas questões dos transtornos mentais (GARBIN, 2014, entrevista).

O sindicato, ele é um espaço interessante, e as pessoas vão realmente buscar solução para os seus problemas. E não é só problema salarial. [...] Ele está denunciando a natureza do trabalho, a gente que tem que ter a capacidade de percepção que está por detrás daquela alteração, emocional, mental, física... (SILVA, 2014, entrevista).

O segundo personagem mais citado nas respostas dos entrevistados foi a academia (universidades), por meio da promoção de pesquisas e publicações enfocando as relações entre trabalho e saúde mental:

[...] eu acho que foi tendo um consenso, você passa a ter uma literatura inclusive nacional, uma produção nacional, acho que essa produção acadêmica brasileira foi muito importante e aí você passa a ter colegas das universidades que vão produzir sobre isso, vão documentar, vão registrar (SILVEIRA, 2013, entrevista).

Você tem as universidades que vêm atuando [...]. A faculdade e as universidades, quando são demandadas para pesquisa (SILVA, 2014, entrevista).

Eu lembro que no CEREST, nós fazíamos uma apresentação de teses, de dissertações... Então esse tema também acabava aparecendo. Já sendo pesquisado na academia (GARBIN, 2014, entrevista).

Também são citadas as atuações do Ministério do Trabalho (sobretudo as Delegacias Regionais do Trabalho - DRTs), do Ministério da Saúde, do Ministério Público e Justiça do Trabalho, e do Ministério da Previdência Social. 
Os serviços de referência em saúde do trabalhador, como CERESTs ou ambulatórios universitários também teriam desempenhado importante papel na discussão das relações entre trabalho e saúde mental:

Os colegas de serviço, muitos não tinham nenhuma formação específica em saúde mental, mas começam a contar em seus registros gerenciais, nos congressos, nos encontros do próprio sistema de saúde, como era importante, como no dia a dia você lidava e isso se apresentava no serviço o tempo inteiro, começa a denunciar o fato da Previdência Social não reconhecer os casos (SILVEIRA, 2013, entrevista).

\subsubsection{Categorias profissionais com maior incidência de Transtornos Mentais e do Comportamento Relacionados ao Trabalho}

Considerando que os Transtornos Mentais e do Comportamento Relacionados ao Trabalho são a terceira maior causa de concessão de benefícios acidentários (relacionados ao trabalho), se consideradas apenas as doenças relacionadas ao trabalho (como mostrado na Tabela 2), indagou-se aos entrevistados quais seriam as categorias profissionais mais afetadas, e sua avaliação sobre se estaria sendo observado um aumento no "adoecimento" relacionado ao trabalho, ou em seu reconhecimento.

As categorias profissionais citadas pelos entrevistados como de maior incidência dos Transtornos Mentais e do Comportamento Relacionados ao Trabalho foram: atendentes de telemarketing/telefonistas e bancários (4 menções); motoristas e cobradores de ônibus (3 menções); professores, trabalhadores de serviços de vigilância, metalúrgicos (2 menções); caixas de supermercado, trabalhadores do agronegócio, trabalhadores de serviços gerais, metroviários, servidores do Poder Judiciário, médicos/profissionais da área de saúde (1 menção). ${ }^{192}$

192 O Gráfico 21 (Apêndice D) apresenta esse perfil de categorias profissionais com maior incidência de Transtornos Mentais e do Comportamento Relacionados ao Trabalho citadas pelos entrevistados. Já o Gráfico 5 (Apêndice C) apresenta os percentuais das principais profissões, por CBO, com Transtornos Mentais e do Comportamento Relacionados ao Trabalho notificados no Brasil, de 2007 a 2013. 
6.3.1.4 Aumento do reconhecimento e do "adoecimento" em Transtornos Mentais e do Comportamento Relacionados ao Trabalho

$\mathrm{Na}$ avaliação da maioria dos entrevistados, estaria ocorrendo crescimento tanto no reconhecimento das relações entre saúde mental e trabalho, sobretudo após a implantação do NTEP (como será apresentado na seção 6.3.1.19), bem como, também, na produção do "adoecimento" mental/psíquico relacionado ao trabalho:

\begin{abstract}
Nós temos um problema muito grave que é de aumento do número de doenças psíquicas. [...] acho que vêm aumentando os transtornos psíquicos relacionados ao trabalho em todas as categorias profissionais; inclusive naquelas categorias que normalmente se destacaram pelo grande número de acidentes e outras doenças físicas, os transtornos psíquicos vêm aumentando (MAENO, 2014, entrevista).

Eu acho que nós temos um boom de produção [do adoecimento] também (CORRÊA FILHO, 2014, entrevista).

Desde 2009 eu estou na assistência novamente. E eu fiquei muito surpreendida com o que eu estou chamando de intensificação do adoecimento. Eu acho que os trabalhadores estão mais adoecidos, adoecendo mais precocemente. [...] 0 mundo do trabalho está adoecendo muito (SILVA, 2013, entrevista).

Eu acho que [...] tem um aumento do adoecimento mental [..., por exemplo, eu que estou no serviço público, eu percebo claramente o número de pessoas que estão adoecendo, a questão do absenteísmo cada vez maior e por questões ligadas ao transtorno mental (GREGGIO, 2014, entrevista).

Você tem, nas doenças mentais, crescimento fantástico (SILVA, 2014, entrevista).

Eu acho que a gente teve a reformulação do mundo do trabalho e [...] ela trouxe uma criação de condições para que as pessoas adoecessem (JACQUES, 2014, entrevista).
\end{abstract}

\title{
6.3.1.5 Elementos determinantes / promotores dos Transtornos Mentais e do Comportamento Relacionados ao Trabalho
}

Indagou-se então aos entrevistados quais seriam os elementos determinantes/promotores desse adoecimento, sendo mencionados: condições e organização do trabalho (12 menções); cobrança ou pressão no ambiente de trabalho (10 menções); violência vivida pelo trabalhador, no trabalho ou fora dele (5 menções); reestruturação produtiva, perda do significado do trabalho, problemas ligados à mobilidade urbana (4 menções); desemprego, articulação entre história de vida e condições de trabalho, introdução de novas tecnologias (3 menções); precarização do trabalho, categoria econômica da produção (2 menções); necessidade de esconder a doença (1 menção). 
O elemento mais citado nas respostas dos entrevistados (citado por quase todos) foi o papel desempenhado pela organização do trabalho.

A própria organização do trabalho leva para o afeto e para a cognição a demanda do trabalho (CODO, 2014, entrevista).

Eu acho que essa coisa da organização do trabalho, ela é fundamental e eu diria que ela é a variável mais importante (SILVEIRA, 2013, entrevista).

Onde eu vou, as pessoas falam dos transtornos psíquicos e acho que é muito por conta da organização do trabalho, da mudança do processo de trabalho, da gestão, do sistema de gestão que vem impondo ritmos [mais acelerados] aos trabalhadores [...] (MAENO, 2014, entrevista).

Questão de organização do trabalho (CODO, 2014, entrevista).

Os primeiros textos que aparecem sobre saúde, ligados ao trabalho, já dizem assim: "Olha, tem a ver com a organização do trabalho..." (JACQUES, 2014, entrevista).

Acho que não é o trabalho [que promove o adoecimento]. Acho que poderíamos pensar em relações de trabalho (BRANT, 2014, entrevista).

Essa relação de trabalho, que é uma relação de trabalho consumista, nada tem valor. O ser humano não tem valor (SILVA, 2013, entrevista).

As cobranças e pressões no ambiente de trabalho (relacionadas à organização do

trabalho) foram mencionadas, também, pela maioria dos entrevistados:

Tem uma gestão de pessoas muito cruel, muito exigente, que estabelece metas irreais para as pessoas, que exige um nível de escolarização que é crescente, as pessoas são muito assediadas moralmente no trabalho, principalmente quando elas têm baixo nível de escolaridade, são mais vulneráveis (SILVEIRA, 2013, entrevista).

Se esse chefe pode subir em cima da cabeça de 3 ou 4 e buzinar o dia inteiro em cima deles, [...] 2 ou 3 pessoas vão adoecer rapidamente, pela intensidade da pressão (CORRÊA FILHO, 2014, entrevista).

Eu prefiro falar da administração do trabalho, da maneira como o trabalho é comandado, controlado. Para ficar mais nítida a questão do poder. Porque se você fala só organização, a questão do poder, de quem manda, de quem decide, de quem impõe determinadas formas adoecedoras de trabalhar ou mantém uma comunicação que é em si adoecedora, as formas de impor o trabalho, as formas verbais ou mesmo as ordens, ou a impossibilidade colocada para o trabalhador de responder, de contestar, de indagar... [...] As metas absurdas, o que se torna impossivel de ser discutido sem canal de comunicação. Que é umazzl das coisas que está adoecendo mais hoje em dia, é o que eu e outros autores chamamos de gerenciamento adoecedor, gerenciamento perverso (SELIGMANN-SILVA, 2014, entrevista).

As pressões por metas, pressões de toda ordem... (SILVA, 2014, entrevista).

Noção de competência, um sujeito competente como aquele que é capaz de oferecer resultados. Ou seja, uma grande apologia aos resultados, você é competente pelos resultados que você oferece (BRANT, 2014, entrevista).

No trabalho há pressão. Sim, mas a pressão, de certa forma, é importante para a vida. Isso é falado nos cursos empresariais. Sem pressão o homem não vive, afinal foi com a pressão que nós chegamos até onde nós chegamos. Então pressão, estresse, aquela coisa de você ter um pouco de medo, você é impulsionado para seguir para frente (MAENO, 2014, entrevista). 
A pressão por produtividade, por atingimento de metas, as exigências de um processo constante de aprendizado, de aperfeiçoamento, isso é uma pressão muito grande sobre o trabalhador, essa cobrança... [...] Outro dia um trabalhador me falou assim "eu faço tudo, mas parece que tudo é insuficiente. Nunca eu consigo chegar lá. Nunca a empresa está satisfeita, nunca meu chefe está satisfeito, eu faço curso, eu procuro me atualizar, mas nunca chego lá, nunca é satisfatório" (SILVEIRA, 2013, entrevista).

A qualidade de vida no trabalho piorou muito. Então uma coisa é ter qualidade de vida baseada no acesso ao consumo, que eu acho que é pré-discutível. Outra coisa é se a sua qualidade de vida para manter esse padrão se tornou objeto de uma pressão intensa pela produtividade, ao ponto de você cada dia voltar para casa mais cansado e destruído do que antes (CORRÊA FILHO, 2014, entrevista).

Excesso da competitividade entre os trabalhadores (DIAS, 2013, entrevista).

Esse traço desse trabalhador que poderia estar contribuindo para o adoecimento, ele foi muitas vezes aproveitado pela empresa para que ele realmente trabalhasse mais, para que fosse mais comprometido, até o limite. $E$ ai ele ultrapassa esse limite sem perceber (GREGGIO, 2014, entrevista).

\section{Outro elemento elencado pelos entrevistados como contribuinte para o} "adoecimento" mental/psíquico relacionado ao trabalho seria o contexto de violência vivido pelo trabalhador, no trabalho ou fora dele.

[...] a violência. Nós tínhamos [no caso de bancários e vigilantes] também o problema de assaltos a bancos (SILVA, 2014, entrevista).

[Há] a questão da violência em si como causadora do transtorno pós-traumático, entre outros, e ela não é tratada da forma que deveria (GREGGIO, 2014, entrevista).

A maior parte dos nossos trabalhadores [atendidos no Serviço Especializado em Saúde do Trabalhador do Hospital das Clínicas da UFMG] ganha dois salários mínimos nesses serviços, então eles vivem numa situação de penúria econômica muito grande, a maioria mora em locais que são muito violentos. Uma das coisas que tem chamado muito a atenção [...] são os históricos de vitimização [dos trabalhadores atendidos] por violência na comunidade onde moram (SILVEIRA, 2013, entrevista).

Trabalhadores estão mais adoecidos, estão mais graves, estão mais infelizes, mais insatisfeitos, não à toa também, o mundo está muito violento (SILVA, 2013, entrevista).

Estamos vivendo uma crise civilizatória: violência, falta de solidariedade e cooperação, precarização do trabalho e das relações, crises econômicas, miséria... (DIAS, 2013, entrevista).

Também é citado como elemento contribuinte para o "adoecimento" mental/psíquico relacionado ao trabalho, pelos entrevistados, o processo de reestruturação produtiva:

Eu acho que nós temos um boom de produção [do adoecimento psíquico] também. Mudou, a reestruturação produtiva entrou pesado (CORRÊA FILHO, 2014, entrevista).

Agravamento do adoecimento, do sofrimento mental em decorrência das grandes transformações [reestruturação produtiva] do mundo do trabalho (DIAS, 2013, entrevista).

Reestruturação produtiva, já que os bancos tinham consolidado a implantação das tecnologias e de informatização do processo (SILVA, 2014, entrevista). 


\section{Alguns entrevistados também estabelecem uma relação entre o "adoecimento" mental/psíquico relacionado ao trabalho e a "perda" ou "falta" de sentido do trabalho:}

Castração da possibilidade de se realizar. Uma castração do seu desejo. As pessoas entram no trabalho e elas estão infelizes (SILVA, 2013, entrevista).

O adoecimento está muito vinculado a essa perda do desejo, perda do significado. Quando o trabalho deixa de ter sentido, e eu vou naquele trabalho [apenas] para garantir a minha sobrevivência material, eu estou a um passo desse sofrimento (SILVA, 2013, entrevista).

[...] um divórcio entre o fazer e o produto, a fragmentação (MAENO, 2014, entrevista).

A natureza do trabalho bancário, onde você não consegue ver o produto final, aquilo que você produz, te dá uma sensação de vazio, chega no final da tarde: "o que eu fiz hoje?" Você não consegue ver o final do teu trabalho, parece que ele nunca acaba! E aí você leva ele para casa ainda mentalmente (SILVA, 2014, entrevista).

O bancário não consegue se reconhecer no trabalho [...]. Ele não consegue construir a identidade dele (CODO, 2014, entrevista).

Outro fator apontado são os problemas ligados à mobilidade urbana - transporte urbano precário/de má qualidade, trânsito intenso em horários de pico/engarrafamentos, que fazem com que o trabalhador leve até mesmo horas para chegar ou sair do trabalho:

Nos grandes centros urbanos a qualidade de vida das pessoas é muito ruim. Então, por exemplo, na região metropolitana, que é a origem da maior parte dos pacientes [atendidos no Serviço Especializado em Saúde do Trabalhador do Hospital das Clínicas da UFMG], a condição de mobilidade urbana, ela é muito ruim. Então, em média, os nossos pacientes relatam gastar em torno de duas a três horas só para ir ou voltar do trabalho. Pode parecer uma trivialidade, mas isso, em termos de perda da convivência familiar, da convivência na comunidade, da fadiga, da condição de transporte coletivo muito ruim, isso rouba horas de sono das pessoas, então isso tudo contribui (SILVEIRA, 2013, entrevista).

Você vai hoje pegar um trânsito também pesado, você tem a mobilidade na rua, você não consegue chegar em casa, você está ansioso para chegar em casa e comer alguma coisa, descansar a cabeça (SILVA, 2014, entrevista).

Fica horas no trânsito, além de sair tarde do seu trabalho (MAENO, 2014, entrevista).

Também é apontada uma relação entre desemprego (ou falta de trabalho) e o "adoecimento" mental/psíquico relacionado ao trabalho:

Eu me lembro no início da década de 90, quando o país viveu uma recessão $e$ que nós tínhamos muitos pacientes que traziam o problema da falta do trabalho como um fator possível de adoecimento. Muitas vezes eles eram demitidos doentes, isso se agravava durante o processo de desemprego prolongado, de penúria, de precariedade, de privação material (SILVEIRA, 2013, entrevista).

Ele [Pedro Gabriel Delgado] estava muito interessando em mostrar o sofrimento mental no trabalho e também principalmente com a perda do vínculo com o 
trabalho, que pode adoecer. [...] Ele fez esse trabalho, ele mostrou que as pessoas que perderam o trabalho foram parar dentro do hospital psiquiátrico do mesmo distrito lá no Rio de Janeiro (SELIGMANN-SILVA, 2014, entrevista).

É dramaticamente já registrada a questão do desemprego, da instabilidade (DIAS, 2013, entrevista).

Três das entrevistadas, psicólogas, chamam atenção para o "adoecimento" mental/psíquico relacionado ao trabalho na perspectiva da articulação entre história de vida e vivência do trabalho.

Nós não podemos esquecer da história do indivíduo, enquanto indivíduo, enquanto sujeito, e do seu mundo de trabalho aonde ele entrou. [...] Por que uns adoecem e outros não? (JACQUES, 2014, entrevista).

Eu não acho que é da ordem do individual ou do trabalho. Eu acho que é de uma articulação, da história de vida, da biografia do sujeito com o seu mundo de trabalho (JACQUES, 2014, entrevista).

A incorporação de novas tecnologias de informação e comunicação (relacionadas à reestruturação produtiva) foi mencionada, também, pelos entrevistados:

Reestruturação produtiva, já que os bancos tinham consolidado a implantação das tecnologias e de informatização do processo (SILVA, 2014, entrevista).

Novas tecnologias, novas formas de produção (DIAS, 2013, entrevista).

Uma série de equipamentos eletrônicos, elétricos e de informatização, o que fez com que acelerasse o processo do trabalho bancário (SILVA, 2014, entrevista).

[...] estão fazendo [...] uma seleção natural, agora em nome da saúde mental, [...] de modo que [...] permaneçam na cena do trabalho apenas aqueles mais "adequados" [...] às novas tecnologias informacionais e comunicacionais (BRANT, 2014, entrevista).

Também é mencionada a categoria econômica da produção de origem:

O Paulo Rogério [Albuquerque Oliveira] ${ }^{193}$ percebeu, como engenheiro, que as frequências de afastamento registradas no mercado formal pela Previdência tinham a ver com a origem das pessoas, e que não tinham a ver necessariamente com a ocupação dela, mas com o lugar de onde elas estavam vindo. Ou seja, a categoria econômica da produção (CORRÊA FILHO, 2014, entrevista).

A precarização do trabalho (relacionada à reestruturação produtiva) foi mencionada também pelos entrevistados como contribuinte para o "adoecimento" mental/psíquico relacionado ao trabalho:

Talvez nem todas as pessoas consigam um emprego com todos os benefícios ou empregos formalizados, mas trabalho não falta. Mas o trabalho que tem é um trabalho muito ruim. Ele é precário sob todos os aspectos (SILVEIRA, 2013, entrevista).

193 Autor do NTEP e do Fator Acidentário de Prevenção (FAP), Coordenador-Geral de Monitoramento de Beneficio por Incapacidade do MPS. Disponível em: http://lattes.cnpq.br/0797997338651068 
Você junta uma condição de trabalho muito precária com uma condição de vida também muito precária (SILVEIRA, 2013, entrevista).

Precarização do trabalho e das relações. [...] Da precarização dos vínculos, das más condições de trabalho (DIAS, 2013, entrevista).

A Figura 2, a seguir, representa graficamente os principais elementos citados pelos entrevistados, bem como suas inter-relações.

Figura 2 - Fatores que promoveriam os Transtornos Mentais e do Comportamento Relacionados ao Trabalho, na percepção dos entrevistados

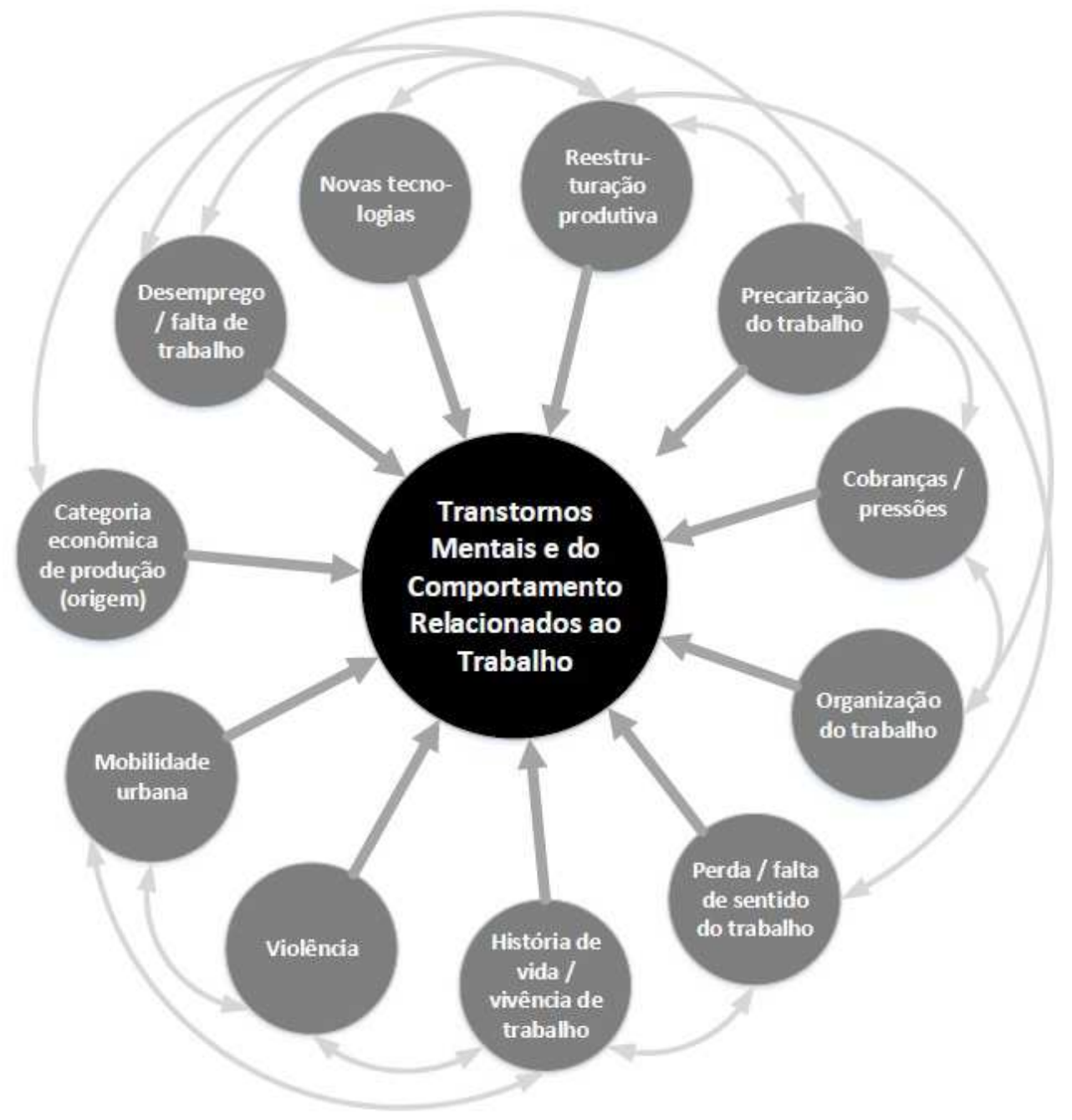

Fonte: produzido pela autora (dados da pesquisa), 2015.. 
6.3.1.6 Subnotificação dos Transtornos Mentais e do Comportamento Relacionados ao Trabalho

Mesmo considerando que os Transtornos Mentais e do Comportamento Relacionados ao Trabalho são a terceira maior causa de concessão de benefícios acidentários (relacionados ao trabalho), se tomadas apenas as doenças relacionadas ao trabalho, indagou-se aos entrevistados sua percepção sobre se os dados oficiais representariam a realidade do número de casos de "adoecimento".

Na avaliação da maioria dos entrevistados, estaria ocorrendo tanto a caracterização dos Transtornos Mentais e do Comportamento Relacionados ao Trabalho como doença "comum", bem como sua subnotificação:194

O acidente do trabalho, mesmo reconhecido como um acidente de trabalho [...], geralmente não é notificado, nós temos que notificar todos os acidentes graves, mas a gente sabe que, praticamente a gente não notifica (GREGGIO, 2014, entrevista).

Pensando na rede de saúde, pensando que o psiquiatra, de um CAPS, de um equipamento assim faça a notificação é muito raro, muito difícil. Eu não vou dizer que não tenha... Mas é uma luta [...]. Nós temos uma dificuldade enorme de conseguir uma notificação da rede [de saúde]. Eu acho que hoje, o que eu vejo, é que os dados que vão aparecendo são dados de notificação dos próprios CEREST (GARBIN, 2014, entrevista).

$\mathrm{Na}$ justiça estadual, como também em todas as instâncias, existe [subnotificação]. Na Assistência, os serviços especializados, os CAPS, por exemplo, não notificam muitos problemas relacionados ao trabalho. Eu conheço pessoas que já foram aos CAPS e verificaram que várias pessoas que têm $o$ problema do alcoolismo, de drogas e de outros transtornos psíquicos que deveriam ser tratados também na relação com o trabalho, e não são (MAENO, 2014, entrevista).

A gente já tem uma diminuição proporcional dos transtornos psíquicos relacionados ao trabalho. Por que essa diminuição? Não é porque esteja diminuindo. Eu não acredito nisso, pelo contrário, acho que vêm aumentando os transtornos psíquicos relacionados ao trabalho em todas as categorias profissionais (MAENO, 2014, entrevista).

Pode-se verificar essa subnotificação (mesmo que os Transtornos Mentais e do Comportamento Relacionados ao Trabalho sejam, como já discutido, de notificação obrigatória), ao comparar os dados do número de benefícios acidentários concedidos em razão de Transtornos Mentais e do Comportamento Relacionados ao Trabalho com o número de casos notificados, apresentados na seção 6.1 e, de forma mais detalhada, no Apêndice C. Os casos notificados correspondem apenas a uma pequena parcela dos

194 Os Transtornos Mentais e do Comportamento Relacionados ao Trabalho são de notificação obrigatória no Sistema de Informação de Agravos de Notificação (SINAN). 
benefícios acidentários concedidos: no período de 2007 a 2014, foram notificados 3.495 casos (Figura 4, Apêndice C), enquanto que foram concedidos, de 2008 a 2012, em termos de benefícios acidentários - auxílio-doença acidentário e aposentadoria acidentária - 63.732 benefícios (Tabela 5, Apêndice C).

\subsubsection{Caracterização dos Transtornos Mentais e do Comportamento Relacionados ao Trabalho como doença 'comum'}

Quanto à apontada caracterização dos Transtornos Mentais e do Comportamento Relacionados ao Trabalho como doença "comum", indagou-se dos entrevistados se os serviços de saúde/a atenção básica conseguiriam fazer a relação/nexo dessas doenças com o trabalho, ou como se daria essa relação. Os entrevistados apontam que essa relação muitas vezes não acontece ou acontece de forma precária.

Uma das questões levantadas pelos entrevistados é a do desconhecimento, pela atenção básica, de procedimentos de diagnóstico (ou mesmo de encaminhamento) de doenças relacionadas ao trabalho.

O colega lá da Atenção Básica, ele não está antenado para isso. E quando está [...], ou ele não sabe como fazer o encaminhamento, não sabe como fazer os fluxos, ou ele também acaba optando por tratar o sintoma. Ele desconhece outras ações que precisam ser feitas (SILVA, 2013, entrevista).

Não consegue e não sabe, inclusive não sabe diagnosticar no ambulatório. Não sabe fazer a relação (JACQUES, 2014, entrevista).

Outra questão apontada se referiria a certo despreparo da atenção básica para lidar com o campo a Saúde do Trabalhador (e com os Transtornos Mentais e do Comportamento Relacionados ao Trabalho), ou mesmo para a lida com a categoria "trabalho".

\footnotetext{
Os serviços de saúde (por exemplo, os CAPS) não estão preparados para lidar com demandas do trabalho. Estão tão sobrecarregados com casos de esquizofrenia, psicose, suicídio e drogadicção, que questões relacionadas ao trabalho passam despercebidas. Estão despreparados para lidar com o próprio foco (DIAS, 2013, entrevista).

$\mathrm{Na}$ rede de atenção, [...] a doença do trabalho dificilmente é reconhecida enquanto doença do trabalho (GREGGIO, 2014, entrevista).

A Atenção Básica não dialoga com a Saúde do Trabalhador (JACQUES, 2014, entrevista).
}

Também foi levantada a questão do desconhecimento ou dificuldade de utilização, pela atenção básica, de materiais (técnicos) específicos sobre saúde do trabalhador, 
sobretudo quanto aos Transtornos Mentais e do Comportamento Relacionados ao Trabalho. (Essa questão será retomada quando forem discutidos a Lista B do Decreto 3048 e o Manual do Ministério da Saúde "Doenças relacionadas ao trabalho: manual de procedimentos para os serviços de saúde").

\subsubsection{Papel dos CERESTS}

Foi indagado aos entrevistados qual seria o papel dos CERESTs. O papel do CEREST mais citado nas respostas dos entrevistados foi a promoção do debate e formação em Saúde do Trabalhador e matriciamento da rede de saúde.

Em seguida, destacou-se o papel do CEREST na proposição e articulação de ações referentes à saúde do trabalhador: ações de vigilância, assistência e promoção da saúde.

O papel do CEREST [...] é estimular, otimizar, organizar as ações de saúde do trabalhador na região de sua referência, ações de vigilância - epidemiológica, dos ambientes de trabalho, das condições de trabalho - ações de assistência, tanto diagnóstico, tratamento quanto reabilitação física, ações de promoção da saúde, dentro da promoção da saúde (SILVA, 2013, entrevista).

No CEREST a gente também faz a vigilância, então é possível a gente ir na empresa, [...], aí você olha a questão da empresa como um todo, você vai pedir documentos. [...] Outro papel que a gente faz é [...] quando a gente identifica $o$ nexo do adoecimento com o trabalho, e [...] que essa pessoa poderia voltar ao trabalho, mas com restrição, e aí ela teria que mudar de setor, ou mudar de área, ou até mesmo de função, a gente encaminha para o SESMT. [...] No CEREST, no caso da reabilitação, [também] temos a reabilitação do INSS. A gente recebe algumas pessoas do INSS que estão por algum motivo, com dificuldade de serem incluídos na reabilitação (GREGGIO, 2014, entrevista).

Por fim, colocou-se também o papel do CEREST no empoderamento dos trabalhadores e no estímulo a ações intersetoriais:

O papel do CEREST [...] é [...] muitíssimo importante, [promover] ações de [...] empoderamento dos trabalhadores, ações intersetoriais, estimular [a realização de] ações intersetoriais, particularmente com o Ministério do Trabalho e Emprego, como com o Ministério da Previdência Social. Uma questão importante que todos os documentos da saúde do trabalhador prescrevem, mas que [...] na prática não está acontecendo adequadamente, é a participação dos trabalhadores na gestão e na condução das políticas de saúde do trabalhador naquela região, conduzida, coordenada pelo CEREST (SILVA, 2013, entrevista). 


\subsubsection{Interdisciplinaridade}

Um elemento destacado por vários dos entrevistados é a necessária interdisciplinaridade implicada na compreensão e lida com os Transtornos Mentais e do Comportamento Relacionados ao Trabalho (e na Saúde do Trabalhador, de forma mais ampla).

A complexidade [da saúde mental] está exigindo de nós um entendimento interdisciplinar e uma intervenção interdisciplinar. Então os campos precisam sair dos seus campos. O campo, por si só, ele já é interdisciplinar, mas ele precisa avançar nisso, ele precisa avançar na construção, talvez, da transdisciplinaridade, de um outro construto teórico (SILVA, 2013, entrevista).

Você precisa de uma intervenção interdisciplinar. $E$ essa intervenção interdisciplinar não pode prescindir do psicólogo. Não pode prescindir do psicólogo, não pode prescindir da assistência social (CODO, 2014, entrevista).

Você precisa de uma intervenção interdisciplinar. [...] A questão é introduzir na problemática de saúde ou de educação [...] o olhar do psicólogo. Aos alunos no começo do curso, digo: "multidisciplinar não é cortar o sujeitinho em cinco, um é psicológico, ou outro é médico, o outro é ortopédico. Interdisciplinar é [ter] olhares diferentes que permitem compor um quadro mais próximo da realidade de um determinado problema, quer seja na área de educação, na clínica etc." (CODO, 2014, entrevista).

A resposta para enfrentar isso tem que ser através das ações interdisciplinares, não vejo outra forma. Médico sozinho não resolve. [...] A gente quer o psicólogo, o sociólogo [...]. Porque o ambiente de trabalho tem as múltiplas facetas que danificam o trabalhador nas suas dimensões física e mental. E isso não cabe apenas a um profissional. Então o ambiente de trabalho, ele tem que ter um olhar da psicologia, tem que ter um olhar da sociologia, um olhar da economia, da medicina, da engenharia (SILVA, 2014, entrevista).

\subsubsection{Concepções / noções sobre a categoria trabalho presentes no campo}

Uma vez que a Saúde do Trabalhador e o debate sobre os Transtornos Mentais e do Comportamento Relacionados ao Trabalho se tratam de campos envolvidos em disputas entre diferentes concepções teórico-políticas, atravessados por múltiplos fatores, uma das questões postas aos entrevistados foi a respeito dos modelos teóricos presentes no campo, mais especificamente, quais as concepções/noções sobre a categoria trabalho.

Uma concepção destacada por vários dos entrevistados, e que se relaciona com as dificuldades do processo de diagnóstico, é a de que a categoria "trabalho" é vista/tratada pelos profissionais da saúde, sobretudo pelos médicos, como um "'apêndice", algo secundário ou não contemplado no diagnóstico. 
O trabalho é um apêndice da anamnese [médica], que só se resume a perguntar o que a pessoa faz (SILVEIRA, 2013, entrevista).

[Porque não se faz a relação com o trabalho?] Eles [médicos] até reconhecem que é o trabalhador de tal empresa, agora, nesse diagnóstico, nesse levantamento das causas, não aparece a questão do trabalho (GARBIN, 2014, entrevista).

Acho que nós, psicólogos, não consideramos na anamnese a ocupação no sentido do que a pessoa faz, a ocupação vem como um dado puramente estatístico (GARBIN, 2014, entrevista).

[o médico] põe essa causa, [...] essa determinação, fora do trabalho (DIAS, 2013, entrevista).

Nos centros de atenção psicossocial você não vê o trabalhador sendo contemplado, a categoria trabalho sendo contemplada, é como se não existisse, é como se não fizesse nenhuma diferença (BRANT, 2014, entrevista).

Quando ele [trabalhador] menciona situações de trabalho, é escutado como se fosse alguma outra situação e não na sua especificidade de trabalho (BRANT, 2014, entrevista).

A categoria trabalho não é escutada (GREGGIO, 2014, entrevista).

Já os profissionais mais ligados ao campo da Saúde do Trabalhador compreendem a categoria trabalho na perspectiva de que a análise do trabalho/processo de trabalho é fundamental para a compreensão do processo saúde/doença, e que os padrões de morbidade relacionados ao trabalho vêm se modificando.

Diferentemente de 30, 40 anos atrás que nós tínhamos ali meia dúzia de doenças profissionais, hoje os trabalhadores adoecem daquilo que o conjunto da população adoece, a diferença é que o trabalho dá uma marca diferente nisso. Ou ele é mais intenso, ou ele é mais grave, ou ele é mais precoce, ele muda o quadro epidemiológico, ele muda a situação, o quadro epidemiológico (SILVA, 2013, entrevista).

[Deve-se investigar] como é que o trabalho se articula, como é que a questão do trabalho se articula na formação de sintoma, e no sintoma psíquico propriamente dito (JARDIM, 2014, entrevista).

Outra concepção mencionada por alguns entrevistados, também relacionada com as dificuldades do processo de diagnóstico, é a de que "o trabalho dignifica o homem", sendo visto como portador de características apenas da ordem da positividade ou, como define um dos entrevistados, um "fetiche".

Eu acho que nós temos um fetichismo muito grande pelo trabalho. "O trabalho enobrece o homem", "o trabalho honra o homem" e mil coisas [...]. Nós colocamos o trabalho como o elemento maior da vida (BERTOLLI FILHO, 2014, entrevista).

O homem [só] é saudável, é normal - seja lá o que for isso - se ele trabalha [...]. Essa hipervalorização do trabalho assalariado [...] vem no fundo desde a antiguidade, o homem é homem porque trabalha, etc. (BERTOLLI FILHO, 2014, entrevista). 
Existe uma ideologia que é muito forte, que é hegemônica, de que o trabalho dignifica o homem. Então porque as pessoas vão adoecer justamente pelo trabalho? (MAENO, 2014, entrevista).

É como se o trabalho fosse uma coisa higiênica e só positiva (JACQUES, 2014, entrevista).

\subsubsection{Estabelecimento do nexo ou relação com o trabalho dos Transtornos Mentais e do Comportamento Relacionados ao Trabalho}

Outra questão colocada para os entrevistados foi sobre como se daria, nos caso dos Transtornos Mentais e do Comportamento Relacionados ao Trabalho, o estabelecimento do nexo ou relação com o trabalho.

Vários entrevistados destacaram que essa relação se estabelece a partir da escuta do relato pessoal do trabalhador, o que implica desde uma anamnese cuidadosa a até mesmo, para favorecer essa escuta, um número maior de encontros, não se tratando de processo "rápido".

Esse relatório, ele não é possivel a gente fazer ele muito rápido, geralmente eu faço esse relatório em cinco, seis, às vezes oito, às vezes dez encontros, não é possivel fazer muito rápido, porque você precisa levantar toda essa questão da história clínica [...] A partir disso, a partir da história do relato, do próprio trabalhador, entrevista muitas vezes com familiares, com pessoas próximas (GREGGIO, 2014, entrevista).

Perguntar: "o que você faz", já dali deriva um monte de coisas. Um monte de hipóteses (JARDIM, 2014, entrevista).

Existe muito epidemiologista que diz: "Não, você tem que fazer o estudo epidemiológico e depois vai ver o que é que causa". Eu sempre achei que em saúde mental a gente tem que ouvir as pessoas primeiro, e daí você vê... Olha as coincidências em determinadas situações que têm determinados elementos ou a situação como um todo, as interações em determinada situação parecem propiciar mais adoecimento (SELIGMANN-SILVA, 2014, entrevista).

Essa escuta diferenciada também deveria atentar-se à dimensão de subjetividade implicada nos Transtornos Mentais e do Comportamento Relacionados ao Trabalho.

É lógico que a manifestação clínica da doença, ela muitas vezes não muda. $O$ sujeito que ficou deprimido porque ele perdeu todos os membros da família num acidente de carro e outro ficou deprimido por um evento do trabalho, a manifestação da tristeza, da perda do gosto pela vida, das manifestações físicas vão ser as mesmas, não vai existir muita diferença, mas, no relato dele, tem diferença e é isso que a gente recupera. A escuta que você faz dele [...] e tem marcas temporais, olha, foi depois que aconteceu isso, ou à medida que isso foi acontecendo no trabalho, é isso que a gente recupera e é com base nisso que a gente constrói o nexo (SILVEIRA, 2013, entrevista).

Eu sempre exercitei um pouco esse raciocínio que é do trabalho que a pessoa consegue dizer de características, de exigências, de conteúdos mais subjetivos, que ela traz, e isso foi me dando mais elementos para pensar no nexo (GARBIN, 2014, entrevista). 
Também foi apontada pelos entrevistados a necessidade, no caso dos Transtornos Mentais e do Comportamento Relacionados ao Trabalho, dada sua maior complexidade, de uma "sensibilidade" do médico/profissional de saúde para a questão do trabalho e de diálogo/interlocução com outros profissionais.

Você tem que ter essa capacitação ou capacidade, ou essa sensibilidade (SELIGMANN-SILVA, 2014, entrevista).

[O transtorno mental exige] uma sensibilidade muito grande para a questão do trabalho e a questão dessa relação desigual entre o trabalho e o capital. [...] Agora, o que eu percebo, na grande maioria, hoje os médicos do trabalho não têm essa visão mais (GREGGIO, 2014, entrevista).

Ele [transtorno mental] exige muito mais do médico que outra doença relacionada ao trabalho. Isso eu não tenho dúvida. Então, embora hoje a gente não tenha a dificuldade que nós tínhamos há vinte anos para fazer um nexo, ele ainda é mais difícil. Então, ele exige um diálogo maior com o médico assistente (SILVEIRA, 2013, entrevista).

\subsubsection{Conflitos presentes no campo}

Dada a complexidade do campo da Saúde do Trabalhador, sobretudo no que se refere aos Transtornos Mentais e do Comportamento Relacionados ao Trabalho, perguntouse aos entrevistados sobre sua percepção de conflitos presentes no campo.

A questão mais destacada pelos médicos entrevistados foi a do conflito existente entre os médicos "patronais" (ligados à Medicina do Trabalho/Saúde Ocupacional) e os médicos atuantes na perspectiva da Saúde do Trabalhador:

Os médicos do trabalho, eles são formados para tratar os problemas pelo ponto de vista da empresa. [...] A impressão que eu tenho é que são aqueles médicos que são menos familiarizados com o mundo do trabalho que podem ser mais sensiveis a isso [...]. Os médicos do trabalho foram formados para isso mesmo, para não reconhecerem, para administrarem os problemas do ponto de vista das empresas [...]. A gente conseguiu envolver médicos, menos do trabalho, porque eles são mais comprometidos com as empresas, trabalham com as empresas (MAENO, 2014, entrevista).

Os médicos do trabalho costumam muito ser identificados com os interesses patronais (SILVEIRA, 2013, entrevista).

Agora para você ver no caso da medicina, [...] ela como produto do próprio capitalismo está legislando as relações de trabalho em benefício, é claro, do capital, e eu acredito que esse texto [BERTOLLI FILHO, 1993] implicitamente trata desse princípio (BERTOLLI FILHO, 2014, entrevista).

O mundo da medicina do trabalho [é] um mundo corrupto, patronal, servil, hipócrita, você pode colocar todos os adjetivos que quiser. A medicina do trabalho, ela teve que mudar de nome para saúde ocupacional para sair desse beco sem saída em que eles se meteram, já nasceram dentro dele, como a medicina patronal (CORRÊA FILHO, 2014, entrevista).

Então eu procurei distinguir o médico da saúde do trabalhador do médico assessor patronal e tentar tirar a carga moral implícita disso, porque [...] a 
assessoria patronal deve existir, na área de saúde. Eu não estou disposto a exercê-la [assessoria patronal] hoje, porque não acho que existam condições políticas de liberdade para fazer isso. Mas [ela] existe. Então, criam-se lá dois campos: um, o médico do patrão, não põe a mão em trabalhador. E o médico do trabalhador não se subordina ao patrão, portanto, não pode receber dinheiro dele, não pode ser contratado por ele, não pode ser concursado num concurso em que o patrão participe da triagem (CORRÊA FILHO, 2014, entrevista).

Porque na hora que um sanitarista punha o pé num curso de medicina do trabalho, ele se tornava suspeito: "Como é, mudou de lado? você vai lá para o ninho das cobras e vai trabalhar com eles também?" O diferencial que eu vejo é que eu nunca trabalhei para empresa privada. E me mantenho, vamos dizer, nessa coerência até hoje. Nunca aceitei prestar uma consultoria patronal (CORRÊA FILHO, 2014, entrevista).

Tinha um curso que é como você fazer, você, profissional da empresa, para descaracterizar o nexo. Dando as dicas, [...] um protocolo para descaracterizar nexo de doença relacionada ao trabalho a partir do pressuposto de que existe um exagero de uma indústria de nexo, então você tem de aprender como é que você vai defender o seu empregador desfazendo os nexos, tem isso, oferecendo no mercado (SILVEIRA, 2013, entrevista).

Outra questão conflituosa, colocada por psicólogos entrevistados, foi a da centralidade do papel do médico frente às demais categorias de profissionais da saúde (como psicólogos e enfermeiros), e o questionamento dessa relação.

É muito comum você ouvir: "Ah, porque os médicos e os profissionais de saúde". Como se os médicos não fossem profissionais da saúde. Isso no cotidiano, eles continuam com uma hegemonia bem consolidada. Muito consolidada. [...] E sem muita abertura (BRANT, 2014, entrevista).

[Os médicos à frente, e uma pequena participação dos psicólogos?] Acho que é histórico isso, acho que é uma relação de poder, eu cada vez mais me horrorizo com as posições, tanto do Conselho de Medicina, os Conselhos de Medicina, como com os sindicatos médicos. Eu acho que eles estão perdendo o seu lugar social, e estão muito preocupados com isso. Eu acho que eles não conseguem entender a saúde como não sendo só a Medicina porque, historicamente, por exemplo, a Enfermagem era um órgão subalterno, a Psicologia também era, mas aí a Psicologia começou a fazer outro discurso (JACQUES, 2014, entrevista).

Tem uma predominância do papel do médico no serviço, eu diria nos serviços ainda, o CEREST não foge à regra. Mas tem uma predominância, sim, tanto na questão do médico mesmo, tanto que a gente percebe, por exemplo, sem médico não tem CEREST (GREGGIO, 2014, entrevista).

Destaca-se aqui a posição contrária de Wanderley Codo:

O papel central na questão da saúde é o papel do médico. O médico é o profissional que é responsável pela questão da saúde. E ponto (CODO, 2014, entrevista).

Outro elemento conflituoso apontado refere-se à falta de consenso (ou mesmo disputas), no campo da Saúde Mental, ou da Saúde Mental e Trabalho, a respeito das concepções teóricas sobre as relações entre "adoecimento" mental/psíquico e trabalho. 
[...] era muito complicado, porque a gente tinha um desamparo [...] dos próprios colegas que são especialistas em saúde mental, sejam psicólogos, sejam psiquiatras, porque era um campo muito fragmentado, muito dividido e eu me lembro que as discussões que a gente fazia no próprio Hospital Universitário, que na maioria das vezes os nossos colegas não acreditavam que o trabalho pudesse ser uma dimensão da vida que isoladamente explicasse um transtorno mental. Isso nos criava uma grande dificuldade (SILVEIRA, 2013, entrevista).

Como o campo tem tido ainda dificuldades em estabelecer um consenso mínimo, ele deixa flancos abertos para o que fragiliza os pacientes (SILVEIRA, 2013, entrevista).

Não há consenso entre os próprios profissionais especialistas em saúde mental... [...] Eu sou médica do trabalho, eu preciso da parceria, da ajuda do profissional especialista em saúde mental e eles juntavam três e davam uma cisão, não chegavam num acordo (SILVEIRA, 2013, entrevista).

\section{Outra questão conflituosa apontada se refere à não integração ou sobreposição de} políticas públicas na área de Saúde do Trabalhador, notadamente Ministério da Saúde, Ministério do Trabalho e Ministério da Previdência Social, bem como a fragmentação de políticas e ações e dificuldade de articulação das esferas de governo (federal, estadual e municipal).

Porque quando o Ministério da Saúde entrava na empresa para fiscalizar [ações de vigilância], o dono da empresa dizia que quem tem o papel de fiscalizar é o Ministério do Trabalho. [...] Aí, o Programa de Saúde tinha que procurar o Ministério Público para garantir a entrada dentro da empresa (SILVA, 2014, entrevista).

Então você tem um problema sério. Eu tenho muito dúvida da eficácia da atuação do Estado. "Ah, mas nós temos agora uma Política Nacional de Saúde do Trabalhador", se essa política vai funcionar. Se você pegar essa Política Nacional de Saúde do Trabalhador, você vai ver que ela é fragmentada. Qual é a queixa principal nossa, no movimento sindical? É que as políticas do Estado em Saúde do Trabalhador, até novembro de 2011, quando foi promulgada a lei195 pela Dilma, cada ministério fazia uma coisa. Ministério da Saúde resolvia suas políticas públicas através do CEREST, da Vigilância Sanitária, o Ministério do Trabalho precariamente fiscaliza e o Ministério da Previdência paga. [...] Ou descaracteriza e não paga (SILVA, 2014, entrevista).

Do ponto de vista mais político, tem uma discussão ainda muito travada entre Ministério da Saúde, Previdência e Trabalho, nós ainda temos dificuldades embora, em um plano mais federal a gente ouça as reuniões tripartites as discussões mais colegiadas, eu acho que ainda a gente tem um longo caminho para superar, visões fragmentadas e desarticulação de políticas dessa área (GARBIN, 2014, entrevista).

Se você pegar a legislação do Ministério do Trabalho, é uma coisa, da Previdência é outra e da Saúde é outra. Então, se você unificar essa normatização dessa legislação seria ótimo. Mas você tem um conflito para vencer (SILVA, 2014, entrevista).

Então, em Brasília tem o Ministério da Saúde, da Previdência, o Ministério do Trabalho e as centrais sindicais. Mas esse diálogo não existe [...]. Se você for

195 Decreto ${ }^{\circ}$ 7.602, de 7 de novembro de 2011. Dispõe sobre a Política Nacional de Segurança e Saúde no Trabalho (PNSST). 
para as regiões, para os municípios, onde estão as unidades, eles nem se conhecem, não sabem nem o que [o outro] faz (SILVA, 2014, entrevista).

A Saúde do Trabalhador dentro de Ministério [da Saúde], ela sempre ficou nas áreas de programação estratégica, o que não era um lugar nem muito adequado nem muito confortável, porque as grandes áreas do Sistema Único de Saúde são as áreas da Assistencial, que é a SAS [Secretaria de Atenção à Saúde] e da Vigilância. A gente ficava numa coisa assim, num limbo, que sempre nos preocupou, sempre nos incomodou muito, mas estávamos enxergando que tinha a construção de uma linha de propósito político e que as coisas estavam andando (SILVA, 2013, entrevista).

Se você for para as regiões, para os municípios, onde estão as unidades, eles nem se conhecem, não sabe nem o que faz. Agora esse diálogo social, em âmbito do Estado, ele está limitado só à esfera federal (SILVA, 2014, entrevista).

Também foi apontada a situação conflituosa da contestação dos diagnósticos de doença relacionada ao trabalho, ou de Transtornos Mentais e do Comportamento Relacionados ao Trabalho, pelas empresas.

E ainda tem aquele discurso da indústria, das ações na Justiça, que as pessoas querem ter compensações econômicas (SILVEIRA, 2013, entrevista).

As empresas contestam o tempo inteiro. [É melhor ser um B31?]. É muito melhor. Contestam o tempo inteiro. Aliás não contestam só transtorno mental, tem contestado tudo. O transtorno mental até porque é mais fácil delas contestarem. Existe um limbo tão grande que é mais fácil para ela contestar com sucesso (SILVEIRA, 2013, entrevista).

Por fim, apontou-se também a própria dificuldade do INSS (perícia médica, sobre a qual se tratará mais detalhadamente no tópico 6.3.15) em reconhecer os Transtornos Mentais e do Comportamento Relacionados ao Trabalho.

\subsubsection{Dificuldades da atuação no campo da Saúde do Trabalhador e com os Transtornos Mentais e do Comportamento Relacionados ao Trabalho}

Além das situações conflituosas, solicitou-se aos entrevistados que apontassem, em sua perspectiva, as dificuldades da atuação no campo da Saúde do Trabalhador e, em especial, na lida com os Transtornos Mentais e do Comportamento Relacionados ao Trabalho.

Uma questão mencionada por todos os profissionais entrevistados ligados à área da Saúde do Trabalhador (não foi citada apenas pelo historiador entrevistado) refere-se à dificuldade de diagnóstico dos Transtornos Mentais e do Comportamento Relacionados ao Trabalho, dada sua "invisibilidade": 
[Há dificuldades para o diagnóstico?] Eu acho que assim, como a LER, por exemplo. Acho que tem algumas coisas que não são explícitas nem visíveis que colocam [dificuldades] (JACQUES, 2014, entrevista).

A tentativa de vínculo epidemiológico, ela é extremante pobre. Ora, se você trabalha com cimento, e está com problema no pulmão, eu sei direitinho o que é que você tem, porque é que você tem e se eu devo te afastar, e se eu devo te aposentar... Sei direitinho. Já se você me apresenta uma depressão... (CODO, 2014, entrevista).

Me lembro de falas da década de 80, 90, mas até hoje a gente escuta esse tipo de fala, porque a evidência do transtorno mental, ela é diferente da evidência da doença física. [...] Muitas vezes eu tenho uma inchação, um caroço no braço, uma mutilação, ela é visível e testada, o transtorno mental não é (SILVEIRA, 2013, entrevista).

Os transtornos psíquicos, por serem justamente não visiveis como as doenças físicas, ou mensuráveis, eles são mais sujeitos a questionamentos quanto à origem, evolução, simulação, etc. (MAENO, 2014, entrevista).

Precisava inscrever essa identidade, ou seja, que essa identidade tivesse um registro no corpo do trabalhador. Por exemplo, a questão da tristeza, não bastava apenas o diagnóstico F.32 Depressão, precisava encontrar no corpo desse trabalhador um distúrbio da serotonina para que isso fosse marcado. [...] $E^{\prime}$ como se [...] a própria ciência e particularmente a ciência biomédica, ela precisasse ter algo da visibilidade daquilo que ela estava afirmando. Não bastaria apenas ficar numa ordem "discursiva" (BRANT, 2014, entrevista).

\section{A essa dificuldade diagnóstica, somar-se-ia, sobretudo quanto aos Transtornos}

Mentais e do Comportamento Relacionados ao Trabalho, a causada em virtude da rapidez da consulta/procedimentos:

O médico não diagnostica porque ele não tem tempo de avaliar nem de estabelecer um vínculo de confiança, a pessoa já vai para a perícia com medo ou para própria consulta do médico assistente no SUS... Tem que ser rápido, e aí os diagnósticos não são feitos, então dentro do SUS ou dos convênios também, que sofrem as mesmas pressões hoje em dia, você não tem os diagnósticos (SELIGMANN-SILVA, 2014, entrevista).

Eu analiso a dificuldade do diagnóstico por causa da pressa (SELIGMANN-SILVA, 2014, entrevista).

O bom clínico, se ele tiver tempo e disposição de ouvir, ele faria o diagnóstico. $O$ problema é que os médicos hoje trabalham num esquema em que eles não têm tempo para ouvir e nem o sistema favorece o reconhecimento de transtornos psíquicos (MAENO, 2014, entrevista).

Eu acho que o médico tem sido ensinado muito a valorizar a tecnologia, essa tecnologia pesada dos equipamentos e não a tecnologia leve que é a do contato humano, da humanização nas relações com o paciente. [...] Existe um sistema que não favorece essa abordagem mais individualizada, mais humanizada (MAENO, 2014, entrevista).

Então você tem a maneira como é feito o atendimento, a maneira como é feita a perícia também. Eles tinham vinte minutos. Não sei agora (SELIGMANN-SILVA, 2014, entrevista).

E isso [o diagnóstico] exige mais encontros, exige mais conversas, investigação também (GARBIN, 2014, entrevista). 
Outra importante dificuldade, mencionada por quase todos os profissionais entrevistados ligados à área da Saúde do Trabalhador, refere-se a reconhecer que o trabalho pode acarretar em "adoecimento" mental/psíquico; a "doença mental" do trabalhador não teria como causa o trabalho, mas sim questões individuais (problemas na família, afetivos etc.). Essa perspectiva (que também pode estar associada à questão da formação, discutida a seguir) abre margens para a culpabilização do trabalhador pela doença e para a individualização da questão.

A relação com o trabalho não é tão tradicional, ela vem, legalmente, desde [a Constituição de] 1988, então a gente tem uma grande dificuldade ainda de fazer com que os profissionais olhem aquela pessoa que está ali na sua frente como também inseridas no contexto de trabalho. Ou do não trabalho (MAENO, 2014, entrevista).

[No] nosso serviço aqui [da UFMG], eu lembro como se fosse hoje, 1983, 1984, começaram a chegar os trabalhadores da digitação, eram trabalhadores de empresas que prestavam serviços para o setor bancário, faziam compensação de cheques, eram digitadores e que, com essas queixas de dor crônica e queixas de mal-estar, de insatisfação, choro fácil, distúrbios de sono, distúrbios de afetividade... E foi muito complicado naquela época relacionar isso ao trabalho. Muito. Porque se achava que essas queixas eram, primeiro, questões dos indivíduos, problemas particulares, pessoais, afetivos, familiares... Que era apenas isso que explicava. E tem muita gente que tantos anos depois, quase 30 anos depois, continua falando a mesma coisa (DIAS, 2013, entrevista).

Nós temos uma história do transtorno mental e do comportamento sempre pautada na ordem do individual. Então eu acho que nós vamos ter sempre esse viés atravessado. Olha as teorias que embasam toda a nossa compreensão do sofrimento mental, e veja se não são teorias que dão conta da história individual tão somente (JACQUES, 2014, entrevista).

A outra questão em que a gente subestima o dado é que, ainda hoje, a etiologia da Saúde Mental é grudada na família, na sexualidade, na infância, e não no trabalho. Aquelas coisas que eu escrevi lá em 1981 na tese do doutorado de que se você chega num consultório e diz que está sofrendo, e fala do trabalho, o psicólogo imagina que na verdade [...] você está falando mesmo é do pai (CODO, 2014, entrevista).

No fundo, a maior parte das faculdades dessa área da saúde pensam o fato como um fenômeno individual, nunca enquanto um processo coletivo, $e$ isto seria muito importante (BERTOLLI FILHO, 2014, entrevista).

[Existe uma perspectiva] funcionalista, de que o indivíduo [...] fica doente para fugir de suas obrigações sociais, familiares. Então, todo mundo é culpado pela sua enfermidade (BERTOLLI FILHO, 2014, entrevista).

Essa prática hoje se reproduz no aspecto extremamente moralista, culpabilizante e desvinculada do processo de trabalho. Nem se fala em processo de trabalho. $E$ essa culpabilização, isso me chama muito a atenção, cada vez mais ela está assumindo essa conotação de algo que passa pelo interior do sujeito, ou mais precisamente agora da cabeça, do cérebro do sujeito (BRANT, 2014, entrevista).

As questões são tratadas como doença comum, individual, ligadas a fatores de vida, rupturas afetivas etc. do indivíduo (DIAS, 2013, entrevista).

[O Transtorno Mental e do Comportamento Relacionado ao Trabalho é visto como] doença comum, como problema do indivíduo, cada um tem uma explicação, seja um problema afetivo, um desencanto amoroso, um problema 
familiar, um problema da droga, seja o que for, uma perda significativa, e o trabalho fica subsumido nesse mundo (DIAS, 2013, entrevista).

Esses dias conversando com uma enfermeira que coordena o pronto atendimento psiquiátrico aqui em São Bernardo, ela me disse o seguinte: "eu reconheço, mas eu tenho muitas dúvidas [de] quando o trabalho de fato seria $o$ agravante, o desencadeador, e quando a pessoa já traz uma história..." (GARBIN, 2014, entrevista).

Então, é novamente a individualização. Os problemas estão nas pessoas e não nas culturas empresariais, nas corporações etc. Eu acho que isso é generalizado [...]. É uma individualização da responsabilidade e isso acontece em qualquer doença (MAENO, 2014, entrevista).

Não é a empresa que está doente, não é a estrutura da empresa que leva ao adoecimento, mas sim, as pessoas é que adoeceram porque têm problemas de infância, têm um caráter mais fraco, porque sofreram no meio da família por alguma coisa, aconteceu um problema importante na família (MAENO, 2014, entrevista).

[...] o que você vê em última instância, é a culpabilização do sujeito, a culpabilização do trabalhador por aquilo que ele esteja vivendo (BRANT, 2014, entrevista).

Acham que as evidências são frágeis e que outras dimensões da vida daquele indivíduo, que não o trabalho, justificam o adoecimento ou explicam de uma [forma] mais adequada (SILVEIRA, 2013, entrevista).

Soma-se a essa dificuldade a perspectiva de que trabalho não poderia adoecer.

A grande questão é ideológica. Ideologicamente existe uma concepção de que o trabalhador não poderia adoecer por trabalho porque pelo menos emprego ele tem (MAENO, 2014, entrevista).

[...] os nossos colegas [da saúde mental] não acreditavam que o trabalho pudesse ser uma dimensão da vida que isoladamente explicasse um transtorno mental. Isso nos criava uma grande dificuldade (SILVEIRA, 2013, entrevista).

[Há] um forte movimento de negacionismo. Uma das aulas que eu criei na Epidemiologia se chama "O Negacionismo": é negar tudo, qualquer vínculo, qualquer plausibilidade (CORRÊA FILHO, 2014, entrevista).

Tem um peso muito importante o fato do médico não ver no trabalho uma situação de adoecimento, uma situação que propicia o adoecimento. Acho que há uma dificuldade. Não é só no médico, da sociedade como um todo de aceitar, de naturalizar o trabalho como ele é (MAENO, 2014, entrevista).

Acho que é uma discussão de fundo ideológico, é uma discussão de fundo de negação de que o trabalho adoece (SILVA, 2013, entrevista).

Uma dificuldade fortemente destacada pelos entrevistados refere-se à formação ou qualificação dos profissionais de saúde (inclusive os que estão na atenção básica ou nos CAPS) que, de modo geral, não contemplaria discussões sobre a atenção integral ao sujeito, o diálogo/interlocução com outras especialidades, sobre o papel ou a relação do trabalho com o processo saúde-doença, sobre os aspectos culturais envolvidos ou, de forma geral, sobre Saúde Coletiva ou Saúde do Trabalhador. 
E muitos deles [trabalhadores adoecidos] chegam lá na atenção básica e essa relação com o trabalho não é feita. [...] Pela falta de conhecimento (SELIGMANN-SILVA, 2014, entrevista).

Toda a formação dos profissionais de saúde tem que ser modificada. A formação de todos esses profissionais, e a gente não consegue muito isso. Desde que eu me formei até hoje a evolução para isso deve ter sido muito pequena (MAENO, 2014, entrevista).

Eu acho que, infelizmente, os profissionais, nos serviços do SUS, eles são abordados de uma maneira totalmente fragmentada [...]. Quando a abordagem deveria ser a abordagem da pessoa que se vai atender. Mas isso não é fácil. [...] O objeto principal da assistência é a pessoa. Então a pessoa deveria ser vista como mulher, como trabalhadora, como uma pessoa que mora numa determinada região, inserida num determinado contexto, com determinados hábitos, com alcoolismo ou não. Enfim, ela tem que ser vista de uma maneira integral, uma pessoa com todas as suas características e a gente não consegue passar essa concepção para a assistência [...]. A gente não consegue ver a pessoa na sua íntegra. Na sua integridade, sua integralidade. Então isso é que falta. Depende do sistema, depende da formação e do sistema que não produz esse talento (MAENO, 2014, entrevista).

Eu conversava com [...] enfermeiros, e eles defendem [...] que o trabalhador é vagabundo [...]. Não se questionam naquilo que é básico, então se coloca aquilo como um desleixo do indivíduo. Não se pensa no plano cultural (BERTOLLI FILHO, 2014, entrevista).

As próprias faculdades, a faculdade de Medicina, as faculdades da área de saúde, elas dão pouca importância e carga horária em disciplinas em que se mexe com saúde coletiva. E fica sempre com a clínica individual. [...] A maior parte das faculdades dessa área da saúde, elas pensam o fato como um fenômeno individual, nunca enquanto um processo coletivo, e isto seria muito importante. [...] Mas também não é interessante; não é interessante no sentido do próprio sistema capitalista (BERTOLLI FILHO, 2014, entrevista).

A gente tem uma dificuldade muito grande por qualificação dos profissionais que estão na atenção básica (SILVEIRA, 2013, entrevista).

Eu vejo que muitas vezes o psicólogo tem dificuldade realmente, pegar um papel e colocar num relatório o que ele está percebendo, daquele adoecimento. [...] A gente nem é formado para isso (GREGGIO, 2014, entrevista).

Perguntar: "o que você faz", já dali deriva um monte de coisas. Um monte de hipóteses. E isso é que eu acho que tem que ensinar [...]. Isso está muito longe de ser ensinado na Faculdade de Psicologia, na Faculdade de Medicina, continua muito longe (JARDIM, 2014, entrevista).

Eu acho [uma dificuldade] a formação, não tem como não falar, a formação das diversas áreas (GARBIN, 2014, entrevista).

A atenção básica não dialoga com a Saúde do Trabalhador. Nós não temos uma formação nos cursos na área da saúde que possa dar conta dessa temática. Os cursos não falam que trabalho pode ser fator de adoecimento, seja físico, seja psíquico. É como se o trabalho fosse uma coisa higiênica e só positiva (JACQUES, 2014, entrevista).

\section{Mais especificamente, faltaria formação ou qualificação dos profissionais de saúde para a compreensão da dimensão da saúde mental, de modo geral, e em sua relação com o trabalho.}

Eu acho que esse é o caminho que a gente deve fazer: via formação (JACQUES, 2014, entrevista). 
Por que eu acho que os profissionais da atenção básica tem essa dificuldade em estabelecer o nexo? Porque a formação deles, inclusive os cursos de graduação, é muito ruim para a deteç̧ão de agravos relacionados ao trabalho. E eu acho que a formação, estou falando especificamente do médico, em Saúde Mental, ela é muito ruim na graduação. Ela é ruim para todos os agravos, em todos os transtornos mentais, mas, particularmente, quando se fala em transtorno mental relacionado ao trabalho. Então, ele tem dificuldade, ele não tem sensibilidade para detectar, ele nem pensa nessa possibilidade, muitas vezes (SILVEIRA, 2013, entrevista).

Eu acho [um problema] muito sério é a formação de pessoal de saúde mental (SELIGMANN-SILVA, 2014, entrevista).

Pensando na rede de saúde, pensando que o psiquiatra de um CAPS, de um equipamento faça a notificação [de um Transtorno Mental e do Comportamento Relacionado ao Trabalho] é muito raro, muito difícil. Eu não vou dizer que não tenha... Mas é uma luta [...]. Eu acho que em função da formação que eles têm (GARBIN, 2014, entrevista).

Nos cursos de medicina a abordagem à esfera psíquica é uma abordagem muito pobre. Ela não é transversal. Ela é uma abordagem estanque. Então, quando a gente passa pelas cadeiras, pelas disciplinas da psiquiatria, ai é como se fosse uma disciplina e eu acho que não pode ser visto como uma disciplina, porque a esfera psíquica, ela é inerente ao ser humano. [...] Tinha que ser transversal, a abordagem psíquica tinha que estar em todo momento, desde o comecinho até o final. E não está. Então isso passa pela mudança na formação do médico, do fisioterapeuta, do terapeuta ocupacional, de todo mundo (MAENO, 2014, entrevista).

Psicólogo tem aos montes [no Brasil], mas quem é que é formado para ser sensivel ao processo de adoecimento pelo trabalho? Também são poucos, proporcionalmente muito menos, os psicólogos ficam voltadas para outras questões mais puramente assistenciais, muito voltadas a $R H$, então o direcionamento da formação desses psicólogos também é problemático. A gente não conseguiu ter um corpo crítico da assistência que pudesse fazer diagnóstico (MAENO, 2014, entrevista).

O que eu acho que a gente deve fazer: tem que ser pela formação. [...] E tem de fazer, mostrar para as pessoas. No curso de Psicologia, no curso de Enfermagem, no Serviço Social, todas as áreas da Saúde, mostrar a relação [entre saúde mental e trabalho]. Ter disciplinas que mostram essa relação, e as pessoas fazerem residências multidisciplinares que mostrem essa relação (JACQUES, 2014, entrevista).

Eu sempre pensei, puxa vida, outros colegas [psiquiatras] deviam estudar psicopatologia do trabalho, então eu conto [os que estudam] nos dedos (SELIGMANN-SILVA, 2014, entrevista).

Considerando a apontada falta de formação ou qualificação dos profissionais de saúde para a compreensão das relações entre saúde e trabalho e, mais especificamente, entre saúde mental e trabalho, bem como o papel dos CERESTs na promoção do debate e formação em Saúde do Trabalhador e matriciamento da rede de saúde, uma dificuldade apontada pelos entrevistados se referiria à rotatividade dos profissionais de saúde que trabalham com atenção básica, associada ao desestímulo dos médicos para atuar no campo da saúde pública. 
O primeiro problema que eu vejo é que a rotatividade dos profissionais da atenção básica, ela é muito alta (SILVEIRA, 2013, entrevista).

É um desestímulo absurdo. É um sofrimento, eles [médicos] estão num sofrimento. Primeiro, porque ali realmente não era a Medicina que eles queriam fazer, isso está posto. Mas, para além disso, é um local de trabalho, no setor público, onde as relações estão tão deterioradas, onde a violência impera, a violência da população, a violência entre os colegas.... Não é uma violência explícita, ninguém vai bater em ninguém, mas a violência do não sentar $e$ conversar, do não sentar e pactuar [...]. Da competição (SILVA, 2013, entrevista).

Além disso, alguns entrevistados consideram que, no campo da Saúde do Trabalhador, haveria uma dificuldade de "aplicação do modelo"; faltariam "metodologias" ou instrumentalização para as demais áreas da saúde.

Eu acho que o campo da Saúde do Trabalhador, ele é muito intelectualizado, altamente intelectualizado. O braço prático, digamos assim, da práxis da Saúde do Trabalhador, ele é muito fraco (JARDIM, 2014, entrevista).

As abordagens da área da Assistência também são abordagens estanques, abordagens fragmentadas. Então isto é um fator também de dificuldade (MAENO, 2014, entrevista).

Faltam metodologias (DIAS, 2013, entrevista).

No plano institucional, as principais dificuldades mencionadas pelos entrevistados foram: relação com perícia do INSS; fragmentação de políticas e ações em Saúde do Trabalhador e dificuldade de articulação das esferas de governo (federal, estadual e municipal); indefinição do papel dos CERESTs e a falta de profissionais de diversas especialidades para neles atuar; e a "desresponsabilização" do médico pelo paciente.

A relação com a perícia do INSS será discutida na seção 6.3.1.15.

Em relação à formulação de políticas públicas na área de Saúde do Trabalhador, os entrevistados apontaram como dificuldades o fato de a área não ser prioridade no Ministério da Saúde, bem como a fragmentação de políticas e ações em Saúde do Trabalhador e dificuldade de articulação das esferas de governo (federal, estadual e municipal), já apresentada nos conflitos vividos no campo (no na seção, 6.3.1.12).

No caso dos CERESTs, duas questões foram apontadas pelos entrevistados: uma indefinição de seu papel ou de sua operacionalização (apesar da legislação ${ }^{196}$ ), e a

196 As portarias do Ministério da Saúde que definem o papel dos CERESTs são:

Portaria $\mathrm{n}^{0}$ 2.437, de 7 de dezembro de 2005. Dispõe sobre a ampliação e o fortalecimento da Rede Nacional de Atenção Integral à Saúde do Trabalhador - RENAST no Sistema Único de Saúde (SUS) e dá outras providências.

Portaria $\mathrm{n}^{0} 2.728$, de 11 de novembro de 2009. Dispõe sobre a Rede Nacional de Atenção Integral à Saúde do Trabalhador (RENAST) e dá outras providências. 
falta, em alguns casos, de equipes multiprofissionais (uma vez que, de acordo com a legislação, as equipes mínimas de serviços de atenção à saúde do trabalhador devem ser compostas por médicos, enfermeiros, técnicos e auxiliares de enfermagem). ${ }^{197}$

E uma coisa que a Portaria também acaba falhando é definir qual é o papel do CEREST. Os CERESTs hoje são entendidos como unidades de saúde, distribuídos em territórios. Cada estado conformou o seu território de acordo com o número de CERESTs disponibilizados e de acordo com o interesse político para receber o CEREST; o gestor municipal tem que ter interesse político de receber um CEREST que vai se localizar em um município, mas vai responder por uma região (SILVA, 2013, entrevista).

Você tem vários outros [profissionais] que seriam muito importantes numa equipe, dentro de um CEREST, se você pensa a questão da vigilância, da reabilitação [profissional], a questão da educação continuada e do atendimento integral a esse trabalhador, e eles não são definidos como prioritários (GREGGIO, 2014, entrevista).

Outro fator de dificuldade apontado seria, no caso da atenção básica, a ausência de "gestão da clínica" (não orientar o trabalhador quanto à condução de seu tratamento quando em interface com outras especialidades) ou a "desresponsabilização" (não orientá-lo quanto a seus direitos, por exemplo).

[Os trabalhadores ficam] muito perdidos na condução do seu problema de saúde. Seja no Sistema Único de Saúde, seja no setor privado. [...] É aquela coisa de você ter vários médicos e não ter nenhum que dá conta do seu problema, que faça gestão da clínica, da sua clínica, do seu problema. [...] Acho que os pacientes estão muito perdidos e muito sofridos, [...] muito mal orientados, $e$ tudo isso toma uma dimensão maior ainda pela baixa escolaridade (SILVA, 2013, entrevista).

A gente ouve, por exemplo: "Ah, mas isso gera um direito, isso já tem a ver com INSS, não com a gente". [...] É como se [o médico] não se responsabilizasse, no âmbito do seu atendimento, da sua atenção a esse trabalhador. Inclusive muitas vezes quando a gente fala sobre a CAT, que seria um direito fundamental do trabalhador, formal, essas questões vão aparecendo. Então, é uma área também, essa área da Saúde do Trabalhador, que acaba se deparando com essas [...] resistências ou até desresponsabilização... Identificando que é do outro a responsabilidade. Então é [papel] do INSS ou é do CEREST (GARBIN, 2014, entrevista).

Portaria ${ }^{0}$ 1.82, de 23 de agosto de 2012. Política Nacional de Saúde do Trabalhador e da Trabalhadora. $\mathrm{n}^{\circ}$ 1.206, de 24 de outubro de 2013. Altera o cadastramento dos Centros de Referência em Saúde do Trabalhador no Sistema de Cadastro Nacional de Estabelecimentos de Saúde (SCNES).

197 A Portaria $n^{\circ} 2.437$ (Ministério da Saúde), de 7 de dezembro de 2005, especificava como equipe mínima para um CEREST Regional: 6 profissionais de nível universitário, sendo ao menos 2 médicos (20 horas semanais) e 1 enfermeiro (40 horas semanais), e 4 profissionais de nível médio, sendo ao menos 2 auxiliares de enfermagem. Já a Portaria n 1.206 (Ministério da Saúde), de 24 de outubro de 2013, especifica como equipe mínima para um Serviço de Atenção à Saúde do Trabalhador: médicos clínicos, enfermeiros, técnicos e auxiliares de enfermagem. 
Já no âmbito da relação do trabalhador com os serviços de saúde, são apontadas como dificuldades a sua negação da doença, sobretudo no caso dos Transtornos Mentais e do Comportamento Relacionados ao Trabalho; o medo de admitir que adoeceu, sobretudo com Transtornos Mentais e do Comportamento Relacionados ao Trabalho; a autoculpabilização pelo trabalhador pela doença (inclusive mental/psíquica), isentando o papel desempenhado pelo trabalho.

[Quando o trabalhador chega à atenção básica e traz essa queixa mental, vai ser tratada como doença comum?] Ele mesmo traz a queixa da família (CODO, 2014, entrevista).

No primeiro momento até eles negam que estão adoecendo, ou então tem, "ah, estresse, estresse não é doença", "eu estou estressado", então começa a tomar um remédio para dor de cabeça, um remédio para dormir, e continua, eles só chegam mesmo quando eles não conseguem mais (GREGGIO, 2014, entrevista).

Alguns trabalhadores negam que eles estão doentes psiquicamente, às vezes você vê que ele, por exemplo, tem uma doença osteomuscular, mas o que o impede de voltar ao trabalho é o transtorno mental, mas ele não aceita (GREGGIO, 2014, entrevista).

Os próprios trabalhadores negam (SILVA, 2013, entrevista).

Quem está doente e não procura o médico e, muitas vezes, nem quer reconhecer que está doente, acha que vai passar porque teme faltar para ir ao médico $e$ com isso perder [...] prestígio, não ser considerado mais excelente, ser mandado embora [...]. Há um impedimento ao tratamento. Isso é uma coisa que é muito pouco denunciada (SELIGMANN-SILVA, 2014, entrevista).

Havia certo preconceito também, da classe trabalhadora, de incluir a questão da saúde mental, "estão chamando a gente de louco" (CODO, 2014, entrevista).

Muitos, talvez a maioria, chegam se culpabilizando, então é uma certa cultura da culpabilização desse trabalhador, ele mesmo chega: "Ah, eu não devia ter feito isso" e tal; poucos chegam dizendo [...] de uma falha da empresa ou de alguma assistência ou de capacitação de alguma coisa que eles não tiveram. A maioria se culpa. Se os próprios trabalhadores se culpam, você imagina os outros (GREGGIO, 2014, entrevista).

Uma importante questão apresentada é a que os entrevistados chamam de medicalização ou psicologização/psiquiatrização do trabalhador, na medida em que se observa que, uma vez identificado o "adoecimento" mental/psíquico, este é (por vezes excessivamente) tratado via prescrição medicamentosa, sem que, contudo, esse adoecimento seja investigado ou relacionado ao trabalho, sendo, portanto, tratado como algo de ordem estritamente individual.

Essa questão poderia estar relacionada a dificuldades já apresentadas, como: o despreparo da atenção básica para lidar com o campo da Saúde do Trabalhador, ou mesmo para a lida com a categoria "trabalho"; a categoria "trabalho" ser vista/tratada como algo secundário ou não contemplado no diagnóstico, sem que haja o 
estabelecimento do nexo ou relação do adoecimento com o trabalho; a falta de formação ou qualificação dos profissionais de saúde para a compreensão da dimensão da saúde mental, de modo geral, e em sua relação com o trabalho; a dificuldade de diagnóstico dos Transtornos Mentais e do Comportamento Relacionados ao Trabalho; a falta de consenso no campo da Saúde Mental, ou da Saúde Mental e Trabalho, sobre as relações entre "adoecimento" mental/psíquico e trabalho. Outro elemento possivelmente relacionado seria a percepção de que a "doença mental/psíquica" do trabalhador não teria como causa a relação com o trabalho, mas sim questões individuais (problemas na família, afetivos etc.).

\footnotetext{
A nossa função não é chegar e dar um calmante para ele [trabalhador] e mandar ele de novo de volta lá para o andaime. [...] A nossa função é investigar (JARDIM, 2014, entrevista).

O consumo medicamentoso, é absurdo ver o quanto os trabalhadores estão sendo medicalizados, essa é uma crítica muito grande que eu tenho ao movimento antimanicomial (BRANT, 2014, entrevista).
}

De repente nós vamos estar medicalizando o mundo do trabalho, que nem a gente está fazendo com as crianças nas escolas, dá aquele remédio [Ritalina] para todo mundo. E também a gente tem de cuidar, porque daqui a pouco dá antidepressivo para todo mundo, então eu acho que a gente tem que ir devagar (JACQUES, 2014, entrevista).

E muitas vezes os pacientes são medicados [...]. Ele precisa fazer uma terapia, a gente encaminha para um psicólogo, mas não são os primeiros profissionais onde ele chega (SILVEIRA, 2013, entrevista).

Um remédio não vai resolver, porque você não escuta e não investiga realmente de onde veio esse sofrimento. Então a pessoa continua inserida naquilo que a adoece, naquilo que a faz sofrer. Você não trabalha isso (GREGGIO, 2014, entrevista).

E muitas vezes eles já chegam muito medicados, porque eles já passaram por vários médicos, às vezes vários especialistas e já chegaram à psiquiatria (GREGGIO, 2014, entrevista).

Eu acho que é uma tendência de psicologização, psiquiatrização (JACQUES, 2014, entrevista).

Nós temos tido, eu falo "nós", profissionais da saúde, temos muita dificuldade de lidar com isso. [...] De caracterizar melhor, de não homogeneizar, de manejar esses casos, que não seja medicalização... (DIAS, 2013, entrevista).

Por fim, foram apontadas pelos entrevistados a dificuldade de engajamento dos movimentos sindicais em questões de Saúde do Trabalhador, sobretudo com os Transtornos Mentais e do Comportamento Relacionados ao Trabalho, bem como a dificuldade de participação e/ou representatividade dos trabalhadores no SUS.

[E o transtorno mental relacionado ao trabalho, ele está na pauta da discussão do movimento sindical?] Não está. É uma discussão incipiente (SILVA, 2014, entrevista). 
A CUT menciona os Transtornos Mentais e do Comportamento Relacionados ao Trabalho com raridade, o foco é a questão do assédio moral (SILVA, 2014, entrevista).

A gente trabalha de forma muito esporádica e muito fragmentada [com sindicatos], porque dificilmente tem diretores [sindicais] que querem pensar a saúde dos trabalhadores. Então fica mais na questão da pauta salarial mesmo. Mesmo quando isso chega a gente tem tido muita dificuldade (GREGGIO, 2014, entrevista).

$\mathrm{Na}$ verdade isso fala um pouco do declínio dos movimentos sociais, nesse declínio que a gente vive mesmo, nesse engajamento, eu acho que da população como um todo, dos trabalhadores como um todo. Então eu acho que talvez durante certo espaço de tempo nós não vamos ter pessoas engajadas como nós tínhamos antes. E com essa visão (GREGGIO, 2014, entrevista).

As categorias de alto risco de saúde mental, educação, bancários... Algumas categorias como a agrícola com a questão do envenenamento, etc. sempre tiveram muita consciência desse processo, sempre fizeram denúncia desse processo, mas nunca davam importância, nunca foi bandeira (CODO, 2014, entrevista).

Gosto de dizer que Saúde do Trabalhador, a participação dos trabalhadores está no DNA da saúde dos trabalhadores. Sem isso você não faz Saúde do Trabalhador. Isso é um dos pressupostos mais importantes para dizer que você está no campo da Saúde do Trabalhador e não no campo da Saúde Ocupacional, da Medicina do Trabalho, entre outras. Mas a gente tem percebido que essa participação dos trabalhadores tem sido muito difícil, muito complicada, esse fazer da Saúde do Trabalhador cotidiano, esse fazer do SUS, esse fazer da Saúde do Trabalhador pelo SUS, até porque fica sempre a discussão, a indagação de, afinal de contas, quem é que representa os trabalhadores? (SILVA, 2013, entrevista).

\subsubsection{A questão da simulação de Transtornos Mentais e do Comportamento Relacionados ao Trabalho}

Também se perguntou a opinião dos entrevistados sobre se haveria ou não a simulação de doença ligada ao trabalho, sobretudo Transtornos Mentais e do Comportamento Relacionados ao Trabalho.

A maioria dos entrevistados posicionou-se contrariamente à percepção de que os Transtornos Mentais e do Comportamento Relacionados ao Trabalho sejam "simulados", embora vários apontem que, sobretudo entre médicos e peritos, essa seja uma percepção disseminada.

Sempre com a acusação de que eles estavam inventando, de que eles tinham problemas psicológicos, e não problemas reais (JACQUES, 2014, entrevista).

A questão do transtorno mental sempre foi colocada como uma simulação, eu acho que isso ainda passa pela cabeça de muito perito quando ele vê alguém chegando com um transtorno mental (GREGGIO, 2014, entrevista).

Quando a gente está falando da ordem do transtorno mental e da saúde mental, existe [...]. E do velho discurso do "está fingindo" (JACQUES, 2014, entrevista). 
Me lembro de falas da década de 80, 90, mas até hoje a gente escuta esse tipo de fala, porque a evidência do transtorno mental, ela é diferente da evidência da doença física [...] Então, a gente escutava aquelas coisas absurdas, "não, porque tem quatro dias que ele não toma banho, ele já faz de propósito na véspera da perícia, ele simula", e as histórias mais malucas, isso sempre foi parte do argumento, mas para os transtornos mentais de uma forma geral (SILVEIRA, 2013, entrevista).

Os transtornos psíquicos, por serem justamente não visíveis como as doenças físicas, ou mensuráveis, eles são mais sujeitos a questionamentos quanto à origem, evolução, simulação, etc. (MAENO, 2014, entrevista).

Nós temos toda essa visão, na medicina do trabalho, que sempre o paciente [...] está querendo fugir do trabalho, portanto ele inventa doenças, e daí eu [...] conheci [...] o pessoal [...] da Faculdade de Medicina da Santa Casa, trabalhavam com Medicina do Trabalho, nessas grandes siderúrgicas e eles sempre partiam do princípio, [...] de que o trabalhador, ele recorre ao médico para fugir do trabalho (BERTOLLI FILHO, 2014, entrevista).

As ciências de saúde, sempre [discutem]... Será que esse indivíduo não é um doente, isto é ele é um amoral ou imoral que está inventando? E essa nova ideologia que eu odeio que é o Dr. House, 198 "todo mundo mente", "todo paciente mente", revigorou inclusive todo esse tipo de discussão (BERTOLLI FILHO, 2014, entrevista).

Essa dimensão da simulação poderia estar associada também à já apresentada concepção de dignificação do trabalho (ou à "apologia do trabalho").

Para uma entrevistada, a dimensão da simulação estaria associada à dimensão subjetiva do "adoecimento" mental/psíquico, e sua invisibilidade.

Existe a dimensão da subjetividade, da invisibilidade... Da invisibilidade, principalmente. E do velho discurso do "está fingindo" (JACQUES, 2014, entrevista).

Outra entrevistada aponta que, por vezes, o discurso da simulação do adoecimento pelo trabalhador está presente, mas de forma velada.

E às vezes também associada assim com um caso mais, vamos chamar de uma loucura, "ah, mas a pessoa também usa desse modo de reagir", então às vezes não é um dito de maneira tão assumida a simulação, mas dito dessa outra forma (GARBIN, 2014, entrevista).

Contudo, um dos entrevistados chamou atenção para o fato de, dada a "invisibilidade" do adoecimento mental, este se prestar mais à simulação que, em certos casos, ocorreria:

É muito pouca gente que simula. Muito pouca gente. Mas quando simula, simula em saúde mental. Porque não tem exame... [...] E tem treinamento para isso. Tem empresas que te treinam a ter aposentadoria por doença mental. $O$ cara te pega laudo, te dá o laudo de psiquiatra, um laudo falso, te ensina como é que

198 Série televisiva norte-americana, cujo personagem principal é o médico Dr. Gregory House, interpretado pelo ator inglês Hugh Laurie. 
você tem que se comportar na frente do perito, para ele poder dizer que você estava doente (CODO, 2014, entrevista).

\subsubsection{Perícia médica do INSS}

Quando perguntados sobre sua percepção a respeito da perícia médica do INSS, os entrevistados destacaram a discordância ou questionamento, pelos peritos, da relação ou nexo com o trabalho feito pelo serviço de saúde.

Porque, muitas vezes, o nosso maior problema é que ele [perito] não dá a incapacidade para o trabalho, ele às vezes reconhece o adoecimento, mas não dá a incapacidade. Agora, estamos vendo que ele não está dando nexo $e$ acredito que ele está agora exercendo uma prerrogativa que é dele, ele tem que fazer isso, que é de discordar dos nexos técnico-epidemiológicos. Está acontecendo muito em dermatite, LER/DORT nem se fala, aparece bastante, $e$ casos assim que você não entende como que está sendo desconsiderado. [Nos transtornos mentais também?] Ah, com certeza! (SILVA, 2013, entrevista).

Muitas vezes, a perícia nega. [...] Mesmo quando ele [trabalhador] vai [para a perícia] e a gente consegue fazer um nexo com o trabalho, chega na perícia, dificilmente ele consegue estabelecer (GREGGIO, 2014, entrevista).

Por mais que a gente esteja fazendo essa discussão, eu acho que ainda existe uma resistência, ou talvez uma dificuldade técnica dos peritos em reconhecer isso (GREGGIO, 2014, entrevista).

O relatório dele [trabalhador] tinha que ter duas páginas e contando em detalhes para convencer o perito de que aquela trajetória ocupacional explicava o quadro psiquiátrico que ele tinha desenvolvido. Então ele [o Transtorno Mental e do Comportamento Relacionado ao Trabalho] precisa ser muito melhor documentado do que os outros casos e vez por outra a gente ainda tem recursos, porque os peritos acham que as evidências são frágeis e que outras dimensões da vida daquele indivíduo, que não o trabalho, justificam o adoecimento ou explicam de uma [forma] mais adequada (SILVEIRA, 2013, entrevista).

Não existe nenhum impedimento legal escrito no papel de você reconhecer, a Previdência, por exemplo, reconhecer um caso de depressão relacionado ao trabalho. Ele emperra é na hora das evidências técnicas. [...] No passado se falava "isso não tem relação com o trabalho". Hoje não, o Estado reconhece, o transtorno mental pode sim ter relação com o trabalho, cabe a vocês, que são da área, me apresentarem as evidências disso (SILVEIRA, 2013, entrevista).

Todos nós tínhamos problemas com o INSS, que negava os benefícios dos trabalhadores doentes, descaracterizavam doenças relacionadas ao trabalho (SILVA, 2014, entrevista).

Não se esforça para dentre esses benefícios [previdenciários concedidos], dentre esses transtornos psíquicos, não se esforça para reconhecer aqueles que são ocupacionais (MAENO, 2014, entrevista).

[A perícia parece] Dificultar o acesso dos trabalhadores que necessitam aos benefícios por doença (MAENO, 2014, entrevista).

Uma questão que poderia estar associada, e que foi apontada por alguns entrevistados, seria a das deficiências ou falhas na formação ou qualificação dos peritos. 
Eu acho que vai ser o nosso futuro investir na perícia do INSS (JACQUES, 2014, entrevista).

A maioria dos peritos não tem formação (SELIGMANN-SILVA, 2014, entrevista).

O médico perito também, desde criancinha, ouviu dizer que o trabalho é importante, que o trabalhador não gosta de trabalhar muitas vezes, principalmente trabalhador brasileiro, etc., por isso o nosso país está nessa condição etc. e tem a ver com a extração social dos médicos, esse médico, quando ele cai dentro da Previdência Social e não conhece o mundo do trabalho, ele continua sem conhecer o mundo do trabalho na Previdência, porque a Previdência não propicia esse conhecimento. [...] A Previdência, ela privilegia o papel, ela privilegia documentos autodeclaratórios das empresas, documentos normativos de que o trabalho $e$ as condições de trabalho estão em conformidade, de que as condições de trabalho estão boas; o médico da Previdência aceita isso sem questionar de onde vem essa informação, que é da parte interessada (MAENO, 2014, entrevista).

Um perito veio reclamar para mim que ele estava muito incomodado porque os residentes estavam colocando referência bibliográfica nos relatórios. Porque eles recusavam, então: vocês querem evidências? Nós vamos mostrar evidências! E aí criava um problema para eles, porque eles não correm atrás de estudar (SILVEIRA, 2013, entrevista).

\section{Outra questão apontada como dificultadora da relação com a perícia, por alguns entrevistados, seria uma relação mais próxima mantida pelos peritos com as empresas, e/ou sua adesão ao modelo teórico da Medicina do Trabalho/Saúde} Ocupacional.

O perito muitas vezes tem uma adesão [à empresa] por formação... Por formação e por origem (SELIGMANN-SILVA, 2014, entrevista).

[Existe ainda essa barreira para o reconhecimento desse quadro de sintomas como algo patológico?] Existe, mas ela não é a barreira do conhecimento, ela é uma barreira política. [....] Mesmo no caso da doença comum (CORRÊA FILHO, 2014, entrevista).

Os médicos peritos previdenciários, boa parte deles são também médicos do trabalho patronais (CORRÊA FILHO, 2014, entrevista).

Formação de peritos, ela virou um grande negócio no país. Então a gente tem cursos de especialização em formação de peritos, as próprias UNIMEDs têm oferecido esses cursos e eles são bastiões do conservadorismo em relação a isso. [...] formam peritos não só para a Previdência Social, mas formam peritos para a Justiça do Trabalho (SILVEIRA, 2013, entrevista).

Uma das entrevistadas é mais veemente na afirmação de que, por vezes, faltaria ética na relação do médico perito com o trabalhador periciado.

Além de não ter formação, eles não têm compromisso! Ético (SELIGMANN-SILVA, 2014, entrevista).

[os peritos fazem coisas] Para que a pessoa mostre que ela está mentindo. Então criam umas armadilhas na fala, no gesto, tanto para LER como para problemas de saúde mental (SELIGMANN-SILVA, 2014, entrevista). 
Por outro lado, alguns entrevistados apontam também uma percepção mais positiva da relação com a perícia; um dos elementos apontados seria a consideração de que existe um sofrimento (mental) no exercício da função.

Eu acho que a perícia do INSS é muito difícil, mas eu acho que eles também sofrem muito. [...] Eu quero deixar claro que eles também têm problemas de saúde mental por ocupar essa função. Porque ali a gente tem um conflito na origem do que eles fazem lá, na própria função (JACQUES, 2014, entrevista).

Estudei perito. Eu tenho um livro sobre perito. Chama "Julgar e Cuidar". ${ }^{199}$ Foi publicado pela Vozes há pouco tempo... [Eles adoecem?] Sim (CODO, 2014, entrevista).

O outro elemento positivo apontado por alguns entrevistados seria a identificação de movimentos de renovação do quadro de peritos; a substituição do quadro de peritos terceirizados - que recebiam por procedimento - por concursados 200 teria introduzido "mudanças de mentalidade" e o surgimento de (como coloca um dos entrevistados) "peritos do bem".

Você tem os peritos mais antigos se aposentando, os peritos mais jovens têm uma postura um pouco melhor do que os anteriores, e o que a gente tem percebido é que, muitas vezes, eles evitam fazer juízo de valor na frente do paciente (SILVEIRA, 2013, entrevista).

Eu acho que tem a ver também com a mudança de governo mesmo. Então, o fato de você ter um governo que é identificado com o Partido dos Trabalhadores, que trouxe essa agenda para a Previdência, eu acho que isso, de fato, conseguiu trazer algumas mudanças (SILVEIRA, 2013, entrevista).

Mas eu percebi que realmente houve uma renovação dos quadros da Previdência. [...] Até uns dez anos atrás eles tinham muitos quadros que pagavam por procedimento para terceirizados, isso acabou, hoje todo mundo é concursado, isso renovou muito, muita gente saiu e isso mudou um pouco a mentalidade também (SILVEIRA, 2013, entrevista).

[Entre] os médicos peritos da Previdência Social, ao longo desses anos, começaram a surgir os chamados "peritos do bem". Então eles estão aumentando de número (CORRÊA FILHO, 2014, entrevista).

199 CODO, Wanderley. Julgar e Cuidar. Saúde Mental do Perito Médico. São Paulo: LTR, 2013.

200 Lei $n^{\circ}$ 10.876, de 2 de junho de 2004. Cria a Carreira de Perícia Médica da Previdência Social, dispõe sobre a remuneração da Carreira de Supervisor Médico-Pericial do Quadro de Pessoal do Instituto Nacional do Seguro Social - INSS e dá outras providências.

Contudo, a Medida Provisória $n^{\circ}$ 664, de 30 de dezembro de 2014 (Altera as Leis $n^{\circ} 8.213$, de 24 de julho de $1991, n^{\circ} 10.876$, de 2 junho de 2004, $n^{\circ} 8.112$, de 11 de dezembro de 1990, e a Lei $n n^{\circ} 10.666$, de 8 de maio de 2003), estabelece novas regras, que entraram em vigor em 30 de dezembro de 2014: possibilidade de o INSS fazer convênios ou termos de cooperação técnica para que as perícias relacionados com auxílio-doença sejam realizadas por médicos de fora da carreira de Perícia Médica do INSS ( $\S n^{\circ}$ e 60 do art. 60). 


\subsubsection{A Lista B do Decreto 3048 (1999)}

Como discutido na seção 6.1 desse Capítulo, os transtornos mentais e do comportamento foram reconhecidos no Brasil como doenças relacionadas ao trabalho em 1999 por meio da Portaria 1339 do Ministério da Saúde, que publicou uma Lista de Doenças Relacionadas ao Trabalho (constante no Anexo B deste trabalho, com seus respectivos CIDs - códigos na Classificação Internacional de Doenças), e por meio do Decreto 3048. A Lista B201 do Anexo II do Decreto 3048 (BRASIL, 1999a), revogado e atualizado pelo Decreto 6.957 (BRASIL, 2009), institui a relação de Transtornos Mentais e do Comportamento Relacionados com o Trabalho (Grupo V da CID-10) e os respectivos agentes etiológicos ou fatores de risco de natureza ocupacional.

Em se tratando de um marco no reconhecimento legal dos Transtornos Mentais e do Comportamento Relacionados ao Trabalho, perguntou-se aos entrevistados suas percepções sobre essa Lista, seu processo de construção, sua repercussão/impactos.

Segundo relato de Sílvia Jardim (2014), a Lista B foi construída a partir de demanda do Ministério da Previdência e elaborada por grupo coordenado por René Mendes. A relação dos Transtornos Mentais e do Comportamento Relacionados ao Trabalho foi elaborada por grupo que contou, entre outras, com as seguintes participações: Andréia de Conto Garbin (psicóloga, CEREST SP), Edith Seligmann-Silva (psiquiatra, USP/FGV), Ildeberto Muniz de Almeida (médico, UNESP Botucatu, especialista em toxicologia), José Carlos do Carmo "Kal" (médico, CEREST SP), Silvia Rodrigues Jardim (psiquiatra, Instituto de Psiquiatria da UFRJ).

Posteriormente, segundo relato de Andréia Garbin (2014), houve articulação entre os Ministérios da Saúde e da Previdência para que essa Lista da Previdência subsidiasse os materiais do Ministério da Saúde. Em 2001, o trabalho culminou na publicação do Manual "Doenças relacionadas ao trabalho: manual de procedimentos para os serviços de saúde".

O René Mendes foi contratado para elaborar uma primeira lista de agravos em saúde do trabalhador para o INSS. Isso lá por volta de 1998. E nesse momento [...] ele convida algumas pessoas para algumas reuniões. E em uma reunião que

\footnotetext{
201 A Lista B pode ser encontrada no Anexo B deste trabalho (Transtornos Mentais e do Comportamento Relacionados com o Trabalho), Quadro 10- Transtornos Mentais e do Comportamento Relacionados ao Trabalho, quadros nosológicos e agentes etiológicos.
} 
aconteceu em São Paulo, na Faculdade de Saúde Pública [...], pelo CEREST fomos eu e o "Kal" [José Carlos do Carmo], que era um médico. E nessa reunião nós tínhamos a Silvia [Rodrigues] Jardim, [...] tínhamos a professora Edith [Seligmann-Silva], e tínhamos outras pessoas. Eu lembro que a professora Edith chamava a atenção para o ciclo vigília sono, a Sílvia Jardim para o burn-out. Enfim, foi uma reunião que nós tínhamos pessoas [...] conduzidas pelo René Mendes. Depois houve uma articulação [entre os Ministérios da Saúde e da Previdência] para que essa lista que estava encomendada [...] pela Previdência, subsidiasse esse material do Ministério da Saúde. [...] Quem continuou fazendo essa articulação foi ainda o René Mendes, e ele trabalhava com esse material, e que aí culminou lá com a publicação em 2001 [...] do Manual de doenças relacionadas ao trabalho. [...] Eles desencadearam um processo de discussão coletiva, eles chamaram grupos de profissionais (GARBIN, 2014, entrevista).

E qual era a proposta? Era essa de um grupo de técnicos da saúde mental do trabalhador que fizesse ali uma proposta de inclusão numa lista dos transtornos mentais que esse grupo considerasse já reconhecidamente relacionados ao trabalho. [...] E o coordenador técnico dessa reunião foi o René Mendes, que estava ali como consultor [...]. Integrantes desse grupo que compareceram nesse dia: eu, pelo Programa de Organização do Trabalho e Saúde Mental do Instituto de Psiquiatria da UFRJ [...]; Edith Seligmann-Silva, que, na época, [...] já estava aposentada da USP, mas não da FGV; a Andréia [de Conto] Garbin [...] do CEREST, em São Paulo; eu acho que a Maria Maeno estava convidada, mas não pôde ir [...], e do CEREST tinha um médico, que é o Kal [José Carlos do Carmo]. E tinha também um outro, que veio de Botucatu [Ildeberto Muniz de Almeida], que era mais especializado na parte de toxicologia [...]. E que aconteceu? Cada um tinha levado um pouco, a gente levou as anotações, porque havia questões em relação a [...] se fazia sentido uma lista que fechasse, havia uma preocupação em que a lista fechasse em torno de certos conceitos, de certos diagnósticos, melhor dizendo, a relação com o trabalho, e se perdesse a possibilidade de fazer qualquer diagnóstico relacionado ao trabalho. [...] Então nós tínhamos uma lista... E a estrutura da lista, que ela tem duas entradas. [...] Não tem como os transtornos mentais não entrarem aqui, tem que entrar, mesmo que capenga, mesmo que com defeitos, tem que entrar! Não vai perder essa chance histórica de entrar, entra do jeito que der! [...] (JARDIM, 2014, entrevista).

Vários dos entrevistados consideram que a inclusão dos Transtornos Mentais e do Comportamento Relacionados ao Trabalho na Lista de Doenças Relacionadas ao Trabalho era "inevitável", dadas as pressões que vinham sendo feitas por técnicos da saúde e movimentos dos trabalhadores. Essa inclusão é percebida como uma conquista, ${ }^{202}$ uma oportunidade política para dar visibilidade aos Transtornos Mentais e do Comportamento Relacionados ao Trabalho.

[...] Isso foi uma oportunidade política que o René Mendes encontrou (JARDIM, 2014, entrevista).

Foi uma oportunidade rara (JARDIM, 2014, entrevista).

Eu acho que tinha um movimento dos técnicos da área, [...] uma pressão do movimento sindical [...] Quando é revista a lista de doenças relacionadas ao trabalho e a Previdência e a Saúde adotam a mesma lista, [...] o Estado

202 Uma voz claramente dissonante a esse respeito, entre os entrevistados, é a de Luiz Carlos Brant: É uma conquista? É engraçado como num determinado momento da história colocar situações claramente da ordem do psíquico se torna uma conquista. Eu vejo isso com grande temor (BRANT, 2014, entrevista). 
consegue estabelecer um mínimo de consenso, pelo menos com relação à lista, então eu acho que é fruto de uma grande pressão social. Uma pressão que vem dos técnicos, mas que vem também dos trabalhadores (SILVEIRA, 2014, entrevista).

Eu acho que a gente estava num momento em que não tinha mais como esconder isso (JACQUES, 2014, entrevista).

Ela foi muito importante, [...] foi muito importante ter essa Lista, a gente trabalhar com ela (GREGGIO, 2014, entrevista).

Isso é que é interessante na Lista, que ela usa o que já tem. Então tudo já está na $C I D$, na CID 10. Inclusive a coluna 2, dos agentes etiológicos, tudo tem numeração na $C I D$, eles são bem conhecidos. [Então foi também uma estratégia de legitimação da própria Lista?] De legitimação. Uma estratégia de legitimação. Não tinha ninguém ingênuo ali (JARDIM, 2014, entrevista).

Essa Lista não foi inventada do nada. Ela exigiu esforço de várias pessoas especializadas, é uma lista de 200 doenças (MAENO, 2014, entrevista).

Nesse sentido, a Lista B poderia mobilizar/disseminar informações e promover conscientização para a Saúde do Trabalhador.

A construção dessa Lista seria uma forma de disseminar que essas doenças poderiam ser relacionadas ao trabalho. Uma forma de envolver toda a área assistencial, toda a área de vigilância do SUS, também em Saúde do Trabalhador (MAENO, 2014, entrevista).

A Lista $B$, ela também foi impulsionadora, tanto da consciência da população, no geral, quanto dos técnicos com relação a trabalho (CODO, 2014, entrevista).

Contudo, apesar de a Lista B ser considerada um marco e uma vitória política no sentido do reconhecimento legal dos Transtornos Mentais e do Comportamento Relacionados ao Trabalho, são apontadas pelos entrevistados questões como sua não utilização, sua necessidade de aperfeiçoamento/atualização e questões conceituais como o enquadramento ou especificidade dos termos/categorias abarcados.

Quanto à sua utilização, ou impacto, alguns entrevistados têm a percepção de que não ocorreu, ou pelo menos não até o surgimento do NTEP (discutido no tópico 6.3.19).

Mesmo com a Lista [B] sendo bastante generosa [...] do ponto de vista dos números e transtornos de todos os tipos, incluindo os psíquicos, na prática, não funcionava (MAENO, 2014, entrevista).

O impacto foi zero. [...] Eu acho que o impacto, na ocasião, portanto em 1999, 2001, quando eles saíram [Lista B e Manual "Doenças relacionadas ao trabalho: Manual de procedimentos para os serviços de saúde"], é claro que eu estou sendo exigente nesse sentido, mas eu acho que o impacto disso no campo da Saúde do Trabalhador, especificamente, eu acho que fez assim uma marolinha, em São Paulo [...]. No Brasil, eu acho que nem marolinha fez (JARDIM, 2014, entrevista).

A Lista B não produziu impacto algum. Nem para o lado das patologias físicas nem para o lado das patologias mentais. Enquanto não surgiu o NTEP isso continuava embaixo do tapete. Agora isso que eu te disse, é extremamente ofensivo para quem fez a Lista B. O pessoal fica muito bravo quando eu digo isso, inclusive diz assim: "É, não deu trabalho construir essa lista? Essa lista é uma 
vitória!" Eu digo "É uma vitória, só que é uma vitória de Pirro", não produziu efeito (CORRÊA FILHO, 2014, entrevista).

Eu acho que ela não produz tendência nenhuma, uma vez que ela não é automatizada nos computadores das pessoas que diagnosticam (CORRÊA FILHO, 2014, entrevista).

Antes da gente conseguir ampliar esta Lista, a gente tem que entender que ela existe, foi o possível no momento, e eu acho que a gente tem de se dedicar para que as pessoas usem (JACQUES, 2014, entrevista).

A Lista B teria, para alguns entrevistados, necessidade de aperfeiçoamento/atualização como, por exemplo, a inclusão de outras substâncias relacionadas aos Transtornos Mentais e do Comportamento Relacionados ao Trabalho, bem como da depressão não apenas produzida por agentes orgânicos. ${ }^{203}$

[Então a senhora coloca que a Lista B precisa ser aperfeiçoada?] Com certeza! (JACQUES, 2014, entrevista).

É uma lista que está totalmente desatualizada. [...] É uma Lista que eu acho que todo mundo já percebe que hoje a gente teria que ter avançado (GREGGIO, 2014, entrevista).

E nós temos várias outras substâncias com as quais hoje as pessoas trabalham e que também não são citadas [na Lista]. E que são substâncias que também causam transtornos e delírios. Essa Lista na verdade já deveria ter sido repensada há muito tempo (GREGGIO, 2014, entrevista).

Ficaram pouquíssimas doenças de fora, justamente algumas das doenças que ficaram de fora, foram da esfera mental. Por exemplo, a depressão, ela só é reconhecida quando ligada a substâncias químicas nessa lista. Os outros transtornos psíquicos não, mas a depressão sim (MAENO, 2014, entrevista).

É um erro, tem um erro histórico, que até eu já dei uma corrigida nisso [...]. Os transtornos mentais orgânicos, a gente tinha fechado, e o alcoolismo, a gente discutiu bastante mesmo nesse dia [da reunião], de entrar o alcoolismo relacionado ao trabalho, de entrar depressão... Olha o erro onde está, depressão produzida só por agentes orgânicos, foi um erro [...] de formatação, e saiu assim na lei. Tem um artigo [...] meu de 2011, "Depressão no Trabalho", 204 onde eu faço referência a isso aqui, e corrijo isso inclusive na teoria, tanto a importância de se fazer o diagnóstico diferencial [...] de quadros depressivos com a intoxicação, [...] quanto que depressão não tem como causa apenas $e$ exclusivamente intoxicações... Então foi um erro de diagramação, de formatação (JARDIM, 2014, entrevista).

A Lista B também teria, para alguns entrevistados, questionamentos conceituais, como o enquadramento ou especificidade dos transtornos/doenças abarcados.

\footnotetext{
203 No Apêndice E - “O processo de inclusão dos TMCs na Lista B" apresentam-se excertos da entrevista realizada em 18 de setembro de 2014 pela autora com Silvia Rodrigues Jardim, uma das envolvidas no processo de construção da Lista B (Decreto 3048, de 1999) e responsável pela redação do capítulo sobre os Transtornos Mentais e do Comportamento Relacionados ao Trabalho da obra "Doenças relacionadas ao trabalho: manual de procedimentos para os serviços de saúde" (2001).
}

204 JARDIM, Sílvia. Depressão e trabalho: ruptura de laço social. Rev. bras. saúde ocup. , São Paulo, vol. 36, n. 123, jun. 2011. 
A questão da violência em si, como causadora do transtorno pós-traumático, entre outros, não é tratada da forma que deveria (GREGGIO, 2014, entrevista).

Havia consenso em relação... Um consenso, digamos assim, momentâneo, porque havia dúvidas no grupo todo em relação se a Lista era uma boa ou não, mas acabou ganhando isso de não deixar os transtornos mentais de fora, deixar lá pelo menos a ponta do iceberg, sabendo que o continente era muito maior... Poderia ser muito maior (JARDIM, 2014, entrevista).

Eles [condutores do processo] queriam enxugar a Lista [...] Mas não tem como os transtornos mentais não entrarem aqui, tem que entrar, mesmo que capenga, mesmo que com defeitos, tem que entrar! Não vai perder essa chance histórica de entrar, entra do jeito que der (JARDIM, 2014, entrevista).

A gente deveria [...] ter formas de especificar melhor, inclusive tanto a questão do adoecimento, mas os sintomas também, [...] porque os sintomas muitas vezes vão dizer de um sofrimento, e eu sei que a gente precisa estar caracterizando pela CID, mas se você pega uma lista tão complexa, que aí você pega um balaio de gato, [...] e você não aponta para outros transtornos hoje prevalentes (GREGGIO, 2014, entrevista).

Para mim fica como que o samba do crioulo doido. Você não consegue atingir a especificidade de cada item ou de cada termo colocado aqui. Eu acho que seria muito interessante se nos debruçarmos sobre cada um desses termos $e$ fizéssemos toda uma genealogia epistêmica para que pudéssemos realmente ter clareza no que isso aqui está querendo dizer (BRANT, 2014, entrevista).

\subsubsection{Questões conceituais e terminologias usadas com relação aos Transtornos}

Mentais e do Comportamento Relacionados ao Trabalho na Lista B

Ainda relacionadas à Lista $B$, outras questões conceituais foram apontadas como polêmicas pelos entrevistados: as divergências (ou sugestões de reflexão) a respeito das terminologias usadas com relação aos Transtornos Mentais e do Comportamento Relacionados ao Trabalho, notadamente "transtorno" e "sofrimento" (divergência possivelmente relacionada à já apresentada falta de consenso ou mesmo disputa, no campo da saúde mental, ou da saúde mental e trabalho, sobre as relações entre "adoecimento" mental/psíquico e trabalho).

Duas das entrevistadas, que participaram do processo de construção da Lista B, expuseram a necessidade de construir uma Lista que "acomodasse" essas divergências.

Eu acho que se acabou seguindo uma lógica [...] dessas classificações tradicionais, acho que o reconhecimento [...] de terminologias que nós [...] identificávamos que [...] não refletiriam exatamente o que a gente quer falar em termos de saúde mental... [...] Mas, enfim, penso que eles optaram ali por uma tradição, mais clássica... E usando já a CID, coisas dessa natureza... E não sei também [...], para ser sincera, se seria tão fácil chegar a um consenso sobre outra denominação. Muito das diferentes abordagens, quando você faz referência a uma terminologia, então você vincula isso com um determinado autor (GARBIN, 2014, entrevista). 
Esses aqui que entraram [transtornos da lista] foram o nosso consenso naquela época. Nesse grupo, havia consenso, digamos assim, momentâneo (JARDIM, 2014, entrevista).

Havia uma preocupação em que a Lista fechasse em torno de certos conceitos, de certos diagnósticos. [...] A Lista não fecha o processo do estabelecimento do nexo. Por isso que ela é boa, não é porque ela é fechada, é porque ela é aberta (JARDIM, 2014, entrevista).

\section{O primeiro questionamento, colocado por alguns entrevistados, foi o da necessidade de distinguir "sofrimento mental" de "adoecimento" (ou de não reduzir um ao outro).}

Burn-out não é doença, é um sofrimento. [...] Em primeiro lugar não é doença. Em segundo lugar, é um sofrimento provocado pela impossibilidade de trabalhar (CODO, 2014, entrevista).

Eu tenho muito incômodo e mal-estar mesmo com o que eu chamo de uma redução de se chamar o sofrimento mental e rotulá-lo de adoecimento. Eu acho que são coisas distintas. Mal-estar no trabalho, o sofrimento no trabalho e o adoecimento no trabalho são coisas distintas e que a gente não pode misturar (DIAS, 2013, entrevista).

Isso que nós estamos chamando de sofrimento ou adoecimento mental, eu acho que tem muitas discussões inclusive em relação a essas terminologias (SILVA, 2013, entrevista).

Eu vejo que essa questão da transformação do sofrimento em adoecimento é um debate que precisa ser ampliado. E a própria categoria sofrimento, ela precisa de uma visibilidade, de uma socialização, de ampliar esse debate em torno da categoria sofrimento como uma dimensão humana. E não como algo a ser evitado, reparado, medicado, consertado ou qualquer coisa (BRANT, 2014, entrevista).

\section{Outros entrevistados questionam o emprego da terminologia "transtorno", em vez da terminologia "doença”, e apontam implicações decorrentes dessa diferença.}

Se nós temos uma lista de doenças, tem doenças que são mentais, ou psicomentais, então se deveria tratar como doença, não de uma forma tão generalizada assim (GREGGIO, 2014, entrevista).

Você dizer que uma pessoa tem um estresse pós-traumático, [...] você diminui essa carga, se você dá um nome a esse adoecimento ao invés de falar que tem um "transtorno" e aí você generaliza. Eu acho que você não estaria rotulando essa pessoa, principalmente porque quando você fala que tem uma doença, você pensa que isso não é o sujeito doente, você tem uma doença e passível de tratar. Então se você tem um "transtorno", muitas vezes, a pessoa "ah, é transtorno mental, é doido". Então, eu acho que o peso é maior (GREGGIO, 2014, entrevista).

Quando coloca "transtorno", é inclusive uma estratégia jurídica diferente de quando você coloca, por exemplo, "doença". Porque eu colocando "doença", você é chamado pela própria ciência, pelo que ela conseguiu construir até hoje, para você conseguir como se fosse estabelecer um nexo, provar ou não, alguma coisa nessa ordem. Mas quando você coloca a palavra "transtorno", você dilui de uma tal forma no discurso da ciência atual, cuja consequência maior de tudo isso, não é mais a pergunta pela cura (BRANT, 2014, entrevista).

[Quais seriam as implicações de se utilizar a categoria "Transtorno"?] É o controle. [...] Hoje o objetivo não é você ter a cura de alguém que foi diagnosticado como detentor de um transtorno mental, mas que você tenha esse 
indivíduo sob seu controle. [...] Eu vejo isso como um enorme controle sobre o trabalhador, a questão dos transtornos psíquicos ou dos transtornos mentais (BRANT, 2014, entrevista).

Outros entrevistados questionam o emprego da terminologia "transtorno", em vez da terminologia "sofrimento".

[O que a senhora acha do nome transtorno?] Eu acho um horror. Não é transtorno, é sofrimento. Mas eu acho que é uma tendência de psicologização, psiquiatrização, até que eu acho que é melhor o termo, e eu acho horrível. Eu acho que a gente deveria usar a palavra sofrimento (JACQUES, 2014, entrevista).

O entrevistado Luiz Carlos Brant problematiza também os termos "sofrimento", "adoecimento" e "doença mental".

O que eu vejo é exatamente, um sofrimento manifestado no trabalho, e eu não consigo ver "ah, isso é sofrimento psíquico, isso é sofrimento físico", ou qualquer coisa dessa ordem. Porque quando eu coloco o adjetivo psíquico, eu já estou qualificando esse substantivo sofrimento e sinalizando a existência de outros sofrimentos. Mas ninguém fala de outros sofrimentos, sofrimento psíquico, se é psíquico deve ter outros, deve ter sofrimento moral, deve ter sofrimento, sei lá o que, espiritual (BRANT, 2014, entrevista).

Adoecimento entendido, sobretudo, como atribuição ao trabalhador da identidade de doente. Aí que estava exatamente o que eu chamo desse jogo perverso da instituição (BRANT, 2014, entrevista).

E na minha concepção, não existe doença mental. O que existe são maneiras de ser, de viver, de trabalhar, com todas as suas diferenças (BRANT, 2014, entrevista).

Acho que toda classificação é uma grande forma de aprisionamento. De enquadramento. Isso é um enorme enquadramento. [O senhor é o único entrevistado que não considerou a Lista B como uma conquista]. Em última instância, a aposentadoria por invalidez por uma causa mental, é uma verdadeira condenação. Para o resto da vida. É diferente daquele que aposentou por um câncer, por uma outra coisa (BRANT, 2014, entrevista).

\subsubsection{Manual "Doenças relacionadas ao trabalho: manual de procedimentos para os} serviços de saúde" (2001)

Em 2001, a partir da relação da Lista B de doenças relacionadas ao trabalho, houve a publicação pelo Ministério da Saúde, com apoio da Organização Panamericana de Saúde, do Manual "Doenças relacionadas ao trabalho: manual de procedimentos para os serviços de saúde", elaborado sob a coordenação geral de Elizabeth Costa Dias. O capítulo específico sobre os Transtornos Mentais e do Comportamento Relacionados ao Trabalho foi redigido por Sílvia Rodrigues Jardim.

Ela [Jacinta de Fátima Senna da Silva, coordenadora da Área Técnica de Saúde do Trabalhador do Ministério da Saúde] convidou quatro pessoas para fazerem o Manual. [José] Tarcísio [Penteado] Buschinelli, a Elizabeth [Costa] Dias, Ildeberto 
Muniz [de Almeida] e o René Mendes [...]. Então essas pessoas foram convidadas para fazerem esse Manual (MAENO, 2014, entrevista).

Em 1999, eu recebi um e-mail [...] da Elizabeth [Costa] Dias, dizendo [...] que eles tinham conseguido pelo Ministério da Saúde, com o apoio da OPAS [...]fazer um manual das doenças relacionadas ao trabalho [...], e que a Elizabeth Dias, era a coordenadora desse trabalho, e tinha convidado a Edith Seligmann [Silva] para escrever esse capítulo, e que a Edith não tinha podido, e que tinha me indicado. Então [...] comecei a escrever. Foi só em 2000 que [...] eu retomei e fechei [...] o [capítulo do] manual. [...] E aí saiu daquele jeito. [...] E aí foi o Manual, que saiu pelo Ministério da Saúde (JARDIM, 2014, entrevista).

Da mesma forma que a Lista B, a publicação do Manual foi considerada importante:

O Manual é uma consequência da Lista. Você tem a Lista, você tem uma lista e [...] então, em que circunstâncias você vai considerar aquela doença relacionada ao trabalho? Porque existem algumas doenças que só podem ser relacionadas ao trabalho, silicose, intoxicação por manganês, intoxicação por chumbo... Essas doenças são só do trabalho. Mas a maior parte das doenças, incluindo os transtornos psíquicos, podem ser relacionadas ou não ao trabalho. Então, em que circunstâncias nós devemos considerá-las relacionadas ao trabalho? Então você precisa de um Manual fácil porque o Sistema Único de Saúde vai acompanhar esse problema. Então era importante esse Manual (MAENO, 2014, entrevista).

Quanto à sua utilização, ou impacto, alguns entrevistados têm a percepção de que não ocorreu, similarmente à Lista B:

Eu diria que [a repercussão] não foi lá muito grande. Eu acho que, infelizmente, os profissionais, os serviços do SUS, eles são abordados de uma maneira totalmente fragmentada (MAENO, 2014, entrevista).

O impacto foi zero. [...] Eu acho que agora, [...] passados 15 anos, [...] eu acho que agora é que nós temos assim uma distância histórica... [E as pessoas perguntam:] "Mas isso existe?" "Mas já existe? Oh!" (JARDIM, 2014, entrevista).

Você acredita que [o coordenador da área de benefícios do INSS] não conhecia a Lista [B]? [...] E nós levamos, entregamos este livro [o Manual] para eles lá, eles agradeceram muito, eles não conheciam o livro do Ministério da Saúde das Doenças Relacionadas ao Trabalho publicado em $2001 \mathrm{com}$ a lei e todas as listas (SELIGMANN-SILVA, 2014, entrevista).

\subsubsection{NTEP - Nexo Técnico Epidemiológico Previdenciário (2007)}

Como discutido na seção 6.1, outra significativa mudança foi introduzida em 2006, com a publicação da Medida Provisória 316, de 11 de agosto de 2006, convertida na Lei 11.430, de 2006 (BRASIL, 2006), que instituem o Nexo Técnico Epidemiológico Previdenciário (NTEP), que entrou em vigência em abril de 2007. Com a nova metodologia, passaram a serem considerados também casos onde houvesse suspeita de nexo entre a doença e o trabalho (casos presumidos), por meio do cruzamento de informações epidemiológicas sobre a incidência da doença e o ramo de atividade da 
empresa na qual o trabalhador atua (classificação da empresa na Classificação

Nacional de Atividades Econômicas - CNAE).

Como ocorreu com relação à Lista $B$, vários dos entrevistados consideram a instituição

do NTEP (inclusive politicamente) como uma conquista, um avanço importante.

Na prática isso, pensando na nossa atuação, representou um avanço bem significativo. A gente poder contar com essa nova condição para o trabalhador, $e$ também considerar que o INSS, em função desse nexo, também teve que se reestruturar em termos das notificações, e do reconhecimento das notificações de agravos (GARBIN, 2014, entrevista).

Ele é um salto extremamente importante (CODO, 2014, entrevista).

Eu acho que já foi um avanço (JACQUES, 2014, entrevista).

Eu acho que o nexo técnico-epidemiológico é indiscutivelmente [...] um marco de mudança (DIAS, 2013, entrevista).

Eu acho que ele traz muitos avanços. E o questionamento mais importante que ele suscita é o questionamento de que ele vai contra a lógica médica. Ele vai contra a lógica médica biológica, individual (SILVA, 2013, entrevista).

Ele foi um avanço sem dúvida nenhuma (SELIGMANN-SILVA, 2014, entrevista).

O nexo técnico epidemiológico, ele veio, ele fez uma inflexão positiva, você pode dizer assim, agora a tendência é voltar ao normal. E que normal é? É a negação (SILVA, 2013, entrevista).

O NTEP é percebido por alguns entrevistados como fundamental para o diagnóstico, visibilidade e mesmo reconhecimento dos Transtornos Mentais e do Comportamento Relacionados ao Trabalho.

Então eu acho que a gente teve uma grande repercussão com o nexo técnico epidemiológico. [...] A depressão, ela só é reconhecida como relacionada a questões organizacionais etc. em 2006, 2007 com o nexo técnico epidemiológico. [...] Quando surgiu o nexo técnico epidemiológico em 2006, 2007, isso aí aumentou muito em notificação, claro, mas não aumentou tanto proporcionalmente quanto as doenças psíquicas. Porque essas sim estavam absolutamente escondidas, ocultas, até 2006, 2007 (MAENO, 2014, entrevista).

Eu acho que ele [NTEP] tem um lado interessantíssimo porque ele deu visibilidade a um problema e ele colocou isso de uma forma inquestionável para os empregadores (DIAS, 2013, entrevista).

O NTEP ajudou muito, por conta da prevalência estatística. Se não fosse isso, os transtornos mentais relacionados ao trabalho continuariam sendo negados (SILVA, 2014, entrevista).

A variação, de aumento das doenças por transtornos mentais, em percentual, aumentou de forma fantástica. LER/DORT saiu também de um patamar mínimo, que não eram registrados, lá para cima também. Doenças do "sistema nervoso" [Transtornos Mentais e do Comportamento Relacionados ao Trabalho] aumentaram uma barbaridade também. [...] O NTEP mostrou a fragilidade do Estado, nas suas fiscalizações, nas políticas públicas, mostrou a fragilidade do SESMT (SILVA, 2014, entrevista).

O reconhecimento também aumenta na medida em que se foi estudando mais a questão, e melhorou mais ainda com a fixação do método do nexo técnico epidemiológico, foi muito importante. [...] Houve um aumento do 
reconhecimento, muitas pessoas, pessoas de boa fé, peritos de boa fé se interessaram, têm estudado o assunto, têm procurado (SELIGMANN-SILVA, 2014, entrevista).

Ele [NTEP] é muito importante em termos de Saúde do Trabalhador, reconhecimento (CODO, 2014, entrevista).

O próprio INSS, com o nexo técnico epidemiológico, acabou revelando também mais esses dados do adoecimento no sentido dos transtornos mentais (GARBIN, 2014, entrevista).

[O NTEP favorece] o reconhecimento das doenças vinculadas ao trabalho até provarem o contrário (CORRÊA FILHO, 2014, entrevista).

Não frearam a aplicação do NTEP nas agências da Previdência Social. Então com isso caiu a obrigação do trabalhador carregar a maldita comunicação de acidente do trabalho, e na hora que isso caiu, abriu a porteira. Começou a entrar tudo aquilo que não se permitia registrar. Então teve um aumento de 14 a 15\% nas estatísticas previdenciárias de acidente do trabalho, de doenças (CORRÊA FILHO, 2014, entrevista).

O NTEP também traria avanços na medida em que pressupõe/estabelece a inversão do ônus da prova, bem como a evidência ou associação de natureza epidemiológica, permitindo o levantamento de hipóteses a serem investigadas do ponto de vista etiológico.

[O NTEP veio] rompendo com a lógica tradicional da responsabilidade pela caracterização de um determinado agravo por parte do trabalhador, colocando essa responsabilidade, a partir destes dados epidemiológicos, nas mãos das próprias empresas (GARBIN, 2013, entrevista).

E inverteu o ônus da prova. Isso é fundamental. Fundamental em termos políticos, fundamental em termos científicos também. Não tem nenhuma associação entre o câncer no pulmão e a padaria? Ótimo! Mostre! (CODO, 2014, entrevista).

Eu acho que o NTEP também vem dar uma contribuição que é a evidência de natureza epidemiológica, porque ele chega e mostra o seguinte, olha, a gente tem uma ocorrência muito maior desse tipo de adoecimento em determinadas categorias profissionais, então é muito pouco provável que isso seja aleatório. Isso não é aleatório. Então, acho que hoje os próprios peritos já tem um convencimento de que isso é possivel, de que isso existe, mas, ao mesmo tempo, a gente ainda precisa estudar muito sobre isso (SILVEIRA, 2013, entrevista).

Ele é extremamente importante de um ponto de vista cientifico. Porque ele te traz a associação. E no mínimo, levanta uma hipótese a ser investigada de um ponto de vista etiológico (CODO, 2014, entrevista).

Estudo de qual é a atividade, de qual é o risco daquela atividade, de como se organiza, muitas vezes a gente pega através do nexo técnico epidemiológico mesmo, ou de outros relatos do que acontece naquela empresa (GREGGIO, 2014, entrevista).

A metodologia introduzida pelo NTEP permitiria melhor identificar a incidência de doenças relacionadas ao trabalho e, especificamente, dos Transtornos Mentais e do Comportamento Relacionados ao Trabalho, e sua relação com as categorias profissionais, via Lista C do Anexo II do Decreto 6.957 (BRASIL, 2009) (que apresenta a 
relação entre os Transtornos Mentais e do Comportamento Relacionados ao Trabalho

e a CNAE - Classificação Nacional de Atividade Econômica).

Eu acho que o nexo técnico-epidemiológico veio colocar um marco, "não, gente, olha aqui", os dados estão mostrando que você tem uma concentração ou uma distribuição diferenciada de adoecimento em algumas categorias profissionais, isso não é um problema dos indivíduos. Então isso é um avanço indiscutivelmente (DIAS, 2013, entrevista).

Indiscutivelmente nós estamos diante de alguns dados inquestionáveis, que são da concessão de benefícios pela Previdência Social por quadros mentais em algumas categorias, concentrados em algumas categorias profissionais (DIAS, 2013, entrevista).

[O NTEP] através desse cruzamento do CID com o CNAE, ele trouxe um conceito de prevalência estatística, que revela o ambiente de trabalho nas empresas (SILVA, 2014, entrevista).

Só com o surgimento do NTEP como vínculo automático, é que a terceira lista, que é a Lista C passou a conduzir a um reconhecimento (CORRÊA FILHO, 2014, entrevista).

É a partir da Lista C que a gente começa a ter uma visibilidade maior para esses transtornos... Porque aparece na tela do computador [do perito], essa doença é ocupacional, é ocupacional (CORRÊA FILHO, 2014, entrevista).

O NTEP é visto também como positivo na medida em que traria maior agilidade para a realização do nexo do adoecimento com o trabalho.

Muitos dos casos que nós acompanhávamos como uma via crucis desse trabalhador, hoje nós não temos, hoje nós não nos deparamos com isso, para algumas categorias. [...] $O$ que antes nós teríamos que ter uma luta, e o trabalhador uma via crucis para conseguir isso (GARBIN, 2014, entrevista).

Antigamente, para você provar que você ficou doente dentro da empresa, você tinha que ir com um caminhãozinho de laudos médicos, que os caras nem olhavam. Então, você demorava vários dias, meses, até anos para provar que você ficou doente dentro da empresa. Com o NTEP, o ônus da prova ficou por conta do empresário (SILVA, 2014, entrevista).

O NTEP também auxiliaria na configuração e reconhecimento de um padrão coletivo de adoecimento, minimizando a individualização desse adoecimento ("culpa" do trabalhador).

O nexo técnico epidemiológico [...] vem trazer uma luz coletiva sobre um problema que, embora tenha manifestação individual, todas as cores que o indivíduo traz para aquilo, mas ele é eminentemente um fenômeno coletivo (SILVA, 2013, entrevista).

O nexo técnico epidemiológico [...] retira um pouco daquele individualismo para o coletivo, então eu já acho que é um avanço (JACQUES, 2014, entrevista).

Se tirar fora o NTEP e deixar por conta dos médicos, aí vai muito das interpretações e da subjetividade. Eu acho que a gente não conseguiria desenvolver políticas públicas só com a posição de um médico, de um psiquiatra... Eu acho que o processo produtivo, ele tem um padrão (SILVA, 2014, entrevista). 
Mesmo se considerado um avanço, são apontadas pelos entrevistados questões relativas ao NTEP, como sua lógica de "causa-efeito", a necessidade de aperfeiçoamento/atualização e questões conceituais, como a não inclusão de algumas doenças como relacionadas ao trabalho, ou a exclusão de algumas categorias profissionais da relação da Lista C.

Com relação à lógica de estabelecimento de nexo causal com o trabalho, dois dos psicólogos entrevistados consideram não ser possível, sobretudo com relação aos Transtornos Mentais e do Comportamento Relacionados ao Trabalho.

Do ponto de vista epistemológico, eu não vejo possibilidade de construir um nexo causal. Eu não consigo vislumbrar isso, pode ser por uma ignorância minha ou uma falta, mas do ponto de vista epistemológico, eu não consigo pensar na possibilidade de um nexo causal. [...] Eu acho que a ciência vai ter que caminhar muito e vai ter que ter uma mudança de queda de paradigma grande. Acho que a pergunta tem que ser outra (BRANT, 2014, entrevista).

O nexo técnico epidemiológico tenta melhorar um pouco isso, mas ele mantém a lógica, que é a lógica da causa e efeito. [...] É muito complicada a lógica do nexo causal para entender os chamados transtornos mentais ou de sofrimento psíquico. É muito difícil. Essa lógica causal que pauta o modelo biomédico, ela não dá conta, assim como não dá conta da LER (JACQUES, 2014, entrevista).

São apontadas pelos entrevistados críticas feitas ao NTEP em razão não de questões técnicas, mas de natureza ideológica, da ordem dos valores e crenças.

As contestações ao NTEP não são de natureza epidemiológica, são de natureza ideológica, reconvertida em método epidemiológico (CORRÊA FILHO, 2014, entrevista).

Eu vejo uma resistência científica-obscurantista entre colegas meus na área de epidemio[logia], na área assim chamada Saúde Ocupacional (CORRÊA FILHO, 2014, entrevista).

O nexo técnico epidemiológico, ele veio, ele fez uma inflexão positiva, você pode dizer assim, agora a tendência é voltar ao normal. E que normal é? É a negação. Aí é uma questão ideológica. [...] Na verdade, todos nós temos ideologias. Todos. Mesmo aqueles que dizem que não têm ideologias. Todo mundo tem ideologia, se a gente for entender e estudar o que é ideologia todos nós temos (SILVA, 2013, entrevista).

O conflito ideológico, puxando razões supostamente científicas, mas são falsas essas razões, na minha concepção (CORRÊA FILHO, 2014, entrevista).

Até porque você entra em choque com esse campo de valores, de uma certa forma, de crença mesmo. Eu acredito na Medicina assim, eu não acredito na Medicina, assado. Isso tem todo um campo de valores, de crenças, que alimentam isso (SILVA, 2013, entrevista).

Outro ponto de resistência e críticas ao NTEP apontado pelos entrevistados seria a perícia médica do INSS. 
[Há] resistência [ao NTEP] junto aos próprios peritos do INSS (SILVA, 2013, entrevista).

Houve no processo de elaboração do NTEP um isolamento, tanto do meio científico quanto dos peritos. Então, o perito encheu de "porrada" o NTEP, porque não foi consultado (CODO, 2014, entrevista).

[Quando se consegue] Afastar tendo esse nexo do adoecimento mental relacionado ao trabalho, geralmente as pessoas comemoram, porque não é uma coisa rotineira, não é uma coisa assim, dada [...], continua não sendo. Mesmo após o NTEP (GREGGIO, 2014, entrevista).

Também são apontadas pelos entrevistados as resistências e questionamentos ao NTEP por parte das empresas, e mesmo suas tentativas de burlá-lo (por exemplo, por meio da terceirização).

Quem tem crítica pesada ao NTEP são os empresários (SILVA, 2014, entrevista).

Mas há uma resistência e naturalmente incomodou muito as empresas, e aí você tem todas essas discussões da prova, do ônus da prova que passa agora a ser da empresa (SELIGMANN-SILVA, 2014, entrevista).

O reconhecimento das doenças vinculadas ao trabalho até provarem o contrário. Esse é que é o lance. Se faz uma conta e diz assim: "olha, tem cinco vezes mais doentes mentais no banco", portanto cabe ao banqueiro provar que ele não produziu isso. Como ele não pode provar que ele não produziu, porque ele produziu, todo mundo sabe, ele não prova. Então diz: "Já que você produz cinco vezes mais doentes, você paga cinco vezes mais imposto" [FAP]. Aí o cara não gosta (CORRÊA FILHO, 2014, entrevista).

Aí entrou a indústria pesada, federação da indústria, contratando estatístico para dizer que 20 milhões era uma estatística furada. Quer dizer, eles acreditam em estatística de dez pessoas, mas de 20 milhões, não. [...] Contrata um bando de epidemiologistas, que aprendeu epidemiologia e tirou o doutorado ontem, para dizer que estudos ecológicos não prestam, e que a exposição econômica não vale. Contratam um bando de estatísticos a peso de ouro para dizer que estatística com 20 milhões de pessoas é uma coisa insegura! E que aumenta a variabilidade da amostra (CORRÊA FILHO, 2014, entrevista).

Terceirização é para fugir a imposto, direito trabalhista e também [...] fugir do NTEP. [As empresas] pegaram a primeira lista do NTEP que foi de 2007 ou 2008, e estão subcontratando e terceirizando todos os ramos em que o NTEP detectou que elas estavam produzindo danos. Agora o trabalhador da Chevrolet de Porto Alegre quando fica com LER/DORT vai ao INSS e descobre que virou comerciário, ele não é metalúrgico (CORRÊA FILHO, 2014, entrevista).

As empresas criam mecanismos de manipulação do NTEP. Então, por exemplo, tem metalúrgico, que quando vai fazer o registro, eles colocam como comerciário. Então descaracteriza a doença que o cara adquiriu no setor metalúrgico para evitar a prevalência estatística (SILVA, 2014, entrevista).

\subsubsection{Protocolo clínico para Transtornos Mentais e do Comportamento Relacionados} ao Trabalho

Após a publicação da Lista B de doenças relacionadas ao trabalho e do Manual “Doenças relacionadas ao trabalho: manual de procedimentos para os serviços de 
saúde", definiu-se como estratégia, pelo Ministério da Saúde, a elaboração de protocolos para os dez grupos de agravos elencados:

Depois então que nós tivemos esse momento da finalização das listas de agravos, e como a lista B do INSS e aquela lista do Ministério da Saúde que é do Manual, [...] eles definiram como uma estratégia do Ministério [da Saúde], que para cada um dos dez agravos que estavam elencados [...] seriam elaborados protocolos (GARBIN, 2014, entrevista).

A proposta dos Protocolos visaria atender os trabalhadores com suspeita de agravos à saúde relacionados ao trabalho desde o primeiro atendimento até a notificação (de acordo com a Portaria GM/MS 104/2011), oferecendo recomendações e parâmetros para seu diagnóstico, tratamento e prevenção (COSAT-SSMT, 2015).205

Um dos protocolos a ser construído seria o referente aos Transtornos Mentais e do Comportamento Relacionados ao Trabalho. Contudo, após idas e vindas, o protocolo não foi concluído (os relatos de três das entrevistadas que participaram, em algum momento, desse processo, encontra-se no Apêndice $F$ - O processo de construção do protocolo para TMCs). Questionou-se a alguns dos entrevistados, mais cientes desse processo, quais seriam as razões, em sua opinião, de a construção desse protocolo não ter sido bem-sucedida.

Para vários dos entrevistados, a não construção do protocolo se deveu à já apresentada falta de consenso (ou mesmo disputas) no campo da saúde mental ou da Saúde Mental e Trabalho sobre as relações entre "adoecimento" mental/psíquico e trabalho.

A gente nunca se entendeu. Por que iria se entender para fazer um protocolo, que é uma coisa extremamente complicada? (CODO, 2014, entrevista).

Acho que tem uma certa divergência entre a categoria psi na questão de se relacionar o adoecimento com o trabalho, ou as questões [...] psicossociais com o adoecimento mental, principalmente o adoecimento grave. Então existe uma divergência teórica, que eu acho que é importante (GREGGIO, 2014, entrevista).

Essa divisão aí, essa disputa, acho que pode ser um dos fatores... (JACQUES, 2014, entrevista).

As pessoas tinham que estar concordando pelo menos um mínimo para se poder fazer isso. E eu acho que tem outros interesses, se você me perguntar quais, eu não sei (GREGGIO, 2014, entrevista).

205 Protocolos/diretrizes elaborados (COSAT-SSMT, 2015): 1. Trabalho Infantil; 2. Anamnese Ocupacional; 3. Acidentes de Trabalho; 4. Exposição a Materiais Biológicos; 5. Expostos ao Chumbo Metálico; 6. Perda Auditiva Induzida por Ruído (PAIR); 7. Pneumoconioses; 8. Risco Químico; 9. Câncer Relacionado ao Trabalho; 10. Dermatoses Ocupacionais. 
Não houve um desfecho favorável por discordância de grupos [...]. Discordância de grupos, de linhas, de grupos, de quem sabe mais, de quem que é o grande conhecedor da área e, portanto, quem merece escrever o protocolo. Você tem desde uma disputa pessoal, vaidosa, até de campo teórico. Um pouquinho de cada coisa. O resultado foi que não deu em nada. Não temos Protocolo (SILVA, 2013, entrevista).

[Você acha que essas divergências teóricas são um dos fatores dificultadores desse processo?] Para ser sincera, eu acho que [...] foram muito mais questões políticas, mas não nesse sentido política partidária, mas relações entre profissionais, entre instituições, também. Eu acho que, diferente dos outros grupos, não houve um consenso, um movimento mais organizativo conciliador, digamos assim (GARBIN, 2014, entrevista).

Isso ficou "peruando" o Brasil inteiro, juntou um punhado de gente, deu uma brigalhada danada, mas na prática não saiu o protocolo. O que sinaliza a dificuldade que o próprio campo da Saúde do Trabalhador tem de discutir esta questão. Passou por pessoas boas, pessoas que são reconhecidas na área, são profissionais experientes na área de saúde mental, mas não foi possível estabelecer um protocolo (SILVEIRA, 2013, entrevista).

Não há consenso entre os próprios profissionais especialistas em saúde mental... Continua não havendo (SILVEIRA, 2013, entrevista).

Quando chegava na hora do protocolo em saúde mental era uma confusão, porque havia realmente um conflito muito grande. Várias escolas, com visões diferentes. E não se conseguiu extrair nem o mínimo denominador comum de todas elas para construir um protocolo (SILVEIRA, 2013, entrevista).

Uma questão apontada por alguns entrevistados seria a dificuldade de "operacionalização" ou utilização do protocolo pelos profissionais de saúde. Essa questão poderia estar relacionada a dificuldades já apresentadas, como o despreparo da atenção básica para lidar com o campo da Saúde do Trabalhador, ou mesmo para a lida com a categoria "trabalho"; a falta de formação ou qualificação dos profissionais de saúde para a compreensão da dimensão da saúde mental, de modo geral, e em sua relação com o trabalho; a dificuldade de diagnóstico dos Transtornos Mentais e do Comportamento Relacionados ao Trabalho; a percepção de que a "doença mental" do trabalhador não teria como causa/origem o trabalho, mas sim questões individuais (problemas na família, afetivos etc.).

Outro elemento importante e possivelmente relacionado seria a ausência de profissionais "psi" (psiquiatras, psicólogos) em muitos serviços, e mesmo em alguns CERESTs (faltam, em alguns casos, equipes multiprofissionais, uma vez que, de acordo com a legislação, as esquipes mínimas de serviços de atenção à saúde do trabalhador devem ser compostas por médicos, enfermeiros, técnicos e auxiliares de enfermagem).

Fizeram [dois psiquiatras que procuravam construir o protocolo] com muita boa vontade, com muito esforço, mas me pareceu que esquecendo que, na maior parte do nosso serviço de saúde, não existem nem psiquiatras, nem psicólogos, e 
muito menos aqueles com formação em psicopatologia do trabalho para poder preencher o que eles formularam. E havia algumas perguntas infelizes, por exemplo, um dos protocolos começava com uma das primeiras perguntas: "Você já sofreu assédio moral?" [...] E quantos trabalhadores sabem? Hoje em dia muitos sabem, mas o mais humilde lá do interior, sabe o que é assédio moral? (SELIGMANN-SILVA, 2014, entrevista).

No caso da atenção básica, nós temos alguns materiais que foram produzidos diretamente para serem utilizados. [...] Eles não utilizam em função de serem materiais extensos, materiais que trazem questões técnicas que [...] demandam discussões, etc. Então às vezes o material dessa natureza [protocolo], eu acho que não chegaria na ponta, na atenção básica com a mesma repercussão que ele teria para as nossas equipes [de CERESTs] (GARBIN, 2014, entrevista).

Eu acho que o principal problema não é a falta de conhecimento, não é o protocolo em si. Existe um Manual de doenças relacionadas ao trabalho, então se não tem um protocolo, consulta o Manual de doenças relacionadas ao trabalho, qual é o problema? Está disponível, está online por aí. A grande questão é que nós não conseguimos fazer ainda com que a assistência se envolva com o trabalhador ou com a pessoa com todas as suas características (MAENO, 2014, entrevista).

Bem, por mim, se faria o protocolo, mas um protocolo que fosse muito aberto também. Acho que tinha que ser um protocolo que desse orientação, e, de certa forma, isso já está escrito. [...] O pessoal faz umas coisas enormes! (JARDIM, 2014, entrevista).

Porque que o pessoal fica achando que o instrumento, que se aplicar uma escala de burn-out, vai conseguir melhorar o diagnóstico. Não vai! (JARDIM, 2014, entrevista).

Quando você faz um protocolo, você demanda que as pessoas realmente assumam que elas têm que, por exemplo, fazer relatórios, que ela tem que avaliar, que elas têm que diagnosticar. E eu acho que o psicólogo hoje ainda tem dificuldade de fazer isso, eu vejo que muitas vezes o psicólogo tem dificuldade realmente, pegar um papel e colocar num relatório o que ele está percebendo, daquele adoecimento (GREGGIO, 2014, entrevista).

\section{Outro fator de dificuldade apontado por Edith Seligmann-Silva seria a própria plasticidade dos transtornos mentais e do comportamento:}

Você sabe que os transtornos são muitos e as diferenças são outras, e você tem que avaliar sempre uma correlação [...] entre a situação de trabalho e a situação daquele indivíduo na empresa [...]. Você tem que avaliar também outra coisa que geralmente dá uma contestação danada no INSS inclusive, porque é que eu dou um diagnóstico hoje de depressão e amanhã eu dou de psicose? Por que o meu paciente de estresse pós-traumático que eu pedi o B91, porque foi no trabalho que ele teve o trauma, por que agora ele está psicótico e eu mando um diagnóstico que ele está com psicose? [...] Porque você tem uma plasticidade muito grande na patologia psíquica, psiquiátrica (SELIGMANN-SILVA, 2014, entrevista).

Os quadros evoluem e mudam. [...] Então, esses enquadres dos diagnósticos são discutidíssimos em psiquiatria geral ou em psicopatologia geral [...], você tem a transformação, [...] e isso traz um outro agravante para o protocolo ser levado a sério, [...] enquanto você não puder dar uma formação maior para os peritos... (SELIGMANN-SILVA, 2014, entrevista). 
Para alguns dos entrevistados, embora reconheçam a utilidade do protocolo como instrumento, sua inexistência não seria impeditiva, por exemplo, para um bom diagnóstico, uma vez que existem outros recursos passíveis de serem utilizados.

Não localizo isso como principal problema. Eu acho que é importante ter, mas eu acho que há outros recursos possíveis de serem utilizados (MAENO, 2014, entrevista).

Embora a gente possa dizer que sim, seria benéfico para a nossa atuação, também não seria possivel dizer que não tem condições de fazer, não tem conhecimento, e não tem até a experiência acumulada de outros agravos, em que a gente se orienta e busca como apoio também (GARBIN, 2014, entrevista).

Por outro lado, também, isso não nos impede, não nos limita de fazer uma anamnese relacionada, no caso, ao sofrimento mental, em função da ausência desse material, porque nós temos muita produção teórica, nós temos muitos profissionais envolvidos e militantes até dessa causa da saúde do trabalhador (GARBIN, 2014, entrevista).

Contudo, uma vez que os entrevistados têm seu exercício profissional em regiões de amplo acesso à informação (SP, RJ, MG, DF, RS), uma ponderação de Andréia De Conto Garbin se coloca. Em sua atuação profissional, a entrevistada tem contatos profissionais com integrantes de CERESTs de várias regiões do país, inclusive regiões mais distantes, para as quais considera que, talvez, o protocolo fosse importante para o matriciamento da rede de saúde.

Eu sempre busco dizer [...] que ter esses materiais de referência, por exemplo, ter um manual, ter um protocolo sobre anamnese ocupacional, para a gente, na prática, é muito útil. É um material que a gente usa. A gente discute com a equipe, então é um facilitador (GARBIN, 2014, entrevista).

Eu me lembro do relato dela [Lorena Mercucci Freire, psicóloga e coordenadora do Grupo de Saúde Mental e Trabalho da Amazônia Legal no Tocantins], dizendo de como era importante ter aquele material para ajudar. Então uma profissional numa região bem [distante]... Porque a gente aqui [em São Paulo], nós estávamos num ambiente bastante propício para ter contato com profissionais. Talvez lá ela tivesse mais essa carência e aí o documento, ele se mostra mais importante ainda (GARBIN, 2014, entrevista).

Por fim, dadas as dificuldades apresentadas, algumas entrevistadas questionam se 0 melhor instrumento seria realmente um protocolo.

Eu participei da elaboração de outro [protocolo] [...] que foi sobre o trabalho infantil. [...] E no caso, [...] nós chegamos à conclusão de que não deveria ser chamado de protocolo. Tanto é que ele aparece como diretrizes para a atuação (GARBIN, 2014, entrevista).

Talvez, na área de saúde mental, em minha opinião, nós também tivéssemos que exercitar que o protocolo ia ser mais difícil de chegar a algum consenso, e que talvez nós tivéssemos que partir para outra lógica de construção, de algum documento norteador, orientador e tudo mais (GARBIN, 2014, entrevista). 
O pessoal fica querendo muito o protocolo... [...] Enfim, tem aquele livro lá da Raquel Rigotto e da Lys Esther Rocha, ${ }^{206}$ ali tem uma anamnese... Aquilo é um protocolo que serve para tudo, para qualquer especialidade. Se fizer aquilo ali! (JARDIM, 2014, entrevista).

Quer saber qual seria o meu protocolo para a saúde mental? A história de trabalho que tem lá [roteiro citado], que eu transformei num protocolo daqui. [...] A Edith [Seligmann-Silva] já fala isso há séculos, ela diz: a história de trabalho, ou então: história pessoal, história de vida, com enfoque na questão do trabalho, na anamnese... Mas é aí que está, não é? Ninguém quer ouvir (JARDIM, 2014, entrevista).

\title{
6.3.1.21 Papel e importância da Psicologia no campo da saúde e trabalho
}

Algumas das questões colocadas para os entrevistados se referiam à sua percepção sobre o papel, a função, a importância da Psicologia no campo da Saúde do Trabalhador.

Primeiramente, questionou-se a respeito de uma visão mais crítica da Psicologia, por vezes percebida como um campo científico que historicamente se dedicou à questão da adaptação.

Um dos entrevistados, Gilberto Salviano Silva, apresentou sua percepção da Psicologia como ciência que possui ligação com o capital e trabalha a favor dele.

\begin{abstract}
Eu acho que a Psicologia, assim como a Medicina, como a Engenharia, ela está a serviço do capital. Diferente dos profissionais da Psicologia, de alguns profissionais da Medicina, da Engenharia e de outros setores que tem uma sensibilidade, tem a humanidade e trabalha numa lógica de melhorar a qualidade de vida. Eu não tenho muita esperança na ciência, enquanto ela estiver a serviço do capital. No momento eu vejo a ciência a serviço do capital (SILVA, 2014, entrevista).

Então, quando a Psicologia produz conhecimento e esse conhecimento chega na gerência da empresa de relações humanas, a organização da empresa, e se usa aquela ciência para aumento dos seus bens de capital, através do controle do trabalho, eu fico questionando a Psicologia, a Medicina (SILVA, 2014, entrevista).
\end{abstract}

Contudo, a perspectiva de uma Psicologia mais "normativa" ou "adaptacionista" viria se transformando, segundo alguns dos entrevistados.

Parte da Psicologia não é mais aquela Psicologia dos anos 40, dos anos 20 que era aquilo, era a própria dinâmica da modernização do saber e da sociedade que caminham juntos (BERTOLLI FILHO, 2014, entrevista).

206 RIGOTTO, Raquel Maria. Investigando a relação entre saúde e trabalho. IN: ROCHA, Lys Esther; RIGOTTO, Raquel Maria; BUSCHINELLI, José Tarcísio Penteado (org.) Isto é trabalho de gente? Vida, Doença e Trabalho no Brasil. Petrópolis: Vozes, 1993. 
Eu acredito que o psicólogo, o profissional de Psicologia, ele é um cidadão. E ele vive as tensões típicas de qualquer cidadão. Ele tem um conhecimento, conhecimento específico, é um conhecimento de um lado normativo, estabelece um conjunto de regras, estabelece uma série de [...] paradigmas do normal e anormal... [...] Então eu acredito que o psicólogo, de um lado, ele seja, basicamente formado como um [profissional] normatizador da sociedade, ao estabelecer critérios específicos para dizer, normal ou anormal, saudável ou doente. Mas por outro lado, a nossa própria cultura, [...] esse processo de pósmodernidade [...] flexibilizou o que é ser normal ou anormal, a própria sociedade de um jeito ou de outro, ela se tornou mais elástica aceitando comportamentos, vamos chamar de exóticos. E a Psicologia, eu acredito, esteja indo exatamente por esse caminho, então o profissional de um lado, ele vive essa tensão entre [...] normal e patológico como um saber, mas a própria Psicologia diretamente mais aberta (BERTOLLI FILHO, 2014, entrevista).

Eu acho que [...] a partir de um determinado momento, a gente fez um rompimento com uma Psicologia adaptacionista... Eu acho que a Psicologia é adaptacionista, que a Psicologia tem ainda a raiz adaptacionista, mas [...] dizer que alguns movimentos ou algumas pessoas foram responsáveis por mudar esse percurso, eu acho que não é legal. [...] Eu sou de uma concepção [...] de que a construção teórica, empírica, metodológica, ela vai sendo como se fosse um fermento num bolo: vai pondo, até que de repente o bolo começa a crescer. $E$ de repente a gente começa a ter aquelas bolhas no bolo, que são as explosões que aparecem aqui e ali. Essa me parece uma analogia (JACQUES, 2014, entrevista).

\section{Também é apontada por alguns entrevistados a busca da Psicologia em se constituir}

como um campo autônomo, com legitimidade própria, inclusive na área da saúde. ${ }^{207}$

Esses profissionais que trabalham ao lado dos médicos, psicólogos, enfermeiro, fisio [terapia], TO [terapia ocupacional], sempre esses saberes são construídos, como, vamos dizer, [...] apêndices da Medicina e, portanto, o médico sempre tinha que ser o coordenador geral, o supervisor do trabalho desse pessoal. Eu acredito que, mais recentemente, $e$ inclusive refletindo as tendências internacionais, a Psicologia, a Fisioterapia, a Terapia Ocupacional, todas elas buscam uma autonomia neste sentido, no sentido de ter um poder, ter um campo lá na perspectiva do Bourdieu 208 para fugir desse jugo médico. [...] Então, a comunidade médica de certa forma estigmatiza essas outras profissões,

207 A esse respeito, uma voz dissonante é a de Wanderley Codo:

O pessoal que for ler tua tese vai ficar muito bravo comigo, mas... O papel central na questão da saúde é o papel do médico. O médico é o profissional que é responsável pela questão da saúde. [...] É uma tolice e uma arrogância dos psicólogos ou das entidades de Psicologia querer disputar o espaço com o médico quando a questão é saúde. [...] Não vai ter, porque não é essa a formação e nem a especialidade nossa. A nossa atuação em saúde é uma das atuações, não é a mais importante [...]. Pode formar todos os psicólogos em Psicologia da saúde que você nunca vai ter uma intervenção digna de se responsabilizar ou sozinha ou partícipe por uma questão de saúde. A nossa atuação de saúde, ela tem uma dimensão estreita, dentro da nossa área de atuação. [...] Ela tem uma atuação limitada do ponto de vista de que ela não tem instrumental para intervir na maior parte dos problemas de saúde. [...] E nosso instrumental sempre vai ter que ser um instrumental compartilhado [...]. Com exceção de raríssimos problemas que são de ordem estritamente psicológica - estou falando de saúde pública- que são da ordem psicológica, estritamente psicológica, o resto todo, a grande maioria você tem que dividir com outros profissionais que também são da área (CODO, 2014, entrevista).

208 BOURDIEU, Pierre. O poder simbólico. Rio de Janeiro, Bertand Brasil; Lisboa, Difusão Editorial, 1989. 
para garantir uma predominância sobre esse outros. Em sentido oposto, eu acredito que todo esse pessoal, Enfermagem, Psico [logia] [...], está se estruturando, enquanto instituições representativas, e também enquanto saberes, de uma maneira bem mais [...] vigorosa nessas últimas décadas, e [...] essa emancipação da tutela [faz parte] (BERTOLLI FILHO, 2014, entrevista).

Quando eu fui fazer Psicologia, na década de 60, o meu pai disse assim: "Ela vai fazer uma coisa chamada "Psipsi não sei o quê". Por quê? Porque a gente não tinha uma representação do que era ser psicólogo, e hoje nós temos. Quer dizer, na década de 60, que eu estou te trazendo, no final da década de 60 até agora, e não é muito tempo. São 50 e poucos anos. Então eu acho que nós estamos construindo a nossa representação, os nossos espaços (JACQUES, 2014, entrevista).

Eu acho que já mudou um pouco, eu acho que quando a Psicologia vai para o espaço da saúde pública, ela passa a ter mais liberdade para pensar. E ela vai para um espaço onde talvez a saúde coletiva seja discutida de outra forma. E eu acho que nós tivemos várias pessoas que participaram realmente da construção do movimento da reforma sanitária, vindo para esse campo. Então eu acho que a partir disso a gente pôde realmente fazer uma diferença e pensar a Psicologia em outro lugar (GREGGIO, 2014, entrevista).

\title{
Outra questão apontada por alguns dos entrevistados é a necessidade de que a Psicologia estabeleça diálogos, internamente e com outras categorias.
}

\begin{abstract}
A Psicologia não é homogênea, [...] ela é plural, ela é diversa, e eu acho que a gente tem de saber dialogar, e eu acho que esse é um exercício muito complexo para todos nós (JACQUES, 2014, entrevista).

Então, cada vez mais se precisa do olhar do psicólogo e se reconhece a necessidade do olhar do psicólogo. [...] E se isso não anda mais depressa, nós temos muita culpa nisso. A gente não faz uma intervenção. Quando a gente está na instituição, a gente não faz uma intervenção aberta para os outros profissionais. [...] Não faz a leitura de um ponto de vista mais institucional, e não dialoga... Os médicos são muito ruins nisso, mas ainda são melhores que a gente. Eles vêm pedir palpite para você, sabe? E você não vai lá, pedir palpite para eles (CODO, 2014, entrevista).
\end{abstract}

Os papeis mais destacados da Psicologia, no âmbito da Saúde do Trabalhador, seriam o da compreensão do trabalho naquilo que representa para os trabalhadores e em sua dimensão de constituição de subjetividade, bem como a investigação (ou "desvelamento") das circunstâncias que o determinam.

O que eu acho que a gente tem que tentar ver: como o trabalho constitui- esse é o papel da Psicologia, na minha opinião- como o trabalho constitui o sujeito, e como nessa constituição do sujeito a gente se articula com o processo de saúde e doença (JACQUES, 2014, entrevista).

E a relação entre o trabalho do psicólogo e essa redescoberta, usando o termo que a Márcia Hespanhol [Bernardo] gosta, e a Leny [Sato] também, o desvelamento, que vai além da questão de simplesmente revelar o fato, mas as circunstâncias que o determinam, então para colocar o termo no sentido filosófico de desvelar, isso é uma pressão dos psicólogos sobre mim, porque eu não saberia isso se eu não tivesse sido educado por psicólogos (CORRÊA FILHO, 2014, entrevista). 
Eu acho que a Psicologia [...] é fundamental para a gente escutar o trabalho, realmente naquilo que ele representa hoje, para o sujeito, para as pessoas (GREGGIO, 2014, entrevista).

A articulação entre a história de cada um dos sujeitos no mundo do trabalho e o sofrimento psíquico desses sujeitos (JACQUES, 2014, entrevista).

\section{Outro papel destacado por Maria Regina Greggio é o da escuta:}

A Psicologia tem esse papel fundamental, de conseguir fazer com que as pessoas realmente escutem, num mundo em que ninguém pode escutar o sofrimento. Então eu acho que esse é o papel principal da Psicologia nos serviços de saúde, principalmente, eu acho que em outros serviços também, mas principalmente dos serviços de saúde (GREGGIO, 2014, entrevista).

A Psicologia, como ela possibilita uma escuta, e eu acho que isso é o que todo serviço carece, então eu acho que a psicologia tem esse papel fundamental, de chamar a atenção dos profissionais para essa escuta, não como uma coisa mecânica, mas realmente uma escuta de um sujeito que chega até o serviço com sofrimento, e que muitas vezes esse sofrimento não está nomeado (GREGGIO, 2014, entrevista).

Já Maria da Graça Jacques destaca a necessidade de atuação socialmente responsável da Psicologia:

Eu acho que a gente tem que ter uma Psicologia de responsabilidade social. Não gosto muito da palavra compromisso social, que eu acho muito viciada. Eu gosto da palavra responsabilidade social. Eu acho que a gente tem que ter responsabilidade social. E a Saúde do Trabalhador nos remete a isso, à responsabilidade social (JACQUES, 2014, entrevista).

Outra questão levantada é sobre a participação da Psicologia nos CERESTs. Embora seja apontada sua participação em muitos CERESTs, a categoria não é uma das consideradas necessárias pela legislação para composição da equipe mínima.

Eu tenho visto muitos psicólogos que estão estudando, estão sensibilizados, estão trabalhando nos CERESTs (SELIGMANN-SILVA, 2014, entrevista).

E eu sempre questiono o seguinte, por que o psicólogo não é um profissional necessário para a abertura de um CEREST, ele só é recomendado? [...] Um dos papéis do CEREST é o matriciamento da rede, não só assistência, mas um matriciamento da rede e uma assistência especializada. Então o que eu percebo nos CERESTs que não têm o psicólogo, como Belo Horizonte e outros, [...] a gente encaminha e as pessoas não são acolhidas, não acolhidas no que elas precisam, porque a categoria trabalho não é escutada. Então mesmo que ela seja escutada no CEREST por alguém que acompanha, quando ela é encaminhada para a rede ela não é. E não tem ninguém no CEREST que faça matriciamento da rede, considerando a questão do adoecimento mental e o trabalho, não tem ninguém, então na verdade isso não é trabalhado (GREGGIO, 2014, entrevista).

Outra questão que eu acho importante é essa questão realmente de capacitação da rede, de chamar a atenção da rede para essas questões como a dos transtornos mentais relacionado ao uso de produtos químicos como agrotóxicos e outros, e várias outras questões relacionadas à organização do trabalho, que não têm como você matriciar a rede se você não tiver um psicólogo do trabalho no CEREST (GREGGIO, 2014, entrevista). 
Deveríamos entender qual é o nosso papel, que muitas vezes não é claro. Isso não é claro durante a formação e isso não é claro após a formação também. Então eu acho que entender a importância, na equipe, e o psicólogo se fazer importante, eu acho que é o maior desafio (GREGGIO, 2014, entrevista).

Contudo, é apontado por alguns dos entrevistados que a Psicologia e o trabalho do psicólogo, na Saúde do Trabalhador, têm sido cada vez mais valorizados.

Cada vez mais se precisa do olhar do psicólogo e se reconhece a necessidade do olhar do psicólogo (CODO, 2014, entrevista).

Acho que a área da Psicologia, a formação da Psicologia, ajuda a gente a compreender algumas coisas (MAENO, 2014, entrevista).

E agora em termos de discussão mais de equipe da área, onde a gente se insere mesmo, aí eu acho que tem sim uma valorização (GARBIN, 2014, entrevista).

Eu acho que o psicólogo pode apontar algumas questões que o médico sozinho não apontaria (GREGGIO, 2014, entrevista).

Você precisa de uma intervenção interdisciplinar. $E$ essa intervenção interdisciplinar não pode prescindir do psicólogo. Não pode prescindir do psicólogo, não pode prescindir da assistência social (CODO, 2014, entrevista).

\subsubsection{Principais desafios no campo da Saúde do Trabalhador e quanto aos} Transtornos Mentais e do Comportamento Relacionados ao Trabalho

Além dos conflitos e dificuldades presentes no campo da Saúde do Trabalhador, em especial no que se refere aos Transtornos Mentais e do Comportamento Relacionados ao Trabalho, solicitou-se aos entrevistados que apontassem quais seriam os principais desafios a respeito vividos atualmente.

O primeiro desafio, já anteriormente apresentado e apontado por todos os profissionais entrevistados ligados à área da Saúde do Trabalhador, refere-se à dificuldade de diagnóstico dos Transtornos Mentais e do Comportamento Relacionados ao Trabalho, dada sua "invisibilidade".

Associado a esse desafio, somar-se-ia o de compreender/atentar-se à dimensão de subjetividade implicada sobretudo nos Transtornos Mentais e do Comportamento Relacionados ao Trabalho.

A nossa função é entender que ele está falando nervoso e, ao que ele se refere, a nossa função então é investigar (JARDIM, 2014, entrevista).

A questão da subjetividade, ela esteve durante muito tempo afastada das considerações [...] da saúde pública (DIAS, 2013, entrevista). 


\section{Apontado por quase todos os entrevistados, outro desafio seria o de promover a integração, no âmbito do SUS, entre as estratégias de Saúde da Família, da Saúde Mental e da Saúde do Trabalhador, e de mais contatos intrainstitucionais.}

Para compor a Rede Nacional de Atenção Integral, o que você faz? Você precisa de ações de Saúde do Trabalhador na atenção básica. Claro, a atenção básica é a porta de entrada, você precisa de ações de saúde para o trabalhador na rede de urgência e emergência (SILVA, 2013, entrevista).

No posto de saúde, na ponta, na saúde básica, na atenção primária, na saúde de familia... [...] Eu acho que os especialistas em Saúde do Trabalhador têm que ir lá na atenção primária, tem que ir lá, qualificar com a sua presença, com essas intervenções, a atenção primária (JARDIM, 2014, entrevista).

[Há o] desafio de pensar atenção à Saúde do Trabalhador ou o próprio campo da Saúde do Trabalhador no âmbito da atenção primária. [...] tentando pensar essa questão da Saúde do Trabalhador na atenção primária, isso é um grande desafio, que é exatamente o profissional com toda uma formação biomédica conseguir abordar aquele usuário ali na sua frente a partir desse lugar de trabalhador (BRANT, 2014, entrevista).

Eu acho que a gente tem de fazer uma articulação com a atenção básica; a atenção básica é um problema não só para a Saúde do Trabalhador, é um problema até para saber se está com sarampo ou não (JACQUES, 2014, entrevista).

Você entra ou pela atenção básica ou pela urgência e emergência. Você precisa de ações nas especialidades. Você precisa de ações no ponto da vigilância. $E$ você precisa de ações na promoção da saúde. Pronto. Só que juntar isso vem se tornando mais complexo, mais complicado (SILVA, 2013, entrevista).

Por mais que a gente tenha feito algumas capacitações, a gente não recebe ninguém encaminhado da rede suspeitando de um transtorno mental relacionado ao trabalho (GREGGIO, 2014, entrevista).

Nós precisamos abrir esse diálogo, essa conversa, essa mudança de prática com o campo da saúde mental. o campo da saúde mental e o campo da Saúde do Trabalhador precisam se encontrar. $E$ não se encontram. Se encontrar na perspectiva da elaboração de outro construto, porque com os construtos de cada um, não está dando (SILVA, 2013, entrevista).

Nós precisamos ter mais contatos intrainstitucionais no SUS (SELIGMANN-SILVA, 2014, entrevista).

A necessidade que nós teríamos de um entrosamento, no nível do SUS, maior, entre a estratégia de saúde da família, a saúde mental, a Saúde do Trabalhador $e$ todos os atendimentos de adulto que se faz em centros de saúde. Continua tudo muito compartimentado (SELIGMANN-SILVA, 2014, entrevista).

Também fica o desafio de criar novas formas de dialogar [...]. A rede está num outro movimento, e nós estamos com alguns modelos que já não cabem nessa nova lógica, que é a ideia do matriciamento, mas que é a ideia de olhar mais para um território, também uma concepção de território, de identificação daquele espaço, compreender o que acontece naquele local, com aqueles trabalhadores (GARBIN, 2014, entrevista).

Serviços de saúde (por exemplo, os CAPS) não estão preparados para lidar com demandas do trabalho. Estão tão sobrecarregados com casos de esquizofrenia, psicose, suicídio e drogadiç̧ão, que questões relacionadas ao trabalho passam despercebidas (DIAS, 2013, entrevista). 
Outro desafio muito destacado, e já anteriormente apresentado, seria a formação ou qualificação dos profissionais de saúde (inclusive os que estão na atenção básica ou nos CAPS) que, de modo geral, não contemplaria discussões sobre o papel ou a relação do trabalho com o processo saúde-doença ou, mais especificamente, das relações entre trabalho e "adoecimento"mental/psíquico.

Também já apresentado previamente, um desafio apresentado por vários dos entrevistados refere-se à falta de consenso (ou mesmo disputas), no campo da Saúde Mental, ou da Saúde Mental e Trabalho, sobre as relações entre "adoecimento" mental/psíquico e trabalho.

Outro desafio, possivelmente relacionado à falta de formação ou qualificação dos profissionais de saúde para a lida com as relações entre trabalho e saúde mental, bem como à falta de consenso no campo teórico, seria a necessidade de ampliação do debate acerca dos Transtornos Mentais e do Comportamento Relacionados ao Trabalho, na perspectiva de estruturação e compartilhamento do conhecimento produzido no campo.

[É necessário] discutir concepções de Saúde do Trabalhador e agravos em saúde mental (GARBIN, 2014, entrevista).

Eu acho que isso é um desafio. A estruturação do conhecimento dentro do próprio campo... Porque é isso que legitima do ponto de vista político e legal (SILVEIRA, 2013, entrevista).

A gente foi ver que isso foi nascendo [produção em Saúde Mental e Trabalho] e infelizmente desconectadamente (SELIGMANN-SILVA, 2014, entrevista).

E em termos de discussão com a rede de saúde, pensando atenção básica, atenção especializada, também acho que tem um longo processo de construção de informação, e de enfrentamento de alguns discursos [...] de concepções que são mais duvidosas, do adoecimento (GARBIN, 2014, entrevista).

Então [é necessária] uma articulação teórica [para] dar conta da categoria trabalho como uma categoria constitutiva do sujeito, teoricamente falando, $e$ também que a gente tenha estudos empíricos que nos mostrem como se dá essa articulação no nosso cotidiano de vida, na nossa trajetória (JACQUES, 2014, entrevista).

Então eu acho que para a rede de saúde, a gente tem desafios dessa natureza, de disseminar a questão da saúde mental relacionada ao trabalho em todos os pontos: atenção básica, especializada, urgência e emergência (GARBIN, 2014, entrevista).

Um desafio destacado, e também já anteriormente apresentado, é a necessária interdisciplinaridade implicada na compreensão e lida com os Transtornos Mentais e do Comportamento Relacionados ao Trabalho (e na Saúde do Trabalhador, de forma 
mais ampla), e a falta, em alguns casos, nos CERESTs, de equipes multiprofissionais (ou com a presença da Psicologia). Nesse sentido, para alguns entrevistados ainda haveria também o desafio de conscientização da importância do psicólogo no campo da Saúde do Trabalhador.

[é um desafio] conseguir perceber a importância da Psicologia do Trabalho (GREGGIO, 2014, entrevista).

Mais um desafio apontado pelos entrevistados e anteriormente apresentado se refere à não integração ou sobreposição de políticas públicas na área de saúde do trabalhador, notadamente Ministério da Saúde, Ministério do Trabalho e Ministério da Previdência Social.

A já apresentada perspectiva de que o trabalho não poderia adoecer, ou de que "o trabalho dignifica o homem", sendo algo apenas da ordem da positividade ou, como define um dos entrevistados, um "fetiche", traria o desafio de impedimentos para uma atuação mais concreta para melhorar o trabalho.

Essa negação é lamentável, porque à medida que nós negamos nós estamos fazendo obstáculos para melhorar o ambiente e o mundo do trabalho. Se a gente [...] reconhece que o trabalho está adoecendo fisicamente, emocionalmente, socialmente, nossa sociedade está muito adoecida, nós vamos atuar para melhorar esse trabalho, essa prática do trabalho (SILVEIRA, 2013, entrevista).

As já apresentadas deficiências ou falhas na formação ou qualificação dos peritos também seriam desafios apontados por vários entrevistados.

Também se apresenta como desafiadora a necessidade de difundir uso da Lista B no campo da saúde, para além dos CERESTs.

\footnotetext{
Porque esse impacto [da Lista B], ele precisa ser realmente produzido. Ele não cai do céu, ele não cai pelo fato da gente ter conseguido, em um dado momento, [...] que o Ministério da Previdência e o Ministério da Saúde assinassem isso aí (JARDIM, 2014, entrevista).

Antes da gente conseguir ampliar esta lista, a gente tem que entender que ela existe, foi o possível no momento, e eu acho que a gente tem de se dedicar para que as pessoas usem (JACQUES, 2014, entrevista).
}

Haveria também a necessidade de conscientização dos profissionais de saúde para a responsabilização para com os pacientes e com o território no qual trabalham, com relação à saúde do trabalhador. 
Uma responsabilização diferente dos profissionais de saúde, também, considerando equipes, as equipes se responsabilizando por aqueles usuários $e$ aquele território (GARBIN, 2014, entrevista).

Outro desafio: a necessidade de reintroduzir o debate sobre a saúde nas pautas do movimento sindical.

\footnotetext{
[Por que a discussão sobre saúde não está na pauta sindical?] Porque no movimento sindical a lógica ainda é econômica. O nosso desafio é fazer essa conexão do desenvolvimento socioeconômico, tecnológico com a saúde. $E$ isso. [A reivindicação ainda é de cunho salarial?] É. A grande maioria é. Se você pegar os acordos coletivos das categorias, você vai ver que são poucas as cláusulas de saúde do trabalhador. Nós não estamos nem falando em riscos psicossociais, estamos falando em saúde do trabalhador (SILVA, 2014, entrevista).

O processo das negociações, para você melhorar salário, condições de trabalho, saúde, não pode ser uma vez por ano, porque o trabalhador não fica doente uma vez por ano. Ele pode ficar doente a qualquer momento (SILVA, 2014, entrevista).
}

Por fim, apontou-se como um desafio a questão da promoção do empoderamento dos trabalhadores.

[Discutimos] quais as "estratégias de empoderamento", para que possam ser potencializadas, socializadas. Mesmo o trabalhador em condições mais precárias é capaz de demostrar potência (DIAS, 2013, entrevista).

Agora, para você ter o compromisso com a agenda do trabalho decente, você precisa ter diálogo social dentro do local de trabalho (SILVA, 2014, entrevista).

Estamos precisando [...] incorporar essas outras formas de organização do movimento social do movimento dos trabalhadores (SILVA, 2013, entrevista).

\subsubsection{Principais avanços no campo da Saúde do Trabalhador e quanto aos} Transtornos Mentais e do Comportamento Relacionados ao Trabalho

Perguntou-se aos entrevistados sobre os principais avanços ou conquistas no campo da Saúde do Trabalhador, mais especificamente com referência aos Transtornos Mentais e do Comportamento Relacionados ao Trabalho.

Primeiramente, foi destacada a importância do próprio reconhecimento dos transtornos mentais e do comportamento como relacionados ao trabalho.

Também se identifica como positiva a maior atenção do poder público para com a Saúde do Trabalhador.

É percebida como avanço a mudança de mentalidade de alguns peritos do INSS, e a melhoria, em alguns casos, da relação dos peritos com os trabalhadores. 
A perícia é sempre um momento de conflito, tem conflito de interesses sim, mas houve uma melhora dessa forma de contato (SILVEIRA, 2013, entrevista).

Eles negam o benefício, mas aquela coisa de humilhar o segurado, de discutir com ele, de acusá-lo de estar simulando, isso a gente escuta cada vez menos (SILVEIRA, 2013, entrevista).

Percebe-se como positivo o aumento do interesse e da participação de profissionais no campo da Saúde do Trabalhador.

Acho que nós temos mais profissionais atuando na área da Saúde do Trabalhador, temos tanto na área pública - área pública eu quero dizer nos CERESTs, que aumentou o número, mas também em outros locais... (GARBIN, 2014, entrevista).

O NTEP, mesmo com os já apontados questionamentos, é percebido como importante avanço para o reconhecimento e diagnóstico dos Transtornos Mentais e do Comportamento Relacionados ao Trabalho.

\footnotetext{
Na prática, pensando na nossa atuação, representou um avanço bem significativo (GARBIN, 2014, entrevista).

[O NTEP trouxe uma] dimensão importante na mudança de lógica da caracterização dos agravos (GARBIN, 2014, entrevista).

A gente poder contar com essa nova condição para o trabalhador, e também considerar que o INSS, em função desse nexo, também teve que se reestruturar em termos das notificações, e do reconhecimento das notificações de agravos (GARBIN, 2014, entrevista).
}

Também foi apontada pelos entrevistados, apesar das já discutidas preponderâncias do papel do médico e ausência de psicólogos em muitos CERESTs, a valorização do papel do psicólogo na Saúde do Trabalhador.

\subsubsection{SÍNTESE DAS ENTREVISTAS}

Como apresentado anteriormente e relatado nas entrevistas, as "discussões sobre as repercussões negativas na saúde mental dos trabalhadores, vinculadas ou decorrentes da forma como o trabalho se organiza, ritmo e condições ambientais, teve crescimento a partir da década 1980" (SILVA, 2011, p. 110). Também o apontam o levantamento de teses e dissertações no período de 1950 a 2002 realizado por Mendes (2003) e o trabalho de Santana (2006). No que tange aos transtornos mentais, a produção acadêmica se intensificou a partir dos anos 90 (SILVA, 2011; DEUSDEDIT JUNIOR, 2014). 
Desde o início dos anos 80, serviços especializados em atendimento em Saúde do Trabalhador começaram a ser implantados, tanto na saúde pública, como os Programas de Saúde do Trabalhador, quanto em ambulatórios e similares em universidades. Como retratado por diversos entrevistados, os casos de LER que começaram a surgir nesses serviços em meados da década de $80^{209}$ começaram a chamar atenção por sua alta incidência e pelos desafios, inclusive diagnósticos, que traziam. Os trabalhadores acometidos por LER muitas vezes apresentavam sofrimento psicológico, fato destacado por diversos entrevistados - sofrimento devido possivelmente, segundo Sato, Lacaz e Bernardo (2006), às características dessa síndrome e às condições e organização do trabalho que a explicariam. Segundo Maeno, em depoimento a Silva (2011), ao trazer para os profissionais de saúde pública "fenômeno que transcendia as noções do corpo físico", ensejavam discussões a respeito das relações trabalho-saúde mental ou, em seus termos, "os transtornos mentais entraram nas discussões políticas pelos casos das Lesões por Esforços Repetitivos (LER) na década de 1980" (SILVA, 2011, p. 148). Ganharam espaço discussões que tomam a saúde como direito, corporificadas na I Conferência Nacional de Saúde do Trabalhador), e que pleiteiam o reconhecimento do adoecimento psíquico como decorrente ou desencadeado pelo trabalho (como na II Conferência Nacional de Saúde do Trabalhador).

Deusdedit Junior (2014) discute como aumenta progressivamente o número de pessoas com transtornos psíquicos, o que despertou interesse em setores ligados à saúde, ao judiciário, ao meio sindical, ao meio acadêmico, entre outros, bem como questionamentos sobre os elementos do trabalho que poderiam estar na origem desses adoecimentos. Na medida em que questões de saúde mental ainda não tinham reconhecida sua ligação com o trabalho, os casos de LER, que muitas vezes apresentavam também problemas psíquicos, acabariam funcionando como "porta de entrada" dessas questões nos serviços de saúde ou, nos termos de Deusdedit Junior (2014, p. 19), "apareceram como um elemento importante que permitiu "denunciar" os transtornos mentais". Os casos de LER trazem à cena a discussão dos aspectos

\footnotetext{
209 Silveira et al. (2013), por exemplo, informam que os primeiros casos de LER atendidos no Serviço Especializado em Saúde do Trabalhador do Hospital das Clínicas (antigo Ambulatório de Doenças Profissionais) da Universidade Federal de Minas Gerais datam de 1984.
} 
relacionados à organização do trabalho e prenunciam "outro aspecto da saúde dos trabalhadores [...] a ganhar espaço nos consultórios. São as repercussões psíquicas do trabalho". Embora a relação trabalho-saúde mental fosse de difícil constatação, "esses agravos à saúde, que até então não eram identificados, também evidenciam a complexidade que envolve a avaliação da relação entre o processo saúde/doença e o trabalho" (SELIGMANN-SILVA et al., 2010, p. 186). Essa demanda provocaria indagações, estudos e ações que apontariam "a insuficiência dos recursos da medicina do trabalho, da engenharia de segurança e da higiene ocupacional para se construir políticas públicas de promoção da saúde, prevenção, assistência e reabilitação profissional" (SELIGMANN-SILVA et al., 2010, p. 186).

Também foram destacados pelos entrevistados como de grande relevância para a discussão das relações entre saúde mental e trabalho e reconhecimento dos Transtornos Mentais e do Comportamento Relacionados ao Trabalho os decretos $\mathrm{n}^{\circ}$ 3.048, de 1999, e $n^{\circ}$ 6.042, de 2007, que estabelecem, respectivamente, a Lista de Doenças Relacionadas ao Trabalho e o Nexo Técnico Epidemiológico (NTEP). A Lista de Doenças Relacionadas ao Trabalho ("Lista B") indica quais diagnósticos de transtornos mentais e do comportamento poderiam ser considerados como doenças relacionadas ao trabalho, desde que o nexo causal entre as atividades e condições/relações de trabalho seja estabelecido pelo perito do INSS. Alguns dos entrevistados participaram ativamente da construção dessa Lista, elaborada primeiramente a partir de demanda do Ministério da Previdência e depois também adotada pelo Ministério da Saúde; participaram também da elaboração de publicação decorrente da implantação dessa Lista, o Manual "Doenças relacionadas ao trabalho: manual de procedimentos para os serviços de saúde" (2001).

Vários entrevistados consideram que a Lista de Doenças Relacionadas ao Trabalho era "inevitável", dadas as pressões que vinham sendo feitas por técnicos da saúde e movimentos dos trabalhadores, constituindo, em sua opinião, um marco e uma vitória política no sentido do reconhecimento dos Transtornos Mentais e do Comportamento Relacionados ao Trabalho. Contudo, destacam também sua necessidade de aperfeiçoamento e atualização ou revisão, por exemplo quanto a critérios de inclusão 
e exclusão de quadros psicopatológicos, ${ }^{210}$ bem como questões conceituais como 0 enquadramento ou especificidade dos termos/categorias abarcados. Quanto à sua utilização, ou impacto, alguns entrevistados têm a percepção de que não ocorreu, ou pelo menos não até o surgimento do NTEP.

A partir da Lei $n^{\circ} 11.430$, de 2006, do Decreto $n^{\circ} 6.042$, de 2007, e da Instrução Normativa do INSS $n^{\circ} 16$, de 2007, o reconhecimento das doenças relacionadas ao trabalho passou a ser identificado, pelo INSS, mediante o estabelecimento de "nexo técnico epidemiológico" ligado à atividade profissional exercida, conferindo novos contornos ao estabelecimento de nexo causal (CFP, 2008).

Como ocorreu com relação à Lista $B$, vários dos entrevistados consideram a instituição do NTEP (inclusive politicamente) como uma conquista, um avanço importante. $\mathrm{O}$ NTEP é percebido por alguns entrevistados como fundamental para o diagnóstico, visibilidade e mesmo reconhecimento dos Transtornos Mentais e do Comportamento Relacionados ao Trabalho. Sua metodologia permitiria melhor identificar a incidência de doenças relacionadas ao trabalho e, especificamente, dos Transtornos Mentais e do Comportamento Relacionados ao Trabalho. A partir do cruzamento das informações de código da Classificação Internacional de Doenças (CID-10) e de código da (Classificação Nacional de Atividade Econômica - CNAE), torna-se possível apontar a existência de relação entre a lesão ou agravo e a atividade desenvolvida pelo trabalhador. Como aponta Deusdedit Junior (2014), com a implementação do NTEP e a retirada da condição de obrigatoriedade de uma comunicação de evento de acidente ou doença do trabalho (CAT), observou-se substancial alteração no perfil da concessão de benefícios acidentários, como discutido na seção 6.1. Para os entrevistados, o NTEP traria avanços na medida em que traria maior agilidade para a realização do nexo do adoecimento com o trabalho; também pressupõe/estabelece a inversão do ônus da prova, bem como a evidência ou associação de natureza epidemiológica, permitindo o levantamento de hipóteses a serem investigadas do ponto de vista etiológico e auxiliando na configuração e reconhecimento de um padrão coletivo de adoecimento, minimizando a individualização desse adoecimento (culpabilização do trabalhador pelo adoecimento).

210 Conferir, a título de exemplo, os questionamentos de Seligmann-Silva (s/d) e Jardim (2011). 
Contudo, como apontado por Lima (2011) e Silva (2011) e pelos entrevistados, o NTEP é objeto de controvérsias. Mesmo se considerado um avanço, são elencadas pelos entrevistados questões como sua lógica de "causa-efeito", a necessidade de aperfeiçoamento/atualização e questões conceituais como a não inclusão de algumas doenças como relacionadas ao trabalho, ou a exclusão de algumas categorias profissionais da relação da lista que faz o cruzamento dos CIDs com a CNAE. Para os entrevistados, as críticas feitas ao NTEP se dariam não por causa de questões técnicas, mas de natureza ideológica, da ordem dos valores e crenças. Outro ponto de resistência e críticas ao NTEP seria a própria perícia médica do INSS. Também são apontadas pelos entrevistados resistências e questionamentos ao NTEP por parte das empresas, e mesmo suas tentativas de burlá-lo (por exemplo, por meio da terceirização).

Como destacam Glina et al. (2001, p. 608), apesar de sua alta incidência, os transtornos mentais e do comportamento relacionados ao trabalho frequentemente deixariam de ser reconhecidos como tais no momento da avaliação clínica. Uma das razões seria devida às próprias características dos distúrbios psíquicos, "regularmente mascarados por sintomas físicos". Bernardo e Garbin (2011, p. 11) também afirmam que, quando esses trabalhadores chegam aos CERESTs ou à rede básica de saúde, muitas vezes são atendidos com relação aos seus sintomas físicos, "desconsiderando a importância do trabalho no desenvolvimento dos sintomas psíquicos". Segundo as autoras, também ocorre o fato de que trabalhadores com problemas de saúde mental relacionada ao trabalho sejam atendidos em serviços de saúde mental sem que essa relação seja estabelecida. Uma das questões levantadas pelos entrevistados a respeito é o desconhecimento pela atenção básica de procedimentos de diagnóstico (ou mesmo de encaminhamento) de doenças relacionadas ao trabalho, em especial de Transtornos Mentais e do Comportamento Relacionados ao Trabalho. Outro elemento possivelmente relacionado seria a ausência de profissionais "psi" (psiquiatras, psicólogos) em muitos serviços, e mesmo em alguns CERESTs. A essa dificuldade diagnóstica, somar-se-ia, sobretudo, quanto aos Transtornos Mentais e do Comportamento Relacionados ao Trabalho, a motivada pela rapidez da consulta/procedimentos, muitas vezes demandada do profissional de saúde na rede 
pública, que comprometeria a investigação diagnóstica e impediria ou dificultaria a realização de anamnese mais detalhada. Como coloca Jacques (2007, p. 116), “o estabelecimento do nexo causal entre trabalho e distúrbio mental impõe a necessidade de uma investigação diagnóstica em que a anamnese ocupacional é o instrumento decisivo".

Essa dificuldade diagnóstica poderia estar associada a outra, fortemente destacada pelos entrevistados, e que se refere à formação ou qualificação dos profissionais de saúde (inclusive os que estão na atenção básica ou nos CAPS) que, de modo geral, não contemplaria discussões sobre a atenção integral ao sujeito; o diálogo/interlocução com outras especialidades; o papel ou a relação do trabalho com o processo saúdedoença; os aspectos culturais envolvidos; e, de forma geral, sobre Saúde Coletiva ou Saúde do Trabalhador. Mais especificamente, faltaria formação ou qualificação dos profissionais de saúde para a compreensão da dimensão da saúde mental, de modo geral, e em sua relação com o trabalho. Outra questão apontada se referiria a certo despreparo da atenção básica/CAPS para lidar com o campo a Saúde do Trabalhador (e com os Transtornos Mentais e do Comportamento Relacionados ao Trabalho) ou mesmo para a lida com a categoria "trabalho". A esse respeito, Lima (2013) destaca que, embora haja crescente interesse sobre a questão das relações entre trabalho e saúde mental, esse interesse nem sempre seria "acompanhado com devido preparo para tratá-la"; e, apesar da vasta produção acadêmica na área, "seu volume não reflete necessariamente um avanço na compreensão e no aprofundamento de questões cruciais" (LIMA, 2013, p. 91).

Ainda no âmbito dos desafios diagnósticos, uma questão mencionada por todos os profissionais entrevistados ligados à área da Saúde do Trabalhador se refere à dificuldade de diagnóstico dos Transtornos Mentais e do Comportamento Relacionados ao Trabalho, dada a sua "invisibilidade". O reconhecimento, a "visibilidade" de uma doença, requer o desenvolvimento de um aparato médicoconceitual que a reconheça, em função de modelos de saúde e doença. A identificação de uma doença do trabalho é um processo que envolveria tanto o aumento das atividades que as produzem quanto o aumento dos seus relatos e notificações. (DWYER, 2000). Essas doenças muitas vezes passariam despercebidas, "invisíveis", pelo 
despreparo das disciplinas encarregadas em detectar e tratar as doenças em efetuar seu diagnóstico, ou mesmo sua negação.

Os Transtornos Mentais e do Comportamento Relacionados ao Trabalho, sobretudo os não induzidos por substâncias tóxicas, em muitos casos não apresentam alterações físicas marcantes ou imediatamente observáveis. Por isso, o diagnóstico muitas vezes deve ser baseado em dados "subjetivos", como o relato do trabalhador sobre seus sintomas, que podem se confundir com os de outras patologias. O peso e a medida atribuídos aos sintomas relatados e ao próprio relato do trabalhador serão diferentes, dependendo da perspectiva técnico-política do grupo de atenção à saúde acionado serviço médico da empresa, rede pública de saúde, serviços públicos especializados em Saúde do Trabalhador, perícia médica. Outro fator de dificuldade apontado por Seligmann-Silva em sua entrevista seria a própria plasticidade dos transtornos mentais e do comportamento. Esses elementos também poderiam favorecer o discurso (por parte de médicos, peritos e empregadores) da simulação dos Transtornos Mentais e do Comportamento Relacionados ao Trabalho.

Sobre a ideia de simulação dos Transtornos Mentais e do Comportamento Relacionados ao Trabalho pelo trabalhador, embora alguns entrevistados tenham afirmado que, ainda que possa ocorrer em casos isolados, uma vez que, dada a "invisibilidade" do adoecimento mental, este se prestaria mais à simulação. A maioria dos entrevistados posicionou-se contrariamente à percepção de que haja a simulação, embora vários apontem que, sobretudo entre médicos e peritos, essa seja uma percepção disseminada. Uma das razões poderia ser a já citada dimensão subjetiva do "adoecimento" mental/psíquico, e sua invisibilidade; a dimensão da simulação poderia estar associada também à concepção de dignificação do trabalho (ou à positivação ou "apologia do trabalho" citada pelos entrevistados). Também poderiam contribuir a questão da formação desses profissionais ou sua filiação a determinadas correntes teóricas; como chamam atenção Silveira et al. (2013), ainda hoje se encontrariam referências à sinistrose no meio médico e pericial.

Um desafio elencado por vários dos entrevistados refere-se à falta de consenso (ou mesmo disputas), no campo da saúde mental, ou da saúde mental e trabalho, a respeito das concepções teóricas sobre as relações entre "adoecimento" 
mental/psíquico e trabalho. Embora, como já apresentado, a maioria da produção em Saúde Mental e Trabalho confira destaque à categoria trabalho, observam-se divergências, sobretudo no que se refere ao papel desempenhado pelo trabalho no adoecimento psíquico, entendido por alguns autores como determinante (estruturador de adoecimento psíquico), por outros, como desencadeante ("porta de entrada" para o adoecimento). Também se encontram presentes no campo, como já discutido, modelos teóricos que não considerariam o trabalho na análise da subjetividade e nos processos relativos à saúde mental, considerando os "problemas" apresentados pelos trabalhadores como de ordem estritamente individual. Segundo Glina et al. (2001), quanto ao diagnóstico, uma dificuldade importante residiria na vinculação entre os quadros clínicos e o trabalho, devido a essas divergências. Já Seligmann-Silva (1994, p. 289) afirma que:

[...] não existe um consenso que tenha permitido uma classificação dos distúrbios psíquicos vinculados ao trabalho, existe uma concordância da importância etiológica do trabalho [no caso das abordagens em Saúde Mental e Trabalho], mas não a respeito do modo como se exerce a conexão trabalho/psiquismo de forma suficiente a permitir um quadro teórico. Os distintos modelos teóricos vêm trazendo dificuldades para a clínica e prevenção.

No que tange a essas divergências, para Lima (2013) o principal obstáculo para o desenvolvimento do campo da Saúde Mental e Trabalho seria a ausência de um real debate entre as diversas correntes que o compõem, e constata dois tipos de atitude da comunidade acadêmica:

[...] ou se instaura o que Chasin (2001) chamou de "guerra do silêncio" - e que consiste simplesmente em ignorar as críticas, tentando, por meio dessa atitude, reduzi-las à insignificância - ou se cria uma espécie de simulacro de aceitação do debate, quando, na verdade, ocorre uma recusa em se aprofundar nas verdadeiras questões. Assim, é comum manifestar a abertura ao diálogo, mas com a condição de que o ponto de partida seja uma série de acordos em torno dos problemas tratados (LIMA, 2013, p. 95).

E prossegue:

Em suma, acreditamos que não conseguiremos cuidar do nosso próprio ofício sem que haja um real debate entre as escolas, o qual nos permita formar um coletivo sólido, suscetível de nos amparar frente às inúmeras dificuldades, tanto teóricas quanto práticas, que devemos enfrentar cotidianamente. $E$, se não cuidarmos do nosso próprio ofício, como poderemos cuidar do ofício do outro? (LIMA, 2013, p. 96). 
Especificamente no caso dos profissionais de saúde mental - especialmente psiquiatras e psicólogos -, a formação ainda seria fortemente influenciada por vertentes individualizantes: “a formação médica em psiquiatria, de um modo geral, preconiza terapêuticas medicamentosas como a solução para a maior parte dos problemas de saúde mental"; 211 já na Psicologia, as teorias predominantes - com destaque para a psicanálise - "enfatizam os aspectos individuais e familiares como as principais causas do adoecimento e do sofrimento psíquico, indicando a psicoterapia como a forma primordial de tratamento" (BERNARDO; GARBIN, 2011, p. 106). Para as autoras, parte dos problemas de integração entre as áreas da Saúde Mental e Saúde do Trabalhador poderia ser atribuída a esse fator.

Para Silva (2011, p. 195), as dificuldades diagnósticas na área da Saúde Mental se constituiriam em um campo de discordâncias, pois "estão presentes discursos contraditórios, que coexistem e buscam ser hegemônicos"; disputariam espaço versões distintas sobre a origem dos problemas mentais, que se vinculariam a temáticas psíquicas e/ou sociais ou a alterações cerebrais em termos físico-químicos, por exemplo. Glina et al. (2001) também acrescentam o fato de que não há, na Classificação Internacional das Doenças, um grupo de diagnósticos de distúrbios psíquicos relacionados com o trabalho.

Uma concepção destacada por vários entrevistados, e que se relaciona com as dificuldades do processo de diagnóstico, é a de que a categoria "trabalho" seria vista/tratada pelos profissionais da saúde, sobretudo pelos médicos, como um "apêndice", algo secundário ou não contemplado no diagnóstico, o que poderia estar relacionado, entre outros fatores, à questão da formação desses profissionais ou sua filiação a determinadas correntes teóricas.

Outro desafio apontado por quase todos os entrevistados seria promover a integração, no âmbito do SUS, entre as estratégias de Saúde da Família, da Saúde Mental e da

211 A esse respeito, Fonseca (2009, p. 474) coloca:

Contudo, é importante não individualizar o problema nos médicos. Eles fazem parte de um sistema de saúde que não é estruturado para atender a demandas não classificadas na nosologia da clínica médica. Soma-se a isso o fato de que, frequentemente, seu próprio treinamento, dentro do recorte da biomedicina, não os capacita para a compreensão de problemáticas que não se encaixam nos diagnósticos médicos de base anatômica. 
Saúde do Trabalhador, e de mais contatos intrainstitucionais. Uma questão conflituosa apontada nas entrevistas se refere à não integração ou sobreposição de políticas públicas na área de Saúde do Trabalhador, notadamente Ministério da Saúde, Ministério do Trabalho e Ministério da Previdência Social, bem como a fragmentação de políticas e ações e dificuldade de articulação das esferas de governo (federal, estadual e municipal). O distanciamento entre equipamentos de atendimento em Saúde Mental e Saúde do Trabalhador dificultaria o diagnóstico e incrementaria a subnotificação dos Transtornos Mentais e do Comportamento Relacionados ao Trabalho.

Também já citado previamente, um problema a ser vencido citado por vários entrevistados refere-se à falta de consenso (ou mesmo disputas) no campo da saúde mental, ou da saúde mental e trabalho, sobre as relações entre "adoecimento" mental/psíquico e trabalho. Nardi e Ramminger (2012) analisam a dificuldade de estabelecer áreas de confluência entre os programas setoriais da Saúde Mental e da Saúde do Trabalhador, porque ambos os programas se conformam de forma diferenciada à estrutura hierarquizada do SUS, por terem optado por centros de referência especializados como ordenadores da rede de Saúde Mental e de Saúde do Trabalhador, respectivamente os CAPS (Centros de Atenção Psicossocial) e os CERESTs (Centros de Referência em Saúde do Trabalhador). Os autores analisam como atualmente a Saúde Mental buscaria sua inserção na atenção básica, enquanto a Saúde do Trabalhador se manteria distanciada da porta de entrada do SUS. Essa forma diferenciada de implantar a atenção poderia ajudar a explicar "porque a discussão relativa às ações no campo da Saúde Mental não se acha incorporada na política de Saúde do Trabalhador, e vice-versa" (NARDI; RAMMINGER, 2012, p. 376). Deusdedit Junior (2014) coloca que, mesmo que seja comum a referência a esses campos como "Rede de Saúde do Trabalho" e "Rede de Saúde Mental", a proposta do Sistema Único de Saúde é clara no sentido de que só existe uma rede, a Rede SUS.

Bernardo e Garbin (2011) destacam em sua análise o gerenciamento dos serviços e das áreas programáticas: desde sua incorporação no sistema de saúde, Saúde Mental e Saúde do Trabalhador tiveram coordenações distintas em todos os níveis do SUS (Ministério da Saúde e Secretarias Estaduais e Municipais de Saúde, em especial em 
municípios de grande porte), ambas apartadas da gestão da atenção básica. Por essa razão, as ações dessas áreas teriam se pautado mais fortemente por suas próprias necessidades e especificidades, a Saúde Mental concentrando-se na consolidação da reforma psiquiátrica, "priorizando a implantação dos CAPS, e a Saúde do Trabalhador ainda busca conquistar o reconhecimento da relação entre o trabalho e o processo saúde-doença" (BERNARDO; GARBIN, 2011, p. 108). A centralização da Saúde Mental nos CAPS, e da Saúde do Trabalhador nos CERESTs, para as autoras, aumentaria a distância entre as duas áreas programáticas e dificultaria o estabelecimento de ações conjuntas com relação ao adoecimento/sofrimento psíquico relacionado ao trabalho.

Bernardo e Garbin (2011) também analisam como, além das apresentadas dificuldades da rede básica, a própria política de saúde mental não propiciaria condições para a atenção aos problemas de saúde mental relacionada ao trabalho, por priorizar o atendimento de casos graves e/ou agudos nos CAPS e nos hospitais. Já a atenção aos casos "leves" ocorreria em equipes de saúde da família, com suporte dos Núcleos de Apoio à Saúde da Família (NASFs). Dessa forma, os casos intermediários, que englobariam a maioria dos casos de saúde mental relacionada ao trabalho, não teriam um sistema estruturado para seu atendimento. As autoras assim sintetizam o que foi colocado pela maioria dos entrevistados:

[...] acreditamos que esse fato [a política de saúde mental] — somado à carência crônica de profissionais na área da saúde pública, à enorme gama de problemas a serem enfrentados no cotidiano dessas equipes e à formação dos profissionais de saúde mais voltada para as "tecnologias duras" do que para as "tecnologias leves" - não favorece a atenção aos problemas de saúde mental e de saúde do trabalhador pela rede básica (BERNARDO; GARBIN, 2011, p. 109).

Deusdedit Junior (2014) enfatiza a divergência teórica dos profissionais que atuam nos diversos serviços de saúde: enquanto profissionais do CAPS tenderiam a focar os problemas de saúde mental no intrapsíquico e a discutir a atividade de trabalho como uma escolha pessoal, profissionais da saúde do trabalhador tenderiam a focar aspectos sociais, indicando o trabalho como um fator fundamental tanto ao diagnóstico quanto ao encaminhamento.

Os entrevistados colocam como também necessária a discussão sobre o nexo causal que, após a implantação do NTEP, ganhou novos contornos, uma vez que "inverte o 
ônus da prova em alguns casos ao determinar o registro automático como doença relacionada ao trabalho de determinadas patologias em função de altas incidências em determinados ambientes de trabalho" (JACQUES, 2007, p. 112). Como destaca Lima (2003), já seria bem conhecida a polêmica e a ausência de consenso no campo da Saúde Mental e Trabalho sobre a existência de nexo causal entre a exposição a certas formas de organização do trabalho e o desenvolvimento de distúrbios mentais específicos.

Codo (2006) afirma que, quer se considere o trabalho como fator desencadeante, quer como uma das causas de um conjunto complexo de determinantes, haveria argumentos jurídicos, como o princípio da concausalidade, que fundamentariam o nexo causal. A título de exemplo, o autor cita o caso das cardiopatias, que a jurisprudência considera como relacionada ao trabalho, quando seu agravamento ou eclosão se dá devido às suas condições. Ainda em 1988, afirmava:

\begin{abstract}
Não somos apenas os profissionais de saúde mental os incomodados por uma "doença latente", nos outros casos, como a cardiopatia, é perfeitamente possível e já foi realizado considerar-se doença de trabalho o indivíduo já portador da doença, cujo agravamento ou eclosão foi provocado pelas condições de trabalho. Estamos diante de um "nexo causal" tão claro quanto qualquer outro, do ponto de vista legal. Em uma outra formulação: o trabalho seria apenas uma das causas de um complexo de fatores determinantes da doença mental. O jurista Cesarino Jr. interpretou e a prática forense consagrou o princípio da "concausalidade", ou seja, "doutrinariamente em matéria de infortunística, o acidente não precisa ser causado exclusivamente e unicamente pelo trabalho", assim, a lei reconhece a existência de infortúnio mesmo que o acidente não tenha causa única. É a concausalidade, que resulta da causa única, ou nexo etiológico, associada com outras causas independentes. Uma outra jurisprudência deve ser lembrada aqui, já nos chamaram de profissionais da dúvida. Segundo os juristas é "pacífico" que: "Em caso de dúvida sobre o nexo causal, a questão se solve a favor do operário", citam-se a seguir várias jurisprudências. As outras teorias que citamos não necessitam ser comentadas, pois defendem exatamente a existência de nexo causal entre Trabalho e Saúde Mental. Os argumentos acima me parecem suficientes para [que seja] perfeitamente possível do ponto de vista jurídico o enquadramento das "doenças mentais" como "doenças profissionais" (CODO, 1988, p. 24).
\end{abstract}

Para Jacques (2007), a relação de causalidade, mesmo que multicausal, que fundamentaria o estabelecimento do vínculo entre saúde/doença mental e trabalho, não daria conta das relações de determinação das manifestações humanas, e acabaria por reduzir o conceito de saúde mental à ausência de transtornos psíquicos. Lima (2013, p. 92) considera um dos limites impostos ao campo da Saúde Mental e Trabalho 
apreender como se dá "a passagem entre uma situação vivida, seja ela qual for, e o distúrbio mental, propriamente dito. Essa questão permanece em aberto para todo o campo das ciências que tratam dos transtornos psíquicos". Especificamente no campo da Saúde Mental e Trabalho, a autora situa que o máximo que se avançou foi explicitar paralelismo entre certas experiências de vida e trabalho e o surgimento de transtornos mentais específicos. Contudo, persistiria e prevaleceria a ideia de causalidade linear entre transtorno mental e trabalho. Nesse sentido, Jacques (2007) e Lima (2013) citam como méritos de Le Guillant:

[...] sua habilidade em compreender a forma pela qual os determinantes sociais e individuais se articulam na gênese das doenças, superando a dicotomia entre subjetividade e objetividade, entre singular e coletivo. Ou seja: a explicação não se encontra em dados subjetivos ou derivados do contexto laboral, mas nas formas pelos quais eles se articulam, construindo uma trama complexa que se traduz na trajetória de cada trabalhador, o que explica porque nem todos expostos a situações semelhantes adoecem ou manifestam o mesmo grau de desgaste (JACQUES, 2007, p. 117)

Vários entrevistados destacaram que o estabelecimento do nexo ou da relação com o trabalho se daria a partir da escuta do relato pessoal do trabalhador, o que implicaria desde uma anamnese cuidadosa a até mesmo, para favorecer essa escuta, um número maior de encontros, não se tratando de processo "rápido". Essa escuta diferenciada também deveria atentar-se à dimensão de subjetividade implicada nos Transtornos Mentais e do Comportamento Relacionados ao Trabalho. Também foi apontada pelos entrevistados a necessidade, no caso desses Transtornos, dada sua maior complexidade, de uma "sensibilidade" do médico/profissional de saúde para a questão do trabalho e de diálogo/interlocução com outros profissionais.

Mesmo após a implementação do NTEP e do aumento do número de benefícios acidentários concedidos pelo INSS para Transtornos Mentais e do Comportamento Relacionados ao Trabalho da ordem de 1.1567\% (SELIGMANN-SILVA et al., 2011; MAENO, 2011), apenas considerando o período de 2006 para 2007, ainda haveria, para os entrevistados, tanto sua caracterização como doença "comum" quanto sua subnotificação. Considerando que esses Transtornos são a terceira maior causa de concessão de benefícios acidentários, se tomadas apenas as doenças relacionadas ao trabalho, na avaliação da maioria dos entrevistados, os dados oficiais não representariam a realidade do número de casos de adoecimento, pois estaria 
ocorrendo tanto a caracterização desses Transtornos como doença "comum", bem como sua subnotificação. Mesmo sendo eles de notificação obrigatória no Sistema de Informação de Agravos de Notificação (SINAN), essa subnotificação poderia ser verificada ao comparar os dados do número de benefícios acidentários concedidos por causa desses Transtornos com o número de casos notificados, que correspondem apenas a uma pequena parcela dos benefícios acidentários concedidos.

Uma importante dificuldade, mencionada por quase todos os profissionais entrevistados ligados à área da Saúde do Trabalhador, refere-se a reconhecer que o trabalho pode acarretar em "adoecimento" mental/psíquico, pois a "doença mental" do trabalhador não teria como causa o trabalho, mas sim questões individuais (problemas na família, afetivos etc.). Essa perspectiva (que também pode estar associada à questão da formação, bem como às diferenças em termos de concepções ou modelos teóricos) abre margens para a culpabilização do trabalhador pela doença e para a individualização da questão. Nesse sentido, o NTEP também auxiliaria na configuração e reconhecimento de um padrão coletivo de adoecimento, minimizando a individualização desse adoecimento ("culpa" do trabalhador). A esse respeito, Lima (2013) chama atenção para a ideia de que problemas no mundo do trabalho tenham sua origem em questões estritamente pessoais, levando por sua vez à ideia de que o modo de saná-los seria por meio de tratamento psicológico individual. Também seria uma ideia subjacente a certas práticas a de que "condições objetivas podem ser modificadas pela simples mudança de atitude, sendo resultado de um ato puramente subjetivo" (LIMA, 2013, p. 93).

Sato et al. (1993) discutem como o entendimento que se tem sobre o "psicológico" estaria eivado de valores morais, como fraqueza, vontade, preguiça, levando à culpabilização dos trabalhadores pela manifestação da doença, pois interpreta-se que "a dimensão psicológica, ao se tratar de fator explicativo da doença, é sinônimo de fraqueza individual. [...] Parece haver o entendimento [...] de que o psicológico é sinônimo de fingimento e, portanto, denota que a doença se instala ou remite de acordo com a vontade das pessoas" (SATO et al., 1993, p. 53).

Para Verthein e Minayo-Gomez (2001), os conflitos, reduzidos ao campo psíquico, seriam tratados como a expressão interna das neuroses dos indivíduos, e os 
trabalhadores seriam, por esse mecanismo, produzidos como neuróticos. Também discutem, a partir de estudo realizado sobre as LER e sua percepção pela perícia médica no Rio de Janeiro, como pareceria existir a representação de "uma personalidade que predispõe o trabalhador, em situações de conflito e tensão, a processos de adoecimento. As dificuldades no trabalho, assim como as pressões de instabilidade social, estariam entre os elementos ansiogênicos", que chamam de ideia de um "sujeito-doente". A ideia de um "sujeito-doente" pressuporia certo tipo de personalidade de características mórbidas, que expressaria sintomas de doença em ambientes ansiogênicos e estressantes; "ao colocar em suspenso as atividades realizadas no trabalho, vai destruindo, de forma estratégica, o campo de possibilidade do trabalho como elemento constituinte desse processo de adoecimento" (VERTHEIN; MINAYO-GOMEZ, 2001, p. 468). Para os autores, haveria uma racionalidade médica que, no agir sobre a saúde, ao privilegiar características subjetivas no processo de adoecimento, imputaria ao sujeito a responsabilidade do adoecer, em uma "concepção etiopatogênica culpabilizante", à medida que

[...] há um tom geral de recriminação moral com relação ao doente, que seria vítima de seus próprios excessos. A doença seria decorrência de descuidos que as pessoas teriam no cuidado de si mesmas... preocupações, perturbações, também levariam ao adoecimento, o que teria contrapartida no imaginário médico na nebulosa categoria do estresse (LUZ, 1996, apud VERTHEIN; MINAYO-GOMEZ, 2000, p. 9).

As discussões sobre o "psicológico" levaram à indagação a respeito da participação da Psicologia nesse cenário. Algumas das questões colocadas para os entrevistados se referiam à sua percepção sobre o papel, a função, a importância da Psicologia no campo da Saúde do Trabalhador. Primeiramente, questionou-se a respeito de uma visão mais crítica da Psicologia, por vezes percebida como um campo científico que se prestaria à "ortopedia social", ao tratar historicamente da questão da adaptação; a perspectiva de uma Psicologia mais "normativa" ou "adaptacionista" viria se transformando, segundo alguns dos entrevistados. Também é apontada por alguns deles a busca da Psicologia em se constituir como um campo autônomo, com legitimidade própria, inclusive na área da saúde, bem como a necessidade de que a Psicologia estabeleça diálogos, internamente e com outras categorias. 
Os papeis mais destacados da Psicologia no âmbito da Saúde do Trabalhador seriam o da compreensão do trabalho naquilo que representa para os trabalhadores e em sua dimensão de constituição de subjetividade, bem como a investigação (ou "desvelamento") das circunstâncias que o determinam.

Também foi discutida a participação da Psicologia nos CERESTs. Embora a categoria não seja uma das consideradas pela legislação para composição da equipe mínima, é apontada por alguns dos entrevistados que a Psicologia e o trabalho do psicólogo, na Saúde do Trabalhador, têm sido cada vez mais valorizados. Dados da RENAST mostram que os CERESTs Estaduais que atuam com apenas a equipe mínima perfazem 38,9\%; os regionais, 39,6\%; no total, seriam 39,5\%. Quanto à participação de psicólogos na equipe, com relação ao quantitativo total de pessoal, nos CERESTs estaduais há 8,5\% de psicólogos; nos regionais, 17,8\% (num total geral de $8 \%$ ). Deve-se observar também que foi considerado no cálculo o quantitativo de pessoal informado por cada CEREST, e não o número de CERESTs (RENAST, 2013), o que não permite avaliar o número de CERESTs que contam com os serviços desse profissional. Na região metropolitana de Belo Horizonte, os CERESTs de Contagem e Betim contam com a presença da Psicologia, e os de Belo Horizonte, não.

Por fim, deve-se destacar que se encontram presentes no cenário dos Transtornos Mentais e do Comportamento Relacionados ao Trabalho atores diversos, e várias formações discursivas ou perspectivas teóricas, em tensão: concepções tradicionais de Medicina do Trabalho-Saúde Ocupacional X Saúde do Trabalhador; concepções dos profissionais da área de Saúde Mental (que enfatizam a dimensão individual e intrapsíquica) X concepções dos profissionais da Saúde do Trabalhador (que priorizam a relação com o trabalho); abordagens/teorias em divergência ou disputa no campo da Saúde Mental e Trabalho, entre outras. Nesse sentido, nos termos de Nardi e Ramminger (2012, p. 375), são "arenas tensas de disputa política e epistemológica"; nos de Bourdieu, um "lócus onde se trava uma luta concorrencial entre os agentes, em torno de interesses específicos que caracterizam a área em questão" (BOURDIEU, 1989, p. 89). 


\section{REFLEXÕES FINAIS}

Esse trabalho buscou investigar como, historicamente, e a partir de quais relações entre representações e práticas, começam a se reconhecer como categoria os "Transtornos Mentais e do Comportamento Relacionados ao Trabalho" e compreender como essa categoria diagnóstica passou a fazer parte das políticas públicas e legislação referentes à relação saúde/trabalho, bem como discutir como implica e é implicada no aparecimento de uma estrutura conceitual voltada a seu tratamento. Partiu-se nessa análise das perspectivas da Saúde do Trabalhador, da Psicologia do Trabalho e da Saúde Mental e Trabalho, e do conceito de determinação social do processo saúdedoença.

Buscou-se analisar o campo científico - na acepção de Bourdieu - ligado a essas doenças, com seus vários grupos socioprofissionais, divergências e acordos teóricos, relações de reciprocidade e de subordinação que mantêm entre si e sua articulação com forças presentes em outros espaços sociais. A análise propôs um recorte histórico do campo de relações entre trabalho-saúde, em especial trabalho e saúde mental, nas perspectivas da determinação social da saúde e da construção social da ciência, para compreender, no que tange aos Transtornos Mentais e do Comportamento Relacionados ao Trabalho, os processos de transformação e as lutas travadas entre os diversos grupos de interesse envolvidos que, por sua vez, têm decisiva contribuição na determinação de critérios para estabelecer o que será considerado saúde e doença, em quais situações e para quais sujeitos.

Em termos da pesquisa e da escrita da tese, apresento algumas considerações sobre experiência das entrevistas realizadas e sobre as implicações (limitações) decorrentes das escolhas metodológicas realizadas. Discute-se também uma questão de fundo que permeia a tese, a da importância ou necessidade do reconhecimento dos transtornos mentais como relacionados ao trabalho. Apresentam-se condições que possibilitaram o reconhecimento legal dos Transtornos Mentais e do Comportamento Relacionados ao Trabalho, aqui apresentadas, bem como disputas ainda presentes no campo que constituem entraves ou dificuldades à efetivação desse reconhecimento, além de desafios e possibilidades que se descortinam. A discussão sobre os Transtornos 
Mentais e do Comportamento Relacionados ao Trabalho mobiliza, historicamente, diferentes grupos, ações político-técnicas e representações sobre saúde e doença, diagnóstico, tratamento e etiologia, que evocam quadros clínicos e sintomatológicos descritos e vivenciados de forma diferenciada, por isso sendo defendido neste trabalho se tratarem os Transtornos Mentais e do Comportamento Relacionados ao Trabalho, a partir de seu reconhecimento legal, uma "nova" doença. Por fim, concluo este trabalho com algumas considerações sobre as implicações de realização desta análise sócio-histórica em termos de minhas escolhas políticas.

\section{- Limitações do trabalho}

Entre as várias limitações deste estudo, gostaria de elencar algumas.

Um percurso por um período de tempo tão longo, dadas as limitações de construção de uma tese, é inevitavelmente lacunar. Este trabalho é simultaneamente fruto de escolhas teóricas e de limitações da autora, e não se pretende uma abordagem histórica stricto sensu, ou uma análise histórica exaustiva.

Não foi possível aprofundar a discussão sobre a participação na questão de importante protagonista, o movimento sindical, uma vez que os interlocutores inicialmente escolhidos, por seu papel histórico, foram Gilberto Salviano (Assessor de Saúde da CUT, ex-integrante do DIESAT), com quem foi realizada entrevista, e o próprio DIESAT. Infelizmente, nos vários contatos por mim estabelecidos não obtive agendamento com representantes ou a possibilidade de in loco tentar "garimpar" materiais. Posteriormente, por meio dos profissionais entrevistados nesta pesquisa, obtive indicações de vários sindicatos, em Belo Horizonte, partícipes da discussão sobre Saúde Mental e Trabalho (como, por exemplo, Sind Rede - Sindicato dos Trabalhadores em Educação da Rede Municipal de Belo Horizonte, Sind UTE Sindicato Único dos Trabalhadores em Educação de Minas Gerais, Sindicato dos Bancários, Sinttel - Sindicato dos Trabalhadores em Telecomunicações de Minas Gerais, Sindicato dos Empregados das Empresas de Segurança e Vigilância do Estado de Minas Gerais). Contudo, já não era mais possível explorar essa vertente (realizando as entrevistas). 
Quanto à área pericial (INSS), também muito relevante para a discussão dos Transtornos Mentais e do Comportamento Relacionados ao Trabalho, tive contatos iniciais promissores com a Divisão de Benefícios - Gerência Executiva de Belo Horizonte - INSS, e abertura para o agendamento, mas não foi possível uma conciliação de agendas que permitisse a (s) entrevista (s).

Também não foram contempladas na análise, dado seu caráter muito recente, algumas mudanças legais que podem trazer significativas transformações para o cenário em discussão e retrocessos em termos de conquistas políticas, as Medidas Provisórias $\mathrm{n}^{\circ}$ 664 e $n^{\circ} 665$ e o Projeto de Lei $n^{\circ} 4.330$. As Medidas Provisórias $n^{\circ} 664$ e nº 665, de 30 de dezembro de 2014, que introduzem mudanças na concessão de pensões, segurodesemprego, auxílio-doença, garantia de emprego (estabilidade) em casos de acidentes de trabalho, bem como em procedimentos periciais, entre outras. O Projeto de Lei $n^{\circ}$ 4.330, de 2004, o "PL da Terceirização", que permitiria a flexibilização de diversas garantias trabalhistas, atualmente em tramitação no Congresso Nacional.

\section{- Sobre as entrevistas}

A riqueza das entrevistas realizadas - dada a grande receptividade, disponibilidade, abertura e contribuições de todos os entrevistados, superou enormemente minhas expectativas. As discussões extrapolaram os limites da discussão dos Transtornos Mentais e do Comportamento Relacionados ao Trabalho, abarcando as origens da atuação e pesquisa em saúde mental e trabalho, a constituição do SUS, os CERESTs e a RENAST, a Psicologia e os psicólogos nesse campo e tantos outros temas que seria virtualmente impossível esgotá-los ou discuti-los adequadamente em seu conjunto. Foi, portanto, necessário estabelecer alguns recortes que mais se ativessem ao tema da tese, e os relatos nela reproduzidos não correspondem à riqueza dos dados coletados.

Nesse sentido, constituiu para mim, como pesquisadora, muito mais que a construção da tese, uma oportunidade ímpar de conhecer e dialogar com personagens fundamentais, não apenas para a compreensão do tema da tese, mas para os campos da Saúde do Trabalhador, da Psicologia do Trabalho, da Saúde Mental e Trabalho de 
uma forma mais ampla - relatos de quem viveu e escreveu (em vários sentidos) esta história, lançando luzes também para minha inserção neste campo como psicóloga.

Também constituiu riquíssima oportunidade de diálogo com autores de textos com os quais convivi e dialoguei durante toda a minha formação, desde os tempos de estudante de Psicologia - para além do diálogo com a palavra escrita, uma interlocução com essas personagens.

Estando em minhas atividades docentes distante da atuação "na linha de frente" do atendimento clínico aos Transtornos Mentais e do Comportamento Relacionados ao Trabalho desde 2001, tornou-se possível compreender os embates, entraves, mas também as transformações no campo, bem como as angústias e esperanças de quem ainda o faz.

\title{
- Por que caracterizar como "B91" e não como "B31"? 212
}

\begin{abstract}
A Previdência deveria ter o interesse de reconhecer esses transtornos psíquicos como relacionados ao trabalho. Por que deveria ter esse interesse? Porque com o reconhecimento acaba aumentando o Fator Acidentário de Prevenção, acaba [favorecendo / tornando possivel] a Previdência Social mover as ações regressivas contra as empresas, pedindo ressarcimento dos custos (MAENO, 2014, entrevista).
\end{abstract}

Essa negação [da relação entre transtornos mentais e trabalho] nossa e é lamentável, porque à medida que nós negamos, nós estamos fazendo obstáculos para melhorar o ambiente e o mundo do trabalho. Se a gente reconhece que o trabalho está adoecendo fisicamente, emocionalmente, socialmente, nossa sociedade está muito adoecida, nós vamos atuar para melhorar esse trabalho, essa prática do trabalho (SILVA, 2013, entrevista).

Uma questão de fundo que permeia a tese e a discussão do reconhecimento dos transtornos mentais e do comportamento como relacionados ao trabalho é a da importância ou necessidade de sua inscrição nesse registro ou caracterização dessa forma (sendo passíveis de pleito, pelo trabalhador, do benefício acidentário, B91) e não como doença comum (que faria jus ao benefício previdenciário, ou B31).

A inscrição desse conjunto de doenças ou transtornos como relacionados ao trabalho teria implicações em aspectos tanto discursivos, quanto representacionais e políticos da questão.

212 B31 e B91 referem-se tanto a códigos de benefícios diferenciados, respectivamente, auxílio-doença previdenciário e auxílio-doença acidentário, como, em alguns meios, de um jargão para se referir à doença comum ou à doença relacionada ao trabalho. 
Para o trabalhador afetado, implicaria em garantias diferenciadas previstas pela legislação, como valor diferenciado do benefício e a estabilidade de um ano quando do retorno ao trabalho. Implicaria, também, no reconhecimento de que seu adoecimento não derivaria de uma "responsabilidade" sua, podendo minimizar os fenômenos da culpabilização (ou autoculpabilização) pelo adoecimento ou acidente - implicações de também de ordem identitárias e de autorrepresentação.

Em termos de políticas públicas, permitiria maior embasamento tanto para ações de promoção da saúde, quanto de pesquisa, assistência e vigilância. Diminuir a subnotificação desses transtornos auxiliaria a identificação mais acurada do perfil de morbidade a elas associado e, em termos previdenciários, o ajustamento de critérios para, por exemplo, o ingresso de ações regressivas contra empresas ou a correta aplicação do FAP (Fator Acidentário de Prevenção).

Sobretudo, descortina possibilidades de intervenção em ambientes/relações de trabalho e não no "sujeito-doente" (nos termos de Verthein e Minayo-Gomez), em operações ortopédico-curativas sobre o indivíduo doente pois, como coloca Lima (2013), ao cuidar do trabalho, em todos os sentidos do termo, se cuidaria, ao mesmo tempo, das pessoas que o realizam. Uma perspectiva ético-política que "arranca a discussão e o diagnóstico do foro privado e o remete a uma instância pública, necessariamente política" (CODO, 1988, p. 21).

\section{- O reconhecimento legal dos Transtornos Mentais e do Comportamento Relacionados ao Trabalho}

Mesmo que em uma incidência inferior à atualmente observada, transtornos ou afeç̧ões de ordem mental ou psíquica sempre estiveram presentes no âmbito das relações entre saúde e trabalho. Contudo, é recente a apreensão dessas questões sob o registro de doenças relacionadas ao trabalho e não mais como derivadas de fraqueza, propensão, inclinação, susceptibilidade, desvio ou degeneração moral, tendências neuróticas, ausência de autocontrole, entre outras representações aqui apresentadas. 
Constataram-se algumas condições que possibilitaram a emergência dos Transtornos Mentais e do Comportamento Relacionados ao Trabalho como categoria legalmente reconhecida, apresentadas de forma sintetizada:

- O contexto socioeconômico (global) de terciarização da economia, reestruturação produtiva, precarização do trabalho, terceirização, trabalho informal, novas formas de gestão (da subjetividade), intensificando o processo de adoecimento psíquico.

- As contribuições das Ciências Sociais, Medicina Social Latino-Americana, Epidemiologia Social e Saúde Coletiva, a introdução dos conceitos de determinação social da saúde e processo de trabalho, e a concepção do processo saúde-doença como um processo biopsíquico e social

- A construção do campo da Saúde do Trabalhador, em oposição ao modelo da prática da Medicina do Trabalho - Saúde Ocupacional.

- Rupturas políticas, epistemológicas e éticas introduzidas no campo das relações saúde/trabalho pelas abordagens da Saúde do Trabalhador, da Psicologia do Trabalho e da Saúde Mental e Trabalho.

- O movimento sindical (Novo Sindicalismo), que incorpora a saúde no trabalho em sua agenda política, e promove debates e pesquisas (como as do DIESAT) que discutem a relação trabalho-saúde mental.

- Estudos e pesquisas promovidos pelo meio acadêmico focando a discussão do processo saúde-doença e sua relação com o trabalho, e debates em torno do reconhecimento do sofrimento, desgaste ou transtorno mental/psíquico como relacionado ao trabalho.

- O movimento da luta antimanicomial e da Reforma Psiquiátrica, que colocam em questão noções como "loucura" e "doença mental" como categoria diagnóstica.

- A alta incidência e visibilidade das Lesões por Esforços Repetitivos, que colocam em cena questões referentes à saúde mental e introduzem a necessidade de análise do trabalho e suas repercussões sobre a saúde, não apenas nas condições até então abordadas, mas também quanto aos aspectos organizacionais, ergonômicos e psicossociais. 
- O processo de redemocratização do país após a ditadura militar, que enseja a promulgação de uma nova Constituição, a "Constituição Cidadã" de 1988 e a Lei Orgânica da Saúde de 1990, que possibilitam a implantação do SUS e a incorporação, como dever do Estado, da promoção da saúde do trabalhador.

- Discussões e a ampliação da noção de saúde, consolidadas na Reforma Sanitária e nas formulações da VIII Conferência Nacional de Saúde e da I Conferência Nacional de Saúde do Trabalhador, incorporadas à Constituição de 1988.

- A realização das Conferências Nacionais de Saúde do Trabalhador, a primeira contribuindo para a incorporação das discussões referentes à saúde do trabalhador à Constituição de 1988 e à Lei Orgânica de Saúde, e a segunda, na qual aconteceram discussões específicas sobre as relações entre trabalho e saúde mental.

- A implantação de unidades de referência em saúde do trabalhador em ambulatórios e hospitais universitários, bem como na rede pública de saúde, como os PSTs, CRSTs e CERSATs, com um olhar crítico para o processo saúde-doença-trabalho.

- O reordenamento da saúde pública, por meio do SUS, com a implantação de uma rede de atenção à saúde do trabalhador em estados e municípios.

- A atuação de técnicos (da saúde e da Previdência Social) demandando ou introduzindo mudanças de critérios para reconhecimento/estabelecimento do nexo para doenças relacionadas ao trabalho, como a lista de doenças/agravos que incluía os Transtornos Mentais e do Comportamento Relacionados ao Trabalho (Lista B, Decreto $n^{0} 3.048,1999$ ).

Conclui-se que é a partir dessas condições que as contribuições dos campos da Saúde do Trabalhador e da Saúde Mental e Trabalho se configuram como as abordagens tanto dos profissionais envolvidos com a construção da Lista de Doenças Relacionadas ao Trabalho (Lista B do Decreto $\mathrm{n}^{0} 3.048$ de 1999), na qual são elencados os Transtornos Mentais e do Comportamento Relacionados ao Trabalho, do Manual do Ministério da Saúde para SUS "Doenças relacionadas ao trabalho: manual de 
procedimentos para os serviços de saúde" (de 2001), do NTEP (2007), e orientam as práticas da maioria dos profissionais envolvidos com a atenção à Saúde do Trabalhador no SUS, notadamente nos CERESTs / RENAST.

O reconhecimento legal desses transtornos como relacionados ao trabalho se dá sob uma "nomenclatura" (mesmo que questionada) ou categoria que os abriga e reúne, inclusive estatisticamente (nos dados dos Ministérios do Trabalho, da Saúde e da Previdência Social), e permite sua visibilidade em conjunto, semelhantemente às LER, um conjunto de doenças e afecções diferentes, mas que mantêm entre si uma identidade ou denominadores comuns inclusive no que tange a agentes etiológicos legalmente reconhecidos, configurando relações de nexo com o trabalho, ensejando debates sobre seu encaminhamento, tratamento e prevenção. São assim discutidos como conjunto de afecções, e não isoladamente; conjuntamente também se tornam agravos de notificação obrigatória.

O agrupamento de CIDs dessas afecções em uma categoria, aliada à mudança de critérios de estabelecimento de nexo (NTEP), dão mais visibilidade a esses agravos, atualmente a segunda causa de concessão de benefícios acidentários por doença relacionada ao trabalho.

\section{- Disputas no campo}

Apesar de seu reconhecimento legal, os Transtornos Mentais e do Comportamento Relacionados ao Trabalho ainda são objeto de controvérsia e divergências entre discursos e práticas, atravessados pelas disputas presentes no campo das relações entre saúde e trabalho.

Disputas se apresentam entre as concepções de Saúde Ocupacional, pautadas por estratégias intervencionistas que desconsideram as questões ligadas à organização do trabalho, pautadas pelo modelo da clínica médica e a de Saúde do Trabalhador, que incorpora conceitos de determinação social da saúde e processo de trabalho, e a concepção do processo saúde-doença como um processo biopsíquico e social.

No campo da Psicologia, disputas se apresentam entre as abordagens da Psicologia do Trabalho, que tem como perspectiva o trabalho, compreendido em seus 
determinantes históricos, sociais, econômicos e culturais, e a da Psicologia Organizacional, que prioriza as questões referentes à gestão de pessoal, com objetivos de classificação e adaptação dos trabalhadores e uma perspectiva reducionista da compreensão do processo saúde/doença mental.

Divergências teóricas se apresentam entre profissionais que atuam nos serviços de saúde mental, que enfatizam os aspectos individuais e familiares como as principais causas do adoecimento e do sofrimento psíquico, e os que atuam nos serviços de saúde do trabalhador, cujo foco de análise é a atividade de trabalho. Essas divergências dificultariam o diagnóstico e incrementariam a subnotificação dos Transtornos Mentais e do Comportamento Relacionados ao Trabalho; dificultariam também o desenvolvimento de ações interinstitucionais e multidisciplinares.

As disputas se apresentam também internamente ao campo da Saúde Mental e trabalho. Embora a maioria da produção em Saúde Mental e Trabalho confira destaque à categoria trabalho, observam-se divergências conceituais, teóricas e metodológicas quanto à definição do que se entende por adoecimento psíquico, elementos que indicariam tal adoecimento, o papel desempenhado pelo trabalho no adoecimento psíquico - entendido por alguns autores como determinante e estruturador de adoecimento psíquico, e por outros, como desencadeante - e a possibilidade de estabelecimento ou determinação do nexo causal entre o trabalho e o adoecimento mental. Essas divergências trariam dificuldades para a criação de procedimentos, para a vinculação entre os quadros clínicos e o trabalho, para o diagnóstico, para a clínica e a prevenção, e possibilitaria tentativas de contestação e descaracterização por posições teórico-políticas contrárias.

\section{- Desafios, possibilidades}

Dois elementos se afiguram, no cenário da discussão sobre os Transtornos Mentais e do Comportamento Relacionados ao Trabalho, simultaneamente, como desafios e possibilidades: a questão da formação dos profissionais de saúde e o debate entre as diversas correntes que compõem o campo da Saúde mental e Trabalho. 


\section{A formação dos profissionais de saúde}

A formação dos profissionais de saúde, em especial para lidar com os Transtornos Mentais e do Comportamento Relacionados ao Trabalho, é alvo de ampla discussão nos achados desta pesquisa, tanto em termos da literatura consultada, quanto nas entrevistas realizadas para a tese. Deficiências ou insuficiências nessa formação são apontadas em vários aspectos: abordagens fragmentadas e com ênfase na saúde como dimensão individual, não como processo coletivo, que não contemplariam diálogo/interlocução com outras especialidades, com poucas discussões sobre o papel ou a relação do trabalho com o processo saúde-doença e, mais especificamente, que não contemplaria a compreensão da dimensão da saúde mental, de modo geral, e em sua relação com o trabalho. Nesse sentido, entrevistadas, como Jacques, Maeno e Seligmann-Silva, e autores, como Glina et al. (2001), CFP (2008), Bernardo e Garbin (2011), colocam em pauta uma formação que qualifique os profissionais de saúde para que considerem a importância da situação de trabalho como um dos determinantes no processo saúde/doença, com ênfase na formação interdisciplinar e conhecimento de políticas públicas, sobretudo aquelas voltadas para a saúde, o que apontaria a necessidade de repensar as diretrizes e matrizes curriculares da área de saúde.

Ou aplicá-las, uma vez que as Diretrizes Curriculares Nacionais (DCN) de Medicina, a título de exemplo, preveem que:

\footnotetext{
O graduado em Medicina terá formação geral, humanista, crítica, reflexiva e ética, com capacidade para atuar nos diferentes níveis de atenção à saúde, com ações de promoção, prevenção, recuperação e reabilitação da saúde, nos âmbitos individual e coletivo, com responsabilidade social e compromisso com a defesa da cidadania, da dignidade humana, da saúde integral do ser humano e tendo como transversalidade em sua prática, sempre, a determinação social do processo de saúde e doença (CNE/MEC, 2014, grifo nosso).
}

Já as DCN de Psicologia estipulam que:

[...] os profissionais devem estar aptos a desenvolver ações de prevenção, promoção, proteção e reabilitação da saúde psicológica e psicossocial, tanto em nível individual quanto coletivo, bem como a realizar seus serviços dentro dos mais altos padrões de qualidade e dos princípios da ética/bioética (CNE/MEC, 2011, grifo nosso). 


\title{
- O debate entre as diversas correntes que compõem o campo as Saúde mental e Trabalho
}

Também são alvo de ampla discussão nos achados dessa pesquisa, tanto em termos da literatura consultada, quanto nas entrevistas realizadas para a tese, as disputas que apresentam internamente ao campo da Saúde Mental e Trabalho - divergências conceituais, teóricas e metodológicas. Nesse sentido, Lima (2013) coloca que um dos maiores obstáculos no campo seria a ausência de um real debate entre as diversas correntes que o compõem. Para a autora, haveria dois tipos de atitude na comunidade acadêmica, a postura de ignorar as críticas, ou a de um simulacro de debate sem aprofundamento nos problemas tratados.

Longe de considerar que essas divergências em si mesmas sejam contraproducentes, ou que o debate não se estabeleça, o desafio seria o de radicalização desse debate, no sentido da proposta de Lima (2013) de consolidação de coletivos no âmbito acadêmico:

\begin{abstract}
Por consolidação de coletivos no âmbito acadêmico, entendemos a criação de equipes interdisciplinares nas quais haja um real debate entre as disciplinas de modo que as diferenças (e mesmo as divergências) encontrem espaço para serem expostas. Nos termos precisos de Lhuillier (2012), a real "cooperação científica interdisciplinar" é aquela que supera o "narcisismo das pequenas diferenças" para alcançar o patamar das "controvérsias autenticamente científicas" (LIMA, 2013, p. 96).
\end{abstract}

\section{- Uma "nova doença"?}

Mesmo que discussões a respeito das relações entre trabalho e saúde / "doença" mental sejam conhecidas desde Ramazzini (1700/2000), haveria atualmente uma conjuntura nova, que indicaria uma mudança de status dessas afecções: a altíssima incidência observada nos últimos anos, diretamente associada a mudanças nos processos de trabalho, como a introdução de novas tecnologias e a reestruturação produtiva. Coloca-se então uma questão fundamental: trata-se ou não, agora, da mesma "doença"?

Autores como, por exemplo, Silva (2011), discutem o processo de construção social ou reconhecimento dos Transtornos Mentais e do Comportamento Relacionados ao Trabalho a partir de uma concepção de linearidade temporal, de uma evolução diagnóstica. Silva (2001) baseia a construção de sua tese na perspectiva teórica por ela 
nomeada "construcionista", considerando a linguagem como eixo central das produções sociais. Nessa perspectiva, sua análise se detém sobre a "linguagem que focalizou a nomeação dos Transtornos Mentais e do Comportamento Relacionados ao Trabalho nos documentos apreciados", a saber, os "relacionados à legislação sobre as doenças no âmbito das relações profissionais e os referentes às Conferências Nacionais de Saúde do Trabalhador" (SILVA, 2011, p. 17).

Para além das diferenças metodológicas - Silva trabalhou com análise do discurso, a partir de documentos oficiais, e eu, com análise de conteúdo das entrevistas realizadas -, outra distinção se delineia: para a autora, o objetivo de seu trabalho foi "entender quando, no tempo longo da história, foi construída a categoria Transtornos Mentais e do Comportamento Relacionados ao Trabalho" (SILVA, 2001, p. 19, grifo nosso). No caso desta tese, a pergunta não seria quando, mas como se deu essa construção. Seu trabalho visaria "Entender como os transtornos mentais no contexto das políticas públicas voltadas à saúde dos trabalhadores foram, ao longo do tempo, sendo nomeadas até se constituírem como um grupo de diagnósticos reconhecidos como doença relacionada ao trabalho na perspectiva da seguridade social" (SILVA, 2001, p. 19, grifo nosso). O que se buscou discutir, ao longo desta tese, é que a questão do reconhecimento dos Transtornos Mentais e do Comportamento Relacionados ao Trabalho, para além de uma questão de nomeação/nomenclatura, envolve diferentes concepções de saúde, trabalho, doença, "mental” e políticas.

Como tratado nesta tese, a discussão sobre os Transtornos Mentais e do Comportamento Relacionados ao Trabalho mobiliza, historicamente, diferentes grupos, "tratamentos", ações político-técnicas e, sobretudo, representações. Nesse sentido, mesmo as representações sobre saúde e doença, diagnóstico, tratamento e etiologia que mobilizam são diferentes. Essas representações e nomenclaturas evocam quadros clínicos e sintomatológicos descritos, estudados e vivenciados de forma diferenciada.

Analisar esses diferentes quadros como referentes a uma mesma doença confere-lhes um caráter de continuidade, a despeito de se manifestarem e serem reconhecidos (como discutido nesta tese) em atividades profissionais, situações e contextos sociopolíticos muito diversos. 
A ideia de analisar esses diferentes quadros nosológicos como doenças distintas não implicaria necessariamente em uma noção disruptiva de cortes. O que se busca com esta análise é uma compreensão, no que tange a esses quadros nosológicos, dos processos de transformação e das lutas travadas entre os diversos grupos de interesse envolvidos que, por sua vez, têm decisiva contribuição na determinação de critérios para estabelecer o que será considerado saúde e doença, em quais situações e para quais sujeitos. Esses diferentes grupos de interesse mobilizam também diferentes expectativas de "tratamento", "prognóstico" e outras condutas; a essas diferentes expectativas correspondem papéis sociais distintos, bem como diferentes agenciamentos mobilizados, em torno e a partir dessas definições.

\section{- Análise sócio-histórica e escolhas políticas}

O objetivo da análise foi o de investigar como e por que práticas políticas, econômicas e sociais fazem parte das condições de emergência e funcionamento de certo discurso, no caso, sobre os Transtornos Mentais e do Comportamento Relacionados ao Trabalho. Buscou-se reconstituir o processo de construção social dos Transtornos Mentais e do Comportamento Relacionados ao Trabalho no contexto da discussão em torno da consolidação dos campos da Medicina e Trabalho (Medicina do Trabalho, Saúde Ocupacional, Saúde do Trabalhador), da Psicologia e Trabalho (Psicologia Industrial, Psicologia Organizacional, Psicologia do trabalho) e da Saúde Mental e Trabalho, na perspectiva enunciada por Foucault:

\footnotetext{
Quando se dirige a um tipo singular de discurso [...] é para estabelecer, por comparação, seus limites cronológicos: é também para descrever, ao mesmo tempo que eles e em correlação com eles, um campo institucional, um campo de acontecimentos, de práticas, de decisões políticas, um encadeamento de processos econômicos que figuram oscilações demográficas, técnicas de assistência [...] etc. (FOUCAULT, 1995a, p. 180).
}

Como aponta Foucault (1995a, p. 197), quando se afirma que certa formação discursiva substituiu outra - como os diferentes paradigmas dos campos anteriormente citados, ou as diversas "terminologias" sob as quais a questão do psíquico ou mental (ou moral) em sua relação com o trabalho é tratada - trata-se de uma transformação nas relações que não altera, necessariamente, todos os seus elementos, conceitos, ou que "todo um mundo de objetos, enunciações, escolhas 
teóricas absolutamente novas, [surja] já armado e organizado em um texto que o situaria de uma vez por todas". Procurei demonstrar como, no caso dos Transtornos Mentais e do Comportamento Relacionados ao Trabalho, concepções diversas de Medicina e trabalho, Psicologia e trabalho, saúde e doença coexistem, se opõem e se superpõem.

Por trás das escolhas técnicas, inclusive a proposta neste trabalho, "agem e reagem ideias, projetos sociais, utopias, interesses econômicos, estratégias de poder" (LÉVY, 2000, p. 24). A proposta de um olhar sobre os Transtornos Mentais e do Comportamento Relacionados ao Trabalho é marcada também pela minha própria especificidade cultural e ideológica. A escolha do objeto de estudo também foi uma escolha política, segundo Goldman (1995, p. 38):

\footnotetext{
[a escolha do objeto] tratar-se-á de uma escolha política, mas no sentido preciso atribuído ao termo por Michel Foucault; a determinação do objeto deveria passar por uma espécie de diagnóstico do presente, procedendo em função do mapeamento e seleção de questões e lutas contemporâneas [...]. Se admitimos que essas questões e lutas devam ser encaradas [...] como pistas a seguir, não como oposições definitivas em relação às quais seria preciso alinhar-se de modo simplista - devemos reconhecer que este modelo abre a possibilidade de uma [análise] capaz de questionar criticamente tanto o campo teórico em que está incluída quanto a sociedade na qual se desenvolve.
}

Escolha política, não apenas pela eleição de um tema polêmico e atual, os Transtornos Mentais e do Comportamento Relacionados ao Trabalho, mas por meu próprio envolvimento e pertinência ao campo, tanto na perspectiva colocada por Spink (2003) do campo-tema como por adesão prática e teórica iniciada, desde a graduação, por uma prática interventiva, como psicóloga, filiada a um modelo de atuação - a Saúde do Trabalhador - que postula um envolvimento teórico, técnico e político com as questões relacionadas a saúde e trabalho.

Nesse sentido, é minha própria atuação como participante do campo de disputas em torno de concepções de saúde e doença que o trabalho de análise desta tese buscou problematizar. Como coloca Spink (2003, p. 39),

Precisamos [...] estar preparados para discutir como negociamos nossa presença nas diferentes partes da matriz do campo-tema e como lidamos com a questão ética nos lugares onde fomos e nas conversas que tivemos [...]. Precisamos lembrar que psicólogos e psicólogas sociais são, antes de mais nada, seres sociais... 


\section{REFERÊNCIAS}

A SITUAÇÃO da saúde mental do trabalhador. Psicol. cienc. prof., Brasília , vol. 8, n. 2, 1988. Disponível em: $<$ http://www.scielo.br/scielo.php?script=sci_arttext\&pid=S1414$98931988000200002 \&$ Ing=en\&nrm=iso $>$. Acesso em: 15 jan.2015.

ABPA - Associação Brasileira para a Prevenção de Acidentes. Dia 27 de julho, Dia Nacional de Prevenção de Acidentes do Trabalho. Disponível em:

$<$ http://www.abpa.org.br/component/content/article/100-dia-27-de-novembro-dia-nacional-doengenheiro-e-do-tecnico-de-seguranca / ABPA 2014>. Acesso em: 14 nov. 2014.

ABRAHÃO, Julia et al. Introdução à Ergonomia: da teoria à prática. São Paulo: Edgar Blucher, 2009.

AGUENA, Paulo. Lutas sindicais sob a ditadura militar e a fundação da CUT. IN: PSTU - Partido Socialista dos Trabalhadores Unificado. Publicado em 6 jun. 2006. Disponível em <http://www.pstu.org.br/teoria_materia.asp?id=5179\&ida=0>. Acesso em 15 out. 2011.

ALBUQUERQUE-OLIVEIRA, Paulo Rogério. O Nexo Técnico Epidemiológico Previdenciário - NTEP. IN: MACHADO, Jorge; SORATTO, Lúcia; CODO, Wanderley. Saúde e trabalho no Brasil: uma revolução silenciosa: o NTEP e a Previdência Social. Petrópolis: Vozes, 2010.

ALMEIDA, Maria Celeste G. de. Característica emocionais determinantes da LER. IN: CODO, Wanderley; ALMEIDA, Maria Celeste G. de (org). LER: diagnóstico, tratamento e prevenção - uma abordagem interdisciplinar. $2^{\text {a }}$ edição. Petrópolis: Vozes, 1995 a.

ALMEIDA, Maria Celeste G. de. Em busca de uma linguagem. IN: CODO, Wanderley; ALMEIDA, Maria Celeste G. de (org). LER: diagnóstico, tratamento e prevenção - uma abordagem interdisciplinar. $2^{\text {a }}$ edição. Petrópolis: Vozes, 1995b.

ALVES, Natália Cristina Ribeiro. Corpos entre Saúde e Trabalho: a construção sociopolítica da LER como doença. 2004. Dissertação (Mestrado em Sociologia). Faculdade de Filosofia e Ciências Humanas, UFMG, Belo Horizonte, 2004.

ALVES, Natália Cristina Ribeiro. Grupos de acompanhamento psicológico a portadores de LER em Centro de Saúde da Prefeitura de Belo Horizonte. IN: Caderno de Resumos. VIII Colóquio Internacional de Sociologia Clínica e Psicossociologia. Transformações Sociais, Subjetividades e Política. Belo Horizonte: UFMG, 2001.

ALVES, Paulo Henrique R. O Psicossocial e a LER. IN: OLIVEIRA, Chrysóstomo R. e col. Manual Prático da LER - Lesões por Esforços Repetitivos. Belo Horizonte: Health, 1997.

AMADO, Gilles; ENRIQUEZ, Eugène. Psicodinâmica do trabalho e Psicossociologia. IN: BENDASSOLLI, Pedro F.; SOBOLL, Lis Andrea P. (org.). Clínicas do Trabalho: Novas perspectivas para compreensão do trabalho na atualidade. São Paulo: Atlas, 2011.

ANTUNES, Ricardo. As respostas do capital à sua crise estrutural: a reestruturação produtiva e suas repercussões no processo de trabalho. IN: Os sentidos do trabalho. Ensaio sobre a afirmação e a negação do trabalho. São Paulo: Boitempo Editorial, 2009.

ANTUNES, Ricardo. Dimensões da precarização estrutural do trabalho. IN: DRUCK, Graça; FRANCO, Tânia (org.) A perda da razão social do trabalho: terceirização e precarização. São Paulo: Boitempo, 2007. 
ANTUNES, Ricardo; POCHMANN, Marcio. A desconstrução do trabalho e a explosão do desemprego estrutural e da pobreza no Brasil. IN: CIMADAMORE, Alberto D.; CATTANI, Antonio David (org.). Produção de pobreza e desigualdade na América Latina. Porto Alegre: Tomo Editorial/CLACSO, 2007. Disponível em:

<http://bibliotecavirtual.clacso.org.ar/ar/libros/clacso/crop/cattapt/08antu.pdf>. Acesso em: 12 set. 2011.

ANTUNES, Ricardo; RIDENTI, Marcelo. Operários e estudantes contra a Ditadura: 1968 no Brasil. Mediações, vol. 12, n. 2, p. 78-89, jul/dez. 2007. Disponível em <http://www.uel.br/revistas/uel/index.php/mediacoes/article/viewFile/3319/271>. Acesso em: 15 out. 2011.

ARAÚJO, Agostinho Vitorino; NUNES, Rosângela Barros. Contribuição da psicologia - relato de uma experiência com grupos de portadores de LER. IN: OLIVEIRA, Chrysóstomo R. e col. Manual Prático de LER - Lesões por Esforços Repetitivos. Belo Horizonte: Editora Health, 1997.

ARAÚJO, José Newton G. Psicoterapia e LER. IN: ARAÚJO, José Newton G ; LIMA, Maria Elizabeth A; LIMA, Francisco P. A. (org.). LER: Dimensões ergonômicas e psicossociais. Belo Horizonte: Health, 1997.

ARAÚJO, José Newton Garcia de. Lesões por Esforços Repetitivos (LER), Políticas Públicas e Resistência. IN: Caderno de Resumos. VIII Colóquio Internacional de Sociologia Clínica e Psicossociologia. Transformações Sociais, Subjetividades e Política. Belo Horizonte: UFMG, 2001.

ARAÚJO, José Newton G.; LIMA, Maria Elizabeth A.; LIMA, Francisco de Paula A. (org). LER Dimensões ergonômicas e psicossociais. Belo Horizonte: Editora Health, 1997.

ARAÚJO, José Newton G. et al. As representações sobre a LER e seus efeitos nas políticas de enfrentamento, vigilância, prevenção, tratamento e reabilitação. Relatório Final do Projeto de Pesquisa, enviado ao CNPq. Belo Horizonte: UFMG, 1999.

ARAÚJO, Tânia Maria. Revisão de abordagens teórico-metodológicas sobre saúde mental e trabalho. IN: MINAYO-GOMEZ, Carlos; MACHADO, Jorge Mesquita Huet; PENA, Paulo Gilvane Lopes (org.). Saúde do Trabalhador na Sociedade Brasileira Contemporânea. Rio de Janeiro: Editora Fiocruz, 2011.

ASSIS, Benedito de. Compêndio de Psicologia Industrial. Curso de 20 aulas ministrado sob o patrocínio do Departamento da Produção Industrial (DPI) da Secretaria do Trabalho, Indústria e Comércio. São Paulo: Rothschild Loureiro, 1954.

ATHAYDE, Milton. Saúde 'mental' e trabalho: questões para discussão no campo da saúde do trabalhador. IN: MINAYO-GOMEZ, Carlos; MACHADO, Jorge Mesquita Huet; PENA, Paulo Gilvane Lopes (org.). Saúde do Trabalhador na Sociedade Brasileira Contemporânea. Rio de Janeiro: Editora Fiocruz, 2011.

ATHAYDE, Milton; BRITO, Jussara. Ergologia e clínica do trabalho. IN: BENDASSOLLI, Pedro F.; SOBOLL, Lis Andrea P. (org.). Clínicas do Trabalho: Novas perspectivas para compreensão do trabalho na atualidade. São Paulo: Atlas, 2011.

AUTUORI, Marina. Fazendo história. Uma reflexão sobre esse campo na área da psicologia. IN: ENCONTRO NACIONAL DA ABRAPSO, XV, 2009, Maceió. Anais... Maceió: Associação Brasileira de Psicologia Social, 2009. Disponível em:

<http://www.abrapso.org.br/siteprincipal/images/Anais_XVENABRAPSO/329.\%20fazendo\%20hist \%D3ria.pdf>. Acesso em: 25 out.2014. 
BAIRD, Andrew. Repetitive Strain Injury (RSI) - An Ergonomist's View. Leicestershire: Human Application, 1996. Disponível em:

<http://www.humanapps.co.uk/publications/articles/rsiview.pdf>. Acesso em: 4 out. 2013.

BAMMER, Gabrielle; MARTIN, Brian. The arguments about RSI: an examination. Community Health Studies, Vol. 12, n., 1988. Disponível em:

<http://www.uow.edu.au/arts/sts/bmartin/pubs/88chs.html>. Acesso em: 4 out. 2013.

BAMMER, Gabrielle; MARTIN, Brian. Repetition strain injury in Australia: medical knowledge, social movement, and de facto partisanship. Social Problems, Vol. 39, n. 3, August 1992. Disponível em: <http://www.uow.edu.au/arts/sts/bmartin/pubs/92sp.html>. Acesso em: 4 out. 2013.

BAMMER, Gabrielle; MARTIN, Brian. When experts disagree. IN: RANNEY, Don. Chronic Musculoskeletal Injuries in the Workplace. Philadelphia: W. B. Saunders. Disponível em: <http://www.uow.edu.au/arts/sts/bmartin/pubs/96Ranney.html>. Acesso em: 4 out. 2013.

BARBOSA-BRANCO, Anadergh; ALBUQUERQUE-OLIVEIRA, Paulo Rogério; MATEUS, Márcia. Epidemiologia das licenças do trabalho por doenças mentais no Brasil, 1999-2002. IN: FERREIRA, Januário Justino (coordenação geral); PENIDO Laís de Oliveira (coordenação científica). Saúde mental no trabalho: coletânea do Fórum de Saúde e Segurança no Trabalho do Estado de Goiás. Goiânia: Cir Gráfica, 2013. Disponível em: <https://bibliotecaprt21.files.wordpress.com/2013/09/livro-saude-mental-no-trabalho-2013prt18.pdf>. Acesso em: 21 out. 2013.

BARROS, Sergio Paes. A Promoção da Qualidade de Vida para os Trabalhadores: Discurso, Poder e Disciplina. Dissertação (Mestrado em Psicologia Social). Universidade de São Paulo. São Paulo, 2010.

BAUMGARTEN, Maíra. Reestruturação produtiva e industrial. IN: CATTANI, Antonio David. Dicionário Crítico de Trabalho e Tecnologia. 4a edição revista e ampliada. Petrópolis: Vozes; Porto Alegre: Editora da UFRGS, 2002.

BENDASSOLLI, Pedro F.; SOBOLL, Lis Andrea P. Introdução às clínicas do trabalho: aportes teóricos, pressupostos e aplicações. IN: BENDASSOLLI, Pedro F.; SOBOLL, Lis Andrea P. (org.). Clínicas do Trabalho: Novas perspectivas para compreensão do trabalho na atualidade. São Paulo: Atlas, 2011.

BERGAMINI, Cecília Whitaker; TASSINARI, Rafael. Psicopatologia do Comportamento Organizacional. Organizações desorganizadas, mas produtivas. São Paulo: Cengage Learning, 2008.

BERNARDO, Marcia Hespanhol et al. Ainda sobre a saúde mental do trabalhador. Rev. bras. saúde ocup., São Paulo, vol.35, n.122, dez. 2010. Disponível em:

<http://www.scielo.br/pdf/rbso/v36n123/a02v36n123.pdf>. Acesso em: 12 mar.2013.

BERNARDO, Marcia Hespanhol; GARBIN, Andréia De Conto. A atenção à saúde mental relacionada ao trabalho no SUS: desafios e possibilidades. Rev. bras. saúde ocup., São Paulo, vol.36, n.123, jun. 2011. Disponível em: <http://www.scielo.br/scielo.php?script=sci_arttext\&pid=S0303-

$76572011000100010 \&$ Ing=en\&nrm=iso>. Acesso em: 12 mar.2013.

BERTOLLI FILHO, Claudio. Medicina e trabalho: as "ciências do comportamento" na década de 40. Rev. hist. São Paulo, n. 127-128, jul. 1993. Disponível em:

$<$ http://www.revistasusp.sibi.usp.br/scielo.php?script=sci_arttext\&pid=S0034$83091993000100003 \&$ Ing=pt\&nrm=iso>. Acesso em: 27 jun. 2012.

BERTOLLI FILHO, Claudio. Belo Horizonte (via Skype), 21 ago. 2014. 1 arquivo .MP4 (56min 15seg). Entrevista concedida a Natália Cristina Ribeiro Alves. 
BILLIARD, Isabelle. Santé mentale et travail. L'émergence de la psychopathologie du travail. Paris : La Dispute, 2001.

BOFF, Bernadete M; LEITE, Dóris F; AZAMBUJA, Maria Inês R. Morbidade subjacente à concessão de benefício por incapacidade temporária para o trabalho. Rev. Saúde Pública, São Paulo, vol.36,n.3, jun.2002 . Disponível em: <http://www.scielosp.org/scielo.php?script=sci_arttext\&pid=S0034$89102002000300013 \&$ lng=pt\&nrm=iso $>$. Acesso em: $10 \mathrm{fev} .2012$.

BOHADANA, Estrella. Experiências de participação popular nas ações de saúde. IN: IBASE (Instituto Brasileiro de Análises Sociais e Econômicas). Saúde e Trabalho no Brasil. 2a edição. Petrópolis: Vozes, 1983.

BOHADANA, Estrella; AZEVEDO, Vânia Maria Ramos de; PEGO, Raquel Abrantes. Condições de Vida / Diagnóstico das condições de vida e saúde no Brasil. IN: IBASE (Instituto Brasileiro de Análises Sociais e Econômicas). Saúde e Trabalho no Brasil. 2ª edição. Petrópolis: Vozes, 1983.

BOLTANSKI, Luc. As classes sociais e o corpo. Rio de Janeiro: Graal, 1989.

BORGES, Zulmira Newlands. A Construção Social da Doença: um estudo das representações sobre o transplante renal. IN: LEAL, Ondina Fachel (org.). Corpo e Significado: Ensaios de Antropologia Social. Porto Alegre: Editora da Universidade/ UFRGS, 1995.

BORSOI, Izabel Cristina Ferreira. Da relação entre trabalho e saúde à relação entre trabalho e saúde mental. Psicol. Soc., Porto Alegre, vol. 19, n. spe, 2007. Disponível em:

$<$ http://www.scielo.br/scielo.php?script=sci_arttext\&pid=S0102-

$71822007000400014 \&$ Ing=en\&nrm=iso >. Acesso em: 15 fev.2015.

BOSI, Ecléa. Memória e Sociedade: lembranças de velhos. 11a edição. São Paulo: Companhia das Letras, 2004. (2004a)

BOSI, Ecléa. O Tempo Vivo da Memória: Ensaios de Psicologia Social. 2a edição. São Paulo: Ateliê Editorial, 2004. (2004b)

BOURDIEU, Pierre. O poder simbólico. Rio de Janeiro, Bertand Brasil; Lisboa, Difusão Editorial, 1989.

BRANDÃO JUNIOR, Paulo Starling. Biossegurança e AIDS: as dimensões psicossociais do acidente com material biológico no trabalho em hospital. Dissertação (Mestrado em Saúde Pública). Escola Nacional de Saúde Pública da Fundação Oswaldo Cruz, Rio de Janeiro, 2000. Disponível em: $<$ http://portalteses.icict.fiocruz.br/transf.php?script=thes_chap\&id=00001702\&lng=pt\&nrm=iso>. Acesso em: 28 dez. 2012.

BRANT, Luiz Carlos. Belo Horizonte, 22 ago. 2014. 1 arquivo .WAV (1h 25min 22seg). Entrevista concedida a Natália Cristina Ribeiro Alves.

BRANT, Luiz Carlos; MINAYO-GOMEZ, Carlos. A temática do sofrimento nos estudos sobre trabalho e saúde. IN: MINAYO-GOMEZ, Carlos; MACHADO, Jorge Mesquita Huet; PENA, Paulo Gilvane Lopes (org.). Saúde do Trabalhador na Sociedade Brasileira Contemporânea. Rio de Janeiro: Editora Fiocruz, 2011.

BREILH, Jaime. Fundamentos Teóricos y Metodológicos para la investigación de Salud y Trabajo. IN: Nuevos conceptos y técnicas de investigación - Guia pedagógica para um taller de metodologia. Quito: CEAS, 1994. 
BRUNO, Antônio Miguel Leão. A perícia médica nos casos de simulação em infortunística. Revista de Medicina. São Paulo, vol.25, n.90, 1941. Disponível em:

<http://www.revistas.usp.br/revistadc/article/view/50516/54632>. Acesso em: 15 nov.2014.

CÂMARA dos Deputados. A 2a República. Agosto/2008. Disponível em:

<http://www2.camara.leg.br/a-camara/conheca/historia/historia/a2republica.html>. Acesso em: 15 fev. 2015.

CARNEIRO, Cristina Miranda. Perfil social da LER. IN: OLIVEIRA, Chrysóstomo R. e col. Manual Prático da LER. Belo Horizonte: Health, 1997.

CARRARA, Sérgio. Entre cientistas e bruxos - Ensaios sobre os dilemas e perspectivas da análise antropológica da doença. IN: ALVES, Paulo César; MINAYO, Maria Cecília de Souza (org). Saúde e Doença: um olhar antropológico. Rio de Janeiro: FIOCRUZ, 1994.

CARRARA, Sergio. Tributo a Vênus. A luta contra a sífilis no Brasil, na passagem do século aos anos 40. Rio de Janeiro: FIOCRUZ, 1996.

CARRETEIRO, Teresa Cristina O; BARROS, Vanessa Andrade de. Clínicas do trabalho: contribuições da psicossociologia no Brasil. IN: BENDASSOLLI, Pedro F.; SOBOLL, Lis Andrea P. (org.). Clínicas do Trabalho: Novas perspectivas para compreensão do trabalho na atualidade. São Paulo: Atlas, 2011.

CARVALHO, Alexandre Magno Teixeira de. Trabalho e higiene mental: processo de produção discursiva do campo no Brasil. Hist. cienc. saúde-Manguinhos . Rio de Janeiro, vol.6 n.1, 1999.

Disponível em: <http://www.scielo.br/scielo.php?pid=S0104-

59701999000200007\&script=sci_arttext>. Acesso em: 15 nov.2014.

CARVALHO, Alexandre Magno Teixeira de. Higiene mental, eugenia e "elemento psychico" no trabalho humano: texto e contexto. Mnemosine. Rio de Janeiro, vol. 6, n.2, 2010. Disponível em: <http://www.mnemosine.com.br/ojs/index.php/mnemosine/article/view/205>. Acesso em: 15 nov.2014.

CARVALHO, Alexandre Magno Teixeira de. Da Higiene Mental do Trabalho à Saúde Mental do Trabalhador: uma leitura da produção discursiva no Brasil (1925-1995). Mnemosine. Rio de Janeiro, vol.7, n.2, 2011. Disponível em:

<http://www.mnemosine.com.br/ojs/index.php/mnemosine/article/view/227 >. Acesso em: 15 nov.2014.

CARVALHO, Alexandre Magno Teixeira de; SANTOS, Elizabeth Moreira dos. A Psicologia Industrial e Organizacional: um exemplo de sofisticação discursiva. IN: JACÓ-VILELA, Ana Maria; CEREZZO, Antônio Carlos; RODRIGUES, Heliana de Barros Conde (org). Clio-Psyché: Paradigmas:

Historiografia, Psicologia, Subjetividades. Rio de Janeiro: Relume Dumará/FAPERJ, 2003.

CASTRO, Celso. O golpe de 1964. IN: CPDOC (Centro de Pesquisa e Documentação de História Contemporânea do Brasil) - Fundação Getulio Vargas. Disponível em:

<http://cpdoc.fgv.br/producao/dossies/Jango/artigos/AConjunturaRadicalizacao/O_golpe_de_196 4>. Acesso em: 15 fev.2015.

CBCD - Centro Colaborador da OMS para a Classificação de Doenças em Português. Classificação Estatística Internacional de Doenças e Problemas Relacionados à Saúde - CID-10. Disponível em: <http://www.datasus.gov.br/cid10/V2008/cid10.htm>. Acesso em 16 jan. 2015.

CFP - Conselho Federal de Psicologia. Resolução CFP no 02/2001 - Altera e regulamenta a Resolução CFP no 014/2000 que institui o título profissional de especialista em psicologia e o 
respectivo registro nos Conselhos Regionais. Brasília: CFP, 2001. Disponível em: <http://www2.pol.org.br/legislacao/doc/resolucao2001_2.doc>. Acesso em: 15 fev.2015.

CFP - Conselho Federal de Psicologia. Saúde do Trabalhador no âmbito da Saúde Pública: referências para a atuação do(a) psicólogo(a). Brasília: CFP, 2008. Disponível em: $<$ http://crepop.pol.org.br/novo/wpcontent/uploads/2010/11/saude_do_trabalhador_COMPLETO.pdf>. Acesso em: 15 nov.2014.

CHAUÍ, Marilena. Introdução - A Universidade na Sociedade. IN: Escritos sobre a Universidade. São Paulo: Ed. Unesp, 2001.

CHIESA, Anna Maria et al. As repercussões emocionais das LER/DORT no cotidiano do trabalhador: a invisibilidade ameaçadora. Rev. bras. saúde ocup. 2002, vol.27, n.101/102. Disponível em: <http://www.fcm.unicamp.br/departamentos/preventiva/revista/artigo-ilidio-frame.htm>. Acesso em: 4 out. 2013

CLAPARÈDE, Édouard. Prefacio da Edição Franceza. IN: WALTHER, Leon. Techno-Psychologia do Trabalho Industrial. São Paulo: Companhia Melhoramentos São Paulo, 1929.

CLOT, Yves . Préface à la seconde édition. IN : CLOT, Yves (org). Les histoires de la psychologie du travail. Approche pluridisciplinaire. 2a edição, Reimpressão. Toulouse: Octarès Éditions, 2009.

CLOT, Yves. Entrevista: Yves Clot. Cad. psicol. soc. trab., São

Paulo, vol.9, n.2, dez. 2006. Disponível em:

$<$ http://pepsic.bvsalud.org/scielo.php?script=sci_arttext\&pid=S1516-

37172006000200008\&lng=pt\&nrm=iso >. Acesso em: 12 mar. 2013.

CLOT, Yves. A função Psicológica do Trabalho. Petrópolis: Vozes, 2007.

CLOT, Yves. A psicologia do trabalho na França e a perspectiva da clínica da atividade. Fractal, Rev. Psicol., Rio de Janeiro, vol. 22, n. 1, abr. 2010. Disponível em: $<$ http://www.scielo.br/scielo.php?script=sci_arttext\&pid=S1984$02922010000100015 \& \operatorname{lng}=e n \& n r m=i s o>$. Acesso em: 15 nov.2014.

CLOT, Yves. Clínica do trabalho e Clínica da Atividade. IN: BENDASSOLLI, Pedro F.; SOBOLL, Lis Andrea P. (org.). Clínicas do Trabalho: Novas perspectivas para compreensão do trabalho na atualidade. São Paulo: Atlas, 2011.

CLOT, Yves. O ofício como operador de saúde. Cad. psicol. soc. trab., São Paulo, v. 16, n. spe, 2013. Disponível em: <http://pepsic.bvsalud.org/scielo.php?script=sci_arttext\&pid=S1516$37172013000300002 \&$ lng=pt\&nrm=iso>. Acesso em: 14 mar. 2015.

CODO, Wanderley. Saúde mental e trabalho: uma urgência prática. Psicol. cienc. prof., Brasília, vol.8,n.2, 1988. Disponível em: <http://www.scielo.br/scielo.php?script=sci_arttext\&pid=S1414$98931988000200008 \&$ Ing=en\&nrm=iso>. Acesso em: 12 mar.2013.

CODO, Wanderley. O papel do psicólogo na organização industrial (notas sobre o "lobo mau" em psicologia). IN: LANE, Silvia Tatiana Maurer; CODO, Wanderley (org.). Psicologia Social. O homem em movimento. 12a edição. São Paulo: Brasiliense, 1984/1994. (1984/1994a)

CODO, Wanderley. O fazer e a consciência. IN: LANE, Silvia Tatiana Maurer; CODO, Wanderley (org.). Psicologia Social. O homem em movimento. 12ª edição. São Paulo: Brasiliense, 1984/1994. (1984/1994b) 
CODO, Wanderley. Um diagnóstico integrado do trabalho com ênfase em saúde mental. IN: JACQUES, Maria da Graça Corrêa; CODO, Wanderley. (org.) Saúde mental \& trabalho: leituras. Petrópolis: Vozes, 2002.

CODO, Wanderley. Por uma psicologia do trabalho: Ensaios recolhidos. São Paulo: Casa do Psicólogo, 2006.

CODO, Wanderley. São Paulo, 30 ago. 2014. 3 arquivos .WAV (1h 52min 49seg). Entrevista concedida a Natália Cristina Ribeiro Alves.

CODO, Wanderley. Educação - Carinho e Trabalho: Burnout, a síndrome da desistência do educador, que pode levar à falência da educação. Petrópolis: Vozes, 1999.

CODO, Wanderley; ALMEIDA, Maria Celeste G. de (org.). LER - diagnóstico, tratamento e prevenção - uma abordagem interdisciplinar. Petrópolis: Vozes, 1995.

CODO, Wanderley; SAMPAIO, José Jackson Coelho (org.). Sofrimento psíquico nas organizações. Petrópolis: Vozes, 1995.

CODO, Wanderley; SAMPAIO, José Jackson Coelho; HITOMI, Alberto Haruyoshi. Indivíduo, Trabalho e Sofrimento. Uma abordagem interdisciplinar. Petrópolis: Vozes, 1993.

CODO, Wanderley; SAMPAIO, José Jackson Coelho; HITOMI, Alberto Haruyoshi. Saúde Mental e Trabalho: Indicações para um Método de Pesquisa. IN: FIOCRUZ (Fundação Oswaldo Cruz). Guia de fontes e catálogo de acervos e instituições para pesquisas em saúde mental e assistência psiquiátrica no Estado do Rio de Janeiro. Rio de Janeiro: Laboratório de Estudos e Pesquisas em Saúde Mental (LAPS), 2004. Disponível em:

<http://www.abrasme.org.br/conteudo/view?ID_CONTEUDO=642>. Acesso em: 14 nov. 2014.

CODO, Wanderley, SORATTO, Lucia; VASQUES-MENEZES, lone. Saúde Mental e Trabalho. IN: ZANELLI, José Carlos; BORGES-ANDRADE, Jairo Eduardo; BASTOS, Antonio Virgílio Bittencourt (org.). Psicologia, Organizações e Trabalho no Brasil. Reimpressão 2007. Porto Alegre: Artmed, 2004.

COHN, Amélia; MARSIGLIA, Regina G. Processo e Organização do Trabalho. IN: ROCHA, Lys Esther; RIGOTTO, Raquel Maria; BUSCHINELLI, José Tarcísio P. (org.) Isto é trabalho de gente? Vida, Doença e Trabalho no Brasil. Petrópolis: Vozes, 1993.

CORRÊA FILHO, Heleno Rodrigues. Belo Horizonte (via Skype), 29 ago. 2014. 1 arquivo .MP4 (1h $1 \mathrm{~min} 18 \mathrm{seg})$. Entrevista concedida a Natália Cristina Ribeiro Alves.

CRUZ JUNIOR, Amaury José da. Questões/problemas em perícias médicas nos casos de depressão. Revista Hospital Universitário Pedro Ernesto, Rio de Janeiro, vol.10, n.2, abr./jun. 2011. Disponível em: <http://revista.hupe.uerj.br/detalhe_artigo.asp?id=116>. Acesso em: 12 mar.2013.

CRUZ, Roberto Moraes. Saúde, trabalho e psicopatologias. IN: AUED, Bernadete Wrublevski. (org.) Traços do trabalho coletivo. São Paulo: Casa do Psicólogo, 2005.

DECCA, Maria Auxiliadora Guzzo. A vida fora as fábricas: cotidiano operário em São Paulo (19201943). Rio de Janeiro: Paz e Terra, 1987.

DECCA, Maria Auxiliadora Guzzo. Indústria, trabalho e cotidiano: Brasil, 1880 a 1930. São Paulo: Atual, 1991. 
DEJOURS, Christophe. A loucura do trabalho. Um estudo em psicologia do trabalho. $5^{a}$ edição ampliada. São Paulo: Cortez-Oboré, 1992.

DEJOURS, Christophe; ABDOUCHELY, Elisabeth. Itinerário teórico em psicopatologia do trabalho. IN: DEJOURS, Christophe; ABDOUCHELI, Elisabeth; JAYET, Christian. Psicodinâmica do trabalho: contribuições da escola dejouriana à análise da relação prazer, sofrimento e trabalho. São Paulo: Atlas, 1994.

DEUSDEDIT JUNIOR, Manoel. Revisando algumas bases teóricas na investigação da relação entre trabalho e saúde mental. IN: SEMINARIO DE SAUDE DO TRABALHADOR DE FRANCA, 8, 2012, Franca. Anais... Franca: Unesp Franca, 2012. Disponível em:

$<$ http://www.proceedings.scielo.br/scielo.php?script=sci_arttext\&pid=MSC0000000112012000100 018\&lng=en\&nrm=abn>. Acesso em: 15 nov. 2014.

DEUSDEDIT JUNIOR, Manoel. O papel do trabalho na redução do fosso entre os serviços da Saúde Mental e da Saúde do Trabalhador. Tese (Doutorado em Psicologia Social). Universidade Federal de Minas Gerais. Belo Horizonte, 2014.

DIAS, Elizabeth Costa. Aspectos atuais da Saúde do Trabalhador no Brasil. IN: ROCHA, Lys Esther; RIGOTTO, Raquel Maria; BUSCHINELLI, José Tarcísio P. (org.) Isto é trabalho de gente? Vida, Doença e Trabalho no Brasil. Petrópolis: Vozes, 1993.

DIAS, Elizabeth Costa. O manejo dos agravos à saúde relacionados ao trabalho. IN: MENDES, René. Patologia do Trabalho. Rio de Janeiro: Editora Atheneu, 1995.

DIAS, Elizabeth Costa. Belo Horizonte, 15 out. 2013. 1 arquivo .WAV (21min). Entrevista concedida a Natália Cristina Ribeiro Alves.

DIAS, Elizabeth Costa; HOEFEL, Maria da Graça. O desafio de implementar as ações de saúde do trabalhador no SUS: a estratégia da RENAST. Ciênc. saúde coletiva, vol.10, n.4, 2005. Disponível em: <http://www.scielo.br/pdf/csc/v10n4/a07v10n4.pdf>. Acesso em: 28 dez. 2012.

DUARTE, Luiz Fernando Dias. Da vida nervosa das classes trabalhadoras urbanas. Rio de Janeiro: Jorge Zahar/CNPq, 1988.

DUARTE, Luís Fernando Dias. Investigação Antropológica sobre Doença, Sofrimento e Perturbação: Uma Introdução. IN: DUARTE, Luís Fernando Dias; LEAL, Ondina Fachel (org.). Doença, sofrimento, perturbação: perspectivas etnográficas. Rio de Janeiro: FIOCRUZ, 1998.

DUTRA, Eliana Regina de Freitas. Caminhos Operários nas Minas Gerais. Um estudo das práticas operárias em Juiz de Fora e Belo Horizonte na Primeira República. São Paulo: HUCITEC; Belo Horizonte: Editora da UFMG, 1988.

DWYER, Tom. LER no setor de serviços - sucessor de doenças de trabalho industrial, precursor de doenças de uma sociedade informacional: uma perspectiva da Sociologia-Política. IN: SZNELWAR, Laerte I.; ZIDAN, Leila N. (org). O trabalho humano com sistemas informatizados no setor de serviços. São Paulo: Plêiade, 2000.

EDITORIAL. Psicol. cienc. prof., Brasília , vol. 8, n. 2, 1988. Disponível em: $<$ http://www.scielo.br/scielo.php?script=sci_arttext\&pid=S141498931988000200001\&lng=en\&nrm=iso >. Acesso em: 15 jan.2015.

ELÍO, Mariano Noriega; RODRÍGUEZ, Jorge Villegas. La investigación participante en salud laboral (avances y limitaciones a diez años de distancia). IN: ALONSO, Ángel Cárcoba (coord.) La salud no se 
vende ni se delega, se defiende. El Modelo Obrero. Madrid: Ediciones GPS, 2007. Disponível em: <http://148.206.107.15/biblioteca_digital/articulos/4-99-1355dfb.pdf>. Acesso em: 11 out.2011

ENRIQUEZ, Eugène. Prefácio. IN: LIMA, Maria Elizabeth Antunes. Os equívocos da excelência: as novas formas de sedução na empresa. Petrópolis: Vozes, 1996.

PEREIRA, Maristela de Souza. As concepções sobre saúde do trabalhador, as práticas profissionais e o contexto de atuação de psicólogos organizacionais. Tese (Doutorado em Psicologia Social). Universidade de São Paulo. São Paulo, 2015.

FAIMAN, Carla Julia Segre. Psicoterapia em ambulatório de saúde do trabalhador: possibilidades e desafios. Tese (Doutorado em Psicologia Clínica). Universidade de São Paulo. São Paulo, 2012. Disponível em: <http://www.teses.usp.br/teses/disponiveis/47/47133/tde-13062012152309/publico/faiman_do.pdf>. Acesso9 em: 15 fev. 2015.

FALZON, Pierre. Ergonomia. São Paulo: Edgar Blucher, 2007.

FELDMAN, Maurice Philip. A Psicologia do Ambiente Industrial. São Paulo: Difel, 1971/1976.

FERREIRA, Arthur Arruda Leal. A história das ciências e a nova história: indícios para os estudos históricos no campo da saúde. Cad. saúde colet. Rio de Janeiro, 13(2): 471-492, abr-jun. 2005. Disponível em: <http://www.psicologia.ufrj.br/nucc/?get=texto\&texto=texto/arthur/017>. Acesso em: 27 jun. 2012.

FERREIRA, Marieta de Moraes. As reformas de base. IN: CPDOC (Centro de Pesquisa e Documentação de História Contemporânea do Brasil) - Fundação Getulio Vargas. Disponível em: <http://cpdoc.fgv.br/producao/dossies/Jango/artigos/NaPresidenciaRepublica/As_reformas_de_b ase>. Acesso em: 15 fev.2015.

FISCHER, Frida Marina. Relevância dos fatores psicossociais do trabalho na saúde do trabalhador. Rev. Saúde Pública, São Paulo, vol. 46, n. 3, 2012. Disponível em: $<$ http://www.scielo.br/scielo.php?script=sci_arttext\&pid=S0034$89102012000300001 \&$ Ing=en\&nrm=iso>. Acesso em: 11 out.2013

FONSECA, Cristina M. O. Saúde pública no Governo Vargas. IN: PONTE, Carlos Fidélis; FALLEIROS, lalê (org.). Na corda bamba de sombrinha: a saúde no fio da história. Rio de Janeiro: Fiocruz/COC; Fiocruz/EPSJV, 2010. Disponível em: <http://observatoriohistoria.coc.fiocruz.br/local/File/livro-nacorda-bamba-de-sombrinha.pdf>. Acesso em: 15 jul.2013.

FONSECA, Maria Liana Gesteira. Diferenças culturais entre profissionais de saúde e clientela acerca do nervoso: da distância à compreensão da diversidade. Revista de APS. Rio de Janeiro, vol. 12, n.4, 2009. Disponível em: <aps.ufjf.emnuvens.com.br/aps/article/view/607>. Acesso em: 15 nov.2014.

FOOT HARDMAN, Francisco; LEONARDI, Victor. História da Indústria e do Trabalho no Brasil. Das origens aos anos 20. São Paulo: Ática, 1982.

FOUCAULT, Michel. A arqueologia do Saber. 4a edição. Rio de Janeiro: Forense Universitária, 1995. (1995a)

FOUCAULT, Michel. Microfísica do poder. 11a reimpressão. Rio de Janeiro: Graal, 1995. (1995b)

FOUCAULT, Michel. Vigiar e Punir. 19ạ edição. Petrópolis: Vozes, 1999.

FRANCO, Tânia. Padrões de Produção e Consumo nas Sociedades Urbano-Industriais e suas Relações com a Degradação da Saúde e do Meio Ambiente. IN: MINAYO, Maria Cecília de Souza; 
MIRANDA, Ary Carvalho de (org.) Saúde e Ambiente Sustentável: estreitando nós. Rio de Janeiro: Editora Fiocruz, 2002.

FRANCO, Tânia; DRUCK, Graça; SELIGMANN-SILVA, Edith. As novas relações de trabalho, o desgaste mental do trabalhador e os transtornos mentais no trabalho precarizado. Rev. bras. saúde ocup., São Paulo, vol.35, n.122, dez. 2010. Disponível em:

$<$ http://www.scielo.br/scielo.php?script=sci_arttext\&pid=S0303-

76572010000200006\&lng=en\&nrm=iso>. Acesso em: 12 mar.2013.

FREHSE, Fraya. Os informantes que jornais e fotografias revelam: para uma etnografia da civilidade nas ruas do passado. Estudos Históricos. Rio de Janeiro, n.36, jul-dez 2005. Disponível em: <http://bibliotecadigital.fgv.br/ojs/index.php/reh/article/viewArticle/2247>. Acesso em: 27 jun. 2012.

FREIRE, Américo. Redemocratização e eleições de 1945. IN: CPDOC (Centro de Pesquisa e Documentação de História Contemporânea do Brasil) - Fundação Getulio Vargas. Disponível em: http://cpdoc.fgv.br/producao/dossies/AEraVargas2/artigos/DoisGovernos/Redemocratizacao

FRIAS JUNIOR, Carlos Alberto da Silva. A saúde do trabalhador no Maranhão: uma visão atual e proposta de atuação. Dissertação (Mestrado em Saúde Pública). Escola Nacional de Saúde Pública da Fundação Oswaldo Cruz, Rio de Janeiro, 1999. Disponível em:

$<$ http://portalteses.icict.fiocruz.br/pdf/FIOCRUZ/1999/friasjrcasm/capa.pdf>. Acesso em: $28 \mathrm{dez}$. 2012.

FUNDACENTRO - Fundação Jorge Duprat Figueiredo de Segurança e Medicina do Trabalho. História. Disponível em: <http://www.fundacentro.gov.br/institucional/historia>. Acesso em: 17 dez. 2014.

GALERY, Augusto Dutra. LER e Psicologia: uma visão dos relatos de experiência. IN: Simpósio de Psicologia da UEMG: os desafios da Psicologia no século XXI, III. Anais... Divinópolis, UEMG/ INESP, 26 a 28 de agosto de 1998.

GARBIN, Andréia De Conto. Belo Horizonte (via Skype), 13 set. 2014. 1 arquivo .WAV (1h $12 \mathrm{~min}$ 25seg). Entrevista concedida a Natália Cristina Ribeiro Alves.

GERAB, Willian Jorge; ROSSI, Waldemar. Indústria e trabalho no Brasil: limites e desafios. São Paulo: Atual, 1997.

GIANNOTI, Vito. O ano de 1968 e o movimento operário no Brasil (artigo originalmente publicado no ${ }^{\circ} 22$ da Revista ADVIR, da UERJ - outubro de 2008). IN: Núcleo Piratininga de Comunicação. Disponível em <http://www.piratininga.org.br/novapagina/leitura.asp?id_noticia=3927\&topico=Hist\%F3ria>. Acesso em: 15 out. 2011.

GLINA, Débora Miriam Raab et al. Saúde mental e trabalho: uma reflexão sobre o nexo com o trabalho e o diagnóstico, com base na prática. Cad. Saúde Pública, Rio de Janeiro, vol.17, n.3, junho 2001. Disponível em:

$<$ http://www.scielo.br/scielo.php?script=sci_arttext\&pid=S0102-

311X2001000300015\&lng=en\&nrm=iso>. Acesso em: 12 mar.2013.

GOLDMAN, Marcio. Antropologia Contemporânea, Sociedades Complexas e Outras Questões. Anuário Antropológico 93. Rio de Janeiro: Tempo Brasileiro, 1995.

GOMES, Ângela de Castro. O movimento sindical urbano. IN: CPDOC (Centro de Pesquisa e Documentação de História Contemporânea do Brasil) - Fundação Getulio Vargas. Disponível em: 
$<\mathrm{ttp}$ //cpdoc.fgv.br/producao/dossies/JK/artigos/Politica/MovimentoSindicalUrbano>. Acesso em: 15 fev.2015.

GORZ, André. O Trabalho Imaterial. IN: O imaterial: conhecimento, valor e capital. São Paulo: Annablume, 2005.

GREGGIO, Maria Regina. Belo Horizonte, 27 ago. 2014. 1 arquivo .WAV (1h 1min 25seg). Entrevista concedida a Natália Cristina Ribeiro Alves.

GUERIN, François et al. Compreender o trabalho para transformá-lo. São Paulo: Edgar Blucher, 2001.

GUIA Trabalhista. Normas Regulamentadoras - Segurança e Saúde do Trabalho. Disponível em: <http://www.guiatrabalhista.com.br/obras/seguranca.htm>. Acesso em 18 out. 2013.

GUIMARÃES, Liliana Andolfo Magalhães; GRUBITS, Sonia (org). Saúde Mental e Trabalho. Volume I. São Paulo: Casa do Psicólogo, 1999.

HELOANI, José Roberto; CAPITAO, Cláudio Garcia. Saúde mental e psicologia do trabalho. São Paulo Perspec., São Paulo , v. 17, n. 2, jun. 2003. Disponível em:

$<$ http://www.scielo.br/scielo.php?script=sci_arttext\&pid=S0102-

$88392003000200011 \& \operatorname{lng}=e n \& n r m=i s o>$. Acesso em: 25 jan. 2015.

HOBSBAWM, Eric. A Era dos Extremos: o breve século XX: 1914-1991. 2ª edição, 11a reimpressão. São Paulo: Companhia da Letras, 1998.

HOMCl, Arthur Laércio. A evolução histórica da previdência social no Brasil. Revista Jus Navigandi, Teresina, ano 14, n. 2104, 5 abr. 2009. Disponível em: <http://jus.com.br/artigos/12493>. Acesso em: 25 jan. 2015.

JACQUES, Maria da Graça Corrêa. Abordagens teórico-metodológicas em saúde/doença mental \& trabalho. Psicol. Soc. 2003, vol.15, n.1. Disponível em:

$<$ http://www.scielo.br/scielo.php?script=sci_pdf\&pid=S0102-

$71822003000100006 \&$ Ing=en\&nrm=iso\&tlng=pt>. Acesso em: 13 set. 2013

JACQUES, Maria da Graça. O nexo causal em saúde/doença mental no trabalho: uma demanda para a psicologia. Psicol. Soc., Porto Alegre, vol. 19, n. spe, 2007. Disponível em:

$<$ http://www.scielo.br/scielo.php?script=sci_arttext\&pid=S0102-

$71822007000400015 \& \operatorname{lng}=e n \& n r m=i s o>$. Acesso em: 24 nov.2013.

JACQUES, Maria da Graça Corrêa. Doença dos nervos: o ser trabalhador como definidor da identidade psicológica. IN: JACQUES, Maria da Graça Corrêa et al. Relações sociais e ética. Rio de Janeiro: Centro Edelstein de Pesquisas Sociais, 2008. Disponível em:

<http://books.scielo.org/id/6j3gx/pdf/jacques-9788599662892-08.pdf>. Acesso em: 11 out.2013.

JACQUES, Maria da Graça Corrêa. Belo Horizonte, 28 ago. 2014. 2 arquivos .WAV (56min 13seg). Entrevista concedida a Natália Cristina Ribeiro Alves.

JARDIM, Sílvia. Depressão e trabalho: ruptura de laço social. Rev. bras. saúde ocup., São Paulo, vol. 36, n. 123, jun. 2011 . Disponível em:

$<$ http://www.scielo.br/scielo.php?script=sci_arttext\&pid=S0303-

$76572011000100008 \&$ Ing=pt\&nrm=iso $>$. Acesso em: 11 out.2013

JARDIM, Sílvia Rodrigues. Rio de Janeiro, 18 set. 2014. 2 arquivos .WAV (1h 26min 16seg).

Entrevista concedida a Natália Cristina Ribeiro Alves. 
JARDIM, Sílvia; SILVA FILHO, João Ferreira da (org). A danação do Trabalho: organização do trabalho e sofrimento psíquico. Rio de Janeiro: Te Corá Editora, 1997.

JUSTICIA, Juan Muñoz. Análisis cualitativo de datos textuales con Atlas.ti 5. Universitat Autónoma de Barcelona, 2005. Disponível em: <http://www.fcp.uncu.edu.ar/upload/Atlas5_manual.pdf>. Acesso em: 15 jan. 2015.

KELLE, Udo. Análise com auxílio de computador: codificação e indexação. IN: BAUER, Martin W; GASKELL, George. Pesquisa Qualitativa com Texto, Imagem e Som: um manual prático. Petrópolis: Vozes, 2002.

KOMPIER, Michiel A. J.; KRISTENSEN, Tage S. As intervenções em estresse organizacional. Cad. psicol. soc. trab., São Paulo, vol. 6, dez.2003 . Disponível em:

$<$ http://pepsic.bvsalud.org/scielo.php?script=sci_arttext\&pid=S1516-

$37172003000200004 \&$ Ing=pt\&nrm=iso >. Acesso em: 15 fev.2015.

KORNIS, Mônica Almeida. Parlamentarismo: sim ou não? IN: CPDOC (Centro de Pesquisa e Documentação de História Contemporânea do Brasil) - Fundação Getulio Vargas. Disponível em: <http://cpdoc.fgv.br/producao/dossies/Jango/artigos/NaPresidenciaRepublica/Parlamentarismo_si m_ou_nao >. Acesso em: 15 fev.2015.

KORNIS, Mônica Almeida; MONTEIRO, Débora Paiva. O movimento sindical urbano e o papel do CGT. IN: CPDOC (Centro de Pesquisa e Documentação de História Contemporânea do Brasil) Fundação Getulio Vargas. Disponível em:

<http://cpdoc.fgv.br/producao/dossies/Jango/artigos/NaPresidenciaRepublica/O_movimento_sind ical_urbano_e_o_CGT>. Acesso em: 15 fev.2015.

L'ABBATE, Solange. A análise institucional e a saúde coletiva. Ciênc. saúde coletiva, Rio de Janeiro, vol. 8,n. 1, 2003. Disponível em: <http://www.scielo.br/scielo.php?script=sci_arttext\&pid=S141381232003000100019\&lng=en\&nrm=iso>. Acesso em: 28 nov. 2013.

LACAZ, Francisco Antonio de Castro. Saúde do Trabalhador: um estudo sobre as formações discursivas da academia, dos serviços e do movimento sindical. Tese (Doutorado em Medicina / Saúde Coletiva). Faculdade de Ciências Médicas da Universidade Estadual de Campinas (UNICAMP). Campinas, 1996.

LACAZ, Francisco Antonio de Castro. Saúde dos trabalhadores: cenário e desafios. Cad. Saúde Pública, Rio de Janeiro, vol. 13,supl. 2, 1997. Disponível em:

$<$ http://www.scielo.br/scielo.php?script=sci_arttext\&pid=S0102-

311X1997000600002\&lng=en\&nrm=iso>. Acesso em: 28 dez. 2012.

LACAZ, Francisco Antônio de Castro. Qualidade de vida no trabalho e saúde/doença. Ciênc. saúde coletiva, Rio de Janeiro, vol.5, n.1, 2000. Disponível em:

<http://www.scielo.br/scielo.php?script=sci_arttext\&pid=S1413-

$81232000000100013 \&$ Ing=en\&nrm=iso>. Acesso em: 21 out. 2013.

LACAZ, Francisco Antonio de Castro. O campo Saúde do Trabalhador: resgatando conhecimentos e práticas sobre as relações trabalho-saúde. Cad. Saúde Pública, Rio de Janeiro, vol.23, n.4, abr. 2007. Disponível em:

$<$ http://www.scielo.br/scielo.php?script=sci_arttext\&pid=S0102-

311X2007000400003\&lng=en\&nrm=iso>. Acesso em: 11 out.2013. (2007a)

LACAZ, Francisco Antônio de Castro. Conhecimentos, práticas em Trabalho-Saúde e as abordagens da medicina social e da medicina do trabalho no Brasil: final do século XIX até os anos 1950-60. 
Cad. psicol. soc. trab. Jun. 2007, vol.10, n.1. Disponível em: <http://pepsic.bvspsi.org.br/pdf/cpst/v10n1/v10n1a07.pdf>. Acesso em: 3 dez. 2011. (2007b)

LACAZ, Francisco Antônio de Castro; SATO, Leny. Humanização e qualidade do processo de trabalho em saúde. In: DESLANDES, Suely Ferreira. (org.) Humanização dos Cuidados em Saúde: conceitos, dilemas e críticas. Rio de Janeiro: Editora Fiocruz, 2006.

LAURELL, Asa Cristina. La construcción teórico-metodológica de la investigación sobre la Salud de los Trabajadores. IN: LAURELL, Asa Cristina (coord.) Para la investigación sobre La Salud de los Trabajadores. Washington: OPAS, 1993. Disponível em: <http://iris.paho.org/xmlui/handle/123456789/3293>. Acesso em: 28 dez. 2012.

LAURELL, Asa Cristina. Los Enfoques Teóricos. IN: FRANCO, Saúl et al (org.) Debates en Medicina Social. Quito: Organización Panamericana de La Salud/ Alames, 1991.

LAURELL, Asa Cristina; NORIEGA, Mariano. Processo de produção e saúde: trabalho e desgaste operário. São Paulo: HUCITEC, 1989.

LE GUILLANT, Louis et al. A neurose das telefonistas. Rev. bras. saúde ocupacional, Fundacentro; 12(47):7-11, 1956/1984.

LEAL, Ondina Fachel (org). Corpo e Significado: Ensaios de Antropologia Social. Porto Alegre: Editora da Universidade/ UFRGS, 1995.

LEITE, Márcia de Paula. A experiência brasileira da reestruturação e suas implicações sociais. IN: Trabalho e sociedade em transformação: mudanças produtivas e atores sociais. São Paulo: Editora Perseu Abramo, 2003.

LEMOS, Jadir Camargo. Cargas Psíquicas no Trabalho e Processos de Saúde em Professores Universitários. Florianópolis, 2005. Tese (Doutorado em Engenharia de Produção). Centro Tecnológico, Universidade Federal de Santa Catarina, 2005. Disponível em: <http://www.tede.ufsc.br/teses/PEPS4705.pdf>. Acesso em 28 dez. 2012.

LÉVY, Pierre. As tecnologias têm um impacto? IN: Cibercultura. 2a edição. São Paulo: Editora 34, 2000.

LEWIS, Bernard T.; PEARSON, William W. Manual de Psicologia Industrial. Rio de Janeiro: DENISA, $1960 / 1964$.

LHUILIER, Dominique. Filiações teóricas das clínicas do trabalho. IN: BENDASSOLLI, Pedro F.; SOBOLL, Lis Andrea P. (org.). Clínicas do Trabalho: Novas perspectivas para compreensão do trabalho na atualidade. São Paulo: Atlas, 2011.

LIEDKE, Elida Rubini. Trabalho. In: CATTANI, Antônio David. (org.) Dicionário Crítico sobre Trabalho e Tecnologia. 4a edição revista e ampliada. Petrópolis: Vozes; Porto Alegre: Ed. Universidade, 2002.

LIMA, Alexandre Bonetti. Reflexões sobre o processo de organização de um movimento social de portadores de LER. IN: Caderno de Resumos. VIII Colóquio Internacional de Sociologia Clínica e Psicossociologia. Transformações Sociais, Subjetividades e Política. Belo Horizonte: UFMG, 2001.

LIMA, Alexandre Bonetti; OLIVEIRA, Fábio de. Abordagem Psicossocial da LER: ideologia da culpabilização e grupos de qualidade de vida. IN: CODO, Wanderley; ALMEIDA, Maria Celeste G. de (org). LER: diagnóstico, tratamento e prevenção - uma abordagem interdisciplinar. $2^{a}$ edição. Petrópolis: Vozes, 1995. 
LIMA, Francisco de Paula Antunes. Noções de Organização do Trabalho. IN: OLIVEIRA, Chrysóstomo R. e col. Manual Prático da LER - Lesões por Esforços Repetitivos. Belo Horizonte: Health, 1997. (1997a)

LIMA, Francisco de Paula Antunes. Ergonomia e prevenção da LER: possibilidades e limites. IN: ARAÚJO, José Newton G.; LIMA, Maria Elizabeth Antunes; LIMA, Francisco de Paula Antunes (org.). LER - Dimensões ergonômicas e psicossociais. Belo Horizonte: Editora Health, 1997. (1997b)

LIMA, Júlio César França. A política nacional de saúde nos anos 1990 e 2000: na contramão da história? IN: PONTE, Carlos Fidélis; FALLEIROS, lalê (org.). Na corda bamba de sombrinha: a saúde no fio da história. Rio de Janeiro: Fiocruz/COC; Fiocruz/EPSJV, 2010. Disponível em: <http://observatoriohistoria.coc.fiocruz.br/local/File/livro-na-corda-bamba-de-sombrinha.pdf>. Acesso em: 15 jul.2013.

LIMA, Maria Elizabeth Antunes. A pesquisa em saúde mental e trabalho. IN: TAMAYO, Alvaro; BORGES-ANDRADE, Jairo Eduardo; CODO, Wanderley. (org.). Trabalho, Organizações e Cultura. São Paulo: CAA - Cooperativa de Editores Associados, 1996. (1996a)

LIMA, Maria Elizabeth Antunes. Os equívocos da excelência: as novas formas de sedução na empresa. Petrópolis: Vozes, 1996. (1996b)

LIMA, Maria Elizabeth Antunes. A dimensão psicológica. IN: ARAÚJO, José Newton G.; LIMA, Maria Elizabeth A.; LIMA, Francisco de Paula Antunes (org.). LER - Dimensões ergonômicas e psicossociais. Belo Horizonte: Editora Health, 1997 (1997).

LIMA, Maria Elizabeth Antunes. A Psicopatologia do trabalho. Psicol. cienc. prof., Brasília,vol.8,n.2,1998. Disponível em:

$<$ http://www.scielo.br/scielo.php?script=sci_arttext\&pid=S1414-

98931998000200003\&lng=en\&nrm=iso>. Acesso em: 21 jul. 2013.

LIMA, Maria Elizabeth Antunes. Informatização e Saúde no Setor de telecomunicações. O problema das Lesões por Esforços Repetitivos. IN: SZNELWAR, Laerte I.; ZIDAN, Leila N. (org). O trabalho humano com sistemas informatizados no setor de serviços. São Paulo: Plêiade, 2000.

LIMA, Maria Elizabeth Antunes. A questão do método em Psicologia do Trabalho. IN: GOULART, Iris Barbosa (org.) Psicologia organizacional e do trabalho: teoria, pesquisa e temas correlatos. São Paulo: Casa do Psicólogo, 2002.

LIMA, Maria Elizabeth Antunes. A polêmica em torno do nexo causal entre distúrbio mental e trabalho. Psicologia em Revista, Belo Horizonte, vol.10, n.14, dez.2003. Disponível em: <http://www.pucminas.br/imagedb/documento/DOC_DSC_NOME_ARQUI20041213154638.pdf>. Acesso em: 12 mar.2013.

LIMA, Maria Elizabeth Antunes. A relação entre distúrbio mental e trabalho: evidências epidemiológicas recentes. IN: CODO, Wanderley (org.). O trabalho enlouquece? Petrópolis: Vozes, 2004.

LIMA, Maria Elizabeth Antunes. Transtornos mentais e trabalho: o problema do nexo causal. Revista de Administração FEAD. Belo Horizonte, vol. 2, n. 1, 2005. Disponível em: <http://revista.fead.br/index.php/adm/article/view/88>. Acesso em 14 out. 2013.

LIMA, Maria Elizabeth Antunes (org.). Escritos de Louis Le Guillant - da Ergoterapia à Psicopatologia do Trabalho. Petrópolis: Vozes, 2006. 
LIMA, Maria Elizabeth Antunes. Esboço de uma crítica à especulação no campo da saúde mental e trabalho. IN: JACQUES, Maria da Graça; CODO, Wanderley (org). Saúde Mental \& Trabalho: leituras. 5a edição. Petrópolis: Vozes, 2011. (2011a)

LIMA, Maria Elizabeth Antunes. Trabalho e saúde mental no contexto contemporâneo de trabalho: possibilidades e limites de ação. IN: VIZZACCARO-AMARAL, André Luís; MOTA, Daniel Pestana; ALVES, Giovanni (org). Trabalho e saúde: a precarização do trabalho e a saúde do trabalhador no Século XXI. São Paulo: LTr, 2011. (2011b)

LIMA, Maria Elizabeth Antunes. Saúde mental e trabalho: limites, desafios, obstáculos e perspectivas. Cad. psicol. soc. trab., São Paulo, vol. 16, n. spe, 2013. Disponível em: $<$ http://pepsic.bvsalud.org/scielo.php?script=sci_arttext\&pid=S1516$37172013000300009 \&$ lng=pt\&nrm=iso >. Acesso em: 15 nov.2014.

LINO, Domingos; DIAS, Elizabeth Costa. A globalização da economia e os impactos sobre a saúde e segurança dos trabalhadores. In: Saúde e Trabalho Online [portal]. Disponível em: <http://www.saudeetrabalho.com.br/download/global-lino.doc>. Acesso em: 18 out. 2013

LOURENÇO FILHO, Manuel Bergström. Prefacio do Traductor. IN: WALTHER, Leon. TechnoPsychologia do Trabalho Industrial. São Paulo: Companhia Melhoramentos São Paulo, 1929.

LUCA, Tania Regina de. Indústria e trabalho na História do Brasil. São Paulo: Contexto, 2001.

LUCIRE, Yolande. Neurosis in the workplace. The Medical Journal of Australia, 145 (6/out), 1986. Disponível em:

$<$ http://members.ozemail.com.au/ /ucire/documents/Neurosis_in_the_workplace.htm>. Acesso em: 5 jul. 2003.

LUCIRE, Yolande. Origins of the concept RSI. Disponível em:

<http://members.ozemail.com.au/ lucire/documents/social_iatrogenesis.htm>. Acesso em: 5 jul. 2003. (2003a)

LUCIRE, Yolande. Repetitive Strain Injury - An Epidemic of Craft Palsy. Proceedings of the MedicoLegal Society of NSW. Vol. 8. Disponível em:

<http://members.ozemail.com.au/ /ucire/documents/chapter_on_RSI.htm>. Acesso em: 5 jul. 2003. (2003b)

LUCIRE, Yolande. Social iatrogenesis of the Australian disease 'RSI'. Community Health Studies, 12 (2), 1988. Disponível em:

<http://members.ozemail.com.au/ lucire/cv_References/social_iatrogenesis.htm>. Acesso em: 5 jul. 2003.

MAENO, Maria. Ser médico. IN: VIZZACCARO-AMARAL, André Luís; MOTA, Daniel Pestana; ALVES, Giovanni (org). Trabalho e saúde: a precarização do trabalho e a saúde do trabalhador no Século XXI. São Paulo: LTr, 2011.

MAENO, Maria. Belo Horizonte (via Scopia - videoconferência), 25 set. 2014. 2 arquivos .WAV (50min 54seg). Entrevista concedida a Natália Cristina Ribeiro Alves.

MAENO, Maria. Por que conversamos ainda sobre LER/DORT? (201-). Disponível em: $<$ http://www.fetecsp.org.br/index.php?option=com_content\&view=article\&id=50263:artigo-porque-conversamos-ainda-sobre-lerdort\&catid=39:saude\&Itemid=143>. Acesso em: 21 dez. 2014.

MANSANERA, Adriano Rodrigues; SILVA, Lúcia Cecília da. A influência das ideias higienistas no desenvolvimento da psicologia no Brasil. Psicol. estud., Maringá, vol. 5, n. 
1, mar. 2000. Disponível em: <http://www.scielo.br/scielo.php?script=sci_arttext\&pid=S1413$73722000000100008 \&$ Ing=en\&nrm=iso>. Acesso em: 15 nov.2014.

MATTOS, Marcelo Badaró. Greves, sindicatos e repressão policial no Rio de Janeiro (1954-1964). Rev. Bras. Hist., São Paulo, v. 24, n. 47, p. 241-270, 2004. Disponível em: $<$ http://www.scielo.br/scielo.php?script=sci_arttext\&pid=S010201882004000100010\&lng=en\&nrm=iso >. Acesso em: 15 fev.2015.

MELO, Luiz Eduardo Alcântara de; PRADO, Rogério Ruscitto do. A aplicação da metodologia do FAP. IN: TODESCHINI, Remígio; CODO, Wanderley (org). O novo seguro de acidente de trabalho e o novo FAP. São Paulo: LTr, 2009.

MENDES, Jussara Maria Rosa. Acidente de Trabalho. IN: CATTANI, Antonio David. Dicionário Crítico de Trabalho e Tecnologia. 4 ed. Petrópolis: Vozes; Porto Alegre: Editora da UFRGS, 2002.

MENDES, René. O impacto dos efeitos da ocupação sobre a saúde de trabalhadores: I. Morbidade. Rev. Saúde Pública. 1988, vol.22, n.4. Disponível em: <http://www.scielo.br/pdf/rsp/v22n4/07.pdf>. Acesso em: 18 out. 2013

MENDES, René. Aspectos históricos da Patologia do Trabalho. IN: Patologia do Trabalho. Rio de Janeiro: Editora Atheneu, 1995.

MENDES, René. Produção Científica Brasileira Sobre Saúde e Trabalho, Publicada na Forma de Dissertações de Mestrado e Teses de Doutorado, 1950-2002 - parte 1. Rev. Bras. Med. Trab., Belo Horizonte. Vol.1, n.2, out-dez 2003. Disponível em:

<http://www.anamt.org.br/site/pagina_geral.aspx?pagid=45>. Acesso em: 15 jan. 2015.

MENDES, René; DIAS, Elizabeth Costa. Da medicina do trabalho à saúde do trabalhador. Rev. Bras. Saúde Pública, São Paulo, vol. 25, n. 5, out. 1991. Disponível em: $<$ http://www.scielo.br/scielo.php?script=sci_arttext\&pid=S0034$89101991000500003 \&$ Ing=en\&nrm=iso>. Acesso em 28 dez. 2010.

MENDES, René; DIAS, Elizabeth Costa. O que é a Medicina do Trabalho. IN: Associação Mineira de Medicina do Trabalho. Disponível em: <http://www.amimt.org.br/medicina_trabalho.html>. Acesso em: 9 maio 2003 (2003a).

MENDES, René; DIAS, Elizabeth Costa. O campo da saúde dos trabalhadores e a saúde pública. Disponível em: <http://saudepublica.medicina.ufmg.br/mest_saudetrabalho_1.htm>. Acesso em: 09 maio 2003 (2003b).

MENDES, René; DIAS, Elizabeth Costa. A produção de conhecimento sobre as relações TrabalhoSaúde-Doença e de Alternativas de Atenção à Saúde do Trabalhador. Disponível em: <http://saudepublica.medicina.ufmg.br/mest_saudetrabalho_2.htm>. Acesso em: 09 maio 2003 (2003c).

MERLO, Álvaro R. de C.; JACQUES, Maria da Graça Corrêa; HOEFEL, Maria da Graça Luderitz. Trabalho de Grupo com Portadores de LER / DORT: Relato de Experiência. Psicologia: Reflexão e Crítica. 2001, vol.14, n.1. Disponível em:

$<$ http://www.scielo.br/scielo.php?script=sci_arttext\&pid=S0102-

$79722001000100021 \& \operatorname{lng}=e n \& n r m=i s o>$. Acesso em 19 ago. 2013.

MERLO, Álvaro R. de C. et al. Protocolo de investigação, diagnóstico, tratamento e prevenção de Lesão por Esforços Repetitivos / Distúrbios Osteomusculares Relacionados ao Trabalho. Ministério da Saúde, Secretaria de Políticas de Saúde, Departamento de Ações Programáticas e Estratégias, Área Técnica de Saúde do Trabalhador. Brasília: Ministério da Saúde, 2000. Disponível em: 
$<$ http://dtr2001.saude.gov.br/sps/areastecnicas/trabalhador/conteudo/publicacoes.htm>. Acesso em 19 ago. 2013.

MINAYO, Maria Cecília de Souza. O desafio do conhecimento: pesquisa qualitativa em saúde. 12a edição. São Paulo: Hucitec, 2010.

MINAYO-GOMEZ, Carlos; THEDIM-COSTA, Sonia Maria da Fonseca. A construção do campo da saúde do trabalhador: percurso e dilemas. Cad. Saúde Pública. 1997, vol.13, supl.2. Disponível em: $<$ http://www.scielo.br/scielo.php?script=sci_arttext\&pid=S0102-

311X1997000600003\&lng=pt\&nrm=iso>. Acesso em: 15 out. 2013.

MINAYO-GOMEZ, Carlos; THEDIM-COSTA, Sonia Maria da Fonseca. Precarização do trabalho e desproteção social: desafios para a saúde coletiva. Ciênc. saúde coletiva, vol.4, n.2, 1999.

Disponível em: <http://www.scielo.br/pdf/csc/v4n2/7123.pdf>. Acesso em: 18 out. 2013

MINAYO-GOMEZ, Carlos; THEDIM-COSTA, Sonia Maria da Fonseca. Incorporação das ciências sociais na produção de conhecimentos sobre trabalho e saúde. Ciênc. saúde coletiva. 2003, vol.8, n.1. Disponível em: $<$ http://www.scielo.br/scielo.php?script=sci_arttext\&pid=S1413-

$81232003000100010 \&$ Ing=en\&nrm=iso>. Acesso em: 15 out. 2013.

MONTEIRO, Janne C. Lesões por Esforços Repetitivos: um estudo sobre a vivência do trabalhador portador de LER. Dissertação (Mestrado em Engenharia de Produção). Programa de Pós-

Graduação em Engenharia de Produção - UFSC, Florianópolis 1997. Disponível em:

<http://www.eps.ufsc.br/disserta97/monteiro>. Acesso em 19 ago. 2013.

MONTERO, Paula. Da doença à desordem: a magia na umbanda. Rio de Janeiro: Graal, 1995.

MOTTA, Júlia Maria Casulari. Fragmentos da história e da memória da Psicologia no mundo do trabalho no Brasil: relações entre a industrialização e a psicologia. Tese (Doutorado em Saúde Coletiva). Faculdade de Ciências Médicas da Universidade Estadual de Campinas (UNICAMPO, Campinas. 2004. Disponível em:

$<$ http://www.bibliotecadigital.unicamp.br/document/?code=vtls000346477>. Acesso em 21 jul. 2013.

MÜNSTERBERG, Hugo. Psicologia de la actividad industrial. Ensayo de Psicologia Experimental Aplicada. Madrid: Daniel Jorro Editor, 1914.

NARDI, Henrique Caetano. Saúde do Trabalhador. IN: CATTANI, Antonio David. Dicionário Crítico de Trabalho e Tecnologia. 4a edição revista e ampliada. Petrópolis: Vozes; Porto Alegre: Editora da UFRGS, 2002.

NARDI, Henrique Caetano; RAMMINGER, Tatiana. Políticas públicas em saúde mental e trabalho: desafios políticos e epistemológicos. Psicol. cienc. prof., Brasília, vol.32, n.2, 2012. Disponível em: <http://www.scielo.br/scielo.php?script=sci_arttext\&pid=S1414-

98932012000200008\&lng=en\&nrm=iso>. Acesso em: 21 jul. 2013.

NARDI, Henrique Caetano; TITTONI, Jaqueline; BERNARDES, Jefferson Souza. Subjetividade e Trabalho. IN: CATTANI, Antonio David. Dicionário Crítico de Trabalho e Tecnologia. 4a edição revista e ampliada. Petrópolis: Vozes; Porto Alegre: Editora da UFRGS, 2002.

NASCIMENTO SOBRINHO, Carlito Lopes. Campos de Saúde Coletiva. Sitientibus. Feira de Santana, n. 13, jul./dez. 1995. Disponível em:

<http://www.uefs.br/sitientibus/sitientibus13/campos_de_saude_coletiva.pdf $>$. Acesso em: 21 jul. 2013. 
NASSIF, Lilian Erichsen. Origens e desenvolvimento da Psicopatologia do Trabalho na França (século XX): uma abordagem histórica. Memorandum, n.8, 2005. Disponível em:

<http://www.fafich.ufmg.br/memorandum/artigos08/artigo07.pdf>. Acesso em: 21 jul. 2013.

NORIEGA, Mariano. Organización laboral, exigências y enfermedad. IN: LAURELL, Asa Cristina (coord.) Para la investigación sobre La Salud de los Trabajadores. Washington: OPAS, 1993.

NOUROUDINE, Abdallah. Como conhecer o trabalho quando o trabalho não é mais o trabalho?. Trab. educ. saúde, Rio de Janeiro, vol.9, supl.1, 2011. Disponível em:

$<$ http://www.scielo.br/scielo.php?script=sci_arttext\&pid=S1981-

77462011000400004\&lng=en\&nrm=iso>. Acesso em: 15 fev. 2013.

NUNES, Elaine E; MENDES, Jussara M. R. A trajetória do trabalhador portador de LER/ DORT: afinal, que caminho é esse?. Revista Textos e Contextos, PUC-RS, ano 1, n.1, 2002. Disponível em: <http://www.pucrs.br/textos/download01/politicasocial02.pdf>. Acesso em: 19 ago. 2013.

OLIVEIRA, Chrysóstomo R. e col. Manual Prático da LER. Belo Horizonte: Health, 1997.

OLIVEIRA, Fábio. A Construção Social dos Discursos sobre o Acidente de Trabalho. Dissertação (Mestrado em Psicologia Social). Instituto de Psicologia da Universidade de São Paulo, São Paulo, 1997.

OLIVEIRA, Fábio de. A persistência da noção de ato inseguro e a construção da culpa: os discursos sobre os acidentes de trabalho em uma indústria metalúrgica. Rev. bras. saúde ocup., São Paulo, vol. 32, n. 115, jun. 2007. Disponível em:

$<$ http://www.scielo.br/scielo.php?script=sci_arttext\&pid=S0303-

$76572007000100003 \&$ Ing=en\&nrm=iso>. Acesso em: 15 fev.2015.

OLIVEIRA, Paulo Antônio Barros. Ergonomia. IN: CATTANI, Antonio David. Dicionário Crítico de Trabalho e Tecnologia. 4a edição revista e ampliada. Petrópolis: Vozes; Porto Alegre: Editora da UFRGS, 2002. (2002a)

OLIVEIRA, Paulo Antônio Barros. Trabalho prescrito e trabalho real. IN: CATTANI, Antonio David. Dicionário Crítico de Trabalho e Tecnologia. 4a edição revista e ampliada. Petrópolis: Vozes; Porto Alegre: Editora da UFRGS, 2002. (2002b)

OMS (Organização Mundial da Saúde). CID-10: Classificação Estatística Internacional de Doenças e Problemas Relacionados à Saúde. Brasília: Ministério da Saúde / DATASUS (Departamento de Informática do SUS). Disponível em: <http://www.datasus.gov.br/cid10/V2008/cid10.htm>. Acesso em: 04 set. 2013.

ORSO, Paulino J. et al. Reflexões Acerca das Lesões por Esforços Repetitivos e a Organização do Trabalho. Revista Online Biblioteca Professor Joel Martins. Campinas: fev. 2001, vol.2, n.2. Disponível em <http://www.bibli.fae.unicamp.br/revbfe/v2n1fev2001/art06.pdf>. Acesso em: 19 ago. 2013.

PALMARES, Gilberto. Projeto de Resolução № 1302/2010. Confere a Medalha Tiradentes ao Sindicato dos Empregados em Estabelecimento Bancários do município do Rio de Janeiro. Rio de Janeiro: Assembleia Legislativa do Estado do Rio de Janeiro, 2010. Disponível em: <http://alerjln1.alerj.rj.gov.br/scpro0711.nsf/e00a7c3c8652b69a83256cca00646ee5/e33a84a4b19 3c802832576fe00659b37?OpenDocument\&ExpandSection=-1>. Acesso em: 21 dez. 2014.

PAULA, Christiane Jalles. O segundo mandato e a crise sucessória. IN: CPDOC (Centro de Pesquisa e Documentação de História Contemporânea do Brasil) - Fundação Getulio Vargas. Disponível em: 
<http://cpdoc.fgv.br/producao/dossies/Jango/artigos/VicePresidenteJanio/O_segundo_mandato_e _a_crise_sucessoria>. Acesso em: 15 fev.2015.

PÊGO, Carlos Américo Abrantes; CARNEIRO, Cristina Miranda; ALMEIDA, Eduardo Henrique Rodrigues de. História da LER no Brasil. IN: OLIVEIRA, Chrysóstomo R. e colaboradores. Manual Prático de LER - Lesões por Esforços Repetitivos. Belo Horizonte: Editora Health, 1997.

PENNELLA, Isabela. LER: Uma Jornada de Sofrimento no Trabalho Bancário. Dissertação (Mestrado em Sociologia). Instituto de Filosofia, Letras e Ciências Humanas, USP, São Paulo, 2001. Disponível em: <http://www.teses.usp.br/teses/disponiveis/8/8132/tde-05102001-

114209/publico/ISABELAPENNELLA_PRN.pdf>. Acesso em: $21 \mathrm{dez} .2013$.

PEREIRA, Maristela de Souza. As concepções sobre saúde do trabalhador, as práticas profissionais e o contexto de atuação de psicólogos organizacionais. Tese (Doutorado em Psicologia Social). Universidade de São Paulo. São Paulo, 2015.

PICALUGA, Izabel F. Saúde e Trabalho / Diagnóstico das condições de vida e saúde no Brasil. IN: IBASE (Instituto Brasileiro de Análises Sociais e Econômicas). Saúde e Trabalho no Brasil. 2a edição. Petrópolis: Vozes, 1983. (1983a)

PICALUGA, Izabel F. Doenças Profissionais / Diagnóstico das condições de vida e saúde no Brasil. IN: IBASE (Instituto Brasileiro de Análises Sociais e Econômicas). Saúde e Trabalho no Brasil. 2a edição. Petrópolis: Vozes, 1983. (1983b)

PINHEIRO, Fernanda Amaral; TROCCOLI, Bartholomeu Torres; CARVALHO, Cláudio Viveiros de. Validação do Questionário Nórdico de Sintomas Osteomusculares como medida de morbidade. Ver. Saúde Pública. 2002, vol.36, n.3. Disponível em:

$<$ http://www.scielosp.org/scielo.php?script=sci_arttext\&pid=S0034-

$89102002000300008 \&$ Ing=pt\&nrm=iso >. Acesso em: 19 ago. 2013.

PIRES-ALVES, Fernando A; FALLEIROS, lalê. Ciência, técnica e fragmentação da saúde. IN: PONTE, Carlos Fidélis; FALLEIROS, lalê (org.). Na corda bamba de sombrinha: a saúde no fio da história. Rio de Janeiro: Fiocruz/COC; Fiocruz/EPSJV, 2010. Disponível em:

<http://observatoriohistoria.coc.fiocruz.br/local/File/livro-na-corda-bamba-de-sombrinha.pdf>. Acesso em: 15 jul.2013.

PONTE, Carlos Fidélis. O Brasil no microscópio. IN: PONTE, Carlos Fidélis; FALLEIROS, lalê (org.). Na corda bamba de sombrinha: a saúde no fio da história. Rio de Janeiro: Fiocruz/COC; Fiocruz/EPSJV, 2010. Disponível em: <http://observatoriohistoria.coc.fiocruz.br/local/File/livro-na-corda-bambade-sombrinha.pdf>. Acesso em: 15 jul.2013. (2010a)

PONTE, Carlos Fidélis. O sanitarismo e os projetos de nação. IN: PONTE, Carlos Fidélis; FALLEIROS, lalê (org.). Na corda bamba de sombrinha: a saúde no fio da história. Rio de Janeiro: Fiocruz/COC; Fiocruz/EPSJV, 2010. Disponível em: <http://observatoriohistoria.coc.fiocruz.br/local/File/livro-nacorda-bamba-de-sombrinha.pdf >. Acesso em: 15 jul.2013. (2010b)

PONTE, Carlos Fidélis. A Liga Pró-Saneamento do Brasil e a criação do Ministério da Educação e Saúde. IN: PONTE, Carlos Fidélis; FALLEIROS, lalê (org.). Na corda bamba de sombrinha: a saúde no fio da história. Rio de Janeiro: Fiocruz/COC; Fiocruz/EPSJV, 2010. Disponível em:

$<$ http://observatoriohistoria.coc.fiocruz.br/local/File/livro-na-corda-bamba-de-sombrinha.pdf>. Acesso em: 15 jul.2013. (2010c)

PONTE, Carlos Fidélis. Entre a saúde pública e a medicina previdenciária. IN: PONTE, Carlos Fidélis; FALLEIROS, lalê (org.). Na corda bamba de sombrinha: a saúde no fio da história. Rio de Janeiro: Fiocruz/COC; Fiocruz/EPSJV, 2010. Disponível em: 
<http://observatoriohistoria.coc.fiocruz.br/local/File/livro-na-corda-bamba-de-sombrinha.pdf>. Acesso em: 15 jul.2013. (2010d)

PONTE, Carlos Fidélis. Política econômica e alterações nos quadros epidemiológico e sanitário do país. IN: PONTE, Carlos Fidélis; FALLEIROS, lalê (org.). Na corda bamba de sombrinha: a saúde no fio da história. Rio de Janeiro: Fiocruz/COC; Fiocruz/EPSJV, 2010. Disponível em:

<http://observatoriohistoria.coc.fiocruz.br/local/File/livro-na-corda-bamba-de-sombrinha.pdf>. Acesso em: 15 jul.2013. (2010e)

PONTE, Carlos Fidélis. A criação do Ministério da Saúde. IN: PONTE, Carlos Fidélis; FALLEIROS, lalê (org.). Na corda bamba de sombrinha: a saúde no fio da história. Rio de Janeiro: Fiocruz/COC; Fiocruz/EPSJV, 2010. Disponível em: <http://observatoriohistoria.coc.fiocruz.br/local/File/livro-nacorda-bamba-de-sombrinha.pdf>. Acesso em: 15 jul.2013. (2010f)

PONTE, Carlos Fidelis; KROPF, Simone Petraglia; LIMA, Nísia Trindade. O sanitarismo (re)descobre o Brasil. IN: PONTE, Carlos Fidélis; FALLEIROS, lalê (org.). Na corda bamba de sombrinha: a saúde no fio da história. Rio de Janeiro: Fiocruz/COC; Fiocruz/EPSJV, 2010. Disponível em:

<http://observatoriohistoria.coc.fiocruz.br/local/File/livro-na-corda-bamba-de-sombrinha.pdf>. Acesso em: 15 jul.2013.

PONTE, Carlos Fidelis; REIS, José Roberto Franco; FONSECA, Cristina M. O. Saúde pública e medicina previdenciária: complementares ou excludentes? IN: PONTE, Carlos Fidélis; FALLEIROS, lalê (org.). Na corda bamba de sombrinha: a saúde no fio da história. Rio de Janeiro: Fiocruz/COC; Fiocruz/EPSJV, 2010. Disponível em: <http://observatoriohistoria.coc.fiocruz.br/local/File/livro-nacorda-bamba-de-sombrinha.pdf>. Acesso em: 15 jul.2013.

PRADO FILHO, Kleber; TRISOTTO, Sabrina. A Psicologia como disciplina da norma nos escritos de M. Foucault. Aulas. Dossiê Foucault. Campinas, n. 3, dez. 2006/mar. 2007. Disponível em: <http://www.unicamp.br/ aulas/pdf3/KLEBER.pdf>. Acesso em: 27 jun. 2012.

PRILLELTENSKY, Isaac. Aspectos políticos e éticos da psicologia organizacional. IN: The moral and politics of psychological discourse and the status quo. (tradução de Fábio de Oliveira). Nova York: State University of New York Press, 1994.

RAMAZZINI, Bernardino. As doenças dos trabalhadores. São Paulo: Fundacentro, 1700/2000.

RAMMINGER, Tatiana; NARDI, Henrique Caetano. Saúde mental e saúde do trabalhador: análise das conferências nacionais brasileiras. Psicol. cienc. prof., Brasília , vol. 27, n.

4, dez. 2007. Disponível em: <http://www.scielo.br/scielo.php?script=sci_arttext\&pid=S141498932007000400009\&lng=pt\&nrm=iso>. Acesso em: 15 nov.2014.

RAMOS, Arlindo. Psicologia Aplicada ao Trabalho. Escolha, Aperfeiçoamento e Direção de Empregados. Rio de Janeiro: Companhia Brasileira de Artes Gráficas, 1948.

REIS, José Roberto Franco. O coração do Brasil bate nas ruas: a luta pela redemocratização do país. IN: PONTE, Carlos Fidélis; FALLEIROS, lalê (org.). Na corda bamba de sombrinha: a saúde no fio da história. Rio de Janeiro: Fiocruz/COC; Fiocruz/EPSJV, 2010. Disponível em:

<http://observatoriohistoria.coc.fiocruz.br/local/File/livro-na-corda-bamba-de-sombrinha.pdf>. Acesso em: 15 jul.2013.

RENAST - Rede Nacional de Atenção Integral em Saúde do Trabalhador. 2o Inventário de Saúde do Trabalhador, 2010-2011: Acompanhamento da Rede Nacional de Atenção Integral em Saúde do Trabalhador, 2010-2011. Brasília: Ministério da Saúde, Coordenação Geral de Saúde do Trabalhador; Fundação Oswaldo Cruz, Diretoria Regional de Brasília; Salvador, Universidade Federal da Bahia, Instituto de Saúde Coletiva, 2013. 
RIBEIRO, Fátima Sueli Neto. Situação no Brasil. IN: ALAMES - Associación Latinoamericana de Medicina Social. Informe Continental sobre la situación Del Derecho a la Salud en el Trabajo, 2008. Disponível em: <http://www.alames.org/documentos/trabajo.htm>. Acesso em: 02 ago. 2011.

RIBEIRO, Herval Pina. Lesões por Esforços Repetitivos (LER): uma doença emblemática. Cad. Saúde Pública. 1997, vol.13, supl.2, 1997. Disponível em:

<http://www.scielo.br/scielo.php?script=sci_arttext\&pid=S0102-

311X1997000600008\&lng=en\&nrm=iso>. Acesso em: 28 dez. 2014.

RIBEIRO, Herval Pina; LACAZ, Francisco Antonio de Castro. De que adoecem e morrem os trabalhadores. São Paulo: DIESAT, 1984.

RIBEIRO, Herval Pina et al. Entrevista: Herval Pina Ribeiro, Francisco Antonio de Castro Lacaz, Carlos Aparício Clemente e Pérsio Dutra falam sobre a história do DIESAT. Cad. psicol. soc. trab., São Paulo, vol.5, dez. 2002. Disponível em:

$<$ http://pepsic.bvsalud.org/scielo.php?script=sci_arttext\&pid=S1516-

$37172002000100007 \&$ Ing=pt\&nrm=iso >. Acesso em: 12 mar.2013.

RIGOTTO, Raquel Maria. Investigando a relação entre saúde e trabalho. IN: ROCHA, Lys Esther; RIGOTTO, Raquel Maria; BUSCHINELLI, José Tarcísio Penteado (org.) Isto é trabalho de gente? Vida, Doença e Trabalho no Brasil. Petrópolis: Vozes, 1993.

ROCHA, Lys Esther; NUNES, Everardo Duarte. Apresentação: por que retomar os caminhos a história?; Os primórdios da industrialização e a reação dos trabalhadores: pré-30; A intervenção do Estado nas relações de trabalho: 1930-1945; Tudo por um "Brasil grande": 1945-1964; O Milagre Econômico e o ressurgimento do movimento social: 1964-1980. IN: ROCHA, Lys Esther; RIGOTTO, Raquel Maria; BUSCHINELLI, José Tarcísio P. (org.) Isto é trabalho de gente? Vida, Doença e Trabalho no Brasil. Petrópolis: Vozes, 1993.

ROUQUIÉ, Alain. O Extremo - Ocidente: Introdução à América Latina. São Paulo: EDUSP, 1991.

RUY, Carolina Maria. 1978. IN: CENTRO DE MEMÓRIA SINDICAL. Trabalho Abstrato - Memória e impressões do trabalho e da vida sindical. Publicado em 28 out. 2010. Disponível em <http://fsmemoriasindical.blogspot.com/2010_10_01_archive.html>. Acesso em 15 out. 2011. (2010a)

RUY, Carolina Maria. Greves de 1968 em Contagem e Osasco: o ressurgimento do sindicalismo. IN: CENTRO DE MEMÓRIA SINDICAL. Trabalho Abstrato - Memória e impressões do trabalho e da vida sindical. Publicado em 19 out. 2010. Disponível em

<http://fsmemoriasindical.blogspot.com/2010/10/greves-de-1968-em-contagem-e-osascoo.html>. Acesso em 15 out. 2011. (2010b)

SAMPAIO, Jáder dos Reis. A psicologia do trabalho em três faces. IN: Qualidade de Vida, Saúde Mental e Psicologia Social: Estudos Contemporâneos II. São Paulo: Casa do Psicólogo, 1999.

SANTANA, Marco Aurélio. Entre a ruptura e a continuidade: visões da história do movimento sindical brasileiro. Revista Brasileira de Ciências Sociais. São Paulo, vol. 14, n. 41,out. 1999. Disponível em <http://www.scielo.br/pdf/rbcsoc/v14n41/1754.pdf>. Acesso em 15 out. 2011.

SANTANA, Vilma Sousa. Saúde do trabalhador no Brasil: pesquisa na pós-graduação. Rev. Saúde Pública, São Paulo, vol. 40, n. spe, ago. 2006. Disponível em <http://www.scielo.br/pdf/rsp/v40nspe/30629.pdf>. Acesso em: 15 jan. 2015. 
SATO, Leny. O psicólogo e a saúde mental do trabalhador na área sindical. IN: CAMPOS, Florianita Coelho Braga (org.). Psicologia e Saúde. Repensando Práticas. Coleção SaúdeLoucura (Textos), Volume 6. São Paulo: Hucitec, 1992.

SATO, Leny. As implicações do conhecimento prático para a vigilância em saúde do trabalhador. Cad. Saúde Pública. Out/dez 1996, vol.12, n. 4. Disponível em: $<$ http://www.scielosp.org/scielo.php?script=sci_arttext\&pid=S0102311X1996000400007\&Ing=en\&nrm=iso>. Acesso em: 15 out. 2013.

SATO, Leny. LER: objeto e pretexto para a construção do campo trabalho e saúde. Cad. Saúde Pública. Jan/fev 2001, vol.17, n.1. Disponível em: <http://www.scielo.br/scielo.php?script=sci_arttext\&pid=S0102311X2001000100015\&lng=en\&nrm=iso>. Acesso em: 19 ago. 2013.

SATO, Leny. Prevenção de agravos à saúde do trabalhador: replanejando o trabalho através das negociações cotidianas. Cad. Saúde Pública. 2002, vol.18, n.5, pp. 1147-1157. Disponível em: <http://www.scielo.br/pdf/csp/v18n5/10988d.pdf>. Acesso em: 18 out. 2013.

SATO, Leny. Psicologia, saúde e trabalho: distintas construções dos objetos "trabalho" e "organizações". IN: CFP - Conselho Federal de Psicologia. Psicologia crítica do trabalho na sociedade contemporânea. Brasília: CFP, 2010. Disponível em: <site.cfp.org.br/wpcontent/uploads/2010/05/psic_trabalhoFINAL.pdf>. Acesso em: 24 nov.2013.

SATO, Leny. Saúde e controle no trabalho: feições de um antigo problema. IN: JACQUES, Maria da Graça Corrêa; CODO, Wanderley; (org.). Saúde mental e trabalho: leituras. 5a edição. Petrópolis: Vozes, 2011.

SATO, Leny. Recuperando o tempo perdido: a psicologia e o trabalho não regulado. Cad. psicol. soc. trab., São Paulo, vol. 16, n.spe, 2013. Disponível em:

$<$ http://pepsic.bvsalud.org/scielo.php?script=sci_arttext\&pid=S1516-

$37172013000300010 \&$ lng=pt\&nrm=iso >. Acesso em: 15 nov.2014.

SATO, Leny; BERNARDO, Márcia Hespanhol. Saúde mental e trabalho: os problemas que persistem. Ciênc. saúde coletiva, Rio de Janeiro, vol. 10, n. 4, Dez. 2005. Disponível em: $<$ http://www.scielosp.org/scielo.php?script=sci_arttext\&pid=S1413$81232005000400011 \& \operatorname{lng}=e n \& n r m=i s o>$. Acesso em: 24 nov.2013.

SATO, Leny; LACAZ, Francisco Antonio de Castro; BERNARDO, Márcia Hespanhol. Psicologia e saúde do trabalhador: práticas e investigações na Saúde Pública de São Paulo. Estud. psicol.

(Natal), Natal, vol.11, n.3, dez. 2006. Disponível em:

$<$ http://www.scielo.br/scielo.php?script=sci_arttext\&pid=S1413-

294X2006000300005\&lng=en\&nrm=iso>. Acesso em: 12 mar.2013.

SATO, Leny et al.. Atividades em grupo com portadores de LER e achados sobre a dimensão psicossocial. Rev. bras. saúde ocup., São Paulo, vol.21, n. 79, 1993. Disponível em:

<http://www.fundacentro.gov.br/arquivos/rbso/Artigos\%2079/V21\%20n79-05.pdf>. Acesso em: 12 mar.2013.

SBPOT - Associação Brasileira de Psicologia Organizacional e do Trabalho. Quem é quem. Disponível em: <http://www.sbpot.org.br/sbpot2/quem_somos.html>. Acesso em: 18 mar.2015.

SELIGMANN-SILVA, Edith. Os vínculos entre condições de trabalho e saúde mental. Psicol. cienc. prof., Brasília, vol. 8, n. 2, 1988. Disponível em: $<$ http://www.scielo.br/scielo.php?script=sci_arttext\&pid=S1414-

98931988000200006\&lng=en\&nrm=iso >. Acesso em: 11 out.2013 
SELIGMANN-SILVA, Edith. A inter-relação trabalho-saúde mental: um estudo de caso. Rev. adm. empres., São Paulo, vol.32, n.4, out. 1992. Disponível em:

$<$ http://www.scielo.br/scielo.php?script=sci_arttext\&pid=S0034-

75901992000400007\&lng=en\&nrm=iso>. Acesso em: 12 mar.2013.

SELIGMANN-SILVA, Edith. Desgaste mental no trabalho dominado. Rio de Janeiro: Editora UFRJ; São Paulo: Cortez Editora, 1994.

SELIGMANN-SILVA, Edith. Psicopatologia e Saúde Mental no Trabalho. IN: MENDES, René Patologia do Trabalho. Edição atualizada e ampliada. Rio de Janeiro: Editora Atheneu, 2005.

SELIGMANN-SILVA, Edith. Trabalho e Desgaste Mental: o direito de ser dono de si mesmo. São Paulo: Cortez Editora, 2011.

SELIGMANN-SILVA, Edith. São Paulo, 3 set. 2014. 1 arquivo .WAV (2h 13min 21seg). Entrevista concedida a Natália Cristina Ribeiro Alves.

SELIGMANN-SILVA, Edith. Psicopatologia no trabalho: aspectos contemporâneos. (Extraído do capítulo "Psicopatologia e Saúde Mental no Trabalho", do livro Patologia do Trabalho). [s.l., s,n., s.d.]. Disponível em:

<ftp://ftp.prt21.mpt.gov.br/ileana/MATERIAL\%20PARA\%20ENAMAT\%20DOUTRINA/4\%29Psicopat ologia\%20Edith_Seligmann_Silva.pdf>. Acesso em: 15 nov.2014.

SELIGMANN-SILVA, Edith et al . O mundo contemporâneo do trabalho e a saúde mental do trabalhador. Rev. bras. saúde ocup., São Paulo, vol.35, n. 122, dez. 2010. Disponível em: $<$ http://www.scielo.br/scielo.php?script=sci_arttext\&pid=S030376572010000200002\&lng=en\&nrm=iso>. Acesso em: 12 mar.2013. (2010a)

SELIGMANN-SILVA, Edith et al. Saúde do Trabalhador no início do século XXI. Rev. bras. saúde ocup., São Paulo, vol.35, n.122, dez. 2010. Disponível em:

<http://www.scielo.br/scielo.php?script=sci_arttext\&pid=S0303-

76572010000200001\&lng=en\&nrm=iso >. Acesso em: 12 mar.2013. (2010b)

SETTIMI, Maria Maeno; SILVESTRE, Miriam Pedrolo. Lesões por Esforços Repetitivos (LER): um problema da sociedade brasileira. IN: CODO, Wanderley; ALMEIDA, Maria Celeste G. de (org). LER: diagnóstico, tratamento e prevenção - uma abordagem interdisciplinar. $2^{\mathrm{a}}$ edição. Petrópolis: Vozes, 1995.

SETTIMI, Maria Maeno et al. Saber LER para Prevenir DORT. São Paulo: Centro de Estudos em Saúde e Trabalho - CEST / CEREST, Instituto Nacional de Prevenção de LER / DORT, 2000 (2000a). Disponível em: <http://www.uol.com.br/prevler/Livros/cartilha.pdf>. Acesso em 19 ago. 2013.

SETTIMI, Maria Maeno et al. Contribuição ao estudo das LER / DORT. São Paulo: Centro de Estudos em Saúde e Trabalho - CEST / CEREST, Instituto Nacional de Prevenção de LER / DORT, 2000 (2000b). Disponível em: <http://www.uol.com.br/prevler/Livros/mm-et-al-1.pdf>. Acesso em 19 ago. 2013.

SETTIMI, Maria Maeno et al. Diagnóstico, Tratamento, Reabilitação, Prevenção e Fisiopatologia das LER / DORT. São Paulo: Centro de Estudos em Saúde e Trabalho - CEST / CEREST, Instituto Nacional de Prevenção de LER / DORT, 2000 (2000c). Disponível em:

<http://www.uol.com.br/prevler/Livros/mm-et-al-2.pdf>. Acesso em 25 fev. 2002.

SETTIMI, Maria Maeno et al. Dilemas, Polêmicas e Dúvidas sobre LER / DORT. São Paulo: Centro de Estudos em Saúde e Trabalho - CEST / CEREST, Instituto Nacional de Prevenção de LER / DORT, 
2000 (2000d). Disponível em: <http://www.uol.com.br/prevler/Livros/mm-et-al-3.pdf>. Acesso em 25 fev. 2002.

SETTIMI, Maria Maeno et al. Lesões Por Esforços Repetitivos (LER), Distúrbios Osteomusculares Relacionados ao Trabalho (DORT). Ministério da Saúde, Secretaria de Políticas de Saúde, Departamento de Ações Programáticas e Estratégicas, Área Técnica de Saúde do Trabalhador, Série A. Normas e Manuais Técnicos, n. ${ }^{\circ}$ 103. Brasília: Ministério da Saúde, 2001. Disponível em: <http://dtr2001.saude.gov.br/bvs/publicacoes/ler_dort.pdf.> Acesso em 19 ago. 2013.

SILVA, Claudia Osório da; BARROS, Maria Elizabeth Barros de; LOUZADA, Ana Paula Figueiredo. Clínica da Atividade: dos conceitos às apropriações no Brasil. IN: BENDASSOLLI, Pedro F.; SOBOLL, Lis Andrea P. (org.). Clínicas do Trabalho: Novas perspectivas para compreensão do trabalho na atualidade. São Paulo: Atlas, 2011.

SILVA, Gilberto Salviano da. São Paulo, 29 ago. 2014. 1 arquivo .WAV (2h 4min 59seg). Entrevista concedida a Natália Cristina Ribeiro Alves.

SILVA, Jandira Maciel da. Belo Horizonte, 30 out. 2013. 2 arquivos .WAV (1h $32 \mathrm{~min} 4 \mathrm{seg}$ ). Entrevista concedida a Natália Cristina Ribeiro Alves.

SILVA, Rafaela Aparecida Cocchiola. A inclusão dos Transtornos Mentais como doença relacionada ao trabalho: discursos sobre as dificuldades de reconhecimento dos nexos causais. Tese (Doutorado em Psicologia Social). Pontifícia Universidade Católica de São Paulo. São Paulo, 2011. Disponível em: <http://www.sapientia.pucsp.br/tde_busca/arquivo.php?codArquivo=13063>. Acesso em: 21 jul. 2013.

SILVEIRA, Andréa Maria. Belo Horizonte, 18 out. 2013. 1 arquivo .WAV (1h 4min 26seg). Entrevista concedida a Natália Cristina Ribeiro Alves.

SILVEIRA, Andréa Maria et al . Compassos e descompassos na trajetória do Serviço Especial de Saúde dos Trabalhadores vinculado ao Hospital das Clínicas da Universidade Federal de Minas Gerais: 30 anos. Rev. bras. saúde ocup., São Paulo, vol.38, n.128, dez. 2013. Disponível em: $<$ http://www.scielo.br/scielo.php?script=sci_arttext\&pid=S0303-

$76572013000200010 \& \operatorname{lng}=e n \& n r m=i s o>$. Acesso em: 15 nov.2014.

SOBES (Sociedade Brasileira de Engenharia de Segurança). Seção Legislação - Normas Regulamentadoras. Disponível em: <http://sobes.org.br/s/legislacao/normas-regulamentadoras/>. Acesso em: 18 out. 2013.

SOUSA, Mayara Santos de. Doenças do trabalho e responsabilidade civil objetiva. Revista Jus Navigandi, Teresina, ano 17, n. 3178, 14 mar. 2012. Disponível em: <http://jus.com.br/artigos/21282>. Acesso em: 25 jan. 2015.

SOUTO, Daphnis Ferreira. Saúde no trabalho: uma Revolução em andamento. Rio de Janeiro: Editora Senac Nacional, 2003.

SOUZA, Lúcia Ribeiro de; VERAS, Renato. Ideologia e Saúde. IN: IBASE (Instituto Brasileiro de Análises Sociais e Econômicas). Saúde e Trabalho no Brasil. 2ª edição. Petrópolis: Vozes, 1983.

SPINK, Mary Jane Paris. Psicologia Social e Saúde: práticas, saberes e sentidos. 6ạ edição. Petrópolis: Vozes, 2009.

SPINK, Peter Kevin. Organização como fenômeno psicossocial: Notas para uma redefinição da psicologia do trabalho. Psicologia \& Sociedade, 8(1), 1996. Disponível em:

<http://www.abrapso.org.br/conteudo/view?ID_CONTEUDO=539>. Acesso em: 12 dez. 2014. 
SPINK, Peter Kevin. Pesquisa de campo em psicologia social: uma perspectiva pós-construcionista. Psicol. Soc. Porto Alegre, vol. 15, n. 2, dez. 2003. Disponível em:

$<$ http://www.scielo.br/scielo.php?script=sci_arttext\&pid=S0102-

$71822003000200003 \&$ Ing=en\&nrm=iso>. Acesso em: 27 jun. 2012.

STERSA, Olívio. Higiene Industrial e Psicologia do Trabalho (noções elementares). Para uso das Escolas Industriais, SESI, SESC, SENAI, SENAC e centros de aprendizagem industrial. São Paulo: Edições Melhoramentos, 1959.

SCHAWRTZ, Yves. Manifesto por um ergoengajamento. IN: BENDASSOLLI, Pedro F.; SOBOLL, Lis Andrea P. (org.). Clínicas do Trabalho: Novas perspectivas para compreensão do trabalho na atualidade. São Paulo: Atlas, 2011.

TAYLOR, Frederick Winslow. Princípios de Administração Científica. 8a edição. São Paulo: Atlas, 1911/1990.

TEIXEIRA, Márcia Cunha. A invisibilidade das doenças e acidentes do trabalho na sociedade atual. Revista de Direito Sanitário, São Paulo, vol.13, n.1, 2012. Disponível em:

<http://www.revistas.usp.br/rdisan/article/view/55696/59112>. Acesso em: 12 mar.2013

TIFFIN, Joseph; McCORMICK, Ernest J. Psicologia Industrial I. São Paulo: EPU / EDUSP, 1958/1975. (1975a).

TIFFIN, Joseph; McCORMICK, Ernest J. Psicologia Industrial II. 1a reimpressão. São Paulo: EPU / EDUSP, 1958/1975. (1975b).

TIFFIN, Joseph; McCORMICK, Ernest J. Psicologia Industrial III. 2a edição. São Paulo: EPU / EDUSP, 1958/1977.

TITTONI, Jacqueline. Saúde Mental. IN: CATTANI, Antonio David. Dicionário Crítico de Trabalho e Tecnologia. 4ạ edição revista e ampliada. Petrópolis: Vozes; Porto Alegre: Editora da UFRGS, 2002.

TRINQUET, Pierre. Trabalho e Educação: o método ergológico. Revista HISTEDBR On-line, Campinas, n. esp., ago.2010. Disponível em:

<http://www.histedbr.fe.unicamp.br/revista/edicoes/38e/art07_38e.pdf>. Acesso em: 25 fev.2015.

TRIVIÑOS, Augusto Nibaldo Silva. Introdução à pesquisa em Ciências Sociais: A pesquisa qualitativa em educação. São Paulo: Atlas, 1987.

TRT 20 - Tribunal Regional do Trabalho da 20a Região - Sergipe. Dia Nacional de Prevenção de Acidentes do Trabalho. 2013. Disponível em:

<http://www.trt20.jus.br/advogados/conteudo.php?var=1374843340\&obj=noticias >. Acesso em: 14 nov. 2014.

VEIGA, Aloysio Corrêa da. Jornada especial dos bancários. Rev. TST, Brasília, vol. 75, n.2, abr-jun 2009. Disponível em:

<http://aplicacao.tst.jus.br/dspace/bitstream/handle/1939/13256/001_veiga.pdf?sequence=>. Acesso em: 21 dez. 2014.

VEIGA, Roque Manoel Perusso. Vigilância em Saúde Ambiental e Saúde do Trabalhador. IN: SEMINÁRIO NACIONAL COM AS CENTRAIS SINDICAIS E ORGANIZAÇÕES SOCIAIS, 2014. Brasília: Conselho Nacional de Saúde, 2014. Disponível em:

http://conselho.saude.gov.br/web_4cnst/docs/03_mar_21e22Mar_Rogue\%20Veiga.ppt>. Acesso em: 12 dez. 2014. 
VERTHEIN, Marilene Affonso Romualdo. Jogos de poder instituindo saber sobre as lesões por esforços repetitivos: as redes discursivas da recusa do nexo. Tese ( Doutorado em Saúde Pública). Fundação Oswaldo Cruz, Escola Nacional de Saúde Pública, 2001. Disponível em: $<$ http://portalteses.cict.fiocruz.br/transf.php?script=thes_chap\&id=00011109\&lng=pt\&nrm=iso . Acesso em 19 ago. 2013.

VERTHEIN, Marilene Affonso Romualdo; MINAYO-GOMEZ, Carlos. A construção do "sujeito-doente" em LER. Hist. cienc. saude-Manguinhos . Rio de Janeiro, vol.7 n.2, 2000. Disponível em: $<$ http://www.scielo.br/scielo.php?script=sci_arttext\&pid=S0104-59702000000300005>. Acesso em: 11 out.2013. (2000a)

VERTHEIN, Marilene Affonso Romualdo; MINAYO-GOMEZ, Carlos. O território da doença relacionada ao trabalho: o corpo e a medicina na LER. PHYSIS - Revista de Saúde Coletiva. Volume 10, n.2, 2000. (2000b)

VERTHEIN, Marilene Affonso Romualdo; MINAYO-GOMEZ, Carlos. As armadilhas: bases discursivas da neuropsiquiatrização das LER. Ciênc. saúde coletiva, São Paulo, vol. 6, n. 2, 2001. Disponível em: <http://www.scielo.br/scielo.php?script=sci_arttext\&pid=S1413-

$81232001000200015 \&$ Ing=en\&nrm=iso $>$. Acesso em: 11 out.2013

VIEIRA, Carlos Eduardo Carrusca; LIMA, Francisco de Paula Antunes; LIMA, Maria Elizabeth Antunes (org.) O cotidiano dos vigilantes: trabalho, saúde e adoecimento. Belo Horizonte: FUMARC, 2010.

VORCARO, Angela Resende. De que adoecem e morrem os trabalhadores? Psicol. cienc.

prof., Brasília, vol. 8, n. 2, 1988. Disponível em:

$<$ http://www.scielo.br/scielo.php?script=sci_arttext\&pid=S1414-

98931988000200012\&lng=en\&nrm=iso>. Acesso em: 24 nov.2013.

WALTHER, Leon. Techno-Psychologia do Trabalho Industrial. São Paulo: Companhia Melhoramentos, 1929.

WALTHER, Léon. Psicologia do Trabalho Industrial. 2a edição, aumentada. São Paulo: Edições Melhoramentos, 1953.

WEBER, Max. Economia e Sociedade. Volume 2. Brasília: Editora UNB, 1922/1999.

WISNER, Alain. Por dentro do trabalho. Ergonomia: método e técnica. São Paulo: FTD / Oboré, 1987.

WUNSCH FILHO, Victor. Perfil epidemiológico dos trabalhadores. Rev. Bras. Med. Trab. Belo Horizonte, vol. 2, n. 2, p.103-117, abr./jun. 2004. Disponível em:

<https://www.nescon.medicina.ufmg.br/biblioteca/imagem/0180.pdf>. Acesso em: 21 out. 2013.

ZANELLI, José Carlos. Formação e atuação em Psicologia Organizacional. Psicol. cienc. prof., Brasília, vol.6 n.1, 1986. Disponível em:

$<$ http://www.scielo.br/scielo.php?script=sci_arttext\&pid=S1414-

98931986000100010\&lng=en\&nrm=iso>. Acesso em: 14 nov. 2014.

ZANELLI, José Carlos; BASTOS, Antonio Virgílio Bittencourt. Inserção Profissional do Psicólogo em Organizações e no Trabalho. IN: ZANELLI, José Carlos; BORGES-ANDRADE, Jairo Eduardo; BASTOS, Antonio Virgílio Bittencourt (org.). Psicologia, Organizações e Trabalho no Brasil. Reimpressão 2007. Porto Alegre: Artmed, 2004. 


\section{REFERÊNCIAS - DOCUMENTOS OFICIAIS}

AEAT InfoLogo - Base de Dados Históricos de Acidentes do Trabalho da Previdência Social. Disponível em: <http://www3.dataprev.gov.br/aeat>. Acesso em 16 jan. 2015.

AEPS InfoLogo - Base de Dados Históricos da Previdência Social. Disponível em: <http://www3.dataprev.gov.br/infologo>. Acesso em 16 jan. 2015.

ALBUQUERQUE-OLIVEIRA, Paulo Rogério. Nota Técnica no 12/2005/MPS/SPS/CGEP - Nexo Técnico Epidemiológico Previdenciário (NTEP). Brasília, 29 de abril de 2005. IN: Secretaria Estadual de Saúde de Santa Catarina. I Conferência Estadual de Saúde do Trabalhador de Santa Catarina. Textos de Apoio para a Conferência. Florianópolis, 7 e 8 de outubro de 2005. Disponível em: <http://www.saude.sc.gov.br/saudetrabalhador/conferencia_estadual/textos_apoio/NEXO_TECNI CO_EPIDEMlologico_PREV.doc >. Acesso em 14 out. 2013.

BRASIL. Constituição (1988). Constituição: República Federativa do Brasil. Brasília: Senado Federal, 1988. Disponível em: < http://www.senado.gov.br/legislacao/const/>. Acesso em: 15 jan. 2015.

BRASIL. Decreto no 3.048, de 6 de maio de 1999. Aprova o Regulamento da Previdência Social, e dá outras providências. Diário Oficial da União, Brasília, DF, 7 maio 1999, republicado 12 maio 1999. Disponível em: <http://www.planalto.gov.br/ccivil_03/decreto/d3048.htm>. Acesso em: 18 out. 2013. (1999a)

BRASIL. Decreto no 6.042, de 12 de fevereiro de 2007. Altera o Regulamento da Previdência Social, aprovado pelo Decreto no 3.048 , de 6 de maio de 1999, disciplina a aplicação, acompanhamento e avaliação do Fator Acidentário de Prevenção - FAP e do Nexo Técnico Epidemiológico, e dá outras providências. Diário Oficial da União, Brasília, DF, 13 fev. 2007. Disponível em:

<http://www.planalto.gov.br/ccivil_03/_ato2007-2010/2007/decreto/d6042.htm>. Acesso em: 18 out. 2013.

BRASIL. Decreto no 6.957, de 9 de setembro de 2009. Altera o Regulamento da Previdência Social, aprovado pelo Decreto no 3.048, de 6 de maio de 1999, no tocante à aplicação, acompanhamento e avaliação do Fator Acidentário de Prevenção - FAP. Diário Oficial da União, Brasília, DF, 10 set. 2009. Disponível em: <http://www.planalto.gov.br/ccivil_03/_ato20072010/2009/decreto/d6957.htm>. Acesso em: 18 out. 2013

BRASIL. Lei no 7.787, de 30 de junho de 1989. Dispõe sobre alterações na legislação de custeio da Previdência Social, e dá outras providências. Diário Oficial da União, Brasília, DF, 3 jul. 1989.

Disponível em:

<http://www010.dataprev.gov.br/sislex/paginas/42/1989/7787.htm\#L_7787_ART_4>. Acesso em: 18 out. 2013.

BRASIL. Lei no 8.080, de 20 de setembro de 1990. Lei Orgânica da Saúde. Dispõe sobre as condições para a promoção, proteção e recuperação da saúde, a organização e o funcionamento dos serviços correspondentes e dá outras providências. Diário Oficial da União, Brasília, DF, 20 set. 1990.

Disponível em: <http://www010.dataprev.gov.br/sislex/paginas/42/1990/8080.htm>. Acesso em: 18 out. 2013.

BRASIL. Lei no 8.212, de 24 de julho de 1991. Dispõe sobre a organização da Seguridade Social, institui Plano de Custeio, e dá outras providências. Diário Oficial da União, Brasília, DF, 25 jul. 1991. Disponível em: <http://www010.dataprev.gov.br/sislex/paginas/45/2002/83.htm>. Acesso em 18: out. 2013. (1991a) 
BRASIL. Lei no 8.213, de 24 de julho de 1991. Dispõe sobre os Planos de Benefícios da Previdência Social e dá outras providências. Aprova o Regulamento da Previdência Social, e dá outras providências. Diário Oficial da União, Brasília, DF, 14 ago. 1991. Disponível em: <http://www.planalto.gov.br/ccivil_03/leis//8213cons.htm>. Acesso em: 18 out. 2013. (1991b)

BRASIL. Lei no 8.689 de 27 de julho de 1993. Dispõe sobre a extinção do Instituto Nacional de Assistência Médica da Previdência Social (INAMPS) e dá outras providências. Disponível em: <http://www.planalto.gov.br/Ccivil_03/LEIS/L8689.htm>. Acesso em: 15 jan. 2015.

BRASIL. Lei no 9.032, de 28 de abril de 1995. Dispõe sobre o valor do salário mínimo, altera dispositivos das Leis no 8.212 e no 8.213, ambas de 24 de julho de 1991, e dá outras providências. Diário Oficial da União, Brasília, DF, 29 abr. 1995. Disponível em: <http://www.planalto.gov.br/ccivil_03/leis/L9032.htm>. Acesso em: 18 out. 2013.

BRASIL. Lei no 9.528, de 10 de dezembro de 1997. Altera dispositivos das Leis nos 8.212 e 8.213, ambas de 24 de julho de 1991, e dá outras providências. Diário Oficial da União, Brasília, DF, 11 dez. 1997. Disponível em: <http://www.planalto.gov.br/ccivil_03/leis/L9528.htm>. Acesso em: 18 out. 2013.

BRASIL. Lei no 9.876, de 26 de novembro de 1999. Dispõe sobre a contribuição previdenciária do contribuinte individual, o cálculo do benefício, altera dispositivos das Leis no 8.212 e no 8.213, ambas de 24 de julho de 1991, e dá outras providências. Diário Oficial da União, Brasília, DF, 29 nov. 1999. Disponível em: <http://www.planalto.gov.br/ccivil_03/leis/L9876.htm>. Acesso: em 18 out. 2013. (1999b)

BRASIL. Lei no 10.666, de 8 de maio de 2003. Dispõe sobre a concessão da aposentadoria especial ao cooperado de cooperativa de trabalho ou de produção e dá outras providências. Diário Oficial da União, Brasília, DF, 5 maio 2003. Disponível em:

<http://www010.dataprev.gov.br/sislex/paginas/42/2003/10666.htm>. Acesso em: 18 out. 2013.

BRASIL. Lei no 10.876, de 2 de junho de 2004. Cria a Carreira de Perícia Médica da Previdência Social, dispõe sobre a remuneração da Carreira de Supervisor Médico-Pericial do Quadro de Pessoal do Instituto Nacional do Seguro Social - INSS e dá outras providências. Diário Oficial da União, Brasília, DF, 3 jun. 2004. Disponível em: <http://www010.dataprev.gov.br/sislex/paginas/42/2004/10876.htm>. Acesso em: 18 out. 2013.

BRASIL. Lei no 11.430, de 26 de dezembro de 2006. Altera as Leis nos 8.213, de 24 de julho de 1991, e 9.796, de 5 de maio de 1999, aumenta o valor dos benefícios da previdência social; e revoga a Medida Provisória no 316, de 11 de agosto de 2006; dispositivos das Leis nos 8.213, de 24 de julho de 1991, 8.444, de 20 de julho de 1992, e da Medida Provisória no 2.187-13, de 24 de agosto de 2001; e a Lei no 10.699, de 9 de julho de 2003. Diário Oficial da União, Brasília, DF, 27 dez. 2006. Disponível em: <http://www010.dataprev.gov.br/sislex/paginas/42/2006/11430.htm\#mensagem_veto_n_1169>. Acesso em: 18 out. 2013. (2006a)

BRASIL. Medida Provisória no 83, de 12 de dezembro de 2002. Dispõe sobre a concessão da aposentadoria especial ao cooperado de cooperativa de trabalho ou de produção e dá outras providências. Diário Oficial da União, Brasília, DF, 13 dez. 2002. Disponível em: <http://www010.dataprev.gov.br/sislex/paginas/45/2002/83.htm>. Acesso em: 18 out. 2013.

BRASIL. Medida Provisória no 316, de 11 de agosto de 2006. Altera as Leis no 8.212 e no 8.213, ambas de 24 de julho de 1991, e 9.796, de 5 de maio de 1999, e aumenta o valor dos benefícios da previdência social. Convertida na Lei no 11.430, de 2006. Diário Oficial da União, Brasília, DF, 11 ago. 2006. Disponível em: <http://www.planalto.gov.br/ccivil_03/_Ato2004-

2006/2006/Mpv/316.htm>. Acesso em: 18 out. 2013. (2006b) 
BRASIL. Medida Provisória № 664, de 30 de dezembro de 2014. Altera as Leis no 8.213, de 24 de julho de 1991, no 10.876, de 2 junho de 2004, no 8.112, de 11 de dezembro de 1990, e a Lei no 10.666, de 8 de maio de 2003. Diário Oficial da União - Edição extra, Brasília, DF, 30 dezembro 2014, republicado em 31 dezembro 2014 - edição extra, retificado em 2 janeiro 2015 - edição extra. Disponível em: <http://www.planalto.gov.br/CCIVIL_03/_Ato20112014/2014/Mpv/mpv664.htm>. Acesso em 19 jan. 2015. (2014a)

BRASIL. Medida Provisória № 665, de 30 de dezembro de 2014. Altera a Lei no 7.998, de 11 de janeiro de 1990, que regula o Programa do Seguro-Desemprego, o Abono Salarial e institui o Fundo de Amparo ao Trabalhador - FAT, altera a Lei no 10.779, de 25 de novembro de 2003, que dispõe sobre o seguro desemprego para o pescador artesanal, e dá outras providências. Diário Oficial da União - Edição extra, Brasília, DF, 30 dezembro 2014. Disponível em:

<http://www.planalto.gov.br/CCIVIL_03/_Ato2011-2014/2014/Mpv/mpv665.htm>. Acesso em 19 jan. 2015. (2014b)

CNE (Conselho Nacional de Educação) / MEC (Ministério da Educação). Resolução no 5, de 15 de março de 2011. Institui as Diretrizes Curriculares Nacionais para os cursos de graduação em Psicologia, estabelecendo normas para o projeto pedagógico complementar para a Formação de Professores de Psicologia. Disponível em:

<http://www.cref14.org.br/boletin/rces005_psicologia.pdf>. Acesso em: 24 mar. 2015.

CNE (Conselho Nacional de Educação) / MEC (Ministério da Educação). Resolução no 3, de 20 de junho de 2014. Institui as Diretrizes Curriculares Nacionais para os cursos de graduação em Medicina e dá outras providências. Disponível em: <http://portal.mec.gov.br/cne/arquivos/pdf/Med.pdf>. Acesso em: 24 mar. 2015.

CGSAT / DSAST / SVS / MS (Coordenação Geral de Saúde do Trabalhador do Departamento de Vigilância em Saúde Ambiental e Saúde do Trabalhador da Secretaria de Vigilância em Saúde do Ministério da Saúde). Informe de Saúde do Trabalhador. Brasília, 18 dez. 2014. Disponível em: <http://www.renastonline.org/recursos/informe-sa\%C3\%BAde-trabalhadornotifica\%C3\%A7\%C3\%B5es-agravos-relacionados-trabalho-2007-2014>. Acesso em: 15 jan. 2015.

COSAT-SSMT (Coordenadoria de Saúde do Trabalhador da Secretaria de Estado de Saúde de Mato Grosso). Protocolos Clínicos. Disponível em:

<http://www.saude.mt.gov.br/cosat/arquivos/225/protocolos-clinicos-de-s-t >. Acesso em: 15 fev.2015.

INSS (Instituto Nacional de Seguridade Social). Instrução Normativa INSS/PRES № 31, de 10 de setembro de 2008. Dispõe sobre procedimentos e rotinas referentes ao Nexo Técnico Previdenciário, e dá outras providências. Diário Oficial da União, Brasília, DF, 18 set. 2008. Disponível em: <http://www010.dataprev.gov.br/sislex/paginas/38/INSS-PRES/2008/31.htm>. Acesso em: 18 out. 2013.

MPS (Ministério da Previdência Social). Anuário Estatístico da Previdência Social 2012 - Seção I (Benefícios). Disponível em: <http://www.previdencia.gov.br/estatisticas/aeps-2012-anuarioestatistico-da-previdencia-social-2012/aeps-2012-secao-i-beneficios/>. Acesso em: 18 out. 2013.

MPS (Ministério da Previdência Social). Histórico da Previdência. Disponível em: <http://www.previdencia.gov.br/a-previdencia/historico>. Acesso em: 17 dez. 2014.

MPS/CNPS (Ministério da Previdência Social/Conselho Nacional da Previdência Social). Resolução MPS/CNPS no 1.236, de 28 de abril de 2004. Nexo Técnico Epidemiológico Previdenciário. Diário Oficial da União, Brasília, DF, 10 maio 2004. Disponível em: <http://www010.dataprev.gov.br/sislex/paginas/72/MPS-CNPS/2004/1236.htm>. Acesso em: 18 out. 2013 
MPS/CNPS (Ministério da Previdência Social/Conselho Nacional da Previdência Social). Resolução MPS/CNPS no 1.269, de 15 de fevereiro de 2006. Nexo Técnico Epidemiológico Previdenciário / O Fator Acidentário Previdenciário. Diário Oficial da União, Brasília, DF, 21 fev. 2006. Disponível em: $<$ http://www010.dataprev.gov.br/sislex/paginas/72/MPS-CNPS/2006/1269.htm>. Acesso em 18 out. 2013.

MPS /MS/MTE (Ministério da Previdência Social/Ministério da Saúde/Ministério do Trabalho e Emprego). Portaria Interministerial no 153, de 13 de fevereiro de 2004. Constitui Grupo de Trabalho Interministerial (GEISAT), composto por representantes dos Ministérios da Previdência Social, da Saúde e do Trabalho e Emprego, e dá outras providências. Diário Oficial da União, Brasília, DF, 16 fev. 2004. Disponível em: <http://portal.mte.gov.br/legislacao/portaria-n-153-de-13-022004.htm>. Acesso em: 15 jan. 2015.

MPS /MS/MTE (Ministério da Previdência Social/Ministério da Saúde/Ministério do Trabalho e Emprego). Portaria Interministerial no 800, de 3 de maio de 2005. Publica o texto-base da minuta de Política Nacional de Segurança e Saúde do Trabalho. Diário Oficial da União, Brasília, DF, 5 maio 2005. Disponível em: <http://www.saude.mt.gov.br/cosat/arquivo/1804/diretrizes-basicas>. Acesso em: 15 jan. 2015.

MPS /MS/MTE (Ministério da Previdência Social/Ministério da Saúde/Ministério do Trabalho e Emprego). Portaria Interministerial no 152, de 13 de maio de 2008. Institui a Comissão Tripartite de Saúde e Segurança no Trabalho, com o objetivo de avaliar e propor medidas para implementação, no País, da Convenção no187, da Organização Internacional do Trabalho - OIT, que trata da Estrutura de Promoção da Segurança e Saúde no Trabalho. Diário Oficial da União, Brasília, DF15 maio 2008. Disponível em:

<http://portal.mte.gov.br/data/files/FF8080812BE914E6012BF4049A46301C/p_20080513_152.pd >. Acesso em: 15 jan. 2015.

MS (Ministério da Saúde). Conselho Nacional de Saúde. Resolução no 287 de 08 de outubro de 1998. Relaciona categorias profissionais de saúde de nível superior para fins de atuação do Conselho. Diário Oficial da União, Brasília, DF, 10 out. 1998. Disponível em:

<http://conselho.saude.gov.br/docs/Resolucoes/Reso287.doc>. Acesso em: 12 abr.2002. (1998a)

MS (Ministério da Saúde). Portaria no 3.120, de 1o de julho de 1998. Aprova a Instrução Normativa de Vigilância em Saúde do Trabalhador no SUS, na forma do Anexo a esta Portaria, com a finalidade de definir procedimentos básicos para o desenvolvimento das ações correspondentes. Disponível em: <http://www.renastonline.org/recursos/portaria-n\%C2\%BA-3120-1\%C2\%BA-julho-1998>. Acesso em: 15 jan. 2015. (1998b)

MS (Ministério da Saúde). Portaria no 3.908, de 30 de outubro de 1998. Estabelece procedimentos para orientar e instrumentalizar as ações e serviços de Saúde do Trabalhador no Sistema Único de Saúde (SUS). Disponível em:

<http://bvsms.saude.gov.br/bvs/saudelegis/gm/1998/prt3908_30_10_1998.html>. Acesso em: 15 jan. 2015. (1998c)

MS (Ministério da Saúde). Portaria no 1339, de 18 de novembro de 1999. Institui a Lista de Doenças relacionadas ao Trabalho, a ser adotada como referência dos agravos originados no processo de trabalho no Sistema Único de Saúde, para uso clínico e epidemiológico, constante no Anexo I desta Portaria. Diário Oficial da União, Brasília, DF, 19 nov. 1999. Disponível em:

<http://dtr2001.saude.gov.br/sas/PORTARIAS/Port99/GM/GM-1339.html>. Acesso em: 18 out. 2013.

MS (Ministério da Saúde). Portaria n. 1679, de 19 de setembro de 2002. Dispõe sobre a estruturação da rede nacional de atenção integral à saúde do trabalhador no SUS e dá outras 
providências. Disponível em: <http://www.saude.mt.gov.br/cosat/arquivo/1812/gestao-da-saudedo-trabalhador>. Acesso em: 15 jan. 2015. (2002a)

MS (Ministério da Saúde). Portaria no 656/GM de 20 de setembro de 2002. Aprova as Normas para o Cadastramento e Habilitação dos Centros de Referência em Saúde do Trabalhador - CRST.

Disponível em: <http://www.saude.sc.gov.br/saudetrabalhador/portarias/Portaria\%20656.doc>. Acesso em: 15 jan. 2015. (2002b)

MS (Ministério da Saúde). Portaria no 666/GM de 26 de setembro de 2002. Dispõe sobre os procedimentos técnicos para a notificação compulsória de agravos à saúde do trabalhador em rede de serviços sentinela específica, no SUS. Disponível em:

$<$ http://www.cvs.saude.sp.gov.br/legis.asp?te_codigo=20\&as_codigo=46\&origem=gt $>$. Acesso em: 15 jan. 2015. (2002c)

MS (Ministério da Saúde). Portaria no 777, de 28 de abril de 2004. Revogada pela Portaria no 104 de 25 de janeiro de 2011. Dispõe sobre os procedimentos técnicos para a notificação compulsória de agravos à saúde do trabalhador em rede de serviços sentinela específica, no Sistema Único de Saúde - SUS. Disponível em: <http://www.renastonline.org/recursos/portaria-n\%C2\%BA-777gm28-abril-2004-notifica\%C3\%A7\%C3\%A3o-compuls\%C3\%B3ria-agravos-sa\%C3\%BAde-trabalhador>. Acesso em: 15 jan. 2015. (2004a)

MS (Ministério da Saúde). Portaria no 1.172/GM, de 15 de junho de 2004. Regulamenta a NOB SUS 01/96 no que se refere às competências da União, estados e municípios e Distrito Federal, na área de Vigilância em Saúde, define a sistemática de financiamento e dá outras providências. Disponível em: <http://bvsms.saude.gov.br/bvs/saudelegis/gm/2004/prt1172_15_06_2004.html>. Acesso em: 15 jan. 2015. (2004b)

MS (Ministério da Saúde). Portaria № 1.125, de 06 de julho de 2005. Revogada pela Portaria no 2.442. Dispõe sobre os propósitos da política de Saúde do Trabalhador para o SUS. Disponível em: <http://bvsms.saude.gov.br/bvs/saudelegis/gm/2005/prt1125_06_07_2005.html>. Acesso em: 15 jan. 2015. (2005a)

MS (Ministério da Saúde). Portaria no 2.437, de 7 de dezembro de 2005. Revogada pela Portaria no 2.728. Dispõe sobre a ampliação e o fortalecimento da Rede Nacional de Atenção Integral à Saúde do Trabalhador - RENAST no Sistema Único de Saúde - SUS e dá outras providências. Disponível em: <http://www.saude.mg.gov.br/images/documentos/portaria2437.pdf >. Acesso em: 15 jan. 2015. (2005b)

MS (Ministério da Saúde). Portaria no 2.458/GM de 12 de dezembro de 2005. Redefine os valores do incentivo para custeio e manutenção dos serviços habilitados como Centros de Referência em Saúde do Trabalhador - CEREST. Disponível em:

$<$ http://www.brasilsus.com.br/index.php?option=com_content\&view=article\&id=1113>. Acesso em: 15 jan. 2015. (2005c)

MS (Ministério da Saúde). Portaria no 399/GM de 22 de fevereiro de 2006. Divulga o Pacto pela Saúde 2006 - Consolidação do SUS e aprova as diretrizes operacionais do referido Pacto. Disponível em: <http://bvsms.saude.gov.br/bvs/publicacoes/prtGM399_20060222.pdf>. Acesso em: 15 jan. 2015. (2006a)

MS (Ministério da Saúde). Portaria no 698/GM de 30 de março de 2006. Define que o custeio das ações de saúde é de responsabilidade das três esferas de gestão do SUS. Disponível em: <http://www.mpba.mp.br/atuacao/cidadania/gesau/pacto/portaria_698.pdf>. Acesso em: 15 jan. 2015. (2006b) 
MS (Ministério da Saúde). Portaria no 1.956, de 14 de agosto de 2007. Dispõe sobre a coordenação das ações relativas à saúde do trabalhador no âmbito do Ministério da Saúde. Disponível em: <http://bvsms.saude.gov.br/bvs/saudelegis/gm/2007/prt1956_14_08_2007.html>. Acesso em: 15 jan. 2015.

MS (Ministério da Saúde). Portaria no 2.728, de 11 de novembro de 2009. Dispõe sobre a Rede Nacional de Atenção Integral à Saúde do Trabalhador (RENAST) e dá outras providências. Disponível em: <http://bvsms.saude.gov.br/bvs/saudelegis/gm/2009/prt2728_11_11_2009.html>. Acesso em: 15 jan. 2015. (2009a)

MS (Ministério da Saúde). Portaria no 3.252, de 22 de dezembro de 2009. Aprova as diretrizes para execução e financiamento das ações de Vigilância em Saúde pela União, Estados, Distrito Federal e Municípios e dá outras providências. Disponível em:

<http://www.saude.mg.gov.br/images/documentos/Portaria_GM_3252_de_22_dezembro_de_200 9.pdf>. Acesso em: 15 jan. 2015. (2009b)

MS (Ministério da Saúde). Portaria no 2.472/GM de 31 de agosto de 2010. Revogada pela Portaria no 104 de 25 de janeiro de 2011. Define as terminologias adotadas em legislação nacional, conforme disposto no Regulamento Sanitário Internacional (RSI 2005), a relação de doenças, agravos e eventos em saúde pública de notificação compulsória em todo o território nacional e estabelecer fluxo, responsabilidades e atribuições aos profissionais e serviços de saúde. Disponível em: <http://bvsms.saude.gov.br/bvs/saudelegis/svs/2010/prt0201_03_11_2010.html>. Acesso em: 15 jan. 2015. (2010a)

MS (Ministério da Saúde). Portaria no 4.279, de 30 de dezembro de 2010. Estabelece diretrizes para a organização da Rede de Atenção à Saúde no âmbito do Sistema Único de Saúde (SUS). Disponível em: <http://bvsms.saude.gov.br/bvs/saudelegis/gm/2010/prt4279_30_12_2010.html>. Acesso em: 15 jan. 2015. (2010b)

MS (Ministério da Saúde). Portaria oo 104, de 25 de janeiro de 2011. Revogada pela Portaria № 1.271, de 6 de junho de 2014. Define as terminologias adotadas em legislação nacional, conforme o disposto no Regulamento Sanitário Internacional 2005 (RSI 2005), a relação de doenças, agravos e eventos em saúde pública de notificação compulsória em todo o território nacional e estabelece fluxo, critérios, responsabilidades e atribuições aos profissionais e serviços de saúde. Disponível em: <http://bvsms.saude.gov.br/bvs/saudelegis/gm/2011/prt0104_25_01_2011.html>. Acesso em: 15 jan. 2015.

MS (Ministério da Saúde). Portaria no 1.823, de 23 de agosto de 2012. Institui a Política Nacional de Saúde do Trabalhador e da Trabalhadora. Disponível em:

<http://bvsms.saude.gov.br/bvs/saudelegis/gm/2012/prt1823_23_08_2012.html>. Acesso em: 15 jan. 2015.

MS (Ministério da Saúde). Portaria no 1.378, de 9 de julho de 2013. Regulamenta as responsabilidades e define diretrizes para execução e financiamento das ações de Vigilância em Saúde pela União, Estados, Distrito Federal e Municípios, relativos ao Sistema Nacional de Vigilância em Saúde e Sistema Nacional de Vigilância Sanitária. Disponível em: <http://www.renastonline.org/blog/olgarios/portaria-13782013-substitui-portaria-32522009>. Acesso em: 15 jan. 2015. (2013a)

MS (Ministério da Saúde). Portaria no 1.206, de 24 de outubro de 2013. Altera o cadastramento dos Centros de Referência em Saúde do Trabalhador no Sistema de Cadastro Nacional de Estabelecimentos de Saúde (SCNES). Disponível em: <http://bvsms.saude.gov.br/bvs/saudelegis/sas/2013/prt1206_24_10_2013.html>. Acesso em: 15 jan. 2015. (2013b) 
MS (Ministério da Saúde). Portaria no 1.271, de 6 de junho de 2014. Define a Lista Nacional de Notificação Compulsória de doenças, agravos e eventos de saúde pública nos serviços de saúde públicos e privados em todo o território nacional, nos termos do anexo, e dá outras providências. Disponível em: <http://renastonline.org/recursos/portaria-n\%C2\%BA-1271-6-junho-2014 >. Acesso em: 15 jan. 2015. (2014a)

MS (Ministério da Saúde). Portaria no 1.984, de 12 de setembro de 2014. Define a lista nacional de doenças e agravos de notificação compulsória, na forma do Anexo, a serem monitorados por meio da estratégia de vigilância em unidades sentinelas e suas diretrizes. Disponível em: $<$ http://renastonline.org/recursos/portaria-n\%C2\%BA-1984-12-setembro-2014-define-listanacional-doen\%C3\%A7as-agravos-notifica\%C3\%A7\%C3\%A3o>. Acesso em: 15 jan. 2015. (2014b)

MS/OPAS. Ministério da Saúde do Brasil / Organização Pan-Americana da Saúde no Brasil. Doenças relacionadas ao trabalho: manual de procedimentos para os serviços de saúde. Coordenação Saúde do Trabalhador. Organizado por Elizabeth Costa Dias; colaboradores Idelberto Muniz de Almeida et al. Brasília: Ministério da Saúde do Brasil, 2001. Disponível em: $<$ http://dtr2001.saude.gov.br/editora/produtos/livros/popup/02_0388.htm>. Acesso em: 27 jun. 2012.

MTE (Ministério do Trabalho e Emprego). Normas Regulamentadoras - Normas Regulamentadoras de Segurança e Saúde no Trabalho. Disponível em: <http://portal.mte.gov.br/legislacao/normasregulamentadoras-1.htm>. Acesso em: 18 out. 2013.

SVS/MS (Secretaria de Vigilância em Saúde do Ministério da Saúde); Plataforma Renast Online. Série Histórica de notificações de agravos relacionados ao trabalho (SINAN/MS). Renast Online: 2014. Disponível em: <http://renastonline.org/s\%C3\%A9rie-hist\%C3\%B3rica-

notifica\%C3\%A7\%C3\%B5es-agravos-relacionados-trabalho-sinanms>. Acesso em: 12 dez. 2014. 


\section{APÊNDICES}




\section{Apêndice A - Informações sobre as entrevistas e entrevistados}

Quadro 4 - Informações sobre as entrevistas e entrevistados

(continua)

\begin{tabular}{|c|c|c|c|c|c|}
\hline Entrevistado & Instituição & $\begin{array}{l}\text { Local da } \\
\text { entrevista }\end{array}$ & $\begin{array}{c}\text { Data } \\
\text { entrevista }\end{array}$ & Duração & Informações biográficas \\
\hline $\begin{array}{l}\text { Andréa Maria } \\
\text { Silveira }\end{array}$ & $\begin{array}{l}\text { Serviço Especial de } \\
\text { Saúde do Trabalhador } \\
\text { do Hospital das } \\
\text { Clínicas; Escola de } \\
\text { Medicina da UFMG }\end{array}$ & $\begin{array}{l}\text { Hospital das } \\
\text { Clínicas da } \\
\text { UFMG (Belo } \\
\text { Horizonte) }\end{array}$ & $\begin{array}{l}18 \text { out. } \\
2013\end{array}$ & $\begin{array}{l}1 \mathrm{~h} 4 \mathrm{~min} \\
56 \mathrm{seg}\end{array}$ & $\begin{array}{l}\text { Graduada em Medicina pela UFMG, mestrado em Sociologia e doutorado em Ciências Humanas pela } \\
\text { UFMG. Gerente de Atenção à Saúde do Hospital das Clínicas e professora adjunta do Departamento de } \\
\text { Medicina Preventiva e Social da Faculdade de Medicina da UFMG. Docente do Mestrado Profissional em } \\
\text { Promoção da Saúde e Prevenção da Violência. Líder do Grupo de Estudos de Agravos Relacionados ao } \\
\text { Trabalho e Organização da Atenção Saúde dos Trabalhadores. (Fonte: Currículo Lattes) }\end{array}$ \\
\hline $\begin{array}{l}\text { Andréia De } \\
\text { Conto Garbin }\end{array}$ & $\begin{array}{l}\text { Secretaria de Saúde, } \\
\text { Prefeitura Municipal } \\
\text { de São Bernardo do } \\
\text { Campo }\end{array}$ & $\begin{array}{c}\text { Via Skype (Belo } \\
\text { Horizonte) }\end{array}$ & $\begin{array}{c}13 \text { set. } \\
2014\end{array}$ & $\begin{array}{l}1 \mathrm{~h} 12 \mathrm{~min} \\
25 \mathrm{seg}\end{array}$ & $\begin{array}{c}\text { Graduada em Psicologia e Direito, mestrado em Saúde Pública pela USP, doutoranda em Saúde Pública } \\
\text { pela USP. Ministra disciplinas na graduação do curso de Psicologia e supervisiona estágios na área da } \\
\text { Psicologia Social vinculados às disciplinas de Psicologia do Trabalho, Saúde Pública, Teorias e Técnicas } \\
\text { Grupais e Diagnóstico Institucional. (Fonte: Currículo Lattes) }\end{array}$ \\
\hline $\begin{array}{c}\text { Claudio Bertolli } \\
\text { Filho }\end{array}$ & UNESP Bauru & $\begin{array}{c}\text { Via Skype (Belo } \\
\text { Horizonte) }\end{array}$ & $\begin{array}{c}21 \text { ago. } \\
2014\end{array}$ & $\begin{array}{l}56 \mathrm{~min} \\
15 \mathrm{seg}\end{array}$ & $\begin{array}{l}\text { Graduado em História pela USP e em Ciências Políticas e Sociais pela Fundação Escola de Sociologia e } \\
\text { Política de São Paulo, mestrado em História Social e doutorado em Ciências pela USP, livre docência em } \\
\text { Antropologia pela UNESP. Professor adjunto na UNESP. (Fonte: Currículo Lattes) }\end{array}$ \\
\hline $\begin{array}{l}\text { Edith } \\
\text { Seligmann- } \\
\text { Silva }\end{array}$ & $\begin{array}{c}\text { Escola de } \\
\text { Administração de } \\
\text { Empresas-FGV; USP }\end{array}$ & $\begin{array}{l}\text { Residência } \\
\text { (São Paulo) }\end{array}$ & $\begin{array}{l}03 \text { set. } \\
2014\end{array}$ & $\begin{array}{l}2 \mathrm{~h} 13 \mathrm{~min} \\
21 \mathrm{seg}\end{array}$ & $\begin{array}{l}\text { Graduada em Medicina pela UFPA, especialização em Saúde Pública e doutorado em Medicina Preventiva } \\
\text { pela USP. Professora aposentada da USP e da Escola de Administração de Empresas de São Paulo (FGV- } \\
\text { SP). (Fonte: Currículo Lattes) }\end{array}$ \\
\hline $\begin{array}{c}\text { Elizabeth Costa } \\
\text { Dias }\end{array}$ & $\begin{array}{l}\text { Serviço Especial de } \\
\text { Saúde do Trabalhador } \\
\text { do Hospital das } \\
\text { Clínicas; Escola de } \\
\text { Medicina da UFMG }\end{array}$ & $\begin{array}{l}\text { Escola de } \\
\text { Medicina da } \\
\text { UFMG (Belo } \\
\text { Horizonte) }\end{array}$ & $\begin{array}{l}15 \text { out. } \\
2013\end{array}$ & $21 \mathrm{~min}$ & $\begin{array}{l}\text { Graduada em Medicina pela UFMG, especialista em Medicina do Trabalho e em Saúde Pública pela Escola } \\
\text { Nacional de Saúde Pública/Escola de Saúde de Minas Gerais, mestrado em Medicina Tropical, doutorado } \\
\text { em Saúde Coletiva (Saúde Ocupacional) pela UNICAMP, pós-doutorado na Jonhs Hopkins School of Public } \\
\text { Health. Professora aposentada do Departamento de Medicina Preventiva e Social da Faculdade de } \\
\text { Medicina da UFMG (área de Saúde do Trabalhador), onde atua como voluntária. Ex-pesquisadora visitante } \\
\text { do Cesteh-Fiocruz. Consultora da Área Técnica de Saúde do Trabalhador do Ministério da Saúde e da } \\
\text { organização Pan-Americana de Saúde. (Fonte: Currículo Lattes) }\end{array}$ \\
\hline $\begin{array}{c}\text { Gilberto } \\
\text { Salviano da } \\
\text { Silva }\end{array}$ & $\begin{array}{l}\text { Secretaria de Saúde } \\
\text { da CUT Nacional }\end{array}$ & $\begin{array}{l}\text { Hotel (São } \\
\text { Paulo) }\end{array}$ & $\begin{array}{c}29 \text { ago. } \\
2014\end{array}$ & $\begin{array}{l}2 \mathrm{~h} 4 \mathrm{~min} \\
59 \mathrm{seg}\end{array}$ & Assessor da Secretaria de Saúde da CUT Nacional. \\
\hline
\end{tabular}


Quadro 6 - Informações sobre as entrevistas e entrevistados

(conclusão)

\begin{tabular}{|c|c|c|c|c|c|}
\hline Entrevistado & Instituição & $\begin{array}{c}\text { Local da } \\
\text { entrevista }\end{array}$ & $\begin{array}{c}\text { Data } \\
\text { entrevista }\end{array}$ & Duração & Informações biográficas \\
\hline $\begin{array}{l}\text { Heleno } \\
\text { Rodrigues } \\
\text { Corrêa Filho }\end{array}$ & UNICAMP; UNB & $\begin{array}{c}\text { Via Skype (Belo } \\
\text { Horizonte) }\end{array}$ & $\begin{array}{c}21 \text { ago. } \\
2014\end{array}$ & $\begin{array}{l}\text { 1h } 1 \mathrm{~min} \\
18 \mathrm{seg}\end{array}$ & $\begin{array}{l}\text { Graduado em Medicina pela UNB, doutor em Saúde Pública pela USP, PD-Fellow pela Johns Hopkins- } \\
\text { JHBSPH e livre docência em Epidemiologia pela UNICAMP. Atuou como sanitarista na rede de serviços do } \\
\text { estado de São Paulo. Ex-professor de Medicina Preventiva na PUC-Sorocaba. Ex-analista de ciência e } \\
\text { tecnologia (CNPq). Professor aposentado da UNICAMP e voluntário na UNB. (Fonte: Currículo Lattes) }\end{array}$ \\
\hline $\begin{array}{l}\text { Jandira Maciel } \\
\text { da Silva }\end{array}$ & $\begin{array}{l}\text { Serviço Especial de } \\
\text { Saúde do Trabalhador } \\
\text { do Hospital das } \\
\text { Clínicas; Escola de } \\
\text { Medicina da UFMG }\end{array}$ & $\begin{array}{l}\text { Escola de } \\
\text { Medicina da } \\
\text { UFMG (Belo } \\
\text { Horizonte) }\end{array}$ & $\begin{array}{l}30 \text { out. } \\
2013\end{array}$ & $\begin{array}{l}1 \mathrm{~h} 32 \mathrm{~min} \\
4 \mathrm{seg}\end{array}$ & $\begin{array}{l}\text { Graduada em Medicina, com Residência em Medicina Preventiva e Social e especialização em Saúde, } \\
\text { mestrado em Engenharia de Produção pela UFMG, doutora em Saúde Coletiva pela UNICAMP. Ex- } \\
\text { coordenadora da área de Saúde do Trabalhador da Secretaria Estadual de Saúde de MG. Professora } \\
\text { adjunta do Departamento de Medicina Preventiva e Social da Faculdade de Medicina da UFMG. } \\
\text { Coordenadora do GT - Saúde do Trabalhador da Abrasco. (Fonte: Currículo Lattes) }\end{array}$ \\
\hline $\begin{array}{l}\text { Luiz Carlos } \\
\text { Brant } \\
\text { (Carneiro) }\end{array}$ & $\begin{array}{l}\text { Núcleo de Gestão em } \\
\text { Saúde da UFMG; } \\
\text { Escola de } \\
\text { Enfermagem da } \\
\text { UFMG }\end{array}$ & $\begin{array}{l}\text { Escola de } \\
\text { Enfermagem } \\
\text { da UFMG (Belo } \\
\text { Horizonte) }\end{array}$ & $\begin{array}{c}22 \text { ago. } \\
2014\end{array}$ & $\begin{array}{l}1 \mathrm{~h} 25 \mathrm{~min} \\
22 \mathrm{seg}\end{array}$ & $\begin{array}{l}\text { Graduado em Psicologia e mestre em Epidemiologia pela UFMG, doutor em Ciências da Saúde pela } \\
\text { Fundação Oswaldo Cruz. Professor Adjunto da UFMG. Pesquisador do Núcleo de Gestão em Saúde da } \\
\text { UFMG. (Fonte: Currículo Lattes) }\end{array}$ \\
\hline $\begin{array}{l}\text { Maria da } \\
\text { Graça Corrêa } \\
\text { Jacques }\end{array}$ & $\begin{array}{l}\text { Departamento de } \\
\text { Psicologia Social e } \\
\text { Institucional, UFRGS }\end{array}$ & $\begin{array}{l}\text { Hotel (Belo } \\
\text { Horizonte) }\end{array}$ & $\begin{array}{c}28 \text { ago. } \\
2014\end{array}$ & $\begin{array}{l}56 \mathrm{~min} \\
13 \mathrm{seg}\end{array}$ & $\begin{array}{l}\text { Graduada em Psicologia, mestrado em Psicologia e doutorado em Educação pela PUC-RS, pós-doutorado } \\
\text { em Psicologia Social pela Universidade Aberta de Portugal. Professora aposentada da UFRGS. (Fonte: } \\
\text { Currículo Lattes) }\end{array}$ \\
\hline Maria Maeno & FUNDACENTRO & $\begin{array}{l}\text { Via Scopia } \\
\text { (vídeo } \\
\text { conferência) } \\
\quad \text { (Belo } \\
\text { Horizonte) }\end{array}$ & $\begin{array}{l}25 \text { set. } \\
2014\end{array}$ & $\begin{array}{l}50 \mathrm{~min} \\
54 \mathrm{seg}\end{array}$ & $\begin{array}{l}\text { Graduada em Medicina e mestrado em Saúde Pública pela USP. Atuou na Secretaria de Estado da Saúde } \\
\text { de São Paulo, integrando a equipe do Programa de Saúde dos Trabalhadores da Zona Norte de São Paulo. } \\
\text { Ex-coordenadora do Centro de Referência em Saúde do Trabalhador do Estado de São Paulo. Atuou como } \\
\text { docente no Curso de Mestrado de Gestão Integrada em Segurança no Trabalho e Meio Ambiente do Senac } \\
\text { SP. Pesquisadora da FUNDACENTRO. Assessora da diretoria do Centro Colaborador da Organização } \\
\text { Mundial da Saúde em Saúde Ocupacional no Brasil. (Fonte: Currículo Lattes) }\end{array}$ \\
\hline $\begin{array}{c}\text { Maria Regina } \\
\text { Greggio }\end{array}$ & $\begin{array}{l}\text { CEREST Contagem } \\
\text { (MG) }\end{array}$ & $\begin{array}{l}\text { Residência } \\
\text { (Belo } \\
\text { Horizonte) }\end{array}$ & $\begin{array}{c}27 \text { ago. } \\
2014\end{array}$ & $\begin{array}{l}1 \mathrm{~h} 1 \mathrm{~min} \\
25 \mathrm{seg}\end{array}$ & $\begin{array}{l}\text { Graduada em Psicologia e mestre em Psicologia pela PUC-MG. Atua como professora de Psicologia, } \\
\text { psicóloga clínica do trabalho e consultoria psicossociológica. Gerente do CEREST Contagem (MG). (Fonte: } \\
\text { Currículo Lattes) }\end{array}$ \\
\hline $\begin{array}{l}\text { Silvia } \\
\text { Rodrigues } \\
\text { Jardim }\end{array}$ & $\begin{array}{c}\text { UFRJ - campus Praia } \\
\text { Vermelha }\end{array}$ & $\begin{array}{l}\text { Instituto de } \\
\text { Psiquiatria da } \\
\text { UFRJ (Rio de } \\
\text { Janeiro) }\end{array}$ & $\begin{array}{l}18 \text { set. } \\
2014\end{array}$ & $\begin{array}{c}1 \mathrm{~h} 26 \mathrm{~min} \\
16 \mathrm{seg}\end{array}$ & $\begin{array}{c}\text { Graduada em Medicina e doutora em Psiquiatria e Saúde Mental pela UFRJ. Psiquiatra da UFRJ, em } \\
\text { exercício no Instituto de Psiquiatria - IPUB/UFRJ. Coordenadora do Programa Organização do Trabalho e } \\
\text { Saúde Mental - OTSAM/IPUB/UFRJ e do Serviço de Atenção em Saúde Mental do Trabalhador - } \\
\text { PRASMET/IPUB/UFRJ. (Fonte: Currículo Lattes) }\end{array}$ \\
\hline $\begin{array}{l}\text { Wanderley } \\
\text { Codo }\end{array}$ & UNB & $\begin{array}{l}\text { Residência } \\
\text { (São Paulo) }\end{array}$ & $\begin{array}{c}30 \text { ago. } \\
2014\end{array}$ & $\begin{array}{c}1 \mathrm{~h} 52 \mathrm{~min} \\
49 \mathrm{seg}\end{array}$ & $\begin{array}{l}\text { Doutor em Psicologia Social pela PUC-SP. Ex-professor da USP Ribeirão Preto. Professor titular da UNB. } \\
\text { Possui diversos artigos, capítulos de livros e livros publicados. Desenvolveu o diagnóstico integrado do } \\
\text { trabalho e o aplicou em mais de } 100.000 \text { trabalhadores desde 2005. (Fonte: Currículo Lattes) }\end{array}$ \\
\hline
\end{tabular}




\section{Apêndice B - Roteiro das entrevistas}

Sobre o entrevistado

- Como se interessou pelas questões / relações entre saúde mental e trabalho?

Sobre os transtornos mentais e do comportamento relacionados ao trabalho

- Como/quando começam a ser "descobertos", relatados, tratados como doenças?

- Desde quando há diagnósticos desses problemas, afastamentos, aposentadorias?

- O que teria levado ao seu "reconhecimento"?

- Como vê, nesse processo, o papel

○ da academia?

- dos serviços de saúde?

- dos movimentos sociais?

- dos movimentos dos trabalhadores?

- Atualmente, são a 3a causa de afastamento do trabalho no país.

- Houve crescimento de "adoecimento"? De reconhecimento? Ambos?

- Mesmo sendo a $3^{\text {a }}$ causa, haveria subnotificação?

- Ainda haveria mascaramento por caracterização como "doença comum" (B31)?

- Os serviços de saúde e a atenção básica conseguem fazer a relação/nexo com trabalho?

- Transtornos mentais e do comportamento relacionados ao trabalho - desafios

○ de caracterização?

○ de estabelecer nexo/relação com o trabalho?

○ de sua "invisibilidade"/"subjetividade"?

○ da interdisciplinaridade que a questão envolve?

- O que mudou?

- Critérios diagnósticos?

- Relação com perícia?

○ Relação com empresas?

- Não se chegou a um "Protocolo" para diagnóstico/encaminhamento dos transtornos mentais e do comportamento relacionados ao trabalho (como houve, por exemplo, com as LER/DORT).

○ Por quê?

- Como se posiciona na discussão sobre a questão da "simulação" dos sintomas "mentais"?

- Em sua opinião, com relação à saúde mental, o trabalho adoece ou não? Ele promove/provoca o adoecimento ou agrava uma condição preexistente? 
Sobre a Lista B - Transtornos mentais e do comportamento relacionados ao trabalho (Grupo V da CID-10) (Decreto 3048 / 1999)

- A que se devem essas mudanças?

- Como se deu a construção?

- Personagens envolvidos?

- Dificuldades do processo?

- Avanços conquistados?

- Limites?

- Questionamentos - Quais? Por quem?

- Diversidade da Lista (B, Decreto 3048) - do agente químico aos efeitos do desemprego: quais são as implicações?

- Quais as implicações de se utilizar a categoria "transtorno"?

Sobre o NTEP (Lei 11430 / 2006)

- A que se devem essas mudanças?

- Como se deu a construção?

- Personagens envolvidos?

- Dificuldades do processo?

- Avanços conquistados?

- Limites?

- Questionamentos - Quais? Por quem?

Sobre o campo da saúde e trabalho

- Quais concepções sobre a categoria trabalho estão presentes no campo?

- No campo da saúde mental, identifica mais consensos ou dissensos sobre os transtornos mentais e do comportamento relacionados ao trabalho?

Sobre a Psicologia no campo da saúde e trabalho

- Muitas críticas foram feitas à Psicologia, sobretudo até os anos 70, como um campo científico que se prestava à "ortopedia social", ao tratar apenas da questão da adaptação. Qual a sua opinião?

- Como vê a participação da Psicologia no cenário?

- O que a Psicologia teria a contribuir?

Sobre o estudo em questão

- Em sua opinião, qual seria a relevância de estudos como esse?

Sobre indicações para o estudo

- Outras questões pertinentes para o estudo?

- Outras discussões / atores / teorias / elementos que possam subsidiar a investigação? 


\section{Apêndice C - Dados estatísticos sobre os TMCs}

A Tabela 3, a seguir, apresenta informações sobre acidentes do trabalho retiradas do sistema AEAT InfoLogo (Base de Dados Históricos de Acidentes do Trabalho da Previdência Social), no período de 1999 a 2012 (período disponibilizado para pesquisa), classificados por tipo de acidente -Típico com CAT (Comunicação de Acidente de Trabalho), de Trajeto com CAT, Doença do Trabalho com CAT e sem CAT cadastrada no INSS -, distribuídos por capítulo da CID-10. Ao lado do número de casos, por tipo de acidente, o respectivo percentual.

O Capítulo V representa 1,54\% dos casos (117.536, de um total de 7.645.909), correspondendo à $6^{\text {a }}$ maior causa; o Capítulo XXI representa 1,7\% dos casos (130.050, de um total de 7.645.909), correspondendo à $5^{\text {a }}$ maior causa; o Capítulo XIX (Lesões, envenenamento e algumas outras consequências de causas externas, $71,4 \%$ dos casos), à $4^{\text {a }}$ maior causa; o Capítulo XIII (Doenças do sistema osteomuscular e do tecido conjuntivo, $14 \%$ dos casos), à $3^{a}$ maior causa; CID ignorado/desconhecido (3,9\% dos casos), à $2^{\text {a }}$ maior causa; e o Capítulo XX (Causas externas de morbidade e de mortalidade, $2,2 \%$ dos casos), à $1^{\text {a }}$ causa.

Se consideradas apenas as doenças relacionadas ao trabalho (excluindo Lesões, envenenamento e algumas outras consequências de causas externas, Causas externas de morbidade e de mortalidade e CID ignorado/desconhecido), o Capítulo V Transtornos mentais e comportamentais - corresponde à $3^{\mathrm{a}}$ maior causa (sendo as Doenças do sistema osteomuscular e do tecido conjuntivo a $1^{\text {a }}$ causa).

Legenda da tabela:

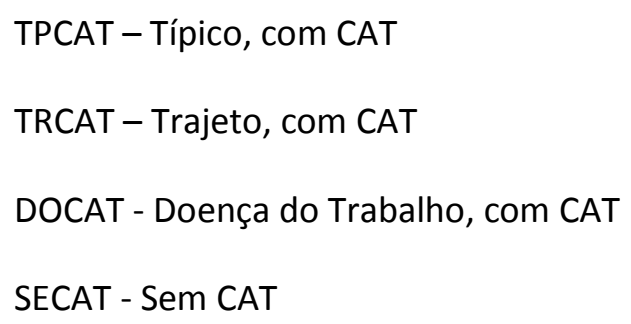


Tabela 3 - Acidentes do trabalho por capítulo da CID: percentuais por motivo/situação (1999-2012)

\begin{tabular}{|c|c|c|c|c|c|c|c|c|c|c|}
\hline Agrupamento CID & $\begin{array}{c}\text { TPCAT } \\
(1999-2012)\end{array}$ & $\%$ & $\begin{array}{c}\text { TRCAT } \\
(1999-2012)\end{array}$ & $\%$ & $\begin{array}{c}\text { DOCAT } \\
(1999-2012)\end{array}$ & $\%$ & $\begin{array}{c}\text { SECAT } \\
(1999-2012)\end{array}$ & $\%$ & $\begin{array}{c}\text { Total } \\
(1999-2012)\end{array}$ & $\%$ \\
\hline Capítulo XIX & 4.202 .669 & 79,36 & 838.677 & 86,32 & 19.540 & 6,24 & 398.342 & 37,38 & 5.459 .228 & 71,40 \\
\hline Capítulo XIII & 352.532 & 6,66 & 42.036 & 4,33 & 191.717 & 61,27 & 477.351 & 44,80 & 1.063 .636 & 13,91 \\
\hline Ignorado (ING) & 259.197 & 4,89 & 26.031 & 2,68 & 13.522 & 4,32 & 1.782 & 0,17 & 300.532 & 3,93 \\
\hline Capítulo XX & 130.844 & 2,47 & 36.358 & 3,74 & 862 & 0,28 & 735 & 0,07 & 168.799 & 2,21 \\
\hline Capítulo XXI 213 & 116.086 & 2,19 & 9.372 & 0,96 & 3.305 & 1,06 & 1.287 & 0,12 & 130.050 & 1,70 \\
\hline Capítulo V & 40.654 & 0,77 & 3.254 & 0,33 & 9.377 & 3,00 & 64.251 & 6,03 & 117.536 & 1,54 \\
\hline Capítulo VII & 76.837 & 1,45 & 1.834 & 0,19 & 850 & 0,27 & 6.332 & 0,59 & 85.853 & 1,12 \\
\hline Capítulo VI & 10.157 & 0,19 & 1.513 & 0,16 & 18.420 & 5,89 & 38.449 & 3,61 & 68.539 & 0,90 \\
\hline Capítulo VIII & 12.163 & 0,23 & 297 & 0,03 & 35.279 & 11,28 & 1.109 & 0,10 & 48.848 & 0,64 \\
\hline Capítulo XI & 10.514 & 0,20 & 949 & 0,10 & 2.809 & 0,90 & 21.677 & 2,03 & 35.949 & 0,47 \\
\hline Capítulo XII & 19.816 & 0,37 & 1.159 & 0,12 & 4.442 & 1,42 & 6.473 & 0,61 & 31.890 & 0,42 \\
\hline Capítulo IX & 8.098 & 0,15 & 1.451 & 0,15 & 2.193 & 0,70 & 20.088 & 1,89 & 31.830 & 0,42 \\
\hline Capítulo II & 15.846 & 0,30 & 1.908 & 0,20 & 956 & 0,31 & 4.430 & 0,42 & 23.140 & 0,30 \\
\hline Capítulo XVIII & 15.632 & 0,30 & 3.973 & 0,41 & 1.137 & 0,36 & 676 & 0,06 & 21.418 & 0,28 \\
\hline Capítulo I & 9.314 & 0,18 & 654 & 0,07 & 2.329 & 0,74 & 10.238 & 0,96 & 22.535 & 0,29 \\
\hline Capítulo X & 4.756 & 0,09 & 692 & 0,07 & 4.430 & 1,42 & 9.262 & 0,87 & 19.140 & 0,25 \\
\hline Capítulo XIV & 3.105 & 0,06 & 466 & 0,05 & 518 & 0,17 & 1.422 & 0,13 & 5.511 & 0,07 \\
\hline Capítulo XVII & 4.612 & 0,09 & 333 & 0,03 & 155 & 0,05 & 43 & 0,00 & 5.143 & 0,07 \\
\hline Capítulo III & 780 & 0,01 & 182 & 0,02 & 653 & 0,21 & 419 & 0,04 & 2.034 & 0,03 \\
\hline Capítulo IV & 871 & 0,02 & 124 & 0,01 & 167 & 0,05 & 848 & 0,08 & 2.010 & 0,03 \\
\hline Capítulo XV & 863 & 0,02 & 240 & 0,02 & 210 & 0,07 & 319 & 0,03 & 1.632 & 0,02 \\
\hline Capítulo XVI & 494 & 0,01 & 115 & 0,01 & 24 & 0,01 & 23 & 0,00 & 656 & 0,01 \\
\hline Total & 5.295 .840 & 100 & 971.618 & 100 & 312.895 & 100 & 1.065 .556 & 100 & 7.645 .909 & 100 \\
\hline
\end{tabular}

Fonte: Produzida pela autora em pesquisa no Sistema AEAT InfoLogo - Base de Dados Históricos de Acidentes do Trabalho da Previdência Social (2015). ${ }^{214}$

213 O Capítulo XXI possui um CID relacionado aos Transtornos Mentais e do Comportamento Relacionados ao Trabalho: Z73.0 - Sensação de Estar Acabado ("Síndrome de Burn-Out", "Síndrome do Esgotamento Profissional").

214 Disponível em: <http://www3.dataprev.gov.br/infologo>. Acesso em 16 jan. 2015. 
A Tabela 4, a seguir, apresenta informações sobre benefícios acidentários por incapacidade concedidos, retiradas do sistema AEPS Infologo (Base de Dados Históricos da Previdência Social), no período de 1999 a 2012 (período disponibilizado para pesquisa), classificados por tipo de benefício (Auxílio-Doença Acidentário ou Aposentadoria Acidentária), distribuídos pelo grupo da CID-10.

Os Transtornos mentais e comportamentais representam 4,1\% dos casos $(63.732$, de um total de 1.574.638), correspondendo à $3^{\text {a }}$ maior causa, após as Lesões, envenenamento e algumas outras consequências de causas externas, 59,6\% dos casos ( $2^{a}$ maior causa), e às Doenças do sistema osteomuscular e do tecido conjuntivo, $14 \%$ dos casos ( $1^{\text {a }}$ maior causa).

Se consideradas apenas as doenças relacionadas ao trabalho (excluindo Lesões, envenenamento e algumas outras consequências de causas externas), os Transtornos mentais e comportamentais correspondem à $2^{\text {a }}$ maior causa, sendo as Doenças do sistema osteomuscular e do tecido conjuntivo a $1^{\text {a }}$ causa.

Deve-se registrar, também, que o Capítulo XXI possui um CID relacionado aos Transtornos Mentais e do Comportamento Relacionados ao Trabalho: 273.0 Sensação de Estar Acabado ("Síndrome de Burn-Out", "Síndrome do Esgotamento Profissional").

Legenda da tabela:

ADA - Auxílio-Doença Acidentário

AA - Aposentadoria Acidentária 
Tabela 4 - Benefícios acidentários por incapacidade concedidos, por CID (2008-2012)

\begin{tabular}{|c|c|c|c|c|c|c|c|c|c|c|c|c|c|c|c|c|c|c|}
\hline \multirow{3}{*}{ Grupo CID } & \multicolumn{15}{|c|}{ Ano / Espécie } & \multirow{3}{*}{$\begin{array}{l}\text { Total } \\
\text { ADA }\end{array}$} & \multirow{3}{*}{$\begin{array}{c}\text { Total } \\
\text { AA }\end{array}$} & \multirow{3}{*}{ Total } \\
\hline & \multicolumn{3}{|c|}{2008} & \multicolumn{3}{|c|}{2009} & \multicolumn{3}{|c|}{2010} & \multicolumn{3}{|c|}{2011} & \multicolumn{3}{|c|}{2012} & & & \\
\hline & ADA & AA & Total & ADA & AA & Total & ADA & AA & Total & ADA & AA & Total & ADA & AA & Total & & & \\
\hline $\begin{array}{l}\text { Lesões, envenenamentos e algumas outras } \\
\text { consequências de causas externas }\end{array}$ & 190.050 & 3.210 & 193.260 & 175.632 & 3.191 & 178.823 & 188.658 & 3.263 & 191.921 & 186.045 & 3.316 & 189.361 & 181.949 & 3.425 & 185.374 & 922.334 & 16.405 & 938.739 \\
\hline $\begin{array}{l}\text { Doenças do sistema osteomuscular e do tecido } \\
\text { conjuntivo }\end{array}$ & 108.844 & 2.244 & 111.088 & 90.076 & 2.607 & 92.683 & 80.980 & 3.144 & 84.124 & 77.012 & 3.365 & 80.377 & 71.107 & 3.465 & 74.572 & 428.019 & 14.825 & 442.844 \\
\hline Transtornos mentais e comportamentais & 12.666 & 258 & 12.924 & 13.348 & 293 & 13.641 & 12.033 & 358 & 12.391 & 12.231 & 465 & 12.696 & 11.544 & 536 & 12.080 & 61.822 & 1.910 & 63.732 \\
\hline Doenças do sistema nervoso & 8.783 & 323 & 9.106 & 7.235 & 290 & 7.525 & 6.583 & 349 & 6.932 & 6.280 & 310 & 6.590 & 5.947 & 352 & 6.299 & 34.828 & 1.624 & 36.452 \\
\hline Doenças do aparelho digestivo & 3.400 & 11 & 3.411 & 5.352 & 15 & 5.367 & 4.238 & 13 & 4.251 & 4.258 & 16 & 4.274 & 4.353 & 13 & 4.366 & 21.601 & 68 & 21.669 \\
\hline Doenças do aparelho circulatório & 4.004 & 191 & 4.195 & 4.316 & 309 & 4.625 & 3.373 & 406 & 3.779 & 3.246 & 378 & 3.624 & 2.799 & 366 & 3.165 & 17.738 & 1.650 & 19.388 \\
\hline Ignorado & 440 & 739 & 1.179 & 614 & 1.065 & 1.679 & 761 & 1.334 & 2.095 & 1.092 & 1.779 & 2.871 & 1.179 & 1.886 & 3.065 & 4.086 & 6.803 & 10.889 \\
\hline Doenças do aparelho respiratório & 1.929 & 131 & 2.060 & 1.816 & 165 & 1.981 & 1.528 & 142 & 1.670 & 1.304 & 190 & 1.494 & 1.159 & 156 & 1.315 & 7.736 & 784 & 8.520 \\
\hline Algumas doenças infecciosas e parasitárias & 1.911 & 36 & 1.947 & 1.572 & 40 & 1.612 & 1.432 & 45 & 1.477 & 1.335 & 54 & 1.389 & 1.167 & 55 & 1.222 & 7.417 & 230 & 7.647 \\
\hline Doenças do olho e anexos & 1.562 & 133 & 1.695 & 1.365 & 119 & 1.484 & 1.390 & 138 & 1.528 & 1.285 & 117 & 1.402 & 1.134 & 124 & 1.258 & 6.736 & 631 & 7.367 \\
\hline Doenças da pele e do tecido subcutâneo & 1.254 & 35 & 1.289 & 1.305 & 49 & 1.354 & 1.206 & 45 & 1.251 & 1.277 & 61 & 1.338 & 1.186 & 54 & 1.240 & 6.228 & 244 & 6.472 \\
\hline Neoplasias [tumores] & 446 & 77 & 523 & 361 & 75 & 436 & 315 & 94 & 409 & 310 & 92 & 402 & 281 & 93 & 374 & 1.713 & 431 & 2.144 \\
\hline $\begin{array}{l}\text { Fatores que influenciam estado de saúde e } \\
\text { contato com serviços de saúde }\end{array}$ & 215 & 2 & 217 & 249 & 3 & 252 & 390 & 3 & 393 & 465 & 3 & 468 & 447 & 7 & 454 & 1.766 & 18 & 1.784 \\
\hline $\begin{array}{l}\text { Causas externas de morbidade e de } \\
\text { mortalidade }\end{array}$ & 0 & 0 & 0 & 0 & 0 & 0 & 295 & 4 & 299 & 636 & 5 & 641 & 749 & 16 & 765 & 1.680 & 25 & 1.705 \\
\hline Doenças do aparelho geniturinário & 287 & 23 & 310 & 281 & 35 & 316 & 236 & 36 & 272 & 231 & 40 & 271 & 183 & 39 & 222 & 1.218 & 173 & 1.391 \\
\hline $\begin{array}{l}\text { Doenças do ouvido e da apófise mastoide } \\
\text { Sintomas, sinais e achados anormais de exames }\end{array}$ & 310 & 43 & 353 & 258 & 42 & 300 & 223 & 33 & 256 & 170 & 32 & 202 & 138 & 22 & 160 & 1.099 & 172 & 1.271 \\
\hline $\begin{array}{l}\text { clínicos e de laboratório, não classificados em } \\
\text { outra parte }\end{array}$ & 0 & 0 & 0 & 0 & 0 & 0 & 159 & 0 & 159 & 335 & 5 & 340 & 384 & 3 & 387 & 878 & 8 & 886 \\
\hline Doenças endócrinas, nutricionais e metabólicas & 147 & 8 & 155 & 185 & 22 & 207 & 138 & 38 & 176 & 146 & 32 & 178 & 139 & 28 & 167 & 755 & 128 & 883 \\
\hline $\begin{array}{l}\text { Doenças do sangue e dos órgãos } \\
\text { hematopoiéticos e alguns transtornos } \\
\text { imunitários }\end{array}$ & 121 & 5 & 126 & 75 & 7 & 82 & 67 & 11 & 78 & 52 & 9 & 61 & 52 & 9 & 61 & 367 & 41 & 408 \\
\hline Gravidez, parto e puerpério & 62 & 0 & 62 & 73 & 0 & 73 & 83 & 0 & 83 & 74 & 0 & 74 & 58 & 0 & 58 & 350 & 0 & 350 \\
\hline $\begin{array}{l}\text { Malformações congênitas, deformidades e } \\
\text { anomalias cromossômicas }\end{array}$ & 3 & 0 & 3 & 4 & 0 & 4 & 7 & 0 & 7 & 25 & 1 & 26 & 11 & 2 & 13 & 50 & 3 & 53 \\
\hline $\begin{array}{l}\text { Algumas afecções originadas no período } \\
\text { perinatal }\end{array}$ & 0 & 0 & 0 & 0 & 0 & 0 & 9 & 0 & 9 & 19 & 0 & 19 & 16 & 0 & 16 & 44 & 0 & 44 \\
\hline Total & 336.434 & 7.469 & 343.903 & 304.117 & 8.327 & 312.444 & 304.104 & 9.456 & 313.560 & 297.828 & 10.270 & 308.098 & 285.982 & 10.651 & 296.633 & 1.528 .465 & 46.173 & 1.574 .638 \\
\hline
\end{tabular}

Fonte: Produzida pela autora em pesquisa no Sistema AEPS InfoLogo - Base de Dados Históricos da Previdência Social (2015). ${ }^{215}$

215 Disponível em: <http://www3.dataprev.gov.br/infologo>. Acesso em 16 jan. 2015. 
As tabelas a seguir apresentam informações sobre benefícios acidentários por incapacidade concedidos, por CID: Tabela 5 - Benefícios acidentários por Incapacidade concedidos por CID e percentual de cada grupo (2008-2012); Tabela 6 - Auxílios-Doença Acidentários por CID e percentual de cada grupo (2008-2012); Tabela 7 - Aposentadorias Acidentárias por CID e percentual de cada grupo (20082012).

A Tabela 5 - Benefícios acidentários por Incapacidade concedidos por CID e percentual de cada grupo (2008-2012), apresenta informações sobre benefícios acidentários por incapacidade concedidos, retiradas do sistema AEPS InfoLogo (Base de Dados Históricos da Previdência Social), no período de 1999 a 2012 (período disponibilizado para pesquisa), classificados por tipo de benefício (Auxílio-Doença Acidentário ou Aposentadoria Acidentária), distribuídos pelo grupo da CID-10. Ao lado do número de casos, por tipo de benefício, o respectivo percentual.

Os Transtornos mentais e comportamentais representam 4,1\% dos casos $(63.732$, de um total de 1.574.638), correspondendo à $3^{\text {a }}$ maior causa, após as Lesões, envenenamento e algumas outras consequências de causas externas, 59,6\% dos casos ( $2^{\mathrm{a}}$ maior causa), e às Doenças do sistema osteomuscular e do tecido conjuntivo, $14 \%$ dos casos ( $1^{\text {a }}$ maior causa). Se consideradas apenas as doenças relacionadas ao trabalho (excluindo Lesões, envenenamento e algumas outras consequências de causas externas), os Transtornos mentais e comportamentais correspondem à $2^{\mathrm{a}}$ maior causa, sendo as Doenças do sistema osteomuscular e do tecido conjuntivo a $1^{\text {a }}$ causa.

A Tabela 6 - Auxílios-Doença Acidentários concedidos por CID e percentual de cada grupo (2008-2012), apresenta informações sobre Auxílios-Doença acidentários concedidos, retiradas do sistema AEPS InfoLogo (Base de Dados Históricos da Previdência Social), no período de 1999 a 2012 (período disponibilizado para pesquisa), distribuídos pelo grupo da CID-10. Ao lado do número de casos, o respectivo percentual.

Os Transtornos mentais e comportamentais representam 4,04\% dos casos $(61.822$, de um total de 1.528.465), correspondendo à $3^{\text {a }}$ maior causa, após as Lesões, 
envenenamento e algumas outras consequências de causas externas, 60,34\% dos casos ( $2^{\mathrm{a}}$ maior causa), e às Doenças do sistema osteomuscular e do tecido conjuntivo, $28 \%$ dos casos ( $1^{a}$ maior causa). Se consideradas apenas as doenças relacionadas ao trabalho (excluindo Lesões, envenenamento e algumas outras consequências de causas externas), os Transtornos mentais e comportamentais correspondem à $2^{a}$ maior causa, sendo as Doenças do sistema osteomuscular e do tecido conjuntivo a $1^{\text {a }}$ causa.

A Tabela 7 - Aposentadorias Acidentárias concedidas por CID e percentual de cada grupo (2008-2012) apresenta informações sobre Aposentadorias Acidentárias concedidas, retiradas do sistema AEPS InfoLogo (Base de Dados Históricos da Previdência Social), no período de 1999 a 2012 (período disponibilizado para pesquisa), distribuídas pelo grupo da CID-10. Ao lado do número de casos, o respectivo percentual.

Os Transtornos mentais e comportamentais representam $4,14 \%$ dos casos $(1.910$, de um total de 46.173), correspondendo à $4^{\text {a }}$ maior causa, após as Lesões, envenenamento e algumas outras consequências de causas externas, 35,5\% dos casos ( $3^{\mathrm{a}}$ maior causa), às Doenças do sistema osteomuscular e do tecido conjuntivo, $32,11 \%$ dos casos ( $1^{\text {a }}$ maior causa) e a CIDs ignorados/desconhecidos, $14,73 \%$ dos casos $\left(2^{\text {a }}\right.$ maior causa). Se consideradas apenas as doenças relacionadas ao trabalho (excluindo Lesões, envenenamento e algumas outras consequências de causas externas, além de CIDs ignorados/desconhecidos), os Transtornos mentais e comportamentais correspondem à $2^{a}$ maior causa, sendo as Doenças do sistema osteomuscular e do tecido conjuntivo a $1^{\text {a }}$ causa.

Deve-se registrar, também, que o Capítulo XXI (Fatores que influenciam o estado de saúde e o contato com os serviços de saúde) possui um CID relacionado aos Transtornos Mentais e do Comportamento Relacionados ao Trabalho: Z73.0 Sensação de Estar Acabado ("Síndrome de Burn-Out", "Síndrome do Esgotamento Profissional"). 
Tabela 5 - Benefícios acidentários por incapacidade concedidos por CID e percentual de cada grupo (2008-2012)

\begin{tabular}{|c|c|c|c|c|c|c|c|c|c|c|c|c|}
\hline \multirow[b]{2}{*}{ Grupo CID } & \multicolumn{2}{|c|}{2008} & \multicolumn{2}{|c|}{2009} & \multicolumn{2}{|c|}{2010} & \multicolumn{2}{|c|}{2011} & \multicolumn{2}{|c|}{2012} & \multicolumn{2}{|c|}{ Total } \\
\hline & $\begin{array}{c}\text { ADA+ } \\
\text { AA }\end{array}$ & $\begin{array}{c}\% \text { do } \\
\text { total } \\
\text { anual } \\
\end{array}$ & $\begin{array}{c}\text { ADA+ } \\
\text { AA }\end{array}$ & $\begin{array}{c}\% \text { do } \\
\text { total } \\
\text { anual } \\
\end{array}$ & $\begin{array}{c}\text { ADA+ } \\
\text { AA }\end{array}$ & $\begin{array}{c}\% \text { do } \\
\text { total } \\
\text { anual } \\
\end{array}$ & $\begin{array}{c}\text { ADA+ } \\
\text { AA }\end{array}$ & $\begin{array}{c}\% \text { do } \\
\text { total } \\
\text { anual } \\
\end{array}$ & $\begin{array}{c}\text { ADA+ } \\
\text { AA }\end{array}$ & $\begin{array}{c}\% \text { do } \\
\text { total } \\
\text { anual } \\
\end{array}$ & $A D A+A A$ & $\begin{array}{c}\% \text { do total do } \\
\text { período } \\
(2008-2012)\end{array}$ \\
\hline $\begin{array}{l}\text { Lesões, envenenamentos e algumas outras consequências de causas } \\
\text { externas }\end{array}$ & 193.260 & 56,20 & 178.823 & 57,23 & 191.921 & 61,21 & 189.361 & 61,46 & 185.374 & 62,49 & 938.739 & 59,62 \\
\hline Doenças do sistema osteomuscular e do tecido conjuntivo & 111.088 & 32,30 & 92.683 & 29,66 & 84.124 & 26,83 & 80.377 & 26,09 & 74.572 & 25,14 & 442.844 & 28,12 \\
\hline Transtornos mentais e comportamentais & 12.924 & 3,76 & 13.641 & 4,37 & 12.391 & 3,95 & 12.696 & 4,12 & 12.080 & 4,07 & 63.732 & 4,05 \\
\hline Doenças do sistema nervoso & 9.106 & 2,65 & 7.525 & 2,41 & 6.932 & 2,21 & 6.590 & 2,14 & 6.299 & 2,12 & 36.452 & 2,31 \\
\hline Doenças do aparelho digestivo & 3.411 & 0,99 & 5.367 & 1,72 & 4.251 & 1,36 & 4.274 & 1,39 & 4.366 & 1,47 & 21.669 & 1,38 \\
\hline Doenças do aparelho circulatório & 4.195 & 1,22 & 4.625 & 1,48 & 3.779 & 1,21 & 3.624 & 1,18 & 3.165 & 1,07 & 19.388 & 1,23 \\
\hline Ignorado & 1.179 & 0,34 & 1.679 & 0,54 & 2.095 & 0,67 & 2.871 & 0,93 & 3.065 & 1,03 & 10.889 & 0,69 \\
\hline Doenças do aparelho respiratório & 2.060 & 0,60 & 1.981 & 0,63 & 1.670 & 0,53 & 1.494 & 0,48 & 1.315 & 0,44 & 8.520 & 0,54 \\
\hline Algumas doenças infecciosas e parasitárias & 1.947 & 0,57 & 1.612 & 0,52 & 1.477 & 0,47 & 1.389 & 0,45 & 1.222 & 0,41 & 7.647 & 0,49 \\
\hline Doenças do olho e anexos & 1.695 & 0,49 & 1.484 & 0,47 & 1.528 & 0,49 & 1.402 & 0,46 & 1.258 & 0,42 & 7.367 & 0,47 \\
\hline Doenças da pele e do tecido subcutâneo & 1.289 & 0,37 & 1.354 & 0,43 & 1.251 & 0,40 & 1.338 & 0,43 & 1.240 & 0,42 & 6.472 & 0,41 \\
\hline Neoplasias [tumores] & 523 & 0,15 & 436 & 0,14 & 409 & 0,13 & 402 & 0,13 & 374 & 0,13 & 2.144 & 0,14 \\
\hline Causas externas de morbidade e de mortalidade & 0 & 0,00 & 0 & 0,00 & 299 & 0,10 & 641 & 0,21 & 765 & 0,26 & 1.705 & 0,11 \\
\hline $\begin{array}{l}\text { Fatores que influenciam o estado de saúde e o contato com os } \\
\text { serviços de saúde }\end{array}$ & 217 & 0,06 & 252 & 0,08 & 393 & 0,13 & 468 & 0,15 & 454 & 0,15 & 1.784 & 0,11 \\
\hline Doenças do aparelho geniturinário & 310 & 0,09 & 316 & 0,10 & 272 & 0,09 & 271 & 0,09 & 222 & 0,07 & 1.391 & 0,09 \\
\hline Doenças do ouvido e da apófise mastoide & 353 & 0,10 & 300 & 0,10 & 256 & 0,08 & 202 & 0,07 & 160 & 0,05 & 1.271 & 0,08 \\
\hline Doenças endócrinas, nutricionais e metabólicas & 155 & 0,05 & 207 & 0,07 & 176 & 0,06 & 178 & 0,06 & 167 & 0,06 & 883 & 0,06 \\
\hline $\begin{array}{l}\text { Sintomas, sinais e achados anormais de exames clínicos e de } \\
\text { laboratório, não classificados em outra parte }\end{array}$ & 0 & 0,00 & 0 & 0,00 & 159 & 0,05 & 340 & 0,11 & 387 & 0,13 & 886 & 0,06 \\
\hline $\begin{array}{l}\text { Doenças do sangue e dos órgãos hematopoiéticos e alguns transtornos } \\
\text { imunitários }\end{array}$ & 126 & 0,04 & 82 & 0,03 & 78 & 0,02 & 61 & 0,02 & 61 & 0,02 & 408 & 0,03 \\
\hline Gravidez, parto e puerpério & 62 & 0,02 & 73 & 0,02 & 83 & 0,03 & 74 & 0,02 & 58 & 0,02 & 350 & 0,02 \\
\hline Algumas afecções originadas no período perinatal & 0 & 0,00 & 0 & 0,00 & 9 & 0,00 & 19 & 0,01 & 16 & 0,01 & 44 & 0,00 \\
\hline Malformações congênitas, deformidades e anomalias cromossômicas & 3 & 0,00 & 4 & 0,00 & 7 & 0,00 & 26 & 0,01 & 13 & 0,00 & 53 & 0,00 \\
\hline Total & 343.903 & 100 & 312.444 & 100 & 313.560 & 100 & 308.098 & 100 & 296.633 & 100 & 1.574 .638 & 100 \\
\hline
\end{tabular}

Fonte: Produzida pela autora em pesquisa no Sistema AEPS InfoLogo - Base de Dados Históricos da Previdência Social (2015). ${ }^{216}$

Legenda: $\quad$ ADA - Auxílio-Doença Acidentário

AA - Aposentadoria Acidentária

216 Disponível em: <http://www3.dataprev.gov.br/infologo>. Acesso em 16 jan. 2015. 
Tabela 6 - Auxílios-Doença Acidentários concedidos por CID e percentual de cada grupo (2008-2012)

\begin{tabular}{|c|c|c|c|c|c|c|c|c|c|c|c|c|}
\hline \multirow[b]{2}{*}{ Grupo CID } & \multicolumn{2}{|c|}{2008} & \multicolumn{2}{|c|}{2009} & \multicolumn{2}{|c|}{2010} & \multicolumn{2}{|c|}{2011} & \multicolumn{2}{|c|}{2012} & \multicolumn{2}{|c|}{ Total } \\
\hline & ADA & $\begin{array}{l}\% \text { do } \\
\text { total } \\
\text { anual }\end{array}$ & ADA & $\begin{array}{l}\% \text { do } \\
\text { total } \\
\text { anual }\end{array}$ & ADA & $\begin{array}{l}\% \text { do } \\
\text { total } \\
\text { anual }\end{array}$ & ADA & $\begin{array}{l}\% \text { do } \\
\text { total } \\
\text { anual }\end{array}$ & ADA & $\begin{array}{l}\% \text { do } \\
\text { total } \\
\text { anual }\end{array}$ & ADA & $\begin{array}{c}\% \text { do total do } \\
\text { período } \\
\text { (2008-2012) }\end{array}$ \\
\hline $\begin{array}{l}\text { Lesões, envenenamentos e algumas outras consequências de causas } \\
\text { externas. }\end{array}$ & 190.050 & 56,49 & 175.632 & 57,75 & 188.658 & 62,04 & 186.045 & 62,47 & 181.949 & 63,62 & 922.334 & 60,34 \\
\hline Doenças do sistema osteomuscular e do tecido conjuntivo & 108.844 & 32,35 & 90.076 & 29,62 & 80.980 & 26,63 & 77.012 & 25,86 & 71.107 & 24,86 & 428.019 & 28,00 \\
\hline Transtornos mentais e comportamentais & 12.666 & 3,76 & 13.348 & 4,39 & 12.033 & 3,96 & 12.231 & 4,11 & 11.544 & 4,04 & 61.822 & 4,04 \\
\hline Doenças do sistema nervoso & 8.783 & 2,61 & 7.235 & 2,38 & 6.583 & 2,16 & 6.280 & 2,11 & 5.947 & 2,08 & 34.828 & 2,28 \\
\hline Doenças do aparelho digestivo & 3.400 & 1,01 & 5.352 & 1,76 & 4.238 & 1,39 & 4.258 & 1,43 & 4.353 & 1,52 & 21.601 & 1,41 \\
\hline Doenças do aparelho circulatório & 4.004 & 1,19 & 4.316 & 1,42 & 3.373 & 1,11 & 3.246 & 1,09 & 2.799 & 0,98 & 17.738 & 1,16 \\
\hline Doenças do aparelho respiratório & 1.929 & 0,57 & 1.816 & 0,60 & 1.528 & 0,50 & 1.304 & 0,44 & 1.159 & 0,41 & 7.736 & 0,51 \\
\hline Algumas doenças infecciosas e parasitárias & 1.911 & 0,57 & 1.572 & 0,52 & 1.432 & 0,47 & 1.335 & 0,45 & 1.167 & 0,41 & 7.417 & 0,49 \\
\hline Doenças do olho e anexos & 1.562 & 0,46 & 1.365 & 0,45 & 1.390 & 0,46 & 1.285 & 0,43 & 1.134 & 0,40 & 6.736 & 0,44 \\
\hline Doenças da pele e do tecido subcutâneo & 1.254 & 0,37 & 1.305 & 0,43 & 1.206 & 0,40 & 1.277 & 0,43 & 1.186 & 0,41 & 6.228 & 0,41 \\
\hline Ignorado & 440 & 0,13 & 614 & 0,20 & 761 & 0,25 & 1.092 & 0,37 & 1.179 & 0,41 & 4.086 & 0,27 \\
\hline $\begin{array}{l}\text { Fatores que influenciam o estado de saúde e o contato com os } \\
\text { serviços de saúde }\end{array}$ & 215 & 0,06 & 249 & 0,08 & 390 & 0,13 & 465 & 0,16 & 447 & 0,16 & 1.766 & 0,12 \\
\hline Causas externas de morbidade e de mortalidade & 0 & 0,00 & 0 & 0,00 & 295 & 0,10 & 636 & 0,21 & 749 & 0,26 & 1.680 & 0,11 \\
\hline Neoplasias [tumores] & 446 & 0,13 & 361 & 0,12 & 315 & 0,10 & 310 & 0,10 & 281 & 0,10 & 1.713 & 0,11 \\
\hline Doenças do aparelho geniturinário & 287 & 0,09 & 281 & 0,09 & 236 & 0,08 & 231 & 0,08 & 183 & 0,06 & 1.218 & 0,08 \\
\hline Doenças do ouvido e da apófise mastoide & 310 & 0,09 & 258 & 0,08 & 223 & 0,07 & 170 & 0,06 & 138 & 0,05 & 1.099 & 0,07 \\
\hline $\begin{array}{l}\text { Sintomas, sinais e achados anormais de exames clínicos e de } \\
\text { laboratório, não classificados em outra parte }\end{array}$ & 0 & 0,00 & 0 & 0,00 & 159 & 0,05 & 335 & 0,11 & 384 & 0,13 & 878 & 0,06 \\
\hline Doenças endócrinas, nutricionais e metabólicas & 147 & 0,04 & 185 & 0,06 & 138 & 0,05 & 146 & 0,05 & 139 & 0,05 & 755 & 0,05 \\
\hline $\begin{array}{l}\text { Doenças do sangue e dos órgãos hematopoiéticos e alguns } \\
\text { transtornos imunitários }\end{array}$ & 121 & 0,04 & 75 & 0,02 & 67 & 0,02 & 52 & 0,02 & 52 & 0,02 & 367 & 0,02 \\
\hline Gravidez, parto e puerpério & 62 & 0,02 & 73 & 0,02 & 83 & 0,03 & 74 & 0,02 & 58 & 0,02 & 350 & 0,02 \\
\hline Malformações congênitas, deformidades e anomalias cromossômicas & 3 & 0,00 & 4 & 0,00 & 7 & 0,00 & 25 & 0,01 & 11 & 0,00 & 50 & 0,00 \\
\hline Algumas afecções originadas no período perinatal & 0 & 0,00 & 0 & 0,00 & 9 & 0,00 & 19 & 0,01 & 16 & 0,01 & 44 & 0,00 \\
\hline Total & 336.434 & 100 & 304.117 & 100 & 304.104 & 100 & 297.828 & 100 & 285.982 & 100 & 1.528 .465 & 100 \\
\hline
\end{tabular}

Fonte: Produzida pela autora em pesquisa no Sistema AEPS InfoLogo - Base de Dados Históricos da Previdência Social (2015). ${ }^{217}$ Legenda: ADA - Auxílio-Doença Acidentário

217 Disponível em: <http://www3.dataprev.gov.br/infologo>. Acesso em 16 jan. 2015. 
Tabela 7 - Aposentadorias Acidentárias concedidas por CID e percentual de cada grupo (2008-2012)

\begin{tabular}{|c|c|c|c|c|c|c|c|c|c|c|c|c|}
\hline \multirow[b]{2}{*}{ Grupo CID } & \multicolumn{2}{|c|}{2008} & \multicolumn{2}{|c|}{2009} & \multicolumn{2}{|c|}{2010} & \multicolumn{2}{|c|}{2011} & \multicolumn{2}{|c|}{2012} & \multirow{2}{*}{\multicolumn{2}{|c|}{$\begin{array}{l}\text { Total } \\
\% \text { do total do } \\
\text { período } \\
(2008-2012)\end{array}$}} \\
\hline & AA & $\begin{array}{l}\% \text { do } \\
\text { total } \\
\text { anual }\end{array}$ & AA & $\begin{array}{l}\% \text { do } \\
\text { total } \\
\text { anual }\end{array}$ & AA & $\begin{array}{l}\% \text { do } \\
\text { total } \\
\text { anual }\end{array}$ & AA & $\begin{array}{l}\% \text { do } \\
\text { total } \\
\text { anual }\end{array}$ & AA & $\begin{array}{l}\% \text { do } \\
\text { total } \\
\text { anual }\end{array}$ & & \\
\hline $\begin{array}{l}\text { Lesões, envenenamentos e algumas outras consequências de causas } \\
\text { externas }\end{array}$ & 3.210 & 42,98 & 3.191 & 38,32 & 3.263 & 34,51 & 3.316 & 32,29 & 3.425 & 32,16 & 16.405 & 35,53 \\
\hline $\begin{array}{l}\text { Doenças do sistema osteomuscular e do tecido conjuntivo } \\
\text { Ignorado }\end{array}$ & $\begin{array}{c}2.244 \\
739\end{array}$ & $\begin{array}{c}30,04 \\
9,89\end{array}$ & $\begin{array}{l}2.607 \\
1.065\end{array}$ & $\begin{array}{l}31,31 \\
12,79\end{array}$ & $\begin{array}{l}3.144 \\
1.334\end{array}$ & $\begin{array}{l}33,25 \\
14,11\end{array}$ & $\begin{array}{l}3.365 \\
1.779\end{array}$ & $\begin{array}{l}32,77 \\
17,32\end{array}$ & $\begin{array}{l}3.465 \\
1.886\end{array}$ & $\begin{array}{l}32,53 \\
17,71\end{array}$ & $\begin{array}{c}14.825 \\
6.803\end{array}$ & $\begin{array}{l}32,11 \\
14,73\end{array}$ \\
\hline Transtornos mentais e comportamentais & 258 & 3,45 & 293 & 3,52 & 358 & 3,79 & 465 & 4,53 & 536 & 5,03 & 1.910 & 4,14 \\
\hline Doenças do aparelho circulatório & 191 & 2,56 & 309 & 3,71 & 406 & 4,29 & 378 & 3,68 & 366 & 3,44 & 1.650 & 3,57 \\
\hline Doenças do sistema nervoso & 323 & 4,32 & 290 & 3,48 & 349 & 3,69 & 310 & 3,02 & 352 & 3,30 & 1.624 & 3,52 \\
\hline Doenças do aparelho respiratório & 131 & 1,75 & 165 & 1,98 & 142 & 1,50 & 190 & 1,85 & 156 & 1,46 & 784 & 1,70 \\
\hline Doenças do olho e anexos & 133 & 1,78 & 119 & 1,43 & 138 & 1,46 & 117 & 1,14 & 124 & 1,16 & 631 & 1,37 \\
\hline Neoplasias [tumores] & 77 & 1,03 & 75 & 0,90 & 94 & 0,99 & 92 & 0,90 & 93 & 0,87 & 431 & 0,93 \\
\hline Doenças da pele e do tecido subcutâneo & 35 & 0,47 & 49 & 0,59 & 45 & 0,48 & 61 & 0,59 & 54 & 0,51 & 244 & 0,53 \\
\hline Algumas doenças infecciosas e parasitárias & 36 & 0,48 & 40 & 0,48 & 45 & 0,48 & 54 & 0,53 & 55 & 0,52 & 230 & 0,50 \\
\hline Doenças do ouvido e da apófise mastoide & 43 & 0,58 & 42 & 0,50 & 33 & 0,35 & 32 & 0,31 & 22 & 0,21 & 172 & 0,37 \\
\hline Doenças do aparelho geniturinário & 23 & 0,31 & 35 & 0,42 & 36 & 0,38 & 40 & 0,39 & 39 & 0,37 & 173 & 0,37 \\
\hline Doenças endócrinas, nutricionais e metabólicas & 8 & 0,11 & 22 & 0,26 & 38 & 0,40 & 32 & 0,31 & 28 & 0,26 & 128 & 0,28 \\
\hline Doenças do aparelho digestivo & 11 & 0,15 & 15 & 0,18 & 13 & 0,14 & 16 & 0,16 & 13 & 0,12 & 68 & 0,15 \\
\hline $\begin{array}{l}\text { Doenças do sangue e dos órgãos hematopoiéticos e alguns transtornos } \\
\text { imunitários }\end{array}$ & 5 & 0,07 & 7 & 0,08 & 11 & 0,12 & 9 & 0,09 & 9 & 0,08 & 41 & 0,09 \\
\hline Causas externas de morbidade e de mortalidade & 0 & 0,00 & 0 & 0,00 & 4 & 0,04 & 5 & 0,05 & 16 & 0,15 & 25 & 0,05 \\
\hline $\begin{array}{l}\text { Fatores que influenciam o estado de saúde e o contato com os serviços de } \\
\text { saúde }\end{array}$ & 2 & 0,03 & 3 & 0,04 & 3 & 0,03 & 3 & 0,03 & 7 & 0,07 & 18 & 0,04 \\
\hline $\begin{array}{l}\text { Sintomas, sinais e achados anormais de exames clínicos e de laboratório, } \\
\text { não classificados em outra parte }\end{array}$ & 0 & 0,00 & 0 & 0,00 & 0 & 0,00 & 5 & 0,05 & 3 & 0,03 & 8 & 0,02 \\
\hline Malformações congênitas, deformidades e anomalias cromossômicas & 0 & 0,00 & 0 & 0,00 & 0 & 0,00 & 1 & 0,01 & 2 & 0,02 & 3 & 0,01 \\
\hline Gravidez, parto e puerpério & 0 & 0,00 & 0 & 0,00 & 0 & 0,00 & 0 & 0,00 & 0 & 0,00 & 0 & 0,00 \\
\hline Algumas afecções originadas no período perinatal & 0 & 0,00 & 0 & 0,00 & 0 & 0,00 & 0 & 0,00 & 0 & 0,00 & 0 & 0,00 \\
\hline Total & 7.469 & 100 & 8.327 & 100 & 9.456 & 100 & 10.270 & 100 & 10.651 & 100 & 46.173 & 100 \\
\hline
\end{tabular}

Fonte: Produzida pela autora em pesquisa no Sistema AEPS InfoLogo - Base de Dados Históricos da Previdência Social (2015). ${ }^{218}$

Legenda: AA - Aposentadoria Acidentária

218 Disponível em: <http://www3.dataprev.gov.br/infologo>. Acesso em 16 jan. 2015. 
As tabelas a seguir apresentam informações sobre benefícios acidentários concedidos, com CAT registrada, por CID e percentual de cada grupo (1999-2012): Tabela 8 Acidentes do trabalho (Doença do Trabalho com CAT) por CID e percentual de cada grupo (1999-2012); Tabela 9 - Acidentes do trabalho (Típico, com CAT) (F/Z*) e percentual de cada grupo (1999-2012).

A Tabela 8 - Acidentes do trabalho (Doença do Trabalho com CAT) por CID (F/Z*) e percentual de cada grupo (1999-2012) apresenta informações sobre Auxílios-Doença Acidentários referentes a Transtornos Mentais e do Comportamento Relacionados ao Trabalho, retiradas do sistema AEAT InfoLogo (Base de Dados Históricos de Acidentes do Trabalho da Previdência Social), no período de 1999 a 2012 (período disponibilizado para pesquisa), distribuídos por diagnóstico. Ao lado do número de casos, o respectivo percentual.

Tabela 8 - Acidentes do Trabalho (Doença do Trabalho com CAT) por CID (F / Z*) e percentual de cada grupo (1999-2012)

\begin{tabular}{l|cc}
\hline \multicolumn{1}{c|}{ CID } & \multicolumn{2}{c}{$\begin{array}{c}\text { Total } \\
\text { \% do total do } \\
\text { período } \\
\text { (1999-2012) }\end{array}$} \\
\hline (F43) Reações ao "stress" grave e transtornos de adaptação & Total & 55,55 \\
(F32) Episódios depressivos & 3.533 & 38,6 \\
(F10) Transtornos mentais e comportamentais devidos ao uso de álcool & 2.455 & 1,26 \\
(F06) Outros transtornos mentais devidos a lesão e disfunção cerebral e a doença & 80 & 0,74 \\
física & 47 & 0,11 \\
(F07) Transtornos de personalidade e do comportamento devidos a doença, a & 7 & 1,64 \\
lesão e a disfunção cerebral & 104 & 1,6 \\
(F48) Outros transtornos neuróticos & 102 & 0,09 \\
(Z73) Problemas relacionados com a organização de seu modo de vida & 6 & 0,33 \\
(F09) Transtorno mental orgânico ou sintomático não especificado & 21 & 0,06 \\
(F51) Transtornos não-orgânicos do sono devidos a fatores emocionais & 4 & 0,02 \\
(F02) Demência em outras doenças classificadas em outra parte & 1 & $\mathbf{1 0 0}$ \\
\hline (F05) Delirium não induzido pelo álcool ou por outras substâncias psicoativas & $\mathbf{6 . 3 6 0}$ & Total \\
\hline
\end{tabular}

Fonte: Produzida pela autora em pesquisa no Sistema AEAT InfoLogo - Base de Dados Históricos de Acidentes do Trabalho da Previdência Social (2015). ${ }^{219}$

* CID relacionado no Decreto no 3.048, de 6 de maio de 1999, como Transtorno Mental e do Comportamento Relacionado ao Trabalho.

219 Disponível em: <http://www3.dataprev.gov.br/aeat>. Acesso em 16 jan. 2015. 
Dos 6.360 Auxílios-Doença Acidentários por Transtornos Mentais e do Comportamento Relacionados ao Trabalho concedidos no período, 55,6\% (3.533 casos) referem-se a Reações ao estresse grave e transtornos de adaptação (CID F43); 38,6\% (2.455 casos), a Episódios depressivos (CID F32). Juntos, esses dois diagnósticos somam 5.998 casos, o que corresponde a $94,2 \%$ de todos os Auxílios-Doença Acidentários concedidos no período.

Os demais diagnósticos (variando de 1,26\% a 0,02\%) são, em ordem decrescente de número de casos: Transtornos mentais e comportamentais devidos ao uso de álcool (F10); Outros transtornos mentais devidos a lesão e disfunção cerebral e a doença física (F06); Transtornos de personalidade e do comportamento devidos a doença, a lesão e a disfunção cerebral (F07); Outros transtornos neuróticos (F48); Problemas relacionados com a organização de seu modo de vida (Z73); Transtorno mental orgânico ou sintomático não especificado (F09); Transtornos não orgânicos do sono devidos a fatores emocionais (F51); Demência em outras doenças classificadas em outra parte (F02); Delirium não induzido pelo álcool ou por outras substâncias psicoativas (F05).

Já a Tabela 9 - Acidentes do trabalho (Típico, com CAT) por CID (F/Z*) e percentual de cada grupo (1999-2012), a seguir, apresenta informações sobre diagnósticos de Transtornos Mentais e do Comportamento Relacionados ao Trabalho relacionados a acidentes de trabalho típicos, retiradas do sistema AEAT InfoLogo (Base de Dados Históricos de Acidentes do Trabalho da Previdência Social), no período de 1999 a 2012 (período disponibilizado para pesquisa), distribuídos por diagnóstico. Ao lado do número de casos, o respectivo percentual.

Dos 34.104 casos de acidentes típicos registrados no período, 92,2\% (31.440 casos) foram relacionados a Reações ao estresse grave e transtornos de adaptação (CID F43), e 4,2\% (1.424 casos), a Episódios depressivos (CID F32). Juntos, esses dois diagnósticos somam 32.874 casos, o que corresponde a $96,45 \%$ dos casos. 
Tabela 9 - Acidentes do Trabalho (Típico, com CAT) por CID (F / Z*) e percentual de cada grupo (1999-2012)

\begin{tabular}{l|cc}
\hline \multicolumn{1}{c|}{ CID } & \multicolumn{2}{c}{$\begin{array}{c}\text { Total } \\
\text { \% do total do } \\
\text { período } \\
\text { (1999-2012) }\end{array}$} \\
\hline (F43) Reações ao "stress" grave e transtornos de adaptação & Total & 92,19 \\
(F32) Episódios depressivos & 31.440 & 4,20 \\
(F10) Transtornos mentais e comportamentais devidos ao uso de álcool & 1.434 & 0,90 \\
(F06) Outros transtornos mentais devidos a lesão e disfunção cerebral e a doença \\
física \\
$\begin{array}{l}\text { (F07) Transtornos de personalidade e do comportamento devidos a doença, a } \\
\text { lesão e a disfunção cerebral }\end{array}$ & 224 & 0,66 \\
(F48) Outros transtornos neuróticos & 291 & 0,85 \\
(Z73) Problemas relacionados com a organização de seu modo de vida & 143 & 0,42 \\
(F09) Transtorno mental orgânico ou sintomático não especificado & 110 & 0,32 \\
(F51) Transtornos não-orgânicos do sono devidos a fatores emocionais & 45 & 0,13 \\
(F02) Demência em outras doenças classificadas em outra parte & 60 & 0,18 \\
(F05) Delirium não induzido pelo álcool ou por outras substâncias psicoativas & 28 & 0,08 \\
\hline$\quad$ Total & 22 & 0,06 \\
\hline
\end{tabular}

Fonte: Produzida pela autora em pesquisa no Sistema AEAT InfoLogo - Base de Dados Históricos de Acidentes do Trabalho da Previdência Social (2015). 220

* CID relacionado no Decreto n 3.048, de 6 de maio de 1999, como Transtornos Mentais e do Comportamento Relacionados ao Trabalho.

Os demais diagnósticos (variando de 0,9\% a 0,06\%) são, em ordem decrescente de número de casos: Transtornos mentais e comportamentais devidos ao uso de álcool (F10); Outros transtornos mentais devidos a lesão e disfunção cerebral e a doença física (F06); Transtornos de personalidade e do comportamento devidos a doença, a lesão e a disfunção cerebral (F07); Outros transtornos neuróticos (F48); Problemas relacionados com a organização de seu modo de vida (Z73); Transtorno mental orgânico ou sintomático não especificado (F09); Transtornos não orgânicos do sono devidos a fatores emocionais (F51); Demência em outras doenças classificadas em outra parte (F02); Delirium não induzido pelo álcool ou por outras substâncias psicoativas (F05).

220 Disponível em: <http://www3.dataprev.gov.br/aeat>. Acesso em 16 jan. 2015. 
A seguir, apresentam-se informações sobre notificações no SINAN referentes aos Transtornos Mentais e do Comportamento Relacionados ao Trabalho: Figura 3 Agravos relacionados ao trabalho notificados no SINAN (2007-2014); Tabela 10Distribuição das notificações de agravos à saúde relacionados ao trabalho, por agravo, segundo o ano de notificação (2007-2013).

A Figura 3 - Agravos relacionados ao trabalho notificados no SINAN (2007-2014) apresenta somatório das notificações totais registradas no SINAN de 2007 a agosto de 2014 (incluídos os acidentes de trabalho). Os Transtornos Mentais e do Comportamento Relacionados ao Trabalho representam $0,42 \%$ do total dos agravos notificados ( 3.495 de um total de 823.643 casos). Excluídos acidentes e violência, as doenças relacionadas ao trabalho perfazem 131.900 casos ( $16 \%$ do montante). No cômputo das doenças relacionadas ao trabalho, os Transtornos Mentais e do Comportamento Relacionados ao Trabalho perfazem 2,65\% do montante.

A Tabela 10 - Distribuição das notificações de agravos à saúde relacionados ao trabalho, por agravo, segundo o ano de notificação (Brasil, 2007-2013) apresenta as notificações de agravos à saúde relacionados ao trabalho, no período de 2007 a julho de 2013, separadas por tipo de agravo. Os Transtornos Mentais e do Comportamento Relacionados ao Trabalho correspondem à $6^{\text {a }}$ causa, com 2.669 casos (num total de 562.670). Se consideradas apenas as doenças relacionadas ao trabalho (excluindo os acidentes e intoxicações exógenas), corresponde à $3^{\text {a }}$ causa, após as LER/DORT (35.238 casos) e as dermatoses (3.548 casos). 
Figura 3 - Agravos relacionados ao trabalho notificados no SINAN (2007-2014) *

SINAN: agravos relacionados ao trabalho

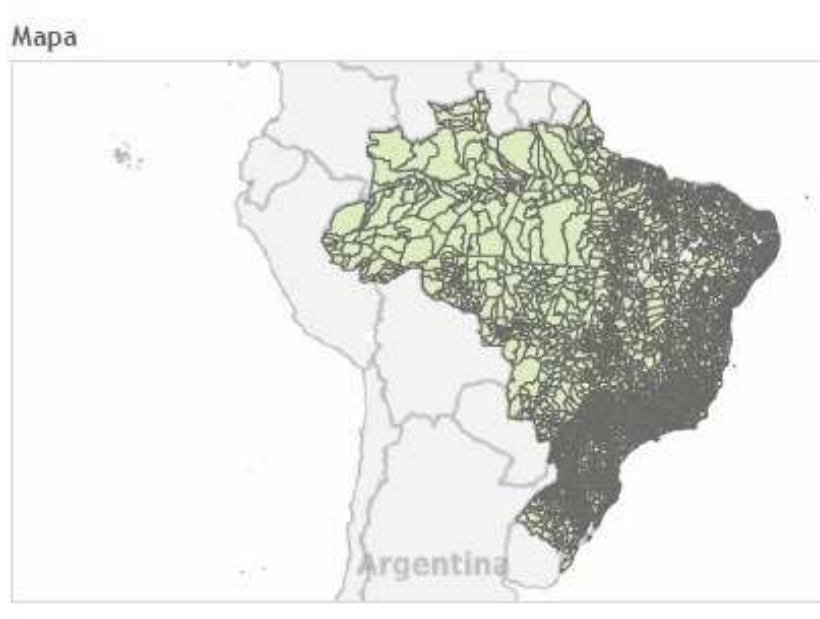
Agravos notificados

\begin{tabular}{|c|c|c|}
\hline Agravo de notificą̧äo & \% do total de Número de not.. & Número de notificą̧ốes \\
\hline Acidente de trabalho com e. & $31.38 \%$ & 258.462 \\
\hline Acidente de trabalho grave f & $46.92 \%$ & 388.489 \\
\hline Acidente por animais peçon. & $4.08 \%$ & 33.624 \\
\hline Cáncer relacionado ao traba. & $0,06 \%$ & 503 \\
\hline Dermatoses ocupacionais !. & $0.53 \%$ & 4.378 \\
\hline Intoxicą̧äo exógena relacio. & $3.42 \%$ & 28.128 \\
\hline Leishmaniose tegumentar a.. & $5,67 \%$ & 48.687 \\
\hline LERIDORT (Z257.9) & $5.31 \%$ & 43.698 \\
\hline PAIR (H83.3) & $0,33 \%$ & 2.740 \\
\hline Pneumoconioses (J64) & $0.28 \%$ & 2.328 \\
\hline Transtornos mentais relacio. & $0.42 \%$ & 3.495 \\
\hline
\end{tabular}

Ocupação

CBO Grande grupo
Näo informado

Trabalhadores da produção

Técnicos de nivel médio Trabalhadores dos servicos... Trabalhadores agropecuário. Profissionais das ciêneias e

Ano
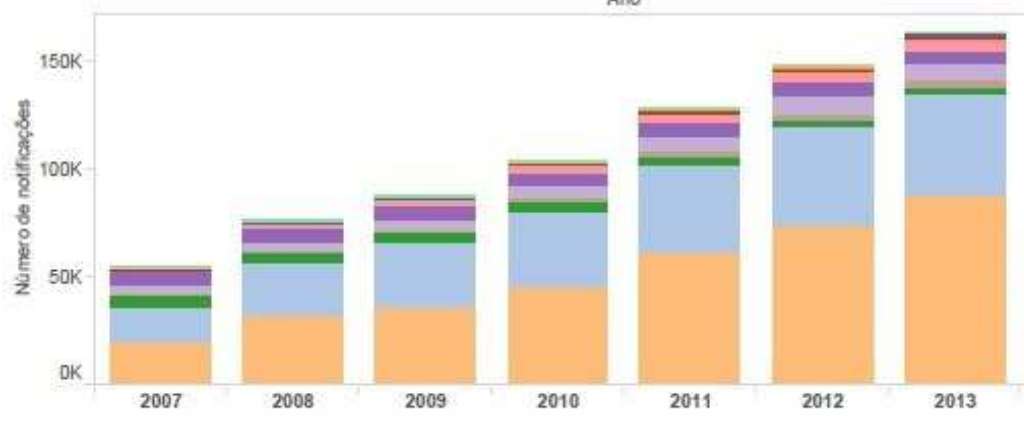

Trabalhadores em servigos .

Membros superiores do pod.

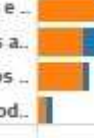

Agravo de notificaçäo

Leishmaniose tegumentar ame.

Tneumoconioses (J84) LERJDORT (Z57.8)

DAIR (H83.3) Violência relacionada ao trabal-

Transtomos mentais relacions. Acidente por animais pegonhe.

Dermatoses ocupacionais (L28. Acidente de trabalho com expo.

Intoxicação exígena relaciona. Acidente de trabalho grave (Yr.

Fonte: SVS/MS; Plataforma Renast Online, 2014.

* Dados de 2014 referentes a notificações registradas até aproximadamente o mês de agosto. 
Tabela 10 - Distribuição das notificações de agravos à saúde relacionados ao trabalho, por agravo, segundo o ano de notificação. Brasil, 2007-2013*

\begin{tabular}{|c|c|c|c|c|c|c|c|c|}
\hline Agravo & 2007 & 2008 & 2009 & 2010 & 2011 & 2012 & $2013^{*}$ & Total \\
\hline $\begin{array}{l}\text { Acidentes fatais, com mutilação } \\
\text { e em menores de } 18 \text { anos }\end{array}$ & 19.725 & 31.317 & 35.321 & 44.357 & 60.865 & 73.298 & 28.324 & 293.207 \\
\hline $\begin{array}{l}\text { Acidentes com Material } \\
\text { Biológico }\end{array}$ & 15.735 & 24.704 & 30.197 & 34.236 & 40.340 & 43.062 & 16.014 & 204.288 \\
\hline LER / DORT & 3.228 & 3.474 & 4.690 & 5.951 & 7.184 & 8.165 & 2.546 & 35.238 \\
\hline $\begin{array}{l}\text { Intoxicação exógena relacionada } \\
\text { ao trabalho }\end{array}$ & 1.895 & 2.445 & 2.564 & 2.719 & 3.612 & 3.858 & 2.032 & 19.125 \\
\hline Dermatoses & 128 & 299 & 392 & 507 & 685 & 1013 & 524 & 3.548 \\
\hline $\begin{array}{l}\text { Transtorno mental relacionado } \\
\text { ao trabalho }\end{array}$ & 122 & 189 & 359 & 402 & 704 & 647 & 246 & 2.669 \\
\hline Pneumoconioses & 104 & 750 & 179 & 205 & 559 & 218 & 146 & 2.161 \\
\hline PAIR & 113 & 204 & 258 & 330 & 559 & 408 & 232 & 2.104 \\
\hline Câncer & 5 & 12 & 30 & 26 & 125 & 71 & 61 & 330 \\
\hline TOTAL & 41.055 & 63.394 & 73.990 & 88.733 & 114.633 & 130.740 & 50.125 & 562.670 \\
\hline
\end{tabular}

Fonte: Veiga, 2014, p.6.

*Dados referentes ao mês de julho de 2013. 
O Gráfico 5 - Percentuais das Principais Profissões, por CBO, com Doenças Relacionadas ao Trabalho notificadas: Transtornos Mentais e do Comportamento Relacionados ao Trabalho (Brasil, 2007 a 2013), a seguir, apresenta informações sobre as notificações de Transtornos Mentais e do Comportamento Relacionados ao Trabalho (incluídos os acidentes de trabalho), no período de 2007 a julho de 2013, classificadas no Banco de Dados do SINAN a partir do Cadastro Brasileiro de Ocupação (CBO) com maior percentual de registros.

Os Transtornos Mentais e do Comportamento Relacionados ao Trabalho representam $0,42 \%$ do total dos agravos notificados ( 3.495 de um total de 154.427 casos).

A seguir, apresentam-se as ocupações mais notificadas, em ordem descrescente, por ano de notificação:

- 2007 - 1) cobrador de transportes coletivos (exceto trem); 2) assistente administrativo; 3) motorista de ônibus urbano.

- 2008 - 1) professor da educação de jovens e adultos do ensino fundamental (quase o dobro de notificações da segunda ocupação notificada); 2) motorista de ônibus urbano; 3) auxiliar de escritório, em geral.

- 2009 - 1) motorista de ônibus urbano; 2) vigilante; cobrador de transportes coletivos (exceto trem); faxineiro; 3 ) operador de caixa.

- 2010 - 1) vigilante; 2) motorista de ônibus urbano; 3) cobrador de transportes coletivos (exceto trem); vendedor de comércio varejista.

- 2011 - 1) professor da educação de jovens e adultos do ensino fundamental; 2) motorista de ônibus urbano; 3) vigilante; assistente administrativo.

- 2012 -1) motorista de ônibus urbano; operador de caixa; 2) vigilante; professor da educação de jovens e adultos do ensino fundamental; 3) operador de máquinas fixas, em geral.

- 2013 - 1) professor da educação de jovens e adultos do ensino fundamental; 2) motorista de ônibus urbano; 3) vendedor de comércio varejista.

Em todo o período analisado, sobressaem-se quatro ocupações mais notificadas, em ordem descrescente: 1) motorista de ônibus urbano; 2) vigilante; 3) professor da educação de jovens e adultos do ensino fundamental; 4) cobrador de transportes coletivos (exceto trem). 
Gráfico 5 - Percentuais das Principais Profissões, por CBO, com Doenças Relacionadas ao Trabalho notificadas: Transtornos Mentais e do Comportamento Relacionados ao Trabalho (Brasil, 2007 a 2013)

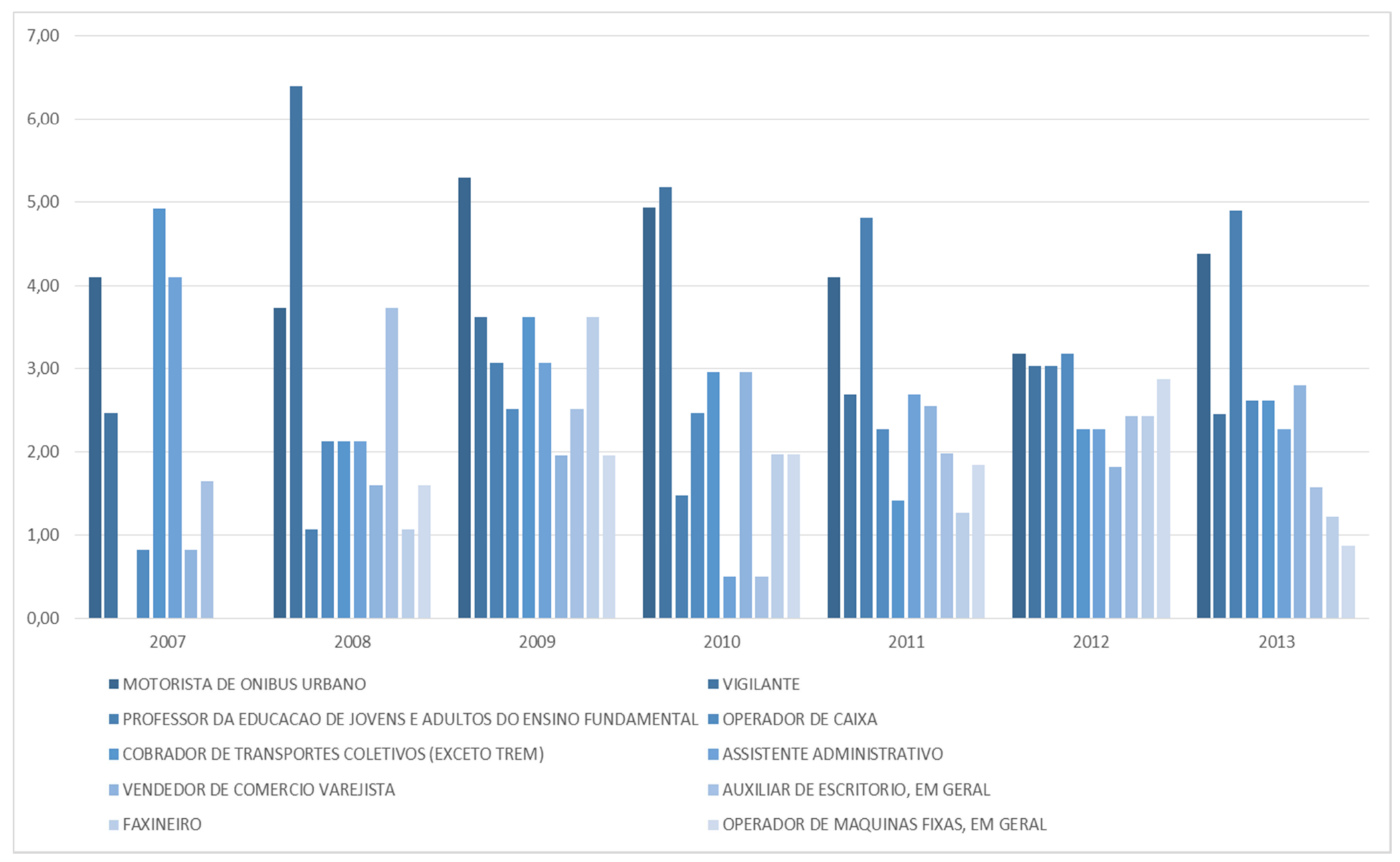

Fonte: Veiga, 2014, p.16. 


\section{Apêndice D - Livro de Códigos e Gráficos}

Após a identificação das principais unidades básicas de análise (conceitos) do conteúdo das entrevistas, transformadas em códigos, foram construídas categorias de análise ("famílias"), constituídas por agrupamentos de códigos que direcionam para o entendimento de uma mesma questão. As "famílias" construídas nessa pesquisa são apresentadas a seguir. Após cada "família", encontra-se gráfico representativo do número de respostas dadas pelos entrevistados quanto às categorias (códigos) em questão. Embora a perspectiva analítica empregada não seja de caráter quantitativo, entendeu-se que, em alguns casos, a recorrência de respostas ou posicionamentos similares dos entrevistados pudesse ser significativa, por isso procedeu-se à construção dos gráficos, a partir de ferramentas do sistema ATLAS.ti.

Família 1.carac_atencao_basica: como o entrevistado caracteriza (ou qualifica) a atenção básica na relação com a Saúde do Trabalhador e com os Transtornos Mentais e do Comportamento Relacionados ao Trabalho (TMCs).

- 1.1.caract_atencao_basica_import_saud_trab: atenção básica tem papel fundamental na relação com a Saúde do Trabalhador.

- 1.2.caract_atencao_basica_desconhec_saud_trab: atenção básica desconhece procedimentos ou métodos de como diagnosticar uma doença (inclusive mental) que possa estar relacionada ao trabalho.

- 1.3.caract_atencao_basica_dific_material_tecnico: atenção básica não utiliza o material técnico que fala sobre a saúde do trabalhador/TMCs. O material que trata da saúde do trabalhador/TMCs não tem uma repercussão significativa na atenção básica.

- 1.4.caract_atencao_basica_sem_atenc_doen_trab: a atenção básica está despreparada para lidar com o campo da saúde do trabalhador (e com os TMCs) - ou por não saber fazer o diagnóstico relacionado ao trabalho ou por não dar importância à categoria "trabalho".

Gráfico 6 - A atenção básica no campo da saúde e trabalho e os TMCs

A atenção básica e a relação com o campo da saúde e trabalho e os TMCs

número de entrevistados

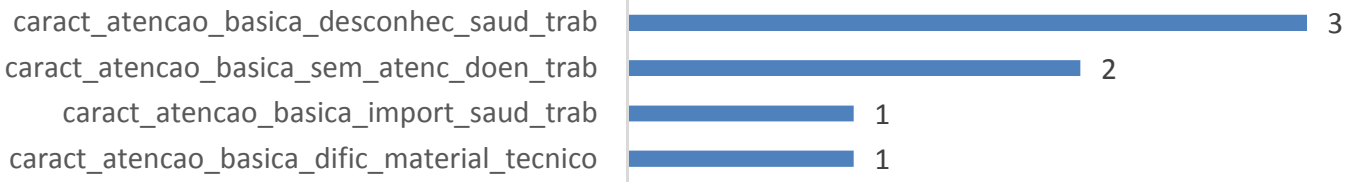

Fonte: Produzido pela autora no Sistema ATLAS.ti, a partir de dados das entrevistas da pesquisa de campo (2015).

Família 2.atuacao_inst: atores que o entrevistado aponta como importantes no campo da saúde do trabalhador, sobretudo na discussão dos TMCs

- 2.1.atuacao_inst_CERESTs: atuação dos CERESTs.

- 2.2.atuacao_inst_minist_publico: atuação do Ministério Público.

- 2.3.atuacao_inst_minist_trabalho: atuação do Ministério do Trabalho.

- 2.4.atuacao_inst_minist_saude: atuação do Ministério da Saúde.

- 2.5.atuacao_inst_minist_previdencia: atuação do Ministério da Previdência.

- 2.6.atuacao_inst_mov_sindical: atuação do movimento sindical.

- 2.7.atuacao_inst_sec_estadual_saude: atuação de Secretaria Estadual de Saúde.

- 2.8.atuacao_inst_universidade: atuação das universidades/academia (pesquisa e denúncia).

- 2.9.atuacao_inst_just_trab: atuação da Justiça do Trabalho 
Gráfico 7 - Atores relevantes na discussão dos TMCs

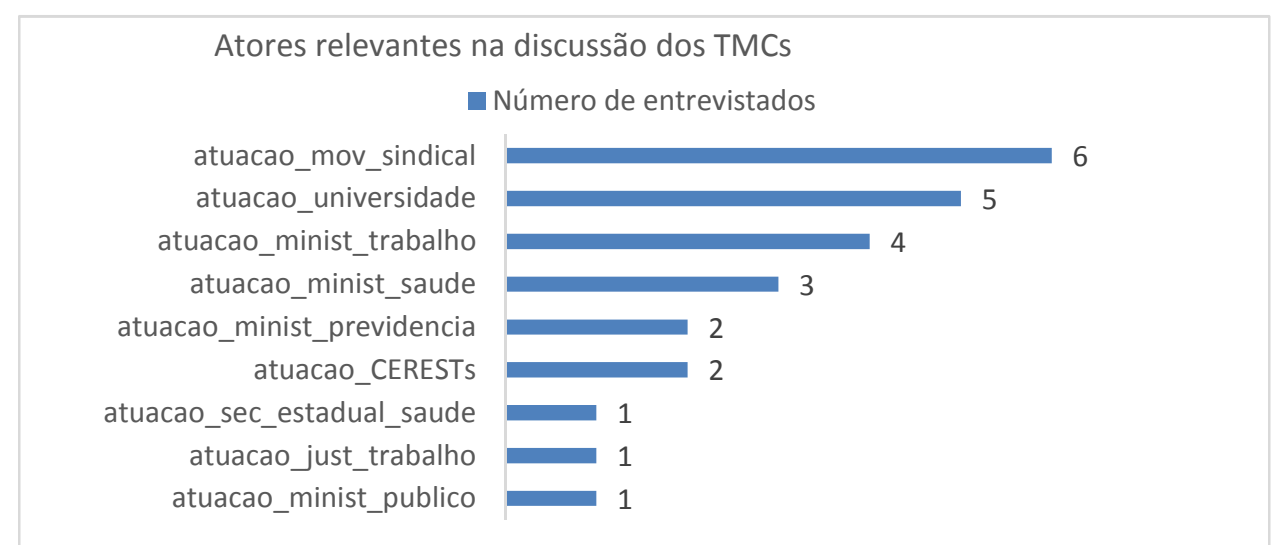

Fonte: Produzido pela autora no Sistema ATLAS.ti, a partir de dados das entrevistas da pesquisa de campo (2015).

Família 3.caract_campo: como o entrevistado caracteriza o campo da saúde do trabalhador em sua relação com os TMCs.

- 3.1.caract_campo_interdisciplinar: campo da saúde do trabalhador é interdisciplinar (exige várias categorias de profissionais de saúde e campos científicos para lidar com TMCs)

- 3.2.caract_campo_nao_recente: olhar sobre TMCs não é recente

- 3.3.caract_campo_recente: olhar sobre TMCs é recente

- 3.4.caract_campo_cresc_producao_doença: campo da saúde do trabalhador é caracterizado pelo crescimento da produção da doença mental ligada ao trabalho. $O$ entrevistado observa 0 aumento da "produção" dos TMCs.

Gráfico 8 - Características do campo da Saúde do Trabalhador em relação aos TMCs

Características do campo da Saúde do Trabalhador em relação aos TMCs

Número de entrevistados

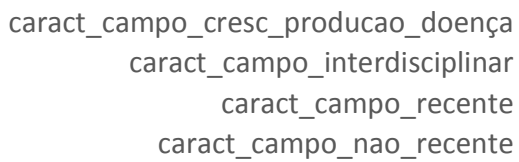

Fonte: Produzido pela autora no Sistema ATLAS.ti, a partir de dados das entrevistas da pesquisa de campo (2015).

Família 4.caract_doenca_saud_trab: qual é a forma (ou o que é requerido), segundo o entrevistado, para a caracterização de uma doença "mental" relacionada ao trabalho (para estabelecer o nexo).

- 4.1.caract_doenca_saud_trab_relato_pessoal: a doença "mental" ligada ao trabalho é caracterizada por meio da escuta do relato pessoal do paciente.

- 4.2.caract_doenca_saud_trab_sensib_dialogo_medico: para a caracterização do trabalho como fator de adoecimento "mental", é necessário que o médico tenha uma sensibilidade (percepção) bastante aguçada e/ou diálogo com outros médicos.

- 4.3.caract_doenca_nexo_relatos_pacientes: nexo construído a partir dos relatos dos trabalhadores (subjetividade da doença do trabalho).

Gráfico 9 - Exigências para caracterização dos TMCs

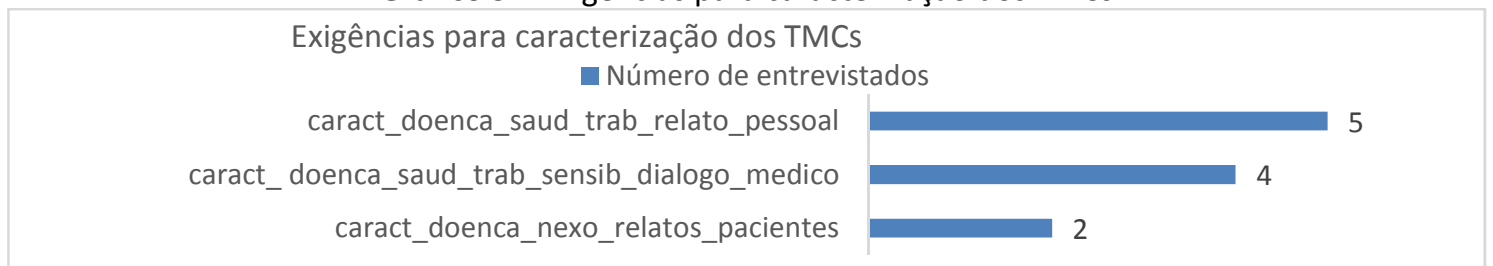

Fonte: Produzido pela autora no Sistema ATLAS.ti, a partir de dados das entrevistas da pesquisa de campo (2015). 
Família 5.concep_trab: como o entrevistado identifica as relações saúde/trabalho, e a percepção sobre a categoria trabalho presente no campo.

- 5.1.concep_trab_apendice_ou_nao_contemplado: a categoria "trabalho" é um apêndice na área médica (algo secundário, sem importância) ou não é contemplada ao se fazer um diagnóstico.

- 5.2.concep_trab_influencia_sintoma_morbidade: trabalho produz sintoma ou altera padrão de morbidade.

- 5.3.concep_trab_fetiche_dignifica: concepção de que o trabalho dignifica o homem. Trabalho como um fetiche.

- 5.4.concep_trab_metodo_tratamento: concepção de que o trabalho funciona como um método terapêutico, um tratamento (visão crítica)

- 5.5.concep_trab_nao_simples_tarefa: o trabalho não é uma simples tarefa que usa somente o corpo: ele também influencia o psicológico do indivíduo.

Gráfico 10 - Concepções sobre Trabalho

Concepção sobre trabalho

número de entrevistados

concep_trab_apendice_ou_nao_contemplado

concep_trab_influencia_sintoma_morbid

concep_trab_fetiche_dignifica

concep_trab_nao_simples_tarefa

concep_trab_metodo_tratamento

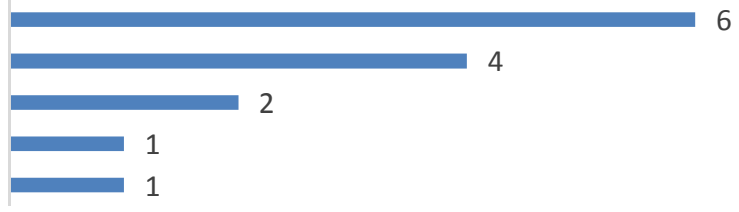

Fonte: Produzido pela autora no Sistema ATLAS.ti, a partir de dados das entrevistas da pesquisa de campo (2015).

Família 6.papel_CEREST: papel ou importância que o entrevistado relaciona aos Centros de Referência em Saúde do Trabalhador (CERESTs).

- 6.1.papel_CEREST_empoderamento_trab: o papel do CEREST é empoderar os trabalhadores, estimulando ações conjuntas (intersetoriais) entre eles e órgãos governamentais, por exemplo.

- 6.2.papel_CEREST_promover_acoes_saud_trab: o papel do CEREST é promover ações referentes à saúde do trabalhador (ações de vigilância, assistência, etc.).

- 6.3.papel_CEREST_promover_debate_formacao: um papel do CEREST é promover debate e formação em Saúde do Trabalhador.

Gráfico 11 - Papel do CEREST

Papel do CEREST

Número de entrevistados

papel_CEREST_promover_debate_formacao

papel_CEREST_promover_acoes_saud_trab

papel_CEREST_empoderamento_trab

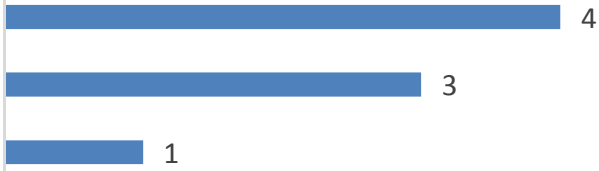

Fonte: Produzido pela autora no Sistema ATLAS.ti, a partir de dados das entrevistas da pesquisa de campo (2015).

Família 7.conflito_campo: conflitos que o entrevistado percebe como existentes no campo da Saúde do Trabalhador, sobretudo quanto aos TMCs.

- 7.1.conflito_campo_medicos_outras_categorias: centralidade do papel do médico frente às demais categorias da área de saúde (psicólogos, enfermeiros, etc.)

- 7.2.conflito_campo_med_patronal_e_med_saud_trabal: conflito existente entre os médicos patronais (do trabalho) e os médicos da abordagem da Saúde do Trabalhador.

- 7.3.conflito_campo_competencias_minist: conflito existente entre as competências dos ministérios relativas à saúde do trabalhador. 
- 7.4.conflito_campo_divisao_falta_consenso_profissionais: conflito referente à falta de consenso quanto a ideias, ao diagnóstico relacionado aos TMCs, terminologias, etc.

- 7.5.conflito_campo_empresa_contesta_diagnostico: contestação das empresas dos diagnósticos.

- 7.6.conflito_INSS_e_decreto: dificuldade do INSS em reconhecer o que está no decreto (transtornos mentais relacionados ao trabalho).

Gráfico 12 - Conflitos no campo da Saúde do Trabalhador

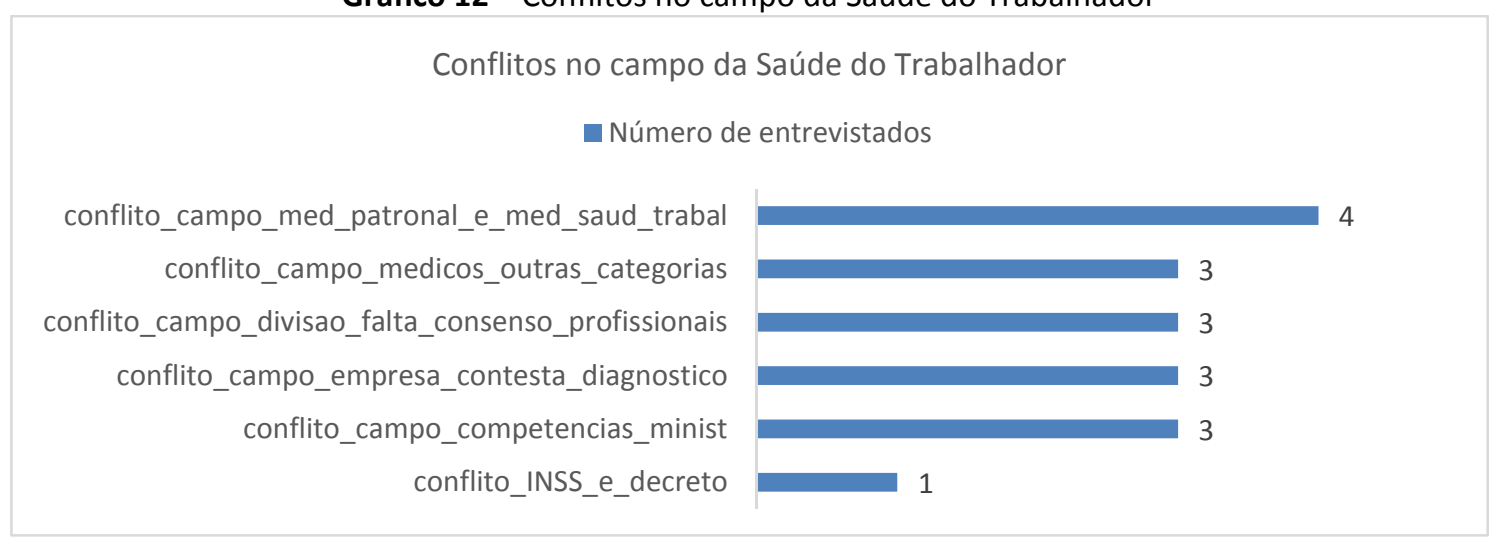

Fonte: Produzido pela autora no Sistema ATLAS.ti, a partir de dados das entrevistas da pesquisa de campo (2015).

Família 8.desafio_campo: desafios percebidos pelos entrevistados do campo da saúde do trabalhador, sobretudo quanto aos TMCs.

- 8.1.desafio_campo_ampliacao_debate: necessidade de ampliação do debate da academia com os serviços de saúde acerca dos TMCs.

- 8.2.desafio_campo_articulacao_poder_pub: necessidade de diálogo e articulação entre os órgãos do poder público.

- 8.3.desafio_campo_consenso_especialistas: necessidade de consenso entre os especialistas sobre os TMCs.

- 8.4.desafio_campo_interdiscip: necessidade de interdisciplinaridade no campo.

- 8.5.desafio_campo_caracterizacao_falta_concreto_visivel: dificuldade de diagnóstico dos TMCs, dada sua "invisibilidade"

- 8.6.desafio_campo_enfrentamento_discursos: necessidade de enfrentamento dos discursos hegemônicos, de que trabalho não adoece, por exemplo.

- 8.7.desafio_campo_formacao_qualificacao_profissional: necessidade de melhora da formação/qualificação dos profissionais da saúde com relação à saúde do trabalhador, sobretudo quanto aos TMCs.

- 8.8.desafio_campo_import_psicol_trab: necessidade de conscientização da importância do psicólogo no campo da Saúde do Trabalhador.

- 8.9.desafio_campo_formacao_pericia: necessidade de se investir na perícia do INSS.

- 8.10.desafio_campo_saude_trab_dialogo_saude: necessidade de se levar a Saúde do Trabalhador para a atenção básica, saúde da família, saúde mental.

- 8.11.desafio_campo_subjetividade_TMC: necessidade de se refletir sobre a subjetividade nos TMCs.

- 8.12.desafio_campo_uso_lista_B: necessidade de se difundir o uso da Lista B no campo da saúde.

- 8.13.desafio_campo_responsabilizacao: necessidade de conscientização dos profissionais de saúde da responsabilização para com os pacientes e com o território no qual trabalham com relação à Saúde do Trabalhador.

- 8.14.desafio_campo_mov_sind_pauta_saude: necessidade de reintroduzir o debate sobre a saúde nas pautas do movimento sindical.

- 8.15.desafio_campo_empoder_trabalhadores: necessidade de empoderar os trabalhadores. 
Gráfico 13 - Desafios no campo da Saúde do Trabalhador, sobretudo quanto aos TMCs

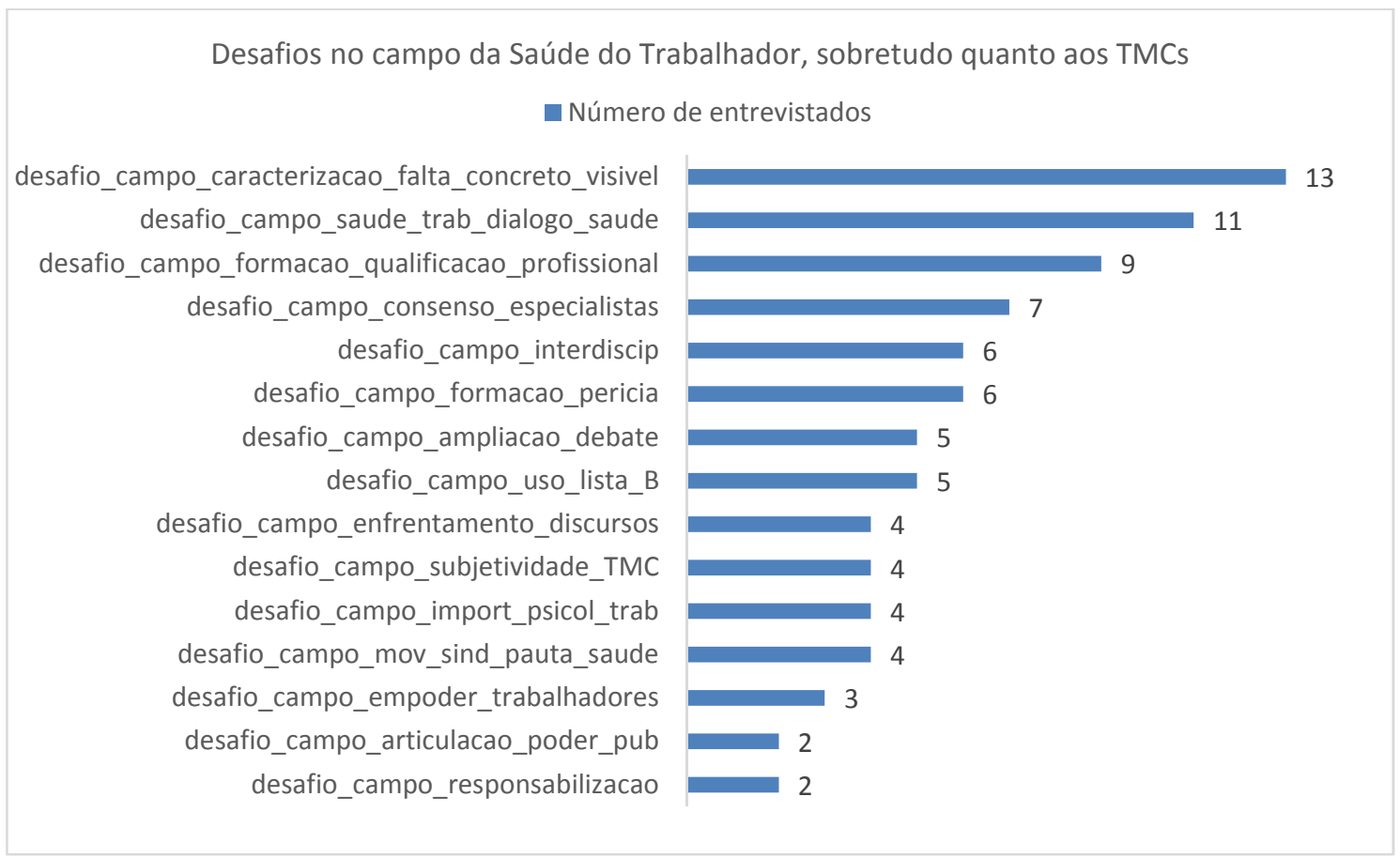

Fonte: Produzido pela autora no Sistema ATLAS.ti, a partir de dados das entrevistas da pesquisa de campo (2015).

Familia 9.determ_social: fatores, segundo os entrevistados, que determinam/promovem o "adoecimento" do trabalhador, sobretudo quanto aos TMCs.

- 9.1.determ_social_cobranca_pressao_no_trabalho: cobrança ou pressão no ambiente de trabalho.

- 9.2.determ_social_categ_econ_trabalhador: categoria econômica de origem do trabalhador.

- 9.3.determ_social_hist_cond_trab: TMCs como articulação entre história de vida e organização/condições de trabalho.

- 9.4.determ_social_desemprego: estar desempregado favorece/influencia o adoecimento.

- 9.5.determ_social_dific_mobilidade_urbana: mobilidade urbana (dificuldade de transporte público, trânsito caótico, etc.) gera estresse.

- 9.6.determ_social_sentido_trabalho: perda do sentido do trabalho.

- 9.7.determ_social_org_trabalho: organização do trabalho desempenhado pelo trabalhador.

- 9.8.determ_social_nov_TICs: novas tecnologias de informação e comunicação influenciam em como o trabalhador entende e realiza o trabalho; promoveriam "Seleção natural" dos que seriam mais adequados.

- 9.9.determ_social_precarizacao_trab: precarização do trabalho.

- 9.10.determ_social_reestrut_produtiva: reestruturação produtiva.

- 9.11.determ_social_trab_mal_visto_pela_empresa: necessidade de esconder a doença (trabalhador quando fica doente é malvisto pela empresa).

- 9.12.determ_social_violencia: violência vivida pelo trabalhador (no trabalho ou fora dele). 
Gráfico 14 - Fatores que influenciam no adoecimento, sobretudo quanto aos TMCs

Fatores que influenciam no adoecimento, sobretudo quanto aos TMCs

número de entrevistados

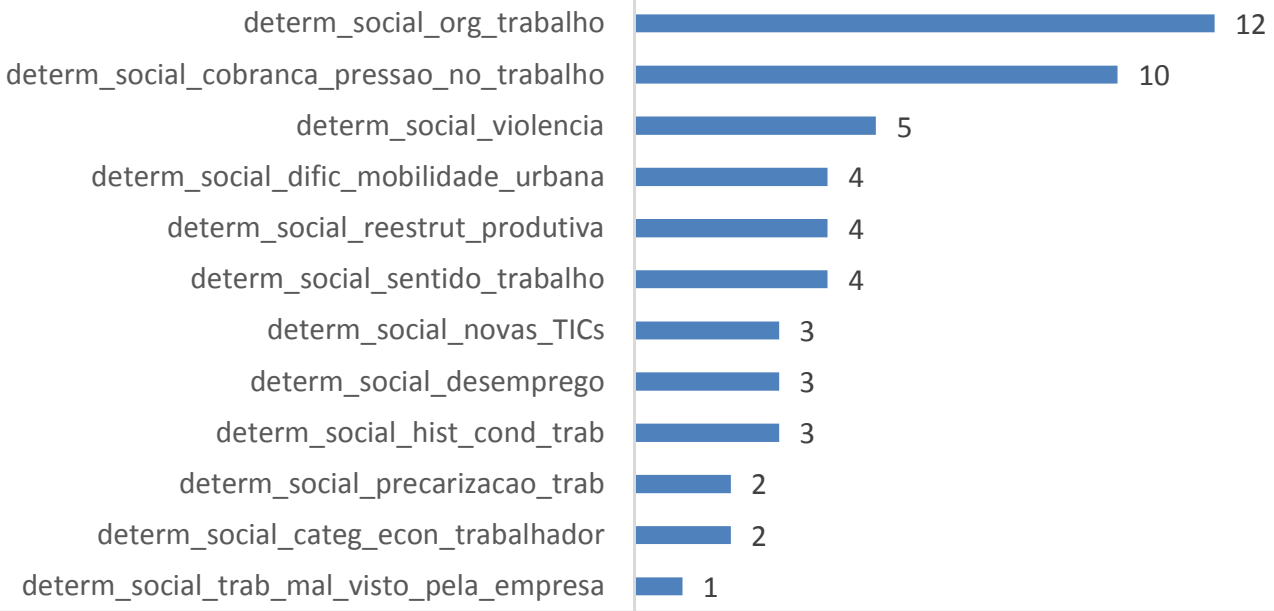

determ social_cobranca pressao no trabalho

Fonte: Produzido pela autora no Sistema ATLAS.ti, a partir de dados das entrevistas da pesquisa de campo (2015).

Família 10.dific_campo: dificuldades que o entrevistado aponta como limitadores para a atuação no campo da Saúde do Trabalhador, sobretudo quanto aos TMCs

- 10.1.dific_campo_articulacao_esferas_gov: dificuldade de articulação das esferas de governo (federal, estadual e municipal).

- 10.2.dific_campo_auto_culpab_paciente: autoculpabilização do trabalhador pela doença (inclusive mental), isentando a responsabilidade da empresa.

- 10.3.dific_campo_nao_prioridade_MS: a saúde do trabalhador não era uma prioridade política no Ministério da Saúde.

- 10.4.dific_campo_capacitacao_prof_saude: falta capacitação dos profissionais de saúde na área da Saúde do Trabalhador, sobretudo quanto à identificação dos TMCS. Dificuldade de reconhecimento pela atenção básica do trabalho como um fator de adoecimento (sobretudo quanto aos TMCs).

- 10.5.dific_campo_caract_rapidez_consulta: dificuldade no diagnóstico, sobretudo quanto aos TMCs, por causa da rapidez da consulta/procedimentos (não há tempo para o trabalhador relatar questões que possam identificar o trabalho como causa da doença).

- 10.6.dific_campo_caracterizacao_invisibilidade: dificuldade de diagnóstico dos TMCs dada sua "invisibilidade" (não é algo fácil de se identificar, é difícil o nexo com o trabalho), o que dificulta o convencimento médico nesses casos. Os médicos não possuem sensibilidade para identificar casos de TMCs.

- 10.7.dific_campo_desresponsabilizacao_medica: os médicos (atenção básica) não se "responsabilizam" pelo paciente, não o orientam quanto à condução de seu tratamento quando em interface com outras especialidades ou não o orientam quanto a seus direitos, p.ex.

- 10.8.dific_campo_dificuldade_modelo_aplicacao: modelo da Saúde do Trabalhador muito "intelectualizado", e faltariam metodologias; abordagem da assistência muito fragmentada.

- 10.9.dific_campo_falha_def_papel_CERESTs: falha na definição do papel dos CERESTs.

- 10.10.dific_campo_falta_profissionais: falta de profissionais de diversas áreas nos CERESTs.

- 10.11.dific_campo_ideologia_trabalho: ideologia de que o trabalho não poderia adoecer.

- 10.12.dific_campo_institucional_tecnica: dificuldade institucional/técnica sobretudo na relação com a perícia.

- 10.13.dific_campo_integracao_esferas_saude_gov: fragmentação de políticas e ações em Saúde do Trabalhador.

- 10.14.dific_campo_medicos_desestimulados: médicos desestimulados para atuar no campo de Saúde do Trabalhador. 
- 10.15.dific_campo_medicos_trabalho_lig_empresa: médicos do trabalho (patronais) são ligados às empresas e defendem seus interesses.

- 10.16.dific_campo_medo_paciente: medo em admitir que adoeceu no trabalho (sobretudo com os TMCs) por conta da possibilidade de perder o emprego/ ser retaliado pela empresa.

- 10.17.dific_campo_negacao_paciente: trabalhador nega que esteja doente (sobretudo com os TMCs).

- 10.18.dific_campo_particip_mov_trabalhador_pol_saud: dificuldade de engajamento dos movimentos sindicais em questões de saúde do trabalhador (sobretudo com os TMCs).

- 10.19.dific_campo_formaçao_profiss_saude: falta de formação dos profissionais de saúde quanto à Saúde do Trabalhador, sobretudo quanto aos TMCs.

- 10.20.dific_campo_reconhec_trab_doenca_mental: dificuldade de reconhecer que o trabalho pode acarretar "doença mental"; a "doença mental" do trabalhador não tem o trabalho como causa, mas, sim, questões individuais (problemas na família, afetivos etc.); culpabilização do trabalhador pela doença e individualização da questão.

- 10.21.dific_campo_rotatividade_profiss_saude: rotatividade dos profissionais de saúde que trabalham com atenção básica.

- 10.22.dific_campo_represent_mov_trab: dificuldade de representatividade dos trabalhadores no SUS.

- 10.23.dific_campo_INSS_neg_doenca_trab: o INSS nega a doença causada pelo trabalho (sobretudo os TMCs) e dificulta o acesso ao benefício pelo trabalhador.

- 10.24.dific_campo_medicalizacao: medicalização/psiquiatrização do trabalhador/ do trabalho.

Gráfico 15 - Dificuldades existentes no campo da Saúde do Trabalhador, sobretudo quanto aos TMCs

Dificuldades existentes no campo da Saúde do Trabalhador, sobretudo quanto aos TMCs

número de entrevistados

dific_campo_caracterizacao_invisibilidade 13

dific_campo_reconhec_trab_doenca_mental

dific_campo_formaçao_profiss_saude

dific_campo_capacitacao_prof_saude

dific_campo_institucional_tecnica

dific_campo_medicalizacao

dific_campo_particip_mov_trabalhador_pol_saud

dific_campo_negaçao_paciente

dific_campo_dificuldade_modelo_aplicacao

dific_campo_INSS_neg_doenca_trab

dific_campo_medo_paciente

dific_campo_integraçao_esferas_saude_gov

dific_campo_caract_rapidez_consulta

dific_campo_desresponsabilizacao_medica

dific_campo_falta_profissionais

dific_campo_represent_mov_trab

dific_campo_ideologia_trabalho

dific_campo_rotatividade_profiss_saude

dific_campo_auto_culpab_paciente
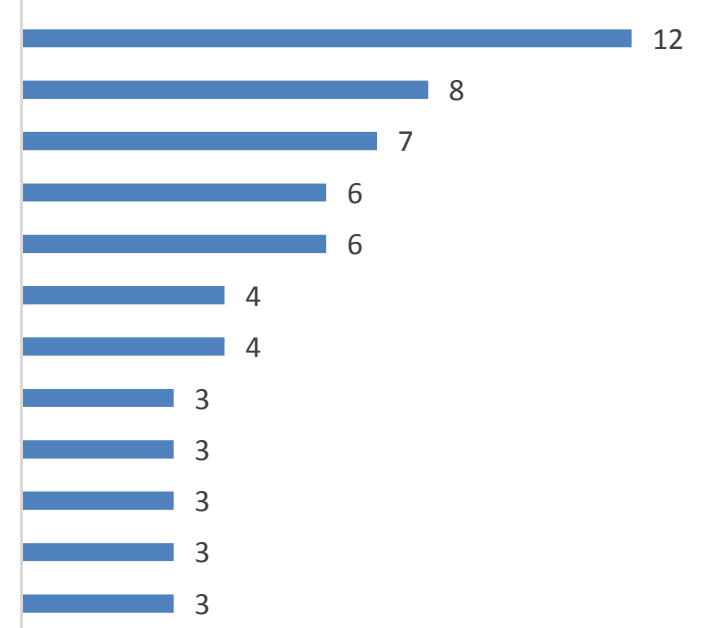
3

3

3

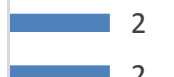

2
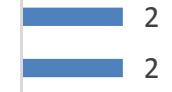

dific_campo_medicos_trabalho_lig_empresa

dific_campo_medicos_desestimulados

dific_campo_nao_prioridade_MS
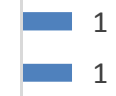

$$
1
$$


Família 11.encaminhamento: de onde vem o encaminhamento de trabalhadores adoecidos (sobretudo com TMCs).

- 11.1.encaminhamento_atencao_basica: encaminhamento vem da atenção básica.

- 11.2.encaminhamento_espontaneo: o próprio trabalhador procura o órgão de referência em saúde do trabalhador.

- 11.3.encaminhamento_sindicato: encaminhamento vem do sindicato.

- 11.4.encaminhamento_poucos_atenc_basica: poucos encaminhamentos da atenção básica.

- 11.5.encaminhamento_poucos_empresas: poucos encaminhamentos vêm das empresas.

- 11.6.encaminhamento_poucos_previdencia: poucos encaminhamentos vêm da previdência.

Gráfico 16 - Fontes de encaminhamento dos TMCs

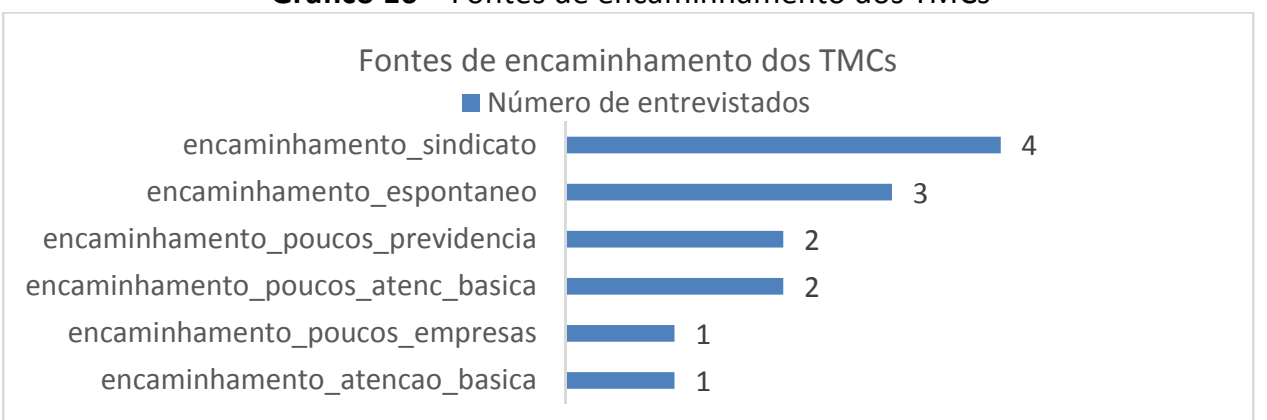

Fonte: Produzido pela autora no Sistema ATLAS.ti, a partir de dados das entrevistas da pesquisa de campo (2015).

Família 12.interes_campo_entrev: motivo pelo qual o entrevistado se interessou pelo campo da Saúde do Trabalhador.

- 12.1.interesse_campo_entrev_academia: interesse devido à academia (universidade).

- 12.2.interesse_campo_entrev_CEREST: interesse devido ao trabalho do CEREST.

- 12.3.interesse_campo_entrev_exper_pratica: interesse devido à experiência prática na área/em interface com Saúde do Trabalhador.

- 12.4.interesse_campo_entrev_pesquisa: interesse devido à pesquisa realizada no campo de saúde do trabalhador.

- 12.5.interesse_campo_atuacao_mov_sind: interesse devido à atuação no movimento sindical.

Gráfico 17 - Motivação do interesse do entrevistado pelo campo da Saúde do Trabalhador

Motivação do interesse do entrevistado pelo campo da Saúde do Trabalhador

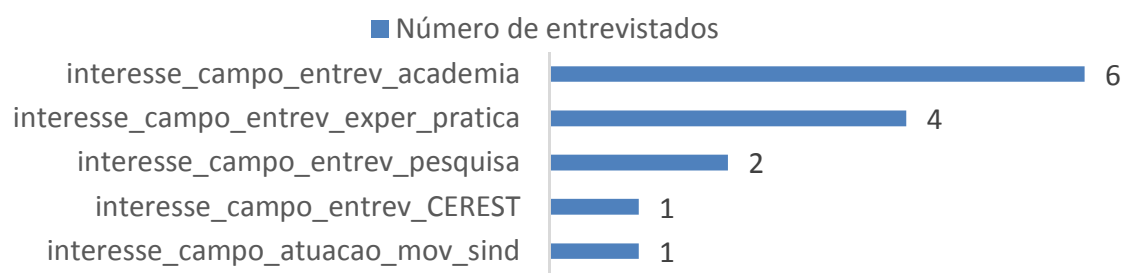

Fonte: Produzido pela autora no Sistema ATLAS.ti, a partir de dados das entrevistas da pesquisa de campo (2015).

Família 13.LISTA BeC: opiniões dos entrevistados quanto às listas B (Decreto 3048/1999) e C (Decreto 6957/2009).

- 13.1.LISTAB_aperfeicoamento: Lista B precisa de aperfeiçoamento/atualização.

- 13.2.LISTAB_conquista: Lista $B$ foi uma conquista política.

- 13.3.LISTAB_discussao_coletiva: Lista $B$ foi fruto de uma discussão coletiva.

- 13.4.LISTAB_conscientizacão: Lista B mobilizaria/disseminaria informações e promoveria conscientização para a Saúde do Trabalhador (inclusive os TMCs).

- 13.5.LISTAB_problem_enquadramento: Lista B tem problema de enquadramento das categorias.

- 13.6.LISTAB_problem_sem_especificidade_termo: Lista B tem o problema de não ter a especificidade dos termos/categorias abarcados.

- 13.7.LISTAB_sem_uso: Lista B não é utilizada/não teve impacto.

- 13.8.LISTAC_util_operacionalizavel: Lista C é boa por ser operacionalizável. 
Gráfico 18 - Opiniões dos entrevistados quanto às Listas " $B$ " e " $C$ "

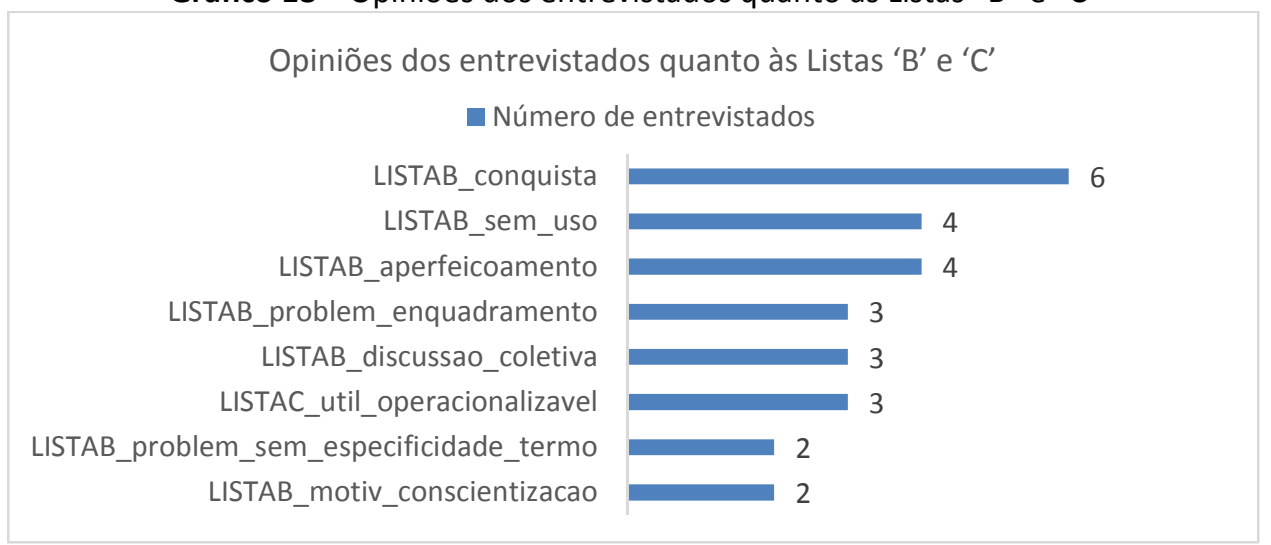

Fonte: Produzido pela autora no Sistema ATLAS.ti, a partir de dados das entrevistas da pesquisa de campo (2015).

Família 14.manual: opiniões dos entrevistados sobre o manual "Doenças relacionadas ao trabalho: Manual de procedimentos para os serviços de saúde".

- 14.1.manual_conseq_LISTAB: o manual foi consequência da Lista B.

- 14.2.manual_falha_repasse_prof_saude: o manual não foi bem repassado (ou não foi repassado) para os profissionais de saúde.

_ 14.3.manual_importante: o manual foi um passo importante (direcionamento).

Gráfico 19 - Opiniões dos entrevistados sobre o Manual do Ministério da Saúde

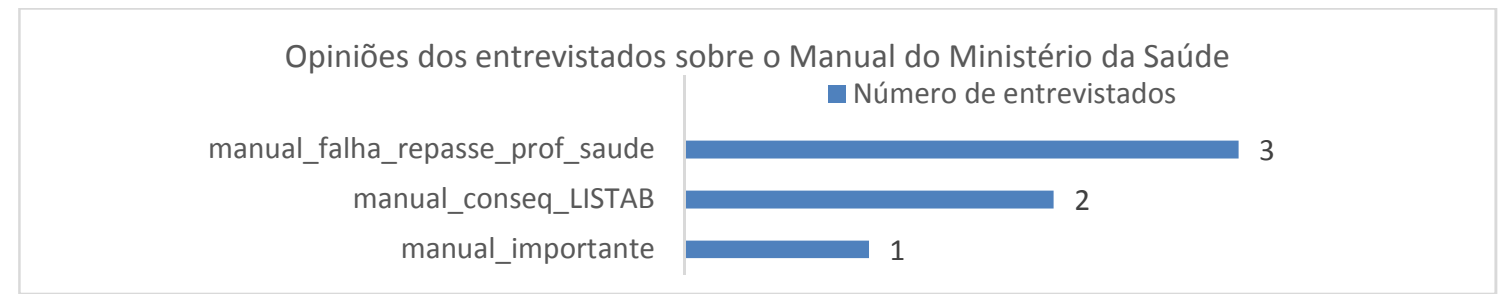

Fonte: Produzido pela autora no Sistema ATLAS.ti, a partir de dados das entrevistas da pesquisa de campo (2015).

Família 15.NTEP: opiniões dos entrevistados sobre o Nexo Técnico Epidemiológico Previdenciário (NTEP).

- 15.1.NTEP_conquista: NTEP foi uma conquista.

- 15.2 NTEP import epidemiologia: NTEP epidemiologia/diagnóstico/etiologia.

- 15.3.NTEP_import_padrao_doenca: NTEP é importante porque ajuda a configurar um padrão coletivo da doença.

- 15.4.NTEP_mais_dados_doenca: NTEP possibilita que se tenha mais dados sobre incidência da doença relacionada ao trabalho (inclusive os TMCs).

- 15.5.NTEP_ajuda_reconhecimento_visibilidade: NTEP propicia maior reconhecimento/visibilidade das doenças relacionadas ao trabalho, sobretudo TMCs.

- 15.6.NTEP_minimiza_ideia_doenca_individual: NTEP minimiza a ideia de doença individual (culpa do trabalhador).

- 15.7.NTEP_posit_agilidade_nexo: NTEP é positivo porque traz agilidade para a realização do nexo.

- 15.8.NTEP_pode_avancar: NTEP tem falhas e precisa de aperfeiçoamento, necessita de atualização.

- 15.9.NTEP_diverg_ideologia: NTEP é alvo de divergências ideológicas.

- 15.10.NTEP_empr_burlam_terceiriz: NTEP é burlado pelas empresas por meio da terceirização.

- 15.11.NTEP_impossibilidade_nexo_causal: com o NTEP é impossível fazer, epistemologicamente, nexo causal.

- 15.12.NTEP_incomodo_empresas: NTEP incomoda/é questionado pelas empresas.

- 15.13.NTEP_resistencia_pericia: NTEP é alvo de resistência da perícia. 
Gráfico 20 - Opiniões dos entrevistados sobre o NTEP

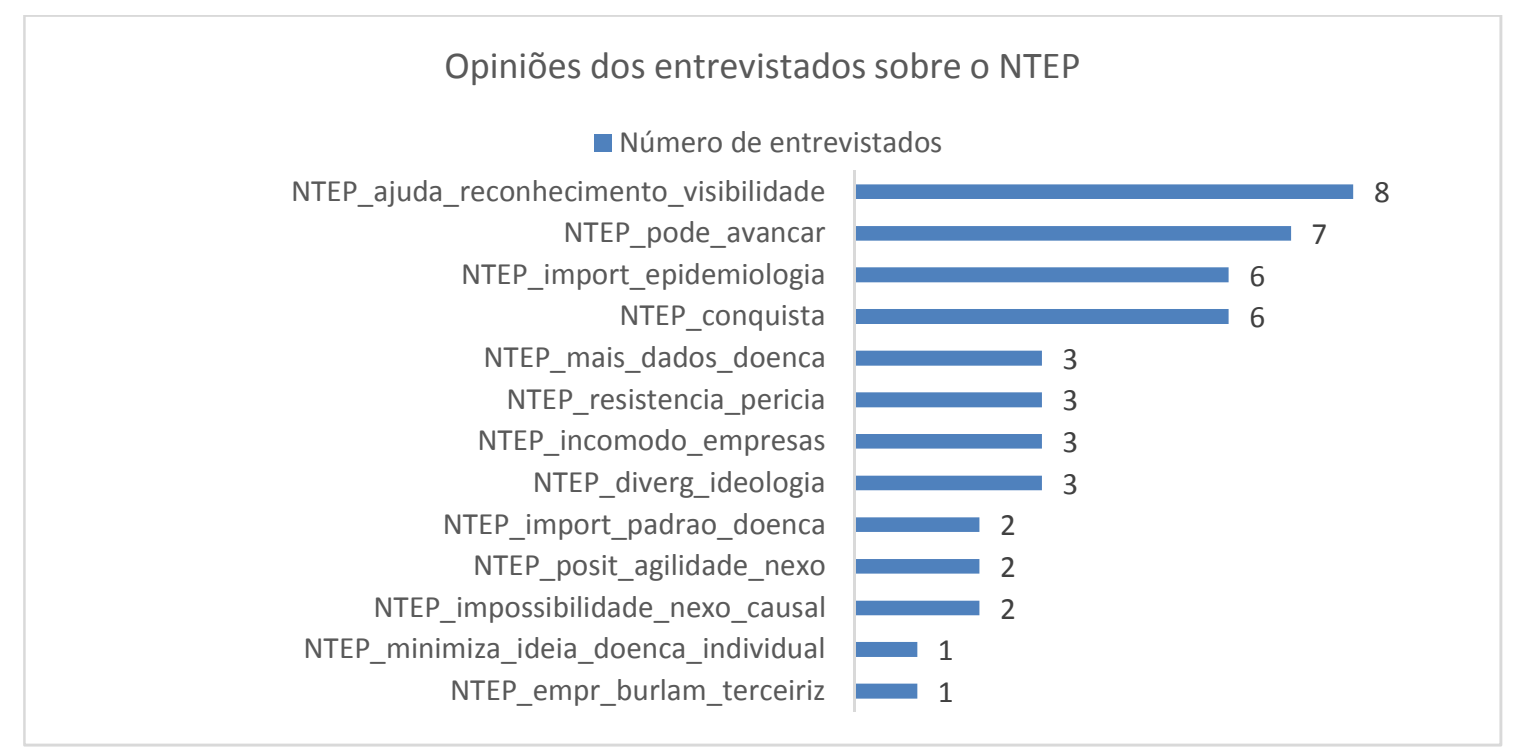

Fonte: Produzido pela autora no Sistema ATLAS.ti, a partir de dados das entrevistas da pesquisa de campo (2015).

Família 16.perfil_trab: categorias profissionais citadas pelos entrevistados com maior incidência de TMCs.

- 16.1.perfil_trab_bancarios: bancários.

- 16.2.perfil_trab_caixas_supermercado: caixas de supermercado.

- 16.3.perfil_trab_medicos: médicos (profissionais da área de saúde).

- 16.4.perfil_trab_metalurgicos: metalúrgicos.

- 16.5.perfil_trab_metroviarios: metroviários.

- 16.6.perfil_trab_motoristas_cobradores_onibus: motoristas e cobradores de ônibus.

- 16.7.perfil_trab_professores: professores.

- 16.8.perfil_trab_servidores_justica: servidores do Poder Judiciário.

- 16.9.perfil_trab_telemarketing: atendentes de telemarketing e telefonistas.

- 16.10.perfil_trab_agronegocio: trabalhadores do agronegócio.

16.11.perfil_trab_servicos_gerais: trabalhadores de serviços gerais.

16.12.perfil_trab_vigilantes: trabalhadores de serviços de vigilância.

Gráfico 21 - Perfil de profissões com maior incidência de TMCs

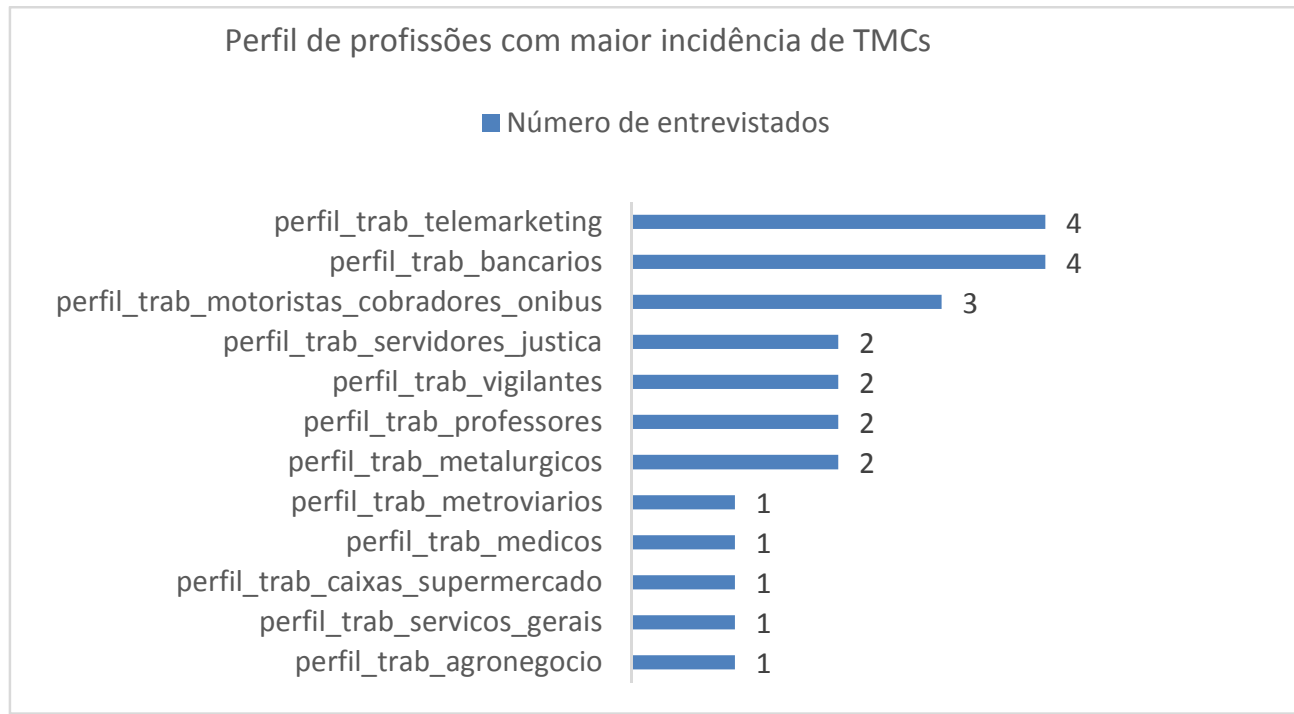

Fonte: Produzido pela autora no Sistema ATLAS.ti, a partir de dados das entrevistas da pesquisa de campo (2015). 
Família 17.pericia : opiniões dos entrevistados sobre a perícia do INSS.

- 17.1.pericia_sofre_funcao: perito tem sofrimento em sua função.

- 17.2.pericia_cota_afastamentos: perícia tem uma cota para afastamentos por doença do trabalho (os peritos só poderiam afastar determinado número de pessoas).

- 17.3.pericia_discorda_nexo: perícia discorda/questiona nexo feito pelo serviço de saúde.

- 17.4.pericia_do_"bem": existem peritos "do bem".

- 17.5.pericia_relacao_empresa: médico perito tem ligação/relação com as empresas e/ou adesão à Medicina do Trabalho.

- 17.6.pericia_renovacao: perícia se renovou.

- 17.7.pericia_sem_etica: peritos não têm ética.

- 17.8.pericia_sem_formacao: peritos não têm formação.

Gráfico 22 - Opiniões dos entrevistados sobre a perícia médica

Opiniões dos entrevistados sobre a perícia médica

- Número de entrevistados

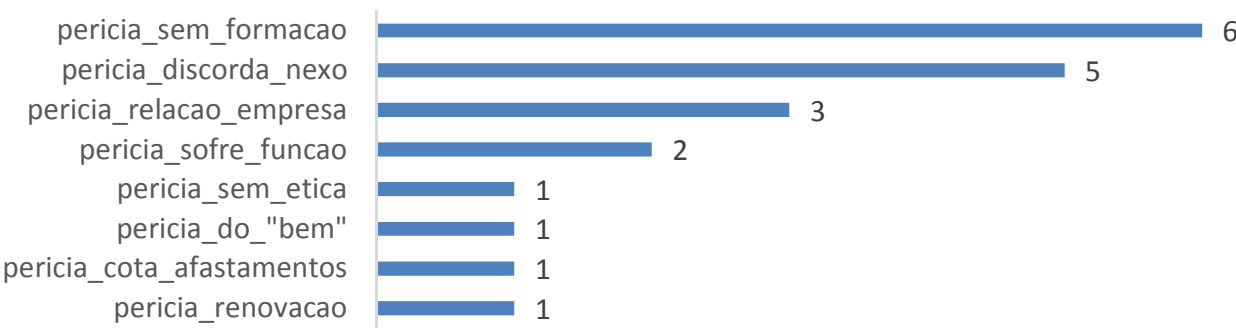

Fonte: Produzido pela autora no Sistema ATLAS.ti, a partir de dados das entrevistas da pesquisa de campo (2015).

Família 18.protocolo: opiniões dos entrevistados sobre o protocolo clínico para os TMCs.

- 18.1.protocolo_bom_instrum_mas_substituivel: protocolo seria um bom instrumento, mas é substituível, isto é, sua falta não impede que se faça um bom diagnóstico, por exemplo.

- 18.2.protocolo_mec_util_facilitador: protocolo é um instrumento que funcionaria como facilitador.

- 18.3.protocolo_dific_discordancia_grupos: protocolo não avançou porque havia discordância entre os grupos que participavam de sua elaboração.

- 18.4.protocolo_dific_operacionalizacao: protocolo não avançou por ser de difícil operacionalização.

- 18.5.protocolo_dific_recursos_prazos: protocolo não avançou por conta dos prazos curtos e/ou escassez de recursos.

- 18.6.protocolo_saude_protocolizada: práticas em saúde são cada vez mais protocolizadas.

- 18.7.protocolo_construcao_grupos_responsaveis: a construção do protocolo (tentativa) se deu por grupos de especialistas responsáveis.

- 18.8.protocolo_construcao_processo_participativo: a construção do protocolo (tentativa) se deu em um processo participativo.

- 18.9.protocolo_dific_plasticidade_TMC: a construção do protocolo é difícil por causa da plasticidade dos transtornos mentais e do comportamento.

- 18.20.protocolo_ou_outro_instrumento: questionamento se protocolo seria o melhor instrumento.

Gráfico 23 - Opiniões dos entrevistados sobre o Protocolo

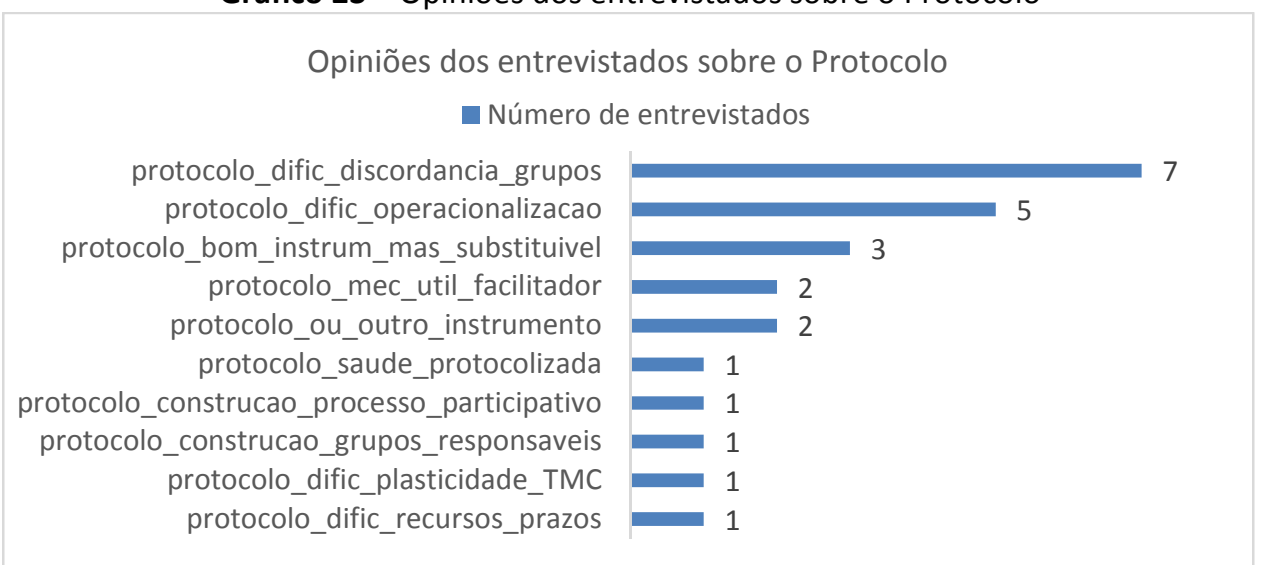

Fonte: Produzido pela autora no Sistema ATLAS.ti, a partir de dados das entrevistas da pesquisa de campo (2015). 
Família 19.psicologia: opiniões dos entrevistados sobre o papel, a função, a importância da Psicologia no campo da Saúde do Trabalhador.

- 19.1.psicologia_papel: papel importante da Psicologia nas relações entre trabalho e saúde.

- 19.2.psicologia_socialmente_responsavel: Psicologia deve ter atuação socialmente responsável.

- 19.3.psicologia_escuta: Psicologia como uma área da saúde que permite a escuta do relato do trabalhador.

- 19.4.psicologia_CEREST: importante participação da Psicologia nos CERESTs.

- 19.5.psicologia_lig_capital: a Psicologia possui ligação com o capital e trabalha a favor dele.

- 19.6.psicologia_sofreu_mudanca: a Psicologia sofreu mudanças.

- 19.7.psicologia_precisa_dialogo: a Psicologia precisa estabelecer diálogos, internamente e com outras categorias.

- 19.8.psicologia_almeja_campo_autonomo: a Psicologia almeja ser um campo autônomo.

- 19.9.psicologia_valorizacao_psicologo: valorização do trabalho realizado pelo psicólogo.

Gráfico 24 - Opiniões dos entrevistados sobre o papel da Psicologia na Saúde do Trabalhador

Opiniões dos entrevistados sobre o papel na Psicologia na Saúde do Trabalhador

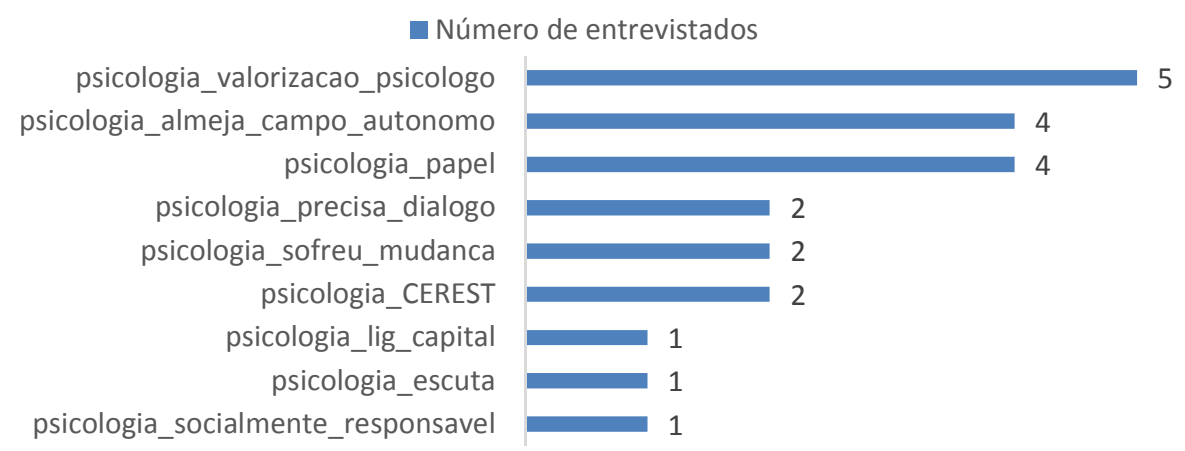

Fonte: Produzido pela autora no Sistema ATLAS.ti, a partir de dados das entrevistas da pesquisa de campo (2015).

Família 20.simulacao: opinião dos entrevistados sobre a simulação de doença ligada ao trabalho, sobretudo nos TMCs

- 20.1.simulacao_acusacao_fingimento: os médicos acusam os pacientes de fingirem TMCs.

- 20.2.simulacao_dignificacao_trab: discurso da simulação associado à concepção de dignificação do trabalho ("apologia do trabalho").

- 20.3.simulacao_subjet_invisib_doenca: simulação associada à dimensão subjetiva da doença (invisibilidade).

- 20.4.simulacao_dita_outra_forma_med: simulação é dita de outra forma pelo médico, isto é, o médico diz de outra maneira que o paciente está simulando.

- 20.5.simulacao_trabal_existe: alguns trabalhadores simulam de verdade.

Gráfico 25 - Opiniões dos entrevistados sobre "simulação"' de doenças, sobretudo dos TMCs

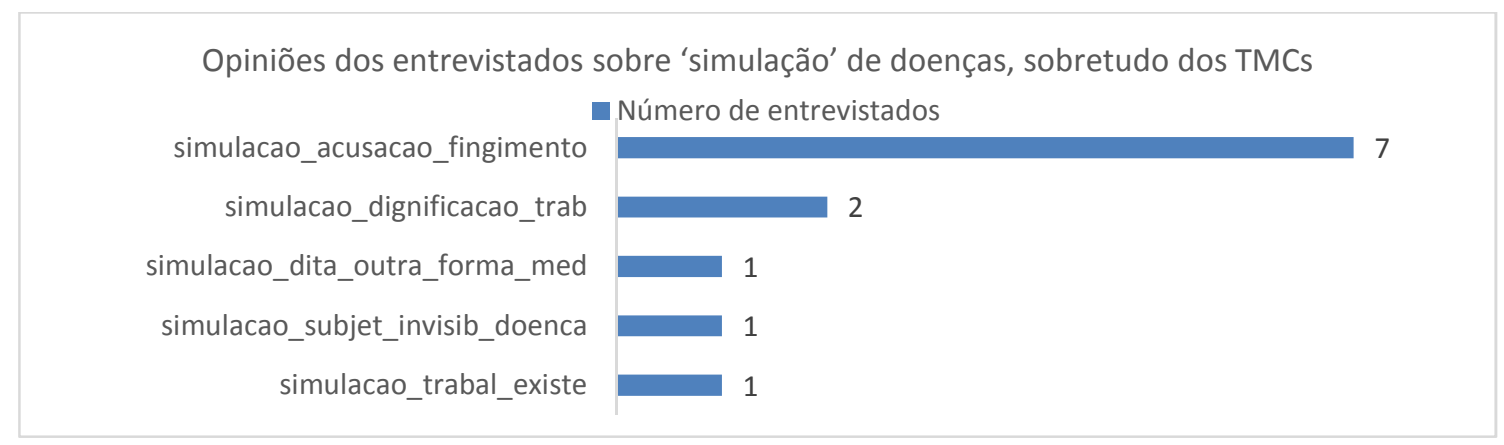

Fonte: Produzido pela autora no Sistema ATLAS.ti, a partir de dados das entrevistas da pesquisa de campo (2015). 
Família 21.terminologia_campo: divergências (ou sugestões de reflexão) citadas pelos entrevistados sobre terminologias usada no campo da saúde do trabalhador.

- 21.1.terminologia_campo_adoecimento: reflexão sobre o termo "adoecimento"/identidade do doente.

- 21.2.terminologia_campo_doenca_mental_nao_existe: “doença mental” não existe.

- 21.3.terminologia_campo_medicina_do_trabalho_pejorativo: medicina do trabalho/médicos patronais têm uma conotação negativa, pejorativa.

- 21.4.terminologia_campo_sofrimento: reflexão sobre o termo "sofrimento" no campo de saúde do trabalho.

- 21.5.terminologia_campo_sofrimento_mental_dif_adoecimento: "sofrimento mental" é diferente de "adoecimento".

- 21.6.terminologia_campo_transtorno_dif_doenca: "transtorno" é diferente de "doença".

- 21.7.terminologia_campo_transtorno_dif_sofrimento: "transtorno" é diferente de "sofrimento".

- 21.8.terminologia_campo_transtorno_implica_controle: o uso do termo "transtorno" implica o controle e não a cura.

- 21.9.terminologia_campo_psicol_social_dif_psicol_organizacoes: “psicologia do trabalho" é diferente da "psicologia das organizações".

Gráfico 26 - Reflexões sobre terminologias usadas no campo da Saúde do Trabalhador, sobretudo sobre os TMCs

Reflexões sobre terminologias usadas no campo da Saúde do Trabalhador, sobretudo com relação aos TMCs

- Número de entrevistados

terminologia_campo_sofrimento_mental_dif_adoecimento

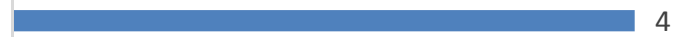

terminologia_campo_psicol_social_dif_psicol_organizacoes

terminologia_campo_medicina_do_trabalho_pejorativo

terminologia_campo_transtorno_dif_doenca

terminologia_campo_sofrimento

terminologia_campo_doenca_mental_nao_existe

terminologia_campo_transtorno_implica_controle

terminologia_campo_transtorno_dif_sofrimento

terminologia_campo_adoecimento

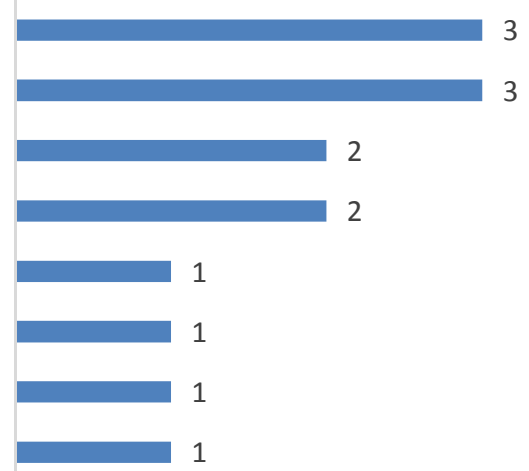

3

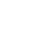

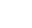

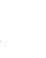


- 22.7.visibilidade_campo_surg_LER: o campo da saúde mental e trabalho ganhou visibilidade a partir do surgimento das Lesões por Esforço Repetitivo (LER).

- 22.8.visibilidade_campo_stress: o campo da saúde mental e trabalho ganhou visibilidade a partir das discussões sobre estresse.

- 22.9.visibilidade_campo_Le_Guillant: o campo da saúde mental e trabalho foi inspirado pela obra de Le Guillant.

Gráfico 27 - Quando/por que começa a visibilidade da Saúde Mental e Trabalho/dos TMCs

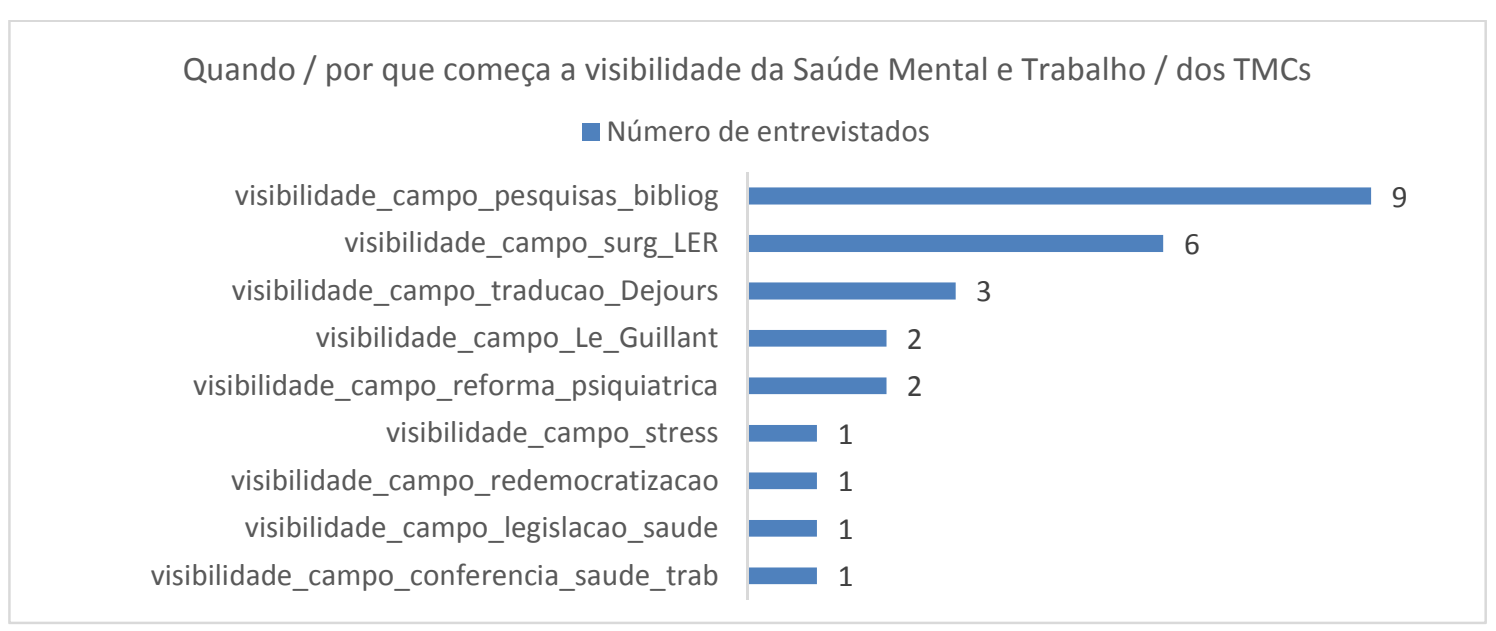

Fonte: Produzido pela autora no Sistema ATLAS.ti, a partir de dados das entrevistas da pesquisa de campo (2015).

Família 23.pont_positivo_campo: pontos positivos/avanços do campo da Saúde do Trabalhador identificados pelo entrevistado.

- 23.1.pont_positivo_campo_reconh_transtorno_mental: o entrevistado identifica como positivo o reconhecimento de que o transtorno mental pode ser gerado pelo trabalho.

- 23.2.pont_positivo_campo_positivo_atencao_poder_publ: o entrevistado identifica maior atenção do poder público para com a Saúde do Trabalhador/TMCs.

- 23.3.pont_positivo_campo_melhora_relacao_pericia: o entrevistado identifica mudança mentalidade e/ou melhor relacionamento com a perícia do INSS.

- 23.4.pont_positivo_campo_positivo_mais_profis_saude_trabalho: o entrevistado identifica maior quantidade de profissionais no campo da Saúde do Trabalhador.

- 23.5.pont_positivo_campo_NTEP: o entrevistado identifica a relevância/importância do NTEP para o reconhecimento dos TMCs.

- 23.6.pont_positivo_campo_valorizacao_psicologo: o entrevistado identifica a valorização da relevância/importância do papel do psicólogo.

Gráfico 28 - Pontos positivos / avanços do campo da Saúde do Trabalhador

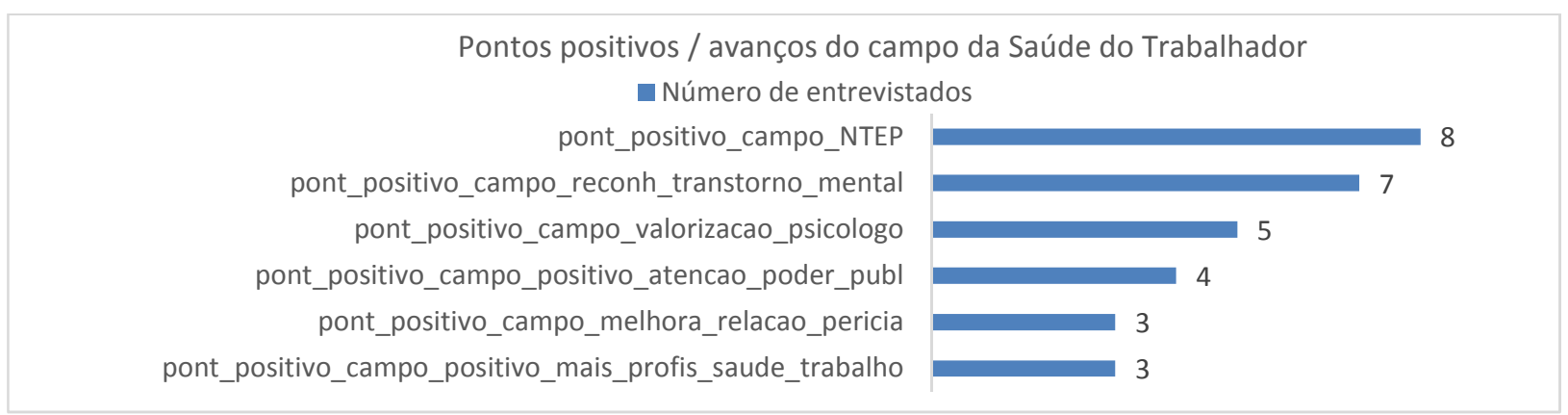

Fonte: Produzido pela autora no Sistema ATLAS.ti, a partir de dados das entrevistas da pesquisa de campo (2015). 


\section{Apêndice $E-O$ processo de inclusão dos TMCs na Lista B}

A seguir, apresentam-se excertos da entrevista realizada em 18 de setembro de 2014 pela autora com Silvia Rodrigues Jardim, uma das envolvidas no processo de construção da Lista B (Decreto 3048, de 1999) e responsável pela redação do capítulo sobre os Transtornos Mentais e do Comportamento Relacionados ao Trabalho da obra "Doenças relacionadas ao trabalho: manual de procedimentos para os serviços de saúde" (2001).

Esses aqui que entraram [transtornos da lista] foram o nosso consenso naquela época. [...] Um consenso, digamos assim, momentâneo, porque havia dúvidas no grupo todo em relação se a lista era uma boa ou não, mas acabou ganhando isso de não deixar os transtornos mentais de fora, deixar lá pelo menos a ponta do iceberg, sabendo que o continente era muito maior... Poderia ser muito maior (JARDIM, 2014, entrevista).

Isso é que é interessante na lista, que ela já usa o que tem [classificação da CID]. Então tudo já está na CID, na CID 10. Inclusive a coluna 2, dos agentes etiológicos, tudo tem numeração na CID, eles são bem conhecidos. [Então foi também uma estratégia de legitimação da própria Lista?] Uma estratégia de legitimação. Não tinha ninguém ingênuo ali (JARDIM, 2014, entrevista).

Quadro 5- Processo de inclusão das doenças na Lista B

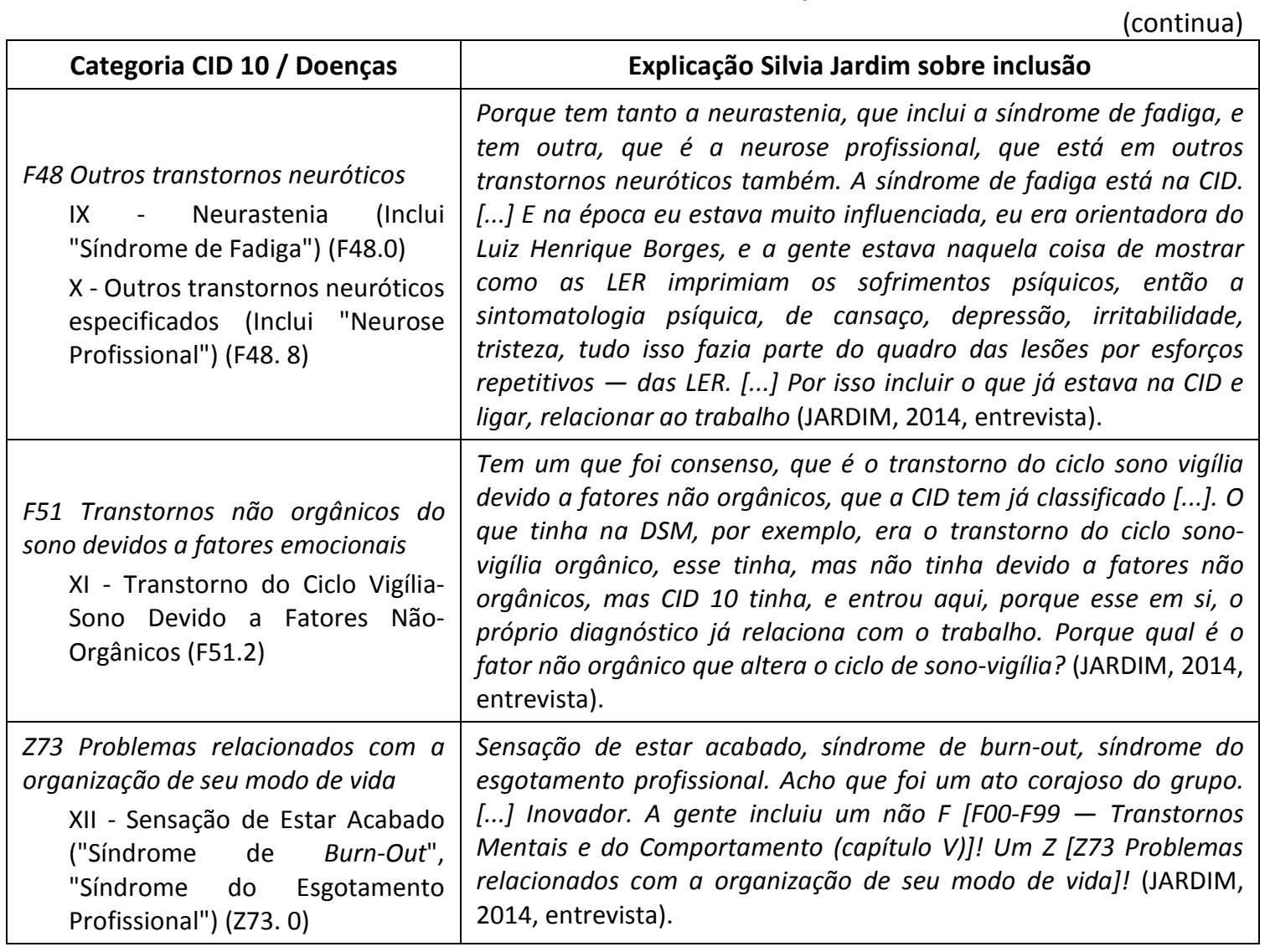


Quadro 5 - Processo de inclusão das doenças na Lista B

(conclusão)

\begin{tabular}{|c|}
\hline Categoria CID 10 / Doenças \\
\hline $\begin{array}{l}\text { F02* Demência em outras doenças classificadas em } \\
\text { outra parte }\end{array}$ \\
\hline $\begin{array}{l}\text { I - Demência em outras doenças específicas } \\
\text { classificadas em outros locais (F02.8) }\end{array}$ \\
\hline $\begin{array}{l}\text { F05 Delirium não induzido pelo álcool ou por outras } \\
\text { substâncias psicoativas }\end{array}$ \\
\hline $\begin{array}{l}\text { II - Delirium, não sobreposto a demência, como } \\
\text { descrita (F05.0) }\end{array}$ \\
\hline
\end{tabular}

F06 Outros transtornos mentais devidos a lesão $e$ disfunção cerebral e a doença física

III - Outros transtornos mentais decorrentes de lesão e disfunção cerebrais e de doença física (F06.-): Transtorno Depressivo Orgânico (F06.32); Transtorno Afetivo Misto Orgânico (F06.33); Transtorno Cognitivo Leve (F06.7)

III - Outros transtornos mentais decorrentes de lesão e disfunção cerebrais e de doença física (F06.-): transtorno cognitivo leve (F06.7) (Redação dada pelo Decreto no 3.265, de 1999)

F07 Transtornos de personalidade $e$ do comportamento devidos a doença, a lesão $e$ a disfunção cerebral

IV - Transtornos de personalidade e de comportamento decorrentes de doença, lesão e de disfunção de personalidade (F07.-): Transtorno Orgânico de Personalidade (F07.0); Outros transtornos de personalidade e de comportamento decorrentes de doença, lesão ou disfunção cerebral (F07.8)

F09 Transtorno mental orgânico ou sintomático não especificado

V - Transtorno Mental Orgânico ou Sintomático não especificado (F09.-)

\section{Explicação Silvia Jardim sobre inclusão}

Tem cinco categorias de transtornos mentais orgânicos e houve a intenção de fazer isso porque, exatamente, muitas vezes quadros de déficit cognitivo leve, e que aparecem como nervosismo, têm uma base orgânica relacionada ao trabalho, exatamente isso é que passa mais despercebido, inclusive pelos especialistas.

[...] Então, tem outra coisa que é o consenso, isso foi mais fácil, então por isso que a gente colocou cinco cinco! - para a demência. E eu fiz questão, isso eu vou colocar em nome próprio, do delírio, que é um quadro agudo ou subagudo, mas que passa muito despercebido, porque, por exemplo, é o coma ou o estado confusional pós traumatismo cranioencefálico. [...] Ou intoxicação com monóxido de carbono, [tem] por aí à vontade. E isso está tudo escrito depois lá no Manual. A pessoa desenvolve um quadro confusional, sai falando muito bem, obrigado, só que a lesão ficou.

Então é por isso que entrou transtorno de personalidade, comportamento devido a doença, a lesão e disfunção cerebral. Porque nós já tínhamos visto aqui, nós atendemos aqui um segurança, um segurança da universidade, um rapaz que levou uma coronhada, desenvolver um quadro de total transtorno de personalidade. Agora, cabe segurança que virou uma besta, o pessoal vai dizer que é porque ele já era uma besta antes. Mas não é não! Ele teve um afundamento craniano, lesou exatamente o lobo frontal esquerdo, e fez um quadro "de livro", que a gente apresentou aqui numa sessão clínica, exercendo seu trabalho. Ele desenvolveu um transtorno de personalidade. E o transtorno mental orgânico sintomático não especificado, exatamente para pegar os casos leves. É por isso que entrou tantas vezes (JARDIM, 2014, entrevista).

F10.- Transtornos mentais e comportamentais devidos ao uso de álcool

VI - Transtornos mentais e comportamentais devidos ao uso do álcool: Alcoolismo Crônico (Relacionado com o Trabalho) (F10.2)

F43 Reações ao "stress" grave e transtornos de adaptação

VIII - Reações ao Stress Grave e Transtornos de Adaptação (F43.): Estado de Stress PósTraumático (F43.1)
O alcoolismo, a gente discutiu bastante mesmo nesse dia [da reunião realizada] de entrar o alcoolismo relacionado ao trabalho (JARDIM, 2014, entrevista).

O transtorno de "stress" pós-traumático, por exemplo, está [na CID-10 e no DSM] por causa dos americanos, foi uma pressão, isso inclusive está no registro, foi uma pressão especialmente daquela Associação dos Veteranos de Guerra... E também do pessoal americano ligado aos bairros pobres, o Hart e a Yehuda [...] (JARDIM, 2014, entrevista).

Fonte: entrevista realizada pela autora com Silvia Rodrigues Jardim em 18 de setembro de 2014. 


\title{
Apêndice $\mathrm{F}-0$ processo de construção do protocolo para TMCs
}

\author{
A seguir, apresentam-se excertos de entrevistas realizadas em 2014 pela autora com \\ Andreia De Conto Garbin, Silvia Rodrigues Jardim e Edith Seligmann-Silva, envolvidas \\ (em momentos distintos) no processo de tentativa de construção de protocolo para os \\ Transtornos Mentais e do Comportamento Relacionados ao Trabalho.
}

\begin{abstract}
Depois então que nós tivemos esse momento da finalização das listas de agravos, e como a Lista B do INSS e aquela lista do Ministério da Saúde, que é do Manual, aí já o Marco [Antonio Gomes] Pérez [Ministério da Saúde], já com esse novo grupo, [...] eles definiram como uma estratégia do Ministério [da Saúde], que para cada um dos dez agravos que estavam elencados [...] seriam elaborados protocolos (GARBIN, 2014, entrevista).
\end{abstract}

Então novamente houve uma mobilização de profissionais que foram convidados, [...] com uma organização um pouquinho diferente da anterior. $\mathrm{Na}$ anterior eram grupos [...] mais informais. [...] Quando chegou o momento do protocolo, houve uma organização com [...] pessoas responsáveis pelo protocolo de tal coisa, de tal doença, de tal agravo (GARBIN, 2014, entrevista).

No caso dos transtornos mentais, a primeira pessoa que ficou responsável foi uma médica do Espírito Santo, Denise [Rozindo Bourguignon]. [...] E o processo de elaboração, ele seria um processo participativo. Então, de novo ali a ideia de chamar e convidar pessoas de universidades, de serviços, profissionais atuantes na área. Mas esse protocolo de saúde mental, ele foi desde esse momento, patinando um pouco, patinando. Enquanto alguns conseguiram então estruturar os grupos de discussões, alguns realizaram pequenos eventos, debates, fóruns, e tudo mais, esse de saúde mental, ele acabou... ficando (GARBIN, 2014, entrevista).

Nós não tínhamos notícias, e depois, em um segundo momento, aí nós tínhamos a notícia que a Denise [...] não conseguiria conduzir o trabalho, [...] ai houve um contato com o professor Álvaro [Roberto Crespo] Merlo, lá do Rio Grande do Sul. Então também foi [...] um profissional envolvido nessa discussão do protocolo. Aí [...] acho que tinha algumas questões já de prazos, de recursos, envolvidos nisso tudo, e que dificultaram também o encaminhamento (GARBIN, 2014, entrevista).

Depois nós tivemos o momento e o esforço grande do Drummond [Francisco Drummond Marcondes de Moura Neto], que estava no Ministério [da Saúde], de que o protocolo fosse elaborado. E aí ele tentou fazer um movimento bem [...] grande, de procurar, contatar vários profissionais da área da saúde mental, muitos [...] dos serviços, outros da academia, e aí lembro que também de novo nós tivemos reuniões [...]. Ele usou uma estratégia assim de tentar mobilizar por agravos. E aí também era difícil, pensar em muitos grupinhos discutindo o tema por agravos. Também foi um processo que ficou um pouco moroso, com reuniões, mas que faltou [...] uma proposta assim mais formatada, uma condução por, talvez, já alguns parâmetros para elaboração do documento, e aí ele não avançou (GARBIN, 2014, entrevista). 
Então [...] talvez, na área de saúde mental, em minha opinião, talvez na área de saúde mental nós também tivéssemos que exercitar que o protocolo ia ser mais difícil de chegar a algum consenso, e que talvez nós tivéssemos que partir para uma outra lógica de construção, de algum documento norteador, orientador [...] (GARBIN, 2014, entrevista).

Já dando um salto, [a questão do protocolo] ainda foi tema de discussão já agora há um ano e meio atrás. Eu participei de uma reunião lá em Brasília, sob a gestão do Carlos [Augusto] Vaz [de Souza] no Ministério [da Saúde], com ainda tentativas de rearticular uma atividade, uma construção coletiva desse, que [...] nós chamamos sempre de protocolo, mas que poderia ser em outra configuração. Nessa reunião mais recente estávamos eu, a Márcia Hespanhol [Bernardo] lá de Campinas, o próprio Drummond, o Álvaro Merlo, que fez uma recuperação desse processo, por isso que eu sei de algumas coisas que ele contou, tinha a Silvia Jardim lá do Rio de Janeiro também... Enfim, foi uma discussão de um grupo menor, mas que tinha ainda essa [...] luz de podermos continuar. Mas aí já acho que não tivemos depois nenhum movimento de elaboração, de construção do protocolo (GARBIN, 2014, entrevista).

[...] A Coordenação de Saúde do Trabalhador no Ministério [da Saúde] me chamou uma vez, depois falou que ia chamar mais, e nada aconteceu (JARDIM, 2014, entrevista).

Vou te dizer sinceramente, eu participei de várias reuniões sobre esse protocolo, porque o protocolo estava sendo cobrado por todo mundo, e houve dois psiquiatras que procuravam fazer o protocolo e houve reuniões para discutir esses protocolos que eles formularam e eu li, eu tenho inclusive tudo isso, um material enorme [...]. Era inviável! Fizeram com muita boa vontade, com muito esforço, mas me pareceu que esquecendo que, na maior parte do nosso serviço de saúde, não existem nem psiquiatras nem psicólogos, e muito menos aqueles com formação em psicopatologia do trabalho para poder preencher o que eles formularam (SELIGMANN-SILVA, 2014, entrevista).

Não quero questionar. [...] E havia algumas perguntas infelizes, por exemplo, um dos protocolos começava com uma das primeiras perguntas: "Você já sofreu assédio moral?" Você já imagina se a pessoa vai se retrair diante dessa pergunta [...]. E quantos trabalhadores sabem? Hoje em dia muitos sabem, mas o mais humilde lá do interior, tal, sabe o que é assédio moral? (SELIGMANNSILVA, 2014, entrevista). 


\section{Apêndice G - As Conferências Nacionais de Saúde do Trabalhador (CNST)}

\section{CNST (1986)}

A I Conferência Nacional de Saúde do Trabalhador, realizada em 1986, marcou-se pelas discussões que visavam formular conteúdos para a Política Nacional de Saúde do Trabalhador, que seriam, posteriormente, incorporados na Constituição Federal de 1988 e na Lei n ${ }^{\circ} 8080$, de 1990 . A coordenação da organização da conferência foi realizada pelo CESTEH/FIOCRUZ (Centro de Estudos da Saúde do Trabalhador e Ecologia Humana, da Escola Nacional de Saúde Pública), sendo que, dos delegados participantes, apenas $1 \%$ representava o empresariado. O relatório final da Conferência estabelecia que a saúde dos trabalhadores extrapolaria os limites da saúde ocupacional; introduzia o conceito ampliado de saúde; afirmava a necessidade de revisar a legislação e de ampliação das listas de doenças ocupacionais; destacava a necessidade de uma legislação única que assegurasse os mesmos direitos a todos, fossem trabalhadores urbanos, rurais, de instituições públicas ou empresas privadas. Enfatizou-se também a necessidade da criação de um Sistema Único de Saúde, da criação de programas específicos de atendimento ao trabalhador, bem como do descredenciamento da rede privada para esses atendimentos. As ações de fiscalização deveriam ser de responsabilidade do SUS, com a participação dos trabalhadores, evitando conflitos éticos de profissionais vinculados a empresas participando dessa fiscalização. Criticou-se também a subordinação dos SESMTs (Serviços de Engenharia, Segurança e Medicina do Trabalho) às empresas, sugerindo-se que estes estivessem sob o controle dos sindicatos ou de associações de classe. O relatório também destacou a necessidade de se envolverem os sindicatos na questão da saúde como objetivo de luta e, em seu eixo "Política Nacional de Saúde dos Trabalhadores", estabelecia os direitos básicos de saúde do trabalhador (NARDI; RAMMINGER, 2012).

\section{CNST (1994)}

A II Conferência Nacional de Saúde do Trabalhador ${ }^{221}$ foi realizada em 1994, já sob os marcos estabelecidos pela Constituição Federal (de 1988) e da Lei Orgânica da Saúde (de 1990) de incorporação da atenção à saúde dos trabalhadores como papel do SUS; - o tema central da Conferência foi a unificação das ações de Saúde do Trabalhador no SUS e a discussão das dimensões dessa política políticas, sociais, econômicas, técnicas e gerenciais (NARDI; RAMMINGER, 2012). Nessa conferência, ocorreram quatro mesas-redondas e oito painéis específicos, entre eles, um sobre Saúde Mental, coordenado por Leny Sato, que representou o DIESAT. Sato indicou que, apesar de já há décadas ocorrer internacionalmente o reconhecimento de que determinadas formas de organização do trabalho, produtos químicos e novas tecnologias pudessem ser nocivas à saúde mental do trabalhador, no Brasil,

221 Os Anais da II Conferência Nacional de Saúde do Trabalhador não foram encontrados para consulta. O Ministério da Saúde foi contatado por meio de e-mails encaminhados a diferentes áreas, mas não houve resposta. 
esse reconhecimento se deu, sobretudo, a partir da década de $80^{222}$, quando pesquisadores brasileiros da área começaram a contribuir para o campo da Saúde do Trabalhador, subsidiando e ampliando as atuações tanto dos serviços públicos como dos sindicatos (SILVA, 2011; NARDI; RAMMINGER, 2012). A avaliação da coordenadora do painel destacou que, não obstante as discussões sobre saúde mental e trabalho não constituírem tema prioritário para várias categorias de trabalhadores, sua atuação se concentrando em questões como acidentes fatais e graves, contaminações e doenças profissionais incapacitantes (SILVA, 2011), observava-se maior número de sindicatos atuantes nessa discussão (NARDI; RAMMINGER, 2012).

Outro expositor desse painel foi Pérsio Dutra, também representando o DIESAT e à época diretor do DIESAT e do Sindicato dos Trabalhadores em Processamento de Dados e Empregados em Empresas de Processamento de Dados do Estado de São Paulo. Sua exposição reforçou a questão de a saúde mental e trabalho não se constituir como preocupação generalizada do movimento sindical, sendo tratada como "um problema localizado para algumas categorias profissionais, que só recentemente passaram a Ihe dar a importância devida" (DUTRA, 1994 apud SILVA, 2011, p.121). Os "problemas de sofrimento mental" geralmente chegariam aos sindicatos mascarados como manifestações orgânicas ou de problemas nas relações interpessoais dentro ou fora do trabalho. Dutra destacou também a necessidade do reconhecimento da relação de causalidade entre o trabalho (e sua organização) e os agravos mentais, criticando a prática usual de imputar os "problemas mentais" a características individuais do trabalhador, negando sua relação com as condições de trabalho e de vida. Outras dificuldades para se estabelecer essa relação de causalidade (nexo) seriam a negação por parte de médicos de empresas em fazê-lo, o despreparo dos sindicatos para esse reconhecimento e sua defesa, dificuldades dos profissionais da rede de saúde pública, bem como a frequente atribuição, pela perícia do INSS, dos agravos identificados a questões individuais, portanto sem relação com o trabalho (NARDI; RAMMINGER, 2012). Também constituiriam dificuldades as próprias características dos "problemas mentais", sobretudo em seu aspecto de 'invisibilidade' ou, nos termos de Silva (2011, p.127), "pelo caráter pouco objetivo de suas manifestações". Outro fator dificultador adicional seria o preconceito ou discriminação enfrentados pelos trabalhadores perante representantes sindicais, médicos e a sociedade em geral.

Outro participante do painel, Luiz Henrique Borges, médico psiquiatra e pesquisador da Fundacentro, ressaltou que, a partir do novo conceito de saúde introduzido a partir da I CNST, que considerava a subjetividade dos trabalhadores nos estudos, tornou-se possível a compreensão do surgimento de questões como alguns tipos de doenças mentais entre os digitadores, as manifestações das LER e os "altos índices de suicídio, uso de bebidas alcoólicas e drogas, vício pelo trabalho (workaholics), mortes e

222 A coordenadora do painel destacou que, embora tenham existido outros estudos antes desse período, "talvez por não contar com outros segmentos da sociedade preocupados com a questão, não se inseriam no âmbito da discussão de saúde do trabalhador" (SATO, 1994 apud SILVA, 2011, p. 125). 
adoecimento por estafa e estresse mental, distúrbios psicossomáticos, etc." (BORGES, 1994 apud SILVA, 2011, p. 125).

Em sua análise dos documentos da II CNST, Silva (2011) destaca que um importante elemento para a compreensão da inclusão dos transtornos mentais na agenda de discussão da Conferência seria o próprio conceito de saúde, ampliado a partir das discussões da VIII CNS e da I CNST, ocorridas em 1986. Também são destacadas as variadas denominações ou repertórios discursivos associados aos "problemas mentais" presentes nos documentos da Conferência: esforço e desgaste mental, enfermidade mental, deficiência física e mental, determinantes biopsíquicos, bem-estar físico e mental, estafa mental, além das expressões saúde e transtorno mental, com predominância da expressão “sofrimento mental" (SILVA, 2011, p. 130). Essa "polissemia” de termos levaria ao questionamento de sobre quais concepções teóricas estariam assentadas tais nomeações. O predomínio da expressão "sofrimento mental", para a autora, apontaria para dois aspectos relevantes: a influência das propostas teóricas de Christophe Dejours no âmbito das discussões sobre saúde mental e trabalho nos anos 80/90 e para o fato de que "as diversas maneiras de nomear e, por consequência, definir o adoecimento mental no trabalho, podem ter contribuído para as dificuldades no reconhecimento dos transtornos mentais no contexto profissional". Apoiando-se nos questionamentos de Lima (1998, 2003, 2005, 2011a), Silva (2011) pontua que, como, para Dejours, o sofrimento não seria em si doença, tornaria mais difícil se estabelecer o nexo de reconhecimento entre agravo e o trabalho, uma vez que o trabalho não seria o "causador de doenças mentais, podendo no máximo desencadeá-las e, ainda assim, sob certas circunstâncias bastante específicas" (LIMA, 1998, p. 14).

A autora também chama atenção para o fato de que, quando da realização da II CNST, já havia certo acúmulo de pesquisas sobre a temática da Saúde Mental e Trabalho, produzidas pela academia ou pelo movimento sindical (por exemplo, as pesquisas realizadas pelo DIESAT), e estavam em atividade alguns Programas de Saúde do Trabalhador e Centros de Referência em Saúde do Trabalhador que, em sua proposta de atuação multi/interdisciplinar, contavam com profissionais da área "psi", configurando um "cenário em que algumas questões de doenças [mentais] dos trabalhadores passaram a chamar a atenção para os aspectos do trabalho como fator importante na relação com a saúde" (SILVA, 2011, p. 169). Nardi e Ramminger (2012) destacam do relatório da II CNST a necessidade de se contemplarem aspectos de saúde mental no reconhecimento de doenças profissionais, bem como a sugestão de que as empresas públicas e privadas mantivessem programas educativos em relação ao alcoolismo. Silva (2011) também evidencia que foi a partir da II CNST que se esboçou uma proposta específica sobre o reconhecimento legal do nexo causal entre trabalho e adoecimento mental. Nos termos da autora,

[...] percebe-se que, por meio das propostas e discussões presentes na produção discursiva da II CNST, uma nova perspectiva estava sendo formulada sobre as doenças no âmbito do trabalho, aliada à construção do campo da Saúde Mental e Trabalho no Brasil. A temática do sofrimento ou da doença mental ganha contornos de reivindicação política, pelos atores envolvidos na II CNST, uma vez que os trabalhadores, sindicalistas, profissionais da saúde e estudiosos abordaram o problema do reconhecimento do nexo causal nesses casos de saúde mental, nas discussões das políticas voltadas à Saúde do Trabalhador (SILVA, 2011, p. 171). 


\section{CNST (2005)}

A III Conferência Nacional de Saúde do Trabalhador, realizada em 2005, foi pela primeira vez convocada em conjunto pelos Ministérios da Saúde, do Trabalho e Emprego, e da Previdência Social, e marcou-se pelas discussões a respeito da Política Nacional sobre Saúde e Segurança do Trabalho, a política intersetorial proposta, a integração e a implantação da Rede Nacional de Atenção Integral à Saúde do Trabalhador (RENAST), implantada em 2002, e propostas do INSS: o Nexo Técnico Epidemiológico Previdenciário (NTEP), o Perfil Profissiográfico Previdenciário (PPP) e a flexibilização do Seguro de Acidentes de Trabalho (SAT) (NARDI; RAMMINGER, 2012; SILVA, 2001). A conferência propôs três eixos temáticos, em forma de perguntas: "Como garantir a integralidade e a transversalidade da ação do Estado em saúde dos(as) trabalhadores(as)?", "Como incorporar a saúde dos(as) trabalhadores(as) nas políticas de desenvolvimento sustentável no País?", "Como efetivar e ampliar o controle social em saúde dos(as) trabalhadores(as)?”. Com relação à discussão da saúde mental, Nardi e Ramminger (2012, p. 381) destacam:

\footnotetext{
Foram aprovadas 362 resoluções, sendo que apenas 10 delas [...] versam, ainda que de forma incipiente, sobre o tema Saúde Mental e Trabalho. Destas, destacam-se medidas relacionadas ao assédio moral no trabalho [...], garantia à atenção integral à saúde, incluindo Saúde Mental [...], e as demais sugerem que crimes contra a higidez física e mental do trabalhador integrem o Código Penal [...], apoiam a inserção de portadores de transtornos mentais no mundo do trabalho [...], defendem métodos e técnicas de prevenção aos desconfortos físicos e mentais no trabalho [...] e destacam os temas que devem ser priorizados nos estudos e pesquisas, entre eles as doenças (inclusive mentais) relacionadas ao uso de agrotóxicos.
}

Contudo, segundo Lacaz (2007) e Nardi e Ramminger (2012), as resoluções da III CNST ora ratificariam resoluções da II CNST, ora expressariam um retorno às formulações da saúde ocupacional. "O conservadorismo presente nas resoluções é fruto da fragilidade atual do movimento sindical aliada à postura pouco engajada da Academia e ao desenvolvimento de políticas públicas reducionistas" (LACAZ, 2007, p. 764).

\section{CNST (2014)}

A IV Conferência Nacional de Saúde do Trabalhador e da Trabalhadora realizou-se em dezembro de 2014 e teve como tema central "Saúde do Trabalhador e da Trabalhadora, Direito de Todos e Todas e Dever do Estado". Guiada pelo eixo principal "A Implementação da Política Nacional de Saúde do Trabalhador e Trabalhadora (PNSTT)", como subeixos foram trabalhados: “I - O Desenvolvimento socioeconômico e seus Reflexos na Saúde do Trabalhador e da Trabalhadora"; "Il - Fortalecer a Participação dos Trabalhadores e das Trabalhadoras, da Comunidade e do Controle Social nas Ações de Saúde do Trabalhador e da Trabalhadora"; "III - Efetivação da Política Nacional de Saúde e do Trabalhador e da Trabalhadora, considerando os princípios da integralidade e intersetorialidade nas três esferas de governo"; e "IV Financiamento da Política Nacional de Saúde do Trabalhador, nos municípios, estados e União" (MS, 2014). Não foi possível a análise das discussões realizadas nessa conferência, uma vez que seus relatórios ainda não estão disponíveis para consulta. 


\section{ANEXOS}




\section{Anexo A - Capítulos da CID-10}

O Quadro 6, a seguir, apresenta a relação dos capítulos da CID-10 (Classificação Estatística Internacional de Doenças e Problemas Relacionados à Saúde). O capítulo relacionado aos Transtornos Mentais e do Comportamento Relacionados ao Trabalho pelo Decreto no 3.048, de 6 de maio de 1999 é o Capítulo V - Transtornos mentais e comportamentais (F00-F99).

Quadro 6 - Capítulos da CID-10

\begin{tabular}{|c|c|c|c|}
\hline $\begin{array}{l}\text { Número do } \\
\text { capítulo }\end{array}$ & $\begin{array}{l}\text { Código } \\
\text { Inicial }\end{array}$ & $\begin{array}{l}\text { Código } \\
\text { Final }\end{array}$ & Descrição \\
\hline 1 & A00 & B99 & Capítulo I - Algumas doenças infecciosas e parasitárias \\
\hline 2 & $\mathrm{COO}$ & D48 & Capítulo II - Neoplasias [tumores] \\
\hline 3 & D50 & D89 & $\begin{array}{l}\text { Capítulo III - Doenças do sangue e dos órgãos hematopoiéticos e } \\
\text { alguns transtornos imunitários }\end{array}$ \\
\hline 4 & E00 & E90 & Capítulo IV - Doenças endócrinas, nutricionais e metabólicas \\
\hline 5 & F00 & F99 & Capítulo V - Transtornos mentais e comportamentais \\
\hline 6 & G00 & G99 & Capítulo VI - Doenças do sistema nervoso \\
\hline 7 & $\mathrm{HOO}$ & H59 & Capítulo VII - Doenças do olho e anexos \\
\hline 8 & $\mathrm{H} 60$ & H95 & Capítulo VIII - Doenças do ouvido e da apófise mastoide \\
\hline 9 & 100 & 199 & Capítulo IX - Doenças do aparelho circulatório \\
\hline 10 & J00 & J99 & Capítulo X - Doenças do aparelho respiratório \\
\hline 11 & KOO & K93 & Capítulo XI - Doenças do aparelho digestivo \\
\hline 12 & LOO & L99 & Capítulo XII - Doenças da pele e do tecido subcutâneo \\
\hline 13 & M00 & M99 & $\begin{array}{l}\text { Capítulo XIII - Doenças do sistema osteomuscular e do tecido } \\
\text { conjuntivo }\end{array}$ \\
\hline 14 & NOO & N99 & Capítulo XIV - Doenças do aparelho geniturinário \\
\hline 15 & $\mathrm{O} 00$ & 099 & Capítulo XV - Gravidez, parto e puerpério \\
\hline 16 & P00 & P96 & Capítulo XVI - Algumas afecções originadas no período perinatal \\
\hline 17 & Q00 & Q99 & $\begin{array}{l}\text { Capítulo XVII - Malformações congênitas, deformidades e anomalias } \\
\text { cromossômicas }\end{array}$ \\
\hline 18 & ROO & R99 & $\begin{array}{l}\text { Capítulo XVIII - Sintomas, sinais e achados anormais de exames } \\
\text { clínicos e de laboratório, não classificados em outra parte }\end{array}$ \\
\hline 19 & SOO & T98 & $\begin{array}{l}\text { Capítulo XIX - Lesões, envenenamento e algumas outras } \\
\text { consequências de causas externas }\end{array}$ \\
\hline 20 & V01 & Y98 & Capítulo XX - Causas externas de morbidade e de mortalidade \\
\hline 21 & ZOO & Z99 & $\begin{array}{l}\text { Capítulo XXI - Fatores que influenciam o estado de saúde e o contato } \\
\text { com os serviços de saúde } 223\end{array}$ \\
\hline 22 & U04 & U99 & Capítulo XXII - Códigos para propósitos especiais \\
\hline
\end{tabular}

Fonte: CBCD, 2014. 224

223 O Capítulo XXI (Fatores que influenciam o estado de saúde e o contato com os serviços de saúde) possui um CID relacionado aos Transtornos Mentais e do Comportamento Relacionados ao Trabalho: Z73.0 - Sensação de Estar Acabado ("Síndrome de Burn-Out", "Síndrome do Esgotamento Profissional").

224 Disponível em: <http://www.datasus.gov.br/cid10/V2008/cid10.htm>. Acesso em 16 jan. 2015. 


\section{Anexo B - Transtornos Mentais e do Comportamento Relacionados com o Trabalho (Grupo V da CID-10)}

O Quadro 7, a seguir, apresenta as nosologias classificadas como Transtornos Mentais e do Comportamento Relacionados ao Trabalho e seus respectivos agentes etiológicos ou fatores de risco de natureza ocupacional.

Quadro 7 - Transtornos Mentais e do Comportamento Relacionados ao Trabalho, quadros nosológicos e agentes etiológicos

(continua)

\begin{tabular}{|c|c|c|}
\hline CATEGORIA CID $10 *$ & DOENÇAS ** & AGENTES ETIOLÓGICOS OU FATORES DE RISCO DE NATUREZA OCUPACIONAL ** \\
\hline $\begin{array}{l}\text { F02* Demência em outras } \\
\text { doenças classificadas em outra } \\
\text { parte }\end{array}$ & $\begin{array}{l}\text { I - Demência em outras doenças específicas } \\
\text { classificadas em outros locais (F02.8) }\end{array}$ & $\begin{array}{l}\text { 1. Manganês X49.-; Z57.5) (Quadro XV) } \\
\text { 2. Substâncias asfixiantes: CO, } \mathrm{H}_{2} \mathrm{~S} \text {, etc. (sequela) (X47.-; Z57.5) (Quadro XVII) } \\
\text { 3. Sulfeto de Carbono (X49.-; Z57.5) (Quadro XIX) }\end{array}$ \\
\hline $\begin{array}{l}\text { F05 Delirium não induzido pelo } \\
\text { álcool ou por outras substâncias } \\
\text { psicoativas }\end{array}$ & $\begin{array}{l}\text { II - Delirium, não sobreposto a demência, como } \\
\text { descrita (F05.0) }\end{array}$ & $\begin{array}{l}\text { 1. Brometo de Metila (X46.-; Z57.4 e Z57.5) (Quadro XIII) } \\
\text { 2. Sulfeto de Carbono (X49.-; Z57.5) (Quadro XIX) }\end{array}$ \\
\hline $\begin{array}{l}\text { F06 Outros transtornos mentais } \\
\text { devidos a lesão e disfunção } \\
\text { cerebral e a doença física }\end{array}$ & $\begin{array}{l}\text { III - Outros transtornos mentais decorrentes de lesão e } \\
\text { disfunção cerebrais e de doença física (F06.-): } \\
\text { Transtorno Depressivo Orgânico (F06.32); Transtorno } \\
\text { Afetivo Misto Orgânico (F06.33); Transtorno Cognitivo } \\
\text { Leve (F06.7) } \\
\text { III - Outros transtornos mentais decorrentes de lesão e } \\
\text { disfunção cerebrais e de doença física (F06.-): } \\
\text { Transtorno cognitivo leve (F06.7) (Redação dada pelo } \\
\text { Decreto no 3.265, de 1999) }\end{array}$ & $\begin{array}{ll}\text { 1. } & \text { Tolueno e outros solventes aromáticos neurotóxicos (X46.-; Z57.5) (Quadro III) } \\
\text { 2. } & \text { Chumbo ou seus compostos tóxicos (X49.-; Z57.5) (Quadro VIII) } \\
\text { 3. Tricloroetileno, Tetracloroetileno, Tricloroetano e outros solventes orgânicos halogenados } \\
\text { neurotóxicos (X46.-; Z57.5) (Quadro XIII) } \\
\text { 4. Brometo de Metila (X46.-; Z57.4 e Z57.5) (Quadro XIII) } \\
\text { 5. Manganês e seus compostos tóxicos (X49.-; Z57.5) (Quadro XV) } \\
\text { 6. Mercúrio e seus compostos tóxicos (X49.-; Z57.4 e Z57.5) (Quadro XVI) } \\
\text { 7. Sulfeto de Carbono (X49.-; Z57.5) (Quadro XIX) } \\
\text { 8. Outros solventes orgânicos neurotóxicos (X46.-; X49.-; Z57.5) }\end{array}$ \\
\hline $\begin{array}{c}\text { F07 Transtornos de } \\
\text { personalidade e do } \\
\text { comportamento devidos a } \\
\text { doença, a lesão e a disfunção } \\
\text { cerebral }\end{array}$ & $\begin{array}{l}\text { IV - Transtornos de personalidade e de } \\
\text { comportamento decorrentes de doença, lesão e de } \\
\text { disfunção de personalidade (F07.-): Transtorno } \\
\text { Orgânico de Personalidade (F07.0); Outros transtornos } \\
\text { de personalidade e de comportamento decorrentes de } \\
\text { doença, lesão ou disfunção cerebral (F07.8) }\end{array}$ & $\begin{array}{l}\text { 1. Tolueno e outros solventes aromáticos neurotóxicos (X46.-; Z57.5) (Quadro III) } \\
\text { 2. Tricloroetileno, Tetracloroetileno, Tricloroetano e outros solventes orgânicos halogenados } \\
\text { neurotóxicos (X46.-; Z57.5) (Quadro XIII) } \\
\text { 3. Brometo de Metila (X46.-; Z57.4 e Z57.5) (Quadro XIII) } \\
\text { 4. Manganês e seus compostos tóxicos (X49.-; Z57.5) (Quadro XV) } \\
\text { 5. Mercúrio e seus compostos tóxicos (X49.-; Z57.4 e Z57.5) (Quadro XVI) } \\
\text { 6. Sulfeto de Carbono (X49.-; Z57.5) (Quadro XIX) } \\
\text { 7. Outros solventes orgânicos neurotóxicos (X46.-; X49.-; Z57.5) }\end{array}$ \\
\hline
\end{tabular}


Quadro 7- Transtornos Mentais e do Comportamento Relacionados ao Trabalho, quadros nosológicos e agentes etiológicos

(continuação)

\begin{tabular}{|c|c|c|}
\hline CATEGORIA CID $10 *$ & DOENÇAS ** & AGENTES ETIOLÓGICOS OU FATORES DE RISCO DE NATUREZA OCUPACIONAL ** \\
\hline $\begin{array}{l}\text { F09 Transtorno mental orgânico } \\
\text { ou sintomático não especificado }\end{array}$ & $\begin{array}{l}\text { V - Transtorno Mental Orgânico ou Sintomático não } \\
\text { especificado (F09.-) }\end{array}$ & $\begin{array}{l}\text { 1. Tolueno e outros solventes aromáticos neurotóxicos (X46.-; Z57.5) (Quadro III) } \\
\text { 2. Tricloroetileno, Tetracloroetileno, Tricloroetano e outros solventes orgânicos halogenados } \\
\text { neurotóxicos (X46.-; Z57.5) (Quadro XIII) } \\
\text { 3. Brometo de Metila (X46.-; Z57.5) (Quadro XIII) } \\
\text { 4. Manganês e seus compostos tóxicos (X49.-; Z57.5) (Quadro XV) } \\
\text { 5. Mercúrio e seus compostos tóxicos (X49.-; Z57.4 e Z57.5) (Quadro XVI) } \\
\text { 6. Sulfeto de Carbono (X49.-; Z57.5) (Quadro XIX) } \\
\text { 7. Outros solventes orgânicos neurotóxicos (X46.-; X49.-; Z57.5) }\end{array}$ \\
\hline $\begin{array}{l}\text { F10.- Transtornos mentais e } \\
\text { comportamentais devidos ao uso } \\
\text { de álcool }\end{array}$ & $\begin{array}{c}\text { VI - Transtornos mentais e comportamentais devidos } \\
\text { ao uso do álcool: Alcoolismo Crônico (Relacionado com } \\
\text { o Trabalho) (F10.2) }\end{array}$ & $\begin{array}{l}\text { 1. Problemas relacionados com o emprego e com o desemprego: Condições difíceis de } \\
\text { trabalho (Z56.5) } \\
\text { 2. Circunstância relativa às condições de trabalho (Y96) }\end{array}$ \\
\hline F32 Episódios depressivos & VII - Episódios Depressivos (F32.-) & $\begin{array}{l}\text { 1. Tolueno e outros solventes aromáticos neurotóxicos (X46.-; Z57.5) (Quadro III) } \\
\text { 2. Tricloroetileno, Tetracloroetileno, Tricloroetano e outros solventes orgânicos halogenados } \\
\text { neurotóxicos (X46.-; Z57.5) (Quadro XIII) } \\
\text { 3. Brometo de Metila (X46.-; Z57.4 e Z57.5) (Quadro XIII) } \\
\text { 4. Manganês e seus compostos tóxicos (X49.-; Z57.5) (Quadro XV) } \\
\text { 5. Mercúrio e seus compostos tóxicos (X49.-; Z57.4 e Z57.5) (Quadro XVI) } \\
\text { 6. Sulfeto de Carbono (X49.-; Z57.5)(Quadro XIX) } \\
\text { 7. Outros solventes orgânicos neurotóxicos (X46.-; X49.-; Z57.5) }\end{array}$ \\
\hline $\begin{array}{l}\text { F43 Reações ao stress grave e } \\
\text { transtornos de adaptação }\end{array}$ & $\begin{array}{l}\text { VIII - Reações ao Stress Grave e Transtornos de } \\
\text { Adaptação (F43.-): Estado de Stress Pós-Traumático } \\
\text { (F43.1) }\end{array}$ & $\begin{array}{l}\text { 1. Outras dificuldades físicas e mentais relacionadas com o trabalho : reação após acidente } \\
\text { do trabalho grave ou catastrófico, ou após assalto no trabalho (Z56.6) } \\
\text { 2. Circunstância relativa às condições de trabalho (Y96) }\end{array}$ \\
\hline
\end{tabular}


Quadro 7 - Transtornos Mentais e do Comportamento Relacionados ao Trabalho, quadros nosológicos e agentes etiológicos

(conclusão)

\begin{tabular}{|c|c|c|}
\hline CATEGORIA CID $10 *$ & DOENÇAS ** & AGENTES ETIOLÓGICOS OU FATORES DE RISCO DE NATUREZA OCUPACIONAL ** \\
\hline $\begin{array}{c}\text { F48 Outros transtornos } \\
\text { neuróticos }\end{array}$ & IX - Neurastenia (Inclui "Síndrome de Fadiga") (F48.0) & $\begin{array}{l}\text { 1. Tolueno e outros solventes aromáticos neurotóxicos (X46.-; Z57.5) (Quadro III) } \\
\text { 2. Tricloroetileno, Tetracloroetileno, Tricloroetano e outros solventes orgânicos halogenados } \\
\text { (X46.-; Z57.5) (Quadro XIII) } \\
\text { 3. Brometo de Metila (X46.-; Z57.4 e Z57.5) (Quadro XIII) } \\
\text { 4. Manganês e seus compostos tóxicos (X49.-; Z57.5) (Quadro XV) } \\
\text { 5. Mercúrio e seus compostos tóxicos (X49.-; Z57.4 e Z57.5) (Quadro XVI) } \\
\text { 6. Sulfeto de Carbono (X49.-; Z57.5) (Quadro XIX) } \\
\text { 7. Outros solventes orgânicos neurotóxicos (X46.-; X49.-; Z57.5) }\end{array}$ \\
\hline $\begin{array}{l}\text { F48 Outros transtornos } \\
\text { neuróticos }\end{array}$ & $\begin{array}{l}\text { X - Outros transtornos neuróticos especificados (Inclui } \\
\text { "Neurose Profissional") (F48.8) }\end{array}$ & $\begin{array}{l}\text { Problemas relacionados com o emprego e com o desemprego (Z56.-): } \\
\text { - } \quad \text { Desemprego (Z56.0); } \\
\text { - } \quad \text { Mudança de emprego (Z56.1); } \\
\text { - } \quad \text { Ameaça de perda de emprego (Z56.2); } \\
\text { - } \quad \text { Ritmo de trabalho penoso (Z56.3); } \\
\text { - } \quad \text { Desacordo com patrão e colegas de trabalho (Condições difíceis de trabalho) (Z56.5); } \\
\text { - } \quad \text { Outras dificuldades físicas e mentais relacionadas com o trabalho (Z56.6) }\end{array}$ \\
\hline $\begin{array}{l}\text { F51 Transtornos não-orgânicos } \\
\text { do sono devidos a fatores } \\
\text { emocionais }\end{array}$ & $\begin{array}{l}\text { XI - Transtorno do Ciclo Vigília-Sono Devido a Fatores } \\
\text { Não-Orgânicos (F51.2) }\end{array}$ & $\begin{array}{l}\text { 1. Problemas relacionados com o emprego e com o desemprego: Má adaptação à } \\
\text { organização do horário de trabalho (Trabalho em Turnos ou Trabalho Noturno) (Z56.6) } \\
\text { 2. Circunstância relativa às condições de trabalho (Y96) }\end{array}$ \\
\hline $\begin{array}{l}\text { Z73 Problemas relacionados com } \\
\text { a organização de seu modo de } \\
\text { vida }\end{array}$ & $\begin{array}{l}\text { XII - Sensação de Estar Acabado ("Síndrome de Burn- } \\
\text { Out", "Síndrome do Esgotamento Profissional") (Z73.0) }\end{array}$ & $\begin{array}{l}\text { 1. Ritmo de trabalho penoso ( } \mathrm{Z} 56.3) \\
\text { 2. Outras dificuldades físicas e mentais relacionadas com o trabalho (Z56.6) }\end{array}$ \\
\hline
\end{tabular}

* Fonte: OMS (CID 10).

** Fonte: Decreto 3048 (BRASIL, 1999a), revogado e atualizado pelo Decreto 6.957 (BRASIL, 2009).

NOTA: As doenças e respectivos agentes etiológicos ou fatores de risco de natureza ocupacional listados são exemplificativos e complementares (BRASIL, 2009). 


\title{
Anexo C - Benefícios Acidentários Relacionados ao Trabalho
}

\author{
O Quadro 8, a seguir, apresenta os benefícios acidentários relacionados ao trabalho.
}

\section{Quadro 8 - Benefícios Acidentários Relacionados ao Trabalho}

Benefícios acidentários relacionados ao trabalho: O benefício acidentário é devido ao segurado acidentado, ou ao(s) seu(s) dependente(s), quando o acidente ocorre no exercício do trabalho a serviço da empresa, equiparando-se a este a doença profissional ou do trabalho ou, ainda, quando sofrido no percurso entre a residência e o local de trabalho, provocando lesão corporal ou perturbação funcional que cause a morte ou a redução da capacidade para o trabalho. ${ }^{1}$

(continua)

\begin{tabular}{|c|c|}
\hline Benefício & Disposições \\
\hline $\begin{array}{c}\text { B-91 } \\
\text { Auxílio- } \\
\text { doença } \\
\text { acidentário }\end{array}$ & 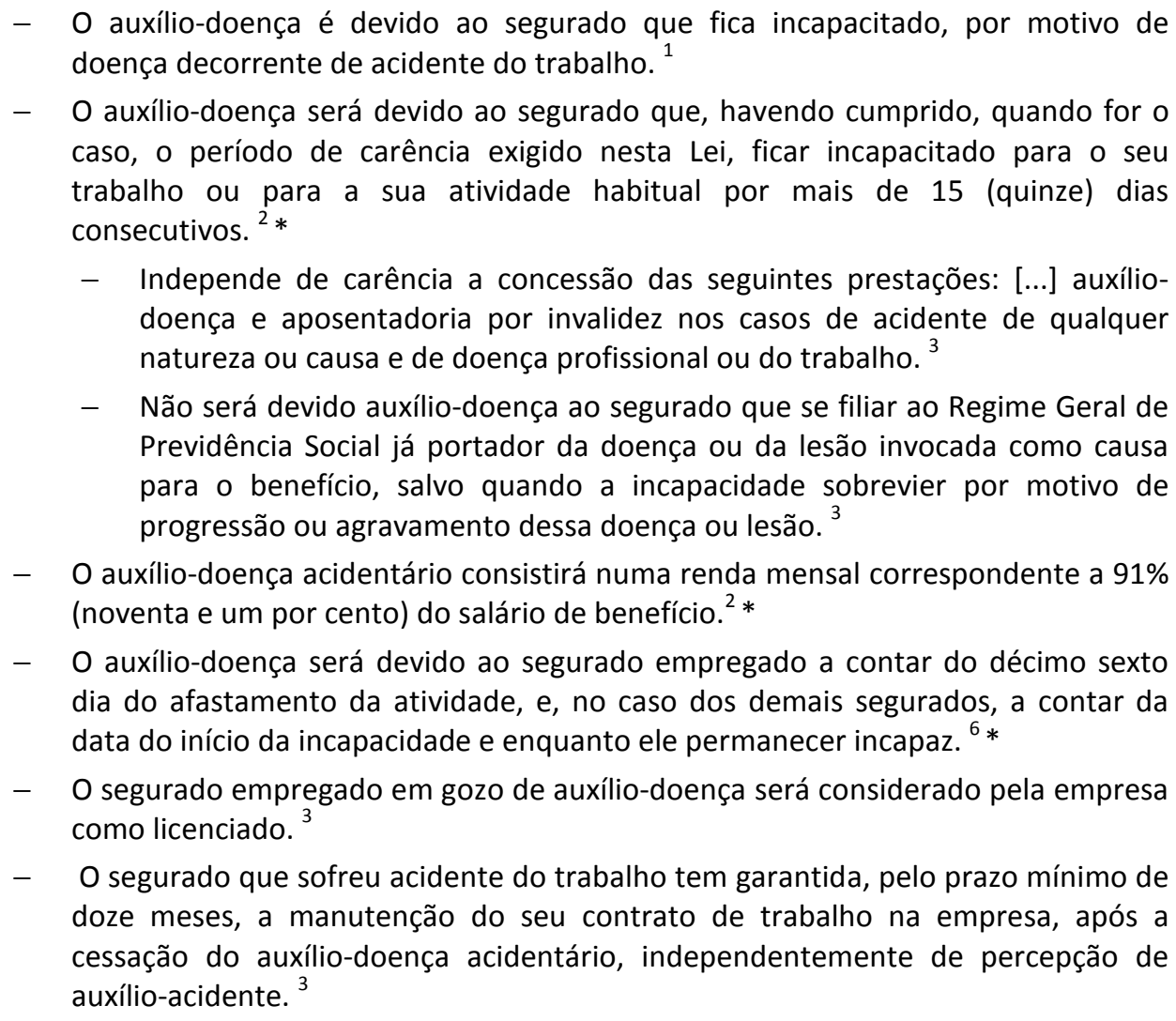 \\
\hline $\begin{array}{c}\text { B-92 } \\
\text { Aposentadoria } \\
\text { por invalidez } \\
\text { acidentária }\end{array}$ & $\begin{array}{l}\text { - Tem direito à aposentadoria por invalidez o segurado acidentado que, estando ou } \\
\text { não em gozo de auxílio-doença acidentário, é considerado incapaz e insuscetível } \\
\text { de reabilitação para o exercício de atividade que lhe garanta a subsistência. }{ }^{1} \\
\text { - } \quad \text { A aposentadoria por invalidez consistirá numa renda mensal correspondente a } \\
100 \% \text { (cem por cento) do salário de benefício. }{ }^{2}{ }^{*} \\
\text { - } \quad \text { o valor da aposentadoria por invalidez do segurado que necessitar da assistência } \\
\text { permanente de outra pessoa será acrescido de } 25 \% \text { (vinte e cinco por cento. }{ }^{2} \\
\text { - } \quad \text { Vitalícia, ou enquanto permanecer nessa condição. }{ }^{3} * \\
\text { - } \quad \text { Independe de carência a concessão das seguintes prestações: }[. . .] \text { auxílio-doença e } \\
\text { aposentadoria por invalidez nos casos de acidente de qualquer natureza ou causa } \\
\text { e de doença profissional ou do trabalho. }\end{array}$ \\
\hline
\end{tabular}


Quadro 8 - Benefícios Acidentários Relacionados ao Trabalho

\begin{tabular}{|c|c|}
\hline Benefício & Disposições \\
\hline $\begin{array}{c}\text { B-93 } \\
\text { Pensão por } \\
\text { morte } \\
\text { acidentária }\end{array}$ & $\begin{array}{l}\text { - A pensão por morte é devida ao(s) dependente(s) do segurado que falece em } \\
\text { consequência de acidente [ou doença] do trabalho. }{ }^{1} * \\
\text { - } 0 \text { valor mensal da pensão por morte será de cem por cento do valor da } \\
\text { aposentadoria que o segurado recebia ou daquela a que teria direito se estivesse } \\
\text { aposentado por invalidez na data de seu falecimento. }{ }^{4} \\
\text { - Independe de carência a concessão das seguintes prestações: [...] pensão por } \\
\text { morte, }[\ldots] \text { auxílio-acidente. }\end{array}$ \\
\hline $\begin{array}{l}\text { Auxílio- } \\
\text { acidente }\end{array}$ & 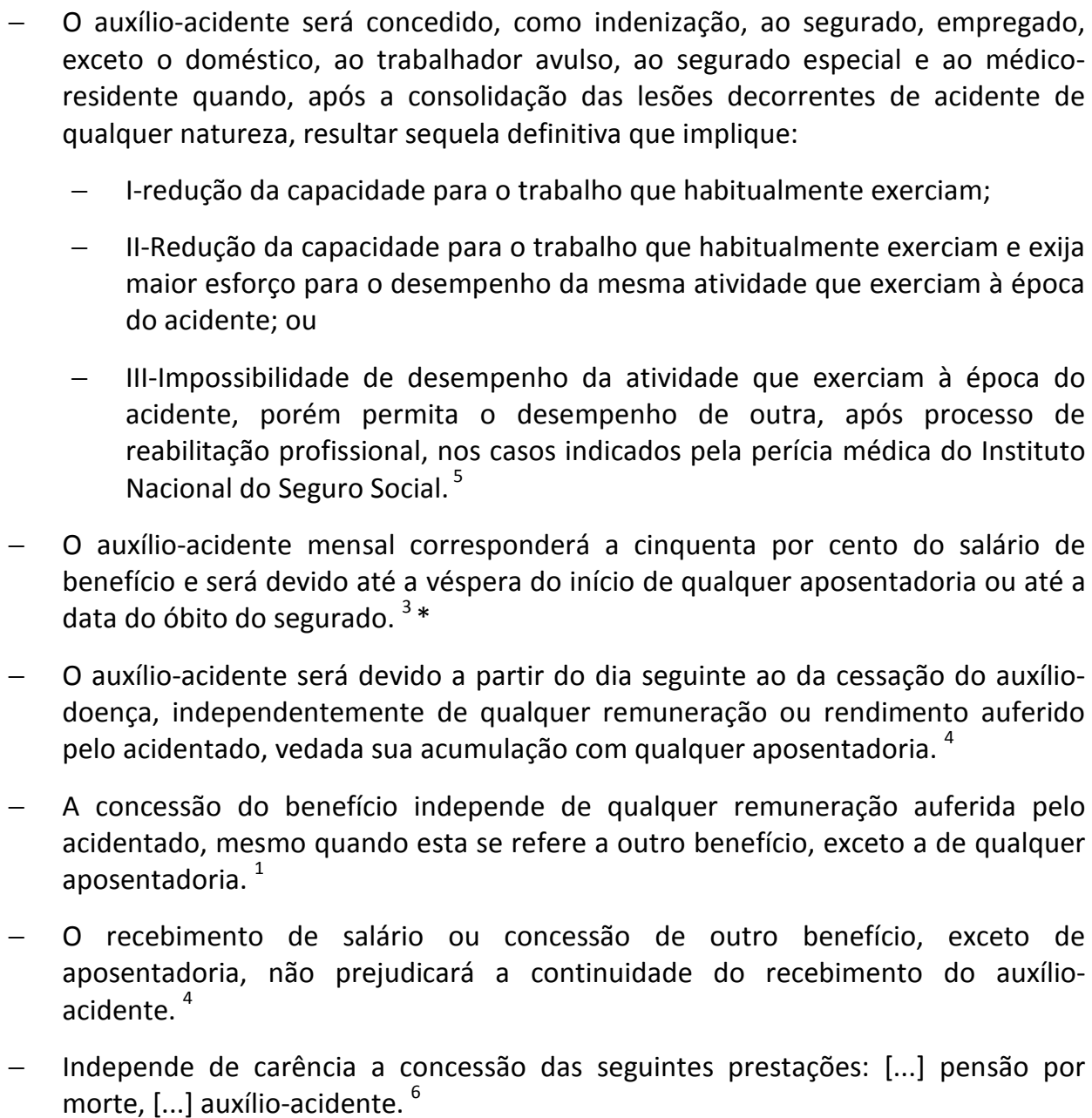 \\
\hline
\end{tabular}

* Benefícios alterados pela Medida Provisória $n^{\circ} 664$, de 30 de dezembro de 2014, que entrou em vigor em $1^{\circ}$ de março de 2015 (altera as Leis $n^{\circ} 8.213$, de 24 de julho de 1991; $n^{\circ} 10.876$, de 2 junho de 2004; $n^{\circ} 8.112$, de 11 de dezembro de 1990 e a Lei $n^{\circ} 10.666$, de 8 de maio de 2003).

Fontes:

1 - Anuário Estatístico da Previdência Social (MPS, 2012)

2 - Lei 9.032 (BRASIL, 1995)

3 - Lei 8.213 (BRASIL, 1991b)

4 - Lei 9.528 (BRASIL, 1997)

5 - Decreto 3.048 (BRASIL, 1999a)

6 - Lei 9.876 (BRASIL, 1999b) 


\title{
Anexo D - Normas Regulamentadoras de Segurança e Saúde no Trabalho do Ministério do Trabalho
}

\author{
O Quadro 9, a seguir, apresenta as Normas Regulamentadoras de Segurança e Saúde no \\ Trabalho do Ministério do Trabalho.
}

Quadro 9 - Normas Regulamentadoras de Segurança e Saúde no Trabalho

(continua)

\begin{tabular}{|c|c|}
\hline Norma $^{1}$ & Tema \\
\hline NR 1 - Disposições Gerais & $\begin{array}{l}\text { Estabelece o campo de aplicação de todas as Normas Regulamentadoras de Segurança e Medicina do } \\
\text { Trabalho do Trabalho Urbano, bem como os direitos e obrigações do Governo, dos empregadores e dos } \\
\text { trabalhadores no tocante a este tema específico. }{ }^{2}\end{array}$ \\
\hline NR 2- Inspeção Prévia & $\begin{array}{l}\text { Estabelece as situações em que as empresas deverão solicitar ao Ministério do Trabalho a realização de } \\
\text { inspeção prévia em seus estabelecimentos, bem como a forma de sua realização. }{ }^{2}\end{array}$ \\
\hline $\begin{array}{l}\text { NR } 3 \text { - Embargo ou } \\
\text { Interdição }\end{array}$ & $\begin{array}{l}\text { Estabelece as situações em que as empresas se sujeitam a sofrer paralisação de seus serviços, } \\
\text { máquinas ou equipamentos, bem como os procedimentos a serem observados, pela fiscalização } \\
\text { trabalhista, na adoção de tais medidas punitivas no tocante à Segurança e à Medicina do Trabalho. }{ }^{2}\end{array}$ \\
\hline $\begin{array}{l}\text { NR } 4 \text { - Serviços } \\
\text { Especializados em } \\
\text { Engenharia de Segurança e } \\
\text { em Medicina do Trabalho } \\
\text { (SESMT) }\end{array}$ & $\begin{array}{l}\text { Estabelece a obrigatoriedade de as empresas públicas e privadas, que possuam empregados regidos } \\
\text { pela CLT, de organizarem e manterem em funcionamento, Serviços Especializados em Engenharia de } \\
\text { Segurança e em Medicina do Trabalho (SESMT), com a finalidade de promover a saúde e proteger a } \\
\text { integridade do trabalhador no local de trabalho. }\end{array}$ \\
\hline $\begin{array}{l}\text { NR } 5 \text { - Comissão Interna de } \\
\text { Prevenção de Acidentes } \\
\text { (CIPA) }\end{array}$ & $\begin{array}{l}\text { Estabelece a obrigatoriedade de as empresas públicas e privadas organizarem e manterem em } \\
\text { funcionamento, por estabelecimento, uma comissão constituída exclusivamente por empregados com } \\
\text { o objetivo de prevenir infortúnios laborais, através da apresentação de sugestões e recomendações ao } \\
\text { empregador para que melhore as condições de trabalho, eliminando as possíveis causas de acidentes } \\
\text { do trabalho e doenças ocupacionais. }\end{array}$ \\
\hline $\begin{array}{l}\text { NR } 6 \text { - Equipamentos de } \\
\text { Proteção Individual (EPI) }\end{array}$ & $\begin{array}{l}\text { Estabelece e define os tipos de EPIs que as empresas estão obrigadas a fornecer a seus empregados, } \\
\text { sempre que as condições de trabalho o exigirem, a fim de resguardar a saúde e a integridade física dos } \\
\text { trabalhadores. }{ }^{2}\end{array}$ \\
\hline $\begin{array}{l}\text { NR } 7 \text { - Programa de } \\
\text { Controle Médico de Saúde } \\
\text { Ocupacional (PCMSO) }\end{array}$ & $\begin{array}{l}\text { Estabelece a obrigatoriedade de elaboração e implementação, por parte de todos os empregadores e } \\
\text { instituições que admitam trabalhadores como empregados, do Programa de Controle Médico de Saúde } \\
\text { Ocupacional (PCMSO), com o objetivo de promoção e preservação da saúde do conjunto dos seus } \\
\text { trabalhadores. }\end{array}$ \\
\hline NR 8 - Edificações & $\begin{array}{l}\text { Dispõe sobre os requisitos técnicos mínimos que devem ser observados nas edificações para garantir } \\
\text { segurança e conforto aos que nelas trabalham. }{ }^{2}\end{array}$ \\
\hline $\begin{array}{l}\text { NR } 9 \text { - Programas de } \\
\text { Prevenção de Riscos } \\
\text { Ambientais (PPRA) }\end{array}$ & $\begin{array}{l}\text { Estabelece a obrigatoriedade de elaboração e implementação, por parte de todos os empregadores e } \\
\text { instituições que admitam trabalhadores como empregados, do Programa de Prevenção de Riscos } \\
\text { Ambientais (PPRA), visando à preservação da saúde e da integridade física dos trabalhadores, através } \\
\text { da antecipação, reconhecimento, avaliação e consequente controle da ocorrência de riscos ambientais } \\
\text { existentes ou que venham a existir no ambiente de trabalho, tendo em consideração a proteção do } \\
\text { meio ambiente e dos recursos naturais. }\end{array}$ \\
\hline $\begin{array}{l}\text { NR } 10 \text { - Instalações e } \\
\text { Serviços em Eletricidade }\end{array}$ & $\begin{array}{l}\text { Estabelece condições mínimas exigíveis para garantir a segurança dos empregados que trabalham em } \\
\text { instalações elétricas, em suas diversas etapas, incluindo elaboração de projetos, execução, operação, } \\
\text { manutenção, reforma e ampliação, assim como a segurança de usuários e de terceiros, em quaisquer } \\
\text { das fases de geração, transmissão, distribuição e consumo de energia elétrica, observando-se, para } \\
\text { tanto, as normas técnicas oficiais vigentes e, na falta destas, as normas técnicas internacionais. }\end{array}$ \\
\hline
\end{tabular}


Quadro 9 - Normas Regulamentadoras de Segurança e Saúde no Trabalho

(continuação)

\begin{tabular}{|c|c|}
\hline Norma ${ }^{1}$ & Tema \\
\hline $\begin{array}{l}\text { NR } 11 \text { - Transporte, } \\
\text { Movimentação, } \\
\text { Armazenagem e Manuseio } \\
\text { de Materiais }\end{array}$ & $\begin{array}{l}\text { Estabelece os requisitos de segurança a serem observados nos locais de trabalho, no que se refere ao } \\
\text { transporte, à movimentação, à armazenagem e ao manuseio de materiais, tanto de forma mecânica } \\
\text { quanto manual, objetivando a prevenção de infortúnios laborais. }\end{array}$ \\
\hline $\begin{array}{l}\text { NR } 12 \text { - Máquinas e } \\
\text { Equipamentos }\end{array}$ & $\begin{array}{l}\text { Estabelece as medidas prevencionistas de segurança e higiene do trabalho a serem adotadas pelas } \\
\text { empresas em relação à instalação, operação e manutenção de máquinas e equipamentos, visando à } \\
\text { prevenção de acidentes do trabalho. }{ }^{2}\end{array}$ \\
\hline $\begin{array}{l}\text { NR } 13 \text { - Caldeiras e Vasos } \\
\text { de Pressão }\end{array}$ & $\begin{array}{l}\text { Estabelece todos os requisitos técnicos-legais relativos à instalação, operação e manutenção de } \\
\text { caldeiras e vasos de pressão, de modo a se prevenir a ocorrência de acidentes do trabalho. }{ }^{2}\end{array}$ \\
\hline NR 14 - Fornos & $\begin{array}{l}\text { Estabelece as recomendações técnico-legais pertinentes à construção, operação e manutenção de } \\
\text { fornos industriais nos ambientes de trabalho. }{ }^{2}\end{array}$ \\
\hline $\begin{array}{l}\text { NR } 15 \text { - Atividades e } \\
\text { Operações Insalubres }\end{array}$ & $\begin{array}{l}\text { Descreve as atividades, operações e agentes insalubres, inclusive seus limites de tolerância, definindo, } \\
\text { assim, as situações que, quando vivenciadas nos ambientes de trabalho pelos trabalhadores, ensejam a } \\
\text { caracterização do exercício insalubre, e também os meios de proteger os trabalhadores de tais } \\
\text { exposições nocivas à sua saúde. }\end{array}$ \\
\hline $\begin{array}{l}\text { NR } 16 \text { - Atividades e } \\
\text { Operações Perigosas }\end{array}$ & $\begin{array}{l}\text { Regulamenta as atividades e as operações legalmente consideradas perigosas, estipulando as } \\
\text { recomendações prevencionistas correspondentes. }{ }^{2}\end{array}$ \\
\hline NR 17 - Ergonomia & $\begin{array}{l}\text { Visa estabelecer parâmetros que permitam a adaptação das condições de trabalho às condições } \\
\text { psicofisiológicas dos trabalhadores, de modo a proporcionar um máximo de conforto, segurança e } \\
\text { desempenho eficiente. }{ }^{2}\end{array}$ \\
\hline $\begin{array}{l}\text { NR } 18 \text { - Condições e Meio } \\
\text { Ambiente de Trabalho na } \\
\text { Indústria da Construção }\end{array}$ & $\begin{array}{l}\text { Estabelece diretrizes de ordem administrativa, de planejamento de organização, que objetivem a } \\
\text { implementação de medidas de controle e sistemas preventivos de segurança nos processos, nas } \\
\text { condições e no meio ambiente de trabalho na indústria da construção civil. }{ }^{2}\end{array}$ \\
\hline NR 19 - Explosivos & $\begin{array}{l}\text { Estabelece as disposições regulamentadoras acerca do depósito, manuseio e transporte de explosivos, } \\
\text { objetivando a proteção da saúde e integridade física dos trabalhadores em seus ambientes de trabalho. } \\
2\end{array}$ \\
\hline $\begin{array}{l}\text { NR } 20 \text { - Líquidos } \\
\text { Combustíveis e Inflamáveis }\end{array}$ & $\begin{array}{l}\text { Estabelece as disposições regulamentares acerca do armazenamento, manuseio e transporte de } \\
\text { líquidos combustíveis e inflamáveis, objetivando a proteção da saúde e a integridade física dos } \\
\text { trabalhadores em seus ambientes de trabalho. }{ }^{2}\end{array}$ \\
\hline $\begin{array}{l}\text { NR } 21 \text { - Trabalhos a Céu } \\
\text { Aberto }\end{array}$ & $\begin{array}{l}\text { Tipifica as medidas prevencionistas relacionadas com a prevenção de acidentes nas atividades } \\
\text { desenvolvidas a céu aberto, tais como em minas ao ar livre e em pedreiras. }{ }^{2}\end{array}$ \\
\hline $\begin{array}{l}\text { NR } 22 \text { - Segurança e Saúde } \\
\text { Ocupacional na Mineração }\end{array}$ & $\begin{array}{l}\text { Estabelece métodos de segurança a serem observados pelas empresas que desenvolvam trabalhos } \\
\text { subterrâneos, de modo a proporcionar a seus empregados condições satisfatórias de Segurança e } \\
\text { Medicina do Trabalho. }{ }^{2}\end{array}$ \\
\hline $\begin{array}{l}\text { NR } 23 \text { - Proteção Contra } \\
\text { Incêndios }\end{array}$ & $\begin{array}{l}\text { Estabelece as medidas de proteção contra incêndios, estabelece as medidas de proteção contra } \\
\text { incêndio que devem dispor os locais de trabalho, visando à prevenção da saúde e da integridade física } \\
\text { dos trabalhadores. }\end{array}$ \\
\hline $\begin{array}{l}\text { NR } 24 \text { - Condições } \\
\text { Sanitárias e de Conforto } \\
\text { nos Locais de Trabalho }\end{array}$ & $\begin{array}{l}\text { Disciplina os preceitos de higiene e de conforto a serem observados nos locais de trabalho, } \\
\text { especialmente no que se refere a banheiros, vestiários, refeitórios, cozinhas, alojamentos e água } \\
\text { potável, visando à higiene dos locais de trabalho e a proteção à saúde dos trabalhadores. }{ }^{2}{ }^{2}\end{array}$ \\
\hline $\begin{array}{l}\text { NR } 25 \text { - Resíduos } \\
\text { Industriais }\end{array}$ & $\begin{array}{l}\text { Estabelece as medidas preventivas a serem observadas pelas empresas, no destino final a ser dado aos } \\
\text { resíduos industriais resultantes dos ambientes de trabalho de modo a proteger a saúde e a integridade } \\
\text { física dos trabalhadores. }\end{array}$ \\
\hline $\begin{array}{l}\text { NR } 26 \text { - Sinalização de } \\
\text { Segurança }\end{array}$ & $\begin{array}{l}\text { Estabelece a padronização das cores a serem utilizadas como sinalização de segurança nos ambientes } \\
\text { de trabalho, de modo a proteger a saúde e a integridade física dos trabalhadores. }{ }^{2}\end{array}$ \\
\hline
\end{tabular}


Quadro 9 - Normas Regulamentadoras de Segurança e Saúde no Trabalho

(conclusão)

\begin{tabular}{|c|c|}
\hline Norma ${ }^{1}$ & Tema \\
\hline $\begin{array}{l}\text { NR } 27 \text { - Registro Profissional } \\
\text { do Técnico de Segurança do } \\
\text { Trabalho no Ministério do } \\
\text { Trabalho }\end{array}$ & 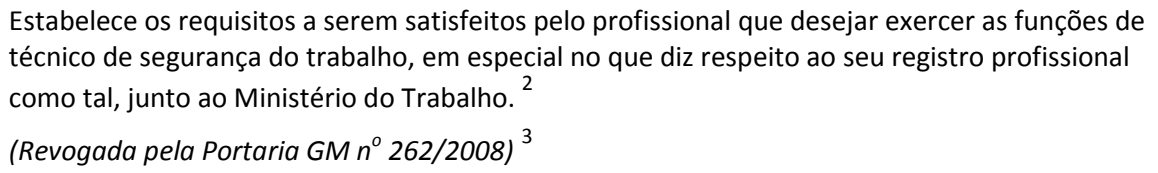 \\
\hline $\begin{array}{l}\text { NR } 28 \text { - Fiscalização e } \\
\text { Penalidades }\end{array}$ & $\begin{array}{l}\text { Estabelece os procedimentos a serem adotados pela fiscalização trabalhista de Segurança e } \\
\text { Medicina do Trabalho, tanto no que diz respeito à concessão de prazos às empresas para a } \\
\text { correção das irregularidades técnicas, como também no que concerne ao procedimento de } \\
\text { autuação por infração às Normas Regulamentadoras de Segurança e Medicina do Trabalho. }{ }^{2}\end{array}$ \\
\hline $\begin{array}{l}\text { NR } 29 \text { - Norma } \\
\text { Regulamentadora de } \\
\text { Segurança e Saúde no } \\
\text { Trabalho Portuário }\end{array}$ & $\begin{array}{l}\text { Tem por objetivo regular a proteção obrigatória contra acidentes e doenças profissionais, } \\
\text { facilitar os primeiros socorros a acidentados e alcançar as melhores condições possíveis de } \\
\text { segurança e saúde aos trabalhadores portuários. }\end{array}$ \\
\hline $\begin{array}{l}\text { NR } 30 \text { - Norma } \\
\text { Regulamentadora de } \\
\text { Segurança e Saúde no } \\
\text { Trabalho Aquaviário }\end{array}$ & $\begin{array}{l}\text { Aplica-se aos trabalhadores de toda embarcação comercial utilizada no transporte de } \\
\text { mercadorias ou de passageiros, na navegação marítima de longo curso, na cabotagem, na } \\
\text { navegação interior, no serviço de reboque em alto-mar, bem como em plataformas marítimas } \\
\text { e fluviais, quando em deslocamento, e embarcações de apoio marítimo e portuário. }{ }^{2}\end{array}$ \\
\hline $\begin{array}{c}\text { NR } 31 \text { - Norma } \\
\text { Regulamentadora de } \\
\text { Segurança e Saúde no } \\
\text { Trabalho na Agricultura, } \\
\text { Pecuária, Silvicultura, } \\
\text { Exploração Florestal e } \\
\text { Aquicultura }\end{array}$ & $\begin{array}{l}\text { Estabelece os preceitos a serem observados na organização e no ambiente de trabalho, de } \\
\text { forma a tornar compatível o planejamento e o desenvolvimento das atividades da agricultura, } \\
\text { pecuária, silvicultura, exploração florestal e aquicultura com a segurança e saúde e meio } \\
\text { ambiente do trabalho. }\end{array}$ \\
\hline $\begin{array}{l}\text { NR } 32 \text { - Segurança e Saúde no } \\
\text { Trabalho em Estabelecimentos } \\
\text { de Saúde }\end{array}$ & $\begin{array}{l}\text { Tem por finalidade estabelecer as diretrizes básicas para a implementação de medidas de } \\
\text { proteção à segurança e à saúde dos trabalhadores dos serviços de saúde, bem como daqueles } \\
\text { que exercem atividades de promoção e assistência à saúde em geral. }{ }^{2}\end{array}$ \\
\hline $\begin{array}{l}\text { NR } 33 \text { - Segurança e Saúde no } \\
\text { Trabalho em Espaços } \\
\text { Confinados }\end{array}$ & $\begin{array}{l}\text { Tem como objetivo estabelecer os requisitos mínimos para identificação de espaços } \\
\text { confinados e o reconhecimento, avaliação, monitoramento e controle dos riscos existentes, de } \\
\text { forma a garantir permanentemente a segurança e saúde dos trabalhadores que interagem } \\
\text { direta ou indiretamente nesses espaços. }\end{array}$ \\
\hline $\begin{array}{l}\text { NR } 34 \text { - Condições e Meio } \\
\text { Ambiente de Trabalho na } \\
\text { Indústria da Construção e } \\
\text { Reparação Naval }\end{array}$ & $\begin{array}{l}\text { Estabelece os requisitos mínimos e as medidas de proteção à segurança, à saúde e ao meio } \\
\text { ambiente de trabalho nas atividades da indústria de construção e reparação naval. }{ }^{3}\end{array}$ \\
\hline NR 35 - Trabalho em Altura & $\begin{array}{l}\text { Estabelece os requisitos mínimos e as medidas de proteção para o trabalho em altura, } \\
\text { envolvendo o planejamento, a organização e a execução, de forma a garantir a segurança e a } \\
\text { saúde dos trabalhadores envolvidos direta ou indiretamente com essa atividade. }{ }^{3}\end{array}$ \\
\hline $\begin{array}{c}\text { NR } 36 \text { - Segurança e Saúde no } \\
\text { Trabalho em Empresas de } \\
\text { Abate e Processamento de } \\
\text { Carnes e Derivados }\end{array}$ & $\begin{array}{l}\text { Estabelece os requisitos mínimos para a avaliação, controle e monitoramento dos riscos } \\
\text { existentes nas atividades desenvolvidas na indústria de abate e processamento de carnes e } \\
\text { derivados destinados ao consumo humano, de forma a garantir permanentemente a } \\
\text { segurança, a saúde e a qualidade de vida no trabalho, sem prejuízo da observância do disposto } \\
\text { nas demais Normas Regulamentadoras (NR) do Ministério do Trabalho e Emprego. }\end{array}$ \\
\hline
\end{tabular}

Fontes:

1 - MT (Ministério do Trabalho), 2013.

2 - SOBES (Sociedade Brasileira de Engenharia de Segurança), 2013.

3 - Guia Trabalhista, 2013. 


\title{
Anexo E - Psicólogo Especialista em Psicologia Organizacional e do Trabalho
}

\author{
Definição da especialidade a ser concedida pelo Conselho Federal de Psicologia, para efeito
}

de concessão e registro do título profissional de Especialista em Psicologia.

Atua em atividades relacionadas à análise e desenvolvimento organizacional, ação humana nas organizações, desenvolvimento de equipes, consultoria organizacional, seleção, acompanhamento e desenvolvimento de pessoal, estudo e planejamento de condições de trabalho, estudo e intervenção dirigidos à saúde do trabalhador. Desenvolve, analisa, diagnostica e orienta casos na área da saúde do trabalhador, observando níveis de prevenção, reabilitação e promoção de saúde. Participa de programas e/ou atividades na área da saúde e segurança de trabalho, subsidiando-os quanto a aspectos psicossociais para proporcionar melhores condições ao trabalhador. Atua como consultor interno/externo, participando do desenvolvimento das organizações sociais, para facilitar processos de grupo e de intervenção psicossocial nos diferentes níveis hierárquicos de organizações.

Planeja e desenvolve ações destinadas a equacionar as relações de trabalho, o sentido de maior produtividade e da realização pessoal dos indivíduos e grupos inseridos nas organizações, estimulando a criatividade, para buscar melhor qualidade de vida no trabalho. Participa do processo de desligamento de funcionários de organizações, em processos de demissões e na preparação para aposentadorias, a fim de colaborar com os indivíduos na elaboração de novos projetos de vida. Elabora, executa e avalia, em equipe multiprofissional, programas de desenvolvimento de recursos humanos. Participa dos serviços técnicos da empresa, colaborando em projetos de construção e adaptação dos instrumentos e equipamentos de trabalho ao homem, bem como de outras iniciativas relacionadas à ergonomia. Realiza pesquisas e ações relacionadas à saúde do trabalhador e suas condições de trabalho. Participa da elaboração, implementação e acompanhamento das políticas de recursos humanos. Elaborar programas de melhoria de desempenho, aproveitando o potencial e considerando os aspectos motivacionais relacionados ao trabalho. Atua na relação capital/trabalho no sentido de equacionar e dar encaminhamento a conflitos organizacionais. Desempenha atividades relacionadas ao recrutamento, seleção, orientação e treinamento, análise de ocupações e profissiográficas e no acompanhamento de avaliação de desempenho de pessoal, atuando em equipes multiprofissionais. Utiliza métodos e técnicas da psicologia aplicada ao trabalho, como entrevistas, testes, provas, dinâmicas de grupo, etc. para subsidiar as decisões na área de recursos humanos como: promoção, movimentação de pessoal, incentivo, remuneração de carreira, capacitação e integração funcional e promover, em consequência, a auto-realização no trabalho.

Fonte: CFP, 2001, p.10-11. 